\title{
UICN
}

\section{El Principio de No Regresión Ambiental en Iberoamérica}

Mario Peña Chacon

Editor

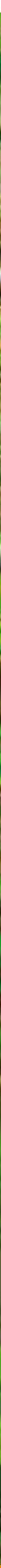

UICN Serie de Política y Derecho Ambiental No. 84

Comisión Mundial de
Derecho Ambiental



El Principio de No Regresión Ambiental en Iberoamérica 



\section{El Principio de No Regresión Ambiental en Iberoamérica}

Mario Peña Chacon

Editor

UICN Serie de Política y Derecho Ambiental No. 84 
La presentación del material en esta publicación y las denominaciones empleadas para las entidades geográficas no implican en absoluto la expresión de una opinión por parte de la UICN sobre la situación jurídica de un país, territorio o zona, o de sus autoridades, o acerca de la demarcación de sus límites o fronteras.

Los puntos de vista que se expresan en esa publicación no reflejan necesariamente los de la UICN.

Publicado por:

Derechos reservados:

Citación:

Ambiental

ISBN:

DOI:

Fotografía de la cubierta:

Diagramado por:

Disponible en:
UICN, Gland, Suiza en colaboración con el Programa de Derecho Ambiental de la UICN

(C) 2015 Unión Internacional para la Conservación de la Naturaleza y de los Recursos Naturales

Se autoriza la reproducción de esta publicación con fines educativos y otros fines no comerciales sin permiso escrito previo de parte de quien detenta los derechos de autor con tal de que se mencione la fuente.

Se prohibe reproducir esta publicación para la venta o para otros fines comerciales sin permiso escrito previo de quien detenta los derechos de autor.

Mario Peña Chacon (Editor). El Principio de No Regresión en Iberoamérica. Gland, Suiza: UICN. xxii + 310 pp.

978-2-8317-1742-5

\subsection{5/IUCN.CH.2015.EPLP.84.es}

shutterstock/lkuni

Centro de Derecho Ambiental de la IUCN

UICN (Unión Internacional para la Conservación de la Naturaleza)

Programa de Derecho Ambiental

Rue Mauverney 28

1196 Gland

Suiza

$\mathrm{Tel}+\quad 41229990000$

Telefax +41229990002

elcsecretariat@iucn.org

www.iucn.org/publications 


\section{ÍNDICE}

Índice . V

Prólogo xiii

Agradecimientos. ...XV

SEMBLANZA DE LOS AUTORES xvii

EL PRINCIPIO DE NO REGRESIÓN AMBIENTAL A LA LUZ DEL PARADIGMA DE LA SOSTENIBILIDAD

1 La Sostenibilidad como guía de acción de la Humanidad ............................................. 3

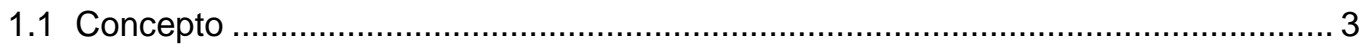

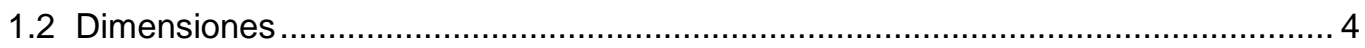

2 El Principio de no regresión ambiental en el contexto de la Sostenibilidad .................... 10

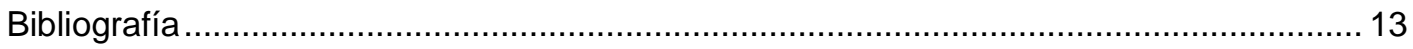

A PROIBIÇÃO DO RETROCESSO COMO GARANTIA DA EVOLUÇÃO SUSTENTÁVEL DO

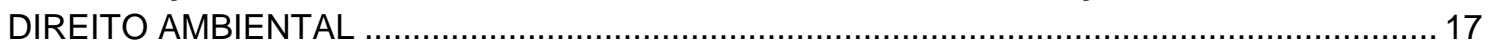

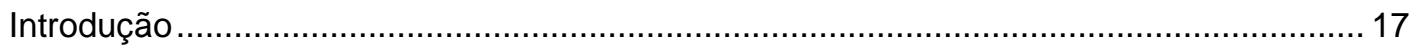

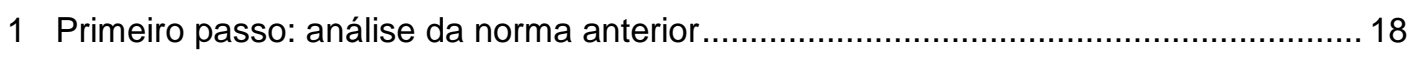

2.1 O Direito regula ex novo um certo componente natural.......................................... 21

2.2 O Direito regula ex novo um determinado sector ambiental .................................. 22

2.3 Direito regula ex novo uma actividade tradicional geradora de impactes

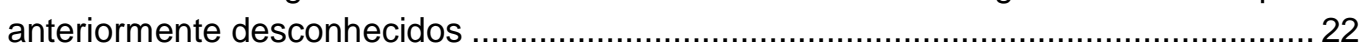

2.4 O Direito regula uma actividade nova e geradora de impactes ambientais............ 23

2.5 O Direito cria um novo instrumento jurídico de proteção ambiental ....................... 23

3 Segundo passo: análise da norma posterior ............................................................. 24

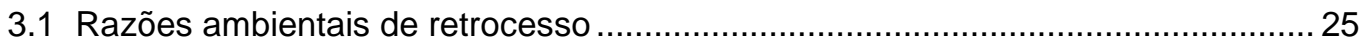

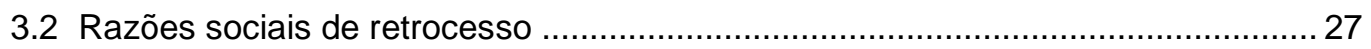

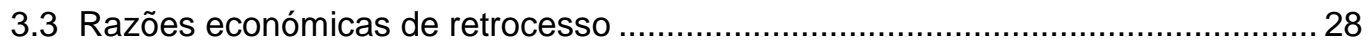

4 Condições gerais de admissibilidade excepcional de normas retrocedentes................. 31

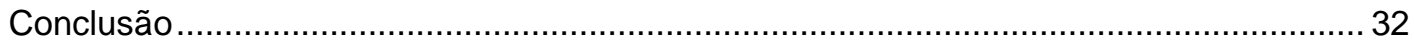

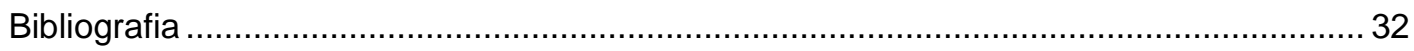

LA «REGRESIÓN» ACECHA AL DERECHO AMBIENTAL. LA DOCTRINA ESTÁ ALERTA. .. 37

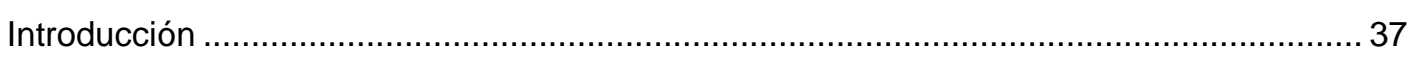

1 El derecho ambiental es «no regresivo» Es «progresivo» .......................................... 37

2 Motivos de la regresión jurídica ambiental y de su disimulo ........................................... 38

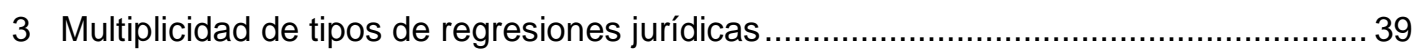

4 Normas autoregresivas. La norma procesal es la más esgrimida ............................... 40

5 La transversalidad típica del derecho ambiental facilita la regresión ............................. 43 
5.1 Por la diversidad de fuentes normativas

5.2 Por que la proliferación de normas puede generar conflictos en su aplicación

5.3 Por que la proliferación de normas induce una proliferación de estructuras administrativas que pueden entrar en conflicto para su aplicación

6 Medición de la «regresión» ........................................................................... 45

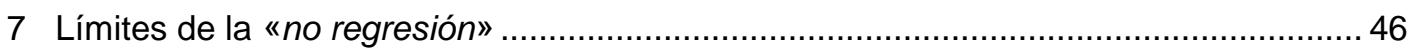

8 Ardides para obstar a la protección jurídica del ambiente ....................................... 46

Ardid 1-Negar la existencia de la norma protectora del ambiente .......................... 46

Ardid 2-Definir a una denominación progresiva en términos contrarios a la progresión 49

Ardid 3-Negar o disminuir la categoría del derecho al ambiente ........................... 49

Ardid 4-Invocar la imposibilidad del cumplimento ............................................ 49

9 La «regresión» acecha al derecho ambiental .............................................. 51

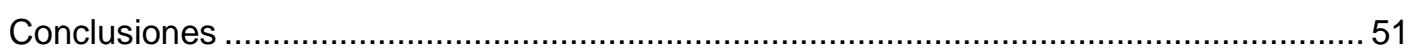

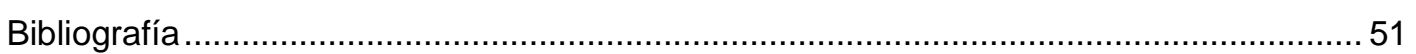

OS DESAFIOS PARA UM CONSTITUCIONALISMO DA VIDA DECENTE EM UMA CULTURA JURÍDICA DE RETROCESSO SOCIOAMBIENTAL: CONTRIBUIÇÕES DA JURISPRUDÊNCIA

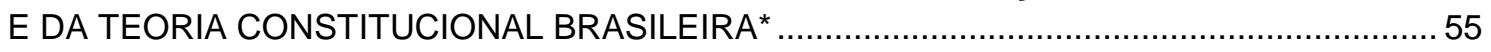

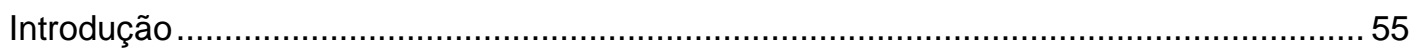

1 Estado ambiental e os problemas ambientais de segunda geração ........................... 57

1.1 Estado de direito como mediador de projetos de vida e o constitucionalismo de uma sociedade decente ........................................................................... 61

1.2. Constitucionalismo verde e o Direito ambiental da sustentabilidade como manifestações de um constitucionalismo da vida decente ......................................6 63

1.3 O que deve ser e o que não pode ser um Estado ambiental? ...........................67

2 O que se deve proteger? Os imperativos de proteção do meio ambiente e das futuras gerações como partes do projeto de comunidade política protegido pela Constituição ..... 70

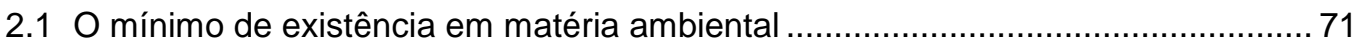

3 Como se deve proteger? O princípio de proibição de retrocesso em matéria ambiental

3.1 Os fundamentos normativos de um imperativo de não retorno nos sistemas internacionais de proteção dos direitos humanos e na constituição brasileira ..... 79

3.2 Há um imperativo relativo na constituição brasileira? Lições de uma cultura jurídica de não retorno no regime jurídico das áreas protegidas (o artigo 225, $§ 1^{\circ}$, inciso III) .. 83

3.3 O teste da retrocessividade das medidas de proteção

4 O Estado brasileiro proporciona, neste momento, a concretização dos objetivos de uma Constituição ambiental? O Estado de retrocesso ambiental na jurisprudência do Supremo

Tribunal Federal

4.1 A formação de uma cultura judicial de não retorno em matéria ambiental na jurisprudência brasileira. O diálogo com o direito privado .......................................... 90

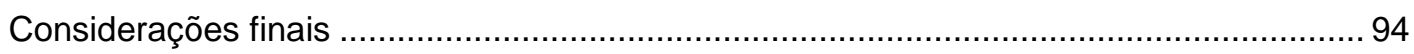


Referências bibliográficas

NUEVO RETO DEL DERECHO AMBIENTAL: LA CONSTRUCCIÓN DEL PRINCIPIO DE IRREVERSI-BILIDAD DE LAS NORMAS DE PROTECCION DEL AMBIENTE ...................... 103

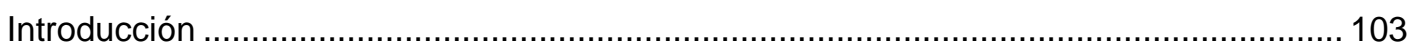

1 Los principios de irreversibilidad y de progresividad de los derechos humanos .......... 105

1.1 El principio de irreversibilidad: el compromiso primario ...................................... 105

1.2 El principio de progresividad: la incorporación de adelantos normativo ............... 107

2 La aplicabilidad de los principios de los derechos humanos al derecho al ambiente y al

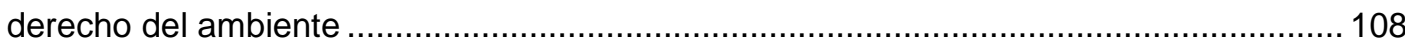

2.1 La aplicabilidad de los principios de los derechos humanos al derecho al ambiente

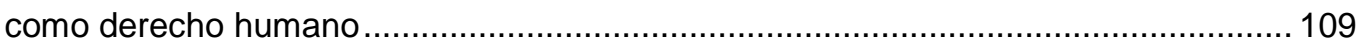

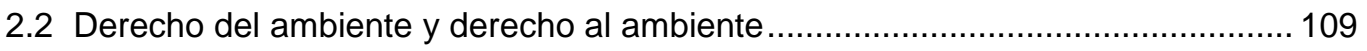

2.3 La aplicabilidad de los principios de los derechos humanos al derecho del ambiente como rama jurídica ........................................................................... 111

3 La consagración del principio de irreversibilidad de las normas ambientales ............. 113

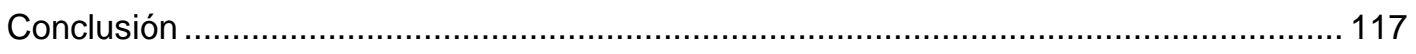

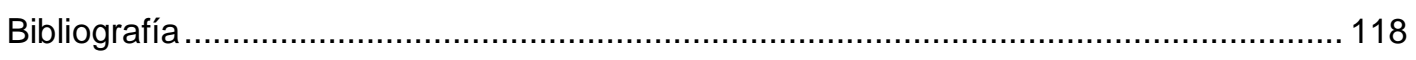

ALGUNOS CASOS DE RETROCESOS EN LA LEGISLACIÓN AMBIENTAL DEL

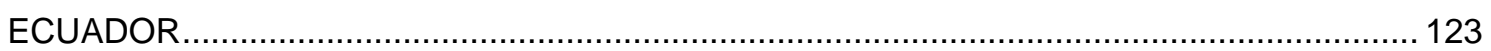

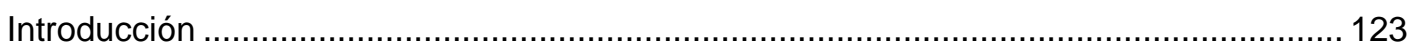

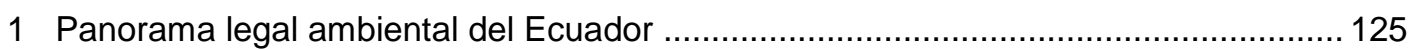

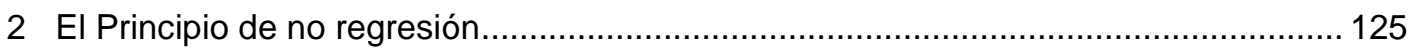

3 Criterios para la verificación de la regresividad en materia ambiental ......................... 128

4 El principio de no regresión en la Constitución del Ecuador ........................................ 129

5 La regresión del los derechos de la naturaleza por la omisión de reglamentación de normas ambientales indispensables para su cumplimiento en la aplicación de la legislación ambiental tornándola absolutamente ineficaz

6 El Caso Yasuní y la Ausencia o insuficiencia de justificación y respaldo técnicocientífico que permita determinar, en grado de certeza, la no afectación al bien tutelado132 7 La falta de reconocimiento del consentimiento en la consulta previa para los pueblos indígenas

8 En materia ambiental son regresivos algunos tipos penales del recientemente expedido

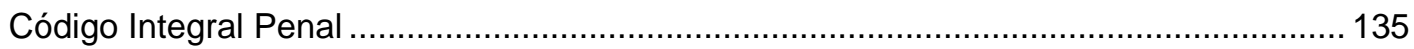

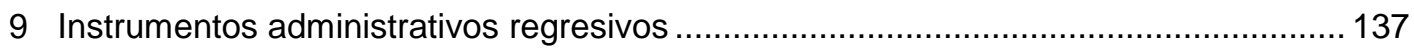

10 Aspectos regresivos de la Ley de Gestión Ambiental ............................................... 138

11 La falta de regulación en materia de responsabilidad por daños ambientales ............. 139

12 La falta de una ley para normar la conservación y uso sostenible de la diversidad

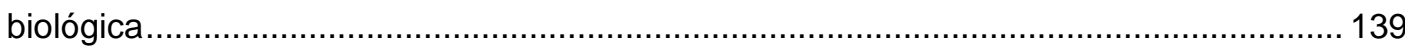

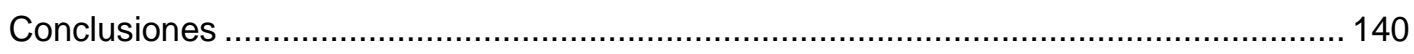

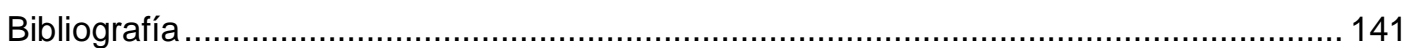


UNA APROXIMACIÓN AL PRINCIPIO DE PROHIBICIÓN DE REGRESO EN CHILE: DESDE LA INTEGRACIÓN INTERNACIONAL A LA APLICACIÓN JURÍDICA ..................................... 145

Introducción

1 Antecedentes políticos para explicar la normativa asociada a la prohibición de regreso en Chile.

2 Creación de las leyes № 19.300 de 1994 de Bases Generales del Medio Ambiente y № 20.417 de 2010 que crea el Ministerio de Medio Ambiente como elementos integradores en la comunidad internacional.

3 Textos legales que se relacionan con el principio de prohibición de regreso en Chile 148

3.1 El principio de gradualidad

3.2 A propósito de las medidas ambientales contempladas en los tratados de libre comercio suscritos por Chile .....

4 Dos casos que denotan de relevancia de considerar el principio de prohibición de

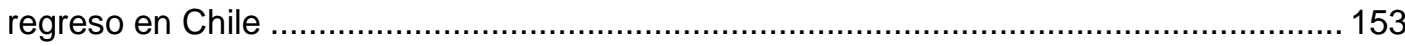

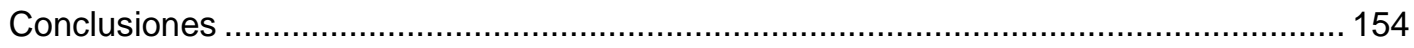

Bibliografía

LA PROTECCIÓN JURÍDICA DE LOS HUMEDALES EN PANAMÁ Y EL PRINCIPIO DE NO

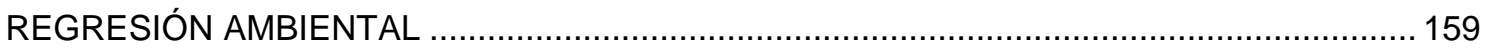

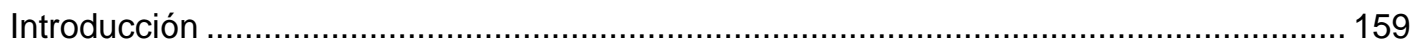

1 Programa de justicia ambiental en Panamá............................................................. 162

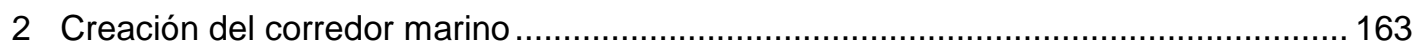

3 El medio ambiente en la Constitución Panameña......................................................... 164

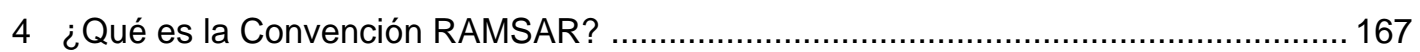

5 Protección jurídica de los humedales en el derecho panameño..................................... 169

6 Protección penal de los humedales ................................................................... 171

7 Jurisprudencia de la Sala Tercera de la Corte Suprema de Justicia de Panamá, en

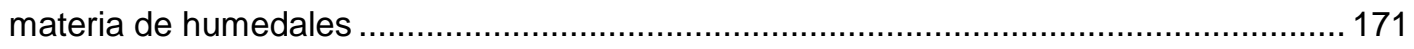

8 El principio de no regresión ambiental ................................................................ 173

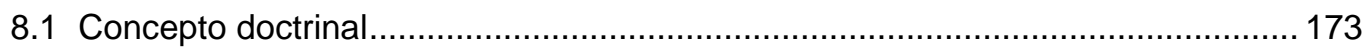

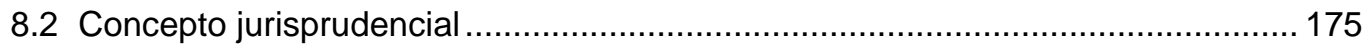

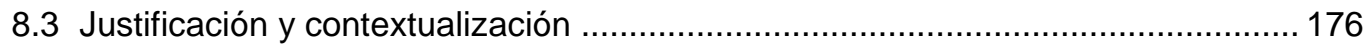

9 El principio de no regresión en la legislación ambiental panameña ............................ 177

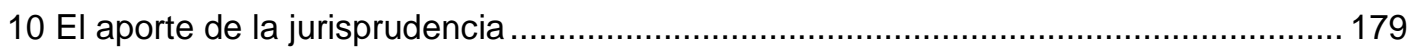

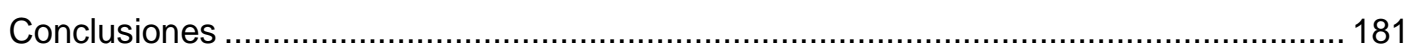

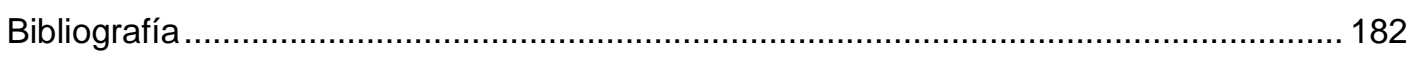

LEY 840, SÍMBOLO DE LA REGRESIÓN EN LA PROTECCIÓN AMBIENTAL

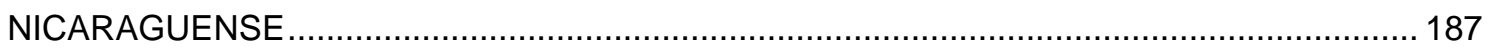

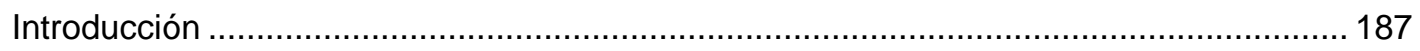

1 Positivación del principio preventivo en la legislación ambiental nicaragüense ........... 189 
2 Protección jurídica a la cuenca hídrica del lago Cocibolca 191

3 Ley 840, Ley Especial para el Desarrollo de Infraestructura y Transporte Nicaragüense, Atingente al Canal, Zonas de Libre Comercio e Infraestructuras Asociadas.................... 192

4 Disposiciones del Acuerdo Marco de Concesión e Implementación (MCA) .................. 195

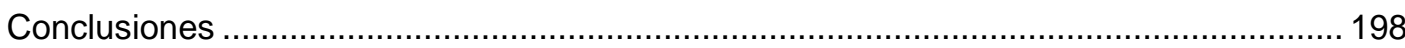

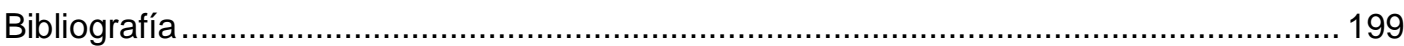

LA PROTECCIÓN LEGAL E INSTITUCIONAL DEL AMBIENTE Y LOS RECURSOS NATURALES DE

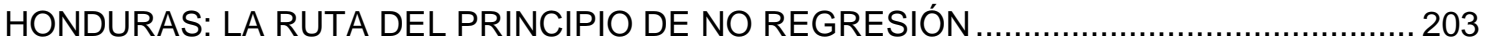

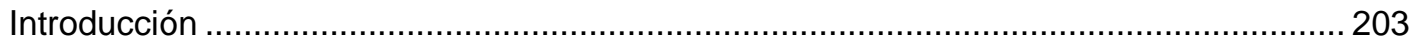

1 Fuentes de progresividad ambiental (y regresión) …................................................ 204

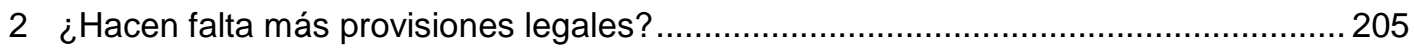

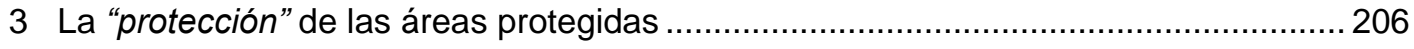

4 La falsa dicotomía entre economía y ambiente....................................................... 206

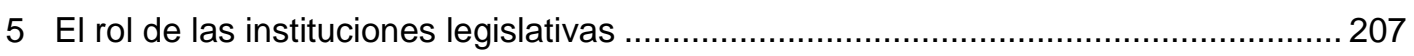

6 El rol de las instituciones administrativas y judiciales ................................................. 207

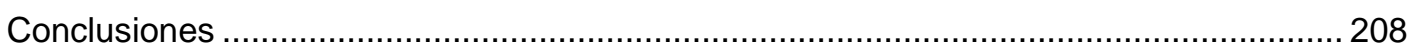

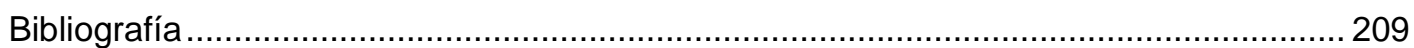

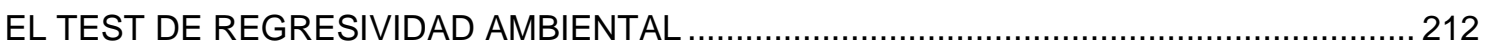

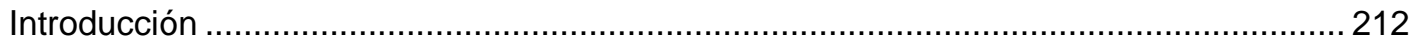

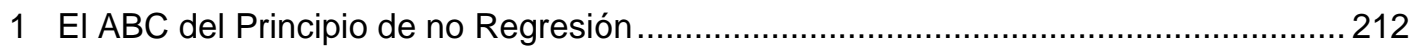

2 Hacia la formulación de un test de regresividad ambiental........................................ 214

2.1 ¿Cuándo una norma puede catalogarse regresiva y por ende violatoria del principio

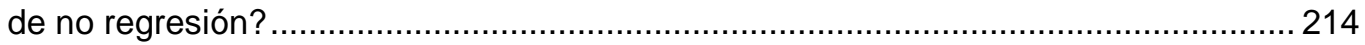

2.2 ¿Cuándo una norma no califica como regresiva? ............................................ 215

2.3 Criterios y lineamientos para un test de regresividad ambiental ......................... 215

2.4 Condicionantes, límites y restricciones a considerar ............................................ 217

3 Test de regresividad ambiental en la práctica ....................................................... 218

3.1 Modificación de conceptos jurídicos ambientales ............................................. 218

3.2 Modificación de criterios, estándares, umbrales, indicadores o requisitos

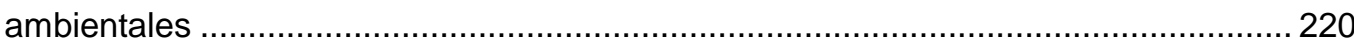

3.3 Desafectación o reducción de espacios naturales sometidos a regímenes especiales de protección ambiental ....................................................................... 222

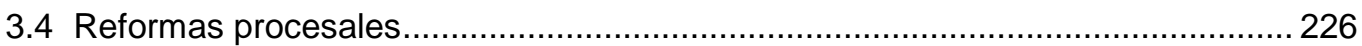

3.5 Denuncia de tratados internacionales ambientales ............................................. 226

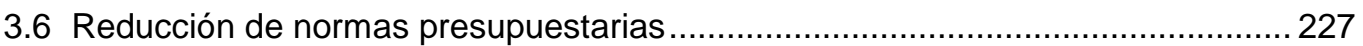

3.7 Omisión al deber de desarrollar vía legal o reglamentaria normas ambientales .. 228

3.8 Falta de aplicación sistemática -espacial o temporal- de la legislación ambiental231 
LÍMITES, RESTRICCIONES Y EXCEPCIONES DEL PRINCIPIO DE PROHIBICIÓN DE

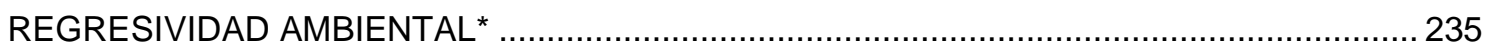

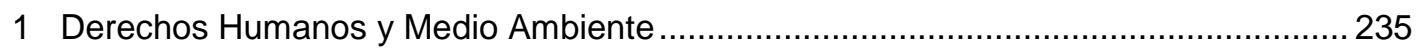

2 Derechos Humanos y Prohibición de Regresividad ...................................................... 237

3 Presunción de invalidez y criterios de justificación de medidas regresivas ..................241

4 Justificaciones válidas para la implementación de medidas regresivas en materia ambiental

5 Justo equilibrio entre el derecho a un ambiente sano y los demás derechos fundamentales. El caso de las comunidades costeras que habitan dentro de áreas silvestres protegidas de Costa Rica

Bibliografía

(IN)JUSTIFICACIONES CONSTITUCIONALES QUE HAN PERMITIDO REGRESIONES

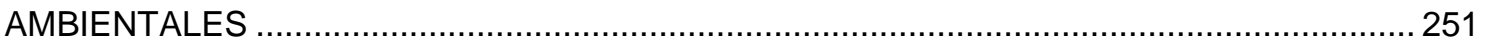

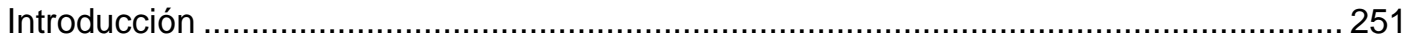

1 La Sala constitucional y su jurisprudencia en Costa Rica.......................................... 252

2 El principio preventivo y el precautorio en regresión.................................................... 254

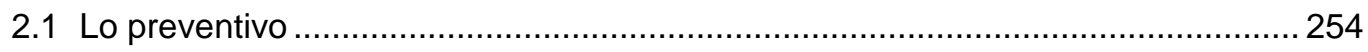

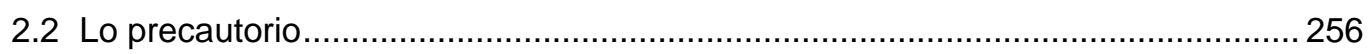

2.3 Las regresiones en lo preventivo y lo precautorio en la jurisprudencia nacional relacionadas con campos electromagnéticos y torres de telefonía celular.................259

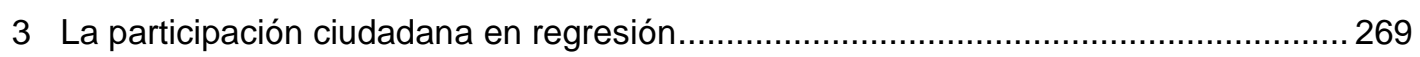

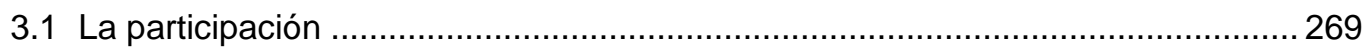

3.2 La participación y las regresiones en el caso de las torres de telefonía................ 272

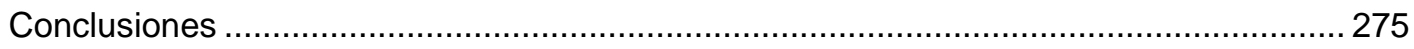

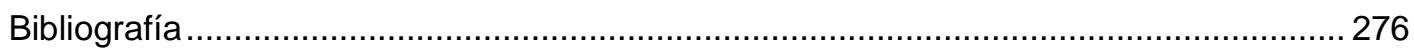

Doing business, una política regresiva del Banco Mundial.................................................. 277

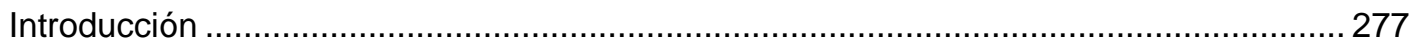

1 Una política regresiva y contraria al desarrollo sostenible ......................................... 277

2 Una política regresiva para el desarrollo sostenible en un ambiente internacional

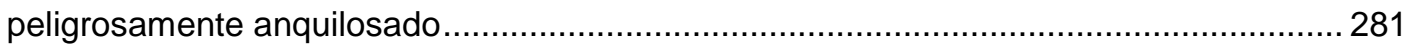

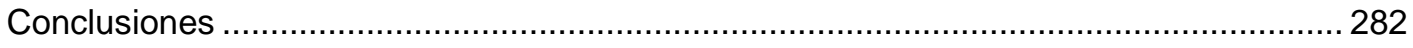

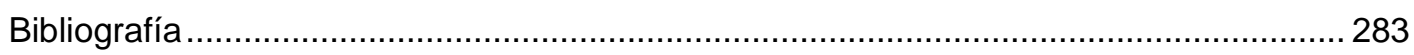

LA REGRESIÓN EN EL ACCESO AL JUEZ CONSTITUCIONAL PARA LA DEFENSA DEL DERECHO AL AMBIENTE EN COSTA RICA: ¿UNA "DIABOLIZACIÓN" DE LA MATERIA

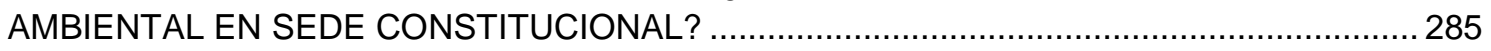

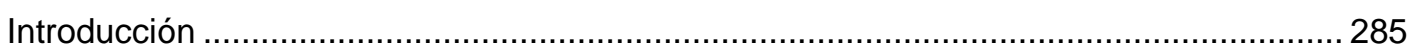

1 La regresión en el acceso al juez constitucional en materia ambiental como consecuencia de iniciativas para reformar la Ley de la Jurisdicción Constitucional

2 La regresión en el acceso al juez constitucional en materia ambiental ante criterios restrictivos de los magistrados para delimitar la competencia de la Sala Constitucional . 290 
2.1 La adopción de criterios amplios anterior a la entrada en vigencia del Código Procesal Contencioso Administrativo ......................................................................... 290

2.2 La adopción de criterios restrictivos posterior a la entrada en vigencia del Código Procesal Contencioso Administrativo ................................................................... 296

2.3 La radicalización más reciente de ciertos magistrados...........................................300

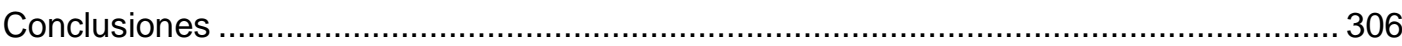

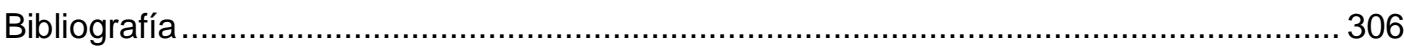





\section{PRÓLOGO}

La Declaración de Estocolmo de 1972 constituyó un hito fundamental para el desarrollo del Derecho Ambiental Internacional, la elaboración de normativa ambiental nacional y la adopción de instrumentos tales como la Declaración de Rio sobre Medio Ambiente y Desarrollo de 1992, la Declaración de Johannesburgo sobre Desarrollo Sostenible de 2002 y el Documento Final de la Conferencia sobre Desarrollo Sostenible Rio+20, "El futuro que queremos" de 2012.

La proliferación de normas ambiental ha ido de la mano de un creciente discurso acerca del desarrollo sostenible, planteado en 1987 en el Informe Brundtland y adoptado como principio del Derecho Ambiental en la Declaración de Rio.

A fin de garantizar la eficacia de los postulados del desarrollo sostenible se han planteado entre otros, conceptos como el de "no regresión" que proponen que ni el ordenamiento jurídico ni la jurisprudencia ambiental pueden ser objeto de revisión si ello conlleva al menoscabo de estándares de protección ambiental alcanzados previamente. Dicho concepto fue adoptado como principio por la Conferencia de las Naciones Unidas sobre el Desarrollo Sostenible Rio+20, misma que en el párrafo 20 de su documento final "El futuro que queremos" ha señalado que es fundamental no dar marcha atrás con los avances en materia de desarrollo sostenible.

Iberoamérica ha sido protagonista del desarrollo del derecho ambiental liderando una cuantiosa producción de normas relativas a la protección de la naturaleza y los recursos naturales. Algunas de estas normas, sin embargo, están siendo coaccionadas, al igual que en otras regiones del mundo, por procesos que buscan flexibilizar y simplificar el ordenamiento jurídico ambiental, so pretexto de defender intereses económicos o de cualquier otra índole por encima de los intereses ambientales.

Menoscabar el ordenamiento jurídico ambiental previamente establecido es inaceptable. Socavar los logros alcanzados en la materia conlleva consecuencias negativas para la naturaleza y el ser humano, toda vez que sin la garantía de contar con un ambiente saludable y apto para el desarrollo de la vida, difícilmente se puede hacer efectivo el pleno goce de los demás derechos fundamentales.

Es esencial que además del principio de no regresión que busca garantizar la integridad del ordenamiento jurídico ambiental se considere su contracara por así decirlo, esto es, el principio de progresividad, ampliamente desarrollado en el contexto de los derechos humanos y proclamado en el Pacto Internacional de Derechos Económicos Sociales y Culturales, mismo que en su articulado establece la necesidad de lograr progresivamente la adopción de medidas legislativas para la plena efectividad de los derechos contenidos en el Pacto y que cualquier restricción o menoscabo a ellos sea inadmisible. Asimismo, la Convención Americana sobre Derechos Humanos determina que sus Estados Partes, se comprometen a lograr progresivamente la plena efectividad de los derechos reconocidos en la Carta de la Organización de Estados Americanos.

En Iberoamérica, el principio de no regresión ha comenzado a permear en las legislaciones nacionales y la jurisprudencia, en donde diversos tribunales han resuelto casos invocando dicho principio. Para lograr este desarrollo normativo y jurisprudencial ha sido fundamental el aporte de juristas como Mario Peña Chacón, quien a través de sus trabajos, han realizado una significativa aportación a la doctrina ambiental. Específicamente en lo que al principio de no regresión atañe, su contribución ha promovido una mayor discusión y profundización de éste con la finalidad de su mejor entendimiento y aplicación por parte de quienes tienen en sus manos la potestad legislativa y jurisdiccional. 
Es dable destacar también el aporte realizado a la presente por parte de autores miembros de la Comisión Mundial de Derecho Ambiental de la UICN, quienes más allá de haber brindado un análisis detallado del principio en comento, han analizado en detalle su aplicabilidad a la realidad lberoamericana.

La Comisión Mundial de Derecho Ambiental de la UICN a través de esta obra muestra una vez más el compromiso de sus miembros en ser pioneros en la conservación de la naturaleza y en el desarrollo y actualización del Derecho Ambiental a nivel mundial.

El Centro de Derecho Ambiental de la UICN se enorgullece en contribuir al fomento del Derecho Ambiental por medio de la presente obra que constituye un aporte para legisladores, jueces, catedráticos y académicos en general quienes buscan expandir, discutir y defender los principios del Derecho Ambiental.

Dra. Grethel Aguilar Rojas

Directora Regional

UICN - Oficina Regional para México,

América Central y el Caribe
Dr. Alejandro Iza

Jefe del Programa de Derecho Ambiental

Director del Centro de Derecho Ambiental 


\section{AGRADECIMIENTOS}

Agradecemos especialmente a los juristas autores de este libro, quienes han dedicado todos sus esfuerzos en presentar artículos que recopilan, analizan y contraponen los principales desafíos y retos que enfrentan sus respectivos países en lograr la aplicación efectiva de los principios de progresividad y no regresión del derecho ambiental.

A la vez, damos las gracias a Anni Lukács por su apoyo y profunda dedicación en la diagramación de esta obra. 



\section{SEMBLANZA DE LOS AUTORES}

\section{GABRIEL REAL FERRER}

Doctor en Derecho por la Universidad de Alicante y Doctor Honoris Causa por la Universidade do Vale do Itajaí (UNIVALI-Brasil), Profesor Titular de Derecho Administrativo de la Universidad de Alicante y Profesor Invitado en diversas Universidades de América y Europa. Ha escrito más de cien trabajos de investigación en los campos del Derecho Ambiental, Derecho del Deporte y Derecho Administrativo general. Ha sido consultor de distintos gobiernos y organizaciones internacionales y ostenta diversos premios y distinciones honoríficas otorgadas en Brasil, Francia, Perú, Cuba, Costa Rica, Colombia, México y España.

\section{ALEXANDRA ARAGÄO}

Doctora en Derecho Público de la Facultad de Derecho de la Universidad de Coimbra, donde es Profesora. Investigadora en el Instituto Jurídico, en el Centro de Estudios de Derecho Ambiental, de Planificación y Medio Ambiente y el Centro de Estudios Sociales de la Universidad de Coimbra. Miembro del Observatorio Jurídico Europeo de Natura 2000 y del Agua, trustee del grupo de expertos de derecho europeo del medio ambiente Avosetta.org y miembro del Consejo Asesor European Environmental Law Forum.

MARIO F. VALLS

Abogado. Doctor en Derecho y Ciencias Sociales. Profesor Titular Consulto de la Universidad de Buenos Aires. Profesor en otras Universidades. Rector/organizador de la Universidad de La Pampa. Consultor durante varios años en organismos internacionales. Autor de numerosos libros sobre Derecho ambiental y de los recursos naturales. Director del Suplemento ambiental de EI DIAL.

\section{PATRYCK DE ARAUJO AYALA}

Profesor Asociado II, en pregrado y maestría en UFMT Derecho. Coordinador Adjunto del Programa de Maestría en Derecho agroambiental UFMT (2011-2013). Maestro y Doctor en Derecho por la Universidad Federal de Santa Catarina (CPGD / UFSC), con pasantía doctoral en la Universidad de Lisboa en 2006 (PDEE / CAPES). Líder del grupo de investigación "JusClima" e investigador del grupo de investigación "Derecho Ambiental y Ecología Política en la Sociedad del Riesgo", ambas acreditadas por el CNPq; coordinador en jurisprudencia de la Revista de Derecho Ambiental (RT), secretario general del el Instituto de Derecho por un Planeta Verde, miembro de la Comisión de Derecho Ambiental de la UICN. Autor y colaborador en varios libros y revistas jurídicas, nacionales e internacionales. Procurador del Estado de Mato Grosso.

\section{ISABEL DE LOS RÍOS}

Abogada, Universidad Central de Venezuela. Doctora en Derecho del Ambiente, Universidad de Estrasburgo. Máster en Ordenación del Territorio. Especialista en Ciencias Penales. Especialista en Contaminación y Molestias Ambientales. Profesora titular de la Universidad Central de Venezuela. Profesora de las cátedras Principios generales del Derecho Ambiental, Derecho Penal del Ambiente y Derecho a un Medio Ambiente Sano.

\section{RICARDO CRESPO PLAZA}

Abogado y Doctor en Jurisprudencia por la Pontificia Universidad Católica del Ecuador desde 1987. Máster en Gestión y Cambio Ambiental por la Universidad de Oxford, Reino Unido en 1997. Consultor en materias legales-ambientales para instituciones públicas y privadas. Miembro fundador del Centro Ecuatoriano de Derecho Ambiental. 


\section{JORGE ARANDA ORTEGA}

Magíster en Derecho. Universidad de Chile. Profesor Asistente. Centro de Derecho Ambiental. Universidad de Chile.

\section{LAURA PALMESE}

Laura Palmese es abogada del interés público, trabaja en la defensa de los derechos humanos que resultan de un medio ambiente sano, a través de gestiones administrativas, denuncias y casos judiciales, representando líderes comunitarios y grupos de la sociedad civil que protegen los recursos naturales de ésta y las futuras generaciones. Actualmente funge como Coordinadora General del Instituto de Derecho Ambiental de Honduras (IDAMHO).

\section{EDUARDO J. MITRE GUERRA}

Doctor en Derecho, Universidad de Zaragoza (España), Máster en Derecho de Aguas, de los Recursos Naturales y Medio Ambiente, Universidad de Zaragoza (España). Asistente de Magistrado de la Corte Suprema de Justicia de Panamá (Sala de lo Contencioso Administrativo). Profesor de Grado y Postgrado de la Universidad de Panamá y en la Universidad Latina de Panamá, en áreas de Derecho Ambiental y Derecho Administrativo.

\section{VICTOR L. BENAVIDES P.}

Víctor Leonel Benavides Pinilla, Abogado, Mediador y Municipalista, egresado con Altos Honores de la Universidad de Panamá, con estudios de Post Grado en Mediación en la Universidad de Panamá, y estudios de Maestría en Gestión Pública Local en la Universidad Carlos III, de Madrid, España. Actualmente es Magistrado de la Sala Tercera de lo Contencioso Administrativo de la Corte Suprema de Justicia y Laboral de Panamá

\section{MARIANELA ROCHA}

Licenciada en Derecho. Abogada y Notario Público. Máster en Evaluación de Impacto Ambiental del Instituto de Investigaciones Ecológicas de Málaga, España. Posgrado en Dirección y Gestión Ambiental de la Universidad de Barcelona, España. Fue Procuradora Ambiental. Es abogada de las áreas de derecho ambiental de las firmas CCA \& Asociados/Nicaragua y OfficiumLex/Centroamérica y República Dominicana.

\section{MARIO PEÑA CHACÓN}

Abogado y magister en Legislación Ambiental de la Universidad para la Cooperación Internacional. Coordinador de la Maestría en Derecho Ambiental de la Universidad de Costa Rica. Investigador del Instituto de Investigaciones Jurídicas (IIJ) y el Centro de Investigación y Estudios Políticos (CIEP) de la Universidad de Costa Rica; Profesor de la Facultad de Derecho y de las Maestrías en Derecho Ambiental y Derecho Público Comparado Francolatinoamericano de la Universidad de Costa Rica. Autor y colaborador en varios libros y revistas jurídicas, nacionales e internacionales. Miembro de la Comisión de Derecho Ambiental de la Unión Internacional para la Conservación de la Naturaleza (UICN).

\section{ÁLVARO SAGOT RODRÍGUEZ}

Consultor ambiental, abogado y notario. Máster en Derecho Ambiental de la Universidad del País Vasco (España). Académico en Universidad Nacional de Costa Rica (UNA) en la Escuela de Ciencias Ambientales del curso de Política y Legislación Ambiental. Profesor en la Maestría de Derecho Ambiental de la Universidad del País Vasco y en la maestría en Desarrollo Sostenible de la Universidad de Costa Rica (UCR). Autor de numerosos libros y publicaciones, nacionales e internacionales sobre derecho ambiental. 
RAFAEL GONZÁLEZ BALLAR

Abogado graduado de la Universidad de Costa Rica con especialidad en derecho público, máster de la Universidad de Burdeos (Francia) en Estudios en Economía y Derecho del Ambiente, doctor en Derecho Ambiental de la Universidad de Bordeaux, Francia. Decano y Profesor de la Universidad de Costa Rica, en la Facultad de Derecho. Profesor de derecho ambiental, administrativo y constitucional de las Maestrías en Derecho Ambiental, Público y la Justicia Constitucional; y del programa de Maestría conjunta de la Universidad de Costa Rica y el Ministerio de Relaciones Exteriores. Miembro de la Comisión de Derecho Ambiental de la UICN.

\section{EDGAR FERNÁNDEZ FERNÁNDEZ}

Doctor en Derecho (2005) y Máster en Derecho Público y Derecho Ambiental (1998) por la Universidad de Nantes, Francia. Investigador invitado en el Collegium de Lyon, Francia (2013). Investigador para el Institut de Recherche pour le Développement (IRD), Francia (2012). Investigador del Instituto de Investigaciones Jurídicas (2012) y Profesor de la Maestría en Derecho Ambiental (2006-2012) de la Universidad de Costa Rica. Miembro de la Comisión Mundial de Áreas Protegidas y de la Comisión de Derecho Ambiental, ambas de la Unión Internacional para la Conservación de la Naturaleza (UICN). 



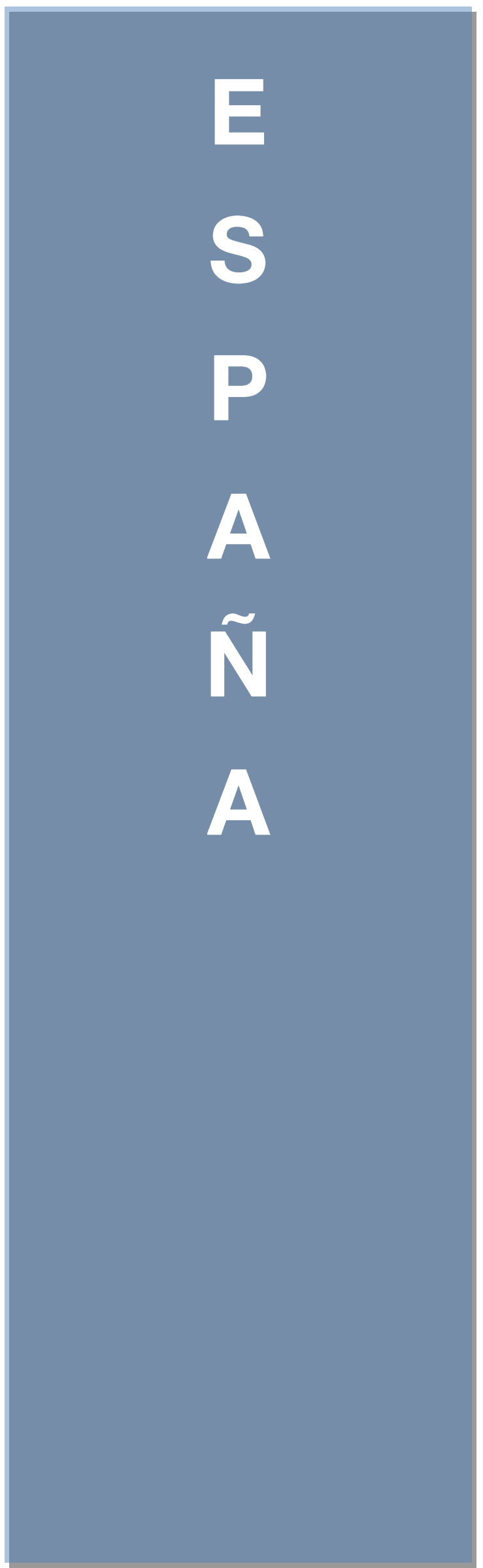





\title{
EL PRINCIPIO DE NO REGRESIÓN AMBIENTAL A LA LUZ DEL PARADIGMA DE LA SOSTENIBILIDAD
}

\author{
Gabriel Real Ferrer
}

\section{La Sostenibilidad como guía de acción de la Humanidad}

\subsection{Concepto}

La sostenibilidad es, sin lugar a dudas, el paradigma de la postmodernidad. Desde hace tiempo somos conscientes de que el modelo de producción y consumo imperante en nuestra sociedad conduce a un colapso ambiental y el Derecho Ambiental no es otra cosa que la reacción frente a esa certeza. Sin embargo, no se trata únicamente de que la Humanidad sobreviva sino de construir para las futuras generaciones una sociedad mejor, más justa e inclusiva, y a ello no da respuesta plena el Derecho Ambiental.

El Derecho Ambiental y, en general, todo lo que tiene que ver con la protección del medio ambiente, entendido como los sistemas naturales, en definitiva, con el ecosistema planetario, nos habla de la supervivencia de la especie. Del mantenimiento de las condiciones que hacen posible la vida humana, pero no de cómo ésta se desarrolla. Pero no nos basta con sobrevivir. Las preocupaciones de la comunidad internacional han ido ampliando su espectro de lo puramente ambiental -nuestra relación con el medio natural- a aspectos que lo que tienen que ver es con la relación con nuestros semejantes, con el modelo de sociedad que tenemos que construir. Una sociedad que no colapse los sistemas naturales pero que, además, nos permita vivir en paz con nosotros mismos, más justa, más digna, más humana. Una sociedad que dé un salto significativo en el progreso civilizatorio que deje atrás o al menos aminore las grandes lacras de la Humanidad que a todos nos deben avergonzar, como el hambre, la miseria, la ignorancia y la injusticia. El deterioro material del Planeta es insostenible, pero también es insostenible la miseria y la exclusión social, la injusticia y la opresión, la esclavitud y la dominación cultural y económica.

Por ello hace bastantes años que vengo sosteniendo que el Derecho Ambiental se ha integrado en una realidad más amplia, holística si se quiere, formando parte inherente e inseparable de ella, se trata del Derecho de la Sostenibilidad ${ }^{1}$. La sostenibilidad es, a la vez, meta y camino ${ }^{2}$. Meta, porque de lo que se trata es de conseguir una sociedad capaz de perpetuarse indefinidamente en el tiempo, y camino, porque en la búsqueda de ese objetivo toda decisión, sea pública o privada, debería tenerla presente como guía de acción, como principio inspirador inexcusable. Visto desde determinada perspectiva, la sostenibilidad no es más que la materialización del instinto de supervivencia social: o somos capaces de alcanzarla o esta

\footnotetext{
* Doctor en Derecho por la Universidad de Alicante y Doctor Honoris Causa por la Universidade do Vale do Itajaí (UNIVALI-Brasil), Profesor Titular de Derecho Administrativo de la Universidad de Alicante y Profesor Invitado en diversas Universidades de América y Europa.

${ }^{1}$ Al respecto, mi trabajo, "Del Derecho Ambiental al Derecho de la Sostenibilidad", PNUMA, Programa regional de capacitación en derecho y políticas ambientales. 2008, disponible en http://www.pnuma.org.

${ }^{2}$ En el primer punto del documento "El futuro de queremos" resultado de la Conferencia Río+20, se dice que "Nosotros, los Jefes de Estado y de Gobierno y los representantes de alto nivel, habiéndonos reunido en Río de Janeiro (Brasil) entre el 20 y el 22 de junio de 2012, con la plena participación de la sociedad civil, renovamos nuestro compromiso en pro del desarrollo sostenible y de la promoción de un futuro económico, social y ambientalmente sostenible para nuestro planeta y para las generaciones presentes y futuras." Viene a decir que el "desarrollo sostenible" es el medio (camino) para conseguir ese "futuro económico, social y ambientalmente sostenible" que no es otra cosa que la sostenibilidad.
} 
sociedad no perdurará, se extinguirá, ya que esa es precisamente la consecuencia de aquello que no es sostenible.

De ahí que el Derecho de la Sostenibilidad sería el conjunto de normas y principios que pretenden asegurar la construcción de una sociedad global viable. Su vocación sería materializar nuestro derecho colectivo al futuro ${ }^{3}$ e incluye, naturalmente, al Derecho Ambiental, pero no sólo, ni siquiera de un modo prevalente.

El derecho de la sostenibilidad deberá articularse como un derecho transnacional cuyo fundamento no trae causa de las soberanías nacionales, aunque se apoye en ellas, sino de la nueva sociedad global. Trae parte de la estructura clásica de los órdenes jurídicos social, económico y ambiental, que son propios de los Estados soberanos, pero desborda claramente ese ámbito. Su vocación es aportar soluciones que sirvan a todos, sin importar donde se encuentren o donde nacieron. Pretende aportar la esperanza de una sociedad futura global y mejor.

\subsection{Dimensiones}

A partir de los Objetivos de Desarrollo del Milenio ${ }^{4}$ y de la Conferencia de Johannesburgo, pasando por Río+20, se ha ido consolidando el concepto de sostenibilidad y la triple dimensión en la que, ya clásicamente, se proyecta: la ambiental, la social y la económica. Algunos autores añaden otras dimensiones, como la institucional, o proponen una concepción holística ${ }^{5}$ pero lo cierto y verdad es que en esas tres dimensiones están incluidas cuantas facetas queramos. En definitiva de lo que se trata es de encontrar una nueva forma de relación, más armónica, con nuestro entorno natural, por una parte, y con nuestros semejantes, por otra.

A las tres conocidas dimensiones debe agregarse, a mi juicio, una cuarta: la tecnológica. Esto es así porque, como luego se verá, por una parte no pueden entenderse ni proyectarse ninguna de las otras dimensiones sin tener presente el componente tecnológico y, por otra, porque el progreso científico y la tecnología que del mismo se deriva, comporta en si mismo enormes riesgos que pueden acabar, literalmente, con la sociedad tal como la conocemos.

\subsubsection{Sostenibilidad ambiental}

Para quienes nos dedicamos al Derecho Ambiental esta es la dimensión más conocida. Desde la Cumbre de Río'92, cuya agenda trató con carácter general los grandes temas ambientales que comprometen la salud del Planeta, y aun antes, tenemos bien identificados los males que aquejan al ecosistema planetario, tenemos idea de cómo minimizarlos y corregirlos y qué debemos cambiar en nuestros comportamientos, individuales y colectivos, para hacer posibles las soluciones. En pocas palabras, sabemos con razonable exactitud que estamos haciendo mal y que es lo que deberíamos hacer para mejorar nuestra relación, en tanto especie, con la naturaleza. El problema es que no parecemos dispuestos a hacer lo necesario para conseguirlo. En este campo, la sostenibilidad supone, ni más ni menos, que la necesidad de

\footnotetext{
${ }^{3}$ Como, con acierto, titula su obra Juarez Freitas, Sustentabilidade: Direito ao Futuro, Forum, Belo Horizonte, 2012.

${ }^{4}$ El 8 de septiembre del año 2000, se celebró la Cumbre del Milenio en la sede de la Organización de Naciones Unidas en Nueva York a la que asistieron 189 Jefes de Estado y de Gobierno declarando que la erradicación de la pobreza mundial debía ser una prioridad para todas las naciones. Se suscribió la Declaración del Milenio, a la que posteriormente se adhirieron otros países, como compromiso con los Objetivos de Desarrollo del Milenio.

${ }^{5}$ Leonardo Boff, propone un noción holística, entendiendo que "Sostenibilidad es toda acción destinada a mantener las condiciones energéticas, informacionales, físico-químicas que sustentan a todos los seres, especialmente a la Tierra viva, a la comunidad de vida y a la vida humana, buscando su continuidad, y atender también las necesidades de la generación presente y de las generaciones futuras, de tal forma que el capital natural se mantenga y se enriquezca su capacidad de regeneración, reproducción y ecoevolución." Sustentabilidade: o que é e o que não é, Vozes, Río de Janeiro, 2012.
} 
alcanzar un pacto con la Tierra de modo que no comprometamos la posibilidad de mantenimiento de los ecosistemas esenciales que hacen posible nuestra subsistencia como especie en unas condiciones ambientales aceptables.

En torno a lo ambiental fue que se construyeron los primeros consensos mundiales para actuar conjunta y coordinadamente dando paso al inicio de transformaciones jurídicas extraordinarias que han generado un ordenamiento revolucionario. Es, también, el área en la que mayores esfuerzos, de todo tipo, se han desplegado y que mayor eco social ha alcanzado. La Sostenibilidad ambiental, por otro lado, constituye expresis verbis uno de los Objetivos de Desarrollo del Milenio ( $\left.7^{\circ}\right)$ pero una visión más amplia de la Sostenibilidad nos servirá para tomar conciencia de que no es alcanzable aisladamente. Las interacciones e interdependencias entre lo ambiental, lo social, lo económico y lo tecnológico son tan estrechas que el progreso debe producirse armónicamente o no se producirá. El proceso hacia la Sostenibilidad es una realidad compleja y global inescindible. La Sostenibilidad ambiental es pues una parte de ese proceso. Esencial, si se quiere, pero una parte.

\subsubsection{Sostenibilidad económica}

La sostenibilidad económica consiste esencialmente en resolver el reto de aumentar la generación de riqueza, de un modo ambientalmente sostenible, y de encontrar los mecanismos para una más justa y homogénea distribución.

La transición hacia una "economía verde" pretende resolver la primera parte de ese reto. El Programa de las Naciones Unidas para el Medio Ambiente (PNUMA) publicó un Informe de Política denominado Nuevo Acuerdo Verde Global $^{6}$ en el que hacía una serie de recomendaciones de cara a esa nueva economía, entre ellas:

1) Privilegiar a los sectores más "verdes" mediante subvenciones o incentivos fiscales, de modo que las inversiones privadas sean dirigidas a éstos;

2) Establecer normas que prohíban el ejercicio de determinadas prácticas o actividades dañinas con el medio ambiente;

3) Aprobar un marco regulador para determinados instrumentos de mercado que ayuden a la conservación del medio natural, entre los que destacan los impuestos y los derechos de emisión.

El planteamiento del PNUMA, que fue parte del debate en Río+20, es fuertemente criticado desde muy diversos sectores. Se afirma, no sin razón, que no sólo no cuestiona el modelo económico actual sino que lo refuerza. Aconseja invertir en sectores "verdes" con fuerte contenido tecnológico, como energías renovables, transporte, etc., o prohibir determinadas prácticas (abiertamente abusivas e insostenibles, por otra parte) pero nada hay que tienda a introducir cambios profundos en la demanda o mínimamente estructurales en el modelo dominante. Se pretenden, pues, reformas cosméticas que reduzcan el impacto de la actividad económica en el medio ambiente, pero no un nuevo modelo de generación de riqueza y de reorientación de la demanda alejándola de los patrones consumistas clásicos.

En cuanto a los mecanismos para alcanzar una más justa distribución de la riqueza generada los progresos, incluso teóricos, son aún menores. En un muy interesante documento del Stockholm Environment Institute publicado en español por la Comisión Económica para América Latina y el Caribe (CEPAL) titulado "La gran transición: La promesa y la atracción del futuro", se dice que "La transición económica implica ir hacia un sistema de producción, distribución y toma de decisiones en armonía con la equidad, la sostenibilidad y la satisfacción

\footnotetext{
${ }^{6}$ Programa de las Naciones Unidas para el Medio Ambiente, PNUMA, Nuevo Acuerdo Verde Global. Informe de Política, 2009

7 VV.AA. La gran transición: La promesa y la atracción del futuro, CEPAL, Santiago de Chile, 2006. Traducción al español de Great Transition. The Promise and Lure of the Times Ahead
} 
de las personas. Deberá equilibrar muchos objetivos: erradicar la miseria humana, reducir la desigualdad, respetar la capacidad de carga del medio ambiente y mantener la innovación. Todo ello implicará con certeza instrumentos políticos tales como ecoimpuestos, subsidios sociales y contabilidad verde."

La tasa "Tobin" sobre las transacciones financieras internacionales o la que ahora mismo está proponiendo Philippe Douste-Blazy, actual Presidente del Consejo de Administración de UNITAID $^{8}$ sobre las operaciones bursátiles (un $0,05 \%$ ) indican el camino, pero queda mucho por recorrer. Un ejemplo tangible es el impuesto que se aplica en quince países sobre los billetes aéreos y que ha recaudado 1.656 millones de euros en cinco años destinados por UNITAID a tratamientos contra el sida la malaria y tuberculosis en países pobres.

También las donaciones voluntarias, como las que en algunas compañías aéreas se pueden hacer para contribuir a paliar el efecto invernadero causado por los vuelos pagando servicios ambientales en países en desarrollo, o las donaciones a través de internet, como la iniciativa Massivegood de la Millennium Foundation ${ }^{9}$ contribuyen, mínimamente, a reducir la brecha entre los que mucho tienen y los que nada tienen.

Todo ayuda, pero debemos asumir que la sostenibilidad económica requerirá de instrumentos globales de redistribución de la riqueza, del mismo modo que operan en el interior de los Estados con fuerte contenido social. La miseria y la pobreza extrema, recordemos, no son sostenibles.

\subsubsection{Sostenibilidad Social}

El espectro de la sostenibilidad social es tan amplio como la actividad humana pues de lo que se trata es de construir una sociedad más armónica e integrada, por lo que nada humano escapa a ese objetivo. Desde la protección de la diversidad cultural a la garantía real del ejercicio de los derechos humanos, pasando por acabar con cualquier tipo de discriminación o el acceso a la educación, todo cae bajo esta rúbrica.

Ahora bien, el debate, sin olvidar muchas otras dimensiones, está ahora mismo centrado en dos aspectos centrales y polimórficos, la lucha contra la exclusión social y la nueva gobernanza.

Por exclusión se entiende la escasez crónica de oportunidades y de acceso a servicios, al mercado laboral, al crédito, a infraestructuras y a la justicia o, también se entiende que la exclusión social se refiere a los procesos y situaciones que impiden la satisfacción de las necesidades básicas de las personas (trabajo, vivienda, educación, acceso a la sanidad) y su participación en la sociedad. En definitiva, el excluido es el que queda al margen del progreso social sin posibilidades reales de incorporarse al mismo. Los excluidos son muchos, pero muchos más aún son los individuos y colectivos en riesgo de exclusión.

Es fácil identificar una doble exclusión, la exclusión planetaria que padecen un grupo de países que quedan totalmente al margen de los procesos de progreso en que, en distinta medida, están inmersos la generalidad de los países, y la exclusión interior, la que sufren personas y colectivos incapaces de formar parte activa de la sociedad en cuyos márgenes se

\footnotetext{
${ }^{8}$ UNITAID es una Organización Gubernamental creada oficialmente el 19 de septiembre de 2006, en Nueva York, con ocasión de la sesión inaugural de la Asamblea General de Naciones Unidas por los representantes de los cinco países fundadores: Francia, Brasil, Chile, Noruega, Reino Unido, en presencia de Kofi Annan, entonces Secretario General de Naciones Unidas. Actualmente cuenta con cerca de treinta miembros. En el comité ejecutivo están representantes de los cinco fundadores, más España. Según su propia presentación, UNITAID es el resultado de un largo esfuerzo de la comunidad internacional para poner al servicio del desarrollo parte de los recursos creados por la mundialización. Su objetivo es mejorar el acceso a los medicamentos en los países en desarrollo, para así luchar contra tres pandemias: el sida, la tuberculosis y el paludismo.

${ }^{9}$ Véase en http://www.millennium-foundation.org/
} 
desenvuelven y que sistemáticamente los aparta. En unos casos son sociedades sin esperanza en las que no cabe más salida que la emigración desesperada, en otros los caldos de cultivo de reacciones antisociales. Son el origen de intermitentes explosiones, manifestaciones de la "rebelión de los excluidos" de difícil digestión institucional.

No es difícil entender que la lucha contra la exclusión social abarca muchos ámbitos. El acceso a la educación, a la cultura y a los servicios de salud, la facilidad de acceso al crédito, las rentas mínimas de inclusión o las ayudas por desempleo y las políticas de integración de minorías van en ese sentido. La Unión Europea declaró el 2010 como Año Europeo de Lucha contra la Pobreza y la Exclusión Social y ha desarrollado múltiples políticas que podrían servir de modelo para estrategias planetarias.

En cuanto a los nuevos modelos de gobernanza ${ }^{10}$, el desafío consiste en “... establecer instituciones para avanzar en el nuevo paradigma de sostenibilidad a través de formas de asociación entre diferentes partes intervinientes y sistemas a nivel local, nacional y global. Si bien las estructuras específicas serán cosa de adaptación y debate, cabe esperar la proliferación de nuevas formas de participación que complementen y desafíen el sistema tradicional gubernamental. En el nuevo paradigma, el Estado se encuentra inmerso en la sociedad civil y la nación inserta en la sociedad planetaria. El mercado es una institución social a ser controlada por la sociedad en aras de la ecología y de la equidad, y no sólo de la generación de riquezas..."11

Al hablar de gobernanza ambiental se suele pensar en una autoridad ambiental de alcance mundial que sea capaz de imponer reglas de conducta a todos los sujetos, sean ciudadanos, corporaciones o gobiernos, contando con mecanismos coactivos para imponer su autoridad. Seguramente sería deseable, pero no es realista pensar en este modelo. En primer lugar porque no veo posible, al menos en muchas décadas, que los Estados formalicen la formidable cesión de soberanía que esta fórmula precisaría. La soberanía, en su concepción tradicional, se está desintegrando acelerada e irreversiblemente, pero lo hace de un modo silencioso, dando lugar a lo que denomino "soberanía híbrida". A los Estados les cuesta reconocerlo. En segundo lugar, porque no se correspondería con las formas de ejercicio de poder propias de la postmodernidad en la que estamos, mucho más líquidas, en su ejercicio y compulsión, que las tradicionales. Antes al contrario, donde ya estamos, y cada día más estaremos, es frente a una constelación de poderes parciales ${ }^{12}$ que gestionan sin estridencias parcelas cada día más numerosas e importantes de las relaciones internacionales. En unos casos, mediante organismos conocidos y altamente visibles, como la OMC, en otros más numerosos por órganos poco conocidos y muy especializados como las secretarías de los innumerables convenios internacionales que rigen silenciosamente las relaciones entre los Estados.

\subsubsection{La Sostenibilidad tecnológica}

La nuestra es una tecno-sociedad, eso es un hecho. El progreso de la Humanidad, en tanto especie, únicamente es explicable si tenemos en cuenta sus capacidades tecnológicas, es decir, su facultad de utilizar los conocimientos sobre la realidad que nos envuelve para transformarla.

\footnotetext{
${ }^{10}$ Véase Glasenapp, Maikon Cristiano y Cruz, Paulo Márcio "Governança e Sustentabilidade: Constituindo novos paradigmas na Pós-Modernidade" en Antunes de Souza, María Claudia da Silva y Siqueira García, Heloise, Organizadoras, VV.AA. Lineamentos sobre Sustentabilidade segundo Gabriel Real Ferrer, pág. 55 y ss., libro electrónico disponible en http://www.univali.br/ppcj/ebook

${ }^{11}$ La gran transición ... o.c., pag. 54.

12 Que suelo denominar, la "galaxia de autoridades". Más información al respecto en mi trabajo "Sostenibilidad, transnacionalidad y trasformaciones del Derecho", en Revista de Derecho Ambiental, Abeledo Perrot, Buenos Aires, no 32, octubre-diciembre 2012, págs. 65-82; y en Maria Cláudia da Silva Antunes de Souza e Denise Schmitt Siqueira Garcia (Orgs.), Direito Ambiental, Transnacionalidade e Sustentabilidade, E-Book, Univali editora, Itajaí, 2013
} 
Esta dimensión ha sido muy poco tratada desde nuestra perspectiva de iusambientalistas pero lo cierto es que es imprescindible su análisis si queremos construir una sociedad sostenible. De hecho, la técnica de la que dispongamos es la que marcará las acciones que podamos poner en marcha para corregir, si es que llegamos a tiempo, el rumbo actual decididamente abocado a la catástrofe. Y la técnica, también, define y ha definido nuestros modelos sociales. La rueda, las técnicas de navegación, el acero, la máquina de vapor, la electricidad, el automóvil o la televisión han definido y conformado nuestras estructuras sociales. Internet, las nanotecnologías y lo que está por llegar, también lo harán. La sociedad del futuro será lo que a través de la ingeniería social seamos capaces de construir institucionalmente y lo que la ciencia y la técnica permitan o impongan. En todo caso, lo que también es evidente es que precisamos urgentemente de un rearme ético capaz de orientar estos procesos hacia un auténtico progreso civilizatorio basado en valores positivos. La ciencia, sumada al egoísmo a ultranza, lo que genera es barbarie.

Brevemente, como conviene a los efectos de este trabajo, las áreas en las que, a mi juicio, debemos trabajar en la dimensión tecnológica si pretendemos construir un futuro sostenible, son:

\section{a) Enfrentar los riesgos difusos}

Tenemos bien interiorizado que la nuestra es una sociedad de riesgo y que, salvo catástrofes $^{13}$ de origen estrictamente natural, el mismo está asociado al progreso tecnológico. Sin embargo, la extraordinaria aceleración en el ámbito de lo conocido y las aplicaciones que de esos conocimientos se están dando o se pueden dar, aumenta también el número y gravedad de los riesgos que corremos. No se trata ya de prevenir o evitar catástrofes puntuales, como Chernóbil o Bhopal, sino de enfrentarse a los efectos, muchas veces desconocidos a corto plazo y siempre desconocidos a largo o muy largo plazo, de numerosas e imprevisibles aplicaciones de la biotecnología o de la biología sintética; de los nuevos materiales e incluso nuevos elementos que se producen con nanotecnologías o los impactos, de todo orden, que producirá la generalización de la robótica y nanorobótica. ¿Qué efectos sobre nuestra salud, sobre el ambiente, sobre la estructura de la sociedad o sobre las relaciones económicas pueden producir los avances que nos esperan?

Frente al imparable progreso científico y los riesgos que puede producir, el único valladar es la aplicación responsable del principio de precaución. En todo caso, debemos reflexionar sobre ello.

b) Hacerla disponible

En la sociedad del conocimiento el control sobre el mismo ha derivado en la principal fuente de poder. Poder económico, en primer lugar, pues ya se está viendo que las grandes -e insultantes- concentraciones de dinero se están produciendo en torno al saber y a sus aplicaciones. Ya no es la detentación de recursos naturales o los procesos de transformación industriales lo que polariza el dinero, sino el control del conocimiento. Lo relevante ya no es la propiedad de la tierra o de los medios de producción, sino la propiedad intelectual.

La sostenibilidad exige que el conocimiento se comparta y que la tecnología llegue adonde es necesaria. Debemos construir el andamiaje jurídico para potenciar el intercambio de saberes y aplicaciones, evitar el tráfico de tecnologías obsoletas y revisar en profundidad el contenido y límites de la propiedad intelectual, sobre todo en áreas o descubrimientos que pueden determinar el futuro de la Humanidad.

\footnotetext{
${ }^{13}$ Al respecto, véase el interesante trabajo de WINTER DE CARVALHO, Délton y DAMACENA, Fernanda Dalla Libera, Direito dos Desastres, Livraria do Advogado, Porto Alegre, 2013.
} 
c) Prevenir y evitar las tecno-catástrofes

Nuestra dependencia tecnológica es absoluta. $\mathrm{Si}$, de repente, nos quedáramos sin internet, un recurso con apenas veinte años de vida efectiva, la sociedad se derrumbaría. Nuestra fragilidad frente a colapsos tecnológicos es mucho mayor o, al menos, más inmediata, que frente a colapsos ambientales. En un interesante libro ${ }^{14}$, el matemático John CASTI analiza once escenarios perfectamente posibles, la mayoría de ellos relacionados exclusivamente con la tecnología, que supondrían el fin de nuestro modelo social. Su teoría, irrefutable, es que el progreso en la complejidad de los sistemas aumenta su fragilidad si no se establecen mecanismos de control, a su vez progresivamente más complejos, un desfase entre la complejidad del sistema y la de sus mecanismos de control conduce inexorablemente, en un momento u otro, al colapso.

No es fácil protegerse frente a esto, pero hay que aplicarse. De entrada y a nivel internacional, deberían establecerse mecanismos de control cooperativo en sectores estratégicos y buscar alternativas para regresar a la simplicidad procesos esenciales sumidos en la hiper-complejidad.

d) Adaptarse a la tecno-sociedad

La nuestra es una tecno-sociedad, ya lo hemos dicho. Eso quiere decir que nuestros modelos sociales vienen determinados por la tecnología disponible. No es en función de nuestro modelo social que es la tecnología que manejamos, es la tecnología disponible la que determina el modelo social en el que nos movemos.

Internet permite interacciones sociales inimaginables hace pocos años y su influencia sobre la sociedad global no ha hecho más que empezar. Para 2020, es decir, mañana, tendremos internet gratuita y ubicua en cualquier rincón del todo el planeta. ¿Qué procesos sociales permitirá este adelanto? En el área de las comunicaciones no es la post-internet lo único que nos espera, están ya en fase de prototipo unos comunicadores "telepáticos" que pueden trasladar los pensamientos de una persona a otra vía Bluetooth. Quizás seamos de las últimas generaciones que utilizan el habla para comunicarse. En otras áreas, equipos de investigación y laboratorios trabajan intensamente con lo que sería el espacio propio del viejo concepto de ciencia-ficción. La producción artificial de vida, los mismo límites entre la vida y la muerte, especies vegetales y animales desconocidas, átomos inventados, biorobótica, materiales milagrosos la lista sería interminable. En definitiva, las transformaciones que nos esperan para los próximos años son, literalmente, imprevisibles y eso alterará profundamente nuestras relaciones sociales y económicas ${ }^{15}$. También, evidentemente, con el medio. La impresión 3-D, como alternativa a los procesos productivos tradicionales, podría acabar con los residuos industriales o la manipulación molecular ofrecernos energía ilimitada, por poner simplemente dos ejemplos.

Sería simplemente ilusorio pretender construir el futuro sin tener en cuenta esta dimensión. Nuestra realidad, extremamente compleja, hace que unas y otras

\footnotetext{
${ }^{14}$ Casti, Jhon, O colapso de tudo, Intrínseca, Rio do Janeiro, 2012, traducción del original X-Events, The colapse of everything

${ }^{15}$ En el Silicon Valley de California hay una institución de creciente prestigio, la Singularity University cuyo objetivo es la formación de dirigentes capaces de enfrentar estas transformaciones.

Muchas ideas acerca de la sociedad del futuro y de los desafíos que afrontamos pueden verse en el interesante libro de Al GORE O Futuro. Seis desafíos para mudar o mundo, HSM, Sao Paulo, 2013, traducción de The Future.
} 
dimensiones se interrelacionen y se condicionen mutuamente haciendo inútil o, al menos, insuficiente, un abordaje analítico y prospectivo parcial ${ }^{16}$.

\section{El Principio de no regresión ambiental en el contexto de la Sostenibilidad}

En tanto guía de acción, la Sostenibilidad se erige como un principio, también en el orden jurídico ${ }^{17}$. En su condición de paradigma de la postmodernidad, podemos decir que se convierte en un "macro principio" al que se subordinan y acompañan otros principios. Más que fundamental, el principio es fundacional, pues la sostenibilidad, es decir, la vocación de perpetuarse, está en la esencia de toda civilización, ninguna planifica su propia destrucción. Por otra parte, todas las sociedades han intentado asegurar su entorno de modo que les permita desarrollarse y evolucionar, solo que ahora se trata de la sociedad global y el entorno es el Planeta. La adecuación a este principio es el filtro por el que deben pasar todo tipo de decisiones, desde nuestras particulares opciones de consumo hasta la producción normativa 0 la articulación institucional de la sociedad global.

Para garantizar su efectividad de cara a introducir en la sociedad los cambios necesarios para hacerla viable, requiere del acompañamiento de otros dos principios que son, en el fondo, dos caras de la misma moneda: el principio progresividad y el de no regresión ${ }^{18}$. En efecto, para salir del modelo de sociedad en el que estamos, claramente insostenible, y caminar hacia un sistema viable necesitamos que todo cambio constituya un progreso en esa dirección y, por supuesto, no dar pasos atrás, no retroceder.

Como es analizado en otros trabajos de esta misma obra colectiva, el principio de progresividad ya se encuentra en documentos internacionales fundamentales como en el Pacto Internacional de Derechos Económicos, Sociales y Culturales (PIDESC) ${ }^{19}$ lo que alcanza a buena parte de las acciones que deben emprenderse en las áreas social y económica.

\footnotetext{
16 Aunque podamos entenderlos aún insuficientes, este tipo de enfoques horizontales ya tiene antecedentes. Al respecto véase el documento de la Unión Europea "COMUNICACIÓN DE LA COMISIÓN AL CONSEJO Y AL PARLAMENTO EUROPEO relativa a la revisión de la Estrategia para un desarrollo sostenible. Plataforma de acción", Bruselas, 13.12.2005 COM(2005) 658 final. Especialmente interesante es sU ANEXO 1 "Declaración sobre los principios rectores del desarrollo sostenible"

17 Al respecto, véase el excelente trabajo de Klaus BOSSELMANN The principle of sustainability. Transforming Law and Governance, Ashgate, Hampshire, England, 2008.

18 Sobre el principio existe ya abundante bibliografía. Son esenciales los trabajos de su principal impulsor el Prof. Michel Prieur, Prieur, Michel, De l'urgente nécessité de reconnaître le principe de " non régression » en Droit de l'environnement, IUCN Academy of Environmental Law e-Journal Issue 2011. "Non-regression in environmental law" en Sapiens, 2012, Vol.5 / n² - IUCN Commissions; La non régression en droit de l'environnement, Bruylant, 2012, obra colectiva dirigida con Sozzo, Gonzalo; y en América Latina los de Mario Peña Chacón, entre ellos la, obra colectiva El principio de no regression ambiental en el derecho comparado latino-americano, PNUD, San José, 2013; "Principio de no regresión ambiental a la luz de la jurisprudencia constitucional costarricense", Revista Iberoamericana de Derecho Ambiental y Recursos Naturales, número 3, febrero 2012; "Los principios de objetivación de la tutela ambiental, irreductibilidad de espacios sometidos a régimen especial de protección y su relación con la prohibición de retroceso" Revista Iberoamericana de Derecho Ambiental y Recursos Naturales, número 7, febrero 2013, o "El Derecho Internacional Ambiental como fundamento del Principio de Prohibición de Retroceso", Revista Iberoamericana de Derecho Ambiental y Recursos Naturales, número 8, mayo 2013. En España también se ha ocupado del asunto Fernando López Ramón, en "El principio de no regresión en la desclasificación de los espacios naturales protegidos en el Derecho Español", Revista Aranzadi de derecho ambiental, ISSN 1695-2588, №. 20, 2011, págs. 13-27. Una muy reciente e interesante aportación em Brasil, la de Morato Leite, José Rubens y Neva Belchior, Germana Parente, "Diálogo das fontes, Hermenêutica e principio da Proibição de Retrocesso Ambiental: Uma nova fundamentação jurídico-reflexiva" em Lineamentos sobre ..., o.p. pág 81

${ }^{19}$ El Pacto Internacional de Derechos Económicos, Sociales y Culturales (PIDESC) fue adoptado por la Asamblea General de NN.UU. en su resolución 2200 A (XXI), de 16 de diciembre de 1966.
} 
En cuanto al principio de no regresión ambiental, lo que aporta su consideración a la luz del paradigma de la sostenibilidad resulta extremadamente importante. El consenso acerca de que caminar hacia la sostenibilidad es el objetivo común de la Humanidad y que el salto civilizatorio que comporta debe materializarse inexorablemente en distintos ámbitos relacionados e interdependientes nos lleva a ampliar su campo de acción.

Al igual que está ocurriendo con el derecho ambiental, que pasa a ser una parte de un fenómeno más amplio, el principio de no regresión ambiental debe entenderse subsumido en el de no regresión en materia de sostenibilidad que debe desenvolverse en todas sus dimensiones. De algún modo esta visión lo relativiza y establece sus límites de aplicación. La sostenibilidad se mueve constantemente en un juego de equilibrios en el que no siempre queda claro cuál es el interés prevalente ni cuáles son los límites razonables en los que unos intereses deben sacrificarse en beneficio de otros. En ese juego de equilibrios debe moverse el principio de no regresión ambiental.

Naturalmente, la posibilidad de no aplicación del principio de no regresión ambiental debe considerarse altamente excepcional pues en la mayor parte de los casos los intereses de otra naturaleza que entren en conflicto podrán será atendidos con soluciones alternativas que no supongan un demérito en los niveles de protección ambiental alcanzados. Sin embargo, tal posibilidad existe, y a la espera de mejores soluciones es posible admitir su excepción. No debe olvidarse que el derecho y, por tanto, también el ambiental y consecuentemente el principio de no regresión, es un producto cultural que debe servir al Hombre y a la sociedad en la que se desenvuelve. ${ }^{20}$

Por último, no quería cerrar esta pequeña aportación sin expresar dos ideas que me inquietan en torno al principio de no regresión ambiental. La primera, tiene que ver con su posible aplicación inadecuada en supuestos en los que, aparentemente, la legislación puede relajar algunas exigencias y la segunda, en silenciosos pero importantes retrocesos que pueden pasar desapercibidos.

Sobre la rebaja de algunas exigencias normativas, entiendo que en determinados casos aunque aparentemente supongan un retroceso pueden estar justificadas y caminar en la buena dirección. El hecho, sobre el que he alertado más de una vez, es que con demasiada frecuencia se ha producido normativa ambiental copiando estándares de otros países sin tener en cuenta ni la realidad social y económica, ni la madurez tecnológica del sistema productivo del país en el que se pretende aplicar. En muchos de estos casos, la normativa es simplemente inaplicable. Se ha cumplido con el trámite político de decir que ya tenemos una norma exigente, pero lo que se produce es una situación de incumplimiento generalizado altamente propicio a la corrupción. En estos casos, lo sensato es rebajar los estándares a niveles que puedan ser realizables, exigir su cumplimiento y planificar temporalmente su progresivo endurecimiento de modo que el sistema productivo, y la sociedad en su conjunto, pueda adaptarse a mayores niveles de exigencia. Lo peor que le puede pasar a una norma ambiental es instalarse en el incumplimiento generalizado.

\footnotetext{
${ }^{20}$ Sobre la cuestión, recupero un párrafo de "Del derecho ambiental ..." o.c. en el que se expresa mi postura: "Por otra parte, es frecuente plantearse la pregunta de si deben otorgarse derechos a la Tierra $o$, por extensión, a la Naturaleza, frente a la depredación humana; lo que nos lleva a otra pregunta que alimentó un intenso debate en los albores del Derecho Ambiental y que reaparece recurrentemente: $i e l$ Derecho Ambiental es ecocéntrico o antropocéntrico? Dicho de otro modo, ¿construimos este derecho para defender al medio ambiente del Hombre, o para proteger al Hombre de sí mismo? Tal como hemos visto, con nuestros patrones culturales la única respuesta posible es la segunda: el Derecho Ambiental está hecho por y para el Hombre y defiende a los ecosistemas, a la Tierra, en la medida y sólo en la medida en que el Hombre entiende que la preservación de determinados valores resulta útil a su existencia actual o futura." No hay que olvidar que lo que está en juego no es la Naturaleza, inestable y evolutiva, sino nuestra supervivencia como especie. Detrás nuestro, la Naturaleza seguirá, quizá con mayor esplendor.
} 
La otra cuestión, en parte relacionada con la anterior ya que tiene que ver con la eficacia del sistema normativo, es el grave problema que tenemos con los sistemas de inspección y control, altamente ineficientes en buena parte de los países, sean de un continente o de otro. Debe considerarse contrario al principio de no regresión toda actuación que tienda a relajar 0 entorpecer su funcionamiento y eficacia. Estas actuaciones pueden no resultar tan visibles como modificar una ley, pero son tanto o más perjudiciales. Rebajar el presupuesto destinado al efecto, reducir funcionarios o rebajar sus capacidades de inspección; relajar los procedimientos sancionadores 0 , simplemente, no seguirlos, son ejemplos de actuaciones poco evidentes que pueden y deben ser consideradas contrarias el principio de no regresión ambiental. 


\section{Bibliografía}

Boff, Leonardo, Sustentabilidade: o que é e o que não é, Vozes, Río de Janeiro, 2012.

Bosselmann, Klaus, The principle of sustainability. Transforming Law and Gobernance, Ashgate, Hampshire, England, 2008.

Casti, Jhon, O colapso de tudo, Intrínseca, Rio do Janeiro, 2012, traducción del original $X$ Events, The colapse of everything.

Freitas, Juarez, Sustentabilidade: Direito ao Futuro, Forum, Belo Horizonte, 2012.

Glasenapp, Maikon Cristiano y Cruz, Paulo Márcio, "Governança e Sustentabilidade: Constituindo novos paradigmas na Pós-Modernidade" en ANTUNES DE SOUZA, María Claudia da Silva y SIQUEIRA GARCÍA, Heloise, Organizadoras, VV.AA. Lineamentos sobre Sustentabilidade segundo Gabriel Real Ferrer, pag. 55 y ss., libro electrónico disponible en http://www.univali.br/ppcj/ebook.

Gore, Albert, O Futuro. Seis desafíos para mudar o mundo, HSM, Sao Paulo, 2013, traducción de The Future.

López Ramón, Fernando, "El principio de no regresión en la desclasificación de los espacios naturales protegidos en el Derecho Español", Revista Aranzadi de Derecho Ambiental, №. 20, 2011.

Morao Leite, José Rubens y Neva Belchior, Germana Parente, "Diálogo das fontes, Hermenêutica e principio da Proibição de Retrocesso Ambiental: Uma nova fundamentação jurídico-reflexiva" en VV.AA. Lineamentos sobre Sustentabilidade segundo Gabriel Real Ferrer, pag. 55 y ss., libro electrónico disponible en http://www.univali.br/ppcj/ebook.

Peña Chacón, Mario (Dir.), El principio de no regresión ambiental en el derecho comparado latino-americano, PNUD, San José, 2013.

Peña Chacón, Mario, "Principio de no regresión ambiental a la luz de la jurisprudencia constitucional costarricense", Revista Iberoamericana de Derecho Ambiental y Recursos Naturales, número 3, febrero 2012.

Peña Chacón, Mario, "Los principios de objetivación de la tutela ambiental, irreductibilidad de espacios sometidos a régimen especial de protección y su relación con la prohibición de retroceso" Revista Iberoamericana de Derecho Ambiental y Recursos Naturales, número 7, febrero 2013.

Peña Chacón, Mario "El Derecho Internacional Ambiental como fundamento del Principio de Prohibición de Retroceso", Revista Iberoamericana de Derecho Ambiental y Recursos Naturales, número 8, mayo 2013.

Prieur, Michel, "De l'urgente nécessité de reconnaître le principe de « non régression » en Droit de l'environnement", IUCN, Academy of Environmental Law e-Journal Issue, 2011.

Prieur, Michel, "Non-regression in environmental law", IUCN Commissions, Sapiens, 2012, Vol.5 / n².

Prieur, Michel y SOZZO, Gonzalo (Dir.) La non régression en droit de l'environnement, Bruylant, 2012.

Real Ferrer, Gabriel, "Del Derecho Ambiental al Derecho de la Sostenibilidad", PNUMA, Programa regional de capacitación en derecho y políticas ambientales. 2008, disponible en http://www. pnuma.org.

Real Ferrer, Gabriel "Sostenibilidad, transnacionalidad y trasformaciones del Derecho", en Revista de Derecho Ambiental, Abeledo Perrot, Buenos Aires, № 32, octubre-diciembre 2012, y 
en Maria Cláudia da Silva ANTUNES DE SOUZA e Denise Schmitt SIQUEIRA GARCIA (Orgs.), Direito Ambiental, Transnacionalidade e Sustentabilidade, E-Book, Univali editora, Itajaí, 2013.

Winter de Carvalho, Délton y Damacena, Fernanda Dalla Libera, Direito dos Desastres, Livraria do Advogado, Porto Alegre, 2013.

VV.AA., La gran transición: La promesa y la atracción del futuro, CEPAL, Santiago de Chile, 2006. Traducción al español de Great Transition. The Promise and Lure of the Times Ahead. 


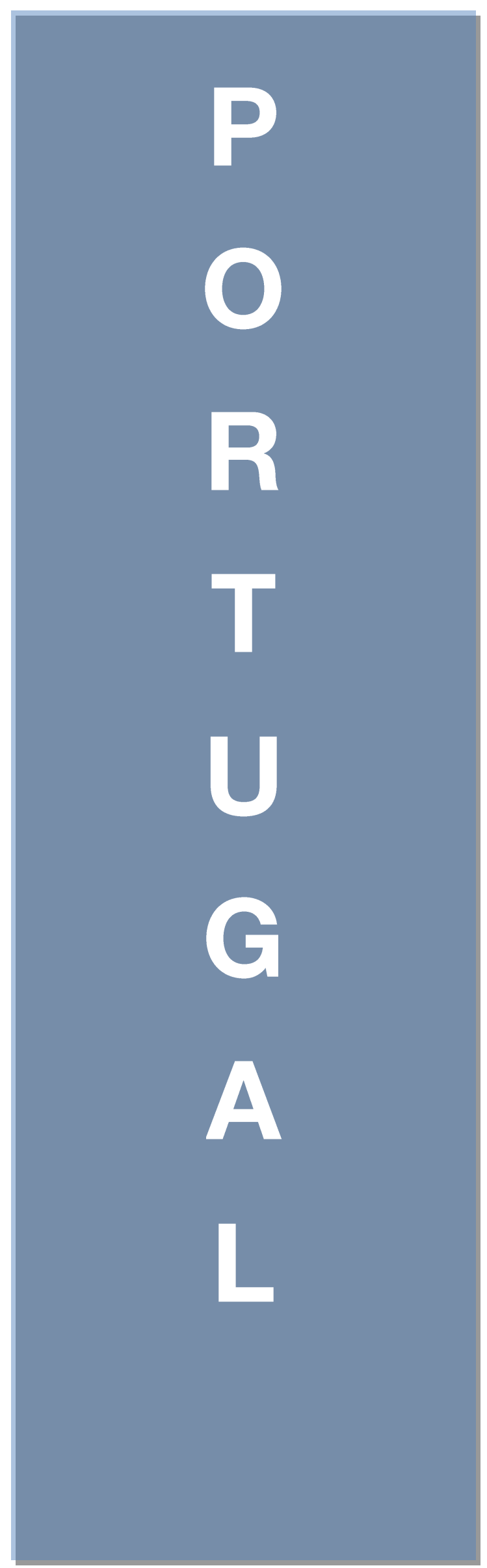





\title{
A PROIBIÇÃO DO RETROCESSO COMO GARANTIA DA EVOLUÇÃO SUSTENTÁVEL DO DIREITO AMBIENTAL
}

\author{
Alexandra Aragão*
}

\section{Introdução}

Fazendo um balanço do processo de afirmação doutrinal do princípio da proibição do retrocesso em Direito Ambiental, podemos identificar dois importantes momentos lógicos.

Primeiro, o momento em que as preocupações se centram na fundamentação jurídica da proibição de retrocesso, como forma de proteção contra a miopia ambiental tanto dos poderes públicos, como dos agentes económicos e mesmo dos cidadãos. Qual a base ou a fonte jurídica do princípio? É um princípio de direito interno, europeu ou internacional? Por quê defender a irreversibilidade da proteção ambiental?

Depois de o princípio ter ganho maturidade doutrinal, e de estar mais clarificada a sua origem, os seus fundamentos e a sua razão de ser $^{1}$, chega o momento de dar mais um passo. Num segundo tempo impõe-se desenvolver critérios operacionais que nos permitam perceber rapidamente, perante um caso concreto, se se trata de uma evolução ambiental juridicamente admissível ou, pelo contrário, de um retrocesso inadmissível.

Ora, a ambição comum a ambientalistas, a produtores e a aplicadores de direito ambiental seria de ter acesso a um "retroscópio", um instrumento científico imaginário - análogo ao macroscópio de Joël de Rosnay ${ }^{2}$ - que permitisse filtrar rapidamente normas jurídicas, atos administrativos ou decisões judiciais retrocedentes. Infelizmente não existem "retroscópios" que nos permitam identificar os retrocessos automaticamente, por isso vamos procurar indicadores de retrocesso ambiental, que nos auxiliem a identificar e rotular, sistematicamente e com segurança, novas normas de direito ambiental.

Isto é importante, sabendo sobretudo que, por vezes, o retrocesso pode não ser deliberado, mas apenas um efeito colateral, pouco percetível, de medidas destinadas a prosseguir objectivos mais nobres. É o que acontece quando o objectivo das medidas é o aperfeiçoamento normativo, pela melhoria da qualidade das técnicas legislativas ${ }^{3}$, ou a

\footnotetext{
* Doutor em Direito Público da Faculdade de Direito da Universidade de Coimbra, onde o professor. Pesquisador Legal do Instituto no Centro de Estudos Ambientais Direito, Planejamento e Meio Ambiente e do Centro de Estudos Sociais da Universidade de Coimbra.

${ }^{1}$ Para uma apresentação sistemática dos fundamentos e limites do princípio ver a obra de Michel Prieur Droit de l'environnement, droit durable, entre as págs. 183-232 (Brylant, Bruxelas, 2014).

$2 \mathrm{Na}$ obra de 1975 intitulada precisamente The Macroscope (disponível on line em http://www.appreciatingsystems.com/wp-content/uploads/2011/05/The-Macroscope.pdf e em versão portuguesa O Macroscópio. Para uma visão global, Estratégias Criativas, Vila Nova de Gaia, 1995), Rosnay desenvolve a ideia de um instrumento que em vez de ver ao longe, como o telescópio, ou ampliar o que é pequeno, como o microscópio, permitisse ver as inter-relações globais entre a sociedade e os ecossistemas.

${ }^{3} \mathrm{Na}$ União Europeia é o movimento de Smart Regulation. Para uma explicação simples da iniciativa "Legislar melhor", designadamente nas dimensões de simplificação e estudo de alternativas veja-se http://ec.europa.eu/smart-regulation/better_regulation/documents/brochure/brochure_pt.pdf.
} 
intenção de tornar as normas compatíveis com a proteção do clima ${ }^{4}$, ou até o propósito de proteger melhor outros direitos humanos essenciais à vida ${ }^{5}$.

Ora, a finalidade do presente estudo ${ }^{6}$ é contribuir com mais uma reflexão ${ }^{7}$ para a operacionalização do princípio da proibição de retrocesso ambiental por via legislativa, desenvolvendo um estudo sobre os "limites aos limites" e construindo uma tipologia de progressos e retrocessos a partir de uma visão portuguesa e europeia.

Como a aferição do retrocesso exige uma comparação entre a situação anterior e a posterior, vamos dividir este estudo em duas partes, que correspondem aos dois momentos lógicos da análise.

\section{Primeiro passo: análise da norma anterior}

O primeiro passo necessário para determinar a existência (ou não) de um retrocesso ambiental associado a uma alteração normativa é analisar a natureza da medida que vai ser objecto de revogação, de derrogação, de suspensão, de modificação, etc.. Só há retrocesso se antes tiver havido um progresso ${ }^{9}$.

Com efeito, nem todas as alterações legislativas que à primeira vista poderiam parecer envolver um risco de retrocesso são, na realidade, regressivas. Algumas podem ser meros afinamentos do instrumentário jus-ambiental.

Por isso é importante começar por perceber quais as normas que promovem progressos ambientais. Ora, progressos ambientais ocorrem quando se alcançam níveis de proteção acrescida do ambiente, que sejam considerados como um salto qualitativo e, portanto, um estádio civilizacional mais elevado.

\footnotetext{
${ }^{4}$ Veja-se, por exemplo, as recomendações sobre "Climate Proofing" of key EU policies" (disponível em http://ec.europa.eu/clima/policies/adaptation/what/docs/ccp_task3_en.pdf).

${ }^{5}$ Como a proteção do direito humano à água potável em boas condições em termos de quantidade, qualidade e custo. Veja-se, por exemplo, a iniciativa de cidadania europeia, subscrita por 1884790 cidadãos da União Euorpeia (disponível em http://www.right2water.eu/), à qual a Comissão Europeia deu uma resposta favorável em 19 de março de 2014 (http://europa.eu/rapid/press-release_IP-14-277_pt.htm)

${ }^{6} \mathrm{O}$ presente texto é baseado no nosso trabalho mais vasto intitulado "Desenvolvimento sustentável em tempo de crise e em maré de simplificação. Fundamento e limites da proibição de retrocesso ambiental", publicado no volume IV da obra Estudos em homenagem a Joaquim Gomes Canotilho, Coimbra Editora, 2012, p. 43 a 90.

${ }^{7}$ Este tema é preocupação e objecto de análise de grandes doutrinadores do retrocesso ambiental, como Mário Peña Chacón. por exemplo, em "Límites, restriciones y excepciones del principio de prohibicón de regresividad ambiental, in Revista de Derecho Ambiental Thompson Reuter de Argentina (no prelo), onde o autor procura analisar as justificações possíveis para a adoção de medidas regressivas em matéria ambiental (pág. 13 e ss.), para identificar requisitos de validade de tais medidas (pág.17), ou, de forma ainda mais concreta, em El test de regressividad ambiental (Revista Internacional Direito Ambiental (RIDA), número 6, dezembro de 2013) onde o jurista costarricense identifica um conjunto de princípios limitadores e condicionantes do retrocesso, mesmo excepcional (pág. 8 e ss.). Também na Europa a doutrina se tem orientado neste sentido. Por exemplo, Isabelle Hachez em «Le principe de non regression en droit de l'environnement: une irreversibilité relative?» e Jean-Marc Lavieille em «Propositions voulant contribuer à rendre plus opérationnel le principe de non régression en droit de l'environnement», (ambos incluidos na obra de referência La non régression en droit de l'environnement, Michel Prieur y Gonzalo Sozzo (dir.) Bruylant, 2012).

${ }^{8}$ A expressão é de Michel Prieur, quando alude aos limites ao princípio de não retrocesso, referindo que "em todo o caso, há limites aos limites tolerados" ("Le nouveau principe de 'non régression', in La non régression en droit de l'environnement, Michel Prieur y Gonzalo Sozzo (dir.) Bruylant, 2012, pág. 44-45).

${ }^{9}$ Gonzalo Sozzo analisa o conceito de progresso in La non régression en droit de l'environnement, Michel Prieur y Gonzalo Sozzo (dir.) Bruylant, 2012, pág. 44-45.
} 
É precisamente nesses saltos qualitativos ${ }^{10}$ que não se deve retroceder. Sempre que uma inovação ou alteração legislativa representa a correção de uma situação que, em virtude da evolução da consciência axiológico-jurídica geral, passa a ser considerada como injusta e insustentável e, portanto, se a nova solução conseguida corresponde a uma situação mais justa, equilibrada e duradoura, é natural que a renúncia a este progresso seja considerada como um retrocesso e não uma mera inflexão.

Com efeito, se consideramos certas medidas como um progresso, é porque passámos a proteger valores emergentes, que são valores importantes do ponto de vista de uma convivência social justa e sã; valores essenciais do ponto de vista da qualidade de vida, na sua estrita dependência da qualidade ambiental; valores fundamentais do ponto de vista da sobrevivência do Homem.

Em qualquer destes casos o retrocesso corresponderia a uma supressão de deveres de prestação ou de respeito, impostos em nome de uma evolução civilizacional importante.

Uma forma fácil de identificar progressos ambientais que impedem o legislador de retroceder, ou seja, patamares irreversíveis de realização do Direito Ambiental é a análise do artigo $66^{\circ}$ da Constituição Portuguesa.

Aí encontramos um conjunto de cliquets constitucionais ${ }^{11}$ como:

- o estatuto ambiental dos cidadãos ${ }^{12}$,

- a organização ambiental do Estado ${ }^{13}$,

- a relação entre o ambiente e as restantes políticas ${ }^{14}$,

- a proteção de locais importantes ${ }^{15}$,

- a proteção dos recursos naturais ${ }^{16} \mathrm{e}$

\footnotetext{
${ }^{10} \mathrm{E}$ não cremos que esta concepção do progresso ambiental possa ser considerada como uma "ingénua concepção ferroviária da História", no sentido da crítica de Vieira de Andrade à fundamentação do pedido de declaração de inconstitucionalidade da norma do Decreto da Assembleia da República que, em 2002, revogava o rendimento mínimo garantido ("O 'Direito ao mínimo de existência condigna' como direito fundamental a prestações estaduais positivas. Uma decisão singular do Tribunal constitucional. Anotação

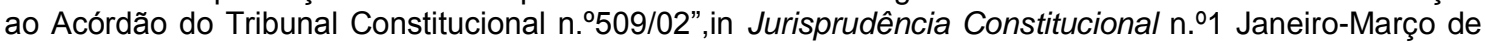
2004, pág. 24, nota 6).

${ }^{11}$ Para recorrer à sugestiva metáfora do "effet cliquet" ou efeito catraca da doutrina francesa, retomada pelo Tribunal Constitucional Português (no Acórdão 509/02, proferido no processo n.-. 768/2002), citando Louis Favoreu (Revue Française de Droit Constitutionnel, 1991, 6, pág. 293) e a jurisprudência francesa do Conseil Constitutionnel (Decisão 83-165, de 20 de Janeiro de 1984).

${ }^{12}$ Reconhecimento do direito ao ambiente como direito subjectivo dos cidadãos; (66ํㅡ, n..1); existência de deveres (individuais e colectivos) de proteção ambiental; (66으. n.․1); reconhecimento do direito de

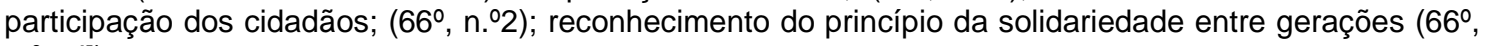
n. $.2 \mathrm{~d}]$ ).

${ }^{13}$ Existência, dentro da estrutura do Estado, de organismos próprios de proteção ambiental (66ำ, n.ํ); poder-dever de colaboração das autarquias locais na proteção do ambiente urbano; $\left(66^{\circ}\right.$, n. .22 e).

${ }^{14}$ Integração do ambiente nas restantes políticas sectoriais, nomeadamente a política de ordenamento do território, a política de educação e a política fiscal; (66으, n.ำ f] b] c] g] h]).

${ }^{15}$ Proteção de sítios de interesse natural (criação de reservas, parques naturais e parques de recreio) e cultural (maxime, histórico ou artístico); (66ํำ n..2 c]); proteção do ambiente urbano, nomeadamente evitando impactes visuais e protegendo as zonas históricas (66으. n.-2 e]). Tratando-se de uma proteção ambiental das zonas históricas encontram-se aqui abrangidas medidas como a proteção contra inundações; a prevenção da poluição atmosférica e luta contra as chuvas ácidas; medidas de gestão rodoviária visando a proteção contra trepidações; medidas paisagísticas, destinadas a evitar impactes visuais, etc.

${ }^{16}$ Promoção de uma gestão duradoura e de uma utilização racional, parcimoniosa e cuidadosa dos recursos naturais, salvaguardando a sua capacidade de renovação e a sua estabilidade ecológica; (66으, n. $.2 \mathrm{~d}])$.
} 
- $\quad$ a prevenção da poluição ${ }^{17}$.

Outros patamares constitucionais de proteção ambiental decorrem:

a) Do direito fundamental à saúde. Artigo 64. ${ }^{\circ 1}$. "Todos têm direito à protecção da saúde e o dever de a defender e promover.2. O direito à protecção da saúde é realizado: (...) b) Pela criação de condições económicas, sociais, culturais e ambientais que garantam, designadamente, a protecção da infância, da juventude e da velhice, e pela melhoria sistemática das condições de vida e de trabalho, bem como pela promoção da cultura física e desportiva, escolar e popular, e ainda pelo desenvolvimento da educação sanitária do povo e de práticas de vida saudável".

b) Da política agrícola. Artigo 93. "São objectivos da política agrícola: (...) d) Assegurar o uso e a gestão racionais dos solos e dos restantes recursos naturais, bem como a manutenção da sua capacidade de regeneração".

c) Dos direitos dos trabalhadores. Artigo 59 n. ${ }^{\circ}$ 1. c) "A prestação do trabalho em condições de higiene, segurança e saúde; $n$. 으 c) A especial protecção do trabalho das mulheres durante a gravidez e após o parto, bem como do trabalho dos menores, dos diminuídos e dos que desempenhem actividades particularmente violentas ou em condições insalubres, tóxicas ou perigosas; e) A protecção das condições de trabalho e a garantia dos benefícios sociais dos trabalhadores emigrantes; f) A protecção das condições de trabalho dos trabalhadores estudantes".

d) Dos direitos dos consumidores. Artigo 60. "1. Os consumidores têm direito à qualidade dos bens e serviços consumidos, à formação e à informação, à protecção da saúde, da segurança e dos seus interesses económicos, bem como à reparação de danos".

Estes são valores constitucionais suficientemente importantes para se considerar que, com a sua concretização pela via legal, se ultrapassou uma etapa, que não deve ser abandonada e em relação à qual um retrocesso configuraria uma inconstitucionalidade material.

Mas, para determinar quais são os patamares do progresso ambiental, um critério formal, que atendesse apenas ao valor do documento legal - a Constituição ou uma lei com valor reforçado - onde o regime ou o instrumento está consagrado, parecer-nos-ia insuficiente ${ }^{18}$.

Julgamos, por isso, que além dos cliquets constitucionais, há ainda cliquets legais, e que o progresso ambiental pode resultar da aprovação de um regime legal específico de proteção de determinados componentes ou sectores ambientais que, independentemente de reconhecimento pela Constituição, seja considerado como um progresso civilizacional $^{19}$.

Por exemplo, a existência dos instrumentos jurídicos da avaliação de impacte ambiental e da avaliação estratégica, representa, na nossa opinião, um salto qualitativo impeditivo do

\footnotetext{
17 Existência de normas destinadas a prevenir e controlar a poluição em todos os meios recetores ambientais, incluindo o solo e a paisagem; $\left(66^{\circ}, \mathrm{n} . \stackrel{-2}{2}\right.$, a] b] e]); existência de normas destinadas a evitar todos os tipos de poluição, incluindo a visual (66으. n..2 a] b] e]).

${ }^{18}$ Se o regime em causa constar de um

a lei que transpõe uma directiva europeia, então a proibição de revogar ou substituir esse regime pode não resultar autonomamente do princípio da proibição do retrocesso, mas simplesmente do dever de respeitar o direito europeu e de colaborar com as Instituições da União na prossecução dos seus objectivos: "Os Estados-Membros tomam todas as medidas gerais ou específicas adequadas para garantir a execução das obrigações decorrentes dos Tratados ou resultantes dos actos das instituições da União. Os Estados-Membros facilitam à União o cumprimento da sua missão e abstêm-se de qualquer medida suscetível de pôr em perigo a realização dos objectivos da União" (artigo $4^{\circ}, n^{\circ} 3$ do Tratado da União Europeia).

19 Também Cristina Queiroz, na senda de Gomes Canotilho e Vital Moreira (em Fundamentos da Constituição, Coimbra Editora, 1991) defende que "o problema do eventual 'retrocesso social' poderá ser chamado à colação" em relação aos "direitos sem assento constitucional" (Princípio da não reversibilidade dos direitos fundamentais sociais. Princípios dogmáticos e prática jurisprudencial, Coimbra Editora, 2006, pág. 117).
} 
retrocesso ambiental, que não teve, no entanto, recepção constitucional, nem tem sequer plena consagração na Lei de Bases do Ambiente, onde a avaliação estratégica está omissa.

Por isso, o critério formal da consagração constitucional não é mais do que um indicador, pelo que deverá sempre proceder-se a uma análise material do regime legal, para determinar se estamos ou não perante um progresso ambiental relevante. Alguns exemplos permitir-nos-ão visualizar melhor o tipo de progresso a que nos referimos.

\subsection{O Direito regula ex novo um certo componente natural}

No domínio da proteção animal, a proteção por via legal começou quando se tornou visível o declínio populacional e o risco de extinção de algumas espécies de animais selvagens em virtude de sobre-caça ou sobre-pesca.

Posteriormente, a proteção legal alargou-se às espécies da fauna classificadas como vulneráveis, nomeadamente pelo seu carácter endémico ou pela dispersão territorial ${ }^{20}$. Actualmente a proteção legal estende-se à própria "biodiversidade doméstica" ${ }^{21}$.

Paralelamente, preocupações com o bem-estar animal levaram à aprovação de legislação interditando métodos de caça especialmente insidiosos (armadilhas, venenos, animais mutilados utilizados como chamarizes vivos, etc. ${ }^{22}$ ) e ao bem-estar dos animais utilizados para fins experimentais, na área da saúde ou da cosmética ${ }^{23}$, dos animais criados em explorações pecuárias $^{24}$, no transporte ${ }^{25}$ e no abate dos animais ${ }^{26}$.

Por fim, cientes da interação profunda entre as espécies e os seus habitats (biocenoses), a proteção estendeu-se aos habitats das espécies protegidas ${ }^{27}$.

Como podemos verificar, a proteção animal passou por várias fases, correspondendo a níveis de proteção cada vez mais elevados, sendo que a transição de um nível para o outro, deve ser considerada um salto qualitativo, ou um progresso.

No caso concreto da proteção animal, alterações legislativas como a redução da lista de animais protegidos ou das técnicas de abate proibidas, só não seriam um retrocesso se fossem

\footnotetext{
${ }^{20}$ Segundo o regime europeu da Rede Natura 2000, rede europeia de áreas de conservação da natureza (artigo 6ำ n.ำ do Decreto-lei n.ำ 49/2005, de 24 de fevereiro, que transpõe para Portugal a Direitva 92/43, de 21 de maio).

21 O Regulamento de Aplicação do Programa de Desenvolvimento Rural do Continente integra, entre outras, a ação designada 'Protecção da biodiversidade doméstica', que identifica as espécies tradicionais portuguesas de bovinos, ovinos, caprinos, suínos, equídeos e galinhas, carecidas de proteção, classificando-as, das mais para as menos carecidas de proteção, como raras, muito ameaçadas, ameaçadas e em risco. Nos bovinos, por exemplo, as raças raras são a Algarvia, a Garvonesa e a Jarmelista; as raças muito ameaçadas são a Cachena e a Marinhoa; as ameaçadas são a Arouquesa, a Maronesa, a Mirandesa e a Preta e as raças em risco são a Minhota e a Barrosã (Portaria n. 0 427-A/2009 de 23 de abril).

${ }^{22}$ A lei consagra uma lista de métodos proibidos de caça de espécies venatórias (Anexo C do Decreto-lei n.. 49/2005, de 24 de fevereiro).

${ }^{23}$ Decreto-lei n. ${ }^{\circ}$ 113/2013, de 7 de agosto, que transpõe a Directiva 2010/63 do Parlamento Europeu e do Conselho, de 22 de Setembro.

24 Decreto-lei n.. 64/2000, de 22 de Abril.

${ }^{25}$ Decreto-lei no 265/2007, de 24 de Julho, alterado pelo Decreto-lei n.ำ 158/2008, de 8 de Agosto.

${ }^{26}$ Regulamento (CE) n.․ 1099/2009 do Conselho, de 24 de Setembro.

27 A lei que regula a Rede Natura 2000 em Portugal "visa contribuir para assegurar a biodiversidade, através da conservação ou do restabelecimento dos habitats naturais e da flora e da fauna selvagens num estado de conservação favorável" (artigo $1^{\circ}$ do Decreto-lei n.․ 49/2005, de 24 de fevereiro). São variadíssimos os tipos de habitats naturais de interesse comunitário, protegidos pela lei (todos elencados no anexo B-I do mesmo diploma): bancos de areia, estuários, recifes, falésias, sapais, dunas, prados, matas, matagais, charnecas, turfeiras, pântanos, vertentes rochosas, grutas, florestas, etc..
} 
devidamente fundamentadas em função dos critérios e requisitos que desenvolveremos mais adiante.

\subsection{O Direito regula ex novo um determinado sector ambiental}

O progresso pode também resultar da identificação de todo um novo sector ambiental que, normalmente pelos piores motivos, ganha relevância e se autonomiza, passando a beneficiar de um regime jurídico próprio.

Foi o que se passou, paradigmaticamente, com o recente direito global do clima ${ }^{28}$ que impôs alterações drásticas nos sistemas produtivos, nos sistemas de transporte e na gestão de resíduos, visando a redução das emissões de gases com efeito de estufa, a melhoria da eficiência energética e a procura de novas fontes energéticas renováveis ${ }^{29}$.

Se forem identificadas causas antropogénicas para as alterações do campo magnético da Terra, registadas em finais de junho de $2014^{30}$, quem sabe se poderá ser necessário um novo salto qualitativo, consubstanciado no novo Direito da Magnetosfera.

\subsection{O Direito regula ex novo uma actividade tradicional geradora de impactes anteriormente desconhecidos}

Noutros casos, o progresso pode decorrer da superveniência de dados científicos relativos aos impactes de actividades tradicionais não submetidas a regulação ambiental, seja por desconhecimento, seja por suposição da irrelevância dos seus impactes ambientais. É o caso da utilização agrícola de biocidas ${ }^{31}$, da pesca de arrasto $^{32}$, da captação de águas subterrâneas $^{33}$ ou da extração de minério de ouro utilizando cianeto ${ }^{34}$. Todas estas actividades exigiram a adopção de um novo regime legal que configurou um progresso ambiental.

\footnotetext{
${ }^{28}$ Desde 2008, o Reino Unido foi o primeiro país da Europa a ter uma lei do clima. A lei britânica, com mais de 100 artigos, estabelece limites vinculantes de emissões de gases com efeito de estufa até ao ano 2050 e cria o Comité sobre Alterações Climáticas.

(http://www.legislation.gov.uk/ukpga/2008/27/introduction/enacted).

${ }^{29}$ As fontes de energias renováveis e as metas nacionais de utilização de energia renovável no consumo final bruto de energia, incluindo os transportes, estão estabelecidas no Decreto-lei n. $0141 / 2010$ de 31 de dezembro, que transpõe a Directiva $n . \stackrel{0}{2009 / 28 / C E}$, do Parlamento Europeu e do Conselho, de 23 de abril.

${ }^{30}$ Mais informações da Agência Espacial Europeia sobre o tema disponíveis em

http://www.esa.int/por/ESA_in_your_country/Portugal/Swarm_revela_mudanca_no_campo_magnetico_da Terra.

31 A norma europeia sobre colocação de produtos biocidas no mercado (Directiva 98/8, de 16 de fevereiro) foi alterada 50 vezes, desde a sua publicação, em 1998.

32 O objectivo da Política Comum das Pescas é "garantir que a exploração dos recursos aquáticos vivos crie condições sustentáveis dos pontos de vista económico, ambiental e social" (§1 do preâmbulo do Regulamento n.1224/2009 do Conselho, de 20 de novembro.

${ }^{33}$ Em Portugal, todos os proprietários e arrendatários de utilizações dos recursos hídricos (poços, noras, furos, minas, charcas, barragens ou açudes, e quer se destine a consumo humano, rega ou actividade industrial) que não disponham de título que permita essa utilização, têm que pedir as devidas autorizações, licenças ou concessões de utilização, junto das autoridades competentes (Decreto-lei no 226A/2007, de 31 de Maio, sobre títulos de utilização dos recursos hídricos). Mais concretamente, no que respeita às águas subterrâneas, a lei "estabelece o "o regime de protecção das águas subterrâneas contra a poluição e deterioração (...) no respeitante à avaliação do estado químico da água subterrânea" (Decreto-lei n.ำ 208/2008, de 28 de outubro). A proteção dos recursos hídricos subterrâneos é também uma preocupação presente na Portaria $n .{ }^{\circ}$ 1284/2009 de 19 de Outubro, que estabelece o conteúdo dos planos de gestão de bacia hidrográfica, tal como previstos na Lei da Água: "A caracterização das massas de águas subterrâneas inclui: 5.5.1 - A localização e os limites das massas de água subterrâneas, discriminando as que se encontram associadas a ecossistemas aquáticos de superfície ou ecossistemas terrestres que delas dependem directamente; 5.5.2 - A identificação das características gerais dos estratos que cobrem a área de drenagem que alimenta as massas de águas subterrâneas; 5.5.3 - A
} 


\subsection{O Direito regula uma actividade nova e geradora de impactes ambientais}

O progresso pode também estar associado ao surgimento ou à generalização de actividades novas, que anteriormente não existiam de todo, ou pelo menos não eram desenvolvidas em grande escala. Os exemplos são a produção agrícola de organismos geneticamente modificados $^{35}$, a produção de energia eléctrica a partir da força motriz das ondas oceânicas ${ }^{36}$ ou a captura e armazenagem geológica de carbono ${ }^{37}$. Já a utilização de nanomateriais é actualmente uma lacuna legislativa, considerada por alguns sectores como uma omissão grave pelos riscos potenciais que comporta ${ }^{38}$. Ora o progresso resulta precisamente da aprovação de legislação enquadradora destas jovens tecnologias.

\subsection{O Direito cria um novo instrumento jurídico de proteção ambiental}

Finalmente, ocorre um progresso, quando é aprovado e posto em funcionamento um novo instrumento jurídico que configure uma abordagem inovadora - e que se venha a revelar justa e eficaz - de um dado problema ambiental.

É o caso da criação dos sistemas de gestão de fluxos de resíduos ${ }^{39}$ aplicável aos óleos, embalagens, equipamentos eléctricos e electrónicos, pneus, pilhas, acumuladores, veículos em fim de vida ou resíduos de construção e demolição.

Outros instrumentos jurídicos são a avaliação do impacte ambiental de projectos ${ }^{40}$, a avaliação estratégica de planos e programas ${ }^{41}$ ou o comércio de licenças de emissão ${ }^{42}$.

avaliação dos recursos hídricos subterrâneos disponíveis, incluindo a taxa de recarga global média anual a longo prazo (...)" (Anexo único).

${ }^{34} \mathrm{O}$ cianeto foi o contaminante presente no grave acidente industrial ocorrido em 30 de Janeiro de 2000 , na Roménia. O rebentamento de um tanque de decantação na mina de ouro pela empresa Aurul, em Baia Mare, levou à condenação da Roménia pelo Tribunal Europeu dos Direitos do Homem, em 2009. A legislação também regula esta matéria em Portugal: "no caso de uma bacia existente à qual esteja associada a presença de cianetos, o operador assegura que a concentração de cianetos (...) é reduzida ao mínimo possível, utilizando as melhores técnicas disponíveis (...) e em caso algum exceda: a) 50 ppm a partir da data de entrada em vigor do presente decreto -lei; b) 25 ppm a partir de 1 de Maio de 2013; c) 10 ppm a partir de 1 de Maio de 2018" (Decreto-lei n. ${ }^{\circ}$ 10/2010, de 4 de fevereiro).

${ }^{35} \mathrm{Na}$ União Europeia existem 16 variedades de organismos geneticamente modificados aprovadas, das seguintes espécies vegetais: soja, milho, colza, algodão e, desde 2010, batata.

${ }^{36}$ O regime jurídico de acesso e exercício da actividade de produção de electricidade a partir da energia das ondas encontra-se previsto no Decreto-lei n. ${ }^{\circ}$ 5/2008, de 28 de Janeiro.

${ }^{37}$ Regulado pela Directiva 2009/31, de 23 de Abril, relativa ao armazenamento geológico de dióxido de carbono, transposta pelo Decreto-lei $n . .60 / 2012$, de 14 de março.

${ }^{38}$ Praticamente sem regulação jurídica, os nano materiais são uma lacuna de difícil resolução já que a legislação sobre substâncias químicas, cujo regime faria sentido aplicar, analogicamente, aos nano materiais, tem sido expressamente afastada, por pressão dos interessados. O Regulamento $n . .9987 / 2008$, de 8 de Outubro, que altera o Regulamento n.o 1907/2006, relativo ao registo, avaliação, autorização e restrição dos produtos químicos (REACH), estabelece expressamente que "a revisão efectuada pela Comissão, nos termos do n. 4 do artigo 138., revelou que três substâncias constantes do anexo IV devem dele ser retiradas (...) [é] o caso do carbono e da grafite, nomeadamente porque os números Einecs e/ou CAS em causa são utilizados para identificar formas de carbono ou grafite à escala nanométrica, que não preenchem os critérios para a inclusão nesse anexo"(preâmbulo, §3).

39 Um fluxo é de resíduos é uma "a categoria de resíduos cuja proveniência é transversal às várias origens ou sectores de actividade, sujeitos a uma gestão específica" (artigo $3^{\circ}$ o) do Decreto-lei $n^{\circ}$ 178/2006, de 5 de Setembro, alterado pelo Decreto-lei $n$. $.73 / 2011$, de 17 de Junho). A propósito do princípio da hierarquia das operações de gestão de resíduos, a lei-quadro dos resíduos prescreve a obrigação de produtores de resíduos procederem à separação dos resíduos na origem, de forma a promover a valorização dos fluxos (artigo 7ํㅜ n.ํ4).

${ }^{40}$ A avaliação de impacte ambiental de projectos públicos e privados, este é um "instrumento de carácter preventivo da política do ambiente, sustentado na realização de estudos e consultas, com efectiva participação pública e análise de possíveis alternativas, que tem por objeto a recolha de informação, 
A supressão de qualquer destes regimes, sem substituição por outro ou por um conjunto de instrumentos igualmente eficazes, redundaria num retrocesso inadmissível.

\section{Segundo passo: análise da norma posterior}

Num segundo momento, deverá analisar-se o conteúdo da nova norma a fim de avaliar a existência e o grau do retrocesso. Aqui é preciso estarmos cientes de que o retrocesso ambiental não ocorre apenas se, subitamente, todo um bloco legislativo for revogado. Seria o caso, por exemplo, de o legislador revogar todas as leis de proteção de um determinado componente ambiental; ou se o exercício de uma actividade geradora de impactes passasse a ser livre de qualquer controlo jurídico; ou se fosse abolido um instrumento jurídico eficaz. É óbvio que, se se suprimissem todas as leis de conservação da natureza, todas as leis de gestão de resíduos ou todas as leis sobre avaliação de impacte ambiental, isso configuraria uma violação flagrantíssima do princípio da proibição do retrocesso.

Porém, estas situações-limite, felizmente, serão raras. Pelo contrário, o mais provável será que, mesmo sem uma supressão total de um domínio de proteção jurídica do ambiente, ocorram algumas pequenas involuções legislativas do direito ambiental.

Vejamos algumas hipóteses de normas suscetíveis de conduzir a um retrocesso gradual:

a) Revogação de normas de classificação de zonas naturais ou espécies selvagens protegidas;

b) Redução de perímetros de proteção em relação a instalações perigosas;

c) Redução ou suspensão de sanções ou incentivos,

d) Redução do número ou tipo de actividades proibidas ou condicionadas,

e) Remoção ou simplificação de processos de controlo (como autorizações prévias, notificações, registos, monitorizações, auditorias, ou fiscalizações);

f) Abolição ou compressão das competências de entidades ou órgãos de fiscalização, autorização ou consulta;

g) Restrição nas condições de acesso à informação ou de exercício do direito de participação;

h) Alterações processuais (regras sobre o ónus da prova, limitações quanto aos meios de prova, redução ou alargamento de prazos, etc.)

identificação e previsão dos efeitos ambientais de determinados projetos, bem como a identificação e proposta de medidas que evitem, minimizem ou compensem esses efeitos, tendo em vista uma decisão sobre a viabilidade da execução de tais projetos e respetiva pós-avaliação" (artigo $2^{\circ} \mathrm{d}$ ] Decreto-lei n.․․ 151-B/2013, de 31 de outubro).

${ }^{41}$ A avaliação ambiental de planos e programas é "a identificação, descrição e avaliação dos eventuais efeitos significativos no ambiente resultantes de um plano ou programa, realizada durante um procedimento de preparação e elaboração do plano ou programa e antes de o mesmo ser aprovado ou submetido a procedimento legislativo, concretizada na elaboração de um relatório ambiental e na realização de consultas, e a ponderação dos resultados obtidos na decisão final sobre o plano ou programa e a divulgação pública de informação respeitante à decisão final" (artigo $2^{\circ}$ a] do Decreto-lei n.ำ 232/2007, de 15 de Junho).

42 As licenças para emitir dióxido de carbono, ou gás equivalente, no âmbito de uma actividade industrial (nomeadamente, produção de energia, transformação de metais, produção de cimento, vidro, cerâmica ou papel) são transferíveis entre as instalações detentoras de títulos de emissão de gases com efeito de estufa, a fim de obter uma redução global das emissões destes gases responsáveis pelo sobreaquecimento global do Planeta. O comércio das licenças de emissões foi adotado em Portugal pelo Decreto-lei n. $.233 / 2004$, de 14 de Dezembro, alterado pelos Decretos -lei n. $.243-A / 2004$, de 31 de Dezembro, 230/2005, de 29 de Dezembro, 72/2006, de 24 de Março, e 154/2009, de 6 de Julho (que o republica). 
É importante notar que pode haver mil e uma formas diferentes de proteger os valores ambientais e, por isso, mil e um tipos de normas retrocedentes ${ }^{43}$.

As novas formas propostas podem ser aceitáveis e não configuram um retrocesso ambiental se forem, pelo menos, tão eficazes e justas do ponto de vista ambiental, como as anteriores. E, claro, será melhor ainda se forem menos onerosas em termos sociais ou económicos. Todavia, em virtude do princípio da precaução, é a quem pretender levar a cabo a alteração legislativa, que cabe fazer prova de que o nível de proteção é equivalente, tanto do ponto de vista da eficácia, como da justiça dos resultados.

Mas serão proibidas, com fundamento na violação do princípio de proibição de retrocesso, todas as alterações legislativas que modifiquem, reduzindo, o nível de proteção das regras de proteção ambiental estabelecidas?

Pensamos que não. Tal como nem todos os reforços na proteção do ambiente configuram progressos geradores do efeito de proibição de retrocesso, também nem todas as medidas redutoras do nível de proteção configuram retrocessos inadmissíveis. Há situações excepcionais em que uma aparente reformatio in pejus é admissível.

Apesar do princípio da proibição do retrocesso parecer apontar para um relativo imobilismo, a proteção legal do ambiente não deixa, mesmo assim, de ser dinâmica ${ }^{44}$ na medida em que haja razões relevantes que justifiquem alterações legislativas.

Assim, se na vigência das normas progressistas de proteção ambiental, os pressupostos subjacentes a tal progresso se alterarem profundamente, poderá haver uma justificação para alterar proporcionalmente as medidas anteriormente adotadas. Será o caso de alterações supervenientes, profundas e imprevisíveis, na conjuntura económica, social, cultural, institucional ou até ambiental em que foi aprovada a lei promotora do progresso. Vamos agrupar estas causas em três grandes categorias ${ }^{45}$ : razões ambientais, sociais e económicas do retrocesso.

\subsection{Razões ambientais de retrocesso}

Alterações ambientais supervenientes ocorrem quando o próprio ambiente evolui e reage positivamente às medidas de proteção ambiental. Assim, o nível de proteção ambiental pode variar - retrocedendo - se as condições ecológicas também tiverem variado, melhorando. Se o estado natural dos recursos evoluir, dispensando (tanta) proteção, a lei pode e deve ser alterada, permitindo a prossecução de outros objectivos sociais prioritários. Esta situação acontece quando as medidas de proteção adotadas produzem finalmente o efeito pretendido, de forma que a proteção legal deixa de ser necessária. Se uma lei foi aprovada no pressuposto de que uma dada espécie animal está em vias de extinção e mais tarde deixar de estar, passando a ser uma espécie abundante, desaparece a ratio da medida legislativa ${ }^{46}$. Em casos

\footnotetext{
${ }^{43}$ Mário Peña dá exemplos de retrocessos decorrentes de alterações de conceitos jurídicos, como aconteceu na Costa Rica com a Lei Florestal número 7575 de 1996, que modificou o conceito de "bosque" ("El test de regressividad ambiental", in Revista Internacional Direito Ambiental (RIDA), número 6, dezembro de 2013, pág. 9).

44 O "dinamismo" no direito administrativo é analisado por Carla Amado Gomes em Risco e modificação do acto autorizativo concretizador de deveres de protecção do ambiente de (Coimbra Editora, 2007).

45 Não analisaremos situações absolutamente excepcionais, que subvertem o estado de normalidade constitucional, como uma guerra ou uma catástrofe natural ou tecnológica.

${ }^{46}$ É o que acontece quando uma espécie da fauna ou da flora selvagens sai da lista vermelha de espécies em perigo, organizada e actualizada pela organização não governamental International Union for Conservation of Nature (IUCN) por o seu estado de conservação ter passado a ser favorável ou, pelo menos, quando muda de um estatuto de grande risco para um estatuto mais confortável. Infelizmente, os exemplos não abundam. Em 2010, por exemplo, o Ognorhynchus icterotis (ou Periquito Orejiamarillo como é conhecido na Colômbia e no Equador), deixou de estar no estado de "perigo crítico" em que
} 
como este, são as próprias causas naturais que levam à aceitação de medidas legislativas redutoras do nível de proteção.

Como não podia deixar de ser, há um "limite ao limite" a ter em consideração neste caso: a melhoria das condições naturais só releva, como causa justificativa do retrocesso, quando seja possível provar que essa melhoria resultou, directa ou indirectamente, da aplicação da lei nacional em causa.

A melhoria direta é a que resulta da classificação e proteção de certas áreas naturais ${ }^{47}$, articulada com a proibição de realizar obras de construção civil em zonas classificadas como zonas de proteção especial no âmbito da Rede Natura $2000^{48}$.

Ou ainda a melhoria consequente à rearborização e reflorestação promovidas pela legislação florestal ${ }^{49}$.

Ou mesmo a melhoria decorrente da proibição de emissão de descarga de poluentes para os cursos de água superficial ou para as águas subterrâneas incluídas nos programa de medidas para cada região hidrográfica nos termos da Lei da Água ${ }^{50}$.

A melhoria indirecta consiste na criação legal de organismos de tutela do ambiente, com competência de fiscalização de agressões ao ambiente e ao património natural, bem como de proteção dos espaços florestais e recursos associados ${ }^{51}$.

Pelo contrário, quando a melhoria das condições naturais decorreu do funcionamento normal de processos naturais (considerando que há ciclos de recessão e expansão que são normais no desenvolvimento natural de populações de espécies animais e vegetais), ou foi consequência de medidas privadas espontâneas (isto é, não impostas pelo ordenamento jurídico $)^{52}$, ou ainda quando derivou de medidas adotadas por outros Estados, noutros locais ${ }^{53}$, o recuo para um nível de proteção mais baixo não é admissível.

estava desde 1994, para estar apenas "em perigo", contando com um total de 11000 indivíduos em 2010. (http://www.iucnredlist.org/about/summary-statistics\#Table_7).

47 "As áreas terrestres e aquáticas interiores e as áreas marinhas em que a biodiversidade ou outras ocorrências naturais apresentem, pela sua raridade, valor científico, ecológico, social ou cénico, uma relevância especial que exija medidas específicas de conservação e gestão, em ordem a promover a gestão racional dos recursos naturais e a valorização do património natural e cultural, regulamentando as intervenções artificiais suscetíveis de as degradar" (artigo 10. ${ }^{\circ}$ n. ${ }^{\circ}$ do Decreto-lei n. ${ }^{\circ}$ 142/2008 de 24 de Julho, que regula a Rede Fundamental de Conservação da Natureza).

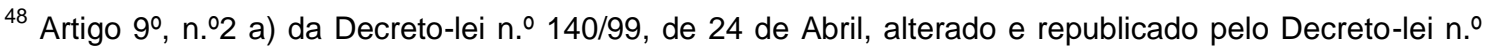
49/2005, de 24 de Fevereiro.

49 Estratégia Nacional para as Florestas (aprovada pela Resolução do Conselho de Ministros n.․․ 114/2006, de 15 de Setembro) e Sistema Nacional de Defesa da Floresta contra Incêndios (Decreto-lei n.으 $124 / 2006$ de 28 de Junho).

${ }^{50}$ Artigo $30^{\circ}$, da Lei n. $58 / 2005$, de 29 de Dezembro, que estabelece as bases e o quadro institucional para a gestão sustentável das águas.

${ }^{51}$ Como o Serviço de Proteção da Natureza e do Ambiente, criado pelo Decreto-lei n.ำ 22/2006, de 2 de Fevereiro, no âmbito da Guarda Nacional Republicana.

52 Como ações de organizações não governamentais ambientais ou medidas de proteção adotadas directamente por empresas, no âmbito da sua actividade económica, ou através de mecenato ambiental (artigo 62ํㅡ. n. .6 c) do Decreto-lei n. ${ }^{\circ}$ 215/89, de 1 de Julho, que aprova o Estatuto dos benefícios fiscais, alterado e republicado pelo Decreto-lei n. ${ }^{\circ}$ 108/2008, de 26 de Junho).

${ }^{53}$ No Acórdão de 20 de Janeiro de 2002, proferido no processo n. ${ }^{\circ}$ 103/00, contra a Grécia, o Tribunal de Justiça da Comunidade Europeia concluiu que o facto de o número de ninhos de tartaruga na ilha grega de Zákynthos, não ter diminuído nos últimos quinze anos não prova a inocuidade dos comportamentos adotados pelos turistas e curiosos, e tolerados pelo Estado grego. Pelo contrário, o Tribunal considerou como perturbadores tais comportamentos, independentemente de a perturbação se reflectir ou não em diminuição efectiva do número de exemplares, considerando que a manutenção ou até o aumento do número de indivíduos daquela espécie de tartarugas pode ser o resultado de medidas de proteção adotadas por outros Estados noutros pontos da Europa ou até fora da Europa. 


\subsection{Razões sociais de retrocesso}

Situação diferente é a que ocorre quando, durante a aplicação das medidas ambientais, se verificar que a sua manutenção tem elevados e imprevistos custos sociais, que as tornam excessivamente onerosas em relação a outros valores socialmente relevantes.

Não há, portanto, retrocesso invalidante quando a redução do nível de proteção resulta de uma alteração superveniente das circunstâncias, seja em virtude da revelação de efeitos laterais inesperados de uma medida ambiental, seja resultante da emergência de novos dados que alteram substancialmente $o$ contexto em que as medidas legislativas foram adotadas ${ }^{54}$.

Em qualquer dos casos, descobre-se que uma medida ambiental, que se supunha necessária, adequada e proporcional, tem, afinal, efeitos excessivos, comportando riscos graves e intoleráveis para valores elevados ${ }^{55}$ como a vida humana $^{56}$, a segurança alimentar $^{57}$, o saneamento básico ${ }^{58}$, a proteção civil ${ }^{59}$ ou a saúde pública ${ }^{60}$.

54 Sobre o paradoxo da insegurança jurídica gerada pelas normas, mesmo quando elas surgem intencionalmente como fontes de segurança jurídica e de redução da incerteza ver a obra de Elisabeth Baraduc e outros, Le traitement juridique et judiciaire de l'incertitude, Thèmes. Commentaires, Dalloz, 2008, pág. 12 e ss.

55 O regime jurídico da Rede Natura 2000 permite que algumas actividades humanas possam vir a ser desenvolvidas dentro de sítios da Rede Natura 2000 se existirem "razões imperativas de reconhecido interesse público" (artigo 10, nº10 do Decreto-lei n 140/99, de 24 de Abril, alterado pelo 49/2005, de 24 de Fevereiro).

${ }^{56}$ Como ocorreria se um crescimento súbito da população de lobos pusesse em risco as populações de zonas rurais e não apenas o gado. A Lei no 90/88, de 13 de Agosto, que estabelece as bases da proteção do lobo ibérico, proíbe o seu abate ou captura em todo o território nacional, mas o Decreto-lei n.ำ139/90 de 27 de Abril, prevê algumas excepções ao regime geral de proteção.

${ }^{57} \mathrm{O}$ estabelecimento de apertados limites à produção de biocombustíveis, ou até a supressão de alguns tipos de biocombustíveis, pode não ser um retrocesso ambiental Os mais graves efeitos laterais da produção agrícola de biocombustíveis são a reafectação sistemática de solos anteriormente dedicados a outras funções mais relevantes, como a produção de bens para alimentação humana ou animal, a produção florestal ou a silvicultura. Entre os céticos do "petróleo verde" veja-se, por exemplo, Lester Brown, em Plano B 4.0. Mobilização para salvar a civilização, Earth Policy Institute, New Content Editora e Produtora Ltda, São Paulo, 2009; Ricardo Abramovay (org.) Biocombustíveis. A energia da controvérsia. Senac, São Paulo, 2009; Heline Sivini Ferreira e José Rubens Morato Leite (org.) Biocombustíveis. Fonte de energia sustentável? Considerações jurídicas, éticas e técnicas Editora Saraiva, 2010). Foram todas estas preocupações que estiveram na origem dos critérios de sustentabilidade para os biocombustíveis e biolíquidos, do artigo $17^{\circ}$ da Directiva $2009 / 28$ de 23 de Abril, relativa à promoção da utilização de energia proveniente de fontes renováveis. Não são sustentáveis nomeadamente, os biocombustíveis produzidos a partir de matérias-primas provenientes de terrenos ricos em biodiversidade.

${ }^{58}$ Precisamente para evitar conflitos graves entre o direito de utilização das águas para abastecimento das populações e outros usos admissíveis é que a Lei da Água prevê uma ordem de preferência de usos: "no caso de conflito entre diversas utilizações do domínio público hídrico são seguidos os critérios de preferência estabelecidos no plano de gestão de bacia hidrográfica, sendo em qualquer caso dada prioridade à captação de água para abastecimento público face aos demais usos previstos, e em igualdade de condições é preferido o uso que assegure a utilização economicamente mais equilibrada, racional e sustentável, sem prejuízo da protecção dos recursos hídricos" (artigo 64\% n. n. ${ }^{\circ}$ da Lei n $^{\circ}$ $58 / 2005$, de 29 de Dezembro). Igualmente na ocorrência de um estado de emergência ambiental as Administrações de Região Hidrográfica devem definir prioridades de utilização dos recursos hídricos (artigo 44. ${ }^{\circ}$ da mesma Lei).

59 Imaginamos aqui o caso de uma hipotética revisão da lei de proteção de sobreiros e azinheiras

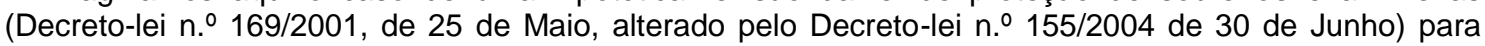
passar a prever expressamente o dever de abater árvores isoladas em situação de elevada instabilidade mecânica e risco de queda para via pública. Tal norma não configuraria uma situação de retrocesso.

60 Seria o caso de as leis de proteção de aves proibirem, em qualquer caso, o abate, mesmo de espécimes portadores do vírus $\mathrm{H} 5 \mathrm{~N} 1$, vulgo, gripe aviária. Na realidade, a lei portuguesa consagra excepções ao regime de proteção das espécies abrangidas pelo seu âmbito de proteção, "desde que não exista alternativa satisfatória, não seja prejudicada a manutenção das populações da espécie em causa num estado de conservação favorável, na sua área de distribuição natural, e quando o acto ou actividade (...) tenha como finalidade, nomeadamente, proteger a flora e a fauna selvagens e conservar os habitats 


\subsection{Razões económicas de retrocesso}

A questão mais complexa, e também a mais frequente, é a que se verifica quando se invocam razões económicas para justificar o retrocesso.

As recentes alterações da conjuntura económica e as constrições orçamentais, impostas pela crise, alimentam as críticas do mundo empresarial à política ambiental e fomentam a pressão social exigindo cortes nas políticas públicas, consideradas supérfluas. A ideia recorrentemente alardeada é a de que o ambiente não pode ser um "obstáculo ao desenvolvimento"61, argumento em relação ao qual estamos em total desacordo. Pensamos, em sintonia com Klaus Bosselmann, que a sustentabilidade ecológica é um pré-requisito do desenvolvimento e não um mero aspecto dele: só o desenvolvimento ambientalmente sadio pode satisfazer as necessidades das gerações actuais e futuras ${ }^{62}$.

Se o que está em causa é a obtenção de recursos financeiros para assegurar necessidades primárias, como a saúde humana, a segurança social ou o saneamento básico, consideramos que os recursos financeiros podem e devem obter-se prioritariamente através de cortes em outras políticas e em despesas menos prementes em termos imediatos: obras públicas não urgentes, algumas iniciativas culturais, apoio a certas competições desportivas, etc..

Sabendo que os valores económicos não devem ser, em regra, relevantes para justificar retrocessos ${ }^{63}$ ecológicos, como conciliar então a necessidade de poupança orçamental e de não sobrecarga das empresas, em época de crise e de recessão económica, com as exigências de manutenção do nível de proteção ambiental vigente?

Para fazer esse exercício de concordância prática, vamos considerar vários tipos de actividades de proteção ambiental com diferentes tipos de encargos:

a) Despesas de proteção ambiental activa através de medidas que implicam investimentos ambientais directos. Estes podem ser investimentos tipicamente

naturais" (artigo $20^{\circ}$, n. ${ }^{\circ} 1$ do Decreto-lei n. ${ }^{\circ} 140 / 99$, de 24 de Abril, alterado e republicado pelo Decreto-lei n. 0 49/2005, de 24 de Fevereiro).

Outro tanto aconteceria se a lei que regula a incineração e co-incineração de resíduos, impedisse a destruição pelo fogo de carcaças de bovinos afectados pela doença de Creutzfeldt-Jacob (encefalopatia espongiforme bovina), para não desrespeitar os valores-limite de emissões gasosas (Decreto-lei n.․․ 85/2005, de 28 de abril). Em Portugal, esta prática foi permitida em 2003 no âmbito das medidas complementares de luta contra a encefalopatia espongiforme bovina no domínio da alimentação animal: "as matérias-primas constituídas por proteínas animais transformadas referidas neste diploma e proibidas na alimentação animal são obrigatoriamente destruídas por incineração, sem prejuízo da destruição por qualquer outra forma que venha a ser considerada cientificamente apropriada de acordo com as melhores práticas internacionais e as normas em vigor de eliminação de resíduos" (artigo $4^{\circ}$ do Decreto-lei n.. 76/2003, de 19 de abril).

${ }^{61}$ Foi o que aconteceu quando a descoberta de uma colónia da espécie selvagem e vulnerável protegida por lei, o rato de Cabrera, obrigou a introduzir alterações ao traçado da estrada IP8, no Alentejo, dando origem a notícias sensacionalistas, como as publicadas no Jornal Expresso, em 4 de Julho de 2009, sob o título "O rato que vale 6,9 milhões de euros: mede entre 11,6 e 13 centímetros, tem pêlo comprido castanho-amarelado. Dá pelo nome científico Microtus Cabrerae e a sua preservação vai custar cerca de 6,9 milhões de euros, correspondentes a um centésimo do investimento total numa estrada no Alentejo". De facto, após a emissão, em Janeiro de 2004, de uma declaração de impacte ambiental favorável ao Traçado do IP8 no trecho Santiago do Cacém / Nó de Brissos, a descoberta do microhabitat do rato de Cabrera, em 2006, determinou a indispensabilidade de novas medidas de minimização sob pena de ficar comprometida a prossecução do projecto. Os estudos ambientais do relatório de conformidade ambiental do projecto de execução, volume I - Sumário Executivo (Alfragide, Dezembro de 2009, disponível em http://www.estradasdeportugal.pt/index), contêm informação pormenorizada sobre estas medidas.

62 The principle of sustainability: Transforming Law and Governance, Ashgate 2008, pág. 97 e ss.

63 Desenvolvendo a ideia ao não retorno de concretização dos direitos sociais, Jorge Miranda afirma que em situação de recessão ou crise financeira, as prestações sociais "devem ser adequadas ao nível de sustentabilidade existente, com eventual redução dos seus beneficiários ou dos seus montantes" (Manual de Direito Constitucional, Direitos Fundamentais, Tomo IV, 4ª ed. Coimbra Editora, 2008, pág. 443). 
públicos (como ações de reflorestação ${ }^{64}$, limpeza de praias por ocasião de marés negras ${ }^{65}$, anilhagem de espécies migratórias ${ }^{66}$ ou colheita de espécies invasoras ${ }^{67}$ ) ou investimentos tipicamente privados (como medidas de adaptação às melhores técnicas disponíveis ${ }^{68}$, medidas de prevenção ou mitigação de danos ${ }^{69}$ ou compensação de impactes $^{70}$ ).

b) Despesas decorrentes do cumprimento de obrigações administrativas, nomeadamente dos processos autorizativos e de controlo, que se traduzem em investimentos indirectos e que podem ser pagamentos ao Estado (taxas, tarifas) ou encargos em tempo e recursos humanos, para cumprir as exigências postas pela administração ambiental $^{71}$.

c) Custos de proteção associados à simples abstenção de novas ações lesivas ou perturbadoras. São os lucros cessantes, decorrentes da não realização de actividades poluentes, ou nocivas para o ambiente, mas que certamente trariam outras vantagens para o promotor da actividade, seja ele publico ou privado, ou até para o

${ }^{64}$ O Código Florestal define rearborização como "a regeneração do coberto florestal por via quer de regeneração natural, com recurso a reprodução vegetativa ou seminal, quer por via de regeneração artificial, com recurso a plantação ou sementeira" (artigo $2^{\circ}$ ooo]) e obriga o proprietário ou produtor florestal de espaços florestais arborizados percorridos por incêndios florestais "a promover o aproveitamento da regeneração natural ou a efectuar a sua rearborização, em solo rural (...)" (artigo $23^{\circ}$ do Decreto-lei n.. 254/2009, de 24 de setembro).

65 De acordo com o Plano de Emergência para o Combate à Poluição das Águas Marinhas, Portos, Estuários e Trechos navegáveis dos Rios, por Hidrocarbonetos e outras Substâncias Perigosas em caso de poluição por hidrocarbonetos, as medidas de intervenção seguem uma ordem de prioridades: contenção e recolha primeiro junto à fonte poluidora, depois no mar, proteção física de locais sensíveis, recolha e limpeza de costas e margens atingidas, aplicação criteriosa de dispersantes, transporte dos produtos recolhidos para tratamento e eliminação adequados (Resolução do Conselho de Ministros no 25/93, de 7 de fevereiro, C - Princípios e procedimentos, n.ํ).

${ }^{66}$ A anilhagem é a "a técnica de estudo biológico das espécies e populações de aves selvagens, que consiste na sua captura, marcação com uma anilha e posterior libertação" (artigo $3^{\circ}, \mathrm{n} .{ }^{\circ} 1 \mathrm{r}$ ) do Decreto-lei n.. 49/2005, de 24 de Fevereiro).

67 A lei que regula a introdução na Natureza de espécies não indígenas da flora e da fauna, interdita, salvo algumas excepções, a disseminação ou libertação na Natureza de espécimes de espécies não indígenas visando o estabelecimento de populações selvagens (artigo $3^{\circ}$ ). Em caso de desrespeito, independentemente da aplicação da coima e das sanções acessórias, o infractor pode ser intimado a proceder, a suas expensas, à erradicação da espécie introduzida (artigo 25). Se não se conseguir identificar o infractor, essa é uma tarefa do Estado (Decreto-lei n.ํ565/99, de 21 de dezembro).

68 Nos termos da Lei que estabelece a prevenção e controlo integrados da poluição (Decreto-lei no 173/2008, de 26 de Agosto) a melhor técnica disponível é "a fase de desenvolvimento mais avançada e eficaz das actividades e dos respectivos modos de exploração, que demonstre a aptidão prática de técnicas específicas para constituir, em princípio, a base dos valores limite de emissão com vista a evitar e, quando tal não seja possível, a reduzir de um modo geral as emissões e o impacte no ambiente no seu todo" (artigo $2^{\circ}$, I]). A aplicação das melhores técnicas disponíveis é uma obrigação dos promotores das actividades listadas em anexo ao diploma.

${ }^{69}$ A Lei de responsabilidade ambiental estabelece que o operador que, independentemente da existência de dolo ou culpa, causar um dano ambiental ou uma ameaça iminente daqueles danos em resultado da sua actividade, é responsável pela adopção de medidas de prevenção e reparação dos danos ou

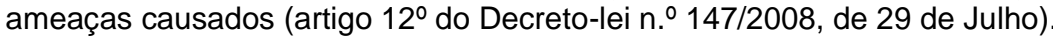

${ }^{70}$ Segundo a Lei de avaliação de impacte ambiental, um dos principais objectivos deste procedimento é prever a execução de medidas destinadas a evitar, minimizar e compensar tais impactes de modo a auxiliar a adopção de decisões ambientalmente sustentáveis" (Artigo $4 .^{\circ}$ do Decreto-lei n.․ 69/2000, de 3 de Maio, alterado e republicado pelo Decreto-lei n. ${ }^{\circ}$ 197/2005, de 8 de Novembro).

${ }^{71}$ De acordo com o Programa de Simplificação Administrativa e Legislativa — Simplex 2006 —, "encargos administrativos são custos para os cidadãos, para as empresas ou outros agentes e sectores de actividade, derivados do cumprimento de formalidades administrativas, de obrigações de prestação de informações e da sujeição a ónus ou encargos, de origem legal ou regulamentar, directa ou indirectamente, ligados ao exercício de direitos e à prática de actos e actividades". A Simplificação Administrativa e Legislativa é um objectivo nacional mas também europeu, aprovado pelo Conselho Europeu de Março de 2007 através do Programa de Ação para a Redução dos Encargos Administrativos na União Europeia. 
país e para o bem-estar geral da população: criação de postos de trabalho, melhoria da mobilidade ferroviária, fluidez do tráfego rodoviário, ampliação da cobertura da rede eléctrica nacional, reforço da produção de energias renováveis, povoamento de zonas rurais desertificadas, eficácia dos sistemas de telecomunicações, reforço da atractividade turística, etc.

Quando se trata de investimentos directos, a conciliação possível entre desenvolvimento económico e proteção do ambiente pode passar por alterar as regras de funcionamento da política ambiental:

Se se trata de medidas públicas e os contribuintes estão muito onerados, considerando-se necessário reduzir as despesas do orçamento de Estado, então deverá equacionar-se a hipótese de internalizar esses custos (tornando-os medidas obrigatórias para os poluidores) ou então imputá-los, pela via extra-fiscal, aos potenciais poluidores, para que as ações públicas de proteção ambiental que impliquem despesas do Estado, se auto-financiem. Esta é a solução preferível por ser a mais compatível com o princípio do poluidor pagador, e por isso mesmo, a mais eficiente e mais justa.

Se, pelo contrário, se trata de medidas privadas, baseadas no princípio do poluidor pagador, e os operadores têm dificuldades em suportar os encargos, deve ser equacionada a hipótese de mudar total ou parcialmente para um financiamento público. Nesse caso o Estado, financiado pelos contribuintes através de um sistema fiscal clássico (baseado na tributação do rendimento do trabalho, do património ou do consumo) passará a suportar, em primeira instância, os encargos que só mais tarde, ou em condições mais favoráveis (maxime, através de pagamentos fraccionados) serão transferidos para os poluidores.

Relativamente aos investimentos indirectos, o reforço da competitividade económica, livre dos espartilhos do cumprimento de desnecessárias obrigações burocráticas (notificações, autorizações, registos, relatórios de monitorização e de conformidade, etc.) é uma das vantagens directas da simplificação administrativa. Mas a simplificação não pode ser um objectivo a prosseguir sem quaisquer limites de natureza ambiental, sob pena de redundar em retrocessos ambientais reais.

Quais são então as formas de simplificação admissíveis ${ }^{72}$, que não conduzem a retrocesso ambiental? Alguns exemplos, são:

a) medidas de simplificação, que consistam numa forma mais simples de cumprimento das obrigações existentes, (por ex. notificações ou registos através de meios electrónicos e telemáticos) mas não em remoção de obrigações;

b) substituição de hetero-controlos por auto-controlos vigiados ou estatisticamente controlados;

c) remoção de obrigações, que se destinassem apenas a confirmar dados já na posse da Administração, ou que possam ser deduzidos ou obtidos por outras vias menos onerosas, como cruzamento de informação disponível em bases de dados informáticas.

\footnotetext{
72 Em Constituição e tempo ambiental (RevCEDOUA nำ4, 2/1999, pág. 11 e ss) Gomes Canotilho apresenta propostas de aceleração procedimental para resolver o problema da "duração justa dos procedimentos adminstrativos ambientalmente relevantes".
} 


\section{Condições gerais de admissibilidade excepcional de normas retrocedentes}

Com base no que foi dito anteriormente, é possível estabelecer algumas condições gerais, que devem ser verificadas para julgar da admissibilidade de medidas retrocedentes:

Uma matriz permite visualizar mais facilmente as várias hipóteses avançadas

\begin{tabular}{|c|c|c|}
\hline $\begin{array}{c}\text { EFEITOS AMBIENTAIS DO } \\
\text { RETROCESSO }\end{array}$ & Pouco graves & Graves \\
\hline Reversíveis & Retrocesso admissível & $\begin{array}{c}\text { Retrocesso admissível } \\
\text { em "estado de necessidade" }\end{array}$ \\
\hline Irreversíveis & $\begin{array}{c}\text { Retrocesso admissível em } \\
\text { "estado de necessidade" }\end{array}$ & Retrocesso não admissível \\
\hline
\end{tabular}

1) Condições temporais. $O$ retrocesso imposto não pode ser permanente, mas antes uma solução temporária para acorrer a uma situação conjuntural. Mais, a medida deve ser aprovada com um horizonte temporal definido ab initio e que não pode ser condicional, como por exemplo se se dissesse que uma medida vigorará "até que passe a crise". Naturalmente que, mantendo-se as circunstâncias, a medida pode ser renovada por novos períodos, mas a provisoriedade obriga à revisão e reponderação periódica.

2) Condições consequenciais. Quando se diz que uma determinada lei leva a um retrocesso é porque o bem fica menos protegido (retrocesso reversível) ou é mesmo aniquilado (retrocesso definitivo). A definitividade ou reversibilidade do retrocesso não dependem de a lei ser revogável ou não, mas sim das consequências ambientais que decorram da aprovação da lei.

Se o efeito da nova lei retrocedente é a aniquilação definitiva do bem jurídico ambiental (extinção da espécie, eutrofização do rio, esgotamento do recurso, destruição da paisagem) então é um retrocesso definitivo. O retrocesso definitivo é grave, pelo que deve ser absolutamente banido.

Se a redução leva à degradação mas não à aniquilação do bem jurídico é apenas um retrocesso reversível, que não é tão grave e, por isso, pode ocorrer pontualmente, em casos justificados, para proteger outros valores juridicamente relevantes.

Sinteticamente, o princípio da proibição do retrocesso destina-se a evitar degradações reversíveis mas graves ou então degradações de menor gravidade embora irreversíveis, ou seja, existe uma proibição do retrocesso definitivo e uma proibição do retrocesso reversível. A proibição de retrocesso, sendo os efeitos reversíveis, é relativa, admitindo compressões em função de outros valores social ou ambientalmente relevantes. Sendo os efeitos irreversíveis, a proibição de retrocesso é absoluta, ou seja, não admite derrogações, salvo em caso de estado de necessidade.

Se não houver certezas, ou seja, se a ocorrência de efeitos danosos for apenas uma possibilidade, também não pode haver retrocesso se os hipotéticos efeitos ambientais forem muito graves ou irreversíveis. Se os efeitos forem reversíveis mas graves, ou então pouco graves mas irreversíveis, entra em jogo a proporcionalidade para ponderar a admissibilidade da medida ${ }^{73}$.

\footnotetext{
73 Sobre "ponderação ecológica" enquanto dever de os "decisores jurídicos" tomarem "em consideração nos seus juízos os efeitos ambientais de obras, actividades, serviços ou planos ecologicamente relevantes", ver "Relações jurídicas poligonais, ponderação ecológica de bens e controlo judicial
} 
3) Condições teleológicas. O retrocesso só é possível para salvaguardar valores jurídicos concretos de grande relevância. Vagas alegações de que "estamos em crise" e de que a proteção do ambiente "é um luxo que não podemos suportar", não são relevantes. $O$ facto de a proteção do ambiente implicar custos e envolver investimentos não é fundamento suficiente para uma aceitação imediata da redução do nível de proteção ambiental. Pelo contrário, as razões invocadas devem ser razões prementes (carecidas de actuação urgente), graves (correspondendo a valores de importância igual ou superior ao ambiental), necessárias (estritamente indispensáveis) adequadas (coerentes e não discriminatórias) e proporcionais (o grau de compressão da proteção ambiental deve ser em medida equivalente à necessidade de promoção do valor conflituante).

\section{Conclusão}

Fruto do reconhecimento da importância vital do equilíbrio ambiental, por um lado, e da insustentabilidade das interferências antropogénicas nos sistemas naturais, por outro, o ambiente ganhou um lugar muito especial na constelação de valores constitucionais protegidos ao nível dos Estados e da União Europeia.

O princípio da proibição do retrocesso surge, assim, como uma garantia de evolução "rumo ao desenvolvimento sustentável" ${ }^{\prime 74}$. Também nas palavras de Morato Leite e Matheus Almeida Caetano, "a proibição do retrocesso ecológico seria um instrumento apropriado para traçar os limites desta Sustentabilidade Material (...)"

O princípio da proibição do retrocesso é a garantia de que, apesar das flutuações políticas e das turbulências eleitorais, apesar das crises profundas e duradouras, apesar da miopia ambiental das presentes gerações, apesar das ideologias cultoras do ceticismo climático e ambiental... a legislação de proteção do ambiente não pode deixar de ter uma certa estabilidade, de forma a permitir a construção de uma sociedade mais justa, mais sustentável e envolta por um ambiente mais íntegro e diversificado.

Em suma, defendemos que o novo entendimento do Estado, como Estado de Direito Ambiental, exige uma política ambiental dinâmica e progressista, em sintonia com 0 desenvolvimento sustentável, porque acreditamos, com Gomes Canotilho, que "o ambiente é caro, mas nunca é demasiado caro"76.

\section{Bibliografia}

Abramovay, Ricardo (org.) Biocombustíveis. A energia da controvérsia. Senac, São Paulo, 2009.

Andrade, Vieira de, $O$ 'Direito ao mínimo de existência condigna' como direito fundamental a prestações estaduais positivas. Uma decisão singular do Tribunal constitucional. Anotação ao

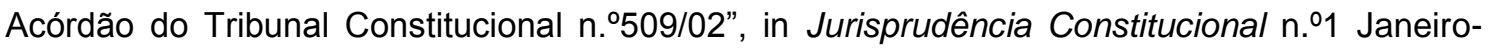
Março de 2004.

preventivo" (in Revista jurídica do Urbanismo e do Ambiente, n.1, 1994, pág. 58 e ss.) de Gomes Canotilho.

74 "Rumo ao desenvolvimento sustentável" era o título do Quinto Programa de Ação em Matéria de Ambiente e Desenvolvimento Sustentável, aprovado dela Resolução do Conselho e dos representantes dos Governos dos Estados-membros em 1 de Fevereiro de 1993.

75 Aproximações à sustentabilidade material no Estado de Direito Ambiental Brasileiro, in José Rubens Morato Leite, Heline Silvini Ferreira e Matheus Almeida Caetano, Repensando o Estado de Direito Ambiental, Funjab, Florianópilis 2012, pág. 180.

${ }^{76}$ Proteção do ambiente e direito de propriedade (crítica de jurisprudência ambiental), Coimbra Editora, 1995, pág. 105. 
Aragão, Alexandra, "Desenvolvimento sustentável em tempo de crise e em maré de simplificação. Fundamento e limites da proibição de retrocesso ambiental", publicado no volume IV da obra Estudos em homenagem a Joaquim Gomes Canotilho, Alves Correia, Jónatas Machado e João Carlos Loureiro (organizadores) Coimbra Editora, 2012.

Baraduc, Elisabeth e outros, Le traitement juridique et judiciaire de l'incertitude, Thèmes. Commentaires, Dalloz, 2008.

Bosselman, Klaus, The principle of sustainability: Transforming Law and Governance, Ashgate 2008.

Brown, Lester, Plano B 4.0. Mobilização para salvar a civilização, Earth Policy Institute, New Content Editora e Produtora Ltda, São Paulo, 2009.

Canotilho, Gomes, "Relações jurídicas poligonais, ponderação ecológica de bens e controlo judicial preventivo" in Revista jurídica do Urbanismo e do Ambiente, n.ำ1, 1994.

Canotilho, Gomes, Constituição e tempo ambiental, RevCEDOUA noㄴ, 2/1999.

Canotilho, Gomes, Protecção do ambiente e direito de propriedade (crítica de jurisprudência ambiental), Coimbra Editora, 1995.

Canotilho Gomes, Relações jurídicas poligonais, ponderação ecológica de bens e controlo judicial preventivo" in Revista jurídica do Urbanismo e do Ambiente, n.ำ1, 1994.

Peña Chacón, Mario (dir), El principio de no regresión ambiental en el derecho comparado latino-americano, PNUD, San José, 2013.

Peña Chacón, Mario, Test de regresividad ambiental in Revista Internacional Direito Ambiental (RIDA), número 6, dezembro de 2013

Peña Chacón, Mario, Límites, restricciones y excepciones del principio de prohibición de regresividad ambiental, in Revista de Derecho Ambiental Thompson Reuter de Argentina (no prelo).

Ferreira, Heline Sivini e José Rubens Morato Leite (org.) Biocombustíveis. Fonte de energia sustentável? Considerações jurídicas, éticas e técnicas Editora Saraiva, 2010.

Gomes, Carla Amado, Risco e modificação do acto autorizativo concretizador de deveres de protecção do ambiente, Coimbra Editora, 2007.

Leite, José Rubens Morato; Ferreira, Heline Silvini e Caetano, Matheus Almeida, Repensando o Estado de Direito Ambiental, Funjab, Florianópilis 2012.

Miranda, Jorge Manual de Direito Constitucional, Direitos Fundamentais, Tomo IV, 4⿳亠丷a ed. Coimbra Editora, 2008.

Prieur, Michel, Droit de l'environnement, droit durable, Brylant, Bruxelas, 2014.

Prieur, Michel e Sozzo, Gonzalo (dir.), La non régression en droit de l'environnement, Bruylant, 2012, pág.5-46.

Queiroz, Cristina, Princípio da não reversibilidade dos direitos fundamentais sociais. Princípios dogmáticos e prática jurisprudencial, Coimbra Editora, 2006.

Rosnay, Joel de, O Macroscópio. Para uma visão global, Estratégias Criativas, Vila Nova de Gaia, 1995 (em versão inglesa - The Macroscope - disponível em http://www.appreciatingsystems.com/wp-content/uploads/2011/05/The-Macroscope.pdf). 


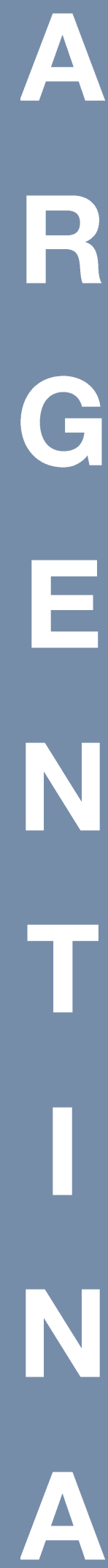



\title{
LA «REGRESIÓN» ACECHA AL DERECHO AMBIENTAL. LA DOCTRINA ESTÁ ALERTA.
}

\author{
Mario F. Valls*
}

"En materia ambiental, detenerse equivale a regresar".

\section{Introducción}

Se expande la preocupación por la regresión jurídica ambiental. A medida que avanza la acción ambiental se encuentran trabas regresivas, a veces en las mismas normas jurídicas que deberían ser progresivas por la motivación de la rama jurídica a que pertenecen.

El egoísmo humano induce la regresión ambiental y el temor a la represión a su disimulo. Errores y sofismas en la formación y aplicación de una creciente cantidad de normas provenientes de diversidad de fuentes facilitan la regresión.

Agréguese a ello la confusión que genera la proliferación de estructuras administrativas que la comunidad crea para aplicarlas y aumentarlas.

Agréguese lo difícil que es medir la regresión y decidir cuales deben ser sus límites y modalidades.

Agréguese la multiplicidad de tipos de regresiones jurídicas posibles y de ardides engendradas por la imaginación humana para escapar de la ley y regresar a disfrutar del despojo y se tendrá la imagen de un caos creciente que aún cuando no solo trabe el progreso ambiental genera la regresión. Todo eso trata la presente colaboración.

\section{El derecho ambiental es «no regresivo» Es «progresivo»}

La regresión ambiental se contradice con el derecho al ambiente.

Por lo menos en el derecho ambiental que conocemos y tratamos de estudiar regresión implica transgredir el derecho humano al ambiente. Por lo tanto, toda norma o acto "regresivo" son antijurídicos. No son válidos. Todo menoscabo del derecho humano al ambiente es siempre una transgresión, sea regresiva o no con relación a una situación jurídica anterior.

En la Argentina la cláusula del progreso de la Constitución Nacional encomienda al Congreso proveer lo conducente a la prosperidad del país, al adelanto y bienestar de todas las provincias (artículo 75 inc. 18), al desarrollo humano, al progreso económico con justicia social y a la productividad de la economía nacional (id. inc. 19) autoriza a interpretar que el Congreso no puede emitir ninguna norma regresiva y que toda norma regresiva que sancionase constituiría un exceso de poder.

Como refuerzo siempre nos auxilia el artículo 33 de la Constitución Nacional que garantiza a todos los derechos que surgen de la soberanía del pueblo y de la forma republicana de gobierno, incluso el derecho al ambiente.

Por otra parte, mirando más arriba y más lejos, vivir honestamente y no perjudicar a tercero son principios eternos del derecho. La regresión ambiental es lo inverso. La regresión ambiental los viola.

\footnotetext{
*Profesor de Derecho Ambiental, Universidad de Buenos Aires, Argentina.
} 
En consecuencia la «no regresión» ambiental debería darse por sobreentendida. La lectura de normas, fallos y opiniones jurídicas ambientales muestra que se la acepta implícitamente como principio del derecho ambiental.

La regresión ambiental de que nos venimos quejando permanentemente los últimos sesenta años responde a razones éticas, filosóficas y jurídicas más que a razones físicas, ecológicas, o económicas.

Cuando a mediados del siglo pasado el mundo advirtió la fuerte regresión ambiental que condujo a reiteradas Conferencias planetarias, también advirtió que se había producido en violación del derecho, de la ética, de la razón y de la religión. ${ }^{1}$

La permanencia y serenidad que se le atribuye al derecho en general no vale en materia ambiental porque el ambiente cambia espontáneamente y por acción antrópica.

La mera preservación del ambiente demanda una acción permanente. El "stand still» no basta en materia ambiental. La casa, los dientes y el ambiente se deben limpiar todos los días. Hasta el éxito de la norma obliga a cambiarla cuando logra su objetivo por normas que apunten a objetivos superadores.

Todo lo expuesto evidencia que no sólo el derecho ambiental no solo debe ser «no regresivo", sino también «progresivo».

Sin embargo, la regresión siempre obstruyó a la norma ambiental y lo hizo más que en otras materias. Obstruyó el recto cumplimiento conocimiento frecuentemente recurriendo a disimulos y sofismas, leguleyos y generalmente antijurídicos.

Es oportuno advertir a los cultores del derecho ambiental de una amenaza que viene de afuera, pero lo entorpece y corroe.

\section{Motivos de la regresión jurídica ambiental y de su disimulo}

El uso, ocupación o menoscabo del ambiente total o parcialmente ajeno genera ventajas y la regresión es una de las formas más cómodas de alcanzarlas y mantenerlas.

El sujeto y los grupos que se benefician con el deterioro del ambiente ajeno suelen ser múltiples y difusos y no todos deterioran desde el mismo lugar, del mismo modo, con la misma magnitud y calidad y en la misma oportunidad. Los perjuicios suelen ser variados y en algunos casos la perjudicada es toda la humanidad. La difusión del perjuicio contribuye a diluirlo y a veces a reducirlo a niveles insuficientes para inducir a cada perjudicado individual a accionar y afrontar las cargas procesales que la tutela de su interés requiere. ${ }^{2}$ La historia ambiental de la humanidad expone una regresión en algunos aspectos y una clara progresión en otros. Es cierto que las selvas naturales de Europa fueron destruidas en gran parte, pero simultáneamente se construyeron ciudades, obras públicas y privadas y se les dio a los seres humanos lugares para vivir y desarrollarse y progresar que nos apresuramos por visitar y admirar.

No hace falta abundar en ejemplos, pero los hay y muchos.

\footnotetext{
${ }^{1}$ Russell, Bertrand, Has Man a Future?, Allen \& Unwin, London, 1961; Carson, Rachel, Silent Spring, Crest, New York, 1969; Ward, Barbara et al, Una sola tierra, Fondo de Cultura Económica, México, 1972., 11 Meadows, Donella et al., The Limits to Growth. A Report for the Club of Rome's Project on the Predicament of Mankind, Potomac, London, 1972, Perón, Juan Domingo, Mensaje a los pueblos y gobiernos del mundo, Madrid, 23 de marzo de 1972.

${ }^{2}$ Coase, Ronald H., premio Nobel de Economía, 1991, "The Problem of Social Cost", Journal of Law and Economics", vol. 3, 1960, p. 1.
} 
Para provocar la regresión basta aprovechar cualquier descuido, distracción u olvido del que la padece. La alevosía y el disimulo la favorece.

El derecho ambiental norma precisamente el uso, ocupación o menoscabo del ambiente ajeno, que puede ser lícito o ilícito según sea el resultado de una prerrogativa o de una usurpación. Norma el drama en la lucha del hombre por su derecho sobre al ambiente contra quién se lo limita, cercena o niega de algún modo.

Quien se beneficia limitándolo, cercenándolo o negándolo suele usar ardides para frustrar ese derecho que, por lo menos postergan la aplicación de la norma y hasta logran disuadir o frustrar el reclamo. En estos casos la litis no se compone con justicia, subsiste la violación de la norma, lo es también ilógico y antiético.

La opción entre progresión y regresión es clara: los seres humanos preferimos el progresión, pero no todos los seres humanos prefieren el progreso del prójimo, sobre todo si es en vez del propio. El uso, ocupación o menoscabo del ambiente ajeno genera ventajas y la regresión es un de las formas más alevosas y disimuladas de alcanzarla. Esto último explica la regresión apuntada. El que la provoca aprovecha cualquier descuido, distracción u olvido del sujeto pasivo. Por eso son tan antiguas, frecuentes y obstructivas.

Como nadie quiere admitir que tiene esa conducta regresiva, simula que no regresa, pero cambia de color como el camaleón y el famoso Príncipe Fabrizio di Salina (El gatopardo) de la conocida novela italiana. Ello explica el disimulo. Quien daña el ambiente ajeno se esconde, como el gato que rompió el florero de la abuela.

Por eso las regresiones ambientales son tan antiguas, frecuentes y obstructivas.

\section{$3 \quad$ Multiplicidad de tipos de regresiones jurídicas}

Pueden distinguirse varios tipos distintos de regresiones, a veces son explícitas, otras son disimuladas por lo que acabamos de comentar.

Una disimulada muy común es dejar una laguna o resquicio para excluir a alguna situación particular. Hay redacciones que parecen hechas por orfebres, otras son mas frontales.

Un ejemplo es el de la ley 26854 sobre las medidas cautelares, tan necesarias en materia ambiental por las características del daño ambiental. El que lo causa, puede premeditarlo y elegir alevosamente la oportunidad de infligirlo, mientras que el que lo padece debe advertirlo y advertir sus efectos cuando ya se produjo o está produciendo.

La ley 26854 impuso una regresión explícita cuando restringió las medidas cautelares en contra del Estado Nacional (arts. $2^{\circ}$, apartado 2, $4^{\circ}$ apartado $3,14,15,16$ ) y prohibió las que afecten, obstaculicen, comprometan, distraigan de su destino o de cualquier forma perturbe los bienes o recursos propios del Estado, impongan a los funcionarios cargas personales pecuniarias.

Otra clara regresión explícita la impone el Artículo 1974 del Código Civil y Comercial que entró en vigencia el primero de agosto de 2015 que reduce a pocos casos y a solo quince metros la calle o camino público de treinta y cinco metros de ancho en toda la extensión del curso de agua en los que el ribereño debía dejar libre y no hacer construcción alguna, reparar las antiguas que existieran, ni deteriorar el terreno que imponía el artículo 2639 del Código Civil derogado.

Además limita la intangibilidad a cauces o riberas aptos para el transporte por agua y al acto que menoscabe el transporte. Más aún, disimula la regresión, cambiándole el nombre por el de camino de sirga que rememora un uso muy antiguo prácticamente ajeno a nuestro país. 
La obligación que se reduce ya existía en el derecho indiano y mantuvo en estado natural millones de hectáreas ribereñas a los cursos que servián a la comunicación por agua, lo que al permitir el normal escurrimiento de las crecidas evita daños a personas y cosas.

No es la olvidada navegación a la sirga la que la reforma propone dejar atrás.

La propuesta priva a la comunidad de precaverse contra actividades susceptibles de causar grandes daños y deja al albur de cada uno la defensa de sus derechos, ya que la prohibición mantiene expeditas vías que podrían ser necesarias para la evacuación de crecidas o para evitar inundaciones.

Reducir esa franja a menos de la mitad equivale a donar el derecho a construir y modificar el terreno sobre los millones de hectáreas ubicados más allá de los quince metros de la ribera.

Además obliga a la comunidad a sancionar la correspondiente ley e indemnizar previamente cada vez que sea necesario suprimir en ese espacio alguna construcción, reparar antiguas o corregir cualquier deterioro del terreno para evacuar crecidas, evitar inundaciones o por cualquier otra causa de utilidad pública.

La reforma disminuye considerablemente el patrimonio natural de la generación presente y de las futuras y genera un riesgo de inundación.

Patrimonialmente invierte la relación de poder entre la comunidad y el ribereño.

El Artículo 41 de la Constitución Nacional reconoce a todos los habitantes el derecho y les impone la obligación de "que las actividades productivas satisfagan las necesidades presentes sin comprometer las de las generaciones futuras".

La propuesta no solo afecta ese derecho de las generaciones futuras y el cumplimiento de esa obligación sino también el de las generaciones presentes sin otra contraprestación que beneficiar a una determinada categoría de propietarios.

Además, establecería sobre el erario público una carga que puede ser gigantesca y comprometer las necesidades de las generaciones presentes y de las futuras.

Si lo que se quiere es permitir a los propietarios de esas áreas de alto valor económico realizar construcciones o modificaciones rentables habría que estudiar alternativas que no lo hagan a costa de los recursos ambientales de la comunidad.

Además de estas claras regresiones normativas, las hay también políticas, administrativas y jurisprudenciales.

Accionando con una misma norma practican regresión al aplicarla los 3 poderes del Estado, el que administra, el que juzga y el que dicta la norma complementaria, como en el caso de los de presupuestos mínimos ambientales. Obviamente, también la practican, cuando pueden, los individuos a quienes beneficia.

\section{Normas autoregresivas. La norma procesal es la más esgrimida}

A veces, el mismo poder emisor de la norma le pone una traba que enerva su cumplimiento.

Por ejemplo encomienda una acción complementaria a quien no tiene interés en realizarla.

El artículo 26 de la ley 25612 publicada en el Boletín Oficial el 29/07/02 supedita la circulación interjurisdiccional de los residuos que norma a un acuerdo interjurisdiccional que todavía no se elaboró. En consecuencia, no hay norma rectora de la circulación interjurisdiccional de esos residuos. 
Claro que si se hubiese elaborado la lista, la ley 25612 tampoco se podría aplicar porque su artículo $7^{\circ}$ establece que la autoridad de aplicación nacional, conforme lo previsto en el art. 57 incisos a) y c), concertará con las provincias en el ámbito del Consejo Federal del Medio Ambiente (COFEMA), los niveles de riesgo que poseen los diferentes residuos. Esa concertación es el pivote sobre el que gira todo el sistema. Es necesaria para cumplir el mandato de los artículos $2^{\circ}, 3^{\circ}, 7^{\circ}, 8^{\circ}, 14,15,17,29,31,57$ incs. a) y c) y 59 . Todavía no lo hizo y todo indica que no lo va a hacer. La justificación es la imposibilidad de hacerlo que se trata en 8.- Ardides para obstar a la protección jurídica del ambiente. Ardid 4.- Invocar la imposibilidad del cumplimento.

El legislador podría haber adoptado la lista aprobada por el Convenio de Basilea para residuos similares, como hizo cuando sancionó la ley 24051 , pero no lo hizo.

Para evitar elusiones como estas, hace un cuarto de siglo un inteligente fallo de la Corte de Justicia de Salta tuvo por legitimado a un grupo de personas agraviadas por las emisiones de una fábrica de ácido bórico con sólo tipificar como difuso el interés invocado aun cuando la Legislatura no había cumplido el mandato de "reglar la legitimación procesal para la defensa jurisdiccional de los intereses difusos" de la Constitución provincial (art. 88) y dispuso el cese de las emisiones. ${ }^{3}$

Otras veces, con la excusa de hacer progresar una norma se la mutila. El pretexto de la recomposición normativa aglutinándola en nuevos cuerpos ayuda a suprimir con disimulo la norma ambiental que se quiere suprimir. Cuando los interesados lo advierten, ya desapareció la norma.

Otras regresiones las imponen normas no ambientales y también ambientales, muchas veces provenientes de conjuntos de normas de otras materias pero que inciden en lo ambiental.

La norma procesal suele ser la más esgrimida.

El Club Sierra impugnó judicialmente la autorización acordada a Walt Disney Enterprises para construir un centro recreativo en la Sierra Nevada alegando que violaba diversos reglamentos del Servicio Forestal. Fundaba su legitimación en que era un grupo de interés público con una larga trayectoria en materia de preservación ambiental, pero no alegaba perjuicio individual.

En 1972 la Suprema Corte de los Estados Unidos la denegó invocando que no cumplía los requisitos impuestos en materia de legitimación por la ley de procedimiento administrativo de 1946 que eran, básicamente, perjuicio real e interés jurídico. ${ }^{4}$

El requerimiento hubiera sido muy fácil de satisfacer, pero la Suprema Corte castigó a quien lo había omitido. Sirvió de lección. Desde ese momento el Club tomo la práctica de agregar a sus argumentos que por lo menos uno de sus integrantes que usara el área degradada sufriría perjuicio que justifique su legitimación.

Poco después otra organización no gubernamental de la singular denominación de Students Challenging Regulatory Agencies Procedures (SCRAP), o sea Estudiantes Impugnadores de Procedimientos de Órganos Reguladores, logró evitar el aumento de tarifas ferroviarias discriminatorias contra el material reciclado que había dispuesto la Interstate Commerce Commission (ICC) con el argumento de que el aumento de las tarifas correlativamente aumentaría la cantidad de residuos en toda la Nación y, por ende su acumulación en los

\footnotetext{
${ }^{3}$ Barrancos, Horacio y otros c/ Hoyos, Simón A., Corte de Justicia, Salta, Sala I, 5/6/90, JA, no 569, 10/10/90, véanse los fundamentos del juez Mario Sosa.

${ }^{4}$ Sierra Club v. Morton, 405 U.S. 727 (1972), decided April 19, 1972.
} 
parques que los estudiantes visitaban y, además aumentaría la actividad minera y la deforestación en la región. ${ }^{5}$

Cuando hace más de un siglo la Provincia de Buenos Aires sancionó el Código de Procedimiento en lo Contencioso Administrativo proyectado por Luis V. Varela parecía estar dando un tribunal altamente calificado, nada menos que la Suprema Corte de Justicia de la Provincia de Buenos Aires, para juzgar, entre otras materias, la aplicación que hacían los poderes administradores de las normas ambientales, pero ese tribunal consideró que el Código solo le otorgaba competencia para resolver sobre la violación de derechos subjetivos y no de meros intereses legítimos, como interpretaba que eran, por ejemplo, el de los vecinos que impugnaban las construcciones en áreas prohibidas era un mero interés legítimo, hasta que el fallo "Rusconi, Oscar v. Municipalidad de La Plata s/demanda contenciosoadministrativa", B 55392 del 4 de julio de 1995 aceptó definitivamente que esos reclamos ambientales se fundaban en "derechos» y no en simples intereses legítimos y juzgó en consecuencia.

Caída la barrera que había levantado el sofisma esgrimido por fallos anteriores de la Corte, se veía venir la avalancha de reclamos Contencioso Administrativos, la Provincia de Buenos Aires sancionó en 1997, por lo que la ley 12.008 de Proceso Administrativo que creó Tribunales especiales y extendió explícitamente la legitimación activa a toda persona que invocase una lesión, afectación o desconocimiento de sus derechos o intereses tutelados por el ordenamiento jurídico (art. 13).

La única alternativa que le quedó a sus autoridades para demorar algo más el juzgamiento de esos reclamos fue demorar la creación y provisión de cargos para la nueva jurisdicción contencioso-administrativa, que hoy funciona ordenada y plenamente.

Así pasó a la historia la negativa de la Suprema Corte de Justicia de la Provincia de Buenos Aires a ejercer cuando se invocaba un interés legítimo la jurisdicción que el Código de Procedimiento en lo Contencioso Administrativo le había acordado.

Una obstrucción regresiva similar se registró en materia penal. Ese mismo año 1997, la misma Suprema Corte de Justicia de la Provincia de Buenos Aires, confirmando fallos de instancias inferiores sentenció que a los individuos que accionaban meramente contra el acto eventualmente delictivo de volcar líquidos que envenenaban el agua del Río de la Plata no les asistía un interés directo, concreto y actual legalmente protegido por alguna norma reparatoria que los habilitara como particular damnificado para perseguir penalmente a presuntos envenenadores de agua que requería el Código Procesal Penal para la Provincia de Buenos Aires. ${ }^{6}$ Opinaba que los recurrentes no habían demostrado que la actividad delictual que atribuían a la imputada de contaminar las aguas del Río de la Plata les produjera un daño o perjuicio; que sólo se refería a los "potenciales perjudicados" que pudieren llegar a beber el agua que resultaría alterada y que - no obstante sus plausibles propósitos- no se encontraban legitimados para intervenir, toda vez que no les asistía el interés directo, concreto y actual legalmente protegido por alguna norma reparatoria y que un posible perjuicio futuro no era título suficiente para constituirse en particular damnificado. Para evitar que en lo sucesivo se dictasen sentencias como la comentada, la Legislatura, advertida de esos fallos, acababa de sancionar un nuevo Código Procesal Penal que atribuyó legitimación a todo ciudadano para instar el juzgamiento de delitos que afectasen intereses colectivos o difusos y así evitó regresiones futuras. ${ }^{7}$

${ }^{5}$ U.S. Supreme Court, United States v. SCRAP, 412 U.S. 669 (1973), No. 72-535, 18, 6/73 http://supreme.justia.com/us/412/669/case.html

${ }^{6}$ Causa P. 52.860 "Castro, Cristina Dolores y Schroder Juan, Presunta infracción art. 200 del Código penal por "Empresa Maleic S.A., Recurso de queja" JURIBA RL 69925 causa P. 52.860, S 8-4-97.

${ }^{7}$ Ley 11922 , artículo 84, Dec. 120, 10/01/97, Publicación :B.O. 23/01/97 № 23.280 (Suplemento). 
La excusa de la legitimación también habilitó a la Corte Suprema de Justicia de la Nación para rechazar la participación de las prestigiosas ONGs Fundación Ciudad, Fundación Metropolitana y Poder Ciudadano alegando no encontrar la vinculación necesaria entre sus respectivos estatutos y la presentación realizada que exige la norma procesal. ${ }^{8}$

\section{La transversalidad típica del derecho ambiental facilita la regresión}

\subsection{Por la diversidad de fuentes normativas}

Las normas del derecho ambiental emanan de distintas fuentes: Estado, provincia o municipio, comunidad internacional y variadas organizaciones humanas.

En materias de fondo las normas se buscan en códigos orgánicos (civil, comercial, procesal, penal, etc.). En materia ambiental hay que buscarlas en una complejo creciente y cambiante de textos, lo que exige una vigilia permanente. Hasta para su búsqueda hay que acudir a variadas voces. Los interesados en aplicarlas desconocen u olvidan su existencia. $\mathrm{Ni}$ los repertorios accesibles por Internet parecen alcanzar para estar al día. La ignorancia de norma vigente del derecho ambiental es un riesgo que acecha en forma permanente al jurista. Además lo ambiental también está sometido a normas distintas de la meramente ambiental. Por todo ello el jurista ambiental deberá ser no solo especialista, sino también generalista.

\subsection{Por que la proliferación de normas puede generar conflictos en su aplicación}

Diseñadores y críticos de políticas y comunicadores sociales piden la sanción de cada vez más normas y prohibiciones ambientales. El resultado es la sanción de posiblemente más reglamentaciones, restricciones, prohibiciones y estímulos que las que la preservación del ambiente la necesita.

Pero, además, un mismo texto o similar o sobre un mismo tema se suele repetir, lo que aumenta y hace que la maraña normativa sea más densa y confusa.

Ese método normativo genera un marco jurídico ambiental heterogéneo, disperso, extenso, cambiante, en expansión acelerada, integrado por normas frecuentemente contradictorias, reiterativas, generadoras de nuevas normas y estructuras administrativas que, a su vez, generan más normas. Ello somete la relación jurídica ambiental a una multiplicidad creciente de normas que, en vez de significar un progreso facilitan la regresión.

Un ejemplo es la Argentina. A partir de 2002, el Congreso Nacional empezó a sancionar una multiplicidad de leyes ambientales que proveyeron una miscelánea de medidas singulares y parciales protectoras del ambiente, uniformes, por ser normas de fondo y presupuestos mínimos que aumentan su dispersión, pero que no alcanzan a proveer un ordenamiento de la legislación ambiental federal ni aún principios generales y menos a resolver la variedad de temas ambientales que se suscitan, por lo que la interpretación y la aplicación del sistema jurídico ambiental se dificultan cada vez más.

Por ejemplo: el art. 1113 del Código Civil derogado atribuía la responsabilidad por daño a los daños que causaren los que están bajo dependencia de otro, o las cosas de las que se sirve o que tiene a su cuidado que es la objetiva.

\footnotetext{
${ }^{8}$ Causa M.1569.XL "Mendoza, Beatriz Silvia y otros c/ Estado Nacional y otros s/ daños y perjuicios daños derivados de la contaminación ambiental Río Matanza - Riachuelo", CSJN, 20/6/06.
} 
En cambio el art. $4^{\circ}$, ley 25.675, sancionada específicamente para proteger el ambiente atribuye la responsabilidad al "generador" del efecto degradante, o sea que la limita al « ejecutor », lo que constituiría una regresión inaceptable. ${ }^{9}$

Summum ius summa iniuria decía Cicerón en su obra De officis. Es imposible querer aplicar correctamente tal maraña legislativa, lo que por un lado coadyuva a la indefensión y por otro facilita la acción temeraria tanto del individuo como de la autoridad.

Además del conflicto de nomas, esos enfoques parciales deja mucho al descubierto de la relación ambiental. Para el abusador ambiental cuánto menos se cubra mejor.

La solución a mano que dan los principios de prevención y precautorio ayudan a frenar el daño futuro.

Otras soluciones hay, pero llevan su tiempo y en materia ambiental, detenerse equivale a regresar.

La contradicción de normas ambientales nacionales con internacionales la resuelve la Constitución Nacional (Arts. 31, 41 y conctes.).

La contradicción de normas ambientales nacionales con locales se la resuelven en parte mediante los presupuestos mínimos de protección (Constitución Nacional, Art. 41).

La contradicción entre normas ambientales de la misma jerarquía la resuelve en parte a favor del ambiente la ley 25675 (Art. 4).

Pero la solución más sólida consiste en analizar transversalmente la relación de esa pluralidad de fuentes normativas y de ramas jurídicas, reconstruyéndolos y ordenando las normas dispersas con metodología de derecho ambiental, sea en un digesto un código o una ley general del ambiente, pero con vocación de integridad.

\subsection{Por que la proliferación de normas induce una proliferación de estructuras administrativas que pueden entrar en conflicto para su aplicación}

Para aplicar esas normas se van creando nuevas estructuras administrativas, muchas veces con misiones y funciones correctoras de conductas administrativas anteriores, porque la función ambiental apunta a que lo que ya se estaba haciendo, se lo haga tomando en cuenta al ambiente veces similares y frecuentemente superpuestas. El resultado es la proliferación de áreas y organismos administrativos ambientales que no alcanzan a satisfacer las expectativas que indujeron su creación. Esa ineficacia induce, a su vez, la creación de nuevas estructuras administrativas para hacer lo que no hacían las anteriores, con las cuales entran en competencia y terminan padeciendo los mismos problemas de ineficiencia operativa. Además de corregir la inflación normativa, también habrá que corregir la inflación administrativa.

La competencia entre organismos con funciones meramente ambientales puede generar regresiones como todo conflicto. Pero ello se agrava cuando los organismos con funciones meramente ambientales compiten con organismos con funciones no ambientales más poderosos, sea porque gestionen materias más exigentes, como la defensa nacional, las relaciones exteriores, el manejo de fondos o estén más próximos al mando superior. Ello pueden obstar al ejercicio de sus funciones ambientales.

Pluralidad de organismos internacionales ejercen funciones ambientales. Solamente dentro del sistema de las Naciones Unidas lo hacen, entre otros la FAO, la UNESCO, la Organización Mundial de la Salud el Banco Mundial, el Fondo Monetario Internacional el Programa de las

\footnotetext{
${ }^{9}$ Derecho Ambiental". Ed. Abeledo-Perrot, Bs.As 2008, $2^{\underline{a}}$ ed. 2012, Sección VI: La responsabilidad por daños y perjuicios ambientales. 7. Limitación legal de la responsabilidad p. 223.
} 
Naciones Unidas para el Desarrollo y, obviamente el específico Programa de las Naciones Unidas para el Medio Ambiente. Si no se los coordina, la regresión actúa.

En el orden interno ocurre lo mismo. En los EE UU la EPA concurre con una pluralidad de organismos. La dependencia de Environmental Protection Agency (EPA) del Poder Ejecutivo puede ayudar a coordinar el sistema administrativo ambiental centrado principalmente en el Departamento del Interior, pero nada más.

En la Argentina, la Secretaría de Ambiente y Desarrollo Sustentable de la Nación depende de la Jefatura de Gabinete de Ministros, lo que también puede ayudar a coordinar el sistema administrativo ambiental, centrado principalmente en el Ministerio de Planificación Federal, Inversión Pública y Servicios, pero también concurre con el Ministerio de Relaciones Exteriores, Comercio Internacional y Culto, el del Interior y otros organismos.

La proximidad burocrática al conductor del gobierno otorga a la decisión ambiental una mayor fuerza política, aun sobre los ministros, pero de todos modos, cualquiera sea el nivel jerárquico que se atribuya a la función ambiental, siempre deberá afrontar la coordinación de las demás áreas administrativas y, en caso de discrepancias entre ellas, acudir a la decisión superior del Presidente que es el Jefe Supremo de la Nación, Jefe del gobierno y responsable político de la administración general del país (Constitución Nacional Art. 99, 1).

En resumen la solución más sólida es, precisamente tratar de coordinar el sistema administrativo ambiental en todos los niveles y la de todos los niveles entre sí, si es posible a nivel planetario. Casi nada.

\section{Medición de la «regresión»}

Como el ambiente se suele evaluar en términos de calidad, cuantificar los niveles de calidad ambiental no es tan fácil como decirlo. La tentación de convertir esa evaluación en expresiones matemáticas choca con la dificultad de expresar la calidad en cantidades.

Lo más sencillo es medir, por ejemplo, la cantidad y calidad de sustancias emitidas y de las contenidas $o$ en las emisiones, efluentes y en los cuerpos receptores, la temperatura, el nivel sónico, los colores, los aromas, la opacidad o luminosidad del elemento o sustancia. Más difícil es cuantificar la estética, la higiene, la salubridad y los valores científicos, históricos y culturales.

Además, la calidad que se pretende tenga el ambiente no es rígida ni absoluta, sino que depende de su destino. Así, por ejemplo, el nivel de infición admisible en el agua varía según se la destine a la navegación, al riego o a la bebida, mientras que el nivel sónico de una biblioteca no es el que se exige a una fundición de acero.

El hombre ha asignado distintos destinos a diferentes porciones del ambiente, instituyendo parques nacionales, parques industriales y la zonificación urbana y rural.

El impacto de las obras y la actividad humana y de la naturaleza sobre el medio ambiente beneficia, perjudica o resulta indiferente para cada persona. La calificación de beneficio, perjuicio o indiferencia es subjetiva, ya que el afectado puede considerarlo de un modo u otro según su criterio e intereses.

Por todo eso la evaluación siempre será convencional. ¿Cómo comparar una presa hidroeléctrica con el estado anterior del área? Hay que decidir cómo y para qué se va a evaluar la «regresión».

Hay una experiencia ganada en la evaluación del impacto ambiental que puede ayudar a medir la «regresión». 
Un criterio que se usa mucho para expresar el nivel de conducta o de calidad ambiental consiste en justificar que una persona cumple o que un producto ha sido elaborado conforme a determinada práctica o norma de aceptación generalizada, como son las normas ISO.

\section{Límites de la «no regresión»}

Corresponde a la ciencia, a la política, a la ética y al derecho definir hasta qué límite puede admitírselo y quién, cuándo y cómo debe responder por ello. Los derechos de las personas sobre el ambiente ajeno sólo pueden emanar de normas jurídicas impuestas por el poder soberano.

La pregunta sería entonces ¿Cuál es el límite de esa «no regresión»?

La respuesta: El que fije la norma jurídica.

\section{Ardides para obstar a la protección jurídica del ambiente}

Además de las normas entorpecedoras autoregresivas citadas, se usan ardides que ya son clásicos para generar la regresión.

Espero que la advertencia resulte útil a quienes luchan por el derecho al ambiente.

\section{Ardid 1-Negar la existencia de la norma protectora del ambiente}

Es el más elemental, pero muy entorpecedor.

Una de las falsedades más reiteradas en materia jurídica ambiental, por lo menos desde los prolegómenos de la Conferencia de las Naciones Unidas sobre Medio Ambiente Humano (Estocolmo, 1972) fue la de que no había normas que prohibieran dañar al ambiente o reguladoras del ambiente.

Las religiones siempre las proponen o tratan de imponer como las prácticas alimentarias del antiguo testamento, el derecho a la sed del Corán y la obediencia a la Pachamama de los americanos originarios

En la Argentina siempre las hubo normas cuando faltaban el legislador las sancionaba. Algunas son anteriores a la organización del Estado.

Ya la Ley 13 , Título 32 , Partida $3^{\circ}$, anticipaba genéricamente los principios de la protección ambiental frente a la acción antrópica cuando mandaba: "maguer el ome haya poder de fazer en lo suyo lo que quisiese; pero debelo fazer de manera que non faga daño nin tuerto a otros".

El Capitán General del Río de la Plata Juan de Garay dictó la Ordenanza el 17 de octubre de 1578, casi dos años antes de fundar Buenos Aires que obligaba a los ganaderos próximos a Asunción del Paraguay a que "hagan corrales donde metan el ganado de noche y de día lo tengan con guarda porque hacen daño a las rozas y labranzas de los indios comarcanos de esta ciudad". Se refería a Asunción del Paraguay. Respecto a si el objetivo fue o no ambiental alguien ironizó que como el ganado vacuno de los conquistadores había proliferado a tal punto que invadía los sembrados de los indios, quienes ante el agravio ambiental, preferían alejarse $y$, de ese modo los encomenderos perdían su mano de obra gratuita. De todos modos constituyó una norma de derecho ambiental de otros tiempos.

De lo que no hay dudas es que Juan de Garay siguió paradigmas ambientales cuando fundó Santa Fe y luego Buenos Aires para abrir puertas a la tierra e impuso la cuadrícula que todavía norma la traza de la Ciudad de de Buenos Aires. 
Fundada Buenos Aires, el Cabildo de Buenos Aires dictó la Ordenanza del 27 de febrero de 1589 que penaba a los propietarios de los caballos que causaren daños en chacras ajenas. ${ }^{10}$

Mateo Sánchez, Procurador de la Ciudad pidió al Cabildo el 2 de Julio de 1590 (Foja 29 vuelta del libro original) que se prohibiese cortar los algarrobos que había en el ejido de la ciudad hacia el Riachuelo de los Navíos alegando que proveían abrigo al ganado vacuno y para que el día que lloviese se recogiese allí y no fuera a hacer daño a las chacras del pueblo. El Cabildo se remitió a la prohibición que, con anterioridad había dispuesto Juan de Garay y, simplemente, mandó que se la pregonase nuevamente. ${ }^{11}$

Una Ordenanza del Cabildo de Córdoba 26 de junio de 1603 imponía la obligación de dejar horca y pendón cuando se cortase un árbol (id. p.51) para facilitar su recrecimiento.

Otra del 6 de mayo de 1639 disponía el alejamiento de las ovejas de Castilla a una legua de la ciudad para proteger los pequeños cultivos de las quintas (id. p.53).

Un bando del Virrey Arredondo del 2 de abril de 1791 mandaba quemar o sepultar las reses que muriesen de carbunclo (id. p.53).

Las autorizaciones a que estaban sometidas las vaquerías tuvieron un profundo sentido conservacionista.

Ya en el período patrio, la ley con forma de decreto del 31 de mayo de 1822 del Gobernador Martín Rodríguez de la Provincia de Buenos Aires refrendado por Bernandino Rivadavia ordenó que los saladeros se establecieran a una legua distante de la ciudad, tomada por la parte del oeste y del norte, desde la barranca, y por la parte del sur al otro lado del Riachuelo no se obedeció.

Una ordenanza municipal del 6 de abril de 1867, prohibió guardar cerdos en pie en la Ciudad de Buenos Aires y otra del 27 de abril de 1868 prohibió bañar caballos en la costa del Río de la Plata de la Ciudad de Buenos Aires. ${ }^{12}$

Tampoco se obedeció el decreto del Gobernador Valentín Alsina del 10 de febrero de 1868, que prohibió arrojar al Riachuelo los desperdicios de la faena de los saladeros.

Vélez Sarsfield incorporó al Código Civil las normas ambientales que consideró adecuadas y siempre tuvo presente la variable ambiental

La ley del 6 de septiembre de 1871, el decreto del 26 de abril de 1877, los decretos del 18 de mayo y del 20 de diciembre del mismo año, el decreto del 4 de enero de 1878 , el decreto del 20 de febrero de 1878, convertido en ley el 2 de noviembre de 1878, la ley del 7 de junio de 1879 prohibieron arrojar al Riachuelo los desperdicios de la faena de los saladeros, por lo que el decreto del 14 de febrero de 1881, confirmado por la ley del 6 de septiembre del mismo año prohibió absolutamente las faenas de los saladeros y graserías.

Cuando la filoxera y la langosta atacaron a los cultivos y la aftosa a los ganados, el legislador argentino impulsó cargas y obligaciones de jurisdicción nacional que la comunidad aceptó. ${ }^{13}$

Es cierto que no todo lo ambiental estaba específicamente normado, pero el artículo 33 de la Constitución Nacional garantiza a todos los derechos, que surgen de la soberanía del pueblo y de la forma republicana de gobierno, incluso el derecho al ambiente.

\footnotetext{
${ }^{10}$ La cita Guillermo Garbarini Islas en su libro “Derecho Rural Argentino”, Ed. Perrot B.A. 1954, p. 51.

${ }^{11}$ http://64.76.123.202/new/0-0/forestacion/revistas/revista34/misce34.

${ }^{12}$ Brailowsky, Antonio E. y Fogelman Dina en "Memoria Verde”, Ed. Sudamericana, B.A. 1991, p. 226.

${ }^{13}$ Ley 2384 de 26/10/1888, ley 2793 de 24/8/ 1891, D. Ses. Sen., 1891, p. 516 y 1113 y D. Ses. Dip., 1891 , t. I, p. 557.
} 
Cuando la Argentina se dio una nueva Constitución en 1949 consagró el derecho del trabajador a un ambiente higiénico (artículo 38), sometió el paisaje natural a la tutela del Estado (id) y mandó dictar el código sanitario nacional (artículo 68, inc. 11).

Cuando lo hizo en 1994 le incorporó el artículo 41, verdadero decálogo ambiental, que reconoce derechos e impone deberes a los habitantes, encomienda al Estado proveer distintas prestaciones ambientales, amplía las atribuciones del Congreso para la protección ambiental y prohíbe introducir al país residuos actual o potencialmente peligrosos y también el artículo 43, que norma un amparo ambiental.

Hemos adelantado que siempre hubo normas protectoras del ambiente y cuando faltaban el legislador las sancionaba. Lo que faltó y mucho, fue acatamiento, pero también cuando fue necesario la Justicia lo impuso. ${ }^{14}$

Las acciones judiciales en defensa del ambiente anteriores a un medio siglo siempre encontraron la norma en qué fundarse. Había que buscarla. La contaminación del río Matanza proviene en su mayor parte de la trasgresión a la ley 2797. Por otra parte, vivir honestamente y no perjudicar a tercero son principios eternos del derecho.

Algo que ayudó a la difusión de la creencia falsa la de que no había normas que prohibieran dañar al ambiente o reguladoras del ambiente fue que la voz ambiente o medio ambiente no aparecía en los repertorios de normas o de jurisprudencia hasta después de la mitad del siglo pasado y si no aparecía, tenía un sentido sociológico, cultural o político y no el actual.

Si buscamos una norma de esa época tenemos que acudir a la pluralidad de voces, por ejemplo: Acuíferos, Agentes contaminantes, Agua, Ambiente, Amparo, Acción de clase, Acción popular, Bonos de Carbono, Cambio Climático, Costas, Cuenca hídrica, Contaminación, Cuerpos receptores, Derecho ambiental, Daño ambiental, Evaluación del impacto ambiental, Incidencia colectiva, Incendios, Instrumentos económicos, Lagos, Lagunas, Mar, Medio Ambiente, Quemas, Reconversión industrial, Residuos peligroso, Residuos industriales, Residuos tóxicos, Residuos sólidos, Residuos urbanos, Ríos, Seguro ambiental, Zona Económica Exclusiva, etc. Hoy también sería prudente hacerlo.

Contribuyen a dar crédito a la negación de la existencia de la norma quienes creyéndolo de buena fe la vuelven a proponer una similar presentándose como innovadores. Suelen usar calificativos como "nuevos derechos" o ley de tercera, cuarta o quinta generación.

La negación de la existencia de la norma no solo desalienta y confunde la acción de la justicia para juzgar las malas conductas ambientales, sino que posterga su actuación a la espera de que el legislador sanciones nuevas normas, lo que lleva su tiempo. Demoró una justa e igualitaria preservación del medio por cuanto permitió a algunos contaminadores aprovechar la confusión para:

a) Excusar alguna mala conducta ambiental ante la comunidad.

b) Desalentar y confundir la acción de la justicia para juzgar esas malas conductas.

Este ardid no solo daña al ambiente humano en sí, sino que incide desfavorablemente sobre quienes respetan las muchas normas ambientales existentes desde siempre haciéndolos incurrir en los mayores costos ambientales, agravados por el deterioro que generan los contaminadores aprovechados. Se falseaba así la competencia en perjuicio del desarrollo económico y social. La fábrica contaminadora amenaza desplazar a la buena o bien la buena se vuelve mala para subsistir.

${ }^{14}$ Corte Suprema de Justicia de la Nación ,"Podestá, Santiago y otros v. Provincia de Buenos Aires s/indemnización de daños y perjuicios", CXVIII, 278 y XXI, 23. 
Una variante de este ardid empalma con el ardid de esconder la norma protectora del ambiente en el pajar de la hipernormativa señalado en: 5.- La transversalidad típica del derecho ambiental facilita la regresión.

\section{Ardid 2-Definir a una denominación progresiva en términos contrarios a la progresión}

La ley 25.675 (art. $4^{\circ}$ ) sienta principios básicos que rigen su interpretación y aplicación y la de toda otra norma a través de la cual se ejecute la política ambiental. Uno de esos principios básicos es el que denomina de progresividad que, paradójicamente impone la gradualidad para la prosecución de los objetivos ambientales.

Si bien la denominación "progresividad" pareciera referirse al principio de non regression la definición que el Congreso agregó al proyecto original lo convirtió en una rémora a la acción inmediata y urgente que suele requerir la protección del ambiente. Cuando manda: «Los objetivos ambientales deberán ser logrados en forma gradual, a través de metas interinas y finales, proyectadas en un cronograma temporal que facilite la adecuación correspondiente a las actividades relacionadas con esos objetivos».

La restricción que la definición impuso al principio enerva el sentido positivo que legitima para accionar a quien tenga derecho a su uso y goce contra quien disminuya o impida ese uso y goce.

\section{Ardid 3-Negar o disminuir la categoría del derecho al ambiente}

Un ardid ingenuo es alegar que como se trata un derecho nuevo sólo protege contra nuevos daños. Más arriba hemos desenmascarado este sofisma. Con picardía se ha dicho que es un derecho de tercera, cuarta o quinta. Seguramente es de primera porque ya regía en el Paraíso.

Se ha negado que sea un Derecho Humano para negarle una jerarquía superior al poder del Estado ignorando la Convención Americana Sobre Derechos Humanos las homólogas de la ONU. Hubo que acordar del Protocolo Adicional a la Convención Americana Sobre Derechos Humanos de El Salvador del 17/11/ 88 aprobado por la ley 24685, cuyo artículo 11 establece el derecho de toda persona a un medio ambiente sano. ${ }^{15}$

\section{Ardid 4-Invocar la imposibilidad del cumplimento}

Como lo acabamos de señalar, la autoridad nacional de aplicación no cumple el mandato de concertar los niveles de riesgo para reglar la gestión de los diferentes residuos objeto de la ley 25612. Parece creer que es imposible hacerlo.

El COFEMA consideró que no es posible determinar niveles de riesgo a través de las características intrínsecas del residuo como indica la Ley 25612 (Acta de Representantes Técnicos Provinciales en II Taller de Reglamentación Ley 25612 del 21/5/04 Informe N 64/04 Respuesta № 517. Participaron las Provincias de. Catamarca, Chaco, Chubut, Córdoba, Corrientes, Entre Ríos, Formosa, Jujuy, La Rioja, Misiones, Salta, San Juan, Santa Cruz, Santa Fe, Tierra del Fuego y Tucumán).

La Comisión Técnica del COFEMA encontró los siguientes inconvenientes para la definición de los niveles de riesgo:

\footnotetext{
${ }^{15}$ Rossi, Alejandro, La defensa supranacional del derecho a un ambiente sano, en Derechos Humanos de Agustín Gordillo y otros, Ed. Fundación de Derecho Administrativo 2ª̣ Ed, pp V-2713, Buenos Aires, 1996.
} 
- La definición del nivel de riesgo de un residuo no solo depende de sus características intrínsecas, sino también de considerar que existen distintos factores que inciden en la determinación del riesgo, como: la exposición, el sitio, la gestión, el entorno, las características del receptor, etc.

- Conforme las variables definidas en el artículo $7^{\circ}$ de la Ley 25612, resulta técnicamente imposible concertar y unificar los niveles de riesgo de un residuo, al considerar que las características de riesgo pueden variar significativamente de una jurisdicción a otra, como la afectación sobre la calidad de vida de la población, el sitio en el cual se realiza la gestión, etc.

- Atento lo anteriormente expuesto, basar un presupuesto mínimo en niveles de riesgo y no en una propiedad intrínseca de un residuo imposibilita la operatividad de la Ley.

Ante esa expresión de la imposibilidad de concertar los niveles de riesgo a la que alude el artículo $7^{\circ}$, la autoridad de aplicación nacional no los fijó, por lo que no aplica la ley 25612.

Todo ello en el ámbito nacional.

Las autoridades locales de aplicación también parecen compartir la convicción de que es imposible cumplir el mandato similar que les impone el artículo $8^{\circ}$ de la ley 25612 por cuanto no hemos encontrado clasificación alguna provincial de los generadores a través de las características intrínsecas del residuo según los niveles de riesgo.

Otro caso es el de los obligados a tomar del seguro de garantía que impone el artículo 22 de la ley 25675, que esgrimieron la imposibilidad para no cumplir la norma es el de la cobertura "suficiente para garantizar el financiamiento de la recomposición del daño", daño que en materia ambiental puede adquirir magnitud catastrófica.

El seguro ambiental voluntario no se practicaba en nuestro país y la ley 25675 lo hizo obligatorio, pero lo difícil que es calcular la tasa de siniestralidad determina que las primas resultaran tan altas que parecían hacer ilusoria su contratación. Por eso es que algunos de los obligados alegaron que la obligación de que la cobertura tuviese "entidad suficiente para garantizar el financiamiento de la recomposición del daño" como enormísima o rayana en lo infinito para no tomar el seguro.

Sin embargo, la práctica de la actividad aseguradora de riesgos tuvo respuestas para proveer un seguro posible.

Con la intención de proveer "los mecanismos operativos para la implementación de los seguros ambientales" la Secretaría de Ambiente y Desarrollo Sustentable dictó las Resoluciones que aprueba normas operativas para la contratación del seguro circunscribiendo el alcance de la cobertura del seguro a los daños de incidencia colectiva irrogados al ambiente en los términos del artículo 27 de la Ley 25675 y los criterios para establecer los montos mínimos asegurables con la "entidad suficiente" (Resolución SA y DS 177/2007 y 303/07, que la complementa y modifica, Resolución SA y DS 1639/07, Resolución Conjunta SA y DS 1973/07 y SF 98/07 y las recientes $177 / 2013$ y la 600/2013 SA y DS que establecieron fórmulas polinómicas para el cálculo de los Montos Mínimos Asegurables de Entidad Suficiente (MMAES).

Es posible que la cobertura no siempre sea "suficiente para garantizar el financiamiento de la recomposición del daño", pero hay un seguro de garantía posible. 


\section{La «regresión» acecha al derecho ambiental}

La doctrina está alerta.

Michel Prieur alertaba en 1984 respecto al derecho ambiental que « il y aura des déviations, des détournements, des régressions, car ce droit, ainsi finalisé va se heurter a des interets economiques...». ${ }^{16}$

Los hubo y Prieur siguió insistiendo sobre el tema hasta hoy.

En nuestra América, Mario Peña Chacón viene tratando el tema desde hace varios años. El año pasado dirigió la obra colectiva "El principio de no regresión ambiental en el derecho comparado latinoamericano, $1 \stackrel{\text { a }}{ } \mathrm{Ed}$. S José CR PNUD, 2013 auspiciada por el Programa de las Naciones Unidas para el Desarrollo (PNUD) para la Maestría Profesional Derecho Ambiental de la Universidad de Costa Rica.

Somos muchos los que sufrimos por de la regresión ambiental y nos esmeramos por evitar que el derecho se use como instrumento de esa regresión.

\section{Conclusiones}

La regresión acecha a la protección ambiental a pesar de todas las proclamas y expresiones a favor del ambiente y de la sanción de una creciente cantidad de normas protectoras.

La doctrina está alerta y advirtiendo quienes y por qué la inducen y las ventajas con que cuentan.

Por eso es necesario que el pensamiento jurídico se concentre en este tema y provea soluciones al flagelo.

\section{Bibliografía}

Berros, María Valera, Construyendo el principio de no regresión en el Derecho argentino, JA, 2011-IV, fasc. N.13, 2011.

Berros, María Valeria y Sbresso Luciana, Primeras señales sobre el principio de no regresión en materia ambiental en Argentina. Un estado de la cuestión, en El nuevo principio de no regresión en derecho ambiental, Bruxelles : Editions Bruylant, 2012.

Esain, José A. El principio de progresividad en materia ambiental, Revista Semanal de Lexis Nexis del 10/10/07.

Equipo de Investigación ECOS Sud - MINCYT, "Adoptar el principio de no regresión del derecho ambiental global: un desafío central para Río+ 20", La Ley, Año XIX, № 1, Buenos Aires, 23 de mayo de 2012.

Fernández Fernández, Edgar, Reflexiones sobre el principio de "no regresión ambiental" en el derecho costarricense, el Dial.com - DC1936, 4/9/2012.

López Ramón, Fernando, Introducción general: regresiones del Derecho ambiental. Observatorio de Políticas Ambientales 2011, Thomson Reuters, Editorial Aranzadi, S A.

Peña Chacón, Mario, "El principio de no regresión ambiental en el derecho comparado latinoamericano, 1를. S José CR PNUD, 2013 Ensayos sobre el principio de no regresión del derecho ambiental" (Obra colectiva).

\footnotetext{
${ }^{16}$ Prieur, Michel, Droit de l'environnement, Dalloz, Paris, 1984, p. 13.
} 
Peña Chacón, Mario, El Derecho Internacional Ambiental como fundamento del Principio de Prohibición de Retroceso, en elDial.com, Biblioteca Jurídica Online, Suplemento de Derecho Ambiental, junio 2013, Argentina.

Peña Chacón, Mario, La Ley Orgánica del Ambiente y el Principio de No Regresión, en Revista Iberoamericana de Derecho Ambiental y Recursos Naturales, número 7, febrero 2013.

Peña Chacón, Mario, Los principios de objetivación de la tutela ambiental, irreductibilidad de espacios sometidos a régimen especial de protección y su relación con la prohibición de retroceso, en Revista Iberoamericana de Derecho Ambiental y Recursos Naturales, número 7, febrero 2013.

Peña Chacón, Mario, El CAFTA-DR y la prohibición de retroceso ambiental en Revista Iberoamericana de Derecho Ambiental y Recursos Naturales, número 7, febrero 2013,

Peña Chacón, Mario, Gobernanza Territorial y principio de no regresión, en elDial.com, Biblioteca Jurídica Online, Suplemento de Derecho Ambiental, julio 2013, Argentina.

Prieur, Michel, Droit de l'environnement, Dalloz, Paris, 1984.

Prieur, Michel, De la nécessité de reconnaître le principe de non régression en droit de l'environnement, en: http://gouvernanceenvironnementale.files..wordpress.com/2011/03/textede-michel-prieur.pdf.

Prieur, Michel, De l'urgente nécessité de reconnaître le principe de "non régression » en droit de l'environnement, IUCN Academy of Environmental Law e-Journal Issue 2011.

Sagot Rodríguez, Álvaro, El principio de no regresión en materia ambiental: análisis de dos casos de directrices transgresoras, en Actualidad Jurídica Ambiental, 4 de marzo de 2013. 


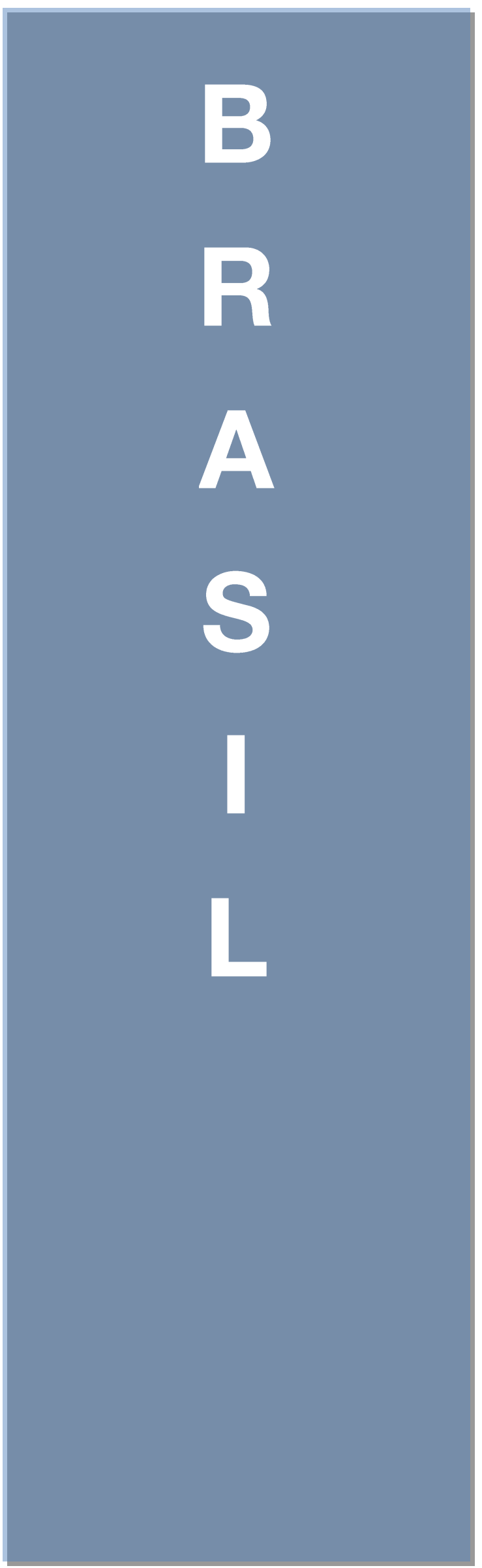





\title{
OS DESAFIOS PARA UM CONSTITUCIONALISMO DA VIDA DECENTE EM UMA CULTURA JURÍDICA DE RETROCESSO SOCIOAMBIENTAL: CONTRIBUIÇÕES DA JURISPRUDÊNCIA E DA TEORIA CONSTITUCIONAL BRASILEIRA*
}

\author{
Patryck de Araújo Ayala*
}

\section{Introdução}

Em um contexto em que resulta cada vez mais visível a aceleração dos processos de modificam de forma extrema os sistemas climáticos globais, e que representam uma real possibilidade de comprometimento dos rumos da existência da humanidade, o problema central que é proposto neste trabalho implica indagar como propostas que exponham a flexibilização de normas de proteção ambiental podem ser admitidas pelo projeto político e de sociedade definido pela ordem constitucional brasileira, analisando as razões que fundamentariam a hipótese proposta.

O texto enfatiza que se foi atribuído ao Estado (e também à coletividade) o dever de proteger 0 meio ambiente por meio de cada uma de suas funções, e assegurar o acesso em igual qualidade aos direitos fundamentais que possam decorrer dessa proteção, e uma vez que 0 exercício dos deveres estatais de proteção e dos deveres fundamentais devem ser contextualizados em um espaço influenciado por uma nova cultura constitucional, o reconhecimento e a afirmação de um dever de solidariedade, [que constitui um dos primados da República], constitui o fundamento capaz de justificar a redefinição do alcance de tais deveres. A questão que ganha ênfase nesse contexto de uma cultura constitucional adaptada à realidade de uma comunidade moral global, e que sujeita esta comunidade a novas respostas é: a que [objetivos] esse Estado está vinculado?

Situando a questão sob o plano ético, o texto propõe que um assim denominado constitucionalismo da vida decente exige um compromisso reforçado de todas as instituições e de toda a sociedade no sentido de não permitir que as pessoas sejam humilhadas por aquelas, considerando-se que as as pessoas o serão sempre que tiverem seus projetos de vida obstados por iniciativas que diminuam ou eliminem os padrões mínimos e indispensáveis para o desenvolvimento da vida.

Sob semelhante perspectiva, a afirmação e a elaboração de deveres para com as futuras gerações, a consideração destes interesses no contexto do conjunto das decisões políticas fundamentais de uma comunidade, e o desenvolvimento de estruturas institucionais ecologicamente sensíveis, baseadas na concretização de princípios cujo sentido depende da consideração direta de juízos de decisão sujeitos a escalas de tempo e a referências morais

\footnotetext{
* Professor adjunto II, nos cursos de graduação e mestrado em Direito da UFMT. Coordenador-adjunto do programa de mestrado em direito agroambiental da UFMT (2011-2013). Mestre e doutor em Direito pela Universidade Federal de Santa Catarina (CPGD/UFSC), com estágio de doutoramento na Universidade de Lisboa no ano de 2006 (PDEE/CAPES). Líder do grupo de pesquisa "Jus-Clima" e pesquisador do grupo de pesquisas "Direito Ambiental e Ecologia Política na Sociedade de Risco", ambos credenciados junto a CNPQ; coordenador de jurisprudência da Revista de Direito Ambiental (RT), secretário-geral do Instituto O Direito por um Planeta Verde, membro da Comission on Environmental Law da IUCN. Autor e colaborador em diversas obras jurídicas e periódicos, nacionais e internacionais. Procurador do Estado de Mato Grosso.
} 
diferenciadas [desenvolvimento sustentável e a responsabilidade de longa duração] proporcionam que se possa justificar severas restrições e condicionamentos às escolhas que poderão ser realizadas pelo Estado para o fim de assegurar que sejam alcançados seus objetivos e concretizadas as tarefas que lhes foram reservadas.

Partindo-se da afirmação de uma imagem de ordem jurídica que seria capaz de favorecer a proteção de todas as formas de vida a partir de um conjunto de pressupostos determinados, e levando-se em consideração um contexto de sistemática flexibilização das normas ambientais no Brasil, o trabalho investiga ao longo de quatro seções: a) se e até que ponto o Estado brasileiro tem condições de, neste momento, proteger adequadamente bens que são essenciais ao desenvolvimento da vida e; b) se seria possível reconhecer na ordem jurídica brasileira, uma realidade de concretização dos direitos fundamentais convergente com os compromissos de um Estado ambiental.

Essas duas questões ainda poderiam motivar a proposição de outras três: O Estado brasileiro está vinculado a um imperativo de não retorno nas suas escolhas sobre como proteger o direito fundamental ao meio ambiente? Este imperativo é relativo? O Estado brasileiro desenvolve seu compromisso com imperativos ecológicos por meio de sua escolhas?

No primeiro momento busca-se esclarecer o que significa admitir a existência de um Estado ambiental para uma determinada experiência jurídica (o que não é um Estado ambiental, e o que poderia ser um Estado Ambiental). No segundo momento pretende-se expor o objeto de proteção desse Estado ambiental, identificando que compromissos e que projetos ele se propõe concretizar, para depois fixar como se dá essa proteção e, se de fato, esse Estado protege os bens e os valores que esta sociedade reputou tão importantes que os posicionou fora do alcance das decisões majoritárias.

Portanto, o texto propõe determinar, primeiro, o que deve ser e o que não pode ser um Estado ambiental para depois identificar que a que valores, projetos e compromissos uma ordem jurídica baseada na imagem de um Estado ambiental se encontra vinculada. Nos dois momentos finais, os problemas de como um Estado ambiental deve proteger tais valores exporão a necessidade de identificar como ele será capaz de proteger uma realidade que proporcione o mínimo existencial em sua dimensão de integridade (social porque também ecológica), enfatizando a importância, nesse processo, da consideração de um imperativo de não retorno, ou de cláusulas de não retrocesso nos níveis de proteção do meio ambiente. $O$ texto trabalha com a premissa de que um Estado ambiental não é capaz de favorecer níveis essenciais de qualidade do meio ambiente senão, e no mínimo, por meio da manutenção e do não retorno nos padrões de proteção já atingidos pela ordem jurídica.

O texto também sugere que em detrimento de uma formação diferenciada de exercício do poder político, o Estado ambiental é e continua a ser um Estado de direito e somente continuará a sê-lo, se puder favorecer a continuidade e o desenvolvimento da vida, sendo, então, o Estado de direito (com tarefas ecológicas), o contexto organizatório indispensável que identifica os padrões mínimos para a formação de uma sociedade decente.

O plano é assim proposto para o fim de preparar adequadamente a reflexão reservada para o seu momento de conclusão. O problema sugerido nessa ocasião seria: se um Estado ambiental depende, antes de tudo, da manutenção e da elevação dos padrões materiais, sociais, e econômicos para viabilizar os compromissos de seu projeto político (que é um projeto de longa duração e comprometido com a vida), seria possível reconhecer na experiência jurídica nacional, e por meio de um teste de retrocessividade, manifestações de um Estado ambiental, ou, na verdade, neste momento suas ações exporiam a (nociva) imagem de um assim denominado Estado de retrocesso ambiental?

Mais do que esboçar linhas sobre a formação de uma jurisprudência do mínimo existencial ecológico no Brasil, o texto procurar propor sob essa perspectiva, algumas reflexões sobre os 
limites e possibilidades para a formação do que poderíamos denominar de um constitucionalismo de uma sociedade decente, por meio de algumas manifestações jurisprudenciais que sinalizam caminhos para uma cultura do não retrocesso em um contexto de ampla transformação flexibilizadora desenvolvida por cada uma das funções estatais nacionais.

Portanto, mais do que um relato sistemático sobre a prática jurisprudencial sobre o tema, a pesquisa tenta colaborar para a compreensão da função exercida por essas transformações, para indicar caminhos a seguinte questão: como e se desejamos efetivamente viver em uma sociedade melhor baseada em valores de maior sensibilidade e humanidade.

O texto não tem, naturalmente, o propósito de eliminar controvérsias, limitando-se tão somente a propor uma abordagem possível ao problema e que parece exigir, neste momento, o seu lugar no centro dos problemas dogmáticos de relevância de nossa comunidade política de riscos.

\section{Estado ambiental e os problemas ambientais de segunda geração}

Em um contexto em que resulta cada vez mais visível a aceleração dos processos de modificam de forma extrema os sistemas climáticos globais, e reconhecendo-se que as ações de conservação da biodiversidade e de restauração de danos ambientais podem contribuir de formadecisiva para cenários de adaptação ${ }^{1}$ e mitigação ${ }^{2}$ de tais efeitos,o problema central proposto neste texto implica indagar como uma determinada experiência jurídica ainda seria capaz de proporcionar níveis de proteção suficientes diante de uma realidade de riscos como a descrita, consubstanciados em riscos climáticos, ou problemas ambientais de segunda geração. $^{3}$

O que estes problemas representam sob o plano prático e qual a razão de merecerem tamanha relevância para as ações de Estados, governos, da comunidade científica, de cada um de nós e de toda a comunidade internacional?

O que sempre foi tratado pelo jurista como um problema que interessava à qualidade de vida, passa a se fixar, em toda a sua realidade, como um cenário que implica que sejam tomadas decisões relacionadas à própria sobrevivência de todas as formas de vida, vinculando de forma reforçada, como nunca se verificou antes, as escolhas que cada pessoa realiza, e que cada

\footnotetext{
${ }^{1}$ Por adaptação, deve-se compreender, nos termos do artigo $2^{\circ}$, inciso I, da lei n. 12.187/2009, o conjunto das "iniciativas e medidas para reduzir a vulnerabilidade dos sistemas naturais e humanos frente aos efeitos atuais e esperados da mudança do clima;" BRASIL. Lei n. 12.187, de 29 de dezembro de 2009. Institui a Política Nacional de Mudanças Climáticas - PNMC e dá outras providências. Disponível em: http://www.planalto.gov.br/ccivil_03/_Ato2007-2010/2009/Lei/L12187.htm. Acesso em: 10 de janeiro de 2010.

${ }^{2} \mathrm{O}$ conceito de mitigação utilizado é aquele proposto pelo 4ํㅡㄹ Relatório do IPCC, e que também foi reproduzido pela lei n. 12.187/2009, que institui a Política Nacional de Mudanças Climáticas. O texto compreende por mitigação, as "mudanças e substituições tecnológicas que reduzam o uso de recursos e as emissões por unidade de produção, bem como a implementação de medidas que reduzam as emissões de gases de efeito estufa e aumentem os sumidouros" em seu artigo $2^{\circ}$, inciso VII, que supõe a intervenção do homem, através de iniciativas tecnológicas." BRASIL. Lei n. 12.187, de 29 de dezembro de 2009. Institui a Política Nacional de Mudanças Climáticas - PNMC e dá outras providências. Disponível em: http://www.planalto.gov.br/ccivil_03/_Ato2007-2010/2009/Lei/L12187.htm. Acesso em: 10 de janeiro de 2010.

${ }^{3}$ A referência a um conjunto de problemas ambientais de segunda geração é do professor Canotilho, exposta em: CANOTILHO, José Joaquim Gomes. Direito constitucional ambiental português: tentativa de compreensão de 30 anos das gerações ambientais no direito constitucional português. In: CANOTILHO; José Joaquim Gomes; LEITE, José Rubens Morato. Direito constitucional ambiental brasileiro. São Paulo: Saraiva, 2007. p. 2.
} 
Estado, sobre os rumos que superam sua própria existência e de suas gerações futuras, alcançando o destino de todos em uma escala global.

A realidade dos atuais problemas ambientais encontra-se muito bem representada pelos efeitos das mudanças climáticas globais: efeitos imprevisíveis, de larga escala, invisíveis, de grande potencial ofensivo, e que redefinem este contexto de uma sociedade de riscos, uma sociedade que é contemporânea e que reforça os liames de solidariedade e de coresponsabilidade de tal modo que nunca se teve notícia anterior.

Sob semelhante contexto, impõe-se investigar que arranjo institucional seria capaz de viabilizar os níveis mínimos de proteção definidos pelos projetos existenciais veiculados pelas ordens constitucionais e por uma ordem global ${ }^{4}$, e mais concretamente, se já seria possível identificar semelhante arranjo na experiência jurídica brasileira.

A influência de uma ordem pública global sobre o sentido das ações públicas no Direito brasileiro pode ser visualizada já a partir de sua arquitetura constitucional, que encontra seu fundamento em um dever geral de solidariedade com a humanidade, mensagem emancipatória que foi considerada no âmbito de um projeto político de sociedade que prioriza e enfatiza o bem-estar coletivo como tarefa determinante da qual depende a manutenção da ordem pública e social.

Sob esse contexto ganha ênfase a posição angular que recebe o princípio da dignidade da pessoa humana em semelhante regime de governança, que projeta suas conseqüências em realidades sociais e ecológicas da existência da pessoa nesse espaço público.

Baseado no primado da dignidade da pessoa humana (artigo 1ㅇ, inciso III) e em um dever geral de solidariedade para com a humanidade (artigo $3^{\circ}$, inciso I e artigo 225, caput), modificações substanciais podem ser constatadas no projeto de ordem social proposto pela Constituição brasileira, e que também se projeta como uma tendência em visível expansão em outras experiências ocidentais. ${ }^{5}$

A afirmação política e normativa de um objetivo de solidariedade e de um compromisso com as gerações presentes e futuras, como os que se encontram expressos nos artigos $3^{\circ}$, inciso I, e 225, caput da Constituição brasileira, impõe a sujeição do Estado e dos particulares ao dever de auto-restrição no livre exercício da autonomia da vontade.

Nem todas as escolhas são toleráveis e admissíveis pelo projeto de sociedade [que neste caso, também é um projeto de futuro] definido pela ordem constitucional brasileira. Cumpre às funções estatais obstar excessos na definição das escolhas sobre como é possível e como se desenvolverá a existência da humanidade.

A subtração de tal capacidade de escolha [que também se encontra assegurada às futuras gerações], e a sujeição dessa sociedade a modelos determinados de desenvolvimento, incapazes de assegurar a existência de todas as formas de vida, representam comportamentos de deslealdade com semelhante proposta de cultura constitucional que orienta o modelo contemporâneo de um Estado comprometido com tarefas sociais, econômicas, culturais e ecológicas.

\footnotetext{
${ }^{4}$ O professor Canotilho faz referência a um constitucionalismo global em: CANOTILHO, José Joaquim Gomes. 'Brancosos' e interconstitucionalidade. Itinerários dos discursos sobre a historicidade constituinte. 2. ed. Coimbra: Almedina, 2008. p. 259-300. Entretanto, a abordagem descrita no projeto supõe um estudo comparado entre as realidades e experiências normativas no âmbito do Brasil, Portugal e na União Européia, propondo-se que a interação e o diálogo entre estas se faça a partir de uma noção de transconstitucionalismo. A escolha visa permitir a elaboração do sentido de uma unidade para a ordem jurídica, no domínio da proteção perante os riscos climáticos. A referência decorre de: NEVES, Marcelo. Transconstitucionalismo. São Paulo: Martins Fontes, 2009.

${ }^{5}$ Para um panorama mais analítico sobre as experiências referidas, conferir: AYALA, Patryck de Araújo. Devido processo ambiental e o direito fundamental ao meio ambiente. Rio de Janeiro: Lumen Juris, 2011. p. 173-230.
} 
Em um modelo de Estado exposto a exigentes desafios e tarefas capazes de interferir sobre realidades existenciais de longo curso, a dignidade da pessoa humana passa a constituir-se em postulado primário para a compreensão do alcance que tais objetivos de proteção, antes associados a uma dimensão antropocêntrica de uma existência efêmera, passaram a assumir nas sociedades contemporâneas.

A dignidade humana situada enquanto primado que condiciona a realização das tarefas estatais, adquire um significado diferenciado quando contextualizada perante um conjunto de valores de uma sociedade plural e de uma comunidade moral axiologicamente complexa, contribuindo, v.g, para a afirmação da inclusão dos animais não-humanos e da natureza, conjuntura que só se faz possível porque a definição dos valores que devem ser protegidos vincula-se e está fundamentada em uma ordem permanentemente aberta. Esta por sua vez, tem na configuração contemporânea de Estado, sua manifestação jurídico-política. (REVORIO: 1997).

Considerando-se o conjunto dos argumentos analisados, e se é correto admitir que a sobrevivência e o livre desenvolvimento da personalidade das pessoas depende de que sejam garantidos ou mantidos determinados níveis de qualidade aos recursos naturais em geral, é possível atribuir à natureza a condição de bem que manifesta valor intrínseco, razão pela qual as ordens constitucionais contemporâneas, situadas que estão no contexto de projetos emancipatórios de qualidade diferenciada, tendem a reconhecer e a exprimir o valor de existência da natureza [e o valor de existência de outras formas de vida] como manifestação de um pluralismo moral na definição das tarefas estatais de proteção.

Sendo assim, a afirmação de um direito fundamental ao meio ambiente [que será analisado adiante] não pode representar necessariamente a afirmação de um antropocentrismo que não seja moderado e que permita ser situado nesta comunidade moral que é plural, admitindo que todas as formas de vida estão sujeitas à proteção estatal. Assim o é porque a sua própria existência constitui a causa que justifica e fundamenta o dever de cooperação coletiva ${ }^{6}$, dever que é, fundamentalmente, um dever de colaboração com a humanidade [vinculada aqui a um sentido de natureza humana que não a reconhece, v.g, em determinados comportamentos lesivos ou que sujeitem outras formas de vida a estados de desfavorabilidade].

A tarefa estatal de assegurar o bem-estar ganha, portanto, a partir da afirmação de um Estado ambiental, dimensões bastante mais extensas em relação ao alcance de semelhante dever. Este lhe impõe severas exigências de escala para a consecução da tarefa de assegurar o bemestar social, pois os valores da sociedade que se quer proteger estão vinculados agora aos interesses de titulares e beneficiários que ainda não participam da comunidade política, a saber, os animais não-humanos e principalmente, as futuras gerações, objeto de interesse desta exposição. ${ }^{7}$

Isso somente se faz possível a partir de um modelo de cultura constitucional fundado em um pluralismo moral [responsável pelo alargamento da comunidade moral que justifica os interesses protegidos], pressuposto indispensável para que sentido do primado da dignidade

\footnotetext{
${ }^{6}$ Para uma análise detalhada sobre o tema, vinculada à afirmação de um dever de solidariedade comunitária, consultar: ANDRADE, José Carlos Vieira de. Os direitos fundamentais na Constitução portuguesa de 1976. 3. ed. Coimbra: Almedina, 2004. p. 160-162.

7 Saliente-se que a tarefa referida já se encontrava desvinculada de uma perspectiva utilitária de otimização das pretensões e expectativas individuais, uma vez que já não é recente na dogmática pública a afirmação de um sentido social, cuja expressão se refletia em objetivos de segurança social à coletividade, próprios de um Estado social de direito. Este por sua vez, representa uma perspectiva de proteção que é adicionada [não exprimindo, portanto, uma noção de superposição ou de substituição de projetos políticos por projetos autônomos] àquela primeira, própria de uma orientação liberal para o exercício do poder político, cuja expressão também se refletia na definição do conteúdo dos direitos fundamentais. Esta definição priorizava a garantia do livre desenvolvimento da personalidade, para a qual era fundamental o livre exercício das liberdades econômicas e civis.
} 
da pessoa humana possa proporcionar uma proteção reforçada para todos os membros capazes de ter seus interesses afetados, e que possam de algum modo, compreender e vivenciar o valor dignidade.

Em um Estado ambiental (BLASBERG: 2008; CALLIES: 2001; KLOEPFER: 2010; KLOEPFER: 1989) que se encontra exposto a ameaças e aos efeitos de problemas ambientais de segunda geração, como podem ser situados os resultantes das alterações climáticas globais, somente se pode conceber uma proteção reforçada para os interesses de uma comunidade moral heterogênea e complexa, a partir de um reforço sobre a própria consideração do primado da dignidade da pessoa humana, situado que está agora, em uma cultura constitucional moralmente plural.

Somente se pode conceber dignidade a partir de uma referência deôntica que considera a coletividade sob uma perspectiva de escala diferenciada, vinculada a noção de humanidade. Portanto, o dever estatal e os deveres fundamentais atribuídos a cada membro desta comunidade política não se esgota, no projeto de sociedade delineado pela Constituição brasileira, na garantia do bem-estar e na qualidade de vida destes mesmos membros, senão aponta para uma tarefa [estatal] e para deveres [estatais e sociais] perante a humanidade. $O$ princípio da dignidade da pessoa humana impõe, nessa direção, deveres estatais e deveres fundamentais sujeitos a uma escala exigente de concretização.

A própria definição do conteúdo das tarefas públicas é visivelmente influenciada pela modificação das relações de poder que se desenvolvem em escala global, e influenciada pelos objetivos e pelos consensos obtidos em um espaço global de negociações. Perante a constatação de ameaças que podem comprometer a existência da humanidade, e que decorrem de maior ou menor contribuição de todos para a redução ou para a aceleração dos processos que alteram drasticamente os sistemas climáticos globais, é requerido que os Estados se responsabilizem com semelhante tarefa também no plano nacional, reproduzindo na forma de deveres, condicionamentos e sujeição, através do exercício das funções legislativa, executiva e judicial, que mediante leis, procedimentos administrativos, instrumentos de proteção e a intervenção judicial, possa ser atingido o objetivo de redução dos riscos. Este resultado decorre assim, de deveres ou de decisões públicas cujo conteúdo tem seu fundamento último, em um compromisso que não é exclusivamente nacional. A atuação legislativa através de legislação e de procedimentos que asseguram a redução das emissões, e de suas fontes, ocorre no plano nacional, mas suas conseqüências se projetam em escalas espaciais diferenciadas, em maior ou menor grau.

Sendo assim, resulta visível que as conseqüências das escolhas públicas têm origem cada vez menos relevante em objetivos exclusivamente nacionais, orientada que estão pela necessidade de se assegurar a concretização de compromissos globais.

Este cenário também expõe uma nova realidade para a arquitetura das relações de poder a partir de padrões de governança, tipicamente associado à forma de se atingir objetivos globais que não podem ser alcançados exclusivamente pela atuação nacional, ou ainda, pela iniciativa de instituições internacionais.

Compromissos como os que se relacionam ao objetivo de assegurar processos eficazes para a adaptação perante os efeitos das mudanças climáticas globais expõem uma preocupação que se vincula ao interesse de toda a humanidade, diante da ameaça real de degradação de sua existência. Entretanto, estes objetivos somente podem ser atingidos pela conjugação de estruturas institucionais capazes de se comunicar e de interagir entre si.

A construção de semelhante arquitetura não resulta da ação exclusiva de instrumentos internacionais e de suas instituições, e muito menos da atuação dos Estados segundo sua própria pauta de prioridades e projetos de desenvolvimento, mas sim da realização de 
semelhantes objetivos, globais, através dos Estados, e no plano de decisões públicas que são tomadas no âmbito e na forma dos próprios arranjos institucionais nacionais.

Trata-se aqui, da exposição de um arranjo que tende priorizar um modelo pelo qual, através de escolhas nacionais, comprometidas com compromissos globais é que pode conceber e assegurar a realização de objetivos comunitários. Entretanto, isto não decorre necessariamente de um processo de internacionalização das ordens nacionais, senão de um extenso e mais profundo processo de transformação da cultura constitucional (HÄBERLE: 2000, p. 36-39), que por sua vez, define o projeto de sociedade que se pretende viabilizar, ou que deve ser viabilizado através das formas políticas e jurídicas.

Situada a questão nesses moldes, é possível reconhecer que ao Estado e a cada um de nós foi atribuído pela ordem constitucional brasileira, um conjunto de deveres perante a humanidade, deveres que resultam em conseqüências que não conhecem limites geográficos ou fronteiras políticas, muito embora ainda decorram de decisões de Estados-nacionais, que são agora, formações influenciadas e integradas na estrutura de uma ordem jurídica que deixa de ser nacional, e que também não pode ser compreendida como internacional, senão como uma ordem global. Esta tem sua organização baseada em uma estrutura de redes, que não contempla a autonomia de padrões, referências morais ou culturais, e que procura atingir seus objetivos a partir da consideração das diferenças, das contradições e das divergências.

O conflito e não o consenso constitui o ponto-de-partida para as decisões e para a organização desta nova ordem, que privilegia a interação entre as experiências em detrimento da autonomia dos sistemas.

\subsection{O Estado de direito como mediador de projetos de vida e o constitucionalismo de uma sociedade decente}

Um Estado de direito, compreendido como um Estado constitucional, é, para Haberle, um Estado que se sustenta, parcialmente, em uma identidade antropológica, que se associa ao homem (HABERLE, 2001).

É um Estado que deve ser capaz de garantir e desenvolver as condições que sejam indispensáveis para a existência do homem, e que deve ser capaz de permitir que o este homem se desenvolva plenamente. Stephan Kirste (KIRSTE: 2013, p. 156-164) Rolf Groeschner (GROESCHNER: 2008, p. 58-81) e Winfried Brugger (BRUGER: 2008, p. 49-94), sintetizam que este homem se desenvolve plenamente quando pode realizar projetos, e é livre para atingi-los e executá-los.

Então este Estado de direito esboça conexões fortes com esta imagem de homem quando se verifica que este, por meio daquele: a) exerce suas liberdades e; b) toma decisões sobre os rumos de sua existência.

Um Estado de direito é, desse modo, o mediador de compromissos e objetivos no interesse desse homem que se apresenta como pessoa.

Entretanto, seus projetos são ameaçados por riscos que ganham complexidade e desafiam a capacidade desse Estado de protegê-lo, ou melhor, de assegurar sua capacidade de realizar projetos. Isso ganha cada vez mais complexidade quando se constata que, neste momento, este mesmo homem que continua a ser destinatário de proteção, é a fonte de proliferação das ameaças à sua própria existência. ${ }^{8}$

Neste momento, as ameaças se estendem para riscos sociais, pessoais, ecológicos, econômicos e culturais, em um contexto que suscita a indagação sobre o que significa ser

\footnotetext{
${ }^{8}$ Em estudo científico recentemente divulgado, indica-se que o homem é capaz de acelerar em mil as taxas de perda de biodiversidade (SCIENCE).
} 
protegido ou o que significa proteger como tarefa estatal? Propõe-se como alternativa para o diálogo desenvolvido neste texto a seguinte hipótese: viabilizar o desenvolvimento de uma sociedade (e de uma vida) decente. Avishai Margalit sugere essa perspectiva do seguinte modo: uma sociedade civilizada é aquela onde as pessoas não se humilham, mas uma sociedade decente é aquela onde as instituições (Estado, mercado) não humilham as pessoas. Não humilhar é não degradar a existência (MARGALIT: 2010, p. 35-44).

É nesse ponto que se retoma a mesma imagem de Haberle para complementá-la e esboçar a imagem contemporânea desse Estado de direito. Se por um lado é tarefa de um Estado de direito favorecer as liberdades, por outro é a de proteger as condições básicas e elementares da existência de uma comunidade. Não se permite atingir o primeiro objetivo se alguns valores (e bens) vitais puderem ser atingidas pelo exercício daquelas em intensidade que thes seja nociva. Então para continuar a ser capaz de proteger as pessoas, e proteger valores e bens que sejam indispensáveis para a existência da vida, níveis de qualidade dos recursos naturais também se integra às tarefas estatais.

Neste momento assiste-se a um conjunto de transformações que atingem o Estado e a sociedade. Da parte do Estado, este não pode tomar decisões sem avaliar previamente as consequências que elas podem produzir sobre a integridade dos bens e valores vitais (FERRAJOLI: 2011, p. 66-85; DWORKIN: 2011, p. 419-423). Pela segunda parte, ninguém pode ter ao seu alcance todas as alternativas. Nem todas elas estão disponíveis para decidir. Nem todas as decisões estão acessíveis. Algumas podem comprometer tudo o que sustenta a vida, ou pelo menos, aquilo que seja indispensável para sustentá-la. Para continuar a existir, não se fala em Estado de direito se também não se falar em compromisso deste Estado com a sustentabilidade. (HABERLE: 2008, p. 200)

Dito de outra forma, teríamos que, se o Estado não for capaz de assegurar a proteção desses bens vitais (ou valores), ou se colaborar para que sejam eliminados, assistiríamos a uma iniciativa que colabora para a degradação existencial de uma sociedade. Nesta sociedade, não é possível desenvolver vida decente.

O Estado de direito tem um compromisso com a vida de uma sociedade decente, e uma sociedade é decente quando todos os valores indispensáveis à existência sejam protegidos e conservados.

Desse modo é possível sugerir uma noção de um assim denominado constitucionalismo de uma sociedade decente (ou para uma vida decente). A Constituição de um Estado de direito representa um compromisso com tarefas ecológicas, e com a necessidade de se proteger projetos de vida plurais, identidades, representações de valores que desafiam a pretensão de universalidade do que conhecemos como direitos fundamentais de decisões nacionais.

Estamos tratando aqui de Constituições que atuam como veículos de comunicação com experiências capazes de favorecer o aprendizado e a sinergia. A constituição de Estados de direito com tarefas ambientais e a Constituição de um Estado cosmopolita (BECK: 2007, p. 77102), que precisa ser capaz d e proteger todos os projetos existenciais decentes dessa sociedade plural.

Estamos tratando aqui, fundamentalmente, de transformações que atingem o próprio significado de moral constitucional de uma determinada experiência. A moralidade constitucional influência e representa até onde se permite alcançar proteção, para que bens e para que valores, no interesse de uma determinada sociedade e contexto.

Então, o que é que se pode esperar de uma experiência moral que define a todos um direito de viverem em um ambiente de qualidade indispensável para a sua existência e de outras formas de vida? 
Algumas respostas distintas tem sido oferecidas por experiências que sugerem escolhas morais diferenciadas, e oferecem, padrões de proteção com significados distintos para o que se deseje entender como mínimo existencial em uma sociedade decente. Algumas delas serão examinadas neste trabalho sob a perspectiva do direito brasileiro sob a perspectiva da produção normativa de suas instituições e sobre a perspectiva da aptidão de sua função judicial de viabilizar os objetivos de tal sociedade (e de tal qualidade material de Estado de direito).

\subsection{Constitucionalismo verde e o Direito ambiental da sustentabilidade como manifestações de um constitucionalismo da vida decente}

No cenário de problemas descritos, a resolução da indagação tende propor relevância para a identificação de um esquema organizatório diferenciado na ordem jurídica. Este suscita identificar manifestações capazes de contribuir para a proteção dos recursos naturais e de assegurar a durabilidade da vida em uma realidade de riscos de segunda geração ${ }^{9}$, que por sua vez, orientam a organização do que trataremos por um Direito ambiental de segunda geração. $^{10}$

No Direito norte-americano há divergência sobre o reconhecimento de possíveis fases da produção normativa matéria ambiental, sendo possível distinguir três, quatro ou cinco gerações de normas ambientais. A primeira geração exporia um modelo de regulação baseado na definição de padrões e de regras rígidos implementados por técnicas de comando e controle que também definiam à sua semelhança, um modelo de litigância. A segunda geração seria definida por uma ênfase em instrumentos econômicos fortemente influenciados por incentivos, instrumentos de mercado, instrumentos de regulação flexível e normas de cumprimento voluntário, além de técnicas de negociação. Em uma terceira geração as normas já seriam definidas sob uma abordagem de instrumentos e técnicas de influência e de participação nos processos decisórios, enfatizando um Direito reflexivo, comprometido com uma matriz normativa principiológica, na qual um princípio de desenvolvimento sustentável teria uma função de evidência. A última geração, proposta por Arnold, proporia normas compatíveis com as demandas emergentes de uma sociedade exposta a riscos de elevada complexidade, que somente poderiam ser geridas adequadamente a partir de um modelo que proporcionasse a interação entre os instrumentos e técnicas disponíveis, em uma abordagem definida como multimodal. Nesta abordagem não se teria uma técnica ou alternativa previamente definida para a resolução dos conflitos ambientais, ao mesmo tempo em que enfatiza que problemas de nova geração, como são os relacionados às transformações climáticas extremas, dependem de uma organização das instituições e uma formação decisória diferenciada. (ARNOLD: 2009).

Visando integrar semanticamente a denominação dos novos problemas ao conjunto de normas e ao modelo de regulação capaz de proporcionar níveis de proteção suficientes perante essa realidade, opta-se nesta investigação por propor uma distinção dual entre as gerações do

\footnotetext{
${ }^{9}$ A referência a um conjunto de problemas ambientais de segunda geração é aqui atribuída ao professor Canotilho e se encontra exposta em: CANOTILHO, José Joaquim Gomes. Direito constitucional ambiental português: tentativa de compreensão de 30 anos das gerações ambientais no direito constitucional português. In: CANOTILHO; José Joaquim Gomes; LEITE, José Rubens Morato. Direito constitucional ambiental brasileiro. São Paulo: Saraiva, 2007. p. 2.

${ }^{10}$ A referência a um Direito ambiental de segunda geração encontra-se exposta aqui no mesmo sentido em que foi empregada pela primeira vez por Nicholas Robinson em: ROBINSON, Nicholas. Challengings confronting the progressive development of a second generation of environmental law. In: LIN-HENG, Lye et al. (Orgs.). Towards a "Second Generation" in Environmental Laws in the Asian and Pacific Region. Cambridge: IUCN, 2003. p. 27-32. No Direito brasileiro a expressão foi inicialmente utilizada e exposta em: AYALA, Patryck de Araujo. Constituição ambiental e sensibilidade ecológica: notas para a reflexão sobre um direito ambiental de segunda geração na jurisprudência brasileira. Revista de Direito Ambiental, vol. 60, p. 11-41, out./dez. 2010.
} 
Direito ambiental. Neste, teria lugar de destaque a resolução dos conflitos suscitados pelos assim denominados problemas ambientais de segunda geração.

Em um Direito Ambiental de segunda geração visualiza-se a organização de regimes específicos de regulação da complexidade dos riscos emergentes, a valorização e a ênfase sobre princípios que propõem níveis diferenciados de proteção, como o princípio da responsabilidade de longa duração e a exigência de um mínimo existencial ecológico [estes mais intensamente relacionados como manifestações específicas de um princípio de desenvolvimento sustentável ou de sustentabilidade] (TORRES: 2009; AYALA: 2011, p. 170178), e o princípio da proibição de retrocesso, (HACHEZ: 2008), além de instrumentos diferenciados com ênfase para instrumentos econômicos que supõem formas voluntárias de compensação financeira para o pagamento por serviços ecossistêmicos ${ }^{11}$, e uma compreensão diferenciada sobre a função que deve ser cumprida por instrumentos tipicamente relacionados a um Direito ambiental de primeira geração. ${ }^{12}$

Sendo assim, propõe-se examinar nesta ocasião, sob que modelo de juridicidade seria possível viabilizar esse novo esquema organizatório. Este se encontra fixado no texto, como o de um Estado ambiental (ou socioambiental) e de uma Constituição ambiental (ou ecológica), que propõe uma ordem jurídica moralmente plural, cuja fonte de juridicidade e a própria identidade material se encontram abertas à interação com experiências normativas, culturais e sociais externas. $^{13}$

Ekeli chega a propor a imagem de um constitucionalismo verde comprometido com um projeto político diferenciado, no qual se encontra reforçado o objetivo de proteger e assegurar proteção para as futura gerações. Em um constitucionalismo verde, seria indispensável a previsão de novas medidas, materiais e procedimentais que pudessem viabilizar a consideração desses interesses, visando concretizar o compromisso político com um projeto de justiça que não se esgota no tempo, e se estende para além das presentes gerações. (EKELI: 2007).

Para que fosse possível identificar a imagem de um constitucionalismo verde, salienta que duas ações seriam requeridas sobre as experiências jurídicas: uma sobre a qualidade das decisões e outra sobre o desenvolvimento dos próprios processos de decisão. A primeira implica a transformação dos processos de decisão, exigindo das instituições e das autoridades públicas a ampliação das decisões e das deliberações orientadas pelo futuro. A segunda exige o aperfeiçoamento dos próprios processos de deliberação pública sobre todas as questões que possam afetar, ainda que remotamente, os interesses das futuras gerações. (EKELI: 2007).

O artigo 225, caput, do texto constitucional brasileiro também define um direito fundamental ao meio ambiente como um dos instrumentos que poderia viabilizar esta realidade adicional para 0 conceito de existência digna, comprometida com um projeto de justiça que não se restringe ao

\footnotetext{
${ }^{11}$ Conforme as conclusões da Avaliação Ecossistêmica do Milênio, realizada pela Organização das Nações Unidas, deve-se compreender por serviços ecossistêmicos todos "[...] os benefícios que as pessoas obtém dos ecossistemas. Entre eles se incluem serviços de provisões como, por exemplo, alimentos e água, serviços de regulação como controle de enchentes e de pragas, serviços de suporte como o ciclo de nutrientes que mantém as condições para a vida na Terra, e serviços culturais como espirituais, recreativos e beneficios culturais.". United Nations. Ecosystems and Human Well-being. Disponivel em: <http://www.millenniumassessment.org> Acesso em 30 de junho de 2010.

12 Para uma definição do modelo de regulação de primeira geração, vale considerar em relação de semelhança, a descrição proposta para o Direito norte-americano em: ARNOLD, Craig Anthony. Fourthgeneration environmental law: integrationist and multimodal. Distinguished Visiting Lecture in Environmental and Land Use Law, Florida State University College of Law, 2009.

${ }^{13}$ Neste aspecto vale ressaltar a possibilidade de se relacionar a viabilidade de concretização do projeto de sociedade e de futuro veiculados por um Estado ambiental, à sua capacidade de integração com experiências externas sob a forma de um transconstitucionalismo. O tema encontra-se desenvolvido em: NEVES, Marcelo. Transconstitucionalismo. São Paulo: Martins Fontes, 2009.
} 
tempo, e que se tem sua definição sujeita à revisão permanente das demandas condicionadas por padrões intergeracionais de justiça.

Sob essa configuração de ordem constitucional esboçada na experiência nacional, o valor solidariedade, e o objetivo dignidade de vida integram-se neste momento, como partes de um projeto de sociedade, de um modelo de organização do poder e, sobretudo, como um dos fundamentos de uma República ecologicamente sensível.

Em uma perspectiva de interdependência, que também é aquela que orienta a compreensão do conteúdo do próprio direito fundamental ao meio ambiente, e do princípio da livre iniciativa, do modo como este se encontra protegido pela Constituição brasileira, as liberdades econômicas somente têm o seu exercício viabilizado sob o condicionamento de imperativos ecológicos, ao mesmo tempo em que a proteção do meio ambiente somente tem sua justificativa na medida em que esta também puder ser integrada com um dos pressupostos que viabilizam a existência humana, e de todas as demais formas de vida. ${ }^{14}$

A existência humana depende de que se assegure proteção simultânea, de níveis de desenvolvimento econômico, mas também de níveis de qualidade dos recursos naturais, não sendo possível conceber-se a proteção autônoma de qualquer uma destas duas realidades, sob pena de se ter uma proteção apenas parcial do imperativo de dignidade da pessoa humana, o qual se constitui em um dos objetivos da República brasileira, conforme ressaltado (artigo 1으, inciso III, CRFB).

Não é outra a mensagem que poderia ser extraída da combinação entre os artigos 225, caput, e 170, caput e incisos II, III e VI, além do artigo 5º, inciso XXIII, todos da CRFB de 1988, dispositivos que reproduzem que a ordem econômica nacional é, antes de tudo, a ordem de uma economia social e ecológica de mercado, na qual se atribui ao Estado o desafio de proporcionar níveis de equilíbrio na proteção dos valores, direitos e interesses relacionados.

Sob o regime de uma ordem econômica de semelhante qualidade, cumpre ao Estado, em colaboração com a coletividade, proporcionar que se proteja a propriedade privada, mas também que se proteja as bases fundamentais da vida (Natürlichen Lebensgrundlagen), das quais depende o exercício dos poderes sobre os espaços (propriedade) e a própria possibilidade do exercício de todas as demais liberdades econômicas. ${ }^{15}$

Nesta nova realidade, as ameaças à existência humana e ao desenvolvimento das bases naturais da vida representadas pelos efeitos extremos das alterações climáticas globais impõem às funções estatais, compromissos reforçados para com o objetivo de redução dos riscos existenciais, tomando-se em consideração a necessidade de integração entre um conjunto extenso de realidades e de necessidades - compreendidas as sociais, econômicas, culturais e as ambientais - além de permear a formação de um novo padrão de governança fortemente influenciado pela produção normativa externa, a qual não se superpõe ou se impõe perante as formações estatais, senão as reforça e as posiciona como parte de uma arquitetura de fontes aberta e em permanente interação.

\footnotetext{
${ }^{14}$ Bosselmann faz referência a limitações ecológicas aos direitos humanos, conceito a partir do qual sustenta que o exercício das liberdades individuais não está condicionada apenas por um determinado contexto social, mas também por um contexto ecológico. Human rights and the environment: redefining fundamental principles? In: GLEESON, Brendan \& LOW (eds.), Nicholas. New York: Palgrave, 2001. p. 2.

${ }^{15} \mathrm{O}$ condicionamento dos direitos humanos (e dos direitos fundamentais) a um imperativo ecológico é sustentado por Bosselmann em: Bosselmann, Klaus. Human rights and the environment: redefining fundamental principles? In: GLEESON, Brendan \& LOW Nicholas (eds.). Governance for the Environment: Global Problems, Ethics and Democracy. New York: Palgrave, 2001. p. 2. A jurisprudência do Tribunal Constitucional das Filipinas define nesse mesmo sentido, que nenhuma liberdade ou direito podem ser plenamente exercitados a menos que seja concretizada a conservação da qualidade dos recursos naturais. MAY, James; DALY, Erin. Vindicating fundamental environmental rights: judicial acceptance of constitutionally entreched environmental rights. Oregon Review of International Law, vol. 11, p. 365440, 2009.
} 
Por outro lado, semelhante realidade de riscos também contribui e influencia a redefinição das funções estatais e dos objetivos que devem ser concretizados sob o ângulo da tarefa de redução dos riscos existenciais, definindo graus mais severos para o seu comprometimento e metas mais exigentes no plano da satisfação do que se deva considerar como um projeto de vida digno. Assim, quando se propõe por meio de uma determinada ordem constitucional, tarefas de proteção ecologicamente condicionadas por tais demandas adicionais, cumpre ao Estado por meio de cada uma de suas funções, assegurar que um projeto de futuro digno possa ser concretizado, guiado por padrões de justiça intra-geracionais e intergeracionais.

Portanto, assegurar um projeto de vida digno na ordem constitucional brasileira representa uma tarefa que expõe um compromisso de justiça para com o futuro, um compromisso moralmente plural (tendo seu conteúdo redefinido por valores adicionais, entre os quais se integram a necessidade de se proteger as bases naturais da vida com parte de todos os demais projetos, individuais ou coletivos), e um compromisso materialmente aberto, cujo resultado determinante é a definição de conteúdos materiais, ou sua redefinição de acordo com a capacidade de interação ou de aprendizagem da ordem interna, com os instrumentos internacionais de proteção dos direitos humanos (e ambientais).

$\mathrm{Na}$ condição de um dever de proteção específico, impõe ao Estado o dever de, primeiro, conformar adequadamente a ordem jurídica através de iniciativa legislativa, pois, como esclarece Novais:

[...] com excepção dos casos em que a própria Constituição ou a lei prevêem a obrigatoriedade de o Estado desenvolver uma concretamente determinada ou determinável acção de prevenção, de protecção ou de ajuda, [...] a escolha do quando e do como da actuação devida é uma incumbência do Estado, e primariamente, do legislador ordinário; (NOVAIS: 2003, p. 89-90).

$\mathrm{Na}$ abordagem que se fixa, resulta claro que sob a ordem constitucional brasileira, não se encontra autorizado a nenhum dos entes da Federação, que exerça suas capacidades legislativas para o fim de proporcionar o rompimento desta relação de equilíbrio que deve ser proporcionada pelas tarefas do Estado no domínio da proteção dos direitos sociais, econômicos e culturais, seja pelo exercício deficiente ou insuficiente de suas funções, seja pelo exercício excessivo das mesmas funções, contexto no qual se revela pertinente a conexão dos deveres estatais de proteção com o âmbito de aplicação de um princípio de proporcionalidade, para o fim de mensurar a legitimidade da intensidade de tais intervenções.

O Direito ambiental de segunda geração está baseado fundamentalmente, em uma estrutura de ação de colaboração entre as funções públicas e privadas para o fim de assegurar a concretização de um projeto político que intenciona assegurar a viabilidade de todas as formas de vida.

Trata-se de um projeto político (e existencial) dependente de uma estrutura de organização particular das instituições e de condicionamento da ação privada, resultante da forma política de Estado socioambiental, que condiciona e orienta a ação conformadora das funções públicas no caminho de um Direito ambiental de sustentabilidade, cuja principal manifestação está na interação entre princípios concretizadores de um objetivo estatal (e comunitário) de sustentabilidade.

Portanto, a proposição das bases de um Direito ambiental de segunda geração é, sobretudo, a afirmação de um Direito ambiental de sustentabilidade. Este Direito de sustentabilidade encontra claro desenvolvimento na ordem jurídica brasileira, associado a partir da Política Nacional do Meio Ambiente, e posteriormente aos objetivos da Constituição ambiental de 1988, expõe coerência com o movimento global de transformação da qualidade da ação pública, e de valorização de um modelo de governança ambiental, os quais levam em consideração às 
novas modalidades de ameaças existenciais, tendo nas mudanças climáticas globais sua principal representação.

Nesse sentido, é possível propor-se a vinculação de um Direito da sustentabilidade a partir da Política nacional do meio ambiente, situada agora como ponto-de-partida para influenciar de forma relevante, a organização e o desenvolvimento de instituições ecologicamente sensíveis, até o ponto de fundamentar a edificação de uma jurisprudência da sustentabilidade. ${ }^{16}$

\subsection{O que deve ser e o que não pode ser um Estado ambiental?}

Se é cada vez mais freqüente e recorrente o uso da imagem de um Estado ambiental pelo aplicador da norma ambiental, considerando-se aquele como se fosse, entre outras abordagens, o Estado que concretiza uma Constituição ambiental, é relevante analisar com um pouco mais prudência o que representa a imagem de um Estado ambiental, o que ele não é e não pode ser.

Deve ser recuperada, em primeiro lugar, a importância da Declaração de Estocolmo, de 1972, que externa uma primeira imagem de desenvolvimento sustentável, que ganhou contornos cada vez jurídicos mais bem definidos em momento ulterior, seja por iniciativa de normas de direito público interno, seja por meio de normas internacionais de direito público, imperativas ou não.

Muito embora fosse um instrumento de soft law, a professora Jutta Brunée já teve a oportunidade de registrar que o principal efeito desse texto é externar um consenso universal sobre a tarefa de proteção dos recursos naturais. Esta tarefa teria de ser considerada por todos os Estados, partir desse momento, uma tarefa inadiável (BRUNÉE: 2008).

Essa premissa influenciou a construção de várias experiências jurídicas no âmbito global. Apenas para restringir a nossa análise à brasileira, convém assinalar que em 1981, por meio da lei de PNMA (lei n. 6.981/1981), já se identifica com clareza a manifestação desse compromisso do Estado brasileiro, com o uso racional dos recursos, e no interesse da proteção de todos os processos ecológicos que sejam indispensáveis para o desenvolvimento da vida. Esse é o conceito de meio ambiente da lei de PNMA, na qual se determina como objeto, uma realidade integrativa e indivisível de realidades.

Então, quando se identifica uma Constituição ambiental na realidade brasileira, deve-se ter a cautela de admitir que esta tão somente reforça e aperfeiçoa as tarefas de proteção que este Estado já detinha, e em um caminho de progressividade (ao menos normativo). O Estado não ficou verde em 1988, mas ficou mais verde, definitivamente. Neste momento, proteger o meio ambiente seria uma tarefa objetiva, inadiável e a ser compartilhada com a coletividade, no interesse das futuras gerações.

Nesse contexto, que atributos ou manifestações poderiam identificar uma experiência jurídica definida por meio de um Estado ambiental, e que manifestações de forma alguma poderiam defini-la sob qualquer circunstância?

\footnotetext{
${ }^{16}$ Uma análise detalhada sobre as manifestações de uma jurisprudência da sustentabilidade no Direito brasileiro encontra-se exposta em: LEITE, José Rubens Morato; AYALA, Patryck de Araujo. Dano ambiental: do individual ao coletivo extrapatrimonial. Teoria e prática. 4. ed. São Paulo: RT, 2011. Nos tribunais internacionais e nas experiências estrangeiras, o tema encontra-se bem desenvolvido em: STEPHENS, Tim. Sustainability discourses in international courts: what places for global justice? In: FRENCH, Duncan (ed.). Global justice and sustainable development. Leiden, Boston: Martinus Niijhoff, 2010. p. 39-56; NAMBIAR, Sridip. Paradigm of 'green'adjudication: developing principles for Indian environmental decision-making in disputes insolving scientific uncertainty. ILI Law Review, vol. 1, n. 1, p. 1-24, 2010; MAY, James; DALY, Erin. Vindicating fundamental environmental rights: judicial acceptance of constitutionally entreched environmental rights. Oregon Review of International Law, vol. 11, p. 365440, 2009.
} 
Em primeiro lugar, o Estado ambiental integra o meio ambiente nos processos de decisão. (KLOEPFER: 1989; KLOEPFER: 2010). Todas as decisões públicas que possam representar intervenções sobre a qualidade dos recursos naturais significa que também podem representar interferência sobre a qualidade de vida das pessoas. Esta perspectiva de indivisibilidade reforça a importância da integração dessa variável, e ela exige transformações em níveis mais profundos das estruturas institucionais públicas, sendo esta a base para o sucesso ou 0 fracasso de um projeto político amigo do ambiente. $O$ fato de se ter uma Constituição ambiental não significa que se tenha um Estado ambiental bem definido. A identidade completa e integral de um Estado ambiental depende, necessariamente, do nível de força normativa de uma determinada experiência jurídica, e do grau de sensibilidade ecológica das instituições. Depende, portanto, da capacidade das instituições e da sociedade, de converterem as tarefas do Estado, em realidades favoráveis no plano socioambiental.

Como segunda manifestação, o Estado ambiental protege o meio ambiente de forma compartilhada. (KLOEPFER: 1989, 2010). Não se consegue obter proteção do meio ambiente por iniciativa exclusiva das próprias funções públicas. A transformação de comportamentos privados, e o compliement podem contribuir e favorecer a ação estatal. Poderá lhe ser exigida menos intensidade em sua iniciativa, se medidas preventivas forem adotadas ou normas forem cumpridas voluntariamente pelos particulares. Assim podem evitar contaminação, poluição, degradação, que se punidas pela ação de polícia estatal, representa incremento na relação entre a intensidade dos custos, e a intensidade da proteção. Uma relação ineficiente é o resultado de falha na ação estatal, decorrente da ausência de controle, e de monitoramento, $A$ presença oportuna da ação pública, v.g, no controle dos desmatamentos e queimadas, pode proporcionar igual ou melhor proteção com menor vinculação financeira para o atendimento dessas mesmas demandas.

O Estado ambiental também é um Estado cooperativo. (KLOEPFER: 1989; KLOEPFER: 2010). Um Estado ambiental poderia ser identificado, v.g, quando se reconhece e quando se proporciona a oportunidade de livre manifestação, por meio de audiências públicas? Isto define - Estado cooperativo proposto por Kloepfer? A resposta é negativa, porque a perspectiva cooperativa reflete a capacidade efetiva de influência na formação das decisões, e no condicionamento das escolhas realizadas pelo gestor. Se não se puder interferir de forma decisiva nas escolhas e na formação das decisões, não se terá cooperação e participação no sentido desejável da representação teórica referida.

Por fim, e baseando-se na mesma orientação teórica, um Estado ambiental não considera o meio ambiente ou os recursos naturais como bens suscetíveis de proveito econômico, senão como fatores para o desenvolvimento livre da personalidade humana.

Sendo assim, não se tem como referência um Estado ecofascista e temos aqui uma tentativa de se equilibrar uma relação que tende a não ter condições de ser equilibrada, porque baseada em uma economia social e ecológica, mas ainda de mercado. A mensagem aqui é: alguns condicionamentos sociais e ecológicos impõem-se para o exercício de todas as liberdades, porque disto depende que se consiga proporcionar projetos dignos de vida, e de forma permanente e duradoura.

Sendo assim, o Estado ambiental seria a resposta para os conflitos socioambientais que tem origem em riscos e ameaças de maior magnitude e invisibilidade? Definitivamente não.

A imagem normativa de um Estado ambiental, per se, não viabiliza a vida assim como também não concretiza realidades dignas. Ele representa uma imagem de compromisso materializado por meio de consensos sobre valores ou bens considerados relevantes a tal ponto de exigirem uma relação de interação necessária entre fatores sociais, econômicos e culturais, além de arranjos de organização que integrem instituições ecologicamente sensíveis (porque capazes de primeiro compreender os conflitos socioambientais e, depois, proporem ponderações 
imparciais e adequadas para tais conflitos), e a colaboração das forças sociais, as quais precisam ser responsabilizadas sobre tal tarefa.

Portanto, a construção normativa de um Estado ambiental, se não concretiza realidades dignas, influencia decisivamente a organização de relações que possam favorecer as condições indispensáveis para o desenvolvimento de todas as formas de vida, além de assegurar que o homem possa realizar projetos dignos para sua existência.

Por meio de um Estado ambiental, o desenvolvimento da vida somente pode ser atingido se for considerada uma relação na qual, de um lado estejam instituições ecologicamente sensíveis e, de outro, forças sociais ecologicamente responsáveis. Responsáveis não porque prudentes (deveres qualificados), senão porque respondem, prestam contas e se vinculam a um dever geral de proteger tais condições. Este dever é preponderante e exige igual grau de comprometimento das funções públicas e da comunidade porque tais condições são indispensáveis para o desenvolvimento da vida.

A Constituição de um Estado ambiental representa consensos sobre alguns valores de especial relevância para a definição do que seja humano, e para a existência duradoura de todas as formas de vida. Essa Constituição exige que uma relação de interdependência entre o Estado e a sociedade seja capaz de proteger as pessoas, proporcionar-Ihes qualidade de vida e padrões mais elevados de bem-estar, supondo que esta definição também integre, necessária e previamente, o meio ambiente como o ponto-de-partida para o exercício de toda e qualquer liberdade econômica.

Ela é, portanto, a constituição de um Estado que protege ao mesmo tempo: a) a vida, b) a vida das futuras gerações e; c) a existência duradoura de todas as formas de vida.

Outro aspecto que precisa ser enfatizado é o de que, se um Estado ambiental não é e não pode ser mais amigo do meio ambiente do que é da cultura, da economia e das liberdades, esse Estado continua a ser um Estado de Direito.

Um Estado de direito é e precisa ser ainda, um Estado que, em primeiro lugar, e por meio da colaboração com as forças sociais, consiga assegurar proteção para as pessoas.

Portanto, um Estado que não considera o meio ambiente nos processos de decisão é um estado que não vai proteger as pessoas, e que não possui nenhum compromisso com a sua comunidade política. Häberle parece chegar a admitir que um Estado de direito que não considere um princípio de sustentabilidade não é um Estado de direito (HÄBERLE: 2008).

O Estado ambiental é, portanto: a) um Estado de sustentabilidade e; um Estado aberto à aprendizagem constitucional. Mas não pode ser: a) um Estado de frustração constitucional e, conforme será sustentado adiante, um Estado de retrocesso ambiental.

Um Estado ambiental é um Estado que favorece e precisa assegurar que melhores níveis de qualidade de vida e de bem-estar estejam ao alcance das pessoas. Ele deve assegurar a proteção do interesse público e como parte do interesse público, como parte de qualquer projeto de bem-estar, deve-se considerar a proteção do meio ambiente.

Conforme bem ilustrado por Perez Luño, Rudolf Smend reforça uma função para as Constituições contemporâneas, por meio da qual elas não se limitam a definir zonas de proteção das liberdades e a separação das funções do poder, senão propõem compromissos e responsabilidades. Metas políticas indispensáveis para a existência de uma determinada comunidade (PEREZ LUÑO: 2012, p. 41-42). A brasileira considerou que o meio ambiente com qualidade deveria ser parte desse projeto político, e desses compromissos, não sendo possível obter bem-estar senão por meio da garantia de níveis elementares de qualidade dos recursos naturais, e dos processos que são vitais para a existência da vida. 
A partir da década de 1980 (KLOEPFER: 1989; SOMMERNAN: 1998, CALLIES: 2001) a proteção do meio ambiente surge como objeto de preocupação da doutrina publicista no âmbito das tarefas estatais, situando-o como parte indivisível das metas que deveriam ser atingidas para que um Estado de direito completo e integral pudesse ser identificado (SOMMERNANN: 1998).

A constituição de um Estado ambiental coloca em evidência as novas tarefas do Estado no âmbito de um constitucionalismo de longo prazo. Constitui uma das metas políticas desse Estado proteger a vida em escala futura e proporcionar sempre níveis duradouros de qualidade de vida (FERRAJOLI: 2011, p. 80-85). Por essa razão a proteção do meio ambiente passa a ser tema de relevância e que perpassa todo o direito público contemporâneo, porque é tarefa desse Estado também assegurar a existência e a conservação da qualidade dos recursos naturais.

Nesse contexto, proteger e defender o interesse público significa assegurar proteção ao meio ambiente, e proporcionar mais qualidade de vida para as pessoas implica, antes de tudo, e da mesma forma, assegurar melhores condições para conservar os processos ecológicos essenciais, sendo estas as condições que definiriam um nível mínimo de qualidade de valores indispensáveis para a existência da comunidade política, e, portanto, de todas as formas de vida, considerando-se que o meio ambiente é um dos valores que a sustentam.

\section{0 que se deve proteger? Os imperativos de proteção do meio ambiente e das futuras gerações como partes do projeto de comunidade política protegido pela Constituição}

Uma primeira possibilidade de resposta para a questão poderia propor, fundamentalmente, o objetivo de bem-estar, mas sob uma perspectiva diferenciada. Quando a ordem jurídica brasileira exige algum nível de compromisso entre escolhas econômicas e a proteção de alguns bens, como o meio ambiente, assim o faz porque alguns bens são indispensáveis para que todas as demais escolhas possam ser realizadas. Os recursos naturais são fatores em relações de produção, mas também são fatores relevantes nas relações sociais e culturais.

Tem-se aqui que compreender que, quando a Constituição brasileira define um direito ao meio ambiente, ela o faz como parte de um projeto existencial mais extenso e mais ambicioso, que se compromete com uma perspectiva de bem-estar de conteúdo distinto (que exige sociedade, cultura e meio ambiente), e de longo prazo. Proteger o meio ambiente e viabilizar o acesso universal de padrões elementares para todos externa, antes de tudo, um compromisso com um projeto de dignidade de vida permanente, que interessa a todos nós neste momento, e que também interessa às futuras gerações.

O direito ao meio ambiente é, nessa perspectiva, um direito social, econômico e cultural (DSEC). Essa realidade, já presente no texto sul-africano (AYALA, 2011; KOÉTZE: 2007), facilita a tarefa de se desenvolver uma realidade de não retrocesso, como manifestação estritamente vinculada ao regime de proteção desses direitos, que são os DSEC.

Não se faz justiça para as futuras gerações diminuindo os níveis de proteção assegurados pela ordem jurídica vigente.

Da mesma forma, não se faz justiça para as futuras gerações dividindo a proteção dos direitos fundamentais: dividir a proteção é diminuir a proteção dos mesmos. Porque razão esta afirmação é verdadeira? Porque não cabe ao Estado, nem mesmo por meio de decisões resultantes de processos democráticos representativos, propor escolhas que resultem em decisões que priorizem ou escolham que realidades devem ser protegidas em detrimento de 
outras. Esse Estado ambiental, que também continua a ser um Estado social, mas que concebe a proteção social sob uma dimensão mais alargada, precisa viabilizar os níveis mínimos de prestações de todos os direitos fundamentais. Isso porque o mínimo indispensável à existência digna das pessoas passa por selecionar não quais direitos serão protegidos, mas que intensidade será possível proporcionar neste momento, sem que seja erodido o âmbito de proteção de qualquer direito. Assim, não se pode proteger o meio ambiente em detrimento de prestações de saúde ou de investimentos em redes de saneamento ambienta ou ensino fundamental, assim como o oposto também é igualmente verdadeiro. As escolhas não são e nunca poderão ser propostas sobre o que proteger, mas sobre o quanto proteger e o como proteger. O mínimo (existencial) e o nível mínimo (de prestações) é inegociável pelos pactos republicanos.

Se ninguém é capaz de definir quais serão as escolhas das futuras gerações, não podemos limitar sua capacidade de escolher, mas também não podemos nos impor sacrifícios intoleráveis em nome dessa proteção, por outro lado, princípios mínimos condicionam e limitam as liberdades que teríamos para dispor sobre a qualidade de vida, que por sua vez, representa uma conexão indivisível com a qualidade dos recursos naturais.

Justiça supõe, antes de tudo, isonomia, e proteção universal do acesso. Todos devem ser capazes de usufruir de padrões essenciais para o desenvolvimento de seus projetos de vida. E estes projetos de vida (que são projetos de bem-estar) supõem a conexão entre vida e os processos ecológicos que Ihes são essenciais, sendo este o núcleo que definirá, conforme será descrito adiante, a imagem de um mínimo de existência em matéria ambiental.

\subsection{O mínimo de existência em matéria ambiental}

A elaboração ou a determinação de uma referência semântica para a noção de mínimo existencial nunca chegou a obter um consenso sobre o seu sentido positivo, na experiência germânica, na qual tem sua origem, sendo ainda mais complexa a determinação do que se poderia considerar como um mínimo de existência sob a perspectiva ecológica. Isto se deve, especialmente porque não se impõe como tarefa singela a de se apontar a que conjunto de prestações o Estado se encontra vinculado.

Entretanto, se não é possível determinar, prima facie, a que espécie de prestações o Estado está vinculado, visando assegurar a proteção dos fundamentais de seus titulares [reforçado aqui, o direito fundamental ao meio ambiente], o desenvolvimento da noção de um mínimo de existência ecológica (CANOTILHO, 2004b, p. 182) ${ }^{17}$ ou de um mínimo vital (PIZOLLATO, 2004), pode ser elaborado a partir de uma determinação negativa.

Partindo de uma análise sobre a ordem constitucional alemã, Luther (LUTHER, 1986, p. 2556) argumenta que a fundamentação de um mínimo ecológico de existência far-se-ia em analogia ao reconhecimento de um mínimo social de existência.

Por meio dessa construção dogmática, Luther (LUTHER, 1986, p. 2557) observa que seria possível propor uma leitura ecológica baseada em um conceito de dignidade humana - pelo qual o homem não poderia ser reduzido a um mero objeto do mundo técnico-industrial - e a partir dos direitos fundamentais à vida, ao livre desenvolvimento da personalidade e do princípio do Estado social.

\footnotetext{
$17 \mathrm{Na}$ ordem constitucional alemã, a ausência de um direito fundamental ao meio ambiente é compensada, entre outras alternativas, exatamente pela afirmação, em um caso concreto, de um mínimo de existência ecológica, exemplificado por Weidner na hipótese de poluição ambiental produzida por iniciativa estatal que pudesse produzir prejuízos à vida, à saúde humana e à propriedade. Somente nos casos em que aquele mínimo de existência ecológica fosse posto em perigo por atividades estatais, seria possível justificar pretensões subjetivas. (WEIDNER, 1995, p. 20).
} 
Tomando-se como referências as funções defensiva e prestacional, é possível argumentar que a elaboração de um direito fundamental ao meio ambiente propõe, essencialmente, obter como efeito da norma preservar, proteger, ou garantir a obtenção do resultado dignidade de vida e do resultado qualidade de vida.

Desse modo, o resultado prático de um direito fundamental ao meio ambiente não poderia ser compreendido senão com o resultado de uma composição de posições jurídicas e de realidades subjetiva e objetiva do direito fundamental, que tendem a orientar a concretização de um mínimo de condições existenciais que permita garantir aquelas finalidades. De forma mais relevante, seria o resultado de uma postura de não eliminação de posições (defensivas) ou de criação das infra-estruturas necessárias e suficientes para sua existência (prestacional); uma existência que supõe uma realidade existencial de múltiplos conteúdos, agregando-se entre eles, uma variável ambiental.

Portanto, uma referência possível para desenvolver a noção de um mínimo de conteúdo ambiental (mínimo de existência ecológica) pode ser associada à suficiente qualidade de vida enquanto resultado de uma leitura de dignidade, compreendida esta como a manifestação de diversas posições jurídicas fundamentais de um direito fundamental como um todo: funções defensiva e prestacional do direito fundamental ao meio ambiente, além de também ser 0 resultado de uma tarefa estatal.

O desenvolvimento dessa noção ainda tem sua relevância reforçada porque pode justificar a consideração de padrões de proteção ambiental mínima perante riscos existenciais, ${ }^{18}$ que, a partir desse mínimo, poderiam ser considerados intoleráveis ou inaceitáveis.

É o que, de certo modo, parece ser possível propor a partir da abordagem que vinculasse a determinação de um mínimo ecológico de existência a uma noção de espaço ecológico ou uma margem de tolerância ecológica, propostos por O'Riordan (O'RIORDAN, 1999, p. 285).

Um mínimo ecológico de existência tem a ver, portanto, com a proteção de uma zona existencial que deve ser mantida e reproduzida; mínimo que não se encontra sujeito a iniciativas revisoras próprias do exercício das prerrogativas democráticas conferidas à função legislativa. É neste ponto que a construção de uma noção de mínimo existencial (também para a dimensão ambiental) estabelece relações com um princípio de proibição de retrocesso, para admitir, também ali, uma dimensão ecológica que deve ser protegida e garantida contra iniciativas retrocessivas que possam, em alguma medida, representar ameaça a padrões ecológicos elementares de existência.

O que importa fixar neste momento é que, se a proteção de um mínimo de existência pode não parecer tão relevante para assegurar o cumprimento de metas mais otimistas para os níveis de proteção do meio ambiente, (CANOTILHO, 2004b, p. 182) ${ }^{19}$ pode justificar, pelo menos, imposições no sentido de organização das estruturas de serviços e de infra-estrutura

\footnotetext{
${ }_{18}$ Ainda que não proponha expressamente esta abordagem (de mínimo existencial como fundamento para a redução de riscos existenciais de natureza ambiental), é conveniente a consulta da posição de Häberle, que argumenta que proteção ambiental mínima é uma manifestação de dignidade humana. (HÄBERLE, 2005, p. 130). Portanto, parece ser lógico sustentar que um dos efeitos de uma garantia de proteção ambiental mínima seria a redução de riscos existenciais e, particularmente, aqueles de especial relevância, seja por sua magnitude, seja por não terem sido suficientemente investigados ou acessíveis ao conhecimento científico disponível. De outro modo é conveniente sustentar que um padrão mínimo de proteção não necessariamente implica considerar que o resultado a ser obtido deverá ser o de garantir riscos mínimos à sociedade. Nesse sentido, diante da consideração de um princípio da precaução, a garantia de um padrão mínimo de proteção seria compatível com a defesa de uma proteção obrigatória, adequada e suficiente sobre determinadas fontes, processos e tecnologias potencialmente arriscadas.

19 A consecução dessa tarefa pode ser justificada através de outro fundamento, o do princípio da responsabilidade de longa duração, que será tratado na seção dos efeitos do sistema objetivo de proteção, que poderia impor ao Estado a orientação vinculante de suas ações, por exemplo, no sentido da organização de um modelo de desenvolvimento econômico compatível com a manutenção dos equilíbrios dinâmicos dos recursos naturais e de seu usufruto no interesse das futuras gerações.
} 
suficientes que possam manter a qualidade desses recursos e oportunizar o acesso eqüitativo aos mesmos.

Além de imposições vinculadas aos resultados fáticos sobre a qualidade dos recursos naturais, a definição de um mínimo de existência também não pode estar dissociada de uma proteção subjetiva que permita impor ao Estado uma estrutura de organização mínima de proteção e garantia desses resultados protegidos pelo direito fundamental, que derivam das imposições fáticas.

É nesse sentido que, com maior ênfase para a função legislativa, vincular seu exercício e vincular a extensão das prestações normativas a um mínimo de existência acarretam um dever de conformação adequada da ordem jurídica.

Em um esforço de consolidação das duas manifestações prestacionais do direito fundamental (que podem ser identificadas na ordem constitucional brasileira), verifica-se que um direito à emanação de pressupostos de existência do direito ao meio ambiente vincula essa existência à presença de pressupostos fáticos, normativos e estruturais, em uma postura bastante próxima da orientação descrita por Pizollato ao analisar a noção de nível essencial.

Explica Pizollato que a noção de nível essencial não pode limitar-se a uma leitura quantivativa do que seja essencial à existência, de modo que, sob a mesma noção, também devem ser consideradas as estruturas de organização que sejam indispensáveis para a garantia e para a existência das liberdades. (PIZOLLATO, 2004, p. 131).

Desse modo, parece ser possível argumentar que, quando se faz referência a um direito a que a proteção do meio ambiente seja conformada adequadamente por meio de prestações estatais, essa proteção não pode ser limitada à noção de mínimo de existência ecológica como o resultado daquelas prestações fáticas que sejam necessárias ao desenvolvimento dos equilíbrios dinâmicos dos recursos naturais, ${ }^{20}$ ou à manutenção de sua qualidade, de forma suficiente, para o acesso por todos os titulares do direito.

Independentemente de se considerar ou não uma noção de mínimo ecológico de existência como uma manifestação das diversas posições jurídicas de proteção emergentes de um direito fundamental ao meio ambiente, parece ser interessante sustentar, a exemplo de posição admitida no plano da interpretação do artigo 20a do texto constitucional alemão, que a fixação de um dever estatal de proteção reforçada que recai sobre o meio ambiente reproduz a imposição ao legislador de um dever de "[...] reduzir fundamentalmente as ameaças à vida e à saúde decorrentes de danos ambientais, tanto para as gerações presentes como para as gerações futuras da forma mais abrangente possível." (KLOEPFER, 2005, p. 168-169). ${ }^{21}$

O que interessa enfatizar neste sentido é a possibilidade de se reconhecer, sob o mesmo argumento, que, independentemente de se considerarem ou não os efeitos que uma noção de mínimo ecológico de existência exerça sobre as diversas realidades normativas de proteção do direito fundamental ao meio ambiente, a própria condição e a posição dos deveres estatais de proteção do meio ambiente enumerados no texto brasileiro permitem que sejam expostas duas conseqüências de grande relevância.

\footnotetext{
${ }^{20}$ Utiliza-se aqui uma noção de equilíbrios dinâmicos como resultado da abordagem ecológica proposta por Botkin, pela qual a noção de natureza, como um conjunto de relações estáveis e capaz de retornar ao seu estado constante, na hipótese em que seja atingida por perturbações, não pode ser admitida como uma representação da realidade física e biológica de como as relações naturais se processam. Cf. BOTKIN, 1990, p. 2-13, 185-192. Para uma análise de síntese e consolidação dessa orientação e da literatura científica relacionada, consultar: AYALA, 2002, p. 69-87.

${ }^{21}$ Convém salientar que Kloepfer também admite que a proteção do meio ambiente tenha sido reforçada como objetivo autônomo em relação à vida e à saúde. (KLOEPFER, 2004, p. 169).
} 
Pela primeira, tem-se que há, também na ordem constitucional brasileira, um dever estatal de reduzir os riscos ao meio ambiente $;^{22}$ pela segunda, que esse dever estatal de reduzir os riscos alcança indistintamente os riscos que estejam acessíveis ao conhecimento científico disponível (redução de seus efeitos) e mesmo os riscos inacessíveis, de forma plena, ao conjunto das manifestações desse conhecimento, reforçando-se - agora sob uma abordagem estrita de uma realidade objetiva do direito fundamental ao meio ambiente - a particularidade do regime de regulação de riscos definido pela Constituição ambiental brasileira.

Trata-se de um regime que propõe uma abordagem preventiva e precaucional, orientada por um dever estatal geral de reduzir os riscos e pelos deveres reforçados de prevenir os riscos vinculados aos efeitos de aplicações tecnológicas e de garantir proteção perante riscos potenciais de processos, técnicas e tecnologias ainda suscetíveis a indefinições científicas esta uma abordagem estritamente precaucional.

A prevenção supõe, portanto, o conhecimento dos riscos e das medidas destinadas a evitar ou a diminuir os danos, enquanto a aplicação do princípio da precaução é determinada em razão das incertezas do não conhecimento. (LE DÉAUT, 2001, p. 58).

Nem sempre a urgência da adoção de medidas de proteção diante de riscos demandará ações precaucionais, já que é possível atendê-los por medidas preventivas. Da mesma forma, se os efeitos negativos de novas tecnologias não necessariamente geram a adoção de medidas de precaução, parece que a afirmação constitucional de um princípio de responsabilidade de longa duração e a potencialidade de que isso afete os interesses das futuras gerações (os quais não podem ser determinados prima facie) impõem aos deveres de proteção, nessa hipótese, não apenas um imperativo de ponderação preventiva, mas um imperativo de ponderação precaucional de suas escolhas na conformação dos deveres de proteção. (CANOTILHO, 2007, p. 9).

O objetivo ou princípio da responsabilidade de longa duração fundamenta o reforço sobre a proteção objetiva do ambiente (deveres de proteção), indicando à ação pública que considere essa dimensão na seleção de suas opções e, mais especificamente, que considere os riscos de cuja existência, causalidade ou magnitude ainda não tenham certeza científica, para o efeito da proposição de quaisquer medidas de regulação.

Uma vez que, no contexto da ordem constitucional brasileira, os deveres de proteção estatal podem se manifestar como imperativos de ponderação preventiva ou imperativos de ponderação precaucional, é possível justificar, considerando a qualidade dos efeitos das fontes responsáveis pelas alterações climáticas extremas, e o princípio da responsabilidade de longa duração, que todos os deveres de proteção definidos pelo $\S 1^{\circ}$, do artigo 225 , possuem a aptidão para veicular uma abordagem precaucional e vinculam os particulares e o próprio Estado.

É assim que, evidenciada, v.g., a existência de riscos marginais de elevada magnitude que não podem ser completamente esclarecidos pelo conhecimento científico disponível, seria possível autorizar a justificação de medidas de proteção nas hipóteses de: a) práticas que pudessem expor a efeitos negativos a função ecológica da fauna e flora; b) processos ou atividades já inseridos na cadeia produtiva que possam produzir prejuízos à saúde humana e ao meio ambiente; c) toda e qualquer iniciativa ou omissão que possa expor a riscos a diversidade e a integridade do patrimônio genético, mesmo quando não se tenha conhecimento científico disponível que possa confirmar a produção dos efeitos enumerados.

\footnotetext{
${ }^{22}$ A consideração da noção de mínimo de existência ecológico trabalha aqui com o problema de que extensão seria exigível das instituições, em relação ao resultado redução dos riscos. Sob essa noção, já se sustentou anteriormente que o mais adequado seria admitir que não está imposto o dever de reduzir os riscos ao mínimo, mas um dever de reduzi-los e não admitir riscos que, por sua magnitude e ignorância sobre seus efeitos, possam comprometer atingir o objetivo protegido por aquela noção: garantir um mínimo de proteção ambiental.
} 
Em síntese, é possível conceber a noção de mínimo ecológico de existência na condição de resultado que decorre da combinação do exercício da iniciativa estatal e dos particulares, objetivando assegurar a proteção de níveis de qualidade dos recursos naturais, que sejam indispensáveis para que se possa assegurar um conjunto de realidades existenciais dignas ao homem, compreendido este sob a forma de uma específica imagem de homem em um Estado de direito, que é social, democrático e ambiental. Compreende-se, sob a noção de um mínimo ecológico de existência que, este homem, pessoa humana que deve ter asseguradas condições para o livre desenvolvimento de sua personalidade, somente pode fazê-lo se the estiverem acessíveis, realidades existenciais capazes de proporcionar o exercício dessas liberdades. Garantias relacionadas a um conjunto mínimo de prestações de conteúdo social, econômico, cultural e, agora, ecológico, constituem o veículo para uma existência digna do homem como pessoa, destinatária da proteção estatal e, não mais como objeto de sua iniciativa.

A noção de mínimo ecológico de existência surge, portanto, conforme salientado como uma conseqüência no plano existencial [no plano ecológico de existência], de um sistema de responsabilidades compartilhadas. Se a coletividade possui o dever de defender e assegurar que seus comportamentos não degradem a qualidade de vida de um bem que é indivisível e, que pode afetar o bem-estar de terceiros, cabe ao Estado, em primeiro lugar, assegurar por sua iniciativa, que esta qualidade não seja degradada, por deficiência em sua proteção normativa, pela ausência de proteção ou por insuficiência na proteção.

\section{Como se deve proteger? O princípio de proibição de retrocesso em matéria ambiental}

Um imperativo de não-retorno sugere (e também exige) que sejam buscadas algumas respostas para a seguinte questão: como proteger o meio ambiente?

Se já se chegou ao momento em que sabe-se muito e sabe-se das consequências, sob o ângulo de uma tarefa que é estatal e social, os poderes públicos podem recusar dar valor para um imperativo de proteção?

Se antes exigir o não retorno propunha uma realidade adicional porque exigia a consideração de níveis elevados de incerteza para justificar ações públicas por meio de precaução, neste momento, o não retorno seria um imperativo. $O$ acesso ao conhecimento científico disponível exige uma resposta e esta resposta não pode impor o retrocesso.

A construção de uma proibição de retrocesso no plano dos níveis de desenvolvimento dos direitos fundamentais geralmente está associada à realização, pelo Estado, de padrões existenciais sociais, econômicos e culturais, e se impõe como uma garantia de que o núcleo essencial desses direitos - que já tenham sido efetivados e realizados pelo legislador — não possa ser removido (por iniciativas de anulação, revogação ou pura aniquilação) sem medidas de compensação. (CANOTILHO, 2004a, p. 340).

O princípio aponta para uma proibição da reversão no desenvolvimento dos direitos fundamentais, e para uma garantia de não-retorno a graus de proteção que já tenham sido ultrapassados. $^{23}$ Por outro lado, também veicularia como efeito uma proibição de reversibilidade dos estágios de desenvolvimento e de proteção de várias realidades

\footnotetext{
${ }^{23}$ A consideração do princípio sob a referência de um não retorno na concretização é atribuída a Jorge Miranda, que, com esta orientação - vinculada à estabilização das expectativas sobre os estágios de realização dos direitos econômicos, sociais e culturais - argumenta que "[...] não é possível eliminar, pura e simplesmente, as normas legais e concretizadoras, suprimindo os direitos derivados a prestações, porque eliminá-las significaria retirar eficácia jurídica às correspondentes normas constitucionais." (MIRANDA, 2000, p. 397).
} 
existenciais os quais foram proporcionados, por iniciativa do Estado, a uma determinada sociedade, residindo neste aspecto o principal problema sobre sua admissão.

É assim que as decisões sobre a forma de realização dos direitos fundamentais dependem de opções que estão atribuídas, inicialmente, ao legislador. Este, em princípio, poderia selecionar as alternativas que melhor atendessem a concretização de realidades existenciais em cada momento, revendo até mesmo essas decisões, levando também em consideração as restrições e limitações materiais e financeiras de cada contexto, não sendo admissível subtrair-lhe a iniciativa de poder, o qual lhe foi atribuído democraticamente. ${ }^{24}$

Não é, entretanto, sob esse âmbito funcional que atua um princípio de proibição de retrocesso, o que reforça que, se o legislador tem o poder de realizar escolhas sobre o estágio de desenvolvimento dos direitos fundamentais, não pode dispor livremente sobre eles, na medida em que a legislação está vinculada aos direitos fundamentais, não sendo, portanto, a dona dos direitos fundamentais, para utilizar a referência de Canotilho. (CANOTILHO, 1994, p. 369).

A proibição de retrocesso não se impõe enquanto um princípio geral (ANDRADE, 2004, p. 408) que veda a revisão de escolhas sobre a concretização dos direitos fundamentais, mas se impõe estritamente sobre a garantia de revisão e de retorno na concretização de um mínimo, cujo conteúdo está materialmente associado à dignidade humana, e é somente este mínimo que se encontraria sob a reserva de revisão pelas decisões estatais. (SARLET, 2006, p. 352$353) .{ }^{25}$

Uma posição diferenciada é apresentada por Novais (NOVAIS, 2003, p. 138) ${ }^{26}$, para quem uma proibição de retrocesso ou de regressividade não poderia ser considerada o resultado da realização de direitos sociais, tampouco possuiria autonomia heterovinculativa sobre 0 legislador.

Mas o fato de não reconhecê-la nessa condição não exclui a possibilidade de admitir a proteção contra a revisibilidade de situações jurídicas estabilizadas sob outras garantias (proteção da confiança ou segurança jurídica), ou, ainda, de direitos sujeitos à reserva do possível, caso se tenha um grau considerável de estabilização de expectativas na sociedade, que orientem a manutenção de um determinado grau de realização. (NOVAIS, 2003, p. 138). ${ }^{27}$

Em outro momento, parece ter proposto um maior desenvolvimento àquela orientação, esclarecendo que o problema não se imporia em termos daquele princípio, mas sim, como um problema de restrições a direitos fundamentais, de modo que, se o legislador pode

24 Isso se deve porque, conforme salienta Vieira de Andrade, "A liberdade constitutiva e a autorevisibilidade, ainda que limitadas, constituem características típicas da função legislativa [...]" (ANDRADE, 2004, p. 408).

${ }^{25}$ Em outro momento, Sarlet reforça sua orientação, ao salientar que relaciona o mínimo existencial concretizado e a dignidade humana, argumentando que "[...] não se poderá esquecer jamais que uma violação do mínimo existencial (ainda tendo em conta o núcleo essencial dos direitos socais legislativamente concretizado) significará sempre uma violação da dignidade da pessoa humana [...]. (Tradução nossa). Lê-se no original: "[...] no pude olvidare jamás que una violación del mínimo existencial (aun teniendo en cuenta el núcleo esencial legislativamente concretado de los derechos sociales) significará siempre una violación de la dignidad de la persona humana [...]"(Tradução nossa.) (SARLET, Ingo Wolfgang. La prohibición de retrocesso en los derechos sociales fundamentales en Brasil. p. 356).

${ }^{26}$ Em outro sentido, Vieira de Andrade menciona a possibilidade de uma posição mais restritiva, que admite essa orientação não como um princípio geral de proibição de retrocesso, mas como uma exceção que poderia justificar, pelo menos, um direito de não ser privado pelo Estado e de ter subtraído pelo Estado o mínimo que já foi adquirido pelo cidadão (sentido negativo da proibição de retrocesso), apesar de não impor, segundo sustenta, uma obrigação de garantir de forma positiva esse mínimo a cada cidadão. (ANDRADE, 2004, p. 404). Sua orientação, entretanto, admite apenas um efeito de constitucionalização da legislação que, excepcionalmente poderia enfraquecer o poder de livre disposição do legislador. (ANDRADE, José Carlos Vieira de. Os direitos fundamentais na Constituição portuguesa de 1976, p. 408-409).

${ }^{27}$ NOVAIS, Jorge Reis. As restrições aos direitos fundamentais não expressamente autorizadas..., p. 138. 
efetivamente revisar e alterar um nível de proteção conferido a um direito fundamental, ele somente pode fazê-lo mediante a apresentação e demonstração de relevantes razões jusfundamentais de justificação. (NOVAIS, 2004, p. 306-307). ${ }^{28}$

Ainda que não se admita um princípio autônomo de proibição de regresso nos graus de realização social, e a menos que ele seja admitido como um princípio de proibição geral, podese argumentar que há relativo consenso que define como efeito a ser considerado a proibição de uma desconstituição sem um efeito compensatório e a proteção perante iniciativas de desconstituição de níveis de organização ou de realização de direitos fundamentais que não tenham justificativas jusfundamentais suficientes.

$\mathrm{Na}$ medida em que, para aqueles que sustentam a elaboração do princípio, um mínimo de existência representaria, na verdade, um argumento jusfundamental relevante para manter determinado nível de realização de um direito fundamental, parece possível reconhecer em sua elaboração um sentido pelo qual, apesar de não proibir a reversão, define-se uma margem de reserva que não pode ser afetada pelas decisões públicas de desenvolvimento social, a menos que uma melhor razão jusfundamental seja apresentada.

A manutenção de um determinado nível de desenvolvimento social estaria justificada em um argumento jusfundamental (mínimo de existência), que imporia um ônus argumentativo extremamente alto para fundamentar uma reversão. É estritamente sob essa orientação que se justifica a abordagem com base em uma referência a um princípio de proibição de retrocesso e, agora, a um princípio de proibição de retrocesso ambiental. ${ }^{29}$

Qualquer abordagem sobre a noção de proibição de retrocesso, incluída aqui uma abordagem ecológica sobre o princípio, não pode prescindir de que se determine, primeiro, de que objeto se ocupa a proteção de retrocesso, mais especificamente, de garantir uma proteção dos efeitos materiais da norma no plano da proteção concreta de bens ou uma proteção de uma determinada realidade normativa (das realidades existenciais proporcionadas, ou de posições jurídicas constituídas), e depois, de que modo pode ser demonstrada uma situação objetiva de retrocesso ou de reversão proibida. ${ }^{30}$

Em relação ao primeiro problema, fazendo referência ao retrocesso nos níveis de proteção do ambiente (nominada como retrocesso ecológico), Canotilho (CANOTILHO, 2004b, p. 183) parece propor que o objetivo protegido é a proteção de realidades normativas, ou o efeito da norma de direito fundamental sobre a definição de uma determinada realidade existencial.

Desse modo, como critério para aferir a evidência de uma situação veiculadora de retrocesso ecológico, considera, em princípio, que a evidência básica deve ser a de agravamento da situação ecológica global, não obstante reconheça que a concretização do princípio, enquanto mandado de proibição, encontra melhores condições de operacionalização se considerados individualmente os recursos naturais. (CANOTILHO, 2004b, p. 182). Isso porque "[...] A água, os solos, a fauna, a flora, não podem ver aumentado o 'grau de esgotamento', surgindo os 'limites do esgotamento' como limite jurídico-constitucional da liberdade de conformação dos poderes públicos." (CANOTILHO, 2004b, p. 184).

\footnotetext{
28 Sob esse argumento, explica que: "[...] o legislador pode optar, amplamente, por outro tipo de realização, por modificá-lo ou substituí-lo, por conferir-lhe um diferente grau, medida ou ritmo de realização; não pode é, a não ser com justificação constitucional bastante, pura e simplesmente, integral ou parcialmente, suprimir a realização que um direito social já obtivera." (NOVAIS, 2004, p. 309).

${ }^{29}$ Faz-se referência ao princípio para manter a uniformidade de sua abordagem na literatura relacionada à sua investigação, não obstante Molinaro proponha sua abordagem sob a referência de um princípio de proibição de retrodegradação socioambiental. (MOLINARO, 2007. p. 91-120).

${ }^{30}$ O segundo problema é enfatizado por Queiroz em: QUEIROZ, 2006a. p. 116. E, no mesmo sentido, em: QUEIROZ, 2006b, p. 74.
} 
Sobre o segundo, Courtis (COURTIS, 2006, p. 42) considera que um critério relevante seria a admissão da noção de progressividade fixada pelo artigo $2^{\circ}$, $\S 1^{\circ}$, do Pacto Internacional dos Direitos Econômicos, Sociais e Culturais (PIDESC), que vincula a iniciativa dos Estados aos níveis de concretização dos direitos econômicos, sociais e culturais. ${ }^{31}$

Desse modo, uma norma deve ser considerada regressiva sempre que o grau de efetividade de um direito veiculado pela nova norma resulte inferior àquele que já havia sido alcançado anteriormente, de modo que somente seria possível afirmar-se uma situação de reversão proibida ou de retrocesso proibido mediante uma análise empírica e comparativa entre as realidades normativas. ${ }^{32} 33$

A composição dessas conclusões importa admitir como efeitos de uma proibição de retrocesso ambiental o fato de não ser possível ao Estado autorizar, tolerar ou atribuir proteção normativa a comportamentos privados que degradem a qualidade dos recursos naturais, ou que os próprios particulares se esquivem de proceder à execução de seus deveres de defesa do ambiente, ou ainda que estes excedam os limites constitucionais para o exercício de suas liberdades econômicas.

Portanto, vinculadas a uma proibição de retrocesso que pode ser justificada no próprio conteúdo definido pelo sistema de proteção objetiva do ambiente na ordem constitucional brasileira - orientado por um princípio de responsabilidade de longa duração - , as decisões privadas, regulatórias (políticas, normativas, legislativas ou judiciais), encontram-se vinculadas a um dever de proteção que somente pode ser corretamente concretizado se protegidos os interesses das futuras gerações. ${ }^{34}$

Como bem acentuado por Canotilho (CANOTILHO, 1999, p. 44), os poderes públicos possuem responsabilidades perante as futuras gerações, e estas responsabilidades tornam-se concretas apenas quando adotados, na condição de deveres, comportamentos privados e públicos, que sejam amigos do ambiente.

Uma vez que as funções estatais e os particulares estão vinculados a um princípio de responsabilidade de longa duração, o processo de formação de suas decisões não pode

\footnotetext{
${ }^{31}$ A redação é do artigo $2^{\circ}, \S 1^{\circ}$, do PIDESC, assim fixada: "Cada Estado Membro no presente Pacto compromete-se a adotar medidas, tanto por esforço próprio como pela assistência e cooperação internacionais, principalmente nos planos econômico e técnico, até o máximo de seus recursos disponíveis, que visem a assegurar, progressivamente, por todos os meios apropriados, o pleno exercício dos direitos reconhecidos no presente Pacto, incluindo, em particular, a adoção de medidas legislativas." (Pacto Internacional dos Direitos Econômicos, Sociais e Culturais, (1966). Disponível em: <http://www.direitoshumanos.usp.br/counter/Onu/Sist_glob_trat/texto/texto_2.html>. Acesso em: 12 mar. 2008).

${ }^{32}$ Portanto, Courtis também considera uma abordagem normativa sobre o fenômeno da regressividade. Cf. COURTIS, Christian. La prohibición de regresividad em materia de derechos sociales, p. 4.

33 Fensterseifer parece propor uma leitura um pouco diferenciada, considerando o critério da progressividade na implementação dos direitos econômicos, sociais e culturais, fixado no artigo $2^{\circ}$ do PIDESC. Para tanto, crê que "[...]o princípio da proibição de retrocesso ambiental (ou ecológico) seria concebido tendo em vista que a tutela normativa ambiental deve operar de modo progressivo no âmbito das relações jurídicas, a fim de ampliar a qualidade de vida existente hoje e atender a padrões cada vez mais rigorosos de tutela da dignidade humana, não retrocedendo jamais a um nível inferior àquele verificado hoje." (FENSTERSEIFER, 2008, p. 261). Ainda que não se divirja de sua conclusão, não parece ser possível considerar que a obrigação de progressividade tenha seu fundamento no princípio da proibição de retrocesso, que parece estar vinculado de forma muito mais próxima à proteção de um mínimo ecológico de existência (e proteção no sentido de que esse mínimo não pode ser erodido sem que haja uma justificação razoável de uma restrição, e que esta seja fundada em princípios constitucionais, após a realização de um juízo de ponderação), do que à idéia de proibição de retrocesso.

${ }^{34}$ Molinaro, baseando-se na literatura alemã, também parece ressaltar a relação do princípio com a proteção das futuras gerações, ao referir-se como subprincípio, além da proibição da degradação, àquele que veicula uma proteção da continuidade ou da existência. (MOLINARO, 2007, p. 110).
} 
produzir como resultado um estado de proteção inferior ao precedente, tampouco um estado de qualidade dos recursos de mesma medida. ${ }^{35}$

Häberle (HÄBERLE, 2001, p. 131) parece admitir a idéia de proibição de retrocesso com base na proteção da dignidade da pessoa humana, concebida como a imagem antropológica de um Estado constitucional, que proibiria a regressão a momento anterior ao reconhecimento das garantias jurídicas revolucionárias de 1789.

Entretanto, o argumento não importa considerar que a referência de dignidade se restrinja à imagem revolucionária do homem, já que seu conceito se mantém aberto aos direitos fundamentais, permanecendo suscetível à revisão, para que possa assumir conteúdos novos e transformadores. (HÄBERLE, 2001, p. 132).

Uma manifestação dessas transformações propõe agora a consideração de que um mínimo de existência também agrega uma concepção não-biologicista e, ecológica, sobre a definição de uma realidade existencial protegida pela proibição de retrocesso, que, vinculada à necessidade de preservação desse mínimo ecológico de existência, não pode ser desconsiderada seja pelo Estado, seja pelos particulares, igualmente vinculados à sua proteção, que é o resultado da composição de realidades subjetivas e objetivas do princípio da dignidade e do próprio direito fundamental ao meio ambiente. (SARLET, 2007, p. 339-342).

Uma vez definidos os fundamentos que sustentam a construção dogmática de um imperativo de não retorno na proteção do direito fundamental ao meio ambiente, ainda se faz necessário determinar os fundamentos por meio dos quais seria possível reconhecê-lo e justificá-lo como instrumento central para a sua concretização.

\subsection{Os fundamentos normativos de um imperativo de não retorno nos sistemas internacionais de proteção dos direitos humanos e na constituição brasileira}

Uma realidade semelhante a que se encontra referida nesta seção como objetivo de investigação pode ser desenvolvida por meio de duas premissas importantes: a) Proporcionar bem-estar por meio de prestações existenciais com essas, exige esforços progressivos, permanentes e ininterruptos do Estado; b) esses níveis de bem-estar nunca poderão ignorar ou desconsiderar padrões mínimos, porque vinculados a um imperativo de proteção coletiva dos direitos de tal natureza.

Por meio deles podem ser localizadas as fontes mais importantes para a fundamentação de um imperativo de não-retorno nos níveis de proteção (do direito fundamental ao meio ambiente). Sua origem concentra-se no direito internacional dos direitos humanos que se vale de um efeito cliquet (MAZZUOLI: 2013) que se encontra associado àquelas obrigações e compromissos definidos por meio de instrumentos convencionais (especialmente os oriundos de normas imperativas de direito internacional) pelos Estados, que, desse modo, comprometem-se a proteger as pessoas com cada vez melhores recursos e visando thes garantir sempre, cada vez mais e melhor proteção. (RUIZ, 2012, p. 244).

Apenas para citar os instrumentos convencionais mais importantes, e sem o propósito de esgotar a enumeração destas fontes, situando-as com o objetivo meramente enunciativo e de contraste entre os sistemas global e regional, podem ser identificados dois de grande influência na interação com as experiências jurídicas nacionais: o Pacto Internacional sobre os Direitos

${ }^{35}$ A vinculação entre um princípio de responsabilidade de longa duração, o princípio da proibição de retrocesso ambiental (nominado de princípio de proibição de retrodegradação socioambiental), e um mínimo existencial ecológico podem ser verificados na obra de Molinaro. (MOLINARO, Carlos Alberto. Direito ambiental, p. 104). Para tanto, Molinaro considera que privilegiar a existência de um mínimo existencial ecológico seria o resultado de uma obrigação de proteção para a posteridade atribuída ao Estado. 
Econômicos, Sociais e Culturais (United Nations: 1966) no âmbito global, e a Convenção Americana de Direitos Humanos (OEA: 1969) e seu respectivo protocolo adicional (OEA: 1998), o qual define o direito ao meio ambiente como parte dos direitos protegidos pela convenção.

Nesses instrumentos, identifica-se um regime de proteção para direitos que favorecem 0 desenvolvimento pleno da vida, tentando assegurar o acesso àquele conjunto de prestações existenciais que pode trazer qualidade de vida a todos. O meio ambiente faz parte dessa perspectiva, ainda que sob um ângulo antropocêntrico, mas que não é utilitário, esclareça-se.

O pacto define em seu artigo 2.1 que todas partes comprometem-se a assegurar o pleno exercício dos direitos definidos no instrumento por meio do compromisso de adoção progressiva de medidas, e até o limite dos recursos que estejam disponíveis, sendo o texto semelhante àquele que viria ser esboçado no artigo 26 da Convenção Americana, em 1969, no qual ganham destaque a) a descrição expressa das medidas legislativas; b) a técnica de não enumeração das demais medidas adequadas a essa finalidade e, principalmente; c) o fato de propor um regime para todos os direitos e liberdades definidos pela convenção como cláusula geral de proteção. Em reforço a essa abordagem definida pela convenção, o sistema regional também a reproduziu por meio do regime de proteção dos direitos econômicos, sociais, e culturais veiculado pelo Protocolo Adicional de San Salvador à Convenção Americana de Direitos Humanos em matéria de Direitos Econômicos, Sociais e Culturais.

O protocolo assegurou no texto dos artigos 1 e 11, o dever de progressividade na adoção das medidas destinadas a viabilizar a concretização de tais direitos, ao mesmo tempo em que reconheceu ser o direito ao meio ambiente um dos DESC, sujeitando-o ao mesmo regime de proteção dos demais direitos humanos definidos pelo instrumento convencional, além de ter fixado expressamente, em seu artigo 11.2, três obrigações que bem delineiam a extensão dos efeitos de um princípio de não retrocesso, ou de não retorno: os deveres de proteção, manutenção de melhoria da qualidade dos recursos naturais. Sob a composição dos três deveres resultam nítidos os dois principais efeitos do regime de proteção dos direitos humanos que interessam à definição do conteúdo de um princípio de não retrocesso: uma cláusula de status quo nos níveis de proteção já atingidos (standstill) e uma cláusula de progressividade, de aperfeiçoamento e de melhoria daqueles níveis que já foram atingidos, a qual exige dos Estados-parte que dêem passos concretos e efetivos de forma continuada e permanente, de acordo com sua capacidade financeira e econômica.

As convenções e tratados internacionais de proteção dos direitos humanos favorecem um sentido de aperfeiçoamento da proteção sobre a biodiversidade, não tendo proposto até 0 momento, uma única realidade que tenha eliminado, diminuído ou mitigado o conjunto de garantias que já foi atingido no plano internacional.

Esse regime de proteção encontra sua representação mais destacada em matéria ambiental no âmbito do conjunto de compromissos que foram fixados pela Convenção da Diversidade Biológica e pela Convenção de Ramsar. Ambas ostentam a condição de normas imperativas de direito internacional (MAZZUOLI, 2013, p. 155-168) e exigem entre outras obrigações, que 0 Estado brasileiro adote ações que também assegurem a conservação in situ, além do dever de elaborar e de manter legislação em vigor capaz de proteger esses espaços, os processos biológicos e as espécies ameaçadas. ${ }^{36}$

Se o direito ao meio ambiente é também um direito humano e se encontra sujeito ao regime e proteção dos DESC, estando todos os instrumentos convencionais referidos integrados à

\footnotetext{
${ }^{36}$ Trata-se do texto do artigo 8 , $\mathrm{k}$, dispositivo que faz parte das obrigações relacionadas às medidas de conservação in situ, da Convenção sobre a Diversidade Biológica. United Nations. Convention on Biological Diversity. Disponível em: <http://www.cbd.int/convention/articles/?a=cbd-08. Acesso em 22 de maio de 2012.
} 
ordem jurídica brasileira em razão do que prescreve o artigo 5 , § 2ํㅡㄹ da Constituição brasileira, também seria, por outro lado, possível reconhecer no âmbito da própria ordem constitucional, manifestações que favorecessem a consideração do princípio, per se?

Como seria possível tratar, portanto, de um efeito de não-retorno na ordem jurídica nacional? Deve-se considerar, antes de tudo, uma composição normativa baseada em um Estado aberto, e em uma ordem jurídica aberta à comunicação com outras experiências, que auxiliam e contribuem para o aperfeiçoamento e o dsenvolvimento da ordem nacional. Pode-se tratar semelhante fenômeno por meio do uso de um diálogo de fontes (JAYME: 1998), ou por meio de uma experiência de transconstitucionalismo (NEVES: 2009), mas o que interessa é o reconhecimento de que a capacidade do Estado proteger o meio ambiente, neste momento, depende e dependerá, cada vez mais, de sua capacidade de aprendizagem com estas experiências.

A ordem jurídica brasileira é uma ordem materialmente aberta e estabelece um diálogo permanente com as fontes, sendo possível que deste diálogo se obtenha um importante efeito sobre as decisões que são tomadas pelos parlamentos. Os tratados e convenções, sejam elas do sistema global ou regional, desenham nitidamente um princípio de progresso na proteção dos direitos do homem, e deste princípio de progresso decorre um imperativo de não retorno, e de não retrocesso.

As obrigações previstas no texto do artigo 2.1 do Pacto Internacional sobre os Direitos Econômicos, Sociais e Culturais; no artigo 26, da Convenção Americana sobre Direitos Humanos; nos artigos 1, 12, e 12.1 do Protocolo Adicional de San Salvador propõem um rigidíssimo bloco de convencionalidade ambiental que não permitiria a desconstituição dos níveis de proteção que já foram atingidos.

Como se dá esta interação na experiência brasileira? O meio ambiente é um direito humano, vinculado ao regime de proteção dos direitos econômicos, sociais e culturais, reconhecido em dois instrumentos, no sistema global e regional que já há algum tempo vigem e obrigam o Estado brasileiro. Constituem não apenas jus cogens, senão também norma imperativa na ordem nacional.

O que isso significa? A consideração de todos os instrumentos referidos e enumerados aperfeiçoa a capacidade de transformação que pode ter origem em nossa Constituição ambiental, e no artigo 225. Este deve ser compreendido da seguinte forma: temos aqui um texto que define uma proteção de realidades existenciais que são indispensáveis para o desenvolvimento da vida, e condiciona decisões de longo prazo. Quais são esses bens? Os recursos naturais.

Se o sincretismo, o diálogo e a interação entre as fontes reforça o processo de aprendizagem constitucional no âmbito a experiência nacional, por outro lado, a própria Constituição brasileira também não se mostra tolerante com comportamentos que violem o efeito cliquet dos instrumentos convencionais. O texto nacional exige que o Estado e toda a comunidade política protejam os processos ecológicos essenciais e se abstenham de realizar escolhas que ameacem as funções ecológicas da flora e da fauna (artigo 225, $\S 1^{\circ}$, incisos I e VII) ${ }^{37}$. Em acréscimo, o texto também define que a proteção daqueles fundamentos naturais indispensáveis ao desenvolvimento da vida se dá no interesse das futuras gerações (artigo 225, caput), e propõem cláusula muito específica destinada a proteger os espaços naturais especialmente relevantes, de quaisquer iniciativas legislativas que proponham sua extinção ou

\footnotetext{
${ }^{37}$ O tema já foi apreciado pelo STJ que reconheceu a definição de um mínimo ecológico na proteção de espaços naturais, por meio dos seguintes acórdãos relatados pelo ministro Herman Benjamin: STJ, EREsp 218781 / PR, S1, rel. Min. Herman Benjamin, j. 09.12.2009, Dje: 23.02.2012; STJ. REsp 1240122 / PR, 2. T. rel. min. Herman Benjamin, Dje: 11.09.2012, j. 28.06.2011.
} 
redução, se tais medidas puderem comprometer, sob qualquer grau de ameaça, os atributos que justificaram sua proteção (artigo 225 , $§ 1^{\circ}$, inciso III).

Há nessas quatro tarefas um claro indicativo de que ninguém está, na república brasileira, autorizado a atingir por meio de suas escolhas, as condições naturais que sejam essenciais ao desenvolvimento da vida. Da mesma forma, há um claro indicativo de que deve ser desenvolvida a proteção que já se pôde obter. Isso porque os compromissos do Estado e os efeitos de suas decisões não se destinam restritivamente à proteção da qualidade de vida da comunidade política existente, senão também a das futuras gerações.

Suas escolhas não podem, desse modo, atingir os limites que definiriam um mínimo existencial ecológico (artigo 225, § 1ํ, incisos I, III e VII), ao mesmo tempo em que devem ser capazes de aperfeiçoar os níveis já atingidos no interesse das futuras gerações (artigo 225, caput).

Em semelhante cenário, o bloco de constitucionalidade ambiental (e de convencionalidade ambiental) proporcionados pela ordem jurídica brasileira não favorecem a admissão de escolhas que obstem a proteção das condições indispensáveis para a continuidade dos processos ecológicos essenciais, dos quais depende a durabilidade da vida (equidade intergeracional), e manutenção das funções ecológicas da flora e da fauna, além da proteção dos espaços naturais especialmente protegidos.

Os dispositivos constitucionais referidos permitem, portanto, o reconhecimento de um imperativo de não retrocesso, independente de sua interação com a ordem jurídica convencional. Essa argumentação poderia ser sustentada por meio da definição de um mínimo existencial ecológico que não poderia ser desconstituído por iniciativa de decisões públicas ou privadas.

Em reforço a essa orientação, ao definir um principio de equidade intergeracional, o artigo 225, caput, propõe um sentido de progressividade para as tarefas estatais (e sociais) de proteção do meio ambiente que não admitem o retorno. (SOZZO, 2012). Se faz parte do compromisso da república brasileira proteger o meio ambiente no interesse das futuras gerações, deve-se reconhecer que o imperativo de sua proteção impõe claramente aos poderes públicos e a toda a coletividade, um dever de não diminuir a qualidade dos recursos naturais, estando aqui o fundamento objetivo de um imperativo de não retorno nos níveis de proteção ambiental.

Um imperativo de não retorno que decorre do conjunto das normas constitucionais referidas constitui, ao mesmo tempo, limite e condição para as decisões parlamentares. Semelhante imperativo não permitiria que decisões parlamentares como a que veiculou os dispositivos comentados, pudessem ser concretizadas.

Por meio do artigo 225, § 1ㄹ, incisos I e VII, da CRFB, o Estado brasileiro tem um compromisso permanente com a manutenção daquelas condições que sejam indispensáveis para 0 desenvolvimento da vida. Há aqui um claro reconhecimento de um imperativo de sustentabilidade porque este Estado deve proteger as pessoas, deve proteger as futuras gerações e deve proteger as condições que asseguram a existência da comunidade política, elementos estes que se agregam em uma relação indivisível.

A proteção normativa da biodiversidade parte de uma premissa fundamental: a de mediar as leis da natureza (BOTKIN: 1989), sendo que a realidade é, em primeiro lugar, e antes de qualquer construção cultural ou sociológica, o conjunto de processos ecológicos que suportem a vida. 


\subsection{Há um imperativo relativo na constituição brasileira? Lições de uma cultura jurídica de não retorno no regime jurídico das áreas protegidas (o artigo $225, \S 1^{\circ}$, inciso III)}

Para que se justifique a proteção que pudesse ser oferecida por meio de um imperativo de não retorno seria exigível a exposição de um imperativo de proteção que pudesse ameaçar em tal grau valores de elevado grau de consideração, como processos que sustentem a vida. Nesse caso uma intervenção legislativa somente poderia remover os níveis que já foram fixados por meio de argumentos suficientemente fortes, geralmente acompanhados de medidas de compensação.

Essa é, em geral a perspectiva por meio da qual o princípio é apresentado nas experiências em que foi suscitado na jurisprudência de tribunais estrangeiros, delineando-se, desse modo, uma imagem de princípio de eficácia relativa, e sujeito à consideração de um princípio de proporcionalidade, além de sujeitá-lo a um imperativo de ponderação (HACHEZ: 2012, p. 513517).

O não retrocesso pode ser explicado por meio de duas perspectivas distintas: uma cláusula de status quo expressa por meio de um princípio de standstill (permanece-se como esta) ou por meio de uma cláusula de progresso, não sendo factível que qualquer experiência jurídica que pretenda propor proteção completa e integral para bens vitais, opte por um deles em detrimento de seu complemento. Uma proteção completa somente poder ser obtida pela associação das duas perspectivas. Não se pode limitar o não retorno ao standstill porque políticas públicas são transitórias (devem resolver problemas e eles devem ser removidos, por isso não podem ser permanentes) e direitos sociais não são satisfeitos, ao menos no plano de proteção de níveis adequados, em alguns contextos, por meio de imobilismo. Da mesma forma, uma leitura de standstill também favorece a perspectiva de obstáculo, de óbice a transformações. Não transformar e não se adaptar as necessidades de uma sociedade em transformação também pode significar retrocesso.

Uma cláusula de standstill favorece uma leitura distorcida de de proteção de direitos adquiridos, fatos consumados, danos consolidados, segurança jurídica e da proteção da confiança, todas manifestações que geralmente se encontram associados à proteção pessoal de posições subjetivas.

O direito constitucional brasileiro contempla quatro possibilidades de explicação e de justificação do não retorno como efeito de uma cláusula de progresso, três possivelmente relacionadas a um dever de standstill (artigo 225, § 1을 incisos I, III, e VII, CRFB) e uma para a progressividade (o artigo 225, caput, CRFB, por meio de um princípio de equidade intergeracional).

Quando a ordem constitucional brasileira obsta iniciativas que ameacem a função ecológica da fauna e da flora, exige iniciativas que mantenham a identidade dos processos ecológicos essenciais e sua restauração quando violada, há sinais claros de que há limites mínimos de proteção que não podem ser ultrapassados (Cf. PRIEUR, 2012, p. 45). Quando se define a proteção dos bens essenciais ao desenvolvimento da vida no interesse das futuras gerações, define-se um imperativo de melhoria e de progressividade na proteção de tais bens.

Definir até que ponto se pode reconhecer um imperativo de não retorno ou, em outras palavras, se esse conjunto de compromissos não admite mitigação por meio da apresentação de razão ou argumento suficientemente relevante é questão que, ao menos sob a experiência constitucional brasileira, parece admitir a consideração de um forte argumento em sentido contrário, indicando-se para si a condição de um princípio dificilmente ponderável ou mitigável.

Isso se explica pelo fato de que todas as razões que justificam um dever de não retornar nos níveis de proteção estão relacionados a garantia dos processos e funções ecológicas da 
biodiversidade. Sob tal perspectiva, dificilmente se teria como possível expor argumento forte 0 suficiente para desconstituir, reduzir ou eliminar aquilo que se apresenta como indispensável para a existência da vida.

O último dos fundamentos normativos veiculados pela Constituição brasileira surge do texto do artigo 225, $\S 1 \%$, inciso III, por meio do qual cumpre ao Estado definir espaços naturais sob proteção especial sendo vetada qualquer iniciativa que ameace os atributos protegidos.

Nesse particular, a proibição de redução dos espaços protegidos senão por meio da demonstração de que o ato não será nocivo à proteção dos atributos que devem ser protegidos parece justificar uma leitura do não retorno como um imperativo absoluto. Se não se pode reduzir a menos que se prove que não serão produzidos danos ou prejuízos, significa que se houver prejuízos, a iniciativa é e será proibida. Se for autorizada a iniciativa significa considerar que $o$ ato não é nocivo e nesse caso não se terá retrocesso.

Portanto, se a Constituição fixa em relação ao regime de proteção dos espaços naturais, um dever expresso de não se reduzir tais espaços se esta iniciativa implicar ameaças ou danos, e se todos os demais deveres se relacionam a proteção das funções e processos ecológicos da biodiversidade, dificilmente se conseguiria justificar o retorno em matéria ambiental por meio da exposição de outro valor ou bem de relevante consideração, uma vez que aqueles definem e identificam o conjunto dos valores mínimos para a formação e desenvolvimento de uma sociedade decente.

Uma cultura jurídica de não retorno favorece e fortalece, na verdade, a proteção de um conjunto de outros princípios, como o da prevenção e da precaução, e situa a atenção para o processo de tomada de decisão, o de explicação e de justificação das escolhas e das decisões, e das conseqüências que algumas decisões podem produzir sobre os recursos naturais.

Quando se tem por objeto de proteção a manutenção dos processos ecológicos essenciais e das funções ecológicas da fauna e da flora, é difícil admitir que se pode justificar o retrocesso sob argumentos e razões fortes de argumentação, por meio de alternativas de proteção, e de compensação. O caso brasileiro parece, desse modo, estar associado à leitura de uma proibição absoluta de retorno. Processos ecológicos não podem ser compensados, não podem ser substituídos, não podem ser alterados e não podem ser diminuídos.

A formação de uma cultura jurídica de não retorno será examinada, adiante, por meio da consideração da jurisprudência dos tribunais nacionais, situando-a perante os padrões de avaliação de retrocessividade veiculados pelo comitê sobre os direitos sociais, econômicos e culturais da Organização das Nações Unidas (ONU).

\subsection{O teste da retrocessividade das medidas de proteção}

Há várias formas de se identificar manifestações normativas retrocessivas por meio das iniciativas públicas, estando as mais relevantes identificadas nos comentários gerais de n. 03, do Comitê sobre os DESC, de 1990 (United Nations: 1990). As quatro principais são: a) políticas incompatíveis; b) revogação de normas indispensáveis para a proteção do mínimo, c) normas que reduzam os níveis que já foram atingidos; d) e redução dos gastos de forma deliberada.

Aparentemente, o Estado brasileiro tem seguido fielmente a lição. Diminuiu investimentos, pretende derrogar a proteção das políticas florestais, propõe políticas públicas contraditórias (incentivos sobre o IPI e o investimento em infra-estrutura de forma desordenada), e a atuação judicial nociva ao desenvolvimento dos direitos fundamentais, sendo este último aspecto destacado na próxima seção para o fim de expor abertamente as contradições e a incapacidade de as estruturas institucionais nacionais concretizarem os compromissos de um Estado ambiental. 
A ordem constitucional brasileira encontra-se organizada na direção da afirmação de um princípio de sustentabilidade. Quando se considera que a sociedade, e cada um de nós temos responsabilidades com as gerações futuras, que envolvem a proteção do meio ambiente em cooperação com o Estado, está sendo assinalado pela Constituição que assegurar a manutenção de condições para a durabilidade de todas as formas de vida, é um imperativo público e social. Temos aqui um imperativo de proporcionar uma realidade existencial sustentável como um compromisso político permanente, com todos os membros da comunidade, e com os não nascidos. No caso dos particulares, o princípio de sustentabilidade (e a responsabilidade de contribuir para a proteção das futuras gerações) está bem refletida na função ecológica da propriedade: todos devem ser capazes de viabilizar a proteção dos processos ecológicos essenciais, e viabilizar o bem-estar coletivo, mantendo parte de sua propriedade vinculada à reserva legal, além de proteger os espaços destinados às áreas de preservação permanente.

Existe, portanto, a hipótese de se construir uma noção de não retorno nos níveis de proteção, tomando-se o contexto da ordem jurídica brasileira. Entretanto, para que possa ser viabilizada, necessário se faz considerar uma construção dogmática de ordem jurídica aberta, que se comunica com outras experiências, em uma relação de sincretismo, sincretismo com experiências externas, e sincretismo com os instrumentos internacionais de proteção dos direitos humanos. A proteção do ambiente dependerá, nesse sentido, da capacidade de aprendizagem da ordem jurídica nacional, que poderá aperfeiçoar as consequências de sua atividade, de acordo com os resultados que já puderam ser proporcionados pela construção realizada por outros tribunais e parlamentos, considerando conflitos socioambientais de semelhante conteúdo.

Sendo assim, se existe um imperativo de sustentabilidade, que se converte em uma tarefa pública e em uma responsabilidade social e coletiva, e se a ação pública não favorece a progressividade nos níveis de qualidade ambiental, a consideração de um princípio de proibição de retrocesso terá pouca utilidade se não se puder tê-lo como um imperativo a serviço de instituições ecologicamente sensíveis.

A próxima seção examinará se, de fato, os compromissos de um Estado ambiental tem condições, neste momento, de ser viabilizados pelas instituições nacionais, especialmente pela função judicial.

\section{Estado brasileiro proporciona, neste momento, a concretização dos objetivos de uma Constituição ambiental? 0 Estado de retrocesso ambiental na jurisprudência do Supremo Tribunal Federal}

O Estado brasileiro fez escolhas e assinalou que está fora do alcance do poder de decisão dos parlamentos, dos particulares, e de quaisquer funções públicas, diminuir os níveis que sejam essenciais ao desenvolvimento da vida. Integrar objetivos ambietnais nas escolhas orçamentárias, além de compreender que a definição de dignidade de vida supõe, essencialmente, como ponto-de-partida, o acesso a níveis adequados de qualidade dos recursos inaturais, influencia a transformação das instituições no caminho do que Perez (PEREZ: 2004) define como uma sensibilização ecológica, ao mesmo tempo em que enfatiza um princípio de sustentabilidade com pedra angular da ação pública e social brasileiras.

Quando se define que a ordem econômica brasileira é uma ordem social e ecológica de mercado, está sendo assinalado que não se autoriza que o particular exerça suas liberdades econômicas de forma incompatível com a tarefa de proteção dos bens ambientais. 
Da mesma forma, está sendo assinalado que não há prevalência ou conflito entre obejtivos e valores que tenham sido protegidos pela ordem constitucional nacional, senão a clara exposição de um compromisso de conciliação, que subtrai de quasiquer atores, o poder de realizar escolhas que desconstituam a tarefa de se atingir a proteção dos processos ecológicos essenciais.

Se a lei, a decisão judicial ou mesmo as escolhas executivas não permitam que os processos ecológicos essenciais sejam conservados ou protegidos, temos então atos sujeitos à censura da ordem constitucional.

Se as noções de progressividade e de proibição de retrocesso são indispensáveis para que se consiga aceder, de forma coletiva a níveis essenciais de qualidade de vida, a afirmação de uma república ecologicamente sensível depende, necessariamente, de instituições sensíveis, que estejam em condições de proporcionar a afirmação desses valores e a transformação das realidades existenciais, em conformidade com as tarefas apontadas no projeto político da Constituição (uma constituição aberta a experiências externas).

Não é este, entretanto, o contexto que se encontra visível, por ora, por meio das escolhas realizadas por cada uma das funções públicas nacionais, que tem apontado em suas manifestações, um processo sistemático de revisão retrocessiva na ordem jurídica brasileira.

Iniciando o exame sobre a qualidade das escolhas realizadas pela função executiva, tem-se o seguinte cenário de decisões recentes capazes de merecer a atenção e a consideração do princípio: a) subtração da participação e dos procedimentos de consulta prévia informada perante os povos indígenas no licenciamento da usina de Belo Monte e o descumprimento da convenção n. 169, da OIT; b) violação de compromissos internacionais sobre resolução de controvérsias no sistema regional de proteção dos direitos humanos por meio do não reconhecimento da autoridade da comissão interamericana de direitos humanos sobre o caso Belo Monte; c) a incapacidade de assegurar a manutenção dos compromissos internacionais com a redução de emissões no âmbito de acordos climáticos com a revogação do Código Florestal pela lei n. 12. 651/2012, d) a aceleração dos procedimentos de licenciamento ambiental, flexibilização do regime diferenciado de contratação (RDC) e a lei geral da Copa do Mundo, e com as novas regras veiculadas pelo órgão ambiental federal; e) a diminuição da dotação orçamentária anual para os órgãos que compõem o sistema nacional do meio ambiente; f) a descentralização sem aperfeiçoamento nas dotações orçamentárias do ICMBIO e fechamento de sedes de unidades administrativas nas capitais brasileiras.

Idêntico cenário também tem sido veiculado pela função legislativa por meio, v.g: a) da revisão da legislação florestal e a proposição de uma legislação imobiliária rural e; b) da lei de biossegurança (lei n. 11.105/2005) que propõe uma estrutura de decisão que não assegura a aquisição do conhecimento científico disponível para viabilizar boas escolhas (e boas escolhas são escolhas seguras e escolhas que possam oferecer proteção coletiva) sobre novos riscos tecnológicos.

Por fim, se a correção de distorções ou de deficiências na proteção teria de encontrar solução na função judicial, seria conveniente realizar uma aproximação sobre a atuação do Supremo Tribunal Federal (STF) para o fim de investigar se essa hipótese pode ser confirmada, sendo estes os principais resultados oriundos das mais relevantes questões que foram levadas ao seu conhecimento nos últimos dez anos:

a) Ação direta de inconstitucionalidade (ADI) n. 3540 (rel. Min. Celso de Mello): foi reconhecida a constitucionalidade de atos normativos que flexibilizarem o regime jurídico das áreas de preservação permanente, autorizando a prática de mineração em tais espaços (BRASIL, 2013a);

b) ADI n. 4218 (rel. Min. Luiz Fux): o ministro julgou inadmissível a Ação Direta de Inconstitucionalidade proposta pela Procuradoria-Geral da República contra o Decreto 
6.640/2008, que trata da proteção das cavernas brasileiras. O ministro considerou que o decreto é um ato normativo secundário, "editado pelo Executivo para esmiuçar e dar cumprimento aos parâmetros gerais previstos em lei para a proteção das cavidades naturais subterrâneas existentes no território nacional", não havendo, portanto, violação direta da Constituição. Como resultado final teve-se que a proteção das cavernas poderia sim ser flexibilizada pela norma regulamentar (BRASIL, 2013b);

c) Petição n. 3388/RO (rel. Min. Menezes Direito e rel. para o acórdão, min. Ayres Britto): foram fixados 16 condicionamentos para o exercício livre e permanente do usufruto sobre as terras indígenas no caso Raposa Serra do Sol, as quais não se encontravam previstas pelo próprio artigo 231 da Constituição, além de divergirem frontalmente do regime definido pela convenção n. 169, da OIT (BRASIL, 2013c);

d) ADI n. 4252/SC e da ADI n. 4253/SC (rel. Min. Celso de Mello): as ações que apreciam a afirmação de inconstitucionalidade do Código Ambiental de Santa Catarina sobre a diminuição dos padrões de proteção dos espaços naturais sequer foi apreciada em liminar pelo ministro relator (BRASIL, 2013d; BRASIL, 2013e).

O tema da intervenção legislativa sobre normas e definições urbanísticas e sobre a proteção de espaços naturais no interesse da exploração mineral foi apreciado pelo STF na ADI n. 3540 (BRASIL, 2013a), já citada neste julgamento, pelo Tribunal Constitucional Colombiano (COLÔMBIA, 2011), e pelo Tribunal Supremo Espanhol, neste caso apenas sobre a proteção dos espaços naturais, e sobre os planos urbanísticos (ESPAÑA, 2011, 2012a, 2012b e 2012c). No primeiro caso o tribunal admitiu como constitucional a revisão realizada no revogado código florestal. No segundo, não se viu violada a proteção contra o retrocesso. No terceiro caso, o resultado confirmado pelo tribunal espanhol reconheceu e considerou um dever estatal de não regresso por ter visualizado ali um imperativo de proteção capaz de exigir algum nível de proteção contra tal ameaça que teve sua fundamentação desenvolvida de forma diferenciada ao longo de cada uma das decisões enumeradas.

No primeiro caso (STS n. 6592/2011), o tribunal considerou que os solos especialmente protegidos como são as áreas verdes e rústicas não podem ser objeto de iniciativa administrativa que proponha sua desqualificação ou desclassificação senão por meio de motivação suficientemente relevante, detalhada e pormenorizada, especialmente diante do fato de que as consequências da ação administrativa nesse contexto podem ser irreversíveis. Sendo assim, exigir-se-ia do ato administrativo, motivação adequada e a consideração do limite de um dever de não retrocesso ,o que implicaria considerar, conforme foi assinalado pelo tribunal na decisão, a obrigação de "[...] proteger os avanços de proteção alcançados no conteúdo das normas ambientais, com base nas razões vinculadas ao caráter finalista do referido direito ao meio ambiente." Essa mesma orientação foi reproduzida posteriormente por meio da decisão STS 2000/2012 (ESPAÑA, 2012a).

Desse modo, em um cenário no qual se assegurou a supressão de áreas verdes previstas em um planejamento anterior, o princípio atua como limite da ação administrativa, dadas as consequências irreversíveis dessa ação.

No terceiro caso (STS n. 5538/2012, ESPAÑA, 2012b) o tribunal considerou que em decorrência de um princípio de não regressão ambiental decorre uma proibição de não retornar e não alterar a proteção especial que tenha sido conferida a um determinado espaço, como são aqueles integrantes da rede Natura 2000 e dos montes preservados, os quais são incompatíveis com a urbanização. De outro modo, o princípio também exigiria um dever de motivação reforçada de todas as ações que propusessem a perda de proteção total ou parcial de referidos solos.

O último caso (STS n. 5432/2012, ESPAÑA, 2012c) tem possivelmente, melhor e maior potencial de colaborar no processo de aprendizagem constitucional que é aqui proposto 
porque, nessa ocasião, o tribunal adotou fundamentação bastante mais aberta no plano material capaz de permitir a justificação do efeito cliquet, ferrolho ou de não retorno que pode decorrer da aplicação de outros princípios igualmente relevantes em matéria de proteção dos bens ambientais, como é o da prevenção e, especialmente, da precaução.

Nesse sentido, o tribunal assinalou que em decorrência de um princípio de precaução, não havendo demonstração segura sob o plano da certeza, de que o espaço natural não mereça proteção, e se há decisões administrativas e legislativas que impliquem a eliminação dessa proteção, medidas provisionais e cautelares podem ser justificadas para afastar os efeitos de referidas decisões.

É essa a orientação que foi exposta no seguintes destaque do acórdão adiante transcrito:

"Em matéria de proteção do meio ambiente foi superado o Direito repressivo perante os danos que se tenha produzido (poluidor-pagador) e se passou a um Direito que faz frente aos riscos conhecidos antes que sejam produzidos (princípio de prevenção) ou a um Direito que preveja e evite ameaças de danos desconhecidos ou incertos (princípio de precaução). Neste caso a prevenção de riscos ambientais justifica a medida cautelar adotada.

O monte de "El Tello" tem um valor potencial como espaço verde perto da localidade e apresentar uma cobertura vegetal arbustiva na qual ainda existem pinheiros que resistiram aos incêndios florestais e está habitado por espécies de fauna típica de matagal, assim como outras que são próprias do meio agrícola. $O$ início da atividade de pedreira, que possibilita o acordo impugnado, suporia um risco de alteração do meio, da paisagem do entorno e da orografia suficiente no momento atual para adotar a medida acordada, pelo que se desestimam os alegados formulados sobre a inexistência de prova de um perigo da demora". (ESPAÑA, 2012c), (tradução livre do autor).

A justificação de um imperativo de não retorno na experiência constitucional brasileira, que não é expresso por um princípio literal, pode ter origem na consideração de alguns deveres estatais enumerados no artigo 225, caput, e $\S 1 \stackrel{0}{\circ}$, incisos I, III e VII, da CRFB e sugerem realidades e consequências muito próximas do que já se pôde observar de cada um dos julgamentos realizados pelo Tribunal Supremo espanhol. A proibição constitucional de diminuir os níveis de proteção assegurados ao meio ambiente poderia, portanto, ser favorecida no plano de seus resultados por meio de um juízo de interação entre experiências jurídicas, o qual exporia, por sua vez, um sincretismo associado a padrões de transnormatividade (NEVES, 2009) que já foi exercido em algum grau pelo próprio STF por ocasião do julgamento da Arguição de descumprimento de preceito fundamental (ADPF) n. 101 (BRASIL, 2013i). Essa alternativa poderia ter influenciado melhores resultados em cada uma daquelas oportunidades enumeradas no âmbito do Supremo Tribunal Federal brasileiro, estando ainda ao alcance desse tribunal neste momento.

Em tempos mais recentes, a legislação revogadora do código florestal (lei n. 12.651/2012) foi objeto de três ações diretas de inconstitucionalidade propostas perante o STF pela procuradoria-geral da república.

A primeira delas (ADI 4901) tem por relator o ministro Luiz Fux e impugnava entre os dispositivos mais relevantes, o artigo 12 (parágrafos $4^{\circ}, 5^{\circ}, 6^{\circ}, 7^{\circ}$ e $8^{\circ}$ ), que tinha por objeto a redução da reserva legal (quando existentes terras indígenas e unidades de conservação no território municipal) e a dispensa de constituição de reserva legal por empreendimentos de abastecimento público de água, tratamento de esgoto, exploração de energia elétrica e implantação ou ampliação de ferrovias e rodovias. A mesma ADI também expõe os prejuízos decorrentes de autorização para compensação de reserva legal sem considerar a identidade ecológica entre as áreas, além da permissão do plantio de espécies exóticas para essa mesma 
finalidade, além de se autorizar a consolidação de áreas desmatadas antes da vigência da nova lei.

Por sua vez, a ADI 4092, tem por relatora a ministra Rosa Weber e se concentra na impugnação de dispositivos da lei que asseguram o perdão de multas e medidas que dificultam o cumprimento do dever de recomposição de áreas já desmatadas.

Por fim, a ADI 4093, distribuída para relato pelo ministro Gilmar Mendes expõe frontalmente a consideração de um princípio de proibição de retrocesso e tem por objeto as alterações que atingiram o regime jurídico das áreas de reserva legal e das áreas de preservação permanente, diminuindo-as perante os padrões normativos que já se encontravam em vigor por normas do Conselho Nacional do Meio Ambiente, e pela lei n. 4.771/1965.

Nenhuma das ações enumeradas foi objeto de apreciação pelo STF sequer para apreciar o pedido de medida liminar formulado em cada uma delas.

Em semelhante cenário, resulta nítido que se fosse possível propor um teste de retrocessividade das medidas por meio da consideração de cada um dos quatro critérios definidos pelos comentários gerais n. 03/1990 já referidos, o Estado brasileiro teria desatendido com larga margem de violações a cada um dos quatro critérios, habilitando-se sem grandes dificuldades, a ocupar a condição de protagonismo em um processo de transformação institucional. Se por um lado a ordem jurídica brasileira expõe abertamente sua aptidão para proteger as condições indispensáveis para a existência duradoura da vida, sob todas as suas formas, cada um dos compromissos que foram fixados pela Constituição e perante a sociedade internacional, tem encontrado cenário que, pelo elevado grau de violações seria capaz de propor uma transformação da imagem de Estado que tem guiado as ações públicas e privadas.

No lugar de um Estado ambiental que precisa ser capaz de concretizar seus compromissos com o desenvolvimento da vida, as decisões e escolhas realizadas pelas funções públicas tem obstado tal processo de concretização por meio de consequências que melhor definiriam e identificariam a imagem de um Estado de retrocesso ambiental.

Se é conhecida a representação positiva que ostenta a qualidade da produção normativa nacional e matéria ambiental, bem como a de seus tribunais, o cenário descrito nesta investigação tem condições de propor, no mínimo, uma profunda reflexão sobre a confirmação de tal hipótese. Ao menos no caso dos tribunais nacionais, se um esforço de sensibilidade ecológica já tem sido confirmado em tribunais superiores, inclusive no que se refere ao reconhecimento do princípio de proibição de retrocesso (que será enumerado adiante, por meio das principais decisões proferidas até o momento), o negativo diagnóstico exposto no espaço do tribunal que define o sentido e o alcance da proteção oferecida pela Constituição não é capaz de confirmar, em absoluto, uma imagem coerente de Estado ambiental.

Fazendo o uso da leitura proposta por Tushnet (TUSHNET: 2008) para a Constituição norteamericana, se naquela experiência, os direitos são fracos e existiria uma tendência de fortalecimento dos tribunais para que, v.g, os DESC pudessem ser concretizados, o Brasil expõe neste momento cenário diametralmente oposto: há direitos muito poderosos mas, sobretudo, tribunais ainda menos fortes do que poderiam ser para o fim de obstar decisões inconsequentes e nocivas à proteção da vida, das presentes e das futuras gerações.

diante serão enumeradas as principais decisões dos tribunais que tentam colaborar, em direção oposta ao diagnóstico referido, caminhos possíveis para a formação de uma cultura judicial de não retorno em matéria ambiental, 


\subsection{A formação de uma cultura judicial de não retorno em matéria ambiental na jurisprudência brasileira. 0 diálogo com 0 direito privado}

Embora não seja visível no STF uma tendência jurisprudencial que favoreça a consideração de um dever de não diminuir os níveis de proteção ambienta já atingidos, orientação oposta é delineada nos tribunais de justiça e no Superior Tribunal de Justiça (STJ) brasileiros, contextos nos quais o princípio emerge por meio de um curioso diálogo com o direito privado e sua conexão com as manifestações de um princípio de segurança jurídica ou de proteção da confiança, como o direito adquirido, o ato jurídico perfeito e a coisa julgada.

Nesta oportunidade serão enumerados alguns dos mais recentes casos apreciados pelo STJ, e pelos Tribunais de Justiça de São Paulo e Minas Gerais para o fim de sistematizar e sintetizar o conjunto de precedentes mais relevantes e que sugerem a importância de se desenvolver caminhos de formação de uma cultura judicial de não retorno mesmo que esta se apresente de forma reflexa e por meio da iniciativa difusa de órgãos judiciais com distintas atribuições.

As duas primeiras decisões são oriundas do $\mathrm{ST} \mathrm{J}^{38}$. A primeira delas ${ }^{39}$ tem origem em conflito exposto em primeiro grau, por meio de ação civil pública ambiental ajuizada pelo Ministério Público do Estado de São Paulo em face de Agropecuária Iracema Ltda., alegando-se, na ocasião, que a ré não teria destinado parte do imóvel para fins de reserva legal. O juízo de primeiro grau condenou a empresa a (i) instituir, medir, demarcar e averbar a reserva legal; (ii) abster-se de explorar a área; (iii) recompor a cobertura florestal; (iv) pagar indenização pelos danos irrecuperáveis, e (v) não receber benefícios ou incentivos fiscais.

Em apelação, o Tribunal de Justiça de São Paulo reformou parcialmente a sentença, excluindo da condenação a ordem de reflorestamento de áreas de preservação permanente e a proibição de obter financiamentos e/ou benefícios e incentivos fiscais e admitindo a implantação da reserva legal no prazo legal, mediante projeto a ser apresentado em 120 dias, e após sua aprovação pelo órgão ambiental estadual competente.

Em acórdão conduzido por voto do Min. Humberto Martins, o Tribunal asseverou que a questão principal a ser enfrentada no recurso reside em saber se é possível valer-se de norma superveniente de cunho material nos processos em andamento e, em especial, em agravo regimental. Para solucionar esse ponto, argumentou que o novo Código Florestal (Lei no 12.651/2012) não pode retroagir para atingir 0 ato jurídico perfeito, direitos ambientais adquiridos e a coisa julgada, citando precedente de relatoria do Min. Herman Benjamin (PET no REsp 1.240.122PR, Segunda Turma, julgado em 02.10.2012, DJe de 19.12.2012.).

O posicionamento da Turma fundamenta-se no argumento de que, em se tratando de norma de conformação da propriedade e de limitação ao seu uso, sua aplicação é imediata, não havendo falar em aplicação retroativa da lei. Ademais, o acórdão ressaltou que 0 art. 68 da Lei 12.6512012 prevê a dispensa da recomposição, da compensação ou da regeneração, nos percentuais previstos em lei, nos casos em que a supressão de vegetação nativa tenha respeitado os percentuais de reserva legal previstos na legislação vigente à época dos fatos, o

\footnotetext{
${ }^{38}$ Uma organização temática da jurisprudência do STJ relacionada ao tema poderia propor a seguinte enumeração de decisões e matérias: a) O mínimo ecológico como representação da proteção dos processos ecológicos essenciais: STJ, EREsp 218781 / PR, S1, rel. Min. Herman Benjamin, j. 09.12.2009, Dje: 23.02.2012; STJ. REsp 1240122/PR, 2. T. rel. min. Herman Benjamin, Dje: 11.09.2012, j. 28.06.2011; b) a definição de direitos ambientais adquiridos: STJ. Pet no REsp № 1.240.122 - PR , 2. t., rel. Min. Herman Benjamin. DJe: 19.12.2012; c) o princípio do não retrocesso em matéria urbanática: STJ. RESp n. 302906/SP, 2. T., rel. Min. Herman Benjamin, Dje: 01.12.2010; d) O princípio do não retrocesso e a proteção contra transformações legislativas supervnientes: STJ. AgRg no AREsp 327687 / SP, 2. T., Rel. Min. Humberto Martins, Dje: 26.08.2013, STJ. AgRg no REsp 1367968 / SP, 2. T., rel. Min. Humberto Martins, Dje: 12.03.2014.

${ }^{39}$ STJ, AgRg no REsp 1.367.968-SP, 2. T., r. Min. Humberto Martins, j. 17/12/2013, DJe 12/03/2014.
} 
que não teria ocorrido na hipótese sob análise. Destacou ainda o caráter propter rem das obrigações associadas às áreas de preservação permanente e reserva legal e a inexistência de direito adquirido à degradação ambiental. Ressaltou que a obrigação de demarcar, averbar e restaurar a área de reserva legal nas propriedades rurais configura dever jurídico (obrigação ex lege) que se transfere automaticamente com a transferência do domínio, podendo, em consequência, ser imediatamente exigível do proprietário atual.

O voto-vista da Min. Eliana Calmon acompanhou o voto do relator, reiterando que não cabe o argumento de aplicação de norma superveniente (Lei $\left.n^{\circ} 12.6512012\right)$ às situações fáticas ocorridas em período anterior.

Dessa forma, o STJ reiterou posicionamento anterior que já havia sido firmado por ocasião do recurso especial $n^{\circ} 1.240 .122$ e do agravo regimental em recurso especial $n-327.687$ (o primeiro, de relatoria do Min. Herman Benjamin; e o segundo, do Min. Humberto Martins), no sentido de que a nova lei ambiental não poderá retroagir para fins de atacar o ato jurídico perfeito, direitos ambientais adquiridos e a coisa julgada. Trata-se de importante posicionamento do tribunal superior, revelando que a Segunda Turma, unanimemente, tem decidido pela impossibilidade de que a Lei no 12.651/2012 retroaja para atingir processos já em andamento referentes a período anterior à citada lei.

A segunda decisão ${ }^{40}$ foi relatada pelo ministro Og Fernandes em agravo regimental interposto pelo Instituto Brasileiro do Meio Ambiente e dos Recursos Naturais Renováveis (IBAMA) contra decisão que afirmou que, se 0 ato ensejador do auto de infração caracteriza contravenção penal, somente o Juízo Criminal seria capaz de aplicar a correspondente penalidade, excluindo a prerrogativa de polícia administrativa do órgão ambiental referido.

O IBAMA sustentou a validade da lavratura de auto de infração ambiental com base no texto do art. 14, I, da Lei $n^{\circ} 6.938 / 81$ (transporte de carvão vegetal sem autorização).

O acórdão foi conduzido pelo voto do relator que destacou que a Lei $\mathrm{n}^{\circ} 12.6512012$, apesar de ter revogado o Código Florestal de 1965 (Lei no 4.771), não teve o condão de conceder anistia aos infratores das normas ambientais. Ao contrário, manteve a ilicitude da violação a normas ambientais, sujeitando os agentes a procedimentos administrativos com vistas à responsabilização administrativa e recomposição do dano.

O acórdão citou precedentes no sentido de que o direito material aplicável deve ser o então vigente à época dos fatos e, além disso, que o novo Código Florestal não anistiou de forma geral e irrestrita as infrações, e tampouco extinguiu a ilicitude de condutas anteriores a 22 de julho de 2008, para o efeito de se justificar pretensa perda superveniente de interesse de agir por parte do IBAMA. Sendo assim, o tribunal confirmou orientação no sentido de que a recuperação do meio ambiente degradado em áreas rurais consolidadas continuaria de rigor, agora por meio de procedimento administrativo, no âmbito de Programa de Regularização Ambiental - PRA, após a inscrição do imóvel no Cadastro Ambiental Rural - CAR e a assinatura de Termo de Compromisso - TC, valendo este como título extrajudicial. Somente a partir daí é que seriam suspensas as sanções aplicadas e, mediante o cumprimento das obrigações previstas no PRA ou no TC, as multas (e somente elas) seriam consideradas convertidas em serviços de preservação, melhoria e recuperação da qualidade do meio ambiente.

Desta feita, os autos de infração já constituídos permanecem válidos e imunes às transformações legislativas supervenientes sob a condição de atos jurídicos perfeitos, suspendendo-se tão somente (e se esse fosse o caso), sua exigibilidade financeira até a satisfação integral das obrigações que foram fixadas no PRA ou no TC. Com isso, está preservado o interesse de agir nas demandas judiciais em curso, não ocorrendo perda de objeto e extinção do processo sem resolução de mérito.

${ }^{40}$ STJ, AgRg no REsp 1.313.443-MG, 2. T., r. Min. Og Fernandes, j. 18/02/2014, DJe 12/03/2014. 
Por derradeiro, o tribunal ressaltou a independência das esferas de responsabilização, de modo que o transporte de carvão vegetal sem autorização constitui, a um só tempo, crime e infração administrativa, podendo, neste último caso, ser objeto de autuação pela autoridade administrativa competente.

A posição fixada pelo tribunal superior continua a desenvolver postura que reforça a formação de uma jurisprudência criativa capaz de oferecer alternativas que protegem os atos de conteúdo ambiental contra pretensões que possam implicar em retorno nos níveis de proteção já assegurados.

Desse modo, ao contrário do que normalmente se poderia enfatizar, a proteção do ato jurídico perfeito não se restringe à proteção dos particulares, estendendo antes, seus efeitos, para todas as modalidades de relações jurídicas e, principalmente, no interesse da proteção de bens e de valores de projeção transindividual.

Entre os tribunais de justiça podem ser destacadas as decisões proferidas pelo Tribunal de Justiça de Minias Gerais e de São Paulo. No primeiro merece ser enfatizado acórdão que debatia a inconstitucionalidade de lei do município de Uberaba, a qual autorizava o plantio e a queimada de palha de cana-de-açucar em perímetro urbano, revogando texto anterior, relatado pelo desembargador Wander Marotta (ação direta de inconstitucionalidade $\mathrm{n}$. 1.0000.12.047998-5/000), e mais recentemente o reconhecimento da invalidade da modificação dos critérios para compensação de reserva legal e sua averbação (da microbacia para o bioma) realizados pela lei que revogou o código florestal), relatado pela desembargadora Hilda Teixeira ${ }^{41}$. $\mathrm{O}$ acórdão em exame tem origem em recurso de apelação cível interposto pelo Ministério Público do Estado de Minas Gerais perante decisão proferida em ação civil pública pela qual se pretendida desconstituir e invalidar as averbações de reserva legal oriundas de compensação que fossem realizadas fora da microbacia geográfica na qual se constatava o seu déficit. A decisão de origem pronunciou a improcedências dos pedidos formulados pelo órgão ministerial porque considerou decisivamente, que a aplicação da lei $n$. $12.651 / 2012$ asseguraria 0 atendimento de normas mais flexíveis sobre o uso da compensação, admitindo-se nesse sentido, a adoção de critério distinto, a saber, o do bioma em detrimento daquele originário do código florestal revogado (microbacia). Segundo argumento exposto pela sentença se circunscreveu ao reconhecimento de que a lei estadual também asseguraria a observação de critério distinto e que, nesse sentido, muito embora tenha sido objeto de declaração de inconstitucionalidade, as áreas nas quais se pretendia a compensação não foram atingidas pelos efeitos daquela decisão.

A relatora referendou os argumentos expostos pela decisão recorrida e expôs voto que desprovia o recurso de apelação para manter a decisão de improcedência da ação civil pública, reconhecendo como principal argumento, o de que o assim denominado novo código florestal deveria ser aplicado às relações jurídicas em curso.

Essa, entretanto, não foi a tese confirmada pelo acórdão em razão da divergência inaugurada pelo voto proferido pelo desembargador Afrânio Vilela (revisor) e reforçada pela intervenção do desembargador Marcelo Rodrigues (vogal).

Em suas razões de voto, o revisor enfatizou o grau de responsabilidade atribuído neste momento à função judicial, consignando que o exercício da condição de um juiz planetário lhe exigiria o atendimento não apenas de um princípio de legalidade, senão de um princípio de juridicidade.

Nesse sentido, afirmou que, muito embora a solução exposta pela sentença e pelo desembargador relator não se afastassem de um juízo de legalidade, não atenderiam a um

${ }^{41}$ TJMG, Apelação cível 1.0702.12.002260-4/0012. Câmara Cível, r. des. Hilda Teixeira da Costa, j. 07/04/2014, DJ 14/04/2014. 
teste de juridicidade. Isso porque, se em primeiro lugar, a lei estadual não foi plenamente atingida pelos efeitos da declaração de sua inconstitucionalidade, a função social da propriedade exigiria que compromissos associados à manutenção de processos ecológicos fossem respeitados por todos os proprietários e, acima de tudo, que os interesses da coletividade (estes relacionados ao exercício de um direito ao meio ambiente sadio) fossem considerados em detrimento da proteção pessoal e subjetiva que poderia ser oposta por qualquer proprietário, a partir de norma que lhe pudesse ser mais favorável.

Por outro lado, o revisor também consignou que o uso do novo critério para a compensação de reserva legal se apresentaria como menos rigoroso do que aquele definido na legislação revogada porque não seria capaz de respeitar a necessidade de se manter a identidade natural que se pretendia resguardar pela aplicação da norma revogada.

Em reforço a essa orientação que objetivava impedir a aplicação de norma mais flexível em detrimento da qualidade do meio ambiente natural, o desembargador Marcelo Rodrigues trouxe à ilustração a necessidade de se considerar a irretroatividade da norma superveniente como fundamento para justificar um compromisso de não retorno nos níveis de proteção já assegurados aos bens ambientais. Suscitando e acolhendo a consideração de um princípio de proibição de retrocesso em matéria ambiental, o desembargador o expôs por meio da regra da irretroatividade das leis, e por meio da proteção dos atos jurídicos perfeitos, tendo relacionado o uso das teses à jurisprudência em formação que se desenvolve no Superior Tribunal de Justiça, especialmente em casos mais recentes como aqueles veiculados no julgamento do AgRg no AREsp 327.687/SP, relatado pelo ministro Humberto Martins. Essa mesma orientação também já foi objeto de consideração (e aplicação) pelo próprio Tribunal de Justiça mineiro por ocasião do julgamento das apelações cíveis n. 1.0702.12.002230-7/001, n. 1.0702.09.603669$5 / 001$, e n. 1.0702.06.304742-8/001 nas quais foi reconhecido que a reserva legal deveria ser objeto de averbação no respectivo órgão notarial até que o novo sistema de cadastro se encontrasse em operação, sob pena de se viabilizar um retrocesso nos níveis de proteção já atingidos.

Do mesmo modo, a tese da irretroatividade da legislação superveniente no interesse de se obstar iniciativas retrocessivas no domínio da proteção do ambiente também já havia sido esboçada no julgamento do recurso de apelação cível n. 1.0016.09.092968-4/009, afastandose de tese oposta (aplicação imediata da nova legislação, salvo nos casos em que atos jurídicos já tivessem sido praticados em favor do meio ambiente) esta última utilizada, por exemplo, no julgamento do recurso de apelação cível 1.0702.11.042298-8/001.

Sob semelhante contexto, a contribuição apresentada pelo Tribunal de Justiça de Minas Gerais demonstra que a construção das bases de um Direito ambiental do não retorno já não mais se restringe a uma teoria jurídica do não retrocesso. A prática e a proposição de soluções para conflitos cada vez mais diversificados colabora ativamente para a construção pragmática de um contexto em expansão, de valorização e de proposição de técnicas e de instrumentos de proteção normativa dos bens ambientais perante transformações legislativas ambientalmente nocivas. Tal esforço que teve início no Superior Tribunal de Justiça, encontra hoje espaço favorável para sua recepção na prática dos tribunais de justiça e dos juízes em primeiro grau de jurisdição.

Por fim, no Tribunal de Justiça de São Paulo pode ser indicado acórdão relatado pelo desembargador João Negrini Filho. ${ }^{42}$ A decisão ressaltou que as disposições da Lei $n^{\circ}$ 12.651/2012 não se aplicam ao caso, uma vez que o trânsito em julgado da sentença homologatória operou em momento anterior à vigência da referida lei, de modo que a questão

42 Tribunal de Justiça de São Paulo. Agravo de Instrumento no 2068453-62.2013.8.26.0000, Primeira Câmara Reservada ao Meio Ambiente do Tribunal de Justiça de São Paulo, r. Desembargador João Negrini Filho, j. 22/05/2014, DJe 30/05/2014. 
encontra-se acobertada pelo manto da coisa julgada. Para reforçar esse argumento, fez o uso e aplicou o princípio da segurança jurídica, o princípio da vedação do retrocesso, e o art. 5으, inciso XXXVI, da Constituição Federal, no sentido de afirmar a irretroatividade da lei nova que pudesse prejudicar o ato jurídico perfeito, o direito (ambiental) adquirido e a coisa julgada, bem como enfatizou o fato de que o direito de propriedade sofre restrições em decorrência da necessidade de preservação e recuperação do meio ambiente. Salientou, ademais, que era de pleno conhecimento das agravantes as faixas de terra em que deveriam se abster ou cessar de intervir com relação ao plantio da cana-de-açúcar, o que demonstra a ilegalidade das atividades agrícolas detectadas nessas áreas. Semelhante orientação foi confirmada em acórdão relatado pelo desembargador Ruy Alberto Leme Cavalheiro ${ }^{43}$, no qual salientou ser incabível a aplicação do novo Código Florestal ao caso, sob pena de afronta ao princípio constitucional da irretroatividade da lei nova para atingir atos jurídicos perfeitos, além do que a questão está acobertada pelo manto da coisa julgada. Além disso, argumentou que embora algumas exigências encontrem dificuldades no cumprimento com as alterações na legislação a exemplo da averbação da reserva legal na matrícula do imóvel -, é certo que a possibilidade de adequações práticas, principalmente no âmbito administrativo, não autoriza a revisão do julgado ou a retroatividade da lei. Reforçando entendimento firmado no Superior Tribunal de Justiça, ressaltou, ainda, que não existe direito adquirido à má utilização dos recursos naturais ou à não preservação do meio ambiente, na medida em que o direito ambiental é intergeracional, regido por normas cogentes de aplicação imediata. Ademais, salientou que o bem ambiental integra o patrimônio da coletividade e que, para sua efetivação, existe a derrogação de várias normas de direito público e de direito privado, sob pena de se tornar inviável e inexecutável a proteção prevista em lei. Por fim, frisou o caráter educativo das decisões judiciais em matéria ambiental, especialmente em uma sociedade que ainda não possui consciência ambiental nem educação ecológica, sobretudo, porque o abrandamento em relação a questões ambientais já acarretou consequências irreversíveis à natureza e à qualidade de vida.

\section{Considerações finais}

O trabalho demonstrou a relação existente entre a definição de um direito ao meio ambiente na condição de direito fundamental, e a elaboração de um sentido alargado de dignidade de vida.

Para tanto, propôs-se que a necessidade de proteção dos elementos naturais decorre de um projeto existencial definido pela ordem constitucional brasileira, que requer a colaboração estatal e coletiva, com vistas a garantir a existência duradoura de todas as formas de vida.

Semelhante tarefa requer a proteção de um nível mínimo de qualidade dos recursos naturais, cujo acesso e existência constituem parte integrante de uma noção ampla de bem-estar, que procura compor necessidades de conteúdo antropocêntrico e biocêntrico, em torno da noção do que se denomina mínimo existencial ecológico.

Sustentou-se no texto que esse nível de proteção, por refletir o que uma determinada organização social admite e requer como indispensável ao desenvolvimento digno da vida, não pode ser eliminada por iniciativas estatais retrocessivas.

Iniciativas como as referidas, geralmente destinadas a mitigar cada vez mais os condicionamentos ecológicos impostos ao exercício das liberdades econômicas, proporcionam e sugerem uma mensagem em sentido diametralmente oposto não só àqueles compromissos globais que o Estado brasileiro assumiu perante a ordem pública global, como com o próprio

43 Tribunal de Justiça de São Paulo. Agravo de Instrumento no 2058963-16.2013, Primeira Câmara Reservada ao Meio Ambiente do Tribunal de Justiça de São Paulo, r. Desembargador Ruy Alberto Leme Cavalheiro, j. 24/04/2014, DJe 01/05/2014. 
compromisso republicano exposto pelo texto constitucional, com um determinado projeto existencial que é em última análise, um projeto prospectivo, um projeto de futuro: propõe um sentido de comprometimento com um determinado cenário de futuro desejável e esperado para a ordem social, econômica, cultural.

Nesse contexto, cumpre ao Estado responder oportunamente e de forma suficiente pelo exercício de seu dever de proteção para o fim de assegurar uma proteção reforçada aos elementos naturais e a todas as formas de vida [preponderantemente, por iniciativa de sua função legislativa ou através de escolhas ou decisões sobre as políticas públicas], de modo a permitir a proteção da pessoa humana, de sua dignidade, e de todas as suas realidades existenciais, assegurando-lhe a liberdade de escolher e de definir os rumos de sua própria existência [autodeterminação da vontade e livre desenvolvimento de sua personalidade].

Baseando-se em uma abordagem de comunicação e de interação entre experiências jurídicas foi possível demonstrar que a ordem constitucional brasileira não assegura proteção constitucional às iniciativas públicas ou privadas que se afastem do dever de proteção dos direitos fundamentais [neste caso, do dever de proteger o ambiente], que proponha redução nos níveis de proteção, configurando-se os excessos em seu exercício, desvios censurados sob o ângulo dos artigos 225, caput, e § 1ํ, incisos I, III, e VII, todos da CRFB de 1988.

Se o Estado não dá respostas a estes novos desafios, se não assegura proteção reforçada, não se verifica apenas a degradação da natureza, da cultura, e dos processos ecológicos, senão a existência da humanidade. Esta se vê comprometida porque será incapaz de ter acesso e se desenvolver plenamente, diante da subtração de uma das realidades existenciais indispensável para que usufrua de condições dignas de vida, a ecológica. Se as políticas públicas são deficientes, se as escolhas são inadequadas, se as opções são insuficientes ou simplesmente ausentes, cabe à função judicial assegurar uma alternativa, uma resposta, que pode até propor caminhos para a ação pública, reforçar ou ainda, auxiliar no processo de deliberação política sobre como se desincumbirá destas tarefas em um cenário de controvérsias, indefinições e multiplicação de posições.

Ao contrário do que se poderia supor de uma experiência normativa que favorece a interdição do retrocesso em matéria ambiental, a realidade apresentada na ordem jurídica brasileira propõe um cenário que é oposto, por meio do qual há direitos muito poderosos, mas tribunais e instituições que ainda precisam desenvolver sua capacidade de influenciar transformações substanciais nas políticas ambientais, e transformações substanciais nos projetos coletivos de vida das pessoas.

Ao mesmo tempo em que um alguns avanços são verificados em alguns tribunais (como o Superior Tribunal de Justiça e mais recentemente, os tribunais de justiça estaduais), no sentido de afirmar sua importância em questões de grande impacto social, como a queima de palha de cana de açúcar, a proteção dos manguezais e facilitando a reparação de danos ambientais decorrentes dos desmatamentos, por outro lado, essa unidade de propósitos ainda não consegue ser identificada no conjunto de tribunais em questões tão ou mais relevantes para a manutenção e o aperfeiçoamento dos compromissos assumidos pelo Estado brasileiro para com a comunidade, e que tem por conteúdo determinante a manutenção de condições duradouras para o desenvolvimento da vida, assegurando-a e viabilizando-a.

Se é certo que não é o legislador o principal destinatário de uma proibição de retorno, senão a função executiva (que tem ao seu alcance o principal instrumento que viabiliza o progresso e o retrocesso, sendo este o orçamento público), a função judicial também se encontra fortemente vinculada e exerce relevante função porque é capaz de corrigir os níveis de proteção deficiente, ao externar interpretação de normas e de políticas públicas que favoreçam proteção no caso de duvida. 
A consideração de um principio de precaução sempre favorece a proibição de retorno no caso de dúvida se uma determinada modificação superveniente e ou não retrocessiva, se diminui ou não a proteção dos valores envolvidos, sendo este um importante instrumento que colaboraria para a formação de uma cultura jurídica de não retorno, fortalecendo o conteúdo e os caminhos de aplicação de um princípio de não retrocesso ambiental.

O principio (de não retrocesso) não favorece a ponderação do direito ao meio ambiente, senão reforça e colabora para enfatizar a solução para o seguinte problema: o que se pode esperar do Estado e das pessoas no plano da proteção de valores que são importantes. Se o retrocesso e possível, quanto retrocesso e quando ele poderia ser autorizado. Uma idéia de não retorno colabora para a valorização de uma cultura de proteção do direito fundamental, e não de reparação de danos por meio de compensações e, nesse sentido, a resposta para o conjunto de indagações seria, ao menos no caso brasileiro, dificilmente aproximável de um imperativo relativo, diante dos fundamentos constitucionais que justificam sua existência e consideração.

O retrocesso não ocorre apenas quando são realizadas escolhas que desconstituam instrumentos e normas que protegiam bens vitais, senão também por meio de decisões que obstem que o progresso na proteção pudesse ocorrer. Em outras palavras, quando o Estado não dá passos e deixa de demonstrar seu compromisso com o desenvolvimento da proteção daqueles bens, por meio de todos os instrumentos que estivessem ao seu alcance, também expõe uma evidência de retrocesso.

Uma cláusula de status quo somente é admitida quando os níveis adequados já forma atingidos. Se ainda não forma, manter o status quo significa e implica retrocesso.

O Brasil está inserido em uma ordem pública global que não admite a interrupção no desenvolvimento das políticas públicas de interesse ambiental.

Tolerar ou inviabilizar o desenvolvimento dos direitos fundamentais em sua dimensão integral e indivisível representa e estimula um estado de frustração constitucional, que cresce e se desenvolve cada vez mais em uma realidade como a brasileira, na qual, as prestações essenciais ao desenvolvimento da vida se aproximam com maior força de demandas existenciais mais realistas como o acesso à água potável, à alimentação adequada, proteção da saúde, trabalho decente e moradia digna, do que realidades que, espantosamente, deveriam ser o ponto-de-partida para a reflexão sobre todas as demais liberdades e não são: a conservação de condições de salubridade dos recursos naturais. Estes são, de fato, os elementos que asseguram minimamente, o desenvolvimento da vida.

Se fosse possível propor uma contribuição neste momento e neste cenário de instabilidades diagnosticado na experiência jurídica brasileira, teria de ser, no mínimo a seguinte: se avanços ou progressos não são possíveis, já se chegou em um momento em que proteger o mínimo se tornou indispensável, ganhando ênfase o efeito de standstill. Se não é possível que sejam dados novos passos, ou ainda, passos mais vigorosos, talvez já tenha chegado a hora de se propor como a manifestação de um consenso global, o de uma cultura universal de não retrocesso. Para a indagação sobre que futuro queremos, e que foi realizada ainda em junho de 2012 no âmbito de uma conferência das nações unidas, talvez a melhor imagem desse futuro que queremos, seja, no mínimo, este. 


\section{Referências bibliográficas}

Andrade, José Carlos Vieira de. Os direitos fundamentais na Constituição portuguesa de 1976. 3. ed. Coimbra: Almedina, 2004.

Ayaka, Patryck de Araújo. Devido processo ambiental e direito fundamental ao meio ambiente. Rio de Janeiro: Lumen Juris, 2011.

Beck, Ulrich. La sociedad del riesgo mundial. En busca de seguridad perdida. Trad. de Rosa Carbó. Barcelona: Paidós, 2007.

Botkin, Daniel. Discordant harmonies. A new ecology for the twenty-first century. New York: Oxford, 1990.

Brasil. Supremo Tribunal Federal. Medida cautelar na ação direta de inconstitucionalidade $\mathrm{n}$. 3540. Tribunal Pleno. Rel. Min. Celso de Mello. Disponível em: <http://www.stf.jus.br>. Acesso em 10 de junho de 2013a.

Agravo regimental na ação direta de inconstitucionalidade n. 3218. Tribunal Pleno. Rel. Min. Luiz Fux. Disponível em: <http://www.stf.jus.br>. Acesso em 10 de junho de 2013b.

Petição n. 3388. Tribunal Pleno. Rel. Min. Carlos Britto. Disponível em: $<$ <ttp://www.stf.jus.br>. Acesso em 10 de junho de 2013c.

Ação direta de inconstitucionalidade n. 4252. Tribunal Pleno. Rel. Min. Celso de Mello. Disponível em: <http://www.stf.jus.br>. Acesso em 10 de junho de 2013d.

Ação direta de inconstitucionalidade n. 4253. Tribunal Pleno. Rel. Min. Celso de Mello. Disponível em: <http://www.stf.jus.br>. Acesso em 10 de junho de 2013e.

Ação direta de inconstitucionalidade n. 4901. Tribunal Pleno. Rel. Min. Luiz Fux. Disponível em: <http://www.stf.jus.br>. Acesso em 10 de junho de 2013f.

Ação direta de inconstitucionalidade n. 4902. Tribunal Pleno. Rel. Min. Rosa Weber. Disponível em: <http://www.stf.jus.br> .Acesso em 10 de junho de 2013g.

Ação direta de inconstitucionalidade n. 4003. Tribunal Pleno. Rel. Min. Gilmar Mendes. Disponível em: <http://www.stf.jus.br>. Acesso em 10 de junho de 2013h.

Arguição de descumprimento de preceito fundamental n. 101. Tribunal Pleno. Rel. Min. Carmen Lúcia. Disponível em: <http://www.stf.jus.br> .Acesso em 10 de junho de 2013i.

Brugger, Winfried.Die Würde des Menschen im Licht des anthropologischen Kreuzes der Entscheidung. In: HARLE, Wilfried; VOGEL, Bernhard. Hrsg. Begründung von Menschenwürde und Menschenrechten. Freiburg/Basel/Wien: Herder, 2008, p. 49-94.

Callies, Peter H. Rechstaat und Umweltstaat. Zugleich ein Beitrag zur Grundrechtsdogmatik im Rahmen mehrpoliger Verfassungsrechtsverhältnisse. Tugingen: Mohr Siebeck, 2001.

Canotilho, José Joaquim Gomes; LEITE, José Rubens Morato (Org.). Direito constitucional ambiental brasileiro. São Paulo: Saraiva, 2007.

Canotilho, José Joaquim Gomes. Direito constitucional ambiental português: tentativa de compreensão de 30 anos das gerações ambientais no direito constitucional português. In: Canotilho, José Joaquim Gomes; LEITE, José Rubens Morato (Org.). Direito constitucional ambiental brasileiro. São Paulo: Saraiva, 2007. p. 1-11.

Direito constitucional e teoria da constituição. 7. ed. Coimbra: Almedina, 2004.

Estudos sobre direitos fundamentais. Coimbra: Coimbra, 2004. 
O direito ao ambiente como direito subjectivo. In: CANOTILHO, José Joaquim Gomes. Estudos sobre Direitos Fundamentais. Coimbra: Coimbra, 2004. p. 77-89.

Constituição dirigente e vinculação do legislador. Coimbra: Coimbra, 1994.

Estado de direito. Lisboa: Gradiva, 1999.

Colombia. Corte Constitucional de Colômbia. Sentencia C-443/09. Demanda de Inconstitucionalidad contra el artículo 34 (parcial) de La Ley 685 de 2001. Disponível em: <http://www.corteconstitucional.gov.co/relatoria/2009/C-443-09.htm>. Acesso em 17 novembro 2011.

Courtis, Christian. (Compilador). Ni un paso atrás. La prohibición de regresividad em materia de derechos sociales. Buenos Aires: Del Puerto, 2006.

La prohibición de regresividad en materia de derechos sociales: apuntes introductorios. In: (Compilador). Ni un paso atrás. La prohibición de regresividad em materia de derechos sociales. Buenos Aires: Del Puerto, 2006. p. 3-52.

De los Ríos, Isabel. El principio de irreversibilidad em el derecho ambiental venezolano. In: Prieur, Michel; SOZZO, Gonzalo. La non regresion en droit de l'environment. Bruxelles: Bruylant, 2012. p. 403-422.

Díaz Revorio, Francisco Javier. La constitución como orden abierto. Madrid: MacGraw-Hill, 1997.

Dworkin, Ronald. Justice for hedgehogs. Cambridge: Harvard University Press, 2011.

España. Tribunal Supremo. Sala de lo Contencioso. Sala Tercera. STS n. 6592/2011.

. Tribunal Supremo. Sala de lo Contencioso. Sala Tercera. STS n. 2000/2012a.

. Tribunal Supremo. Sala de lo Contencioso. Sala Tercera. STS n. 5538/2012b.

. Tribunal Supremo. Sala de lo Contencioso. Sala Tercera. STS n. 5432/2012c.

Ferrajoli, Luigi. Por uma teoria dos direitos e dos bens fundamentais. Trad. de: Alexandre Salim, Alfredo Copeti Neto, Daniela Cadermatori, Hermes Zaneti Júnior e Sérgio Cadermatori. Porto Alegre: Livraria do Advogado, 2011.

Groschner, Rolf. La dignidad humana. Iter Criminis. Revista de ciencias penales, Mexico, n. 2, p. 57-81, marzo-abril 2008.

Häberle, Peter. Nachhaltigkeit und Gemeineuropäisches Verfassungsrecht. In: WOLFGANG KAHL (org.). Nachhaltigkeit als Verbundbegriff, Tübingen, 2008.

. A dignidade humana como fundamento da comunidade estatal. In: SARLET, Ingo Wolfgang. (Org.). Dimensões da dignidade. Ensaios de filosofia do direito e direito constitucional. Porto Alegre: Livraria do Advogado, 2005.

.La imagen del ser humano dentro del estado constitucional. Tradução de Carmen Zavala. Lima: Fondo Editorial de la Pontifícia Universidad Católica del Perú, 2001.

. Teoria de la constitución como ciência de la cultura. Trad. de: Emilio Mikunda. Madrid: Tecnos, 2000.

Hachez, Isabelle. Le principe de non-regression en droit de l'environnement: une irréversibilité relative? In: PRIEUR, Michel; SOZZO, Gonzalo. La non regresion en droit de l'environment. Bruxelles: Bruylant, 2012. p. 501-522.

Kirste, Stephan. Introdução ao estudo do direito. Trad. de: Paula Nasser. Belo Horizonte: Fórum, 2013. 
Kloepfer, Michael. Vida e dignidade da pessoa humana. In: SARLET, Ingo Wolfgang. (Org.). Dimensões da dignidade. Ensaios de filosofia do direito e direito constitucional. Porto Alegre: Livraria do Advogado. 2005. p. 153-184.

Le Déaut, Jean-Yves. Le responsable politique face à la gestion du risque: L'exemple des biotechnologies. In: FERENCZI, Thomas. (Direc.). Les défis de la technoscience. Paris: Complexe, 2001. p. 57-69.

Luther, Jörg. Profili costituzionali della tutela dell'ambiente in Germania. Giurisprudenza costituzionale, v. I, p. 2556, 1986.

Mazzuoli, Valério de Oliveira. Curso de direito internacional público. 6. ed. São Paulo: RT, 2012.

Margalit, Avishai. La sociedad decente. Trad. de: Carme Castells Auleda. Barcelona: Paidos, 2010.

Mestre, Ramón Ojeda. Del eterno retorno a la no regresión. In: PRIEUR, Michel; SOZZO, Gonzalo. La non regresion en droit de l'environment. Bruxelles: Bruylant, 2012. p. 423-436.

Miranda; Jorge. Manual de direito constitucional. Tomo IV. 3. ed. Coimbra: Coimbra, 2000.

Molinaro, Carlos Alberto. Direito ambiental. Proibição de retrocesso. Porto Alegre: Livraria do Advogado, 2007.

Neves, Marcelo. Transconstitucionalismo. São Paulo: Martins Fontes, 2009.

Novais, Jorge Reis. Os princípios constitucionais estruturantes da República Portuguesa. Coimbra: Coimbra, 2004.

As restrições aos direitos fundamentais não expressamente autorizadas pela Constituição. Coimbra: Coimbra, 2003.

O'Riordan, Tim. The politics of the precautionary principle. In: HARDING, Ronnie; FISHER, Elizabeth (Editors). Perspectives on the precautionary principle. New South Wales: Federation Press, 1999.

Organización de los Estados Americanos. 1998.

Pacto Internacional dos Direitos Econômicos, Sociais e Culturais, (1966). Disponível em: <http://www.direitoshumanos.usp.br/counter/Onu/Sist_glob_trat/texto/texto_2.html>. Acesso em: 12 mar. 2008.

Perez, Oren. Ecological Sensitivity and Global Legal Pluralism: Rethinking the Trade and Environment Conflict. London: Hart Publishing, 2004.

Posse, Miguel Patiño. El principio de no regresion en el derecho ambiental colombiano. In: Prieur, Michel; Sozzo, Gonzalo. La non regresion en droit de l'environment. Bruxelles: Bruylant, 2012. p. 437-452.

Luño, Antonio Enrique Pérez. Perspectivas e Tendências Atuais do Estado Constitucional. Trad. de: José Luis Bolzan de Morais e Valéria Ribas do Nascimento. Porto Alegre: Livraria do Advogado, 2012.

Pizollato, Filippo. Il minimo vitale. Profili costituzionali e procesi attuativi. Milano: Giuffrè, 2004.

Prieur, Michel; SOZZO, Gonzalo. La non regresion en droit de l'environment. Bruxelles: Bruylant, 2012.

. Le nouveau principe de non régression en droit de l'environment. In: Prieur, Michel; Sozzo, Gonzalo. La non regresion en droit de l'environment. Bruxelles: Bruylant, 2012. p. 5-46. 
Queiroz, Cristina. Direitos fundamentais sociais. Funções, âmbito, conteúdo, questões interpretativas e problemas de justiciabilidade. Coimbra: Coimbra, 2006a.

O princípio da não reversibilidade dos direitos fundamentais sociais. Princípios dogmáticos e prática jurisprudencial. Coimbra: Coimbra, 2006b.

Sarlet, Ingo Wolfgang. A eficácia dos direitos fundamentais. 9. ed. Porto Alegre: Livraria do Advogado. 2008.

- Mínimo existencial e direito privado: apontamentos sobre algumas dimensões da possível eficácia dos direitos fundamentais sociais no âmbito das relações jurídico-privadas. In: Souza Neto, Cláudio Pereira de; Sarmento, Daniel (Coord.). A constitucionalização do direito: fundamentos teóricos e aplicações específicas. Rio de Janeiro: Lumen Juris, 2007. p. 321-354.

. La prohibición de retroceso en los derechos sociales fundamentales en Brasil: algunas notas sobre el desafío de la supervivencia de los derechos sociales en un contexto de crisis. In: Courtis, Christian. (Compilador). Ni un paso atrás. La prohibición de regresividad em materia de derechos sociales. Buenos Aires: Del Puerto, 2006.

Ruiz, Jose Juste. El principio de progresividad en el derecho internacional del medio ambiente. In: Prieur, Michel; Sozzo, Gonzalo. La non regresion en droit de l'environment. Bruxelles: Bruylant, 2012. p. 237-258.

Sommermann, Karl-Peter. Staatsziele und Staatszielbestimmungen. Mohr Siebeck: Tübingen, 1997.

SOZZO, Gonzalo. El principio de no retroceso en el campo de la teoría jurídica: el progreso como perdurabilidad para las generaciones futuras. In: Prieur, Michel; Sozzo, Gonzalo. La non regresion en droit de l'environment. Bruxelles: Bruylant, 2012. p. 65-90.

Tushnet, Mark. Weak courts, strong rights. Judicial Review and Social Welfare Rights in Comparative Constitutional Law. Princeton University Press, 2009.

Weidner, Helmut. 25 years of modern environmental policy in Germany. Treading a well-worn path to the top of the international field. Discussion paper. Berlin: Wissenschaftszentrum Berlin für Sozialforschung, 1995. 


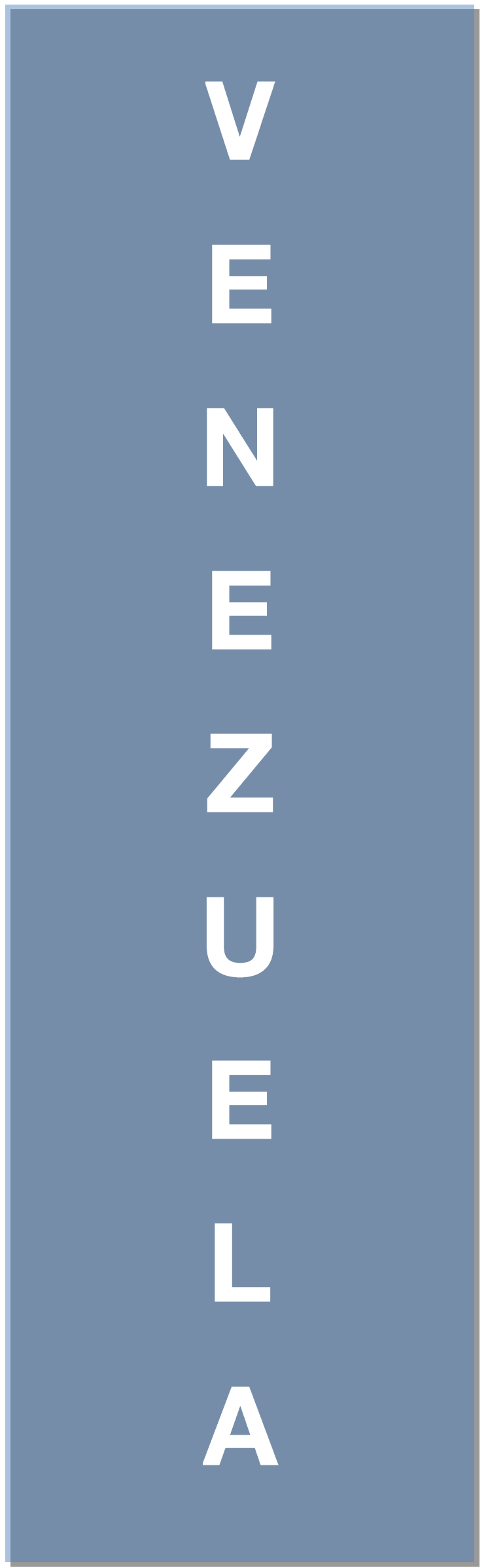





\title{
NUEVO RETO DEL DERECHO AMBIENTAL: LA CONSTRUCCIÓN DEL PRINCIPIO DE IRREVERSI- BILIDAD DE LAS NORMAS DE PROTECCION DEL AMBIENTE
}

\author{
Isabel De los Ríos*
}

La única manera de garantizar un ambiente adecuado, en un estado de derecho, es con reglas claras y severas que impidan su degradación o deterioro o que coadyuven a su mejoramiento; ambos asuntos deben ir de la mano.

\section{Introducción}

Las relaciones económicas y sociales y el derecho en su conjunto están estrechamente unidos, y esta característica se exacerba en la materia ambiental. Las regulaciones de carácter ambiental tienen profundas repercusiones económicas, por lo que las relaciones comercio/ambiente son cada vez más evidentes, aunque no más fuera porque las normas jurídicas implementadas para evitar la degradación ambiental tienen consecuencias traducibles en dinero por los costos adicionales que acarrean. $Y$ no puede pasarse por alto lo relativo al hambre y a la pobreza, eje de "El futuro que queremos", documento final de la Cumbre Río+20, de 2012. Y quizá sea la primera vez que una cumbre mundial en la materia aborda la necesidad de integrar en el desarrollo sustentable sus aspectos económicos, sociales y ambientales y los vínculos entre ellos.

La crisis financiera de 2008, originada en la burbuja inmobiliaria estadounidense con graves secuelas a nivel mundial que la convirtió en crisis planetaria, entre otros efectos produjo que se hayan "registrado contratiempos en algunos aspectos de la integración de las tres dimensiones del desarrollo sustentable, agravados por las múltiples crisis financieras, económicas, alimentarias y energéticas" como señala el documento mencionado supra.

Esos "contratiempos en la integración de las tres dimensiones" eufemísticamente se refieren a las amenazas que se ciernen sobre el equilibrio ambiente-economía-sociedad, para priorizar los aspectos económicos, lo que equivale a decir, con fórmula más cruda, que en caso de conflicto ambiente-desarrollo las normas de protección ambiental, que han costado luchas de decenios, son las que van sufrir un repliegue frente a simples coyunturas financieras desventajosas, tornando vigente la vieja discusión ambiente versus desarrollo, que convertía ambos conceptos en antagónicos, siendo, por el contrario, no solo complementarios sino indisolubles. Y esto es así pues la introducción de las preocupaciones ambientales -y con ellas la variable tiempo- es lo que asegura la perpetuidad del desarrollo, al punto de garantizarlo a las generaciones futuras.

Ante estas amenazas, ya concretadas en algunos países, sobre todo industrializados, se impone la fundamentación de una teoría que pueda oponerse con éxito a los retrocesos

\footnotetext{
* Abogada, Universidad Central de Venezuela. Doctora en Derecho del Ambiente, Universidad de Estrasburgo. Máster en Ordenación del Territorio. Especialista en Ciencias Penales. Especialista en Contaminación y Molestias Ambientales. Profesora titular de la Universidad Central de Venezuela. Profesora de las cátedras Principios generales del Derecho Ambiental, Derecho Penal del Ambiente y Derecho a un Medio Ambiente Sano.
} 
legislativos, administrativos o jurisprudenciales en la materia. Ello motivó que un grupo de juristas, liderados por el francés Michel Prieur, en 2010 emprendiera una investigación con el objeto de construir este nuevo principio, el "Principio de no regresión", que iría a enriquecer los principios jurídicos ya consagrados en las cumbres mundiales ambientales. El término "no regresión" preferí traducirlo al español como principio de irreversibilidad, y así aparece en mis contribuciones al trabajo del equipo, preferible en mi criterio por constituir una construcción gramatical positiva y con una sola palabra, además, por ser vocablo ya consagrado para los derechos humanos.

Es de advertir que a pesar de los esfuerzos hechos por el equipo en las reuniones preparatorias de la Reunión Río+20, y de las discusiones hasta el último minuto, el principio de irreversibilidad no fue aceptado en el documento final "El futuro que queremos"; quedó reducido al reconocimiento de que, respecto a lo insuficiente de los progresos alcanzados desde la última Cumbre Mundial y los contratiempos en algunos aspectos de la integración de las tres dimensiones del desarrollo sustentable, agravados por las múltiples crisis financieras, económicas, alimentarias y energéticas, que han puesto en peligro la capacidad de todos los países, en particular los países en desarrollo, para lograr el desarrollo sostenible, "es esencial que no demos marcha atrás a nuestro compromiso con los resultados de la Conferencia de las Naciones Unidas sobre el Medio Ambiente y el Desarrollo", expuesto en el párrafo 20.

Ante la reticencia encontrada, es todavía de regocijarse por la mención, aunque pálida, a la necesidad de no dar marcha atrás, de no retroceder, aunque no haya quedado plasmado como obligación para los Estados. Resulta paradójico $-\mathrm{y}$ no será la única que se verá en este artículo- que justamente sean los países industrializados y no los en desarrollo, como señala el documento, quienes en primer lugar hayan retrocedido sus compromisos ambientales.

Dentro del marco de las investigaciones encaminadas a formular, instaurar y fortalecer dicho principio, el objetivo de este artículo es identificar en la legislación y la jurisprudencia venezolanas las claves que permitan sustentar dicho principio. Para cumplir con el objetivo proyectado, el trabajo se centró fundamentalmente en las teorías sobre irreversibilidad de las conquistas existentes en el Derecho Internacional de los Derechos Humanos, a la espera de la formulación directa y específica del principio en el derecho del ambiente; y en la relevancia del ambiente para la supervivencia humana y por ende, para el disfrute, en consecuencia, de los demás derechos humanos. Esto por la estrecha relación de ambas ramas, sobre lo que, obligatoriamente, volveremos. Consecuencialmente, fue menester analizar muy brevemente, por un lado, las diferencias entre derecho al ambiente y derecho del ambiente; y por el otro, las relaciones del derecho al ambiente sano con los otros derechos humanos.

$Y$, ni qué decir, se consideró necesario comenzar por recordar, muy sumariamente, los principios de irreversibilidad y de progresividad en esa rama jurídica. Se han dejado de lado expresamente los principios de irretroactividad y el de intangibilidad, puntos vecinos al que nos ocupa, que de haber el espacio disponible merecerían alguna aclaratoria, aun cuando solo fuera para deslindarlos y desambiguarlos, labor esencial ante la perspectiva de construir y fundamentar un nuevo principio.

Baste decir que el primero de ellos significa la imposibilidad de aplicar normas nuevas a hechos acaecidos con anterioridad a su promulgación; la irreversibilidad significa, en contraste, la imposibilidad de que se promulguen nuevas leyes o se apliquen procedimientos menos favorables a los existentes; y ello porque es de esperar que toda ley posterior signifique un avance respecto a la ley que deroga. La retroactividad funciona hacia el pasado: la irretroactividad pretende que la ley nueva rija en lo adelante. La reversibilidad funciona hacia el futuro: la irreversibilidad pretende que la ley anterior de ser más protectora continúe en vigor.

El segundo, el principio de intangibilidad, la posibilidad de suspensión de los derechos humanos en casos de estado de excepción, no se aplica al derecho al ambiente. La intangibilidad solo alcanza las garantías del derecho a la vida, prohibición de la tortura, de la 
esclavitud, y no retroactividad de la ley penal. En el Pacto de los Derechos Civiles y Políticos el principio aloja, además de los mencionados, el reconocimiento de la personalidad jurídica y la libertad de conciencia y religión. La Convención Americana, a más de todos esos, extiende su abrigo a la protección de los derechos del niño y la protección de la familia.

La Constitución Bolivariana de Venezuela añade a los mencionados la igualdad ante la ley; la nacionalidad; la libertad personal; la práctica de desaparición forzada de personas; la libertad de pensamiento; el debido proceso; el amparo constitucional; la participación, el sufragio y el acceso a la función pública; y, por último, la información.

\section{Los principios de irreversibilidad y de progresividad de los derechos humanos}

Los avances científicos y tecnológicos han surgido como respuesta a las necesidades humanas y para facilitar que el ser humano pudiera alcanzar una vida más digna. No obstante, estos mismos avances han originado los desequilibrios ambientales que ponen en peligro su supervivencia. Así, se sufre esta contradicción dialéctica que entrelaza desde el inicio, los derechos humanos y el ambiente. Esas relaciones van mucho más allá, por lo que resulta útil para este trabajo el apoyo en el Derecho Internacional de los Derechos Humanos.

\subsection{El principio de irreversibilidad: el compromiso primario}

Una de las características de los derechos humanos es su irreversibilidad, y sobre esa base, una vez que un derecho humano ha sido consagrado como inherente a la persona humana lo es de manera definitiva, permanente, irrevocable y firme, por lo que no puede ser vulnerado, enervado o revocado, siendo esta irreversibilidad garantizada. $Y$ ello deriva de la misma naturaleza de los derechos humanos: desde que son reconocidos como inherentes a la persona humana, no pueden ser objeto de mudanzas o vicisitudes según los tiempos o las circunstancias.

Esta es la obligación mínima para el Estado y trae aparejado como consecuencia la imposibilidad de su derogatoria y la obligatoriedad de aplicar, entre dos normas diferentes para el mismo caso, aquella más favorable, sin que venga al caso la jerarquía legal. $Y$ es la obligación mínima porque no exige un avance, tan solo impide una desmejora. Por lo demás una obligación negativa, pues representa una inhibición por parte del Estado (al igual que los derechos civiles y políticos). Se encuentra reconocido en el Pacto de los Derechos Civiles y Políticos, derivado de la obligación expuesta en el artículo $5{ }^{1}$.

Igualmente se observa en el artículo 5.2 del Pacto Internacional de Derechos Económicos, Sociales y Culturales ${ }^{2}$, y emana del propio principio de progresividad, que se tratará infra, dado que si los Estados se comprometen a aumentar el nivel de protección, es apenas natural que, como obligación de sustento, se comprometan a no degradar los ya concedidos. En otras

\footnotetext{
${ }^{1}$ PIDCP. Artículo 5: 5. 1. Ninguna disposición del presente Pacto podrá ser interpretada en el sentido de conceder derecho alguno a un Estado, grupo o individuo para emprender actividades o realizar actos encaminados a la destrucción de cualquiera de los derechos y libertades reconocidos en el Pacto o a su limitación en mayor medida que la prevista en él.

5.2. No podrá admitirse restricción o menoscabo de ninguno de los derechos humanos fundamentales reconocidos o vigentes en un Estado Parte en virtud de leyes, convenciones, reglamentos o costumbres, so pretexto de que el presente Pacto no los reconoce o los reconoce en menor grado.

2 PIDESC. Artículo 5.2. No podrá admitirse restricción o menoscabo de ninguno de los derechos humanos fundamentales reconocidos o vigentes en un país en virtud de leyes, convenciones, reglamentos o costumbres, a pretexto de que el presente Pacto no los reconoce o los reconoce en menor grado.
} 
palabras, el principio de progresividad de los derechos pasa, en primer término, por no permitir ninguna merma o retorno a situaciones ya superadas.

Y si bien se obvia en los acuerdos universales, se explicita en acuerdos regionales. Así se constata en el artículo 29 de la Convención Americana de Derechos Humanos ${ }^{3}$.

En Venezuela el principio de no reducir o menoscabar las reivindicaciones conquistadas en materia de derechos fundamentales es reconocido en el artículo 25 constitucional ${ }^{4}$. El respeto a este principio es obligatorio para todos los órganos públicos, en consecuencia, impone al legislador, al juez y al funcionario administrativo la obligación de no reducir el alcance de los derechos fundamentales ya conquistados, ni por leyes ni por procedimientos. $Y$ se corrobora en sentencias como la del Tribunal Supremo de Justicia, donde se ventiló un conflicto entre intereses económicos y ambientales, concretamente por la regulación de vallas publicitarias aledañas a arterias viales que restringía la libertad de promocionar productos ${ }^{5}$ :

"Los principios aludidos de los derechos humanos sin que ello pueda excluir otros derechos y garantías que le son inherentes al ser humano en un Estado Democrático, Social de Derecho y de Justicia, como lo establece el artículo 2 de nuestra Constitución, se pueden resumir así: Principio de autoejecutoriedad; principio de progresividad; principio de irreversibilidad; principio de la opción más favorable a la persona; principio de posición preferida, principio de protección integral. Estos principios están enlazados no sólo con la realidad social, como se dijo, sino también con la propia existencia humana, los cuales han sido desarrollados normativamente por el derecho internacional de los derechos humanos, donde destaca el principio de irreversibilidad y la posición preferente, cuando se pondera intereses en los conflictos de esta naturaleza y la interpretación progresiva de los mismos. (...)

Significa entonces que entre libertad económica o de empresa y dentro del orden de prelación de los derechos humanos que comprende la Constitución de la República Bolivariana de Venezuela, la vida, la integridad física, la sanidad, protección al medio ambiente, el interés social, etc., hace que ceda en el caso de autos la libertad económica prevista en el artículo 112 de la Constitución de la República Bolivariana de Venezuela, como una situación jurídica activa que faculta a todas las personas a ejercer, el oficio, profesión, actividad económica que a bien tenga, pero sin perder de vista, los otros derechos humanos y sus valores con los cuales entra una presunta conflictividad. En razón que la Constitución de la República Bolivariana de Venezuela no es un "catalogo de ilusiones" tratándose como se trata de una Constitución de justicia social, tal como lo prevé en sus artículos 2 y 257 . Así se decide".

\footnotetext{
${ }^{3} \mathrm{CADH}$. Artículo 29: Ninguna disposición de la presente Convención puede ser interpretada en el sentido de: a. permitir a alguno de los Estados Partes, grupo o persona, suprimir el goce y ejercicio de los derechos y libertades reconocidos en la Convención o limitarlos en mayor medida que la prevista en ella; b. limitar el goce y ejercicio de cualquier derecho libertad que pueda estar reconocido de acuerdo con las leyes de cualquiera de los Estados Partes o de acuerdo con otra convención en que sea parte uno de dichos estados; c. excluir otros derechos y garantías que son inherentes al ser humano o que se derivan de la forma democrática representativa de gobierno, y d. excluir o limitar el efecto que puedan producir la Declaración Americana de Derechos y Deberes del Hombre y otros actos internacionales de la misma naturaleza.

${ }^{4}$ Constitución Bolivariana de Venezuela. Artículo 25: Todo acto dictado en ejercicio del Poder Público que viole o menoscabe los derechos garantizados por esta Constitución y la ley es nulo, y los funcionarios y funcionarias públicas que lo ordenen o ejecuten incurren en responsabilidad penal, civil y administrativa según los casos, sin que les sirvan de excusa órdenes superiores.

5 Sentencia 1454, 31de octubre de 2012 Exp. n 09-00987. Ponente: Francisco Antonio Carrasquero López.
} 


\subsection{El principio de progresividad: la incorporación de adelantos normativo}

Este principio, consagrado en los diferentes pactos internacionales, conlleva la obligación para los Estados de adoptar medidas en forma sucesivas y continuas, cada vez más favorables a los ciudadanos. Así, no solo significa la imposibilidad del retorno a una situación anterior, que sería la exigencia límite por parte del Estado -un no hacer-, sino que va un paso más allá pues supone la obligación de incorporar una evolución positiva que asegure un mejor desarrollo de cada uno de esos derechos. Por ello se encuentra muy próximo y es subsecuente al principio de irreversibilidad de las normas relativas a derechos y garantías constitucionales.

Expresamente se encuentra en el preámbulo de la Declaración Universal de Derechos Humanos, la cual hace referencia a que los pueblos y naciones deben asegurar, "por medidas progresivas de carácter nacional e internacional, su reconocimiento y aplicación universales y efectivos...". Por su parte, el Pacto Internacional de los Derechos Económicos, Sociales y Culturales, lo recoge en el artículo $2.1^{6}$, y la Convención Americana sobre Derechos Humanos hace lo propio en el artículo $26^{7 .}$

Tiene su sustento en Venezuela en el artículo 19 del Texto Fundamental ${ }^{8}$. Otras disposiciones vienen en su auxilio, como la de los artículos 23 y $153^{9}$. Más claramente, pero ceñido al derecho del trabajo, se observa el Artículo 89, el cual establece que "ninguna ley podrá establecer disposiciones que alteren la intangibilidad y progresividad de los derechos y beneficios laborales" y "cuando hubiere dudas acerca de la aplicación o concurrencia de varias normas, o en la interpretación de una determinada norma, se aplicará la más favorable al trabajador o trabajadora. La norma adoptada se aplicará en su integridad'.

\footnotetext{
${ }^{6}$ PIDESC. Artículo 2.1. 1. Cada uno de los Estados Partes en el presente Pacto se compromete a adoptar medidas, tanto por separado como mediante la asistencia y la cooperación internacionales, especialmente económicas y técnicas, hasta el máximo de los recursos de que disponga, para lograr progresivamente, por todos los medios apropiados, inclusive en particular la adopción de medidas legislativas, la plena efectividad de los derechos aquí reconocidos.

${ }^{7} \mathrm{CADH}$. Artículo 26. Los Estados Partes se comprometen a adoptar providencias, tanto a nivel interno como mediante la cooperación internacional, especialmente económica y técnica, para lograr progresivamente la plena efectividad de los derechos que se derivan de las normas económicas, sociales y sobre educación, ciencia y cultura, contenidas en la Carta de la Organización de los Estados Americanos, reformada por el Protocolo de Buenos Aires, en la medida de los recursos disponibles, por vía legislativa u otros medios apropiados.

${ }^{8}$ Constitución Bolivariana de Venezuela: Artículo 19: El Estado garantizará a toda persona, conforme al principio de progresividad y sin discriminación alguna, el goce y ejercicio irrenunciable, indivisible e interdependiente de los derechos humanos. Su respeto y garantía son obligatorios para los órganos del Poder Público de conformidad con la Constitución, los tratados sobre derechos humanos suscritos y ratificados por la República y las leyes que los desarrollen.

9 Constitución Bolivariana de Venezuela Artículo 23: Los tratados, pactos y convenciones relativos a derechos humanos, suscritos y ratificados por Venezuela, tienen jerarquía constitucional y prevalecen en el orden interno, en la medida en que contengan normas sobre su goce y ejercicio más favorables a las establecidas por esta Constitución y la ley de la República, y son de aplicación inmediata y directa por los tribunales y demás órganos del Poder Público.
}

Artículo 153: La República promoverá y favorecerá la integración latinoamericana y caribeña, en aras de avanzar hacia la creación de una comunidad de naciones, defendiendo los intereses económicos, sociales, culturales, políticos y ambientales de la región. La República podrá suscribir tratados internacionales que conjuguen y coordinen esfuerzos para promover el desarrollo común de nuestras naciones, y que aseguren el bienestar de los pueblos y la seguridad colectiva de sus habitantes. Para estos fines, la República podrá atribuir a organizaciones supranacionales, mediante tratados, el ejercicio de las competencias necesarias para llevar a cabo estos procesos de integración. Dentro de las políticas de integración y unión con Latinoamérica y el Caribe, la República privilegiará relaciones con Iberoamérica, procurando sea una política común de toda nuestra América Latina. Las normas que se adopten en el marco de los acuerdos de integración serán consideradas parte integrante del ordenamiento legal vigente y de aplicación directa y preferente a la legislación interna. 
Por ello, los derechos humanos, en cuanto irreversibles y progresivos, no pueden derogarse ni disminuirse una vez establecidos, y, en caso de modificación, debe ser para aumentar su goce efectivo. Una sentencia de la Sala de Casación Social del Tribunal Supremo ${ }^{10}$, analiza el alcance del término:

"El texto constitucional reconoce de manera expresa el principio de progresividad en la protección de los derechos humanos (...). Tal progresividad se materializa en el desenvolvimiento sostenido, con fuerza extensiva, del espectro de los derechos fundamentales en tres dimensiones básicas, a saber, en el incremento de su número, en el desarrollo de su contenido, y en el fortalecimiento de los mecanismos institucionales para su protección. En este ámbito cobra relevancia la necesidad de que la creación, interpretación y aplicación de las diversas normas que componen el ordenamiento jurídico, se realice respetando el contenido de los derechos fundamentales. Ahora bien, el señalado artículo 19 constitucional no puede ser interpretado de manera aislada, por el contrario, debe ser interpretado sistemáticamente con los artículos 22 y 23 de, los cuales completan el contenido de aquél, articulándose de esta forma la base dogmática general para la protección de los derechos humanos".

El criterio de gradualidad recogido como principio en algunas legislaciones nacionales, como la salvadoreña ${ }^{11}$ y peruana ${ }^{12}$, difiere del principio de progresividad, porque tradicionalmente no se interpreta como una obligación de evolución, sino muy al contrario, una restricción, un freno a evoluciones drásticas, caso de haberlas: es la obligación de implementar los cambios de modo escalonado y no exigencias bruscas o demasiadas pronunciadas, que puedan generar conflictos con las posibilidad reales para su implementación. Este criterio de gradualidad es un principio clásico en materia de integración, y se observa en la materia ambiental en los dos tratados de integración más importantes de América del Sur, la Organización del Tratado de Cooperación Amazónica (OTCA) y el Mercado Común del Sur (MERCOSUR). Este criterio fue ampliamente aplicado en la mayoría de las legislaciones protectoras del ambiente en los tiempos iniciales de su implementación, como no podía dejar de ser, mientras se alcanzaban estándares aceptables de contaminación.

\section{La aplicabilidad de los principios de los derechos humanos al derecho al ambiente y al derecho del ambiente}

Se partirá de la premisa de la consagración del derecho al ambiente como derecho humano fundamental, por cuanto, si bien no ha sido reconocido en ninguna convención sobre derechos humanos de carácter internacional, al contrario del los derechos civiles y políticos y los derechos sociales, económicos y culturales, se pueden mencionar acuerdos regionales en que los Estados han asumido compromisos en ese camino (Carta de los Derechos Fundamentales de la Unión Europea, Carta Africana sobre los derechos humanos y de los pueblos o Carta de Banjul, y Protocolo de San Salvador, adicional a la Convención Americana sobre Derechos

\footnotetext{
10 Sentencia de fecha 06 días de febrero de 2007. Exp: 06-0898, ponente Jesús Eduardo Cabrera Romero.

${ }^{11}$ Ley de medio ambiente. República de El Salvador, San Salvador Lunes 4 de Mayo de 1998. Art. 47.- La protección de la atmósfera se regirá por los siguientes criterios básicos: (...) b) Prevenir, disminuir o eliminar gradualmente las emisiones contaminantes en la atmósfera en beneficio de la salud y el bienestar humano y del ambiente.

12 Ley General del Ambiente, Perú, 13-10-05. Artículo 33.4. En el proceso de revisión de los parámetros de contaminación ambiental, con la finalidad de determinar nuevos niveles de calidad, se aplica el principio de la gradualidad, permitiendo ajustes progresivos a dichos niveles para las actividades en curso. permitiendo ajustes progresivos a dichos niveles para las actividades en curso.
} 
Humanos o Pacto de San José de Costa Rica) y en la legislaciones nacionales en la mayoría de las constituciones de los países de América.

En efecto, pese a los avances sobre el particular, salvo el derecho al desarrollo, no existe reconocimiento de los derechos de la solidaridad, ni siquiera el referido al ambiente, que es, de lejos, el que mayor progreso ha alcanzado para un consenso planetario. Aunque en el artículo 12 del Pacto de Derechos Económicos, Sociales y Culturales se observa la mención al ambiente, sólo constituyó el establecimiento de la obligación del Estado de mejorarlo a fin de garantizar el derecho a la salud. Los artículos 1 y 25 hace una referencia a los recursos naturales, pero no a su salvaguarda como condición para el disfrute de un ambiente digno, sino a la libertad de disponer de ellos.

El primer documento mundial en que los Estados han suscrito al menos la posibilidad de aceptación del derecho humano al ambiente es la Declaración de Estocolmo, en 1972. Así se observa en el Principio 1 de la Declaración: "El hombre tiene el derecho fundamental a la libertad, la igualdad y el disfrute de condiciones de vida adecuadas en un medio de calidad tal que le permita llevar una vida digna y gozar de bienestar".

\subsection{La aplicabilidad de los principios de los derechos humanos al derecho al ambiente como derecho humano}

En lo tocante a Venezuela, el ambiente que el Estado está obligado a garantizar debe ser sano, seguro y ecológicamente equilibrado: en mi opinión, la cualidad de sano exige un ambiente donde la vida, no solo la humana sino la de todos sus integrantes, sea posible en un nivel óptimo. La Organización Mundial de la Salud ha definido la salud como "el estado de completo bienestar físico, mental y social y no la mera ausencia de enfermedad", lo cual puede extrapolarse al ambiente. La idea del ambiente seguro va ligada a la ausencia de riesgo, porque se han previsto sus causas, sea para descartar el propio acontecimiento riesgoso, sea para eliminar o disminuir sus efectos. Por último el ambiente debe ser ecológicamente equilibrado, lo que supone su funcionamiento de acuerdo a sus propias leyes naturales, sin perturbaciones que produzcan el agotamiento o el exceso de alguno de sus elementos.

Ni qué decir, Venezuela es signataria de la Convención Americana sobre Derechos Humanos y del Protocolo adicional en materia de derechos económicos, sociales y culturales, Protocolo de San Salvador, cuyo artículo 11 es claro al consagrar el derecho al ambiente:

1. Toda persona tiene derecho a vivir en un medio ambiente sano y a contar con servicios públicos básicos.

2. Los Estados partes promoverán la protección, preservación y mejoramiento del medio ambiente."

Así las cosas y como consecuencia lógica, es apenas natural aceptar que, reconocido el derecho al ambiente como uno de los derechos humanos, goza de las mismas características y principios generales de todos los demás, entre ellos, la irreversibilidad y la progresividad de las conquistas, esto es, una vez reconocido como inherente a la persona humana, se encuentra dentro de dicha categoría de derechos, por lo tanto no puede ser vulnerado y su vigencia es permanente, aun cuando hayan sido allanadas las situaciones que los originaron.

\subsection{Derecho del ambiente y derecho al ambiente}

Ahora bien, el punto de discusión es si puede alegarse útilmente para todas las normas ambientales, esto es, para todo el derecho del ambiente, o solo para aquellas con incidencia en el derecho al ambiente, toda vez que ambos términos, no son, ni de lejos, sinónimos. De serlo, no habría necesidad de hacer esfuerzos para incorporar el principio de irreversibilidad de 
las normas más favorables al Derecho Ambiental y aún menos para estructurar una teoría para implementar su aplicación en esta materia.

El asunto es que resultan tan vinculados el derecho del ambiente, en tanto rama jurídica, y el derecho al ambiente, en tanto derecho humano, que ha llevado a algunos interpretes a confundir ambos conceptos, pese a que esta postura supone un grave retroceso filosófico pues significa reducir el ambiente a su consideración respecto al ser humano, obviando su valor per se. En efecto, al ser elevado como bien jurídico y, en consecuencia, como digno de tutela penal, se le otorgó valor por sí mismo, independientemente del que pueda representar para el ser humano o de su utilidad directa.

La confusión incluye a algunos magistrados de cortes supremas o tribunales supremos latinoamericanos, e instituciones como ministerios públicos. Uno de ellos es el Ministerio Público venezolano, el cual sostiene la tesis de la imprescriptibilidad de los delitos ambientales, basado en el artículo 271 de la Constitución ${ }^{13}$, aduciendo que todos los delitos ambientales constituyen violaciones a los derechos humanos. Algunos juristas de otros países sostienen la misma tesis de la imprescriptibilidad basada en el mismo argumento. Si la imprescriptibilidad penal-ambiental está planteada en la legislación nacional de algunos países, no hay nada que objetar, pero de no estar consagrada expresamente, no puede cobijarse en que todos los delitos ambientales constituyen violaciones a los derechos humanos.

El Tribunal Supremo de Justicia venezolano se ha pronunciado reiteradamente sobre el asunto, en especial cuando ha debido examinar el tema de la prescriptibilidad de los delitos ambientales. Con ponencia del magistrado Pedro Rafael Rondón Haaz, el Tribunal Supremo ${ }^{14}$

13. Constitución Bolivariana de Venezuela. Artículo 271: En ningún caso podrá ser negada la extradición de los extranjeros o extranjeras responsables de los delitos de deslegitimación de capitales, drogas, delincuencia organizada internacional, hechos contra el patrimonio público de otros Estados y contra los derechos humanos. No prescribirán las acciones judiciales dirigidas a sancionar los delitos contra los derechos humanos, o contra el patrimonio público o el tráfico de estupefacientes. Asimismo, previa decisión judicial, serán confiscados los bienes provenientes de las actividades relacionadas con tales delitos (...).

14. Sentencia № 537 del 15 de abril de 2005, Exp. 04-2533. “ (...) 1.5 En relación con la colisión que apreció la supuesta agraviante de autos, existente entre el artículo 19 de la Ley Penal del Ambiente y el artículo 29 de la Constitución, observa lo siguiente:

1.5.1. El artículo 29 de dispone que "las acciones para sancionar las violaciones graves a los derechos humanos y los crímenes de lesa humanidad son imprescriptibles".

1.5.2. Los conceptos de violaciones a los derechos humanos y crímenes o delitos de lesa humanidad están vinculados por una relación de género a especie. Así, la expresión "violación a los derechos humanos" comprende todas aquellas conductas -no sólo las punibles- que, constitutivas de infracción a la Ley, producen la consecuencia de lesión a alguno de aquellos derechos que sean calificables como inherentes a la persona humana; esto es, como "derechos humanos". Dentro de tales infracciones quedan comprendidas, como antes se afirmó, aquéllas que están descritas como conductas penalmente castigables. (...).De allí que, con base en el carácter de la tipicidad (...), se concluye que la calificación de delitos contra los derechos humanos o de lesa humanidad -especialmente, en cuanto los efectos jurídico constitucionales de las mismas incidan necesariamente en la estructura del tipo legal-, es materia que compete exclusivamente al legislador y no al intérprete. En efecto, resulta indudable que sólo al funcionario u órgano del Poder Público a los cuales atribuyó la iurisdatio corresponde la determinación de cuáles de esas infracciones penales deben ser calificadas como delitos contra los derechos humanos 0 delitos de lesa humanidad. (...)

1.5.3 En el orden de ideas que se sigue, concluye que la calificación de una infracción penal como delito de lesa humanidad o contra los derechos humanos corresponde al legislador, por razón del principio de legalidad que establecen el artículo 49.6 de y, entre otros, el artículo 9 del Estatuto de Roma, así como en resguardo de la seguridad jurídica y de la garantía constitucional de uniformidad e igualdad en el tratamiento procesal a los respectivos infractores. (...)

2. Por las razones que anteceden, concluye esta Sala que, mediante la decisión sub examine, la legitimada pasiva invadió la competencia del legislador; es decir, actuó fuera de los límites de su competencia material, y, con ello, efectuó un errado control de la constitucionalidad, (...) Así se declara." 
concluyó que la calificación de delitos contra los derechos humanos o de lesa humanidad es materia que compete exclusivamente al legislador y no al intérprete, sobre todo, para los específicos efectos jurídicos que establezcan, en particular, el de la imprescriptibilidad de la acción penal y que por tanto, el artículo 19 de la Ley Penal del Ambiente (que establece los lapsos de prescripción) no colide con la Ley Magna. Es decir, no todos los delitos contra el ambiente constituyen violaciones a los derechos humanos.

Que el derecho al ambiente sea uno de los derechos humanos consagrados en la Ley Mayor, no puede llevar a tal deducción, de ser así, resultarían escasísimos los delitos susceptibles de prescribir. La vida y la propiedad, por nombrar solo dos, están garantizados como derechos humanos fundamentales, de lo que resultaría que los delitos contra estos bienes jurídicos serían imprescriptibles. La confusión, lastimosamente, no acaba allí. Es común ver emplear como sinónimos derecho al ambiente y derecho del ambiente, por sus evidentes conexiones.

$Y$ así como los derechos humanos (entre ellos el derecho al ambiente, obviamente) tienen como características el de ser universales, innatos, inalienables, irrenunciables, intransferibles, imprescriptibles, irreversibles, inviolables, progresivos y acumulativos, indivisibles e interdependientes; el derecho del ambiente como rama jurídica tiene otras características, muy diferentes: es interdisciplinario, dinámico, preventivo, universal, económico, transversal, de legislación copiosa, reparador, transgeneracional, solidario, holístico, vital. E igual ocurre con los principios: son diferentes; no se aplican indistintamente.

No, no pueden ser una y misma cosa, como no pueden serlo el derecho al trabajo y el Derecho del Trabajo; ni el derecho al debido proceso y el Derecho Procesal; el derecho a la familia y el Derecho de Familia; el derecho al libre tránsito y el Derecho del Tránsito, por traer ejemplos de los más gruesos. Y ni qué añadir que el objeto del derecho del ambiente es el ambiente no la persona humana, como es el caso del Derecho Internacional de los Derechos Humanos, pues el titular subjetivo de los derechos humanos es la persona humana. La especificidad del derecho ambiental se basa, principalmente en su objeto diferenciado.

Cabría preguntarse ¿qué pasa cuando la elasticidad de las normas ambientales no se traduce en un quebranto directo al derecho humano al ambiente, verbi gratia, cuando se reduce el territorio de áreas naturales protegidas extremadamente alejadas de centros poblados? ¿Qué podría tener de violación de derechos humanos la flexibilización de las normas sobre estudio de impacto ambiental para la solicitud de licencias ambientales de grandes obras de infraestructura? Si el basamento para demandar la nulidad de normas o procedimientos que signifiquen un desmedro a la protección ambiental previamente adquirida se encuentra en la irreversibilidad de los derechos humanos, habría que concluir que el argumento no es suficiente. Con otras palabras: búsquese como analogía lo que puede ser análogo: el derecho al ambiente y otros derechos humanos, el derecho del ambiente y otras ramas jurídicas.

\subsection{La aplicabilidad de los principios de los derechos humanos al derecho del ambiente como rama jurídica}

Dicho lo anterior, habría que concluir que no es posible aplicar los principios de los derechos humanos a todas las normas ambientales; por lo tanto, en el presente punto más valdría refugiarnos en las normas laborables, por su similitud con las ambientales, en tanto derecho social. El derecho al trabajo es irreversible, como derecho humano, pero además, las normas laborales también gozan de la característica de la irreversibilidad, porque de estas normas depende el goce de aquel derecho. En esa disciplina el asunto se presenta claro porque ha sido zanjado por las diferentes legislaciones nacionales. En Venezuela lo recoge la propia Constitución:

"Artículo 89: El trabajo es un hecho social y gozará de la protección del Estado. La ley dispondrá lo necesario para mejorar las condiciones materiales, morales e intelectuales 
de los trabajadores y trabajadoras. Para el cumplimiento de esta obligación del Estado se establecen los siguientes principios:

1. Ninguna ley podrá establecer disposiciones que alteren la intangibilidad y progresividad de los derechos y beneficios laborales. En las relaciones laborales prevalece la realidad sobre las formas 0 apariencias.

2. Los derechos laborales son irrenunciables. Es nula toda acción, acuerdo o convenio que implique renuncia o menoscabo de estos derechos. Sólo es posible la transacción y convenimiento al término de la relación laboral, de conformidad con los requisitos que establezca la ley.

3. Cuando hubiere dudas acerca de la aplicación o concurrencia de varias normas, o en la interpretación de una determinada norma, se aplicará la más favorable al trabajador o trabajadora. La norma adoptada se aplicará en su integridad. (...)"

Y es así como corolario: de las normas laborales depende el ejercicio del derecho humano al trabajo. Y, por supuesto, es reiterada la opinión del Tribunal Supremo en el mismo sentido. Ahora bien, ¿cómo negar la analogía en materia ambiental? Es pertinente la mención a una sentencia de la Corte Suprema de Costa Rica ${ }^{15}$ :

"Al igual que el derecho de propiedad, el objeto sobre el que recae el derecho al ambiente es externo a la integridad de la persona humana (a diferencia por ejemplo del derecho a la vida), pero también diferente a lo que sucede con el objeto del derecho de propiedad, la persona forma parte del Ambiente, lo integra, de allí que su protección, supone la conservación del contexto esencial para la vida humana y por el contrario, una conducta con efectos negativos sobre él, supone un peligro para la propia existencia humana y una reducción o pérdida del "mayor bienestar" de todos. En este sentido, la Sala Constitucional ha expresado que "el ser humano no se desenvuelve de manera autárquica, sino que su bienestar guarda inmediata relación con la naturaleza que le rodea. Esa interdependencia entre el ser humano y la naturaleza comprende aspectos que exceden la mera preservación de recursos para garantizar el desarrollo económico de la sociedad humana. En realidad, la interacción "naturaleza-ser humano" conforma un fenómeno unitario, un proceso único de influencia recíproca, en el que uno actúa sobre el otro y simultáneamente ambos necesitan uno del otro para su propia supervivencia."(Sentencia de la Sala Constitucional No. 2012-004620).

De mi parte, opino que puede alegarse que cualquier norma ambiental redunda en beneficio del goce al ambiente, pues tiende a garantizar su calidad, y que la derogatoria o relajamiento de alguna norma de protección o mejoramiento del ambiente menoscaba el derecho de los ciudadanos a disfrutar de un ambiente sano, pues la elasticidad en las reglas y políticas ambientales va a disminuir las características ideales o próximas al ideal del ambiente garantizado, que en Venezuela son bien rígidas, toda vez que se exige que sea sano, seguro y ecológicamente equilibrado. Y así tiene que ser considerado, incluso cuando las condiciones del ambiente perturbado no impacten negativamente en ninguna población aledaña, por cuanto el ambiente en sí mismo no puede considerarse sino como un todo.

Esta última aseveración, del enfoque holístico de los asuntos ambientales, no es solo una creación doctrinal de mi parte, por el contrario, tiene sustento constitucional en Venezuela. En efecto, el texto hace numerosas referencias al vocablo ambiente o a lo ambiental y a cuestiones tales como los recursos naturales o la diversidad biológica. Asume el ambiente en su totalidad, abarcando más que los simples recursos naturales renovables, pues incluye la diversidad biológica, la diversidad genética, los procesos ecológicos, los parques nacionales y

${ }^{15}$ Expediente 12-011721-0007-CO. Res. № 2012013367, del 21 de septiembre de 2012. Con ponencia del magistrado 
monumentos naturales y demás áreas de especial importancia ecológica, el aire, las costas, el clima, la capa de ozono, las especies vivas.

El texto engloba los recursos que se encuentran en su territorio, incluidos los genéticos, los de las especies migratorias, sus productos derivados y los componentes intangibles que por causas naturales se encuentren. También aparece como obligación fundamental del Estado garantizar que la población se desenvuelva en un ambiente libre de contaminación, en donde el aire, el agua, los suelos, las costas, el clima, la capa de ozono, las especies vivas, sean especialmente protegidos, de conformidad con la ley. Así, es concluyente que se adhiere al enfoque holístico y sistémico de los asuntos ambientales para comprenderlos en toda su dimensión y complejidad y no fragmentado o tomando en consideración solo sus elementos y no las interrelaciones entre ellos.

Expresado de otra manera: como condición ineludible para poder gozar del derecho al ambiente sano, seguro y ecológicamente equilibrado deben existir unas normas cada vez más rigurosas de protección del ambiente, garantizadoras de las condiciones ambientales aptas para ese disfrute, lo cual no admite un menoscabo, un retroceso, en los niveles de protección del ambiente entendido en su totalidad y por sí mismo. $Y$ esto se torna más patente si se observa el objeto de la principal ley ambiental venezolana, la Ley Orgánica del Ambiente ${ }^{16}$ :

"Artículo 1: Esta Ley tiene por objeto establecer las disposiciones y los principios rectores para la gestión del ambiente, en el marco del desarrollo sustentable como derecho y deber fundamental del Estado y de la sociedad, para contribuir a la seguridad y al logro del máximo bienestar de la población y al sostenimiento del planeta, en interés de la humanidad. De igual forma, establece las normas que desarrollan las garantías y derechos constitucionales a un ambiente seguro, sano y ecológicamente equilibrado."

Deja claro que las disposiciones y los principios rectores para la gestión del ambiente, contribuyen al goce del derecho al ambiente, y, como corolario, que su mengua o retroceso se manifestará en perjuicio del goce del derecho humano al ambiente sano. $Y$ no puede ser de otro modo, pues la única manera de garantizar un ambiente adecuado, en un estado de derecho, es con reglas claras y severas que impidan su degradación o deterioro o que coadyuven a su mejoramiento; ambos asuntos deben ir de la mano.

Y se diría incluso más: no solo el derecho al ambiente, sino el derecho a la vida y a la salud, por nombrar solo dos, dependen de un ambiente adecuado. Esto lleva a decir que, por los momentos, por el bies de la irreversibilidad de los derechos humanos se puede acceder a la irreversibilidad de las normas ambientales, pero no por ser una misma cosa, sino por ser estas el puntal de aquellos. Véase ahora si alguna norma o principio normativo permite la entrada directa del principio al Derecho Ambiental.

\section{La consagración del principio de irreversibilidad de las normas ambientales}

Los principios rectores del derecho ambiental recogidos en las convenciones ambientales generales son diferenciados y autónomos, por lo que se hace difícil amparar en alguno de ellos el principio de irreversibilidad. Ninguno, individualmente, contiene el germen de la irreversibilidad, como no sea el de progresividad, por lo que el apoyo en las convenciones mundiales no se ha revelado particularmente útil. Ni aun el "in dubio pro natura" o "in dubio pro ambiente", como se ha llamado con justicia al principio precautorio, porque al estar circunscrito

\footnotetext{
${ }^{16}$ Gaceta Oficial № 5833 del 22 de diciembre de 2006
} 
a la precaución, esas dudas se refieren a los hechos (la falta de certeza absoluta en cuanto a los riesgos, por ejemplo), no al derecho, al igual que el principio in dubio pro reo, por lo demás.

El principio in dubio pro natura está muy lejos de significar ante la duda, ante cualquier duda, interpretar a favor del ambiente. Si no estuviera amarrado al de precaución podría interpretarse en sentido más lato, pero no es así. No consiste en la posibilidad de entre la duda entre una ley en vigor y otra derogada aplicar la derogada, lo cual iría contra todo el sentido del derecho y significaría violentar las facultades del poder legislativo y erigir al intérprete en legislador. Algunos autores extienden el principio precautorio a la obligación de aplicar la norma más severa entre dos normas válidas, pero considero que esto debe ser así, pero más podría apoyarse en el principio preventivo, siendo el precautorio tan rígido en su concepción.

El principio precautorio representa obligaciones procedimentales (tomar medidas incluso en caso de no existir certeza científica absoluta), mientras que el principio de irreversibilidad contempla mayormente obligaciones legales (no promulgar normas menos favorables a las precedentes) y, en mucho menor medida, no interpretarlas con desventaja o ignorarlas).

Sin embargo, como práctica o costumbre de las convenciones mundiales podría alegarse con elevadas posibilidades de ser admitido. En efecto, se puede observar que cada uno de los principios consagrados en las declaraciones, pactos o tratados planetarios ha sobrevenido a otros, siempre para marcar mayor protección sin anular los anteriores, en tanto son acumulativos. Por ejemplo, al de prevención sucedió el de precaución, no se diga más. El mismo criterio de la gradualidad así lo indica, pues presupone cambios tímidos y paulatinos, pero cambios al fin y al cabo.

Y si es cierto que en las últimas convenciones, de Johannesburgo y Río+20, los resultados fueron muy inferiores a lo esperable en el sentido de no haberse logrado un acrecentamiento de los estándares, de ninguna manera puede hablarse de un retroceso, a lo más de un estancamiento. Esto es suficiente para el principio de irreversibilidad que no pide más: solo no desmejorar los presupuestos actuales. Entiendo que por allí se abre una buena vía para la acción.

Y todavía se abre otra: el principio de irreversibilidad aplicado a normas ambientales (no a su reducción al derechos humano al ambiente), se encuentra explicitado en algunas convenciones sectoriales ambientales, naturalmente, válidas solo para el segmento pactado dentro del gran espectro ambiental y no para todo el ensamble, pero con carácter universal.

Sin ánimo de escudriñar todo el inventario de los documentos internacionales, puede mencionarse, en primer lugar Convención relativa a humedales, firmada en Ramsar en $1971^{17}$, y se observa que sí permite la regresión de la protección, pero sometida al cumplimiento de medidas compensatorias. En efecto, el inciso 2 del artículo 4 expresa:

"Cuando una Parte Contratante, por motivos urgentes de interés nacional, retire de la Lista o reduzca los límites de un humedal incluido en ella, deberá compensar en la medida de lo posible, la pérdida de recursos de humedales y, en particular, crear nuevas reservas naturales para las aves acuáticas y para la protección de una porción adecuada de su hábitat original, en la misma región o en otro lugar."

En segundo término, la Convención sobre el Comercio Internacional de Especies Amenazadas de Fauna y Flora Silvestres Firmada en Washington el 3 de marzo de 1973 y enmendada en Bonn, el 22 de junio de 1979. Así puede leerse en el artículo XIV.1 ${ }^{18}$. En tercer lugar, la

\footnotetext{
17 Convención Relativa a los Humedales de Importancia Internacional Especialmente como Hábitat de Aves Acuáticas, Ramsar, 02-02-1971, modificada según el Protocolo de París, 03-12-1982 y 1 as Enmiendas de Regina, del 28-5-1987.

${ }^{18}$ CITES. Artículo XIV.1 Las disposiciones de la presente Convención no afectarán en modo alguno el derecho de las Partes de adoptar: a) medidas internas más estrictas respecto de las condiciones de
} 
Convención sobre los Derechos del Mar, firmada en Nueva York en 1982, meridiana en cuanto al principio de irreversibilidad. Muchos artículos disponen la necesidad de revisión o reexamen periódico de las normas, pero siempre para imponer mejores condiciones para los recursos marinos o reducir gradualmente la contaminación. Como ejemplo, véanse los artículos 65, 207, $208,209,210,222$ y $234^{19}$.

comercio, captura, posesión o transporte de especímenes de especies incluidas en los Apéndices I, II y III, o prohibirlos enteramente; o

b) medidas internas que restrinjan o prohíban el comercio, la captura, la posesión o el transporte de especies no incluidas en los Apéndices I, II o III.

${ }^{19}$ CODEMAR. Artículo 65. Mamíferos marinos. Nada de lo dispuesto en esta Parte menoscabará el derecho de un Estado ribereño a prohibir, limitar o reglamentar la explotación de los mamíferos marinos en forma más estricta que la establecida en esta Parte o, cuando proceda, la competencia de una organización internacional para hacer lo propio. Los Estados cooperarán con miras a la conservación de los mamíferos marinos $\mathrm{y}$, en el caso especial de los cetáceos, realizarán, por conducto de las organizaciones internacionales apropiadas, actividades encaminadas a su conservación, administración y estudio.

Artículo 207. Contaminación procedente de fuentes terrestres (...) 4. Los Estados, actuando especialmente por conducto de las organizaciones internacionales competentes o de una conferencia diplomática, procurarán establecer reglas y estándares, así como prácticas y procedimientos recomendados, de carácter mundial y regional, para prevenir, reducir y controlar esa contaminación, teniendo en cuenta las características propias de cada región, la capacidad económica de los Estados en desarrollo y su necesidad de desarrollo económico. Tales reglas, estándares y prácticas y procedimientos recomendados serán reexaminados con la periodicidad necesaria.

Artículo 208. Contaminación resultante de actividades relativas a los fondos marinos sujetos a la jurisdicción nacional (...) 3. Tales leyes, reglamentos y medidas no serán menos eficaces que las reglas, estándares y prácticas y procedimientos recomendados, de carácter internacional. (...)

5. Los Estados, actuando especialmente por conducto de las organizaciones internacionales competentes o de una conferencia diplomática, establecerán reglas y estándares, así como prácticas y procedimientos recomendados, de carácter mundial y regional, para prevenir, reducir y controlar la contaminación del medio marino a que se hace referencia en el párrafo 1. Tales reglas, estándares y prácticas y procedimientos recomendados se reexaminarán con la periodicidad necesaria.

Artículo 209. Contaminación resultante de actividades en la Zona. 1. De conformidad con la Parte XI, se establecerán normas, reglamentos y procedimientos internacionales para prevenir, reducir y controlar la contaminación del medio marino resultante de actividades en la zona. Tales normas, reglamentos y procedimientos se reexaminarán con la periodicidad necesaria.

2. Con sujeción a las disposiciones pertinentes de esta sección, los Estados dictarán leyes y reglamentos para prevenir, reducir y controlar la contaminación del medio marino resultante de las actividades en la Zona que se realicen por buques o desde instalaciones, estructuras y otros dispositivos que enarbolen su pabellón, estén inscritos en su registro u operen bajo su autoridad, según sea el caso. Tales leyes y reglamentos no serán menos eficaces que las normas, reglamentos y procedimientos internacionales mencionados en el párrafo 1.

Artículo 210. Contaminación por vertimiento (...) 4. Los Estados, actuando especialmente por conducto de las organizaciones internacionales competentes o de una conferencia diplomática, procurarán establecer reglas y estándares, así como prácticas y procedimientos recomendados, de carácter mundial y regional, para prevenir, reducir y controlar esa contaminación. Tales reglas, estándares y prácticas y procedimientos recomendados serán reexaminados con la periodicidad necesaria. (...)

6. Las leyes, reglamentos y medidas nacionales no serán menos eficaces para prevenir, reducir y controlar esa contaminación que las reglas y estándares de carácter mundial.

Artículo 222. Ejecución respecto de la contaminación desde la atmósfera o a través de ella. Los Estados harán cumplir en el espacio aéreo sometido a su soberanía o en relación con los buques que enarbolen su pabellón o estén matriculados en su territorio y las aeronaves matriculadas en su territorio las leyes y reglamentos que hayan dictado de conformidad con el párrafo 1 del artículo 212 y con otras disposiciones de esta Convención; asimismo, dictarán leyes y reglamentos y tomarán otras medidas para dar efecto a las reglas y estándares internacionales aplicables, establecidos por conducto de las organizaciones internacionales competentes o de una conferencia diplomática, para prevenir, reducir y controlar la contaminación del medio marino desde la atmósfera o a través de ella, de conformidad con todas las reglas y estándares internacionales pertinentes relativos a la seguridad de la navegación aérea.

Artículo 234. Zonas cubiertas de hielo. Los Estados ribereños tienen derecho a dictar y hacer cumplir leyes y reglamentos no discriminatorios para prevenir, reducir y controlar la contaminación del medio 
El Convenio sobre el Control de los Movimientos Transfronterizos de los Desechos Peligrosos y su Eliminación, Basilea 1989, se pronuncia sobre la progresividad en sus artículos 4.11 y 4.13 ; y sobre la irreversibilidad en el artículo $11^{20}$.

De su parte el Convenio sobre la Diversidad Biológica, Río de Janeiro, 5 de junio de 1992, expone el principio en su artículo $8 \mathrm{k}$ ) y lo deja entrever en el artículo $22.1^{21}$. El Protocolo sobre Seguridad de la Biotecnología del Convenio sobre la Diversidad Biológica, Cartagena, febrero 1999 en sus artículos 2.4 y 14.1 , lo expresan claramente ${ }^{22}$, e incluso van más allá: nótese que permite regulaciones más restrictivas que la del Protocolo pero no más blandas.

Aunque más que tímidamente, la Convención sobre Cambio Climático, de Río de Janeiro 1992, expone el principio de progresividad en el Artículo 7.2.e), al prever que la Conferencia de las Partes "Evaluará, sobre la base de toda la información que se le proporcione de conformidad con las disposiciones de la Convención, la aplicación de la Convención por las Partes, los efectos generales de las medidas adoptadas en virtud de la Convención, en particular los efectos ambientales, económicos y sociales, así como su efecto acumulativo y la medida en que se avanza hacia el logro del objetivo de la Convención".

A veces se consiguen algunas perlas, como en la Convención de las Naciones Unidas de Lucha contra la Desertificación, adoptada el 17 de junio de 1994 en París. Su Articulo 5. e) dispone como obligación de los países Partes afectados "crear un entorno propicio, según corresponda, mediante el fortalecimiento de la legislación pertinente en vigor $y$, en caso de que

marino causada por buques en las zonas cubiertas de hielo dentro de los límites de la zona económica exclusiva, donde la especial severidad de las condiciones climáticas y la presencia de hielo sobre esas zonas durante la mayor parte del año creen obstrucciones o peligros excepcionales para la navegación, y la contaminación del medio marino pueda causar daños de importancia al equilibrio ecológico o alterarlo en forma irreversible. Esas leyes y reglamentos respetarán debidamente la navegación y la protección y preservación del medio marino sobre la base de los mejores conocimientos científicos disponibles.

${ }^{20}$ Convenio de Basilea. Artículo 4.11. Nada de lo dispuesto en el presente Convenio impedirá que una Parte imponga exigencias adicionales que sean conformes a las disposiciones del presente Convenio y estén de acuerdo con las normas del derecho internacional, a fin de proteger mejor la salud humana y el medio ambiente.

Artículo 4. 13. Las Partes se comprometen a estudiar periódicamente las posibilidades de reducir la cuantía y/o el potencial de contaminación de los desechos peligrosos y otros desechos que se exporten a otros Estados, en particular a países en desarrollo.

Artículo 11. Acuerdos bilaterales, multilaterales y regionales. 1. No obstante lo dispuesto en el párrafo 5 del artículo 4, las Partes podrán concertar acuerdos o arreglos bilaterales, multilaterales o regionales sobre el movimiento transfronterizo de los desechos peligrosos y otros desechos, con Partes o con Estados que no sean Partes siempre que dichos acuerdos o arreglos no menoscaben el manejo ambientalmente racional de los desechos peligrosos y otros desechos que estipula el presente Convenio. Estos acuerdos o arreglos estipularán disposiciones que no sean menos ambientalmente racionales que las previstas en el presente Convenio, tomando en cuenta en particular los intereses de los países en desarrollo.

${ }^{21}$ Convenio de Diversidad Biológica. Artículo 8: Conservación in situ. Cada Parte Contratante, en la medida de lo posible y según proceda: (...) k) Establecerá o mantendrá la legislación necesaria y/u otras disposiciones de reglamentación para la protección de especies y poblaciones amenazadas;

Artículo 22. Relación con otros convenios internacionales.1. Las disposiciones de este Convenio no afectarán a los derechos y obligaciones de toda Parte Contratante derivados de cualquier acuerdo internacional existente, excepto cuando el ejercicio de esos derechos y el cumplimiento de esas obligaciones pueda causar graves daños a la diversidad biológica o ponerla en peligro.

22 Protocolo de Cartagena: Artículo 2.4: Ninguna disposición del presente Protocolo se interpretará en un sentido que restrinja el derecho de una Parte a adoptar medidas más estrictas para proteger la conservación y la utilización sostenible de la diversidad biológica que las establecidas en el Protocolo, siempre que esas medidas sean compatibles con el objetivo y las disposiciones del presente Protocolo y conformes con las demás obligaciones de esa Parte dimanantes del derecho internacional.

Artículo 14.1: Las Partes podrán concertar acuerdos y arreglos bilaterales, regionales y multilaterales relativos a los movimientos transfronterizos intencionales de organismos vivos modificados, siempre que esos acuerdos y arreglos sean compatibles con el objetivo del presente Protocolo y no constituyan una reducción del nivel de protección establecido por el Protocolo. 
esta no exista, la promulgación de nuevas leyes y el establecimiento de políticas y programas de acción a largo plazo".

El Convenio para la Protección de la Capa de Ozono, Viena, 1985, incluye entre las Obligaciones generales el principio de progresividad de las normas ${ }^{23}$. El Convenio sobre los Contaminantes Orgánicos Persistentes, de Estocolmo, 2001, impone igual rumbo en los artículos 5 y 8.1, e incluye netamente el principio de irreversibilidad en el artículo 6.2.a) ${ }^{24}$.

Es posible que este arsenal resulte si no demasiado, al menos suficiente, porque escaso no es, se trata de 10 documentos mundiales, aunque parciales, pero cuyo conjunto abarca tanto la protección de recursos naturales como la lucha contra la contaminación. Se observa que estos textos en su mayoría han recogido el principio de progresividad, lo que no es malo en sí mismo, todo lo contrario, por aquello de qui potest plus, potest minus. Es posible que a los pertinaces optimistas ambientales se les haya pasado por alto la perspectiva de pensar en un retroceso.

\section{Conclusión}

Ante las nuevas amenazas que sufre la legislación ambiental derivadas de la crisis económica y financiera mundial, algunos países industrializados han desmejorado o flexibilizado leyes ambientales, como modo de disminuir costos, e incluso, han tomado áreas protegidas para incorporarlas a la producción de bienes. Esto ha llevado a algunos juristas a buscar nuevos elementos para su defensa, entendiendo que en un estado de derecho, el Derecho del Ambiente es la respuesta que dio la sociedad al percatarse del peligro que representa el impacto negativo de las actividades humanas incontroladas sobre el entorno $y$, en consecuencia, sobre toda forma de vida.

De otra parte, habiendo sido reconocido regional y nacionalmente como derecho fundamental el disfrute de un ambiente ecológicamente equilibrado, es preciso concluir que, obviamente, goza de los mismos principios de los otros derechos civiles y políticos y económicos, sociales y culturales, consagrados en pactos universales. Entre ellos los de irreversibilidad, que significa el reconocimiento de una conquista mínima; y el de progresividad que se traduce como una evolución sostenida. Esto ha servido de punto de apoyo para alegar, o tratar de alegar, la declaratoria de estos principios básicos no solo para el derecho humano al ambiente sano sino para las normas ambientales en su conjunto.

${ }^{23}$ Convenio de Viena: Artículo 2.3.: Las disposiciones del presente Convenio no afectarán en modo alguno al derecho de las Partes a adoptar, de conformidad con el derecho internacional, medidas adicionales a las mencionadas en los párrafos 1 y 2 de este artículo, ni afectarán tampoco a las medidas adicionales ya adoptadas por cualquier Parte, siempre que esas medidas no sean incompatibles con las obligaciones que les impone este Convenio.

${ }^{24}$ Convenio de sobre los Contaminantes Orgánicos Persistentes. Artículo 5. Medidas para reducir o eliminar las liberaciones derivadas de la producción no intencional. Cada Parte adoptará como mínimo las siguientes medidas para reducir las liberaciones totales derivadas de fuentes antropógenas de cada uno de los productos químicos incluidos en el anexo C, con la meta de seguir reduciéndolas al mínimo y, en los casos en que sea viable, eliminarlas definitivamente:

Artículo 6. Medidas para reducir o eliminar las liberaciones derivadas de existencias y desechos. (...) 2. La Conferencia de las Partes, cooperará estrechamente con los órganos pertinentes del Convenio de Basilea sobre el control de los movimientos transfronterizos de los desechos peligrosos y su eliminación, para, entre otras cosas:

a) Fijar niveles de destrucción y transformación irreversible necesarios para garantizar que no se exhiban las características de contaminantes orgánicos persistentes especificadas en el párrafo 1 del anexo D;

Artículo 8. Inclusión de productos químicos en los anexos A, B y C. 1.Cualquiera de las Partes podrá presentar a la secretaría una propuesta de inclusión de un producto químico en los anexos A, B y/o C. Tal propuesta incluirá la información que se especifica en el anexo D. Al presentar una propuesta, una Parte podrá recibir la asistencia de otras Partes y/o de la secretaría. 
"Es esencial que no demos marcha atrás", reza el documento final de la Cumbre de Río 2012, no se pudo lograr más que un "ojalá", pero no es suficiente un buen deseo, es perentoria su consagración, al menos en las legislaciones nacionales, por ahora.

En la normativa y jurisprudencia venezolanas (y en las continentales, como lo demuestran otros estudios y estudiosos), se han encontrado andamios suficientes para sostener la irreversibilidad y la progresividad de las normas de protección del ambiente. Uno es la aplicabilidad de tales principios a las leyes laborales, que sirven de analogía más que justificada. Otro, que es innegable la consagración de estos dos principios en diez convenciones mundiales aunque sectoriales.

$Y$ un tercero, la necesidad de contar con leyes ambientales eficaces como sustrato de los derechos humanos ( $\mathrm{y}$ no solo el del derecho al ambiente), y la certeza de que cualquier relajamiento en las leyes ambientales repercutiría negativamente en la vida en el planeta (no solo la humana), por cuanto estamos todavía en umbrales bajos de protección, que deberán subir a medida que los conflictos ambientales se tornen más agudos.

Sólo a través de normas cuyo objeto sea la conservación, defensa, y mejoramiento del ambiente es posible para el Estado atender a la obligación de garantizar los derechos humanos (que sí son, incuestionablemente irreversibles y progresivos). Esta vía sesgada debe ser suficiente por los momentos, mientras se logra la entrada de tales principios de forma franca y directa a la legislación ambiental.

Escribí después de Río 92, que si el siglo XX había sido el del principio de prevención, el XXI sería el del principio de precaución. Dicen que no hay nadie más optimista que un ambientalista, y sí, nunca pensé, en mi inagotable optimismo, que a 40 años de Estocolmo, se debería luchar por una reivindicación mínima como el principio de irreversibilidad. Una nuevavieja lucha. Pero no queda otra, esto es lo que hay. $Y$ esto es lo que hay que hacer.

Traicionada por el límite de páginas, dejo en el tintero -o más propiamente, en la computadora-, tres puntos esenciales para una segunda etapa en el tema que nos ocupa: el ambiente como sustrato y condición para el goce de los derechos humanos, los límites del principio de irreversibilidad en materia ambiental y los supuestos para determinar una regresión en las conquistas legales o jurisprudenciales. Volveremos.

\section{Bibliografía}

Abad Castelos, Montserrat. El pluralismo como puente hacia el multilateralismo: el informe del grupo de personas eminentes encargado de examinar la relación entre las Naciones Unidas y la sociedad civil, de 2004. Revista Electrónica de Estudios Internacionales. http://www.reei.org/reeig/reei9.htm.

Cafferatta, Néstor. Introducción al derecho ambiental. SEMARNAT /INE / PNUMA. México, 2004.

Cafferatta, Néstor. Reformulación del principio de progresividad a 10 años de la ley 25675 general del ambiente. Avances y novedades. Revista de Derecho Ambiental de Abeledo Perrot. 8 de noviembre, 2012. Disponible en http://thomsonreuterslatam.com/articulos-deopinion/08/11/2012/doctrina-del-dia-reformulacion-del-principio-de-progresividad-a-10-anos-dela-ley-25675-general-del-ambiente-avances-y-novedades.

De los Ríos, Isabel. El Derecho del Ambiente. Especial referencia a las disposiciones penales. EIDLR. Caracas, 1994.

De los Ríos, Isabel. Principios de Derecho Ambiental. EIDLR. Caracas, 2008.

De los Ríos, Isabel. Comentarios a la Ley Penal del Ambiente. EIDLR. Caracas, 2012. 
De los Ríos, Isabel. El desarrollo del derecho ambiental venezolano después de diez años de la Conferencia de Río. Simposium De Río a Johannesburgo: Perspectivas del Derecho Ambiental en Latinoamérica. Programa de las Naciones Unidas para el Medio Ambiente. México, octubre 2001.

De los Ríos, Isabel. Le développement du Droit de l'Environnement Vénézuélien après les dix ans de la Conférence des Nations Unies sur l'Environnement et Développement. Journées Río plus 10. Societé Française pour le Droit de l'environnement. Limoges nov. 2001.

De los Ríos, Isabel. El principio de irreversibilidad de las normas ambientales en el derecho venezolano. Hacia la conferencia Río+20. Diciembre 2011.

De los Ríos, Isabel. El principio de irreversibilidad de las normas ambientales en algunos países latinoamericanos. Encuentro Mundial de Juristas de Medio Ambiente. Conferencia de las Naciones Unidas sobre Desarrollo Sustentable, Río+20. Río de Janeiro, junio 2012.

Faúndez Ledesma, Héctor. Administración de Justicia y Derecho Internacional de los Derechos Humanos (El derecho a un juicio justo). Universidad Central de Venezuela. Caracas, 1992.

Jordano Fraga, Jesús. La protección del derecho a un medio ambiente adecuado. Bosch Editor. Barcelona, 1995.

Jordano Fraga, Jesús. El derecho ambiental del siglo XXI. Revista de Derecho Ambiental (Aranzadi) núm. 1.- 2002.

Leff, Enrique (Coord.). La transición hacia el desarrollo sustentable. Instituto Nacional de Ecología, México, 2003.

Loperena Rota, Demetrio. El derecho al medio ambiente adecuado. Editorial Civitas, Madrid, 1996.

Peña Chacón, Mario. El principio de no regresión ambiental a la luz de la jurisprudencia constitucional costarricense. Disponible en: huespedes.cica.es/gimadus/24/07.html.

Peña Chacón, Mario. El derecho internacional ambiental como fundamento del principio de no regresión. 2013. Disponible en: http://webcache.googleusercontent.com/search?q=cache.

PNUMA-UICN. De Río a Johannesburgo: perspectivas del Derecho Ambiental en Latinoamérica. PNUMA, México, 2002.

Preiur, Michel y SOZZO, Gonzalo, coord. La non régression en droit de l'environnement". Bruylant, Bruxelles, 2012. 



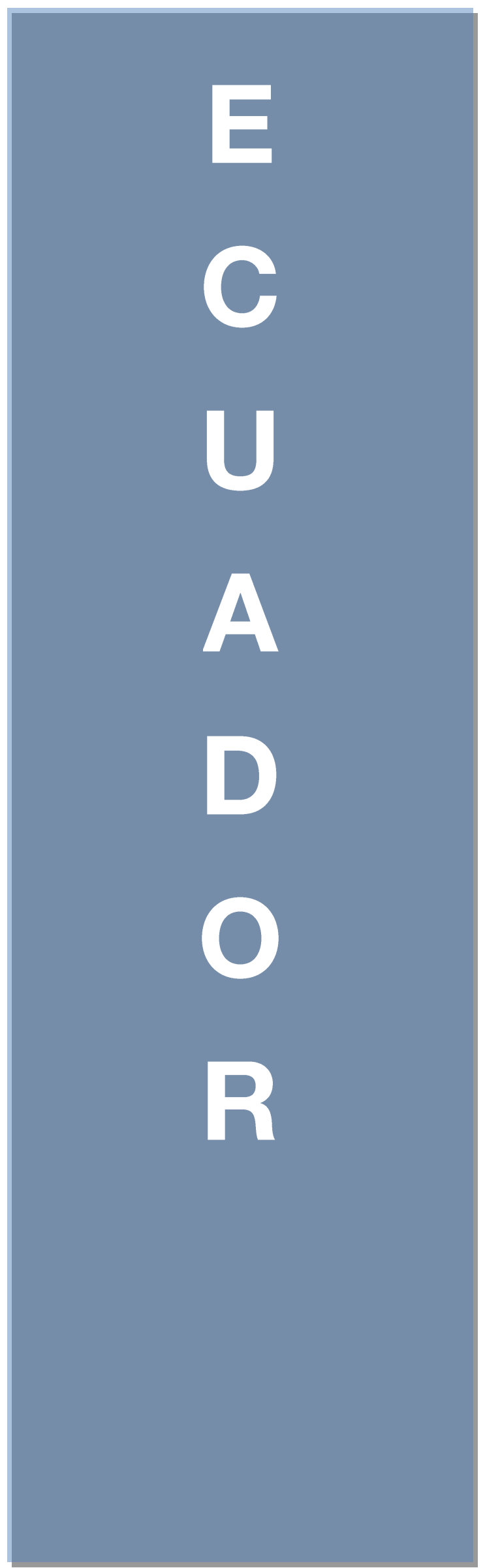





\title{
ALGUNOS CASOS DE RETROCESOS EN LA LEGISLACIÓN AMBIENTAL DEL ECUADOR
}

\section{Ricardo Crespo Plaza *}

\begin{abstract}
"En materia ambiental la legislación tiene como objeto la mejora de la situación del medio ambiente; el postulado es: menos contaminación, más biodiversidad". Michel Prieur
\end{abstract}

“La ausencia de eficacia del derecho aplicable, ya constituye por sí misma una regresión”. Michel Prieur

\section{Introducción}

Los riesgos de retroceder flexibilizando o disminuyendo los parámetros preventivos y protectores de la legislación ambiental, son consecuencia del debate y la tensión existente entre la visión meramente economicista de la relación de los seres humanos con la naturaleza frente a un modelo de sustentabilidad ambiental que respete los límites biofísicos de los ecosistemas. La visión económica clásica entiende a la naturaleza como suministradora ilimitada de bienes y servicios en tanto y en cuanto impliquen un valor económico para la sociedad, por el contrario, el enfoque ecológico o de sustentabilidad ambiental plantea que las actividades económicas y de extracción de recursos naturales respeten los límites biofísicos de la naturaleza. En otras palabras, sigue prevaleciendo el paradigma del llano infinito frente a la nave espacial -tierra, ${ }^{1}$ lo cual se refleja en la poca efectividad del derecho ambiental internacional para solucionar los grandes problemas ambientales globales y en los continuos retrocesos de las legislaciones ambientales nacionales.

\footnotetext{
* Doctor en Derecho, Universidad Católica del Ecuador, MSc por la Universidad de Oxford, Reino Unido en Gestión y Cambio Ambiental. Miembro fundador del Centro Ecuatoriano de Derecho Ambiental CEDA.

1 "Este símil fue formulado por Kennet Boulding en 1968 al criticar el actual modelo de desarrollo. "El vaquero vive en los llanos interminables. Toma lo que quiere de la naturaleza donde quiera que lo encuentre. Los llanos son vastos y sus recursos parecen ser inagotables. Deja caer por el camino cualquier desperdicio o pertenencia que ya no sirve a sus necesidades, para que las fuerzas de la naturaleza se lo lleven....el desempeño esta medido en términos del valor de mercado de los productos elaborados de los recursos. Cuanto más rápido los recursos sean extraídos de la tierra, procesados y desechados, más próspera se considera la gente."

El paradigma de la nave espacial tiene un enfoque completamente contrario, la nave espacial tierra flota en el espacio bajo el soporte de la energía solar, tiene una tripulación humana que depende de unos recursos limitados que deben ser manejados de manera que estos permanezcan en el tiempo aplicando políticas de cooperación y solidaridad entre sus ocupantes. "Esta realidad dicta los principios básicos de la economía de la nave espacial. Un aumento en el bienestar de los miembros de la nave necesariamente depende de que se vuelvan más eficaces y efectivos en el uso sostenible y el reciclaje de los recursos existentes, primero para satisfacer sus necesidades, y luego- al grado que existen excedentes- sus deseos. El desechar cualquier recurso, y por ello perderlo para siempre es, para los habitantes de la nave, un indicio de una falla seria en el sistema. La meta es extender la vida de los productos, más bien que aumentar la velocidad en desecharlos."

"Siempre hemos estado viviendo en una nave espacial y no en un llano interminable" 1 pero ahora los sistemas naturales empiezan a desestabilizarse, hay demasiadas personas, la tecnología no respeta los procesos sistémicos de regeneración natural, estamos destruyendo la biodiversidad y los sistemas climáticos que hacen posible la permanencia de la nave espacial - tierra. El desafío del derecho es hacer posible un sistema normativo que permita la aplicación del paradigma de la nave espacial- tierra, en principio se ha adelantado en el papel, se habla de un derecho ambiental gaseoso, débil, inaplicable, blando. Una nueva ética es necesaria junto con el apoyo político para que este derecho ambiental sea eficaz." (En "Perspectivas Futuras del Derecho Ambiental" Revista IURIS DICTIO. Diciembre 2003. Año III No 7. Ricardo Crespo Plaza.)
} 
Para solucionar esta tensión y este conflicto, el modelo de desarrollo sustentable como paso previo al ecodesarrollo ${ }^{2}$ procura un balance entre lo social, lo económico y lo ambiental garantizando la satisfacción de las necesidades de las generaciones presentes y futuras. El desarrollo sostenible es un paradigma que viene siendo materia de discusión en el seno de las Naciones Unidas desde la Conferencia de Estocolmo de 1972, reafirmándose en la Cumbre de Río de 1992 hasta llegar a la Declaración de Johannesburgo de 2002 y la Declaración sobre el "Futuro que Queremos", de la Conferencia de Rio más 20 celebrada en junio de 2012. Los principios contenidos en las declaraciones de derecho blando proclamadas en estas cumbres han ido permeando gradualmente en las legislaciones internas de los países. Hay que agregar además que la orientación antropocéntrica que aún perdura, es un factor que hace más difícil un cambio de paradigma. François Ost, sobre esto señala, que nuestra visión de la naturaleza sigue siendo la de "un simple decorado" o "medio ambiente", en cuyo centro sienta su trono el hombre que se autoproclama "dueño y señor". Este enfoque antropocéntrico ha aislado a la naturaleza para convertirla en "simple reserva de recursos", o en "vertedero de residuos" en definitiva "el patio de atrás de nuestra tecnosfera". ${ }^{3}$

Frente a esta realidad es clave no dar marcha atrás y seguir progresando en la aplicación de los principios estructurantes del derecho ambiental como los de prevención, precaución, acceso a la información, a la participación y a la justicia y el de quien contamina paga, entre otros. Adicionalmente podríamos afirmar que frente a las fallas que aún obstruyen la eficacia y eficiencia de la legislación ambiental para el logro del desarrollo sostenible, un nuevo principio, el de no regresión o no retroceso en materia ambiental, que se deriva de la declaración " $E l$ Futuro que Queremos" de Rio más 20, viene a constituirse como un nuevo mecanismo jurídico para evitar que la legislación ambiental siga siendo relativizada por los intereses económicos de corto plazo que responden a presiones sectoriales y que pretenden demostrar que ante los problemas ambientales del mundo, siempre habrá una salida tecnológica o artificial, lo cual niega la realidad de un planeta cuyos límites biofísicos deben entenderse como leyes inexorables e indiscutibles.

En este documento se pretende recalcar en síntesis, algunos ejemplos de regresiones de la legislación ambiental del Ecuador, que en gran parte se explican por la tensión existente entre la economía de corto plazo reflejada en políticas macroeconómicas o fiscales implícitas, y las políticas ambientales explícitas contenidas en la legislación ambiental. ${ }^{4}$

\footnotetext{
2 "Ecodesarrollo: Este enfoque trata de reestructurar la relación entre sociedad y naturaleza en un juego de suma positiva mediante la reorganización de las actividades humanas para crear sinergia con los servicios de los ecosistemas. La "ecologización" de la economía implica redefinir el concepto de eficiencia para incluir procesos que imitan a los procesos de los ecosistemas. Es rentable la prevención de la contaminación. Tomando como base el conflicto que existe entre los valores antropocéntricos y los biocéntricos, el ecodesarrollo busca sintetizar el ecocentrismo, rehusándose a colocar a la humanidad por encima o por debajo de la naturaleza."

http://cdam.minam.gob.pe/publielectro/impacto\%20ambiental/Politicaambientalperu.pdf LAS POLÍTICAS AMBIENTALES EN EL PERÚ Silvia Charpentier y Jessica Hidalgo Lima, octubre de 1999.

${ }^{3}$ Ost Francois. "Naturaleza y Derecho. Para un debate ecológico a profundidad." Ediciones Mensajero. 1996. p. 11-12.

4 "Muchas políticas y decisiones no ambientales diseñadas para afectar el comportamiento de los agentes económicos podrían tener efectos imprevistos e indeseados sobre la política ambiental. Estos efectos indirectos raras veces se toman en consideración en el diseño de políticas ambientales, y con frecuencia pasan inadvertidos por los diseñadores de estas políticas. Para efectos de este análisis, estas políticas se llamarán políticas implícitas. Las políticas implícitas pueden emanar de medidas macroeconómicas de aplicación general, 0 de medidas sectoriales específicas. Pueden establecerse en convenios internacionales, en acuerdos de financiamiento externo, o en contratos entre el Estado y el sector privado. También pueden generarse en prácticas y procedimientos de facto, no normados por ley. (Silvia Charpentier y Jessica Hidalgo. Las Políticas ambientales en el Perú 1999.

http://cdam.minam.gob.pe/publielectro/impacto\%20ambiental/Politicaambientalperu.pdf)
} 


\section{Panorama legal ambiental del Ecuador}

Las reformas legales de 1983 introdujeron en la Constitución de 1978 el derecho a vivir en un ambiente sano, mas tarde y luego de la influencia marcada por la Cumbre de Río de 1992 aparecen normas ambientales más amplias en la Constitución de 1998. En la Constitución de 2008 se ensancha la normativa ambiental bajo el enfoque de un paradigma biocéntrico al reconocer derechos a la naturaleza, no sólo impulsado por el derecho internacional y el derecho ambiental comparado sino por una reafirmación de la cosmovisión de nuestras culturas indígenas que reconocen el derecho al buen vivir o sumak kawsay y consideran que el ser humano es parte de un sistema natural integral y circular denominado Pacha Mama. ${ }^{5}$

En materia legal, los esfuerzos para regular las actividades humanas considerando los limites de los ecosistemas se inician en los años cincuenta del siglo pasado con los primeros decretos conservacionistas para las islas Galápagos; en 1976 se expide la Ley para la Prevención y Control de la Contaminación Ambiental, en 1981 entra en vigencia la Ley Forestal y de Conservación de Áreas Naturales y Vida Silvestre, en 1998 se promulga la Ley para la Conservación y Desarrollo Sustentable de la Provincia de Galápagos y en 1999 se promulga la Ley de Gestión Ambiental que introduce en el sistema legal del Ecuador los principios de la Declaración de Río de 1992, institucionaliza al Ministerio del Ambiente como autoridad ambiental nacional rectora del Sistema Nacional Descentralizado de Gestión Ambiental, establece como requisito previo a la iniciación de cualquier actividad de riesgo la evaluación de impacto ambiental y señala algunas políticas ambientales y reglas de procedimiento.

Sin embargo de la vigencia de un amplio marco legal ambiental y pese a que la Constitución vigente intenta romper con el paradigma del antropocentrismo, aún persisten en el Ecuador instrumentos legales y disposiciones regresivas que chocan contra el principio de no regresión.

\section{El Principio de no regresión}

El principio de no regresión se origina en la legislación sobre los derechos humanos con base en la cláusula de progresividad contenida en el Pacto Internacional de Derechos Económicos, Sociales y Culturales ${ }^{6}$ y se traslada al tema ambiental a partir de la Declaración de Río + 20 conocida como "El futuro que queremos" que en el párrafo 20 señala que no se debe retroceder luego de la Cumbre de Río de 1992. ${ }^{7}$ Mario Peña Chacón aclara que "el principio de

\footnotetext{
${ }^{5}$ Constitución de la República: Art. 14.- Se reconoce el derecho de la población a vivir en un ambiente sano y ecológicamente equilibrado, que garantice la sostenibilidad y el buen vivir, sumak kawsay. Se declara de interés público la preservación del ambiente, la conservación de los ecosistemas, la biodiversidad y la integridad del patrimonio genético del país, la prevención del daño ambiental y la recuperación de los espacios naturales degradados.

Art. 71.- La naturaleza o Pacha Mama, donde se reproduce y realiza la vida, tiene derecho a que se respete integralmente su existencia y el mantenimiento y regeneración de sus ciclos vitales, estructura, funciones y procesos evolutivos.

${ }^{6}$ Artículo 2 1. Cada uno de los Estados Partes en el presente Pacto se compromete a adoptar medidas, tanto por separado como mediante la asistencia y la cooperación internacionales, especialmente económicas y técnicas, hasta el máximo de los recursos de que disponga, para lograr progresivamente, por todos los medios apropiados, inclusive en particular la adopción de medidas legislativas, la plena efectividad de los derechos aquí reconocidos.

7 "Reconocemos que desde 1992 los progresos han sido insuficientes y se han registrado contratiempos en algunos aspectos de la integración de las tres dimensiones del desarrollo sostenible, agravados por las múltiples crisis financieras, económicas, alimentarias y energéticas, que han puesto en peligro la capacidad de todos los países, en particular los países en desarrollo, para lograr el desarrollo sostenible. A este respecto, es esencial que no demos marcha atrás a nuestro compromiso con los resultados de la Conferencia de las Naciones Unidas sobre el Medio Ambiente y el Desarrollo. Reconocemos además que uno de los principales problemas actuales de todos los países, especialmente los países en desarrollo, es el impacto de las múltiples crisis que afectan al mundo hoy en día."
} 
no regresión o de prohibición de retroceso enuncia que la normativa y la jurisprudencia ambiental no deberían ser revisadas si esto implicare retroceder respecto a los niveles de protección alcanzados con anterioridad y siempre que no se demuestre que tales retrocesos sean superiores al interés público ambiental ${ }^{8}$

El principio de no regresión se afinca además en el hecho de que toda la legislación ambiental tanto nacional como internacional tiene como objetivo el alcanzar el desarrollo sustentable mediante acciones progresivas que logren mayor biodiversidad y menor contaminación para el planeta. Sin duda la humanidad ha reaccionado frente a las agresiones ambientales desde la Cumbre de Estocolmo de 1972 reafirmando además el concepto de sustentabilidad ambiental en la Cumbre de Río de 1992, pues no es posible continuar ignorando el impacto de las actividades humanas sobre el ambiente biofísico del cual formamos parte, sin embargo como se ha dicho, aún persiste un evidente conflicto con un modelo económico que se resiste a introducir la variable ambiental en todas las actividades económicas y de desarrollo humano, y aún si este se introduce, las políticas implícitas sobre temas económicos, tributarios, fiscales y otros, pueden incidir con objetivos contrarios a las políticas ambientales explícitas contenidas en la legislación, lo cual produce que la política ambiental sea regresiva si la administración pública encargada de hacer cumplir la ley no lo hace o si la misma norma introduce mecanismos regresivos para permitir mayor flexibilidad frente a políticas económicas que se resisten a un modelo de sustentabilidad ambiental.

El pionero del principio de no regresión en materia ambiental es el profesor y tratadista de derecho ambiental Michel Prieur quien en su artículo sobre la "No Regresión en la Legislación Ambiental', ${ }^{9}$ nos dice que estamos frente a una ciencia jurídica que hace muchísimo más visible una política de valores éticos y morales para el ambiente, tal vez recordando al filósofo norteamericano Aldo Leopold que sugirió la constitución de una "ciudadanía biótica inspirada en una ética del suelo", dice el profesor Prieur, que siendo la legislación ambiental un conjunto de normas para la consecución de valores éticos, estas promueven la mejora del bienestar humano y de los demás seres vivos dentro del contexto de la búsqueda permanente del progreso social, por lo tanto, si la legislación ambiental refleja políticas progresivas, al mismo tiempo debe prohibir cualquier intento de retroceso o de políticas regresivas. En su artículo Prieur señala además que desde la conferencia de Estocolmo de 1972, siendo el principal instrumento de aplicación de la política ambiental, la legislación ambiental, tanto a nivel internacional como nacional, ésta debe contribuir a la eliminación de la contaminación y a la preservación de la biodiversidad biológica. Pero el profesor Prieur apunta acertadamente que, varias son las amenazas que enfrenta la legislación ambiental y que pueden encausar políticas regresivas o de retroceso: la primera amenaza es política que mediante actitudes demagógicas permitiría la desregulación frente a la complejidad de los estándares ambientales; la segunda es económica y tendría relación con la visión tecnocrática del problema ambiental que acompañada por la crisis económica global conduce a que algunos sectores mantengan el criterio que ante la reducción de la pobreza y a la necesidad del desarrollo, deban minimizarse las obligaciones ambientales; y la tercera amenaza que apunta Prieur es psicológica, cuando nos dice que la gran cantidad de estándares ambientales presentan un complejísimo panorama que dificulta su entendimiento para no especialistas, lo cual produce regresiones hacia normas ambientales menos restrictivas.

Según el profesor Prieur, es importante notar que las políticas regresivas en materia ambiental pueden reflejarse de varias formas. Internacionalmente la regresión puede ser entendida como la no adhesión o ratificación a un tratado ambiental multilateral, obstaculizando su implementación, o inclusive denunciando el tratado, lo que se presentó por primera vez en el campo del derecho ambiental internacional cuando Canadá decidió denunciar el protocolo de

\footnotetext{
${ }^{8}$ El Principio de No Regresión Ambiental en el Derecho Comparado Latinoamericano PNUD 2013. p. 12

${ }^{9}$ http://sapiens.revues.org/1405
} 
Kioto, durante la Conferencia de las Partes a la Convención de Durban en diciembre de 2011. La regresión ambiental también se ha presentado en la legislación ambiental europea mediante la revisión de ciertas directivas. A nivel nacional las regresiones en materia ambiental han sido más comunes, por ejemplo cuando se modifican procedimientos para dificultar el acceso a la información, a la participación y a la justicia ambiental, o cuando se reducen estándares máximos permisibles de contaminación o se eliminan categorías de protección de áreas protegidas como sucedió el 27 de abril de 2012 cuando la Corte Suprema de Panamá dictó una suspensión provisional del área protegida que había sido otorgada a los manglares de la bahía de Panamá.

El profesor Prieur hace unas importantes acotaciones respecto a los argumentos legales que sustentan el principio de no regresión: Primero, señala que conforme a la teoría jurídica y la filosofía del derecho, se garantiza el concepto de equidad intergeneracional, con fundamento en el artículo 28 del Proyecto de Declaración de los derechos Humanos del 24 de junio de 1793 que señaló: "Una generación no puede obligar a las futuras generaciones a ajustarse a sus leyes". El profesor Prieur, deriva de esta antigua disposición, una clarísima conexión con el concepto de desarrollo sostenible que actualmente nos obliga a pensar de manera distinta en el sentido de que el derecho a la vida y el bienestar de las futuras generaciones no puede ser subestimado, y que por lo tanto, cualquier medida que vaya en su detrimento no debe ser adoptada. En este sentido Prieur indica que minimizar las reglas para proteger el ambiente resultaría en un ambiente degradado para las futuras generaciones. El artículo 28 del Proyecto de la Declaración de 1793, combinado con el principio del desarrollo sostenible, habla de lo que ahora entenderíamos como el principio de no regresión en materia ambiental pues de lo que se trata es de no someter a las futuras generaciones a normas y reglas jurídicas que reducirían la protección ambiental. Un segundo aspecto legal que según Prieur sustenta el principio de no regresión es la teoría de los derechos humanos que procura su desarrollo progresivo lo que se interpreta como la prohibición de no regresión del derecho humano a un ambiente sano. ${ }^{10}$ Prieur además señala que el Comentario General número 3 de diciembre 14 de 1990 de la Comisión de Naciones Unidas para los Derechos Económicos, Sociales y Culturales condenó cualquier medida deliberada de retroceso en materia de derechos humanos. Otro argumento válido que apunta Prieur se refiere al andamiaje creado por el derecho ambiental internacional a través de cuyos tratados y protocolos se ha reflejado el principio 7 de la Declaración de Rio de 1992 que afirma que el desarrollo sostenible se asienta en la conservación, protección y restauración e integridad del ecosistema de la tierra lo que implica indudablemente desechar medidas contrarias a la protección ecológica. Prieur establece también que otra de las bases del principio de no regresión es el derecho constitucional que incluye el derecho humano a un ambiente sano, como las constituciones de Brasil, Portugal y Alemania. Respecto al Ecuador, Prieur enfatiza que el principio de no regresión en materia ambiental es explícito, y en cuanto a la constitución de Bután, afirma que esta declara al $70 \%$ de los bosques del país como bosques eternos. En general Prieur al afirmar que en muchas constituciones de los estados el derecho a un ambiente sano se ha convertido en un derecho fundamental, señala que debería ser posible invocar ante la justicia la obligatoriedad del principio de no regresión. Finalmente Prieur apunta a que siendo la legislación ambiental nacional esencialmente protectora de la naturaleza y preventiva del daño ambiental, en consecuencia no debería admitir medida regresiva alguna y que tanto la jurisprudencia nacional, regional e internacional está respaldando el Principio de No Regresión en materia ambiental.

Para concluir el profesor Prieur se refiere a que en el documento final sobre "El Futuro que Queremos" de la Cumbre de Rio +20 de junio de 2012, la expresión de "principio de no regresión" no se incluyó en el texto dada la oposición de los Estados Unidos, Japón y Canadá y

\footnotetext{
${ }^{10} \mathrm{El}$ derecho humano a un ambiente sano no se refleja aún en los tratados globales ambientales pero si se encuentra instituido en un tratado regional como es el Protocolo de San Salvador a la Convención Interamericana de Derechos Humanos.
} 
de la indecisión de la Unión Europea Suiza y Brasil, por lo que más bien se tradujo en la siguiente frase "... es esencial que no demos marcha atrás con nuestro compromiso con los resultados de la Conferencia de las Naciones Unidas sobre el Medio Ambiente y Desarrollo". Según Prieur el "no dar marcha atrás" es una afirmación equivalente al principio de no regresión que implica no retroceder respecto a las dos convenciones suscritas en Río 1992, ${ }^{11}$ a la Declaración de Río, a la Agenda 21 y a la Declaración sobre Bosques.

Todo lo afirmado por el profesor Prieur en su artículo que hemos sintetizado, admite sin embargo excepciones, en tanto y en cuanto no se contravenga a los objetivos fundamentales de las políticas ambientales, por ejemplo cuando la Convención CITES sobre el Tráfico Internacional de Especies en Peligro de Extinción, determina que se retiren de sus listas las especies que dejan de estar en riesgo o peligro o cuando la prohibición de un determinado contaminante puede ser levantada si se demuestra que ya no plantea un riesgo para la salud. Esto en mi criterio implicaría, que para efectos de realizar un cambio en la legislación se deba realizar una evaluación de la cual se desprenda que la norma materia de la modificación no demuestra la violación del principio de no regresión en base a indicadores técnicos y legales.

\section{Criterios para la verificación de la regresividad en materia ambiental}

Para analizar algunos casos de afectación al principio de no regresión en el Ecuador vamos a considerar los siguientes criterios y lineamientos de verificación de la regresividad ambiental en la legislación según lo señalado por el jurista Mario Peña Chacón en el artículo académico "Test de Regresividad Ambiental". ${ }^{12}$ Ahí se establecen los siguientes criterios:

1. Promulgación de nueva normativa que modifique el nivel de protección ambiental adquirido previamente.

2. Ausencia o insuficiencia de justificación y respaldo técnico-científico que permita determinar, en grado de certeza, la no afectación al bien tutelado

3. Menoscabo o empeoramiento del nivel de protección jurídico preexistente, en cuanto a su alcance, amplitud y efectividad.

4. Omisión de reglamentación de normas ambientales indispensables para su Incumplimiento en la aplicación de la legislación ambiental tornándola absolutamente ineficaz

El principio de no regresión admite excepciones cuando los principios constitucionales de razonabilidad y proporcionalidad o la ciencia y la técnica demuestren que una modificación no afecta al principio y siempre y cuando se considere debidamente la tutela estatal del interés público ambiental, el modelo de desarrollo sostenible, el principio de precaución y el principio in dubio pro natura. ${ }^{13}$

\footnotetext{
${ }^{11}$ Convención Marco de Cambio Climático y la Convención sobre la Diversidad Biológica.

12 Este artículo es producto del Proyecto de Investigación denominado "Las clínicas del Derecho Ambiental y Gestión de Riesgos Climáticos a través de una cultura jurídica de la sostenibilidad y no regresión" inscrito ante la Vicerectoría de Investigación y el Instituto de Investigaciones Jurídicas de la Universidad de Costa Rica bajo el código 722-B3-193.

${ }^{13}$ En este sentido, Mario Peña Chacón señala: "En primera instancia el principio de no regresión no es ilimitado ni irrestricto. Al igual que como sucede con el derecho a un ambiente sano y ecológicamente equilibrado, se encuentra condicionado por los principios constitucionales de razonabilidad y proporcionalidad, así como por las reglas unívocas de la ciencia, técnica, conveniencia y la lógica. A la vez, la actuación del Estado en esta materia se ve limitada por el deber de tutela del interés público ambiental, por los principio de desarrollo sostenible y uso racional, precautorio o evitación prudente y por la vinculatoriedad de la normativa ambiental." Test de Regresividad Ambiental p. 4
} 


\section{El principio de no regresión en la Constitución del Ecuador}

La Constitución de la Republica del Ecuador constituye un hito en la conformación de un modelo ambiental biocéntrico que partiendo del concepto del buen vivir o sumak kawsay, y bajo el fundamento de un estado plurinacional y multicultural, reconoce derechos a la naturaleza, ${ }^{14}$ el derecho a vivir en un ambiente sano, el derecho humano al agua y la obligación de gestionar conjuntamente la biodiversidad y el agua con un enfoque ecosistémico. La Constitución además señala una serie de políticas para la conservación y uso sustentable de la biodiversidad, señala normas sobre la responsabilidad por daño ambiental y articula la tutela ambiental del Estado a través de un sistema nacional descentralizado de gestión ambiental. Todo este andamiaje constitucional está respaldado por los principios señalados en los artículos 11 y 395 de la Constitución.

Mario Melo, ${ }^{15}$ al referirse a los principios contenidos por el artículo 11 de la Constitución del Ecuador, en relación a los derechos de la naturaleza y el derecho a un ambiente sano señala que ... "los derechos humanos y los de la Naturaleza, en el constitucionalismo ecuatoriano, comparten algunos principios clave de interpretación y aplicación, (entre los que se encuentra el principio de no regresión). Así, por citar los más relevantes:

- Se podrán ejercer, promover y exigir de forma individual o colectiva ante las autoridades competentes; estas autoridades garantizarán su cumplimiento.

- Son de directa e inmediata aplicación por y ante cualquier servidora o servidor público, administrativo o judicial, de oficio o a petición de parte.

- Para su ejercicio no se exigirán condiciones o requisitos que no estén establecidos en la Constitución o la ley.

- Son plenamente justiciables. No podrá alegarse falta de norma jurídica para justificar su violación o desconocimiento, para desechar la acción por esos hechos ni para negar su reconocimiento.

- Ninguna norma jurídica podrá restringir su contenido.

- Las servidoras y servidores públicos, administrativos o judiciales, deberán aplicar la norma y la interpretación que más favorezcan su efectiva vigencia.

- Son inalienables, irrenunciables, indivisibles, interdependientes y de igual jerarquía.

- Su reconocimiento no excluirá los demás derechos derivados de la dignidad de las personas, comunidades, pueblos y nacionalidades, que sean necesarios para su pleno desenvolvimiento.

- Su contenido se desarrollará de manera progresiva a través de las normas, la jurisprudencia y las políticas públicas.

- El Estado generará y garantizará las condiciones necesarias para su pleno reconocimiento y ejercicio.

\footnotetext{
${ }^{14}$ Como lo señala Ramiro Ávila: La Constitución de Ecuador, pionera en la ruptura de la concepción tradicional de derechos humanos, reconoce por primera vez el derecho de la naturaleza como un derecho autónomo del ser humano [...]. No cabe ya el término genérico de "derechos humanos" para referirse a los derechos que tienen una protección especial en las Constituciones. Conviene denominarlos derechos fundamentales o derechos constitucionales. Otra ruptura es que la protección a la naturaleza no se la hace porque conviene al ser humano sino por la naturaleza en sí misma. En consecuencia, la concepción jurídica de los derechos deja de ser antropocéntrica. Tercera ruptura, la teoría jurídica tradicional, para entender el derecho, tiene que buscar nuevos fundamentos y renovadas lecturas, que tienen que ver con la ruptura del formalismo jurídico y con una superación de la cultura jurídica imperante (Ávila, 2011). LÍNEASUR 5 REVISTA DE POLÍTICA EXTERIOR MAY/AG0 2013 N. 5, mayo-agosto, 2013 ISNN 13906771 Vol. II, Issue 5, May-August, 2013 Quito, Ecuador.

${ }^{15}$ Melo Mario . Derechos de la Naturaleza, Globalizacióin y Cambio Climático

http://www.lineasur.gob.ec/index.php?option=com_content\&view=article\&id=75\&catid=22
} 
- Será inconstitucional cualquier acción u omisión de carácter regresivo que disminuya, menoscabe $o$ anule injustificadamente su ejercicio.

- El más alto deber del Estado consiste en respetar y hacer respetar los derechos garantizados en la Constitución.

Además, los principios señalados en el artículo 395 de la Constitución del Ecuador obligan al Estado a garantizar un modelo sustentable de desarrollo ambientalmente equilibrado $y$ respetuoso de la diversidad cultural, que conserve la biodiversidad, y asegure la satisfacción de las necesidades de las presentes y futuras generaciones, así como a garantizar la participación activa y permanente de las personas en materia ambiental y a hacer prevalecer la norma más favorable a la naturaleza en caso de conflicto. Los principios del artículo 395 respaldan un modelo no regresivo en materia ambiental. El jurista Wilton Guaranda al respecto señala: "La interrelación de estos elementos como parte constitutiva del derecho ambiental, nos permite comprender que estamos frente a un sistema de protección constitucional garantista y ecosistémico el cual establece reglas claras, profundamente ecológicas y abiertamente participativa para la observancia y cumplimiento tanto del estado, los particulares y las empresas. Esta línea de acción debe ser incorporada en la legislación infra constitucional que para el efecto se expida o se reforme, sin perder de vista los principios de no regresividad y progresividad de los derechos a los que deben someterse los y las Asambleístas."

16 Acciones jurídicas para establecer responsabilidades por daño ambiental en el Ecuador Serie Investigación \# 17 Editora: Sandra Naula Cuenca Presidenta INREDH Autores: Wilton Guaranda Mendoza Fundación Regional de Asesoría en Derechos Humanos, INREDH Av. 10 de Agosto N34 - 80 y Rumipamba - Piso 1 - Quito, Ecuador (Frente a la parada El Florón, del Trolebus sur - norte) Telefax: 593 22446970 Correo: info@inredh.org Web: www.inredh.org

En este contexto constitucional, el principio de no regresión se refleja específicamente en los siguientes artículos de la Constitución de la República del Ecuador:

Art. 11 numeral 8. El ejercicio de los derechos se regirá por los siguientes principios: 8. El contenido de los derechos se desarrollará de manera progresiva a través de las normas, la jurisprudencia y las políticas públicas. El Estado generará y garantizará las condiciones necesarias para su pleno reconocimiento y ejercicio.

Art. 12.- El derecho humano al agua es fundamental e irrenunciable. El agua constituye patrimonio nacional estratégico de uso público, inalienable, imprescriptible, inembargable y esencial para la vida.

Art. 71.- La naturaleza o Pacha Mama, donde se reproduce y realiza la vida, tiene derecho a que se respete integralmente su existencia y el mantenimiento y regeneración de sus ciclos vitales, estructura, funciones y procesos evolutivos.

Art. 83.- Son deberes y responsabilidades de las ecuatorianas y los ecuatorianos, sin perjuicio de otros previstos en la Constitución y la ley: 13. Conservar el patrimonio cultural y natural del país, y cuidar y mantener los bienes públicos.

Art. 395.- La Constitución reconoce los siguientes principios ambientales: 1. El Estado garantizará un modelo sustentable de desarrollo, ambientalmente equilibrado y respetuoso de la diversidad cultural, que conserve la biodiversidad y la capacidad de regeneración natural de los ecosistemas, y asegure la satisfacción de las necesidades de las generaciones presentes y futuras. 4. En caso de duda sobre el alcance de las disposiciones legales en materia ambiental, éstas se aplicarán en el sentido más favorable a la protección de la naturaleza.

Art.- 397 numeral 4: Para garantizar el derecho individual y colectivo a vivir en un

ambiente sano y ecológicamente equilibrado, el Estado se compromete a: 4. Asegurar la intangibilidad de las áreas naturales protegidas, de tal forma que se garantice la conservación de la biodiversidad y el mantenimiento de las funciones ecológicas de los ecosistemas. El manejo y administración de las áreas naturales protegidas estará a cargo del Estado.

Art. 441.- La enmienda de uno o varios artículos de la Constitución que no altere su estructura fundamental, o el carácter y elementos constitutivos del Estado, que no establezca restricciones a los derechos y garantías, o que no modifique el procedimiento de reforma de la Constitución, se realizará..

Art. 423.- La integración, en especial con los países de Latinoamérica y el Caribe será un objetivo estratégico del Estado. En todas las instancias y procesos de integración, el Estado ecuatoriano se comprometerá a: 3 . Fortalecer la armonización de las legislaciones nacionales con énfasis en los derechos y regímenes laboral, migratorio, fronterizo, ambiental, social, educativo, cultural y de salud pública, de acuerdo con los principios de progresividad y de no regresividad. 


\section{La regresión del los derechos de la naturaleza por la omisión de reglamentación de normas ambientales indispensables para su cumplimiento en la aplicación de la legislación ambiental tornándola absolutamente ineficaz}

Un aspecto regresivo en relación a los derechos de la naturaleza según la Constitución del Ecuador es que aún no han sido materia de desarrollo legislativo ni reglamentario. Se requiere normar los derechos de la naturaleza ${ }^{17}$ para resolver cuestiones técnicas y procedimentales así como la ponderación con otros derechos y con los derechos ambientales. Los derechos de la naturaleza deben prevalecer frente a cualquier otro derecho, pues constituyen el sustento para posibilitar los demás derechos como el derecho al agua, al trabajo y a la vida en general. Hasta el momento no ha habido esfuerzo alguno para otorgar contenido a los derechos de la naturaleza. Aunque el artículo 11 numeral 3 de la Constitución señala que todos los derechos son de directa aplicación ${ }^{18}$ y que no podrá alegarse falta de norma jurídica para justificar su violación o desconocimiento, hay algunos temas técnicos que requieren de norma secundaria para evitar que los derechos de la naturaleza queden vaciados de contenido. Entre otros algunos temas que deben ser regulados por medio de una ley son los indicadores ${ }^{19}$ sobre: la integridad de los ecosistemas, los procesos vitales en los ecosistemas (flujos de energía, ciclos de nutrientes, evolución), los cambios en los índices de biodiversidad (riqueza de especies, abundancia relativa de las especies), los cambios en las estimaciones de abundancia de especies introducidas, los cambios en el área total del ecosistema: fragmentación (número y

\footnotetext{
17 Art. 71.- La naturaleza o Pacha Mama, donde se reproduce y realiza la vida, tiene derecho a que se respete integralmente su existencia y el mantenimiento y regeneración de sus ciclos vitales, estructura, funciones y procesos evolutivos.

Toda persona, comunidad, pueblo o nacionalidad podrá exigir a la autoridad pública el cumplimiento de los derechos de la naturaleza. Para aplicar e interpretar estos derechos se observaran los principios establecidos en la Constitución, en lo que proceda.
}

El Estado incentivará a las personas naturales y jurídicas, y a los colectivos, para que protejan la naturaleza, y promoverá el respeto a todos los elementos que forman un ecosistema.

Art. 72.- La naturaleza tiene derecho a la restauración. Esta restauración será independiente de la obligación que tienen el Estado y las personas naturales o jurídicas de Indemnizar a los individuos y colectivos que dependan de los sistemas naturales afectados.

En los casos de impacto ambiental grave o permanente, incluidos los ocasionados por la explotación de los recursos naturales no renovables, el Estado establecerá los mecanismos más eficaces para alcanzar la restauración, y adoptará las medidas adecuadas para eliminar o mitigar

las consecuencias ambientales nocivas.

Art. 73.- El Estado aplicará medidas de precaución y restricción para las actividades que puedan conducir a la extinción de especies, la destrucción de ecosistemas o la alteración permanente de los ciclos naturales.

Se prohíbe la introducción de organismos y material orgánico e inorgánico que puedan alterar de manera definitiva el patrimonio genético nacional.

Art. 74.- Las personas, comunidades, pueblos y nacionalidades tendrán derecho a beneficiarse del ambiente y de las riquezas naturales que les permitan el buen vivir.

Los servicios ambientales no serán susceptibles de apropiación; su producción, prestación, uso y aprovechamiento serán regulados por el Estado.

${ }^{18}$ Art. 11.- El ejercicio de los derechos se regirá por los siguientes principios:3. Los derechos y garantías establecidos en la Constitución y en los instrumentos internacionales de derechos humanos serán de directa e inmediata aplicación por y ante cualquier servidora o servidor público, administrativo o judicial, de oficio o a petición de parte. Para el ejercicio de los derechos y las garantías constitucionales no se exigirán condiciones o requisitos que no estén establecidos en la Constitución o la ley. Los derechos serán plenamente justiciables. No podrá alegarse falta de norma jurídica para justificar su violación o desconocimiento, para desechar la acción por esos hechos ni para negar su reconocimiento.

${ }^{19}$ Propuesta de indicadores y procesos para evaluar la afectación a los derechos de la naturaleza Marzo 2012 Pablo Yépez y Stella de la Torre. 
área de parches), el aumento del área de hábitats borde, etc. Además es necesario normar el tipo de prueba necesaria que debe ser presentada en procesos judiciales sobre afectación a los derechos de la naturaleza.

La abogada Sofía Suarez señala lo siguiente sobre este tema ${ }^{20}$ : "Respecto a este punto es importante resaltar que desde la expedición de la Constitución no se ha logrado el desarrollo de los derechos de la naturaleza en la legislación y normativa secundaria correspondiente, sin embargo, poco a poco se ha ido desarrollando el contenido a estos derechos en el sistema judicial, lo cual es posible debido a uno de los importantes preceptos del neoconstitucionalismo: la aplicación directa e inmediata de las disposiciones constitucionales. El desarrollo jurisprudencial de los derechos de la naturaleza también requiere que el país cuente con instituciones judiciales especializadas en este tema, es decir, tiene que crearse las Judicaturas de la Naturaleza, disposición que ya está prevista en el actual Código Orgánico de la Función Judicial. La materialización de esta disposición judicial permitirá un adecuado desarrollo de los derechos de la naturaleza, siempre y cuando también la ciudadanía conozca sobre estos derechos y su posible exigibilidad en el ámbito judicial."

\section{El Caso Yasuní y la Ausencia o insuficiencia de justificación y respaldo técnico-científico que permita determinar, en grado de certeza, la no afectación al bien tutelado}

En el Segundo Suplemento del Registro Oficial No 106 de 22 de Octubre de 2013, se publicó la declaratoria de interés nacional para permitir la explotación petrolera en el Parque Nacional Yasuní, ${ }^{21}$ situado en la Amazonía ecuatoriana y reconocido como una de las zonas más ricas en biodiversidad del planeta. La declaratoria se fundamenta en el artículo 407 de la Constitución de la República que dispone: Se prohíbe la actividad extractiva de recursos no renovables en las áreas protegidas y en zonas declaradas como intangibles, incluida la explotación forestal. Excepcionalmente dichos recursos se podrán explotar a petición fundamentada de la Presidencia de la República y previa declaratoria de interés nacional por parte de la Asamblea Nacional, que, de estimarlo conveniente, podrá convocar a consulta popular.

En efecto y considerando que la Iniciativa ITT fracasó, ${ }^{22}$ el Presidente de la República dio por terminado el fideicomiso mercantil que se había creado y posteriormente, envió a la Asamblea

20 CEDA Temas de análisis No 27 Noviembre de 2012. "Efectivización de los derechos de la naturaleza: evolución jurisprudencial".

${ }^{21}$ El parque nacional Yasuní forma parte del patrimonio de áreas naturales del Estado que se encuentra regulado por el artículo 66 de la Ley Forestal y de Conservación de Áreas Naturales y Vida Silvestre. Dicho artículo señala los elementos que destacan el valor de las áreas silvestres que conforman dicho patrimonio, los de protección, científico, escénico, educacional, turístico y recreacional; además destaca la importancia de la flora y fauna, así como el hecho de que constituya ecosistemas que contribuyen a mantener el equilibrio del medio ambiente. El parque Yasuní se creó en 1979 mediante decreto interministerial. El antecedente fue el Decreto 1306, del 27 de agosto de 1971, que facultaba "a los ministerios de Producción, Recursos Naturales y Turismo para declarar y delimitar áreas de reserva 0 parques nacionales".

${ }^{22}$ La Iniciativa ITT había sido instituida para que los países industrializados aporten la mitad de la suma total equivalente a la extracción de petróleo del área Imuya, Tiputini Tambococha ( ITT) situada en el Parque Nacional Yasuní, a cambio de no extraer el crudo y dejarlo bajo tierra. Mediante Decreto Ejecutivo No 74 de 15 de Agosto de 2013, el Presidente de la República ordenó la disolución del Fideicomiso de la Iniciativa ITT, lo que hubiera implicado un aporte para reducir el cambio climático mediante emisiones evitadas y la eliminación del riesgo al no realizar actividades petroleras en una zona tan frágil del Parque Nacional Yasuní como es la zona ITT en la que además se encuentran pueblos no contactados. La iniciativa se basaba implícitamente en el principio de la Declaración de Río de 1992 sobre las 
Nacional, conforme al artículo 407 de la Constitución de la República, la Petición Fundamentada de Declaratoria de Interés Nacional para la explotación petrolera de los Bloques 31 y 43, en un área no mayor al uno por mil del Parque Nacional Yasuní.

Las áreas naturales protegidas por su riqueza en biodiversidad como el parque Yasuní son espacios que cuentan con una protección legal adicional, otorgada en razón de la declaratoria de interés público que el propio Estado ha determinado ${ }^{23}$ en los artículos 14 y 400 de la Constitución de la República, y del que se deriva como fin principal, aquel de la conservación de la diversidad biológica existente. Por lo tanto, cualquier actividad que se realice paralelamente sobre el área no puede afectar este fin. Las áreas naturales protegidas, como espacios privilegiados dentro del territorio nacional, merecen un nivel mayor de exigencia en las condiciones que se establezcan para la ejecución de proyectos no solamente de carácter hidrocarburífero, sino también de carácter turístico, de habilitación de infraestructura, etc.

Ni las leyes, ni la política ambiental del Ecuador han determinado cuáles son los parámetros técnicos para justificar el respaldo técnico-científico que permita determinar, en grado de certeza, la no afectación por actividades de alto riesgo como las hidrocarburíferas sobre una área natural protegida y la biodiversidad como bienes tutelados. Lo que sí se ha hecho, es determinar cuáles deben ser los requisitos para admitirla según lo establecido por el artículo 407 de la Constitución. Por otro lado bajo ningún concepto el interés nacional puede contraponer al interés público de conservar la biodiversidad ${ }^{24}$ como aparece del texto del artículo 407 de la Constitución, lo que lo convierte en inconstitucional.

La declaratoria de interés nacional afecta al principio de no regresión pues se deriva del artículo 407 que se le podría considerar regresivo porque se contrapone con el deber constitucional del Estado de garantizar la intangibilidad de las áreas protegidas. Frente al conflicto entre explotar petróleo en áreas protegidas o garantizar su intangibilidad, debió haber prevalecido esta última en función del principio de indubio pro natura que en el artículo 395 numeral 4 de la Constitución señala: "4. En caso de duda sobre el alcance de las disposiciones legales en materia ambiental, éstas se aplicarán en el sentido más favorable a la protección de la naturaleza".

Además, los Tratados internacionales como el Convenio sobre la Flora y Fauna Silvestre y las Bellezas Escénicas de los Países de América; la Convención de Patrimonio Mundial de la Humanidad, la Convención Ramsar sobre los Humedales, la Convención de Especies Migratorias y el Convenio sobre Diversidad Biológica señalan que las áreas protegidas no tienen otro fin que el de ser conservadas para mantener el equilibrio ecológico entre otros aspectos.

responsabilidades comunes pero diferenciadas pero que hasta el momento no ha demostrado ser efectivo.

${ }^{23}$ Art. 14.- Se reconoce el derecho de la población a vivir en un ambiente sano y ecológicamente equilibrado, que garantice la sostenibilidad y el buen vivir, sumak kawsay.

Se declara de interés público la preservación del ambiente, la conservación de los ecosistemas, la biodiversidad y la integridad del patrimonio genético del país, la prevención del daño ambiental y la recuperación de los espacios naturales degradados.

Art. 400.- El Estado ejercerá la soberanía sobre la biodiversidad, cuya administración y gestión se realizará con responsabilidad intergeneracional.

Se declara de interés público la conservación de la biodiversidad y todos sus componentes, en particular la biodiversidad agrícola y silvestre y el patrimonio genético del país.

${ }^{24}$ La mención que hace el artículo 407 de la Constitución sobre el "interés nacional", la entendemos como equivalente de "interés público", pues no puede haber interés nacional que no sea de interés público. Por lo tanto, es obligación del Estado proteger la biodiversidad y la integridad genética del país evitando que las actividades petroleras pongan en riesgo la biodiversidad de las áreas naturales protegidas. 
En este contexto el artículo 407 de la Constitución tiene claros visos de inconstitucionalidad, pues además de violar la intangibilidad de las áreas protegidas, se contrapone con el principio de precaución que en el artículo 396 dispone que "en caso de duda sobre el impacto ambiental de alguna acción u omisión, aunque no exista evidencia científica del daño, el Estado adoptará medidas protectoras eficaces y oportunas".

Es evidente que la decisión de realizar la explotación petrolera en los bloques 31 y 43 que se encuentran dentro de una área tan frágil y rica en biodiversidad como el Parque Nacional Yasuní, afecta al principio de precaución como uno de los pilares del principio de no regresión, dado que estamos frente a un caso de incertidumbre científica sobre los impactos ambientales y sociales de la explotación petrolera en esa zona. El Parque Nacional Yasuní es una zona inundable, lo que hace discutible si la tecnología de punta puede ser una herramienta suficientemente preventiva de daños ambientales en una área de tan alta vulnerabilidad, aunque se afirme que se afectaría solamente el $1 \%$ del parque. Por lo tanto, para determinar la viabilidad de una actividad de tan alto riesgo como la petrolera en una zona de altísima vulnerabilidad, por lo menos debió haberse realizado previamente una evaluación ambiental estratégica que mida los efectos acumulativos y sinérgicos de una posible actividad petrolera en el Parque Nacional Yasuní y permita sopesar la aplicación del principio de precaución.

Lo adecuado hubiese sido que el texto del artículo 407 de la Constitución, claramente regresivo como hemos dicho, señale que la declaratoria de interés nacional no procede en ausencia 0 insuficiencia de justificación y respaldo técnico-científico que permita determinar, en grado de certeza, la no afectación al bien tutelado.

Se aprecia además la prevalencia de una política de desarrollo implícita que se contrapone con la norma constitucional que garantiza la intangibilidad de las áreas protegidas ${ }^{25}$ y por lo tanto, atenta contra el principio de no regresividad cuando dicha declaratoria señala: "La explotación del petróleo del Yasuní generará una demanda agregada y una expansión del mercado interno, que junto a las políticas de protección de la producción nacional, permitirán un crecimiento sostenido y planificado de la economía nacional a través de la inversión y la inyección de los nuevos recursos en el aparato productivo, tanto hacia el sector público y privado como también hacia la economía social y solidaria, considerando además el criterio de la equidad interterritorial."

En conclusión la declaratoria de interés nacional para realizar actividades petroleras en el Parque Nacional Yasuní, afecta al principio de no regresión por las siguientes razones:

- Quebranta el principio de intangibilidad de las Áreas Protegidas y el de progresividad de los derechos, lo que es contrario a la tutela estatal del derecho a un ambiente sano, reconocido por la actual Constitución en el artículo 66 numeral 27 en concordancia con el artículo 397 numeral 4.

- Viola compromisos internacionales adquiridos por el Estado ecuatoriano, referidos a temas de conservación, como la Convención para la Protección del Patrimonio Mundial Cultural y Natural y el Convenio de Diversidad Biológica entre otras. Por tanto, pondría al Estado ecuatoriano en situación de incumplimiento de dichos compromisos, y como agresor a derechos fundamentales reconocidos por la comunidad internacional.

- Se contrapone a los derechos de la naturaleza, como uno de los avances del nuevo texto constitucional para garantizar la conservación de la biodiversidad y el mantenimiento de los procesos naturales.

- Atentaría contra el buen vivir, como un objetivo superior del Régimen de Desarrollo y la prohibición de explotación minera dentro de las Áreas Naturales Protegidas, cuyos

\footnotetext{
${ }^{25}$ Art.- 397 Núm. 4 : Asegurar la intangibilidad de las áreas naturales protegidas, de tal forma que se garantice la conservación de la biodiversidad y el mantenimiento de las funciones ecológicas de los ecosistemas. El manejo y administración de las áreas naturales protegidas estará a cargo del Estado.
} 
principios también han sido ya aprobados por la Asamblea; y especialmente atenta contra derechos colectivos de pueblos y nacionalidades que han habitado ancestralmente en territorios que ahora son parte de Áreas Naturales Protegidas.

- Si bien en esencia todas las Áreas Naturales Protegidas, así declaradas, deben ser intangibles, bajo ningún concepto o excepción podrían ser afectadas con actividades extractivas como la minera o hidrocarburífera en aquellas que integran el Patrimonio de Áreas Naturales del Estado.

\section{La falta de reconocimiento del consentimiento en la consulta previa para los pueblos indígenas}

La consulta previa a los pueblos indígenas está regulada tanto en el Convenio 169 de la OIT, como en la Declaración de las Naciones Unidas sobre los Derechos de los Pueblos Indígenas, estos instrumentos internacionales se reflejan en el artículo 57 numeral 7 de la Constitución que dispone: "Se reconoce y garantizará a las comunas, comunidades, pueblos y nacionalidades indígenas, de conformidad con la Constitución y con los pactos, convenios, declaraciones y demás instrumentos internacionales de derechos humanos, los siguientes derechos colectivos: 7. La consulta previa, libre e informada, dentro de un plazo razonable, sobre planes y programas de prospección, explotación y comercialización de recursos no renovables que se encuentren en sus tierras y que puedan afectarles ambiental $o$ culturalmente; participar en los beneficios que esos proyectos reporten y recibir indemnizaciones por los perjuicios sociales, culturales y ambientales que les causen. La consulta que deban realizar las autoridades competentes será obligatoria y oportuna. Si no se obtuviese el consentimiento de la comunidad consultada, se procederá conforme a la Constitución y la ley".

En cuanto a este tema se aprecia un aspecto regresivo, la abogada Patricia Carrión al respecto nos dice: "en el Ecuador (la consulta previa a los pueblos indígenas) no ha sido regulada de manera adecuada, en especial tomando en consideración los parámetros mínimos que establecen los instrumentos internacionales de derechos humanos analizados en la presente investigación, pues se observa en los casos una clara discrecionalidad en la aplicación del mismo."

Sobre el mismo tema la abogada Carrión señala "El objetivo de la consulta es lograr el consentimiento o acuerdo previo a la adopción de las medidas estatales, de las comunidades, comunas, pueblos o nacionalidades afectadas; lo cual permite la vigencia de otros derechos interrelacionados al derecho de consulta, como el de acceso a la información y justicia; la participación de las colectividades en la toma de decisiones estatales que afecten sus derechos colectivos o territorios; y la libre autodeterminación de los pueblos. Sin embargo, el consentimiento previo, no está reconocido en la Constitución ecuatoriana, pero si en los instrumentos internacionales de derechos humanos que forman parte de nuestra legislación, que incluyen las sentencias de la CIDH."

\section{En materia ambiental son regresivos algunos tipos penales del recientemente expedido Código Integral Penal}

En el derecho penal ambiental se tipifican conductas que pueden tener resultados de peligro para el bien jurídico protegido, son los llamados delitos de peligro concreto y abstracto, este tipo de delitos no aparecen en el recientemente expedido Código Integral Penal ${ }^{26}$ lo que implica un claro retroceso en relación al anterior Código Penal. Respecto a este tipo de delitos

\footnotetext{
${ }^{26}$ Expedido mediante el Suplemento del Registro Oficial No 180, el 10 de Febrero de 2014
} 
la tratadista Isabel de los Ríos afirma::" "Entre varias categorías, los delitos pueden clasificarse en delitos de lesión y de peligro. El tipo de peligro describe conductas que amenazan un bien jurídico de interés colectivo y de trascendencia tan grande que no se requiere que, efectivamente, causen lesión para castigar al sujeto activo; basta poner en peligro el bien tutelado. El delito ecológico es un delito de peligro. Se protege, así, el bien jurídico, el cual no requiere que sea destruido, es suficiente la simple amenaza de degradarlo".

Sobre este tema, es importante recordar que en una visita al Ecuador, el Fiscal Federal de Argentina, Dr. Gustavo Gómez, resaltó el retroceso del Código Integral Penal debido a que no tipifica delitos de peligro sino que enfatiza únicamente el daño. ${ }^{28}$

El cuadro a continuación señala ejemplos comparativos entre los dos cuerpos legales.

\section{Código Penal Anterior}

Art. 437-A.- Quien, fuera de los casos permitidos por la ley, produzca, introduzca, deposite, comercialice, tenga en posesión, o use desechos tóxicos peligrosos, sustancias radioactivas, u otras similares que por sus características constituyan peligro para la salud humana o degraden y contaminen el medio ambiente, serán sancionados con prisión de dos a cuatro años.

Igual pena se aplicará a quien produzca, tenga en posesión, comercialicen introduzca armas químicas o biológicas.

\section{Código Integral Penal}

Artículo 254.- Gestión prohibida o no autorizada de productos, residuos, desechos o sustancias peligrosas.

La persona que, contraviniendo lo establecido en la normativa vigente, desarrolle, produzca, tenga, disponga, queme, comercialice, introduzca, importe, transporte, almacene, deposite 0 use, productos, residuos, desechos y sustancias químicas o peligrosas, y con esto produzca daños graves a la biodiversidad y recursos naturales, será sancionada con pena privativa de libertad de uno a tres años.

Será sancionada con pena privativa de libertad de tres a cinco años cuando se trate de:

1. Armas químicas, biológicas o nucleares.

2. Químicos y Agroquímicos prohibidos, contaminantes orgánicos persistentes altamente tóxicos y sustancias radio-activas.

3. Diseminación de enfermedades o plagas.

4. Tecnologías, agentes biológicos experimentales $u$ organismos genética-mente modificados nocivos y perjudiciales para la salud humana o que atenten contra la biodiversidad y recursos naturales.

Si como consecuencia de estos delitos se produce la muerte, se sancionará con pena privativa de libertad de dieciséis a diecinueve años.

\footnotetext{
27 "La responsabilidad Penal Ambiental" Isabel de los Ríos. http://www.pnuma.org

${ }^{28}$ Ver https://www.youtube.com/watch?v=GGaYMuq5r-k
} 
Art. 437-B.- El que infringiere las normas sobre protección del ambiente, vertiendo residuos de cualquier naturaleza, por encima de los límites fijados de conformidad con la ley, si tal acción causare o pudiere causar perjuicio o alteraciones a la flora, la fauna, el potencial genético, los recursos hidrobiológicos o la biodiversidad, será reprimido con prisión de uno a tres años, si el hecho no constituyere un delito más severamente reprimido.
Artículo 253.- Contaminación del aire.- La persona que, contraviniendo la normativa vigente o por no adoptar las medidas exigidas en las normas, contamine el aire, la atmósfera o demás componentes del espacio aéreo en niveles tales que resulten daños graves a los recursos naturales, biodiversidad y salud humana, será sancionada con pena privativa de libertad de uno a tres años.

\section{Instrumentos administrativos regresivos}

Algunos instrumentos administrativos ambientales del Ecuador son claramente regresivos.

El Decreto Ejecutivo 1040, publicado en el Registro Oficial No. 332, que contiene el Reglamento de Participación establecidos en la Ley de Gestión Ambiental en opinión del abogado Wilton Guaranda "limita el ejercicio de los derechos de los pueblos indígenas y de la ciudadanía en general debido a que no se garantiza que la opinión de los consultados vaya a ser tomada en cuenta por el Estado o los particulares, mucho menos que se busque el consentimiento de las nacionalidades indígenas. Además porque se contradice a la disposición Derogatoria de la Constitución vigente, que establece que "se deroga toda norma contraria a esta Constitución, sólo el resto del ordenamiento jurídico permanecerá vigente en cuanto no sea contrario a la Constitución".

Sobre este decreto Gabriela Muñoz ${ }^{29}$ señala: "El Decreto 1040 deja de lado entonces la posibilidad de participación en espacios previos como son la discusión y formulación de las políticas, estrategias, normas y regulaciones ambientales de las cuales finalmente depende o no el inicio de un proyecto. Por otra parte, es importante mencionar que en caso de que los actores que intervinieron en el proceso de participación se oponen a la actividad o proyecto, esto no es determinante para suspender la actividad, pues finalmente depende de la decisión de la autoridad competente como se lee del Artículo 22 del Decreto 1040: "Si una vez realizada la participación social prevista en este Reglamento, los sujetos de la participación social se opusieren a la actividad o proyecto que genere impacto ambiental, ésta no podrá llevarse a cabo, a menos que la autoridad competente insista en su realización, lo cual será resuelto por la instancia superior".

Pero las críticas al Decreto no terminan allí, pues si bien el Decreto afirma que uno de sus fines es el precisar los mecanismos determinados en la Ley de Gestión Ambiental a ser utilizados en los procedimientos de participación social, excluye uno de los mecanismos más importantes de participación social: la Consulta, estipulada en la Constitución del Ecuador ${ }^{30}$ (artículo 398) no solo como un mecanismo, sino principalmente como un derecho. Así, si bien el principio de participación atraviesa la Constitución y la misma abre puertas importantes para el fomento de

29 ¿Avances o Retrocesos? Participación, derechos y ambiente Gabriela Muñoz Directora Ejecutiva CEDA Julio 2010.

30 "Art. 398.- Toda decisión o autorización estatal que pueda afectar al ambiente deberá ser consultada a la comunidad, a la cual se informará amplia y oportunamente. El sujeto consultante será el Estado. La ley regulará la consulta previa, la participación ciudadana, los plazos, el sujeto consultado y los criterios de valoración y de objeción sobre la actividad sometida a consulta. El Estado valorará la opinión de la comunidad según los criterios establecidos en la ley y los instrumentos internacionales de derechos humanos. Si del referido proceso de consulta resulta una oposición mayoritaria de la comunidad respectiva, la decisión de ejecutar o no el proyecto será adoptada por resolución debidamente motivada de la instancia administrativa superior correspondiente de acuerdo con la ley." 
la participación ciudadana en aspectos que están estrechamente relacionados con el derecho a vivir en un ambiente sano y con la consulta sobre actividades que les afecten; normativas como el Decreto 1040 no solo evidencian un retroceso en estos aspectos, sino también podría derivar en la inconstitucionalidad, que en un momento dado deberán ser resueltas por la Corte Constitucional, que es en última instancia la institución que debe velar porque los derechos plasmados en la Constitución no se vulneren".

Por otro lado, el Decreto Ejecutivo 2187 del año 2007, mediante el cual el Gobierno de Alfredo Palacio determinó los límites del Parque Nacional Yasuní y la Zona intangible, reformando el Decreto Ejecutivo \# 552, publicado en el Registro Oficial Suplemento \#121 del año 1999 en que se declaró inicialmente la zona intangible de conservación afecta al principio de no regresión porque disminuyó la protección de la zona intangible.

En opinión del abogado Wilton Guaranda si bien este Decreto se dictó "bajo la potestad de la anterior Constitución Política que no prescribía la intangibilidad explícita de las tierras de comunidades indígenas, este Decreto disminuyó el grado de protección que se había establecido para los pueblos en aislamiento voluntario, en adelante PAV, debido a que el Decreto de 1999 establecía que la zona intangible de conservación estaba vedada a perpetuidad a todo tipo de actividad extractiva, y que esta zona comprendía las tierras de habitación y desarrollo de los grupos Huaorani conocidos como Tagaeri, Taromenane y otros eventuales que permanecen sin contacto, ubicadas hacia el sur de las tierras adjudicadas a la nacionalidad Huaorani en 1990 y del Parque Nacional Yasuní. Con la expedición del Decreto del año 2007, se delimita la zona intangible a un área que alcanza 758.051 hectáreas (setecientas cincuenta y ocho mil cincuenta y un hectáreas), que se ubican en las parroquias de Cononaco y Nuevo Rocafuerte, cantón Aguarico, provincia de Orellana.

Este Decreto está en clara contraposición a los principios constitucionales de la vigente constitución. Primeramente porque desatiende el principio constitucional de no regresividad y progresividad de los derechos y las políticas públicas en beneficios de la protección de los derechos, segundo, porque limita el área de territorio destinada para los pueblos en aislamiento voluntario, que según expertos en el tema abarca una mayor cantidad, tercero porque desde su concepción el estado inobservó algunas recomendaciones de la Comisión Interamericana de Derechos respecto de medidas cautelares eficaces para la protección de la integridad física de los PAV. Con esta reforma y fijación de límites de zona intangible se ha dado lugar a concesiones petroleras dentro del Parque Nacional Yasuní, en una zona cercana a los sitios donde se ha constatado la presencia de estos grupos."

\section{Aspectos regresivos de la Ley de Gestión Ambiental}

Esta Ley expedida en 1999 establece un marco general de políticas para el manejo ambiental del país, mediante la implantación del Sistema Nacional Descentralizado de Gestión Ambiental, bajo la rectoría del Ministerio del Ambiente como autoridad ambiental nacional. La Ley también señala que el estado deberá desarrollar algunas acciones estratégicas para fortalecer la gestión ambiental, como el llevar a cabo un ordenamiento territorial nacional con enfoque ecosistémico; el valorar el ambiente y la biodiversidad del Ecuador introduciéndolo en las cuentas nacionales y elaborar el plan ambiental ecuatoriano. Estos tres temas claves para la gestión ambiental del país aún siguen en proceso de ser ejecutados lo que demuestra una actitud regresiva del estado considerando que tanto el ordenamiento territorial nacional, la valoración económica del ambiente y la puesta en práctica de un plan ambiental constituyen elementos estructurales para que la política ambiental del Ecuador se oriente hacia enfoques transversales que internalicen la variable ambiental en las políticas de desarrollo. Se podría afirmar que el Código Orgánico de Ordenamiento Territorial Autonomías y Descentralización ya obliga a los gobiernos autónomos descentralizados a incluir dentro de sus planes de desarrollo 
y de ordenamiento territorial, enfoques de sustentabilidad ambiental, lo cual concuerda con los mandatos del Código Orgánico de Planificación y Finanzas Públicas, pero como matriz central se debe lograr que el ordenamiento territorial nacional además incluya la visión ecosistémica como manda la Ley de Gestión Ambiental.

Otro factor que podríamos considerarlo como regresivo en esta Ley es el haber omitido desde 1999, fecha en la que se la expidió, la reglamentación íntegra de la Ley, pues únicamente se han reglamentado principalmente las disposiciones relacionadas con la evaluación de impacto ambiental pero entre otros temas no se ha reglamentado el Sistema Nacional Descentralizado de Gestión Ambiental lo que ha mantenido a esta figura administrativa en la esfera meramente declarativa y que hasta el día de hoy, aunque consta en la Constitución de la República, ${ }^{31}$ no es utilizado como el mecanismo de coordinación y cooperación interinstitucional como manda la Ley. Este sistema es señalado en los considerandos de algunas leyes, reglamentos, acuerdos y resoluciones ministeriales pero ha servido solo como enunciado sin haber operado de manera práctica para llevar adelante una política ambiental transversal. Por último, esta ley no contiene un capítulo completo de sanciones administrativas, mismas que han sido objeto de regulación mediante normas infralegales como el Texto Unificado de la Legislación Ambiental Secundaria contravenido al principio constitucional de reserva de ley. ${ }^{32}$

\section{La falta de regulación en materia de responsabilidad por daños ambientales}

La responsabilidad por daño ambiental incluye, según la Constitución del 2008, entre otros temas la responsabilidad objetiva y la obligación de restaurar integralmente el daño causado o restauración in natura, sin embargo estas especialísimas reglas sobre la responsabilidad por daño ambiental hasta el momento no han sido materia de ley secundaria que desarrolle en detalle la normativa constitucional sobre la responsabilidad por daño ambiental. Esto evita que cuestiones técnicas que se puedan derivar de la responsabilidad por daño ambiental como de los derechos de la naturaleza no tengan suficiente claridad y caigan en la facultad discrecional que tienen los jueces para interpretar la aplicación de las disposiciones constitucionales.

\section{La falta de una ley para normar la conservación y uso sostenible de la diversidad biológica}

Se aprecian políticas regresivas para la implementación del Convenio sobre la Diversidad Biológica si consideramos que la Ley para la Protección de la Biodiversidad del Ecuador expedida en 1996, es una Ley de dos artículos que se limita a declarar a la biodiversidad como un bien nacional de uso público. ${ }^{33}$ La falta de una legislación integral que internalice en el país

\footnotetext{
${ }^{31}$ Art. 399.- El ejercicio integral de la tutela estatal sobre el ambiente y la corresponsabilidad de la ciudadanía en su preservación, se articulará a través de un sistema nacional descentralizado de gestión ambiental, que tendrá a su cargo la defensoría del ambiente y la naturaleza.

${ }^{32}$ Los artículos 80 y 125 del Libro Vi del Texto Unificado de la Legislación Ambiental Secundaria señalan multas contraviniendo al principio de reserva legal establecido por el artículo 76 numeral 3 de la Constitución de la República que señala: Art. 76.- En todo proceso en el que se determinen derechos y obligaciones de cualquier orden, se asegurará el derecho al debido proceso que incluirá las siguientes garantías básicas: Nadie podrá ser juzgado ni sancionado por un acto u omisión que, al momento de cometerse, no esté tipificado en la ley como infracción penal, administrativa o de otra naturaleza; ni se le aplicará una sanción no prevista por la Constitución o la ley. Sólo se podrá juzgar a una persona ante un juez o autoridad competente y con observancia del trámite propio de cada procedimiento.

${ }^{33}$ Estrategia Nacional de Biodiversidad y Plan de Acción 2014 "Durante los últimos años de la década de los noventa del siglo XX, el Ministerio del Ambiente y otros actores comprometidos con la problemática ambiental, entre los que se destacó el Comité Ecuatoriano de Defensa de la Naturaleza, CEDENMA, emprendieron un amplio proceso de debate en torno a una nueva normativa legal que regule la
} 
las obligaciones del Convenio de Diversidad Biológica y sus políticas, evidencian una actitud regresiva del estado en esta materia. La política sobre biodiversidad está sujeta al cumplimiento de las estrategias nacionales que no tienen obligatoriedad jurídica. A la fecha, el país se encuentra actualizando su estrategia nacional de biodiversidad, que por primera vez contiene un plan de acción.

\section{Conclusiones}

El principio de no regresión en materia ambiental en el Ecuador, hasta el momento no ha sido objeto de resoluciones o sentencias judiciales como en otros países, pero cabe afirmar que las contradicciones, falta de claridad, precisión y desarrollo legal de los temas que se han señalado, han creado un panorama regresivo disminuyendo la efectividad de la legislación ambiental. Temas como la utilización del interés nacional en la Constitución para contravenir logros alcanzados por el derecho ambiental internacional con respecto a la intangibilidad de las áreas protegidas, o la falta de un desarrollo legislativo que internalice los preceptos del Convenio de Diversidad Biológica en un país megadiverso como el Ecuador y la inseguridad jurídica que se crea al regular sanciones mediante reglamentos contraviniendo al principio de reserva legal, nos demuestran una actitud regresiva del legislador ecuatoriano en materia ambiental, tal vez influenciada por políticas económicas que se apartan del modelo de sustentabilidad ambiental.

Sin duda el mayor avance en materia de legislación ambiental en el Ecuador ha sido la expedición de la Constitución del 2008, sin embargo como se ha visto, existen algunos temas que podrían ser considerados regresivos tanto en la misma Constitución como en las leyes secundarias y en los reglamentos. En este análisis se destacan tres criterios señalados por el jurista Mario Peña Chacón, que han servido para determinar la regresividad en materia ambiental de la legislación ambiental del Ecuador. El primero es la "ausencia o insuficiencia de justificación y respaldo técnico-científico que permita determinar, en grado de certeza, la no afectación al bien tutelado", lo cual aplica en el caso de la declaratoria de interés nacional para permitir las actividades extractivas en el Parque Nacional Yasuní; el segundo, se refiere a la "omisión de reglamentación de normas ambientales indispensables para su cumplimiento", que se relaciona con el caso de la falta de ley secundaria para regular los derechos de la naturaleza y para internalizar el Convenio sobre Diversidad Biológica y el tercero es "el incumplimiento en la aplicación de la legislación ambiental tornándola absolutamente ineficaz", lo cual tiene que ver con algunos acápites de la Ley de Gestión Ambiental y con los instrumentos administrativos y reglamentarios que han sido señalados.

Frente a este panorama, se espera que la expedición del Código Orgánico del Ambiente que esta siendo discutido actualmente en la Asamblea Nacional dentro del trámite legislativo correspondiente, logre corregir en algunos de los aspectos regresivos que se han señalado en este documento.

conservación y aprovechamiento sostenible de la biodiversidad con criterios acorde a los compromisos que el Ecuador había asumido en Instrumentos Internacionales, especialmente el Convenio de Diversidad Biológica. Ese proceso llevó a la formulación de un Proyecto de Ley para la Conservación y Manejo Sustentable de la Biodiversidad, que fue tramitado en el Congreso Nacional hasta segundo debate, en el año 2003. Falta de consensos con diferentes sectores sociales, impidió la aprobación del proyecto en el Congreso Nacional.

Al final, el 22 de julio de 2004 la legislatura aprobó una Codificación a la Ley que protege la Biodiversidad en el Ecuador, publicada en el Registro Oficial S-418 de 10 de septiembre de 2004, con tan solo dos artículos." 


\section{Bibliografía}

Charpentier S. e Hidalgo J, Las Políticas Ambientales en el Perú 1999. Disponible en: http://cdam.minam.gob.pe/publielectro/impacto\%20ambiental/Politicaambientalperu.pdf.

Crespo Plaza R."Perspectivas Futuras del Derecho Ambiental" Revista IURIS DICTIO. Diciembre 2003. Año III No 7.

El Principio de No Regresión Ambiental en el Derecho Comparado Latinoamericano PNUD 2013 disponible en: https://cmsdata.iucn.org/downloads/principio_no_regresion8.pdf.

Estrategia Nacional de Biodiversidad y Plan de Acción 2014 ( Documento en revisión)

Guaranda W, Acciones jurídicas para establecer responsabilidades por daño ambiental en el Ecuador Serie Investigación \# Octubre 2010. Disponible en:

http://www.inredh.org/archivos/libros/acciones_juridicas.pdf.

Melo M. Los derechos de la Naturaleza. LíNEASUR 5 REVISTA DE POLÍTICA EXTERIOR MAY/AG0 2013 N. 5, mayo-agosto, 2013 ISNN 1390-6771 Vol. II, Issue 5, May-August, 2013 Quito, Ecuador.

Melo M. Derechos de la Naturaleza, Globalización y Cambio Climático http://www.lineasur.gob.ec/index.php?option=com_content\&view=article\&id=75\&catid=22.

Muñoz G. ¿Avances o Retrocesos? Participación, derechos y ambiente, Julio 2010. Disponible en: http://www.accessinitiative.org/blog/2010/07/participacion-derechos-y-ambiente-\%C2\%BF avances-0-retrocesos.

Naciones Unidas. El Futuro que Queremos. Disponible en:

https://rio20.un.org/sites/rio20.un.org/files/a-conf.216-I-1_spanish.pdf.pdf.

Ost F. Naturaleza y Derecho. Para un debate ecológico a profundidad. Ediciones Mensajero. 1996.

Peña Chacón M. El test de regresividad ambiental. Artículo e producto del Proyecto de Investigación denominado "Las clínicas del Derecho Ambiental y Gestión de Riesgos Climáticos a través de una cultura jurídica de la sostenibilidad y no regresión" inscrito ante la Vicerrectoría de Investigación y el Instituto de Investigaciones Jurídicas de la Universidad de Costa Rica bajo el código 722-B3-193.

Suarez S. CEDA Temas de análisis No 27 Noviembre de 2012. "Efectivizarían de los derechos de la naturaleza: evolución jurisprudencial"

Disponible en: http://www.ceda.org.ec/temas-de-analisis/.

Yépez P. De la Torre Stella. Propuesta de indicadores y procesos para evaluar la afectación a los derechos de la naturaleza, Marzo 2012. 


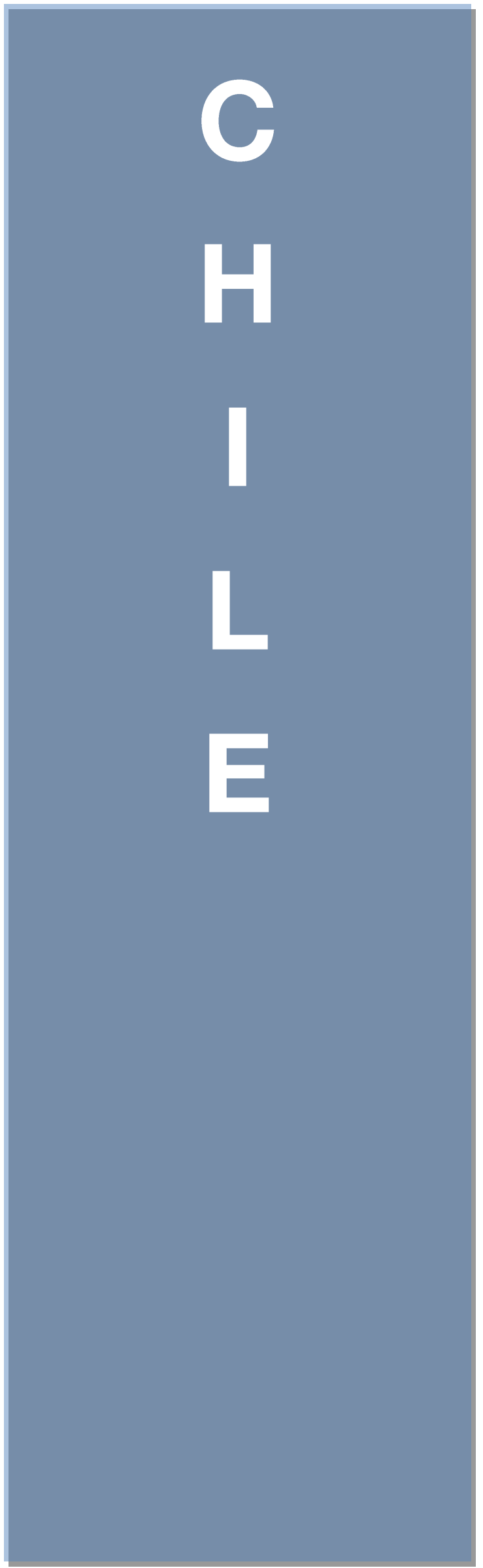





\title{
UNA APROXIMACIÓN AL PRINCIPIO DE PROHIBICIÓN DE REGRESO EN CHILE: DESDE LA INTEGRACIÓN INTERNACIONAL A LA APLICACIÓN JURÍDICA
}

\author{
Jorge Aranda Ortega*
}

\section{Introducción}

La presente entrega intenta delinear elementos para aproximarse al principio de prohibición de regreso en el contexto chileno, asumiendo como punto de partida que no se ha desarrollado ni se ha discutido mayormente en la literatura nacional. Para llevar adelante esta aproximación, primero explicaré el contexto político de apertura comercial que propició la creación de normas que podrían sustentar la prohibición de regreso en Chile; luego, explicaré como se concretó la normativa ambiental chilena para apoyar y acompañar ese proceso político. A continuación, explicaré cómo en detalle los textos que servirían para dar un soporte normativo al principio de prohibición de regreso, a saber, el principio de gradualidad y algunos tratados de libre comercio suscritos por Chile. Con posterioridad, señalaré un par de casos, a propósito de las áreas protegidas, para señalar que tan carente de este principio se encuentra la práctica jurídica chilena, y como podría ayudar en la resolución concreta de cuestiones ambientales, para, finalmente, señalar mis conclusiones.

\section{Antecedentes políticos para explicar la normativa asociada a la prohibición de regreso en Chile}

La historia de las leyes ambientales en Chile es, en buena parte, la historia de su inserción económica en un mundo globalizado. Con esta frase no es mi intención desmerecer el trabajo del activismo ambiental chileno, mas es necesario reconocer que cuando los intereses de integración política y comercial de Chile se han alineado, siquiera parcialmente, con los intereses de protección del entorno, sólo en esas circunstancias, es cuando más se ha avanzado en la protección ambiental a nivel legal.

Para esta afirmación es sólo necesario revisar someramente la historia de la política económica reciente de Chile, desde la dictadura hasta el día de hoy. En primer orden de cosas, con la ascensión al poder de los militares, ellos en lugar de seguir políticas centralistas y de aspiraciones planificadoras, asumieron doctrinas económicas liberales, las cuales fueron influenciadas por la escuela de economía de la Universidad Católica de Chile, la que a su vez fue influenciada por la escuela económica de la Universidad de Chicago ${ }^{1}$. Dentro de estas ideas, una vertebral del programa económico de los militares fue la liberalización y apertura económica. Así, dentro de los objetivos de política económica se aseveró que "...La apertura a1 comercio exterior, el aumento de la competencia y una decidida política antimonopolios son fundamentales para evitar o eliminar estas tendencias [proteccionismo industrial e interferencia del gobierno] en el campo empresarial..."2

\footnotetext{
* Magíster en Derecho. Universidad de Chile. Profesor Asistente. Centro de Derecho Ambiental. Universidad de Chile.

${ }^{1}$ AA.VV. Bases de La política económica del gobierno militar. Centro de Estudios Públicos. Chile. 1992. $7 \mathrm{p}$.

${ }^{2}$ Ibíd. 47p.
} 
Esta política de libre mercado tuvo un fuerte desarrollo a nivel normativo interno en una serie de reformas que liberalizaron el uso de los recursos naturales ${ }^{3}$ y fomentaron la competencia libre entre diversos actores ${ }^{4}$. Sin embargo, la comunidad internacional no acogió totalmente a Chile en su seno, en rechazo a su régimen contrario a la democracia. Por ende, si bien hubo una liberalización económica efectiva en el ámbito interno, ello no necesariamente significó una integración en el ámbito internacional. ${ }^{5}$

Con el término de la dictadura y el surgimiento de la democracia, Chile vio posibilidades de ampliar su integración política y comercial a nivel internacional, abriéndose a nuevas posibilidades para desarrollar una economía basada en el aprovechamiento de recursos naturales. Con todo, el regreso de la democracia no cambió la tendencia liberalizadora del gobierno militar, sino que, y por el contrario, estos procesos se profundizaron con la privatización de empresas estatales ${ }^{6}$, el surgimiento de la educación de mercado ${ }^{7}$, y en el ámbito internacional, mediante la suscripción de tratados de libre comercio ${ }^{8}$.

Así, Chile para poder acceder a nuevos mercados y vender materias primas, constantemente ha tenido que demostrar a la comunidad internacional que cumple con estándares mínimos de respeto al libre comercio de mercancías, al Estado de Derecho y a los Derechos Fundamentales y Humanos para gozar de la aceptación de sus pares en la comunidad internacional. En el campo ambiental, además, se ha tenido que demostrar que se cumple con una protección al medio ambiente no sólo en razón de los deberes de protección mencionados, sino también como una forma de evitar el llamado "dumping ambiental", estos es, abaratar los costos de producción mediante el daño al entorno, en razón de que la generación de externalidades negativas que otros estados internalizan de dichas externalidades negativas de modo adecuado.

Por ello, el asumir estándares ambientales progresivos surge primero a nivel interno post dictadura, para luego comenzar un proceso de expansión y liberalización económica internacional mediante tratados de libre comercio. A continuación, revisaremos cómo la normativa interna se ha adecuado ambientalmente a esta apertura.

\footnotetext{
${ }^{3}$ Un buen ejemplo de ello es la dictación del Código de Aguas de 1981, que establece el derecho real de aprovechamiento, que en la práctica, es la propietarización del uso y consumo de las aguas en Chile, pudiendo estos derechos ser vendidos libremente.

${ }^{4}$ Un buen ejemplo de esta preocupación política y normativa fue la dictación del Decreto Ley 211 que fija las normas para la defensa de la libre competencia en diciembre de 1973, a sólo meses del golpe de Estado.

${ }^{5}$ En relación a la pérdida de integración a la comunidad internacional: Rodríguez, José. Chile: un caso de subdesarrollo exitoso. Del Estado en forma de Portales, al Estado en formación de Lagos. Editorial Andrés Bello. Chile. 2002. pp. 35-39

${ }^{6}$ Para ejemplificar esta cuestión, se puede revisar el proceso de privatización de las empresas sanitarias que comenzó en la dictadura y tuvo continuidad en la democracia. Ver: Pflieger, Géraldine. Historia de la universalización del acceso al agua y alcantarillado en Santiago de Chile (1970-1995). En: EURE. vol.34, n.103. Santiago. Chile. ISSN 0250-7161. pp. 144-145.

${ }^{7}$ Lo que es un reflejo de la antigua Ley Orgánica Constitucional de Enseñanza № 18.962 de 1990, que permitió el tratamiento de la educación como un bien de consumo durante los gobiernos democráticos.

${ }^{8}$ Vid. Supra 4.2.
} 


\section{Creación de las leyes $N^{\circ} 19.300$ de 1994 de Bases Generales del Medio Ambiente y No 20.417 de 2010 que crea el Ministerio de Medio Ambiente como elementos integradores en la comunidad internacional}

La inserción global de Chile, a lo menos en el ámbito del comercio, ha dependido de la modernización de sus políticas, instituciones, y leyes. No es novedad que en el proceso post dictadura de regreso y fortalecimiento de la democracia se han efectuado esfuerzos en ese sentido. El que interesa, para los propósitos de este texto, es la modernización de las leyes e institucionalidad ambiental.

Como se aseveró, parte de la inserción comercial global de Chile dependió de la modificación de su normativa ambiental. Hasta antes de 1994, Chile no contaba con una ley marco del cuidado del medio ambiente, lo que lo dejaba al país rezagado respecto de similares procesos legislativos en la región ${ }^{9}$. En lugar de ello, Chile contaba con 718 textos legales de relevancia ambiental, de diferentes jerarquías ${ }^{10}$, careciendo de principios generales ${ }^{11}$.

Entonces, además de existir una necesidad de dar coherencia a la normativa preexistente y de proteger el derecho a vivir en un medio ambiente libre de contaminación, se expresó manifiestamente, en la discusión parlamentaria de ese entonces, la necesidad de adaptar la normativa ambiental chilena a las necesidades de la apertura comercial ${ }^{12}$.

Fruto de este proceso legislativo, se logró crear una institucionalidad ambiental: La Comisión Nacional de Medio Ambiente, y las Comisiones Regionales de Medio Ambiente ${ }^{13}$. También, a nivel de gestión, se consagró normativamente el sistema de evaluación de impacto ambiental ${ }^{14}$.

Con posterioridad, las reformas del año 2010 en materia ambiental también responden a una idea similar de integración internacional: el ingreso de Chile a la Organización para la

\footnotetext{
9 Buenos ejemplos son la Política Nacional de Medio Ambiente de Brasil de 1981, y el Código de Recursos Naturales Renovables y Protección al Medio Ambiente de Colombia, de 1973.

${ }^{10}$ Biblioteca del Congreso Nacional. Historia de la ley № 19300 de 1994 de Bases Generales de Medio Ambiente. [En línea]

http://www.leychile.cl/Navegar/scripts/obtienearchivo?id=recursoslegales/10221.3/2429/1/HL19300.pdf $10 \mathrm{p}$.

11 Ídem.

12 Podemos revisar las opiniones de la discusión en Sala en el Senado, en el segundo trámite constitucional, del senador de ese entonces Martinez: “...Pues bien, nuestras posibilidades de continuar exportando hacia los actuales mercados y abrir otros nuevos dependen del cumplimiento del requisito de carácter ecológico que nos imponen los países compradores. El incumplimiento de tales requerimientos puede transformarse en obstáculos para las actuales formas de comercio bilateral que desarrollamos y seguramente, dificultará nuestra incorporación a tratados multilaterales de libre comercio..." En: Historia de la ley $\mathrm{N}^{\circ}$ 19.300. Op. Cit. 674p. También las opiniones del entonces senador Álvarez-Salamanca: “...En el nivel internacional, el país deberá seguir participando en la definición de políticas, tratados y acciones de cooperación multilaterales que conduzcan a la reducción del deterioro ambiental de tipo global, así como al otorgamiento de un respaldo técnico y, en lo posible, financiero, a los países más pobres para que manejen sus recursos naturales dentro de criterios, de desarrollo sustentable, procurando transferir hacia ellos toda la experiencia en gestión ambiental y el conocimiento de las soluciones tecnológicas de que disponen los países más avanzados en la materia para evitar con ello la utilización de regulaciones ambientales destinadas a establecer barreras al comercio y las inversiones..." En: Ibíd. 717p. Por su parte, el senador Faulbaum señaló: “...Por lo demás, esto ya se ha entendido en las sociedades más desarrolladas, y por lo mismo crece la imposición que hacen en el sentido de que los productos que se comercialicen hacia sus mercados deban cumplir con exigencias medioambientales cada vez más rigurosas. Allí están, por ejemplo, las exigencias de la Comunidad Económica Europea en esta materia. Sin dudas, nuestro avance en materia de conservación y preservación”... En: Ibíd. 719p. Como se lee, en todas estas opiniones, la integración pasa por la mejora de la normativa ambiental.

${ }^{13}$ Artículos 69 y 70 del texto original de la ley № 19.300 de 1994 de bases generales del medio ambiente.

${ }^{14}$ Artículos 8 y siguientes de la ley $N^{\circ} 19.300$ de 1994 de bases generales del medio ambiente.
} 
Cooperación y el Desarrollo. Ya desde el ingreso del mensaje presidencial al Congreso, se destacó que la necesidad de modernización de la institucionalidad ambiental chilena respondía, entre otras cosas, a que sin dichas reformas se condicionaba el ingreso de Chile a dicha organización ${ }^{15}$. De esta forma, con más prisa que reflexión, y fruto de transacciones políticas, se logró la creación de la institucionalidad originalmente fue ideada, más dos organismos no previstos en el mensaje original de la presidenta Bachelet: un Consejo de Ministros para la Sustentabilidad ${ }^{16}$, para mantener los intereses políticos de diferentes carteras sectoriales en la toma de decisiones en materia ambiental, y los Tribunales Ambientales ${ }^{17}$, como un contrapeso a la labor fiscalizadora de la Superintendencia del Medio Ambiente.

Estas reformas, además de lograr un mejoramiento de la legislación ambiental chilena, han significado la inserción internacional de Chile. No en vano, desde 1994 a la fecha, Chile ha suscrito varios tratados de libre comercio, los cuales, ya sea explícita o implícitamente, tratan del cuidado al medio ambiente para efectos del libre comercio de bienes y servicios. También, Chile logró ingresar a la OCDE en el año 2010.

Desde estas mejoras normativas relacionadas con la apertura de Chile, y al menos desde las noticias que se disponen, nunca la literatura jurídico ambiental chilena ha tratado de forma acabada y en extenso la prohibición de regreso como un principio de derecho ambiental. Sólo se ha tratado de forma explícita la necesidad de reformas graduales a la normativa, sindicado esto como el principio de gradualidad, y en los tratados de libre comercio de modo implícito, señalando que la desmejora de la normativa ambiental no puede ser aceptada, pues se constituiría como una forma vulnerar las reglas de comercio internacional. Veamos a continuación cómo se ha consagrado esto.

\section{Textos legales que se relacionan con el principio de prohibición de regreso en Chile}

Si bien la doctrina reconoce una suerte de inmanencia de los principios de derecho ambiental, siempre es necesario reconocer algún texto, opinión doctrinaria, o práctica legal que permita afirmar su existencia. Así, en mi opinión, el estudio de los principios de derecho ambiental dista de ser una revelación otorgada por un pensamiento jurídico meramente teórico, sino que son una constatación en la práctica y en el discurso jurídico.

Previo a procurar un asidero normativo adecuado, podemos perfilar al principio de prohibición de regreso, señalando que "...la normativa y la jurisprudencia ambiental no deberían ser revisadas si esto implicare retroceder respecto a los niveles de protección alcanzados con

\footnotetext{
${ }^{15}$ En ese sentido: “...El ingreso de Chile a la Organización de Cooperación y Desarrollo Económico, $O C D E$, exigirá en esta materia el sometimiento permanente a escrutinio público de la idoneidad de nuestras políticas ambientales, lo que nos obligará a actuar con seriedad y con criterios de eficiencia y calidad en nuestra gestión ambiental. Esto ya tiene una manifestación concreta en las 52 recomendaciones emanadas de la OCDE, como resultado de la evaluación de desempeño ambiental que le hicieran a nuestro país en el año 2005. Pertenecer a la OCDE impondrá en materia ambiental un elevado estándar a nuestras políticas públicas y a la calidad de nuestro crecimiento. Sólo para tener como referencia, en la precitada organización Medio Ambiente es el sector con mayor número de actos e instrumentos a los cuales los países miembros deben dar respuesta. Estos actos, denominados Decisiones y Recomendaciones -representan alrededor del $20 \%$ del total de actos de la organización- y es Medio Ambiente el área que cuenta con el mayor número de comités operativos, dada la cantidad de temas específicos identificados como relevantes por esta organización..." En: Biblioteca del Congreso Nacional. Historial de la ley 20.417 de 2010. [en línea]

http://www.leychile.cl/Navegar/scripts/obtienearchivo?id=recursoslegales/10221.3/3929/6/HL20417.pdf $6 \mathrm{p}$.

${ }^{16}$ Ibíd. 190p, y 193p., lo que se efectuó vía indicación del poder ejecutivo.

17 Ibíd. 1494p.
} 
anterioridad...,18 Dicho de otro modo, y en atención al mejoramiento continuo de la normativa ambiental, no es posible establecer leyes que, a la posteridad, se tornen menos exigentes en desmedro del cuidado del entorno; si así fuera, la normativa ambiental tendría un rol meramente simbólico, desviándose de su objetivo último, a saber, la protección de los ecosistemas que sirven de soporte de vida en el planeta.

En el caso chileno, podemos atender al principio de prohibición de regreso desde dos elementos relacionados con la apertura del país post dictadura: el principio de gradualidad, y desde las medidas de cuidado al medio ambiente en los tratados de libre comercio celebrados por Chile. Revisemos cada uno de estos elementos.

\subsection{El principio de gradualidad}

El principio de gradualidad es uno de los principios inspiradores de la ley $N^{\circ} 19.300$ de bases generales del medio ambiente, según consta en el texto del mensaje presidencial. Se le señala como un principio de política ambiental, aseverando que no se pueden adoptar las mejoras ambientales súbitamente, apelando a un mero carácter efectista, sino que deben ser paulatinas, permitiendo la posibilidad de una adaptación sostenida, constante y duradera. En ese orden de cosas, el mensaje señala literalmente que "...revertir el curso del deterioro ambiental y buscar una forma en que el desarrollo y el progreso puedan propiciarse, conciliándolos con la conservación de nuestro patrimonio ambiental, requiere de una modificación estructural que trasciende a medidas efectistas o parciales que puedan tomarse en el corto plazo. La institucionalización del tema ambiental en el sector público, la revisión y dictación de normas sectoriales, los procesos educativos tendientes al cambio de actitudes respecto de nuestro medio ambiente, no pueden sino aplicarse gradualmente..."19

La doctrina ambiental chilena ha tratado este principio también, aseverando que "...el desarrollo y cumplimiento de las metas establecidas por la Administración, e incluso de la propia normativa ambiental, debe ser paulatina, tal como se constata en los planes de descontaminación...,20. En la jurisprudencia, si bien no ha sido un tópico común, se le ha expresado a propósito de la acción de amparo de derechos fundamentales, denominada en Chile acción de protección ${ }^{21}$. Así, se le ha utilizado como un argumento en favor del titular del proyecto, asumiendo que éste no está obligado a tomar medidas fuera de las explicitadas en un cronograma de trabajo, a propósito de un proyecto saneamiento y alcantarillado que descarga de residuos líquidos en el litoral. De otro modo, se contravendría la adopción de medidas paulatinas en protección del entorno ${ }^{22}$.

El principio de gradualidad, entonces, es tratado en la doctrina, jurisprudencia y ley ambiental chilena como una suerte de progresividad a favor de los titulares de proyectos, quienes no están obligados a modificar, en plazos irrealizables y súbitos, sus obligaciones ambientales a otras más exigentes, evitando gastos y medidas onerosas que no surtirán efectos; obrar de otro modo, tornaría la gestión ambiental impracticable al largo plazo.

\footnotetext{
${ }^{18}$ Peña, Mario. El principio de no regresión ambiental en la legislación y jurisprudencia costarricense. En: El principio de no regresión en el derecho comparado latinoamericano. PNUD. Costa Rica. 2013. Pp. 1262. $16 p$.

${ }^{19}$ Historia de la ley № 19300. Op. Cit. 12p.

${ }^{20}$ ASTORGA, Eduardo. Derecho Ambiental Chileno. Lexis Nexis. Chile. 2006. 29p.

${ }^{21}$ Por ejemplo: Corte de Apelaciones de Copiapó. Brunilda González Anjel con Empresa de Servicios Sanitarios de Atacama S.A. Rol № 8573-2003. Considerando décimo cuarto. En segunda instancia: Corte Suprema. Brunilda González Anjel con Empresa Servicios Sanitarios de Atacama S.A. Rol № 2787-2003. Considerando sexto.

${ }^{22}$ Corte de Apelaciones de Copiapó. Ibíd.
} 
Con todo, y si bien la progresividad se ha estudiado en Chile sólo en favor de los titulares de proyectos, no podemos desconocer que cada mejora normativa ambiental es, en cierta forma, una conquista socioambiental relevante, de la cual no se puede regresar. Pensar de otra manera, sería relativizar el cuidado del entorno, tornando infectivas y meramente simbólicas las medidas para evitar el daño antrópico, siendo finalmente afectados todos los seres vivos que habitamos en los ecosistemas damnificados. En ese orden de cosas "...Si relacionamos este principio con el de gradualidad, cada vez que los titulares de proyectos se someten a una norma ambiental o a una autorización administrativa, en el futuro no pueden someterse a una restricción menos estricta dado que significaría una vulneración de los derechos ambientales adquiridos por la ciudadanía en razón del interés público involucrado...,23

En ese orden de cosas, el principio de prohibición de regreso guarda, al menos en el caso chileno, una relación estrecha con la gradualidad, estando ambos principios íntimamente relacionados, debiéndose reconocer uno en razón de otro; o dicho coloquialmente, como si fuesen dos caras de una misma moneda. Por una parte, la gradualidad constituiría una garantía de que los cambios en la gestión ambiental serán paulatinos y que no afectarán a los titulares de proyectos, adoptando medidas atendiendo a su posibilidad cierta, mientras que la prohibición de regreso mira a que cada mejora paulatina es una victoria socioambiental permanente, que no podrá ser retirada a los ciudadanos. En otras palabras, desde diferentes perspectivas, ambos principios miran a la protección ambiental de orden intergeneracional, propia del desarrollo sustentable: la gradualidad, por su parte, lo hace pensado en la sostenibilidad económica; por la otra, la prohibición de regreso lo haría pensando en la sostenibilidad social. Negar cualquiera de ambos conceptos, sería incurrir en una contradicción basal con el desarrollo sustentable, consagrado en la legislación chilena como un concepto cardinal de la ley de bases generales de la ley $\mathrm{N}^{\circ} 19.300$ de bases generales del medio ambiente ${ }^{24}$. A mayor abundamiento, desconocer el principio de prohibición de regreso sería alterar el concepto de desarrollo sostenible, transmitiéndole una carga ideológica personal indeseable, ${ }^{25}$ pues se le relacionaría sólo con los intereses de los titulares de proyectos, impidiendo una recta interpretación armónica entre el artículo $1^{\circ}$ inciso $4^{\circ}$ de la Constitución que consagra del desarrollo social y económico ${ }^{26}$, con el artículo 19 № 8 , que consagra el derecho a vivir en un medio ambiente libre de contaminación ${ }^{27} 28$.

Visto de esta manera, si bien en Chile no ha habido un tratamiento legal, doctrinario, judicial, o administrativo explícito al principio de prohibición de regreso, no hacerlo sería, al largo plazo, una vulneración al desarrollo sustentable, pues desconocería la arista social del mismo,

23 Aranda, Jorge. Los principios de derecho ambiental: Su rol argumentativo a propósito de la interpretación jurídica. Tesis para optar al grado de Magíster en Derecho. Chile. 2003. 103p.

${ }^{24}$ Artículo $2^{\circ}$.g. Desarrollo Sustentable: el proceso de mejoramiento sostenido y equitativo de la calidad de vida de las personas, fundado en medidas apropiadas de conservación y protección del medio ambiente, de manera de no comprometer las expectativas de las generaciones futuras. Nótese también en este concepto la idea de mejora sostenida, a saber, continua, relacionada con la prohibición de regreso, pues una mejora constante no admitiría retrocesos en la protección ambiental. Ver también sobre este punto. Fernández, Pedro. Manual de Derecho Ambiental. 2da ed. Editorial Jurídica de Chile. Chile. 2004. pp. 5152.

${ }^{25}$ Bermúdez, Jorge. Fundamentos de derecho Ambiental. Ediciones Universidad de Valparaíso. Chile. 2007. 60p.

${ }^{26}$ Literalmente "...Estado está al servicio de la persona humana y su finalidad es promover el bien común, para lo cual debe contribuir a crear las condiciones sociales que permitan a todos y a cada uno de los integrantes de la comunidad nacional su mayor realización espiritual y material posible, con pleno respeto a los derechos y garantías que esta Constitución establece..."

${ }^{27}$ Literalmente: "La Constitución asegura a todas las personas: El derecho a vivir en un medio ambiente libre de contaminación. Es deber del Estado velar para que este derecho no sea afectado y tutelar la preservación de la naturaleza. La ley podrá establecer restricciones específicas al ejercicio de determinados derechos o libertades para proteger el medio ambiente...".

${ }^{28}$ Esa interpretación de ambos textos legales en: Bermúdez. Op. Cit. 62p. 
mientras que, el principio de gradualidad sería la consideración del desarrollo económico. Consecuencialmente, se reconoce como imperativo su reconocimiento siquiera doctrinal, pues de otra forma, y dicho de modo coloquial, sería "dejar coja la mesa de tres patas" del desarrollo sustentable.

Ya comprendiendo el reconocimiento implícito de este principio a propósito de la ley № 19.300 de bases generales del medio ambiente, revisemos como se contempla en los tratados de libre comercio suscritos por Chile.

\subsection{A propósito de las medidas ambientales contempladas en los tratados de libre comercio suscritos por Chile}

Fruto de la necesidad de Chile de reintegrarse a la comunidad internacional, y gracias a su política de apertura post dictadura, a la fecha se ha suscrito veintitrés acuerdos comerciales vigentes, dos firmados aún no en vigencia, y dos en actual negociación ${ }^{29}$. Dentro es estos acuerdos, los de libre comercio tienen la preocupación fundamental de protección del libre tráfico de bienes y servicios entre los países suscriptores, evitando la adopción de medidas que beneficien a una o más partes en perjuicio de otra u otras.

Dentro de las herramientas que se proponen para evitar esos perjuicios, algunos tratados contemplan artículos asegurando medidas para la protección del medio ambiente. El fundamento básico de estas medidas es que el desatender la protección ambiental, conllevaría una forma de atentar a la libertad de comercio entre los estados suscriptores, pues si en la producción de bienes y servicios se generan externalidades negativas no internalizadas, sería una manera de subsidiar la producción de modo implícito. De este modo, si un Estado es diligente adoptando todo tipo de medidas ambientales para internalizar esos costos, se encuentra en situación de desventaja respecto de otro Estado que no cumple con dichas medidas, protegiendo su industria nacional con deslealtad a costa del sacrificio de las condiciones ambientales que pueda asegurar a sus ciudadanos.

En este sentido, la relación que detenta protección ambiental con el libre comercio, en general, se contempla desde una perspectiva diferente de la determinada por principio de gradualidad. En este caso, se reconoce que la relación proviene de una vulneración al principio contaminador pagador, en razón que, como se aseveró, se dejan de internalizar las externalidades negativas por parte del Estado desleal.

Ahora bien, y revisando en concreto como se estipulan estas medidas en los tratados de libre comercio, podemos observar que hay un artículo que se reitera literalmente en los tratados suscritos con México, Canadá y Corea ${ }^{30}$. También se incorporan artículos relativos al cuidado

\footnotetext{
${ }^{29}$ Ver listado en: Dirección General de Relaciones Económicas Internacionales. Acuerdos comerciales. [en línea] http://www.direcon.gob.cl/acuerdos-comerciales/

30 Tanto en el Decreto Supremo del Ministerio de Relaciones Exteriores № 1020 de 1997 que promulga el tratado de libre comercio, el acuerdo de cooperación ambiental y el acuerdo de cooperación laboral, suscritos con Canadá, artículo G-14.2, como en el Decreto Supremo del Ministerio de Relaciones Exteriores № 1101 de 1999 que promulga el tratado de libre comercio, sus anexos y apéndices, con los Estados Unidos Mexicanos, artículo 9.15.2, y también en el Decreto Supremo del Ministerio de Relaciones Exteriores № 48 de 2004 que promulga el tratado de libre comercio con el Gobierno de la Republica de Corea y sus anexos, artículo 10.18.2, establece el mismo enunciado: “...Las Partes reconocen que es inadecuado estimular la inversión por medio de un relajamiento de las medidas internas aplicables a salud o seguridad o relativas al medio ambiente. En consecuencia, ninguna Parte debería renunciar a aplicar o derogar de cualquier otro modo, u ofrecer renunciar o derogar, dichas medidas como medio para inducir el establecimiento, la adquisición, la expansión o conservación de la inversión de un inversionista en su territorio. Si una Parte estima que la otra Parte ha alentado una inversión por esos medios, podrá solicitar consultas con esa Parte y ambas celebrarán consultas con el fin de evitar incentivos de esa índole." (énfasis agregado).
} 
ambiental en el tratado suscrito con los Estados Unidos ${ }^{31}$, en el acuerdo con Panamá ${ }^{32}$, y en el acuerdo con Colombia ${ }^{33}$. El común denominador de todos estos textos, para efectos de nuestro tema de estudio, es que los Estados firmantes comprenden que debe haber un mejoramiento constante de la normativa ambiental, y que un relajamiento en las medidas de protección del medio ambiente es una forma de atentar con las finalidades de integración comercial, pues, como se señaló, constituyen una forma de reducir los costos de producción en desmedro de la calidad del medio ambiente, implicando una especie de perversos subsidios encubiertos a la producción.

Si abordamos esta prohibición de relajamiento de las normas ambientales no desde un punto de vista meramente comercial, sino buscando una interpretación armónica con el resto de la normativa ambiental, es posible aseverar que resulta inaceptable retroceder en los derechos socioambientales ya conquistados. De este modo, es necesario reconocer, siquiera implícitamente, el principio de prohibición de regreso desde estos textos.

Si bien, y como se señaló, esta consagración no responde a intereses netamente ambientales, los diferentes mecanismos de cumplimiento de los tratados no obstan a que puedan adquirir una utilidad para las finalidades perseguidas por grupos de interés centrados en la protección del entorno. Así, en Chile existe el precedente de la reclamación efectuada por un grupo de activistas por la vulneración del Estado de Chile de las medidas de protección ambiental en el año $2000 .^{34}$

Finalizando esta sección, ya podemos dar algún testimonio de los textos legales que servirían de sustento al principio de prohibición de regreso. Estos son, bien lo sabemos, la ley № 19.300 de bases generales del medio ambiente (en particular su historia), y los diferentes tratados de libre comercio brevemente revisados, cada uno obedeciendo a lógicas diferentes. Así, por una parte, en el caso de la normativa domestica, se obedece a una contraposición al principio de gradualidad, mientras que en la normativa internacional se obedece a una profundización del comercio internacional, cuya consecuencia ulterior es la prohibición de regreso. Con todo, nos queda revisar algunas hipótesis en las que este principio sería útil para la interpretación de la legislación ambiental chilena, cuestión que revisaremos a continuación.

\footnotetext{
${ }^{31}$ Decreto Supremo del Ministerio de Relaciones Exteriores № 312 de 2003 que promulga el tratado de libre comercio con los Estados Unidos de América, sus anexos y las notas intercambiadas entre ambos gobiernos relativas a dicho tratado, artículo 19.2.2: “...Las Partes reconocen que es inapropiado promover el comercio o la inversión mediante el debilitamiento o reducción de la protección contemplada en su legislación ambiental interna. En consecuencia, cada Parte procurará asegurar que no dejará sin efecto o derogará, ni ofrecerá dejar sin efecto o derogar dicha legislación de una manera que debilite o reduzca la protección otorgada por aquella legislación, como una forma de incentivar el comercio con la otra Parte, o como un incentivo para el establecimiento, adquisición, expansión o retención de una inversión en su territorio."

32 Decreto Supremo del Ministerio de Relaciones № 25 de 2008, que promulga el tratado de libre comercio con la República de Panamá y los acuerdos de cooperación ambiental y laboral. En particular, en el acuerdo de cooperación ambiental entre la República de Chile y la República de Panamá contenido en dicho decreto supremo, artículo 2.2 “...Las Partes reafirman su intención de esforzarse en mejorar sus niveles de protección ambiental y de conservación de los recursos naturales y cumplir con los compromisos plasmados en los acuerdos multilaterales ambientales en vigencia o en los planes de acción internacionales, orientados a lograr el desarrollo sostenible."

33 Decreto Supremo del Ministerio de Relaciones № 54 de 2009 que promulga el acuerdo de libre comercio entre Chile y Colombia, artículo 18.2.2: “...Cada Parte se asegurará que sus políticas y leyes promuevan y establezcan altos niveles de protección ambiental y de conservación y uso sostenible de los recursos naturales; y se esforzará por seguir mejorando sus niveles de protección en estas materias..." 4. Las Partes reconocen que es inapropiado promover el comercio o la inversión mediante el debilitamiento o reducción de los niveles de protección contemplados en su legislación ambiental. A su vez, las Partes reconocen que es inapropiado emplear sus políticas, leyes, regulaciones y gestión ambiental como un obstáculo encubierto al comercio."

${ }^{34}$ Ministerio de Medio Ambiente. Resumen de la petición presentada ante la comisión para la cooperación ambiental Chile - Canadá, bajo los artículos 14 y 15 del acuerdo de cooperación ambiental Chile Canadá, № A14-2000-01. [en línea`] http://www.mma.gob.cl/chilecanada/1288/article-29507.html.
} 


\section{Dos casos que denotan de relevancia de considerar el principio de prohibición de regreso en Chile}

Como ya se ha señalado a lo largo de este texto, ni la ley, ni la doctrina, ni la jurisprudencia han desarrollado el principio de prohibición de regreso en Chile. Con todo, me gustaría resaltar dos casos interesantes en los que se denota la carencia de éste y su potencial utilización, a propósito del cuidado de las áreas protegidas. El primero es el caso "Antonio Horvath Kiss y otros contra Comisión de Evaluación Ambiental de la Región de Aysén”, rol № 10.220 de 2012, de la Corte Suprema (en adelante, caso Hidroaysén), en la que conociendo de la apelación a una acción de protección, se pronuncia sobre la aprobación de un proyecto de generación hidroeléctrica de energía de potencia. El segundo caso es la reclamación "Montoya Villarroel con Superintendencia del Medio Ambiente" rol N ${ }^{\circ} \mathrm{R}-2-2014$ (en adelante caso Tres Bocas), en el que se reclama una sanción que imparte la Superintendencia de Medio Ambiente, dado que un proyecto inmobiliario, a emplazarse dentro de un área protegida, eludió el sistema de evaluación de impacto ambiental.

Sobre el primer conflicto jurídico, el caso Hidroaysén se refiere a las acciones de protección interpuestas en contra de la Comisión de Evaluación de la región de Aysén, por haber aprobado el proyecto hidroeléctrico Hidroaysén, presentado por la compañía eléctrica Endesa. En suma, y para efectos de este texto, este es un proyecto de generación de energía hidroeléctrica de gran escala, consta de cinco centrales de embalse, lo que implica la inundación de un amplio número de hectáreas, y la ulterior construcción de un largo tendido eléctrico que cruzaría buena parte del territorio nacional de sur a norte, cuya evaluación ambiental se esperaba presentar una vez aprobado el proyecto de generación. Entre los impactos ambientales esperados, se encuentra la inundación de 18 hectáreas del parque nacional Laguna San Rafael ${ }^{35}$, proponiendo el titular del proyecto una compensación de 100 hectáreas, condicionando la modificación futura del parque, los cuales, al menos en la práctica ambiental chilena, son creados mediante decreto supremo dictado por el Presidente de la República. ${ }^{36}$

En este caso, en la sentencia no se advirtieron motivos para dejar sin efecto la resolución de calificación ambiental, y la Corte Suprema no cuestionó la validez de la resolución de calificación ambiental otorgada. Con todo, recientemente el Comité de Ministros ha dejado sin efecto la resolución de calificación ambiental ${ }^{37}$.

Según mi parecer, es de suyo cuestionable que un acto administrativo dictado por una comisión de evaluación ambiental, de jerarquía inferior a un decreto supremo dictado por el Presidente de la República, condicione la modificación de un área protegida, aunque sea en una proporción ínfima en términos cuantitativos. En términos cualitativos, una modificación de un área protegida además se debería justificar mediante estudios adecuados, asegurando que no acarreará consecuencias a los fines de la misma, cuestión que un procedimiento de evaluación ambiental no estaría en condiciones de hacer, pues evaluaría sólo el proyecto hidroeléctrico y no la modificación de un área protegida.

En este caso en concreto, respecto de la afectación de un área protegida, parece que el principio de prohibición de regreso pudo haber tenido un rol determinante en la argumentación en contra del proyecto. Si bien una compensación podría ser hasta deseable, e incluso

\footnotetext{
${ }^{35}$ Decreto Supremo № 475 del Ministerio de Agricultura de 1959 que crea el Parque Nacional de Turismo Laguna San Rafael.

${ }^{36}$ Corte Suprema. Antonio Horvath Kiss y otros con Comisión de Evaluación Ambiental de la Región de Aysén. Rol № 10220. Chile. 2011. Considerando décimo y siguientes.

37 Para efectos de prensa, revisar: Ministerio de Medio Ambiente. Comité de Ministros acoge reclamaciones presentadas por la ciudadanía y decide rechazar proyecto Hidroaysén. [en línea] http://www.mma.gob.cl/1304/w3-article-56497.html.
} 
contando con previos estudios que justifiquen dicha ampliación... ¿Puede un particular, en la evaluación de un proyecto, requerir a un órgano de la administración que altere la extensión de un área protegida que, en estricto rigor, puede ser modificada sólo por el Presidente de la República? Al parecer no, pues significaría establecer un precedente de relativización de los decretos que establecen áreas protegidas, y justamente, en situaciones como la descrita, la prohibición de regreso se hace más que necesaria para la protección de las mismas.

En otra jurisprudencia reciente, en el llamado "caso Tres Bocas", el fiscalizado reclama ante el tribunal ambiental de Valdivia que la Superintendencia del Medio Ambiente una resolución en la que requiere el ingreso al sistema de evaluación de impacto ambiental de un proyecto inmobiliario emplazado en la isla fluvial Tres Bocas, la que se ubica dentro de un área protegida $^{38}$, a saber, el santuario de la naturaleza Carlos Anwandter ${ }^{39}$. Por su parte, el reclamado alega que, conforme a las cartografías que aporta, se encontraría por ejecutar su proyecto fuera del área protegida. Si bien el Tribunal reconoce que el proyecto debe ingresar al sistema de evaluación de impacto ambiental en caso de emplazarse dentro del área protegida, y que efectivamente así será, declara nulo el proceso de fiscalización porque, al tiempo de la dictación del acto administrativo sancionador, el santuario no contaba con una cartografía oficial, por lo que malamente se le podría obligar a ingresar al sistema de evaluación de impacto ambiental ${ }^{40}$. El mayor problema acá denotado respecto de la actual situación de las áreas protegidas, fue que en Chile ningún organismo crea y centraliza las cartografías oficiales de las mismas, lo que dificulta aún más su protección y real determinación. Sin ir más lejos, se ha logrado determinar que las áreas protegidas en Chile habitadas por personas, son poco a poco disminuidas mediante procesos de regularización de la pequeña propiedad raíz, dado que muchas de éstas inician los procesos para convertirse así en propietarias de los terrenos que habitan en desmedro de su real extensión. ${ }^{41}$

¿Cómo garantizar la prohibición de regreso si las áreas protegidas, como se demostró en el caso Tres Bocas, no tienen cartografía oficial en muchos casos? Es complejo proteger algo que se encuentra indeterminado. Además, cabe resaltar que si bien el principio de prohibición de regreso, pensado y vinculado a una mejora constante de las condiciones socioambientales de los ciudadanos, mirando desde la perspectiva de sustentabilidad social del desarrollo sostenible, parece paradójico que sean justamente éstos, mediante la regularización de la pequeña propiedad raíz, disminuyan la extensión real de las áreas protegidas en Chile. Una falta de delimitación, adecuado manejo de áreas protegidas habitadas, y carencia cartografías oficiales no garantizan, en los hechos, que la prohibición de regreso en la extensión de las áreas protegidas sea efectiva.

\section{Conclusiones}

En Chile no ha sido tratado el principio de prohibición de regreso, no hay referencias explícitas en la legislación ni en la doctrina. Sin perjuicio de lo anterior, existen elementos para afirmar que, al menos, permiten siquiera implícitamente contemplarlo en la práctica legal chilena a futuro.

\footnotetext{
${ }^{38}$ Conforme al artículo 10.p de la ley № 19.300 de bases generales de medio ambiente, los proyectos a ser ejecutados dentro de un área protegida deben ingresar al sistema de evaluación de impacto ambiental.

${ }^{39}$ Decreto 2743 de 1981 del Ministerio de Educación, que declara santuario de la naturaleza la zona húmeda de los alrededores de la ciudad de Valdivia.

${ }^{40}$ Tercer Tribunal Ambiental. Montoya Villarroel con Superintendencia del Medio Ambiente. Rol № R-22014. Considerando $56^{\circ}$.

${ }^{41}$ Fischman, Eliana. Áreas Protegidas: tierra de nadie. En: Actas de las IV Jornadas de Derecho Ambiental. Legal Publishing. Chile. 2008. pp. 227-238. 238p.
} 
Sus antecedentes políticos se explican desde la integración política y comercial de un Chile post dictadura a un mundo globalizado post guerra fría. Sus fundamentos legales los encontramos en el principio de gradualidad, y en la obligación que imponen los tratados de libre comercio de no retroceder en las medidas de protección ambiental, con miras a evitar la generación de ventajas competitivas desleales del país en desmedro de las condiciones ambientales que garantiza a sus ciudadanos. Justamente, desconocer el principio de prohibición de regreso sería, al menos implícitamente, desconocer este proceso de integración y de apertura de Chile que ha acompañado la democratización del país.

En las referencias concretas realizadas en este texto, se puede constatar que lo poco que se ha desarrollado en doctrina es en relación a la historia de la ley 19.300 de bases generales de medio ambiente, a propósito del principio de gradualidad, desde la perspectiva del proceso económico del desarrollo sustentable, lo que en concreto, se centra en una especie de garantía a favor del titular del proyecto y de los regulados de no ser afectados súbitamente por normativas ambientales exigentes.

Con todo, y a modo de epílogo de esta entrega, cabe señalar que durante el periodo que medió entre la redacción de este texto y su publicación final, el Tribunal Ambiental de Santiago reconoció explícitamente este principio, a propósito de la impugnación del proceso de revisión de la norma primaria de material particulado respirable MP 10 , siendo la primera vez que la jurisprudencia nacional da cabida a su uso argumentativo ${ }^{42}$.

Pero más allá de este puntual y grato reconocimiento, en el caso particular de las áreas protegidas en Chile, las deficiencias son evidentes, y junto con el principio de gradualidad, desde una perspectiva tanto de política como de interpretación jurídica, se torna necesaria la consideración de la prohibición de regreso. Dicho principio, ante la dispersión normativa y aspectos ambiguos de la legislación, podría ilustrarnos mejores caminos para sobrellevar los problemas que tenemos en la protección de todos aquellos bienes y servicios ambientales que las áreas protegidas ayudan a custodiar, tales como la belleza escénica, la biodiversidad, la preservación de recursos estratégicos como la provisión de agua potable, sólo por nombrar algunas cosas.

Aún queda mucho por desarrollar de este principio en un medio en el que, principalmente, la teoría y práctica del derecho ambiental se centran en un ámbito meramente administrativo, en desmedro del estudio de otras disciplinas jurídicas que han debido modificar estatutos y elementos propios, heredados de concepciones tradicionales e individualistas. En este sentido, el principio de prohibición de regreso, en su rol interpretativo, puede ser un primer paso a repensar y replantear interpretaciones evolutivas de normas de antigua data, como la Convención de Washington. De esta forma, espero que esta pequeña entrega pueda aportar a la discusión de este principio en el contexto de la literatura jurídico ambiental chilena.

42 República de Chile. Tribunal Ambiental de Santiago. Causa rol R-22-2014, caratulada Fernando Dougnac Rodríguez y otros contra el Ministerio del Medio Ambiente (Decreto Supremo No 20 de 2013). Relacionado con: Norma de Calidad Primaria para Material Particulado Respirable, MP10. Considerando $33^{\circ}$. 


\section{Bibliografía}

AA.VV. Bases de La política económica del gobierno militar. Centro de Estudios Públicos. Chile. 1992.

Aranda, Jorge. Los principios de derecho ambiental: Su rol argumentativo a propósito de la interpretación jurídica. Tesis para optar al grado de Magíster en Derecho. Chile. 2003.

Astorga, Eduardo. Derecho Ambiental Chileno. Lexis Nexis. Chile. 2006.

Bermúdez, Jorge. Fundamentos de derecho Ambiental. Ediciones Universidad de Valparaíso. Chile. 2007.

Biblioteca del Congreso Nacional. Historia de la ley № 19300 de 1994 de Bases Generales de Medio Ambiente. [En línea]

http://www.leychile.cl/Navegar/scripts/obtienearchivo?id=recursoslegales/10221.3/2429/1/HL19 300.pdf 10p.

Biblioteca del Congreso Nacional. Historial de la ley 20.417 de 2010. [en línea] http://www.leychile.cl/Navegar/scripts/obtienearchivo?id=recursoslegales/10221.3/3929/6/HL20 417.pdf.

Corte de Apelaciones de Copiapó. Brunilda González Anjel con Empresa de Servicios Sanitarios de Atacama S.A. Rol № 8573-2003. Considerando décimo cuarto.

Corte Suprema. Antonio Horvath Kiss y otros con Comisión de Evaluación Ambiental de la Región de Aysén. Rol № 10220. Chile. 2011. Considerando décimo y siguientes.

Corte Suprema. Brunilda González Anjel con Empresa Servicios Sanitarios de Atacama S.A. Rol № 2787-2003. Considerando sexto.

Fernández, Pedro. Manual de Derecho Ambiental. 2da ed. Editorial Jurídica de Chile. Chile. 2004.

Fischman, Eliana. Áreas Protegidas: tierra de nadie. En: Actas de las IV Jornadas de Derecho Ambiental. Legal Publishing. Chile. 2008. pp. 227-238.

Peña, Mario. El principio de no regresión ambiental en la legislación y jurisprudencia costarricense. En: El principio de no regresión en el derecho comparado latinoamericano. PNUD. Costa Rica. 2013. pp. 12-62.

Pflieger, Géraldine. Historia de la universalización del acceso al agua y alcantarillado en Santiago de Chile (1970-1995). En: EURE. vol.34, n.103. Santiago. Chile. ISSN 0250-7161.

Rodríguez, José. Chile: un caso de subdesarrollo exitoso. Del Estado en forma de Portales, al Estado en formación de Lagos. Editorial Andrés Bello. Chile. 2002.

Tercer Tribunal Ambiental. Montoya Villarroel con Superintendencia del Medio Ambiente. Rol № R-2-2014. 


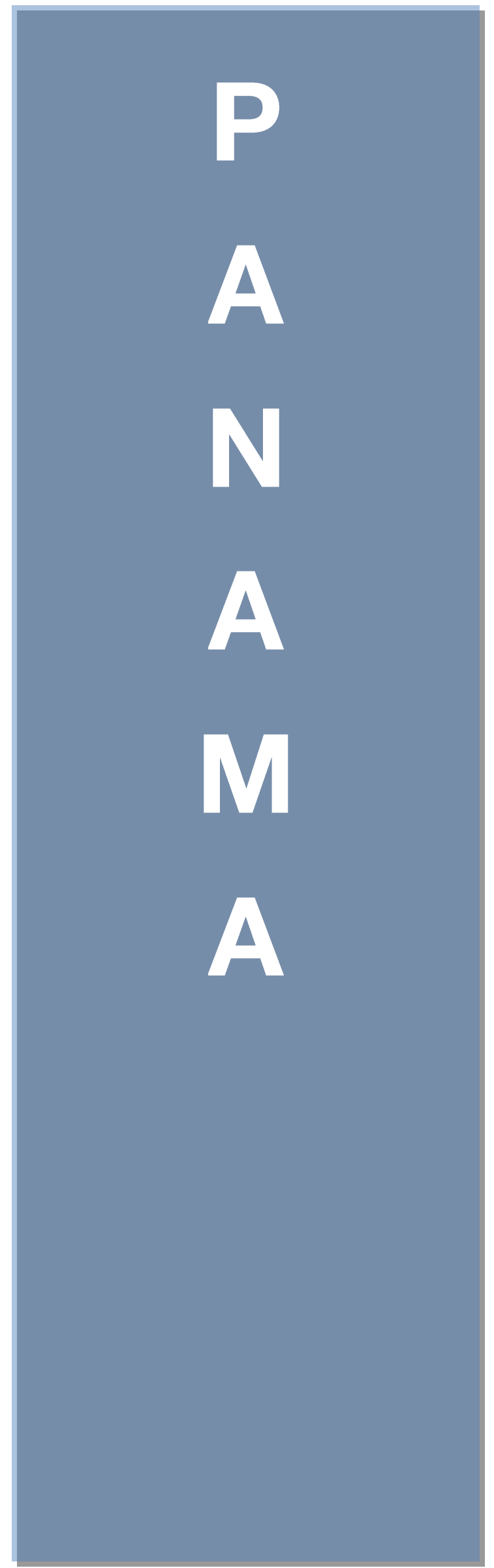





\title{
LA PROTECCIÓN JURÍDICA DE LOS HUMEDALES EN PANAMÁ $Y$ EL PRINCIPIO DE NO REGRESIÓN AMBIENTAL
}

\author{
Víctor Leonel Benavides Pinilla*
}

Eduardo José Mitre Guerra*

\begin{abstract}
"Para el derecho ambiental del siglo XXI tanto es fundamental que el Estado prevenga las posibles amenazas o impactos al medio ambiente como que evite retroceder en la regulación, implementación y desarrollo de las políticas públicas en materia de medio ambiente y recursos naturales"
\end{abstract}

\section{Introducción}

El concepto de desarrollo sostenible, ha alcanzado gran difusión en los últimos años. Su primera formulación, proviene del informe "Nuestro Futuro Común" o "Informe Brundtland", elaborado en 1987 por la Comisión Mundial sobre Medio Ambiente y Desarrollo, por encargo de la Organización de las Naciones Unidas (O.N.U.). En dicho Informe, se señalaba que: "...el desarrollo duradero es el desarrollo que satisface las necesidades de la generación presente, sin comprometer la capacidad de las generaciones futuras, para satisfacer sus propias necesidades".

Luego, la Agenda 21, instrumento programático aprobado en la Conferencia de las Naciones Unidas sobre Medio Ambiente y Desarrollo, realizada en Río de Janeiro, Brasil, en 1992, se pronuncia por integrar las preocupaciones relativas al ambiente y al desarrollo, de tal manera que se satisfagan las necesidades básicas, se eleve el nivel de vida de todos los habitantes, y se consiga al mismo tiempo, una mejor protección y gestión de los ecosistemas.

A partir de estas Conferencias, se integra por vez primera la materia ambiental al concepto de desarrollo, y se propugna por un balance entre los aspectos económico y social, que permitan la satisfacción de las necesidades de las personas que conforman la sociedad, sin tener que deteriorar las condiciones ambientales.

La protección del ambiente y los recursos naturales, tradicionalmente, se ha concebido como una función de la administración pública, que se ejercita a través de ciertos servicios públicos primarios de la administración central o de sus instituciones estatales, creadas específicamente con ese objetivo, incluyendo además, las funciones que históricamente han estado a cargo de los gobiernos locales.

Ciertamente, la aplicación administrativa de la legislación ambiental, mantiene un sitio importante $y$, en consecuencia, los conflictos jurídicos entre la administración y los administrados, predominan en esta esfera jurisdiccional.

Por su parte, la comunidad internacional inició una toma de conciencia respecto a los daños ambientales, a partir de la Conferencia de las Naciones Unidas sobre Medio Ambiente de 1972,

\footnotetext{
* Magistrado de la Corte Suprema de Justicia de Panamá (Sala de lo Contencioso Administrativo y Laboral).

* Asistente de Magistrado de la Corte Suprema de Justicia y Profesor de Derecho Ambiental.
} 
con la cual se promovieron políticas preventivas para evitarlos, y de respuesta, para reparar los posibles daños.

La importancia de los daños ambientales, por sus implicaciones sobre la salud y la calidad de vida de las generaciones presentes y futuras, así como por la impresionante dimensión económica que pudieran tener, motivó la necesidad de buscar soluciones que garantizaran su adecuada reparación. Surgió así la idea de asignar al causante de estos daños, la responsabilidad de repararlos, que vino de la mano de un principio reconocido internacionalmente: "El que contamina paga".

Este postulado plantea que, los costos derivados de la contaminación o de cualquier infracción ambiental, sean cargados al agente causante de ésta, para así sufragar las medidas de prevención, control y compensación, cuya finalidad es que las actividades económicas tomen en consideración, los costos ambientales que conlleven la producción, uso y consumo de bienes económicos ${ }^{2}$.

Por lo anterior, podemos manifestar, que el Derecho Ambiental puede ser conceptuado como el conjunto de principios y normas jurídicas, que regulan las conductas tanto individuales como colectivas, que inciden a su vez, en el ambiente. Igualmente, se le ha definido como: "el conjunto de normas que regulan las relaciones de derecho público y privado, tendientes a preservar el medio ambiente libre de contaminación, o mejorarlo en caso de estar afectado".

Está demás decir, que el Derecho Ambiental es una rama jurídica que:

- Por su carácter interdisciplinario, se nutre de los principios de otras cinéticas;

- Por su carácter sistemático y tutelar de los intereses, se halla en íntima relación con el Derecho Público;

- Por su énfasis preventivo y reparador de los daños particulares, constituye un capítulo importante de Derecho Privado;

- Por su vocación redistributiva, se relaciona con el aspecto económico del derecho; y,

- Por su carácter supranacional, compromete Principios de Derecho Internacional.

Esto último, en razón de que la cuestión ambiental se encuentra impregnada de una fuerte problemática, que requiere soluciones a escala internacional.

Uno de los temas más relevantes dentro de esta innovadora ciencia del Derecho, es la responsabilidad ambiental, que es la imputabilidad de una valoración positiva o negativa, por el impacto ecológico de una decisión, que se refiere, generalmente, al daño causado a otras especies, a la naturaleza en su conjunto, o a las futuras generaciones, por las acciones o las no acciones de otro individuo o grupo, incluso de los Entes Estatales.

La responsabilidad ambiental recae tanto en los individuos, como en las empresas, países y en la especie humana en su conjunto. En la responsabilidad ambiental, también se debe evaluar el hecho de la "reparación por daño ambiental".

Desde el campo de las ciencias jurídicas, pueden surgir diferentes clases de responsabilidades por daño ambiental, a indicar: la responsabilidad civil, la responsabilidad penal, y la responsabilidad administrativa.

\footnotetext{
${ }^{1}$ Benedectis, Leonardo, Seguros Ambientales. Nuevas Formas de la SA y DS, Una visión desde el sector productivo, en Sexto Encuentro Internacional de Derecho Ambiental, Memorias, Foro Consultivo Científico y Tecnológico, México, 2008, disponible en: http://www.foroconsultivo.org.mx/libros_editados/ambientalistas_6.pdf.

${ }^{2}$ Martínez Patiño, Rosales, La Responsabilidad Ambiental en Panamá, Ámbitos Administrativo y Penal, en Sexto Encuentro Internacional de Derecho Ambiental, op cit.
} 
Este proceso de adaptación, comenzó a desarrollarse de manera palpable en los países industrializados a finales de los años setenta, tomando Carta de Naturaleza, a partir de la ya mencionada Conferencia de Estocolmo de 1972, y de la aceptación por la Organización para la Conservación y el Desarrollo Económico, en la misma época. Desde entonces, todos los países industrializados han venido acumulando una extensa normativa medioambiental para el control de las actividades industriales, y en la respuesta a la misma, la tecnología y los métodos de producción industrial, han intentado adaptarse a las nuevas restricciones, aunque con decisión y acierto muy variables, por parte de las diferentes empresas, ramas industriales y países.

Esta situación motivó, que los países industrializados utilizaran tecnologías limpias, y lo más relevante de esto, es la reducción de los desechos no biodegradables, y la autosostenibilidad ambiental, es decir, la reposición del gasto ecológico causado por la actividad manufacturera. Como ventaja del uso de tecnologías limpias, podemos señalar que se refleja en el desarrollo humano sostenible.

En igual medida, la peculiar naturaleza del bien medio ambiente, y el riesgo de un inmediato e irreparable deterioro del mismo, por causas de acciones perturbadoras individuales 0 colectivas, hace que la intervención del Estado asuma una iniciativa de esta materia, que vele para que no se deterioren esos bienes, sino que sancione a quienes lo vulneren.

Es de importancia resaltar, que la integridad del medio ambiente se afecta por una doble vía: por la acción del hombre y por la acción de la propia naturaleza; los cuales no son factores independientes, sino "interdependientes", ya que la acción del hombre afecta la naturaleza, y ésta a su vez, afecta al hombre. Es de todos conocidos, que el cambio climático altera las condiciones de vida de todos los seres que habitan el planeta.

Se producen modificaciones en los recursos hídricos, se calienta la atmósfera por la concentración de anhídrido carbónico, las grandes masas de agua se pueden evaporar en los océanos, produciendo cambios en el régimen de lluvias, lo que significará extensas inundaciones y una marcada subida del mar.

Según un informe de la Cruz Roja, presentado en Ginebra-Suiza, la muerte por desastres naturales en 2004, fue la mayor en treinta (30) años, sumando alrededor de ciento cincuenta mil $(250,000)$ víctimas, en su mayoría causadas por el tsunami en el sudeste asiático, y otras tantas causadas por los huracanes Katrina y Rita, entre otros.

Las repercusiones económicas de las sequías, o las inundaciones, hacen peligrar la seguridad alimentaria, puesto que se produce la disminución o desaparición de alimentos básicos, no existiendo áreas cultivables debido a la erosión de los suelos, desertificación, la desertización, etc.

Así las cosas, el Derecho Ambiental intenta normar la creación, modificación, transformación y extinción de las relaciones jurídicas que condicionan el disfrute, la preservación y el mejoramiento del medio ambiente; aspirando a regular la relación del hombre con la naturaleza, codificándola, sobre la base de los elementos comunes que diversas leyes hasta hoy vigentes, han regulado por separado.

El principio número uno de la Declaración de Estocolmo enuncia que: "El hombre tiene un derecho fundamental a la libertad, a la igualdad y a condiciones de vida satisfactorias en un ambiente, cuya calidad de vida le permita vivir con dignidad y bienestar, y tiene el deber solemne de proteger y mejorar el medio ambiente de las generaciones presentes y futuras".

Es a partir de los trabajos de la Conferencia de Estocolmo de 1972, que muchos Estados introdujeron en sus Cartas Magnas, cláusulas reconociendo la existencia de un Derecho al Medio Ambiente, y cuya formulación se inspiró en este primer paso, dado en la ya mencionada Conferencia de 1972. 
Otro hito importante a destacar, son los principios sobre los cuales se asienta la construcción institucional del Derecho Ambiental, basados en la "Calidad de Vida" por un lado; que se logra mediante la tutela del ambiente; y, el "Desarrollo Sustentable", por el otro; que consiste en preservar los factores ecológicos y culturales, haciendo un uso racional de los recursos naturales y un disfrute conservacionista, y a la vez progresista, de los factores creados por la actividad humana, para poder legarlos a las generaciones presentes y futuras, como patrimonio de la humanidad.

\section{Programa de justicia ambiental en Panamá}

Es menester referirnos, a algunos aspectos relevantes, en cuanto a capacitación sobre el tema medioambiental, llevados a cabo por Entes del Estado Panameño, para que sus servidores conozcan, orienten y pongan en práctica, tales conocimientos.

Las Instituciones Gubernamentales y las de Administración de Justicia en la República de Panamá, han realizado ingentes esfuerzos para capacitar a los servidores públicos y a la sociedad organizada en diversos temas de Derecho Ambiental.

Por ello, se desarrolló un Programa de Justicia Ambiental, que logró el acercamiento de los servidores públicos con la dimensión ambiental.

Este evento tuvo especial relevancia, dado el hecho de que el concepto de Justicia Ambiental en Panamá es relativamente nuevo, y sirvió para afirmar la existencia de garantías, para que los ciudadanos en general, ejerzan su derecho a un ambiente sano, al uso racional de los recursos naturales, a la participación en los procesos de toma de decisiones.

Esta capacitación permitió estudiar la evolución y el impacto en nuestro país de la aplicación de políticas públicas en materia ambiental, verificar las distintas bases legales, las iniciativas y documentos de política ambiental, temas selectos en materia ambiental como lo son el desarrollo sostenible, calidad y ordenamiento ambiental; y algunos aspectos de la legislación ambiental en Panamá, consagrada en la Ley General de Ambiente y sus reglamentos.

Igualmente contempló, leyes ambientales especiales como la Ley sobre el Régimen de Propiedad Intelectual sobre los derechos colectivos de los Pueblos Indígenas, Ley sobre el régimen especial de Cuencas Hidrográficas, Ley sobre el Corredor Marino de Panamá, Ley del Parque Nacional Coiba, la Ley Forestal, la Ley de Vida Silvestre y la Legislación de Aguas de la República de Panamá.

Se discutió, analizó y consensuó entre los diversos operadores de justicia, la Ley 5 de agosto de 2005, que tipificaba delitos que hasta ese momento se encontraban dispersos en la legislación panameña.

Igualmente se desarrolló el Taller sobre las Cuencas Hidrográficas, la Ley sobre el Corredor Marino de Panamá, la Ley del Parque Nacional Coiba, la Ley Forestal, la Ley de Vida Silvestre y la Legislación de Aguas de la República de Panamá, los cuales fueron debidamente evaluados y analizados.

Dentro del marco del desarrollo del Programa de Justicia Ambiental, la oficina de Asesoría Legal de la Autoridad Nacional del Ambiente (hoy Ministerio de Ambiente) con el apoyo de organismos de cooperación internacional, realizó el Seminario "Instituciones de Derecho Ambiental" dirigido a jueces y fiscales, con énfasis en la responsabilidad administrativa ambiental, la valoración del daño ambiental, así como el acceso a la Información y participación ciudadana, Décimo Principio de la Declaración de Río de 1992 y el acceso a la Justicia Ambiental. 


\section{Creación del corredor marino}

Un acuerdo político permitió que Colombia, Costa Rica, Ecuador y Panamá, creen un corredor marino para conservar sus ecosistemas en el Océano Pacífico.

Se trata de un sistema de interconexión de las Islas del Coco, Galápagos, Malpelo y Gorgona y Coiba.

La declaración del "Corredor Marino de Conservación del Pacífico Este Tropical", permitirá la protección de seres que se encuentran en esas aguas, y se considera una iniciativa única en el mundo.

Esto beneficiará a especies migratorias como las pelágicas y mamíferos marinos, por lo que animales como los tiburones, las ballenas y las tortugas baula, frecuentemente amenazados por la pesca indiscriminada, estarán a salvo en costas pacíficas.

De acuerdo al documento, "si hay una especie amenazada en un país, ahora los otros no tendrán ningún problema en incorporar medidas y políticas propias para cooperar en la preservación de esa especie, lo que garantiza un mayor éxito en las gestiones".

El corredor marino, además de preservar y proteger especies, servirá para reproducir a las que están en riesgo por la pesca comercial, como el atún aleta amarilla.

La Organización de Naciones Unidas, se comprometió a aportar veinticinco millones de dólares, para el inicio del proyecto.

Las islas del corredor, comparten características biofísicas similares, con ecosistemas casi intactos e incontables especies endémicas amenazadas por la acción del hombre.

Esta importante iniciativa, encontró eco en la legislación panameña, al expedirse la Ley 13 de 5 de mayo de 2005, publicada en Gaceta Oficial № 25,293 de 6 de mayo de 2005, en la que la República de Panamá crea el Corredor Marino de la República, apostando a la protección y conservación de los mamíferos marinos, comprendido por todas las aguas marinas bajo la jurisdicción de la República de Panamá que, según las describe la Convención sobre el Derecho del Mar, son el mar territorial, la zona contigua y la zona económica exclusiva. En este Corredor se promoverá la investigación de los mamíferos marinos y se impulsará el avistamiento, la recreación, la educación, la investigación y la terapia a campo abierto, así como programas de concienciación ambiental y de vigilancia ciudadana.

Así también se declara a los mamíferos marinos especies de especial protección nacional; por tanto, correspondiéndole al Estado su conservación para lograr la recuperación de su población, el desarrollo de su papel en los ecosistemas marinos, y el cumplimiento del principio de desarrollo sostenible.

Esta Ley creó el Comité Directivo del Corredor Marino de Panamá, instancia responsable de diseñar, aprobar e implementar un programa de administración o un plan de acción del Corredor Marino de Panamá, con los objetivos y las directrices organizativas-participativas siguientes:

1. Desarrollar los objetivos generales y específicos del Corredor Marino.

2. Velar para que la actividad pesquera no afecte las especies de mamíferos marinos que se encuentran dentro del Corredor.

3. Describir las características físicas, biológicas, económicas y sociales de las áreas del Corredor Marino de Panamá, con la inclusión de la identificación de las potencialidades económicas, educativas, científicas y ecoturísticas del corredor marino.

4. Zonificar sobre la base del diagnóstico del estado actual de las poblaciones de mamíferos marinos que se busca proteger, e identificar las zonas en las cuales se podrán realizar las actividades de avistamiento. 
5. Delimitar las zonas prioritarias para la conservación y protección de las especies de mamíferos marinos establecidas en los convenios internacionales, la cual debe considerar las diferentes funciones relacionadas con su ciclo vital, tales como reproducción, alimentación, migración, nacimiento, crianza, crecimiento y aprendizaje.

6. Elaborar el plan de acción a corto, mediano y largo plazo del Corredor Marino, que incluirá programas de protección, seguimiento, vigilancia y fiscalización, educación ambiental y didáctica, investigación científica, desarrollo de actividades recreativas y turísticas, financiamiento, prevención y contingencia y otras que, por las características y objetivos de la presente Ley, sean necesarias.

7. Fomentar el mantenimiento de las condiciones ambientales para la continuidad de las funciones biológicas de los mamíferos marinos a que se refiere la presente Ley, tales como la reproducción, nacimiento, crianza, crecimiento, aprendizaje, migración y alimentación.

8. Incentivar la participación activa de las instituciones científicas y académicas, así como de las sociedades ambientales afines con los objetivos de esta Ley.

9. Coordinar y promover investigaciones pertinentes orientadas a la conservación de todas las especies de mamíferos marinos.

En igual medida, esta Ley contempla prohibiciones y sanciones a quienes incumplan con sus normas. Es así, ya que en los artículos 14,15 y 16 se sostiene lo siguiente:

"Artículo 14. Queda prohibida dentro del Corredor Marino de Panamá la caza o captura de los mamíferos marinos, salvo las excepciones que establezca el Comité Directivo con relación a la captura para el cautiverio."

"Artículo 15. Lo dispuesto en esta Ley no implica restricciones al paso inocente de la navegación local e internacional, a la actividad pesquera legalmente reconocida, ni a las actividades recreativas, científicas y de avistamiento ecoturístico autorizadas, siempre que tales actividades no se realicen en perjuicio de las especies de mamíferos marinos protegidas por la presente Ley."

"Artículo 16. El que viole o incumpla la presente Ley será sancionado por las autoridades competentes de acuerdo con lo establecido en la legislación penal en concordancia con lo señalado en la Ley General de Ambiente y legislaciones complementarias, así como en disposiciones legales sobre la materia, sin perjuicio de la responsabilidad civil que resulte de la acción en términos de legislación aplicable".

\section{El medio ambiente en la Constitución Panameña}

A este respecto, la Constitución Política de la República de Panamá, de 1972, Reformada por los Actos Reformatorios de 1978, por el Acto Constitucional de 1983, los Actos Legislativos $N^{\circ}$ 1 y N ${ }^{\circ} 2$ de 1994 y el Acto Legislativo de 2004, adopta en su Título III: "Derechos y Deberes Individuales y Sociales"; Capítulo $7^{\circ}$, artículos 118 a 121, el Régimen Ecológico de la República de Panamá, el cual da inicio al desarrollo de la política medioambiental, que rige hoy en día en el país ${ }^{3}$.

En el artículo 118 del texto constitucional, se establece que: "Es deber fundamental del Estado garantizar que la población viva en un ambiente sano y libre de contaminación, en donde el aire, el agua y los alimentos satisfagan los requerimientos del desarrollo adecuado de la vida humana".

Igualmente, en el artículo 119 constitucional, se dispone que: "El Estado y todos los habitantes del territorio nacional tienen el deber de propiciar un desarrollo social y económico que

\footnotetext{
${ }^{3}$ Aspectos que se desarrollan con detalle en los Capítulo XXII y XXIII de Benavides Pinilla, Víctor, Compendio de Derecho Público Panameño, Ediciones Jurídicas Andrés Morales, Bogotá, 2012.
} 
prevenga la contaminación del ambiente, mantenga el equilibrio ecológico y evite la destrucción de los ecosistemas".

Para ello, "el Estado reglamentará, fiscalizará y aplicará oportunamente las medidas necesarias para garantizar que la utilización y el aprovechamiento de la fauna terrestre, fluvial y marina, así como de los bosques, tierras y aguas, se lleven racionalmente, de manera que se evite su depredación y se asegure su preservación, renovación y permanencia" (artículo 120 de la Carta Magna).

La propia Constitución Nacional, como norma de superior jerarquía, remite la reglamentación a la Ley, sobre el aprovechamiento de los recursos naturales no renovables, a fin de evitar que del mismo se deriven perjuicios sociales, económicos y ambientales (artículo 121).

De allí que la República de Panamá, incorpora principios constitucionales referentes a los derechos difusos de la población, derivados del deber del Estado a proporcionarle un ambiente sano, libre de contaminación y adecuado para el desarrollo humano sostenible ${ }^{4}$.

En la Conferencia en Conmemoración del Centenario de la República y del Órgano Judicial, realizada el día 31 de julio de 2003, el doctor Arturo Hoyos expuso el tema: "La Administración ante su Juez: La Jurisdicción Contencioso Administrativa en Panamá, durante el último siglo", en el cual nos habla sobre la tutela judicial de los derechos ecológicos y los intereses difusos. Por la importancia que el tema reviste, transcribiremos un extracto del mismo:

"Il.4. La tutela judicial de los derechos ecológicos y de los intereses difusos.

Mediante auto de 12 de marzo de 1993, la Corte consideró, por primera vez en Panamá, el tema de la tutela judicial de los intereses difusos y concluyó que éstos pueden plantearse dentro de un proceso contencioso administrativo de plena jurisdicción, que hasta ahora ha estado reservado a la defensa de derechos subjetivos en su acepción tradicional.

El tratadista italiano Mauro Cappelletti ha señalado que a raíz de los fenómenos de urbanización, industrialización y masificación de la producción y del consumo en nuestras sociedades ha surgido una serie de relaciones humanas que asumen carácter colectivo pues ya incluso ciertos derechos y deberes fundamentales previstos en las declaraciones de derechos de los Siglos XVIII y XIX han sido adicionados por derechos supraindividuales, colectivos, derechos sociales y deberes de las asociaciones, comunidades y grupos sociales. Sin embargo, el mismo autor anota que la concepción tradicional del proceso como un asunto que atañe a dos partes y en el cual generalmente se debaten derechos individuales se ha ido superando por la posibilidad de perjuicios colectivos que puedan producirse dentro de los nuevos esquemas de actividad económica. Esto ha llevado a diversos países a modificar sus sistemas procesales de forma que se otorgue legitimatio ad causam (legitimación procesal) a nuevas instituciones públicas y privadas para actuar como parte en procesos en los que se persiga la defensa de intereses colectivos o difusos, en el sentido de que o bien esos derechos o intereses no pertenecen a ningún individuo en particular o bien que los individuos poseen sólo una porción insignificante de esos derechos. El mismo Cappelletti afirma que en nuestra época "la protección de los derechos difusos ha adquirido una crucial importancia para el progreso y quizás para la sobrevivencia de la humanidad".

\footnotetext{
4 Chandeck, Lucía, La Responsabilidad Administrativa Ambiental en Panamá, en Secretaría de Medio Ambiente y Recursos Naturales, Instituto Nacional de Ecología, PNUMA, Memorias del Segundo Encuentro Internacional de Derecho Ambiental, México, 2004, disponible en:

http://www2.inecc.gob.mx/publicaciones/consultaPublicacion.html?id_pub=446.
} 
Entre los intereses difusos destaca, además de los relacionados con la publicidad engañosa y la colocación en el mercado de productos nocivos para la salud de todos los consumidores, el tema de la protección del medio ambiente y de los recursos naturales. El historiador británico Paul Kennedy ha destacado en una obra publicada en la pasada década que la población mundial se ha duplicado en los últimos 40 años, pero la actividad económica mundial se ha cuadruplicado en el mismo período. Estos factores han creado una intensa explotación de las áreas selváticas y recursos naturales en nuestros países, lo cual se ha acentuado con el avance del proceso de industrialización reciente en países como Panamá. Todo esto tiende a aumentar el daño ecológico. Desde los años 50 se ha estimado que el mundo ha perdido casi un $20 \%$ de tierras cultivables, el $20 \%$ de las selvas tropicales y decenas de miles de especies animales y vegetales. Las consecuencias de esta situación son de interés para todos los miembros de la sociedad panameña no sólo por su impacto actual sino por lo que pueden significar durante el nuevo siglo de vida independiente que iniciamos ahora en 2003 para las generaciones venideras y su bienestar tanto por los problemas de contaminación, cambios del clima, como por la futura disponibilidad de los bienes y servicios que se extraen de esos recursos naturales.

En el auto de 12 de marzo de 1993 citado la Sala reconoció legitimidad activa a una asociación de protectores de la naturaleza para actuar como parte demandante en un proceso de plena jurisdicción contra el Instituto Nacional de Recursos Naturales Renovables a fin de oponerse a una concesión de explotación de madera en el área del Darién. Ello permite a dicha asociación pedir no sólo la anulación del acto sino medidas de reparación por los intereses difusos lesionados"

Otro factor a destacar, es que la Constitución Nacional de Panamá, resalta el aspecto de bienes de uso público, enumerados en el artículo 257; no obstante, en el artículo 258 Constitucional, se disponen los bienes pertenecientes al Estado, cuya característica primordial se circunscribe, en la prohibición de ser objeto de apropiación privada, tales como el mar territorial y las aguas lacustres; las playas y riberas de las mismas y de los ríos navegables, y los puertos y esteros, entre otros.

Estos bienes adquieren relevancia en la presente exposición, por la importancia que ha adquirido el tema de los humedales en la República de Panamá, al ser bienes de uso público, cuya apropiación privada, se encuentra prohibida por mandato Constitucional.

Adicionalmente, el artículo 4 de la Carta Política, advierte que la "República de Panamá acata las normas de Derecho Internacional", de las cuales forman parte, entre otras, los Convenios que se suscriban en las diversas materias. Panamá es signataria de la Convención Relativa a los Humedales de Importancia Internacional, Especialmente como Hábitat de Aves Acuáticas, firmada en 1971 en la Ciudad de Ramsar, Irán, conocida como Convención RAMSAR, siendo aprobada en todas sus partes por la Asamblea Legislativa, mediante la Ley 6 de 3 de enero de 1989, publicada en Gaceta Oficial № 21.211 de 12 de enero de 1989.

\footnotetext{
5 Hoyos, Arturo. El derecho contencioso-administrativo de Panamá (1903- 2005): una introducción histórica de derecho comparado y jurisprudencial. Sistemas Jurídicos. Panamá. 2005. pp. 28-29.
} 


\section{4 ¿Qué es la Convención RAMSAR?}

En el Manual de la Convención RAMSAR, 6ta edición ${ }^{6}$, encontramos una breve reseña de lo qué es la Convención sobre los Humedales de Importancia Internacional, mejor conocida como Convención RAMSAR. Tomemos un extracto de ello:

La Convención sobre los Humedales, es un tratado intergubernamental que sirve de marco para la acción nacional y la cooperación internacional en pro de la conservación y el uso racional de los humedales y sus recursos. Fue adoptada en la ciudad iraní de Ramsar en 1971, y entró en vigor en 1975, y es el único tratado global relativo al medio ambiente que se ocupa de un tipo de ecosistema en particular. Los países miembros de la Convención abarcan todas las regiones geográficas del planeta.

\section{- El cometido de la Convención RAMSAR}

La misión de la Convención es "la conservación y el uso racional de los humedales mediante acciones locales, regionales y nacionales y gracias a la cooperación internacional, como contribución al logro de un desarrollo sostenible en todo el mundo".

La Convención emplea una definición amplia de los tipos de humedales abarcados por esta misión, incluidos pantanos y marismas, lagos y ríos, pastizales húmedos y turberas, oasis, estuarios, deltas y bajos de marea, zonas marinas próximas a las costas, manglares y arrecifes de coral, así como sitios artificiales como estanques piscícolas, arrozales, embalses y salinas.

- ¿Y los humedales?

Los humedales prestan servicios ecológicos fundamentales, y son reguladores de los regímenes hídricos, así como fuentes de biodiversidad a todos los niveles -especies, genético y ecosistema.

Los humedales constituyen un recurso de gran valor económico, científico, cultural y recreativo para la comunidad. Los humedales desempeñan un papel esencial en la adaptación al cambio climático, y en la atenuación de sus efectos.

La progresiva invasión y pérdida de humedales, causa daños ambientales graves y a veces irreparables a la prestación de servicios de los ecosistemas. Los humedales deberían restaurarse y rehabilitarse siempre que sea posible. Los humedales deberían conservarse asegurando su uso racional.

- ¿Qué es el uso racional?

El uso racional de los humedales, se define como: "el mantenimiento de sus características ecológicas, logrado mediante la implementación de enfoques por ecosistemas, dentro del contexto del desarrollo sostenible".

Por consiguiente, la conservación de los humedales, así como su uso sostenible y el de sus recursos, se hallan en el centro del "uso racional" en beneficio de la humanidad.

- ¿Qué hacen las Partes Contratantes?

En el marco de los "tres pilares" de la Convención, las Partes se han comprometido a:

\footnotetext{
${ }^{6}$ Secretaría de la Convención de RAMSAR, Manual de la Convención de RAMSAR: Guía a la Convención sobre los Humedales (RAMSAR, Irán, 1971), 6ta. Edición, Secretaría de la Convención de RAMSAR, Suiza, 2013, disponible en: http://www.ramsar.org/pdf/lib/manual6-2013-sp.pdf.
} 
Trabajar en pro del uso racional de todos los humedales de su territorio mediante la planificación nacional del uso del suelo, normativas y legislación apropiadas, medidas de gestión, y la educación del público;

Designar humedales adecuados que cumplan los criterios para la Lista de Humedales de Importancia Internacional ("Lista de RAMSAR") y garantizar su gestión eficaz; y

Cooperar internacionalmente con respecto a los humedales transfronterizos, los sistemas hídricos compartidos, las especies compartidas y los proyectos de desarrollo que puedan afectar a los humedales.

- ¿Cómo funciona la Convención?

La Conferencia de las Partes Contratantes (COP), se reúne cada tres (3) años y promueve políticas y lineamientos técnicos para impulsar la aplicación de la Convención.

El Comité Permanente, integrado por las Partes que representan a las seis regiones RAMSAR del mundo, se reúne anualmente para orientar a la Convención entre las reuniones de la COP. El Grupo de Examen Científico y Técnico da orientaciones sobre las principales cuestiones para la Convención.

La Secretaría de RAMSAR, que comparte su sede con la Unión Mundial para la Naturaleza (UICN), en Gland (Suiza), administra las actividades corrientes de la Convención.

La Iniciativa MedWet, cuya Secretaría se encuentra en Atenas, sirve de modelo para la cooperación regional de los humedales y es emulada actualmente por las iniciativas regionales adoptadas en el marco de la Convención en muchas partes del mundo.

En el plano nacional, cada Parte Contratante designa una Autoridad Administrativa como coordinador para la aplicación de la Convención. Se alienta a los países a establecer Comités Nacionales de Humedales, en los que participen todos los sectores gubernamentales encargados de los recursos hídricos, la planificación del desarrollo, las áreas protegidas, la biodiversidad, el turismo, la educación, la asistencia para el desarrollo, etc. Se fomenta también la participación de las ONG y la sociedad civil.

Los Sitios RAMSAR, que hacen frente a problemas para mantener sus características ecológicas, pueden ser inscritos por el país interesado en una lista especial, el "Registro de Montreux", y se puede facilitar asistencia técnica para ayudarles a resolverlos.

Los países que cumplen los requisitos pertinentes, pueden solicitar asistencia financiera para ejecutar proyectos de conservación y uso racional de los humedales al Fondo RAMSAR de Pequeñas Subvenciones y al Fondo de Humedales para el Futuro.

\section{- Colaboración}

La Convención colabora estrechamente con otras convenciones mundiales y regionales, relacionadas con el medio ambiente. Cuenta con Planes de Trabajo Conjunto o Memorandos de Entendimiento con el Convenio sobre la Diversidad Biológica, la Convención de Lucha contra la Desertificación, la Convención sobre las Especies Migratorias, la Convención del Patrimonio Mundial y el Programa sobre el Hombre y la Biosfera de la UNESCO. La Secretaría colabora también con instituciones de financiación como el Banco Mundial y el FMAM y autoridades gestoras de cuencas hídricas como las del Lago Chad y la cuenca del Níger.

La Convención cuenta con cinco Organizaciones Internacionales Asociadas, reconocidas oficialmente, tales como: BirdLife International, el Instituto Internacional para el Manejo del Agua (IWMI), Wetlands International, la Unión Mundial para la Naturaleza (UICN) y el Fondo Mundial para la Naturaleza (WWF), que ayudan a las Partes proporcionándoles asesoramiento técnico de expertos a nivel mundial, nacional y local, así como asistencia sobre el terreno. 
La Secretaría mantiene relaciones de cooperación con muchas otras organizaciones no gubernamentales, como la Sociedad de Científicos especializados en Humedales, The Nature Conservancy, la Asociación Internacional de Evaluación de Impacto Ambiental, y Wildfowl and Wetlands Trust, y da cabida en su labor científica y técnica a muchas otras en calidad de invitadas permanentes.

- ¿Quién financia todo esto?

La Conferencia de las Partes adopta un presupuesto básico administrado por la Secretaría de RAMSAR, al que cada Parte aporta un porcentaje acorde con su contribución al presupuesto de las Naciones Unidas.

Muchos países y otros donantes, aportan también contribuciones para proyectos especiales de RAMSAR, incluidos, por ejemplo, el Fondo RAMSAR de Pequeñas Subvenciones, Humedales para el Futuro, la Subvención Suiza para África y, en el sector privado, el Proyecto Evian con el Grupo Danone y Biosphere Connections con las aerolíneas del grupo Star Alliance.

\section{Protección jurídica de los humedales en el derecho panameño}

El Diccionario Esencial de la Lengua Española, define el término "Humedal", como: "terreno de aguas superficiales o subterráneas de poca profundidad".

Observamos así, que los humedales son, desde un punto de vista estrictamente normativo, áreas de especial importancia ecológica. Dicha calidad se deriva del hecho de que la República de Panamá se adhirió a la Convención de Ramsar, relativa a la protección de este tipo de ecosistemas, que ha reconocido la especial importancia de los humedales.

Las Leyes generales de ambiente, constituyen un punto focal de la legislación ambiental administrativa en los países de la región Centroamericana, y Panamá no escapa a esa realidad. Por ello, como en el resto de los países de la región Centroamericana, la legislación ambiental es de naturaleza administrativa.

En cuanto a las normas especiales en materia de humedales, la República de Panamá cuenta con la mencionada Ley 6 de 3 de enero de 1989, que aprueba la Convención Relativa a los Humedales de Importancia Internacional, Especialmente como Hábitat de Aves Acuáticas, conocida como Convención RAMSAR, en cuyo artículo segundo destaca que: "cada parte contratante deberá designar los humedales adecuados de su territorio, que se incluirán en la lista de zonas húmedas de importancia internacional".

Igualmente, el artículo 66 de la Ley 41 de 1 de julio de 1998, crea el Sistema Nacional de Áreas Protegidas (SINAP), conformado por todas las áreas protegidas legalmente establecidas, o que se establezcan, por leyes, decretos, resoluciones o acuerdos municipales.

Dentro de estas medidas proteccionistas, la Alcaldía del Distrito de la Capital Panameña, emitió el Decreto № 2339 de 14 de junio de 2012, el cual prohibió el uso de los Humedales Bahía de Panamá, para frenar algunos rellenos en las zonas de humedales, así como trabajos de construcción que se venían desarrollando dentro de esa zona, hasta ver los resultados de un estudio científico que determinase si alguna actividad, se puede o no desarrollar en esta área.

La información también señala que, "el área de la Bahía de Panamá y sus alrededores, tienen importantes funciones ecológicas como reguladores de los regímenes hidrológicos y son un fundamental hábitat para especies de fauna en peligro de extinción".

Este área, años después y a raíz de una serie de litigios y actuaciones que amenazaban con la reducción de sus límites y proponían su desarrollo inmobiliario, será sujeto de una protección más acentuada, a través de la Ley 1 de 2 de febrero de 2014, por medio de la cual se declara 
área protegida al refugio de vida silvestre Sitio Ramsar Humedal Bahía de Panamá (GO. 27717 de 9 de febrero de 2015).

El numeral tercero del artículo 4 de la Ley 24 de 7 de junio de 1995, establece que el Instituto de Recursos Naturales Renovables (ahora ANAM), a través de la Dirección de Áreas Protegidas y Vida Silvestre, establecerá y administrará áreas protegidas para la conservación de la vida silvestre.

En igual medida, el artículo 95 de la Ley 41 de 1 de julio de 1998 (modificado por el artículo 68 de la Ley 44 de 23 de noviembre de 2006) establece que la Autoridad Nacional del Ambiente y la Autoridad de los Recursos Acuáticos de Panamá darán prioridad, en sus políticas, a la conservación de ecosistemas marinos con niveles altos de diversidad biológica y productividad, tales como los ecosistemas de arrecifes de coral, estuarios, humedales y otras zonas de reproducción y cría.

La República de Panamá, cuenta con varios sitios RAMSAR dentro de su territorio, siendo uno de los más destacados, el área de la Bahía de Panamá y sus alrededores, ya que mantienen importantes funciones ecológicas como reguladores de los regímenes hidrológicos y son un fundamental hábitat, para especies de fauna en peligro de extinción.

Al ser lugar de anidación de las aves acuáticas y playeras, en sus migraciones estacionales, pueden atravesar fronteras, y en consecuencia son consideradas como un recurso internacional.

Las medidas de conservación de humedales, establecen la protección de las aves acuáticas migratorias que utilizan y dependen de estos ecosistemas.

La zona costera de la Bahía de Panamá, se encuentra cubierta de vegetación natural como son los manglares, bosque inundable mixto, bosque inundable de palmas, así como, ciénagas y lagunas.

Debido a la importancia ecológica y económica que representa para el país el área conocida como Humedal Bahía de Panamá, la misma, a petición de la República de Panamá, fue designada como Humedal de Importancia Internacional e incluida en la lista de Sitios RAMSAR de la Convención, el 20 de octubre de 2003, por la Secretaría de dicha Convención, convirtiéndose en el sitio mil trescientos diecinueve (1319) a nivel mundial.

Por cuanto las aves playeras migratorias, dependen para su sobrevivencia de sitios de parada, y que la Bahía de Panamá ha sido reconocida como uno de los sitios al cual llegan millones de estas aves provenientes de Norteamérica, es que el Humedal Bahía de Panamá, fue declarado por la Red Hemisférica de Reservas de Aves Playeras (RHRAP) el 18 de octubre de 2005, como el sitio más importante en Centroamérica para las aves playeras migratorias.

El Estado, consciente de la importancia del Sitio RAMSAR Bahía de Panamá, expidió la Resolución № AG-0072-2009 de 3 de febrero de 2009, publicada en Gaceta Oficial № 26,221 de 11 de febrero de 2009, "Por medio de la cual se declara como área protegida el Humedal Bahía de Panamá"; creando una política orientada a la conservación, protección y administración para el uso sostenible y el beneficio de las generaciones presentes y futuras, tomando en cuenta su valor ambiental, ecológico, genético, científico, estético, recreativo, cultural, educativo, social y económico de sus ecosistemas y componentes, y es de interés nacional por la protección que brinda a las poblaciones aledañas.

Con esta Resolución administrativa, dispuesta por el Estado Panameño, a través de la Autoridad Nacional del Ambiente (ANAM), ser reafirmó el compromiso de fortalecer las acciones de conservación, protección, uso racional y manejo de los ecosistemas y especies que allí habitan, a través de su incorporación al Sistema Nacional de Áreas Protegidas (SINAP). 
Tenemos así, que el Humedal Bahía de Panamá, es una zona cubierta de vegetación natural, por lo que se hace necesario promover su conservación, protección y administración, pues esta conservación y recuperación de los recursos naturales, como la biodiversidad, el agua, el aire $y$, en general, del ambiente deseable para el hombre, la fauna y la flora, es una política estatal que cuenta con su legislación, aunada a la suscripción al Convenio RAMSAR, ya que se propende la preservación y restauración ecológica de los elementos constitutivos del sistema hídrico, como principal conector ecológico del territorio urbano y rural. En suma, el Humedal Bahía de Panamá, está definido como elemento central de la Ciudad y decisivo, en conjunto con los restantes elementos ambientales, en la constitución de condiciones de vida dignas para los residentes de la Ciudad.

\section{Protección penal de los humedales}

En los ecosistemas de humedales, están prohibidas las actividades humanas orientadas a interrumpir sus ciclos naturales, tales como la construcción de diques que eviten el flujo de aguas marinas o continentales, drenajes, desecamiento, relleno o cualquier otra alteración que provoque el deterioro y la eliminación de este tipo de ecosistemas ${ }^{7}$.

Por tanto, son precisamente este tipo de conductas las que alteran, menoscaban y eliminan a los ecosistemas de humedal, y las que han impulsado al legislador a la promulgación de tipos penales que las sancionan, todo con el fin de proteger el bien jurídico "humedal".

El Código Penal de la República de Panamá, en cuanto a la responsabilidad penal ambiental, dispone de una serie de normas, compelidas en el Título XIII, denominado "Delitos contra el Ambiente y el Ordenamiento Territorial", reservando al ecosistema de humedales específicamente, una protección con pena de aprehensión corporal contra el infractor, de tres (3) a seis (6) años, aumentándose en una tercera parte a la mitad, incluso. Este postulado lo desarrolla el artículo 399 de dicho Cuerpo Normativo, el cual textualmente señala:

"Artículo 399. Quien infringiendo las normas de protección del ambiente establecidas destruya, extraiga, contamine o degrade los recursos naturales será sancionado con prisión de tres a seis años.

La pena prevista en este artículo se aumentará de una tercera parte a la mitad en cualesquiera de los siguientes casos:

1. Cuando la acción recaiga en áreas protegidas o se destruyan total o parcialmente ecosistemas costeros marinos o humedales.

2. ....".

\section{Jurisprudencia de la Sala Tercera de la Corte Suprema de Justicia de Panamá, en materia de humedales}

La jurisprudencia es la respuesta o decisión que los Tribunales de Justicia brindan acerca de asuntos o procesos en diversos ámbitos sometidos a su consideración, y que requieren de una solución.

Según el artículo 13 del Código Civil Panameño, cuando no haya Ley exactamente aplicable al punto controvertido, se aplicarán las leyes que regulen casos o materias semejantes, la

\footnotetext{
7 Peña Chacón, Mario, Gestión Integrada del Recurso Hídrico en la Legislación Costarricense, Investigaciones Jurídicas, San José, 2008.

${ }^{8}$ Ibíd.

${ }^{9}$ El subrayado es nuestro.
} 
doctrina constitucional, las reglas generales del derecho, y la moral, siendo general y conforme con la moral cristiana.

Es claro que cuando el Código de referencia, señala a la doctrina constitucional como fuente supletoria del derecho (en casos de vacíos lagunas en el ordenamiento jurídico) es más probable que aluda a la jurisprudencia formada de la interpretación de las normas constitucionales y no a la doctrina legal emanadas de los Tribunales Administrativos, porque para 1917 en nuestro país no existían los Tribunales de este tipo. Tanto en control centralizado de la administración se incluyeron expresamente en la Constitución de 1941.

Hoy la práctica y la experiencia del Foro, otorgan un papel relevante a la jurisprudencia, que ve enriquecidos sus fallos con las opiniones de exponentes autorizados sobre determinados temas que inciden sobre el debate judicial. Todo indica que se apuesta por una escaldada, cada vez mayor, de la jurisprudencia como fuente de derecho en nuestro país, no sólo por la pauta que marca el Código Civil al respecto; sino por el eco que genera en el debate, lo que dicen los Tribunales de Justicia.

Se ha dicho que es preferente una jurisprudencia recurrente para casos similares; sin que sea una camisa de fuerza para que, ante circunstancias variantes se adopten resoluciones acordes con los nuevos ribetes del caso estudiado.

En síntesis, abordamos el tema de los humedales, concernido por la jurisprudencia de la Sala Tercera de lo Contencioso Administrativo de la Corte Suprema de Justicia de Panamá, dentro de la materia ambiental.

Por tratarse de un derecho innovador, son escasas las referencias jurisprudenciales; sin embargo esto no ha sido impedimento para que nuestros Tribunales hayan establecido pronunciamientos sobre materia de índole ambiental, específicamente sobre humedales.

En Fallo de 4 de abril de 2013, la Sala Tercera de la Corte Suprema de Panamá, bajo la ponencia del Magistrado Víctor L. Benavides P., frente a una demanda contencioso administrativa de nulidad, interpuesta por el licenciado Arístides Figueroa, en representación de Constantino González Rodríguez, contra la analizada en este documento, Resolución N AG0072-2009 de 11 de febrero de 2009, emitida por la Autoridad Nacional del Ambiente (ANAM), dispuso:

1. Restituir la vigencia de la Resolución AG-0072-2009 de la Autoridad Nacional del Ambiente (Anam), la cual había sido dejada sin efecto en un fallo anterior de esta misma Sala.

2. Reconoció la "especial importancia ecológica" del humedal y la adhesión de Panamá a la Convención RAMSAR.

3. Propugnó por la conservación y recuperación de los recursos naturales, como la biodiversidad, el agua, el aire y, en general, el ambiente deseable para el hombre, la fauna y la flora.

4. Que es una Política Estatal la conservación y protección del Humedal Bahía de Panamá.

Este tema de actualidad, recobró importancia en todas las esferas de la vida nacional, contando con las voces de especialistas en la materia, de la sociedad civil organizada, y de organizaciones conservacionistas nacionales e internacionales, los cuales mostraron en los diversos foros de opinión, su beneplácito al conocerse la restitución de condición de Sitio RAMSAR del Humedal Bahía de Panamá, y sobre todo, que la Sala Tercera manifestara la importancia del mismo, como una "Política Estatal" que la Resolución impugnada con esta demanda, previamente había trazado.

La Sala Tercera de los Contencioso Administrativo, con posterioridad emite la Sentencia de 23 de diciembre de 2013, sustanciada por el autor, Magistrado Víctor Benavides Pinilla, por medio 
de la cual decide el fondo del asunto planteado e introduce por primera vez entre las consideraciones de la Corte, el -principio de no regresión ambiental-, del que seguidamente nos ocupamos.

\section{$8 \quad$ El principio de no regresión ambiental}

\subsection{Concepto doctrinal}

Como se ha visto, en el derecho panameño existe todo un andamiaje normativo de protección ambiental y dentro de éste el correspondiente a los humedales.

Aun así, debe reconocerse que en paralelo a la regulación nacional como internacional convergen distintas circunstancias de facto o investidas con apariencia de derecho que pueden hacer disminuir los avances alcanzados con la promulgación y aplicación de la ley, es decir, que afectan negativamente la aplicación efectiva de los distintos instrumentos ambientales que contempla la ley ambiental. La razón de la ley ambiental es, pues, prevenir los riesgos y efectos contrarios en el medio ambiente y asegurar la calidad de vida de los individuos. Sin embargo, hoy por hoy, sabemos que el derecho ambiental no sólo tiene por principal desafío prevenir el desarrollo de acciones que directa o indirectamente causen contaminación o daño ambiental, sino que también se encuentra frente a la necesidad de establecer mecanismos que eviten el desmejoramiento de los niveles de protección.

Evitar la regresión o el retroceso en los avances alcanzados en torno a la protección medioambiental, es pues una necesidad de nuestro tiempo, y ya no sólo por la importancia que reviste mantener un uso racional y equilibrado de los recursos naturales, sino porque producto del progreso los planes y objetivos ambientales adoptados desde la mitad de siglo veinte a la fecha, parecen haber llegado a un techo sin que ello se traduzca en muchos casos en un verdadero desarrollo sostenible y sustentable. Así, a pesar de que la mayoría de los países cuenta con un número plural de leyes y reglamentos en materia ambiental, que se han ratificado docenas de instrumentos internacionales referidos a las distintas materias especiales y sectoriales del derecho ambiental y aun cuando los Estados promueven y suscriben todo tipo de compromisos prospectivos, lo cierto es que la constante sigue siendo contraria a la pretensión ambiental.

Es así que en la actualidad, el derecho ambiental ya no trata tanto de ver si la ley es verdaderamente efectiva y/o aplicable; aspecto que no deja de ser importante y necesario. Lo que sucede es que en la actualidad del derecho ambiental, resulta imprescindible que la ley no sólo sea oportuna en cuanto regula y compromete la protección medioambiental, sino también que la ley no sea contraria a los objetivos conservacionistas originalmente propugnados en la Constitución y que resguardan los derechos fundamentales -que actúan como límites a los retrocesos $-{ }^{10}$. En otras palabras, para el derecho ambiental del siglo veintiuno tanto es fundamental que el Estado prevenga las posibles amenazas o impactos al medio ambiente como que evite retroceder en la regulación, implementación y desarrollo de las políticas públicas en materia de medio ambiente y recursos naturales.

No retroceder o evitar el desmejoramiento de la protección ambiental, en el ámbito jurídico encuentra amparo bajo la rúbrica de lo que Michel Prieur ha denominado "principio de no regresión ambiental". De acuerdo con el profesor emérito de la Universidad de Limoges, Francia, lo que está en juego con la formulación del principio de no regresión "es la protección de los avances alcanzados en el contenido de las legislaciones ambientales", es decir que,

${ }^{10}$ Embid Irujo, Antonio, El Derecho Público de la Crisis Económica, en Blasco Esteve, Avelino (coord.), Actas del VI Congreso de la Asociación Española de Profesores de Derecho Administrativo, Palma de Mallorca, Instituto Nacional de Administración Pública, Madrid, 2011, pp. 119. 
desde la óptica del derecho ambiental moderno "los retrocesos constituyen regresiones en la protección del medio ambiente, incluso cuando, [...], no se pueda producir una no regresión absoluta, sino únicamente unos grados de regresión" ${ }^{\prime 11}$.

Michel Prieur, teórico pionero en la defensa del principio de no regresión, sostiene que los retrocesos ambientales pueden producirse de diferentes formas, por un lado, con la abrogación, modificación, derogación de la ley o de los instrumentos de protección ambiental contemplados en la ley, y por el otro, como resultado "de la interpretación del derecho por parte del juez, que, al aplicar el principio de desarrollo sostenible, favorecerá la conciliación de los intereses ambientales y los intereses económicos y sociales $y$, por tanto, podrá arbitrar a favor de los intereses no ambientales $y$, de este modo, poner en entredicho los avances en derecho ambiental'12.

En esa línea, Fernando López Ramón señala que pueden ser manifestaciones de regresión ambiental, la aprobación de leyes encaminadas a rebajar los niveles de protección ambiental para permitir la construcción o la legalización de variadas obras y actividades; la falta de continuidad en las estructuras administrativas, su sometimiento a la pura y dura decisión, sin adecuada justificación; y la desprotección de espacios naturales a través de sentencias por prácticas indebidas del Estado o por la falta de capacidad para la concreción de las medidas dispuestas en torno a la declaración de espacios protegidos ${ }^{13}$.

En tanto que, Mario Peña Chacón, decidido exponente del tema en la región, sostiene que el "principio de no regresión enuncia que la normativa y la jurisprudencia ambiental no deberían ser revisadas si esto implicare retroceder respecto a los niveles de protección alcanzados con anterioridad". Por tanto, de acuerdo con el director y autor de la obra "El Principio de No Regresión Ambiental en el Derecho Latinoamericano Comparado" el principio de no regresión ambiental "[tiene como finalidad evitar la supresión normativa o la reducción de sus exigencias por intereses contrarios que no logren demostrar ser jurídicamente superiores al interés público ambiental, ya que en muchas ocasiones, dichas regresiones pueden llegar a tener como consecuencias daños ambientales irreversibles o de difícil reparación ${ }^{\text {"14 }}$.

El principio de no regresión ambiental o principio de standstill, de antirretorno o de intangibilidad de los derechos fundamentales, como se le conoce en el derecho comparado ${ }^{15}$, es considerado incluso, como lo indica el profesor Ramón Ojeda Mestre, "vinculado a la idea sustancial de la no retroactividad", esto es, que "la evolución jurídica debe llevarnos hacia adelante". Es decir, que "el derecho de mañana ha de tutelar más y mejor los bienes y servicios ambientales o la biodiversidad mejor que ahora o que ayer", pues, "[s]i sucede al revés, el derecho sufre de un retroceso o de una degradación cualitativa"16.

\footnotetext{
${ }^{11}$ Prieur, Michel, El Nuevo «Principio de No Regresión en Derecho Ambiental», en Acto de Investidura del Grado de Doctor Honoris Causa, Prensas Universitarias de Zaragoza, 2010, p. 64.

12 lbíd., p. 60.

${ }^{13}$ López Ramón, Fernando, Introducción General: Regresiones del Derecho Ambiental, en López Ramón, Fernando (dir.), Observatorio de Políticas Ambientales 2011, Aranzadi, Thomas-Reuters, Navarra, 2011, pp. 19-24, disponible en: http://www.actualidadjuridicaambiental.com/wp-content/uploads/2010/06/09_OPAM-11.pdf.

14 Peña Chacón, Mario, El Principio de No Regresión Ambiental en la Legislación y Jurisprudencia Costarricense, en Peña Chacón, Mario (dir.), El Principio de No Regresión Ambiental en el Derecho Latinoamericano Comparado, PNUD, San José, 2013, p. 16.

${ }^{15}$ Prieur, Michel, op cit., p. 63.

${ }^{16}$ Ojeda Mestre, Ramón, Del Eterno Retorno a la No Regresión, en Revuelta Vaquero, Benjamín, y López Ramos, Neófito, Acciones Colectivas. Un paso hacia la Justicia Ambiental, Editorial Porrúa, México, 2012, p. 7.
} 


\subsection{Concepto jurisprudencial}

En particular, la Sentencia de 23 de diciembre de 2013 referida en el apartado ocho de este trabajo, tiene por merito haber introducido el principio de no regresión ambiental en la doctrina de la Corte Suprema de Justicia, donde se adopta como concepto:

"[...] que la estimación de la no regresión en materia ambiental, proviene de un principio del derecho reconocido por la doctrina como principio de no regresión, principio bajo el cual se "enuncia que la normativa y la jurisprudencia no deberían ser revisadas si esto implicare retroceder respecto a los niveles de protección alcanzados con anterioridad" (vid. Peña Chacón, Mario (dir.). El Principio de No Regresión Ambiental en el Derecho Comparado Latinoamericano. PNUD, San José, 2013, p. 16).

Este principio se desprende del principio de progresividad, el cual "ya no solamente surge como una obligación en la esfera de los derechos humanos, sino que aparece según la doctrina, como un principio en materia ambiental, (pues) es una derivación del principio de desarrollo sostenible, que impone un progreso solidario con las generaciones futuras, y cuya solidaridad implica no retroceder nunca en las medidas de protección del medio ambiente" (Mitre, Eduardo. El Derecho al Agua. Naturaleza Jurídica y Protección Legal. lustel, Madrid, 2012, pp. 212-113).

Al referirnos al principio de no regresión ambiental, nos remitimos a un concepto, que además encuentra pleno soporte en la jurisprudencia de distintos países. En ese sentido, por mencionar alguno, podemos hacer mención a la Sentencia 5538/2012 de la Sala de lo Contencioso Administrativo del Tribunal Supremo Español, en la cual se expone que:

"El principio de no regresión, ha sido considerado como una "Cláusula de statu quo" o "de no regresión", con la finalidad, siempre, de proteger los avances alcanzados en el contenido de las normas medioambientales, con base en razones vinculadas al carácter finalista del citado derecho medioambiental, como es el caso del Dictamen del Consejo 3297/2002, que si bien referido a modificación de zonas verdes, salvo existencia acreditada de un interés público prevalente. En otros términos, la superficie de zona verde en un municipio se configura como un mínimo sin retorno, a modo de cláusula stand still propia del derecho comunitario, que debe respetar la Administración. Sólo es dable minorar dicha superficie cuando existe un interés público especialmente prevalente, acreditado y general; no cabe cuando dicho interés es particular o privado, por gran relevancia social que tenga.

Pues bien la viabilidad de este principio puede contar con apoyo en nuestro derecho positivo, tanto interno estatal como propio de la Unión Europea. Ya nos hemos referido, en concreto, al denominado "Principio de desarrollo territorial y urbano sostenible; del que se ocupa el citado artículo $2^{a}$ del vigente TRLS08, que impone a las diversas políticas públicas "relativas a la regulación, ordenación, ocupación, transformación o uso del suelo" la obligación de proceder a la utilización del mismo "conforme al interés general y según el principio de desarrollo sostenible"; por tanto, este principio, ha de estar presente en supuestos como el de autos, en el que si bien no se procede a la supresión de suelos especialmente protegidos resulta incuestionable la afectación negativa que sobre los mismos se puede producir por su inclusión en una actuación urbanizadora y, en consecuencia, este principio ha de actuar como límite y como contrapeso de dicha actuación, dadas las consecuencias irreversibles de la misma.

En consecuencia, y sin perjuicio de su particular influencia en el marco de los principios, obvio es que, con apoyo en los citados preceptos constitucional (artículo 45 Constitución Española) y legales (artículo 2 y concordantes del TRLS08), el citado principio de no regresión calificadora de los suelos especialmente protegidos implica, exige e impone un plus de motivación razonada, pormenorizada y particularizada de 
aquellas actuaciones administrativas que impliquen la desprotección de todo o parte de esos suelos".

\subsection{Justificación y contextualización}

Son varias las razones que justifican la formulación del principio de no regresión. Michel Prieur, los sintetiza en tres aspectos fundamentales ${ }^{17}$. En primer lugar, señala que la consideración de la no regresión se justifica en el carácter finalista del derecho ambiental, es decir, que toda manifestación que disminuya la legislación ambiental y sus políticas se encuentra en contraposición a los fines que persigue el derecho ambiental. En segundo lugar, propone que está intrínsecamente relacionado con el derecho ambiental internacional en cuanto que de éste emerge la idea de que el objetivo fundamental es la progresión de la protección del medio ambiente. $Y$ finalmente, plantea que para entender la base jurídica del principio de no regresión sólo basta con reconocer el carácter de irreversibilidad con el que han sido consagrados los derechos económicos, sociales y culturales; derechos entre los cuales se cuentan los de carácter ambiental.

Desde esta perspectiva, podemos colegir que el principio de no regresión ambiental se sustenta en la noción de desarrollo sostenible y en referencia al principio de progresividad en la aplicación de los derechos humanos. Dicho de otro modo, se trata "de una derivación del principio de desarrollo sostenible, que impone un progreso solidario con las generaciones futuras, solidaridad que implica no retroceder nunca en las medidas de protección del medio ambiente" ${ }^{\prime 18}$.

Así lo explica, además, el reciente Informe del Experto Independiente de Naciones Unidas sobre Derechos Humanos y Medio Ambiente, el cual pone atención que entre las obligaciones que tienen los Estados de adoptar y aplicar marcos jurídicos e institucionales que prevengan daños ambientales, está la obligación de ajustar la legislación a los efectos de que no sea regresiva o interfiera en el aseguramiento de los derechos y libertades de los individuos ${ }^{19}$.

Así pues, el principio de no regresión ambiental es el resultado de la noción de progresividad establecida en el artículo 2 del Pacto Internacional de Derechos Económicos, Sociales y Culturales y a nivel regional con respecto al artículo 26 de la Convención Americana de Derechos Humanos. Tales normas recogen el principio de progresividad en materia de derechos humanos, de lo que se deduce una obligación mínima de no regresividad, es decir, como señala Víctor Abramovich y Christian Courtis $^{20}$, la obligación de adoptar políticas y medidas y, por ende, de sancionar normas jurídicas, que no empeoren la situación de los derechos económicos, sociales y culturales, pues el Estado se obliga a mejorar la situación de estos derechos, y simultáneamente asume la prohibición de reducir los niveles de protección de los derechos vigentes, o, en su caso, de derogar los derechos ya existentes.

En Panamá, de modo particular y ubicándonos en el plano fáctico, son variados los motivos que conducen a hablar de regresión ambiental. Jessica Young en su trabajo "El Principio de No Regresión Ambiental del Derecho Ambiental en el contexto legal y jurisprudencial de la República de Panamá", es especialmente precisa al describir algunos de los principales

\footnotetext{
${ }^{17}$ Prieur, Michel, op. cit., p. 65.

${ }^{18}$ López Ramón, Fernando, El Principio de No Regresión en la Desclasificación de los Espacios Naturales Protegidos en el Derecho Español, Revista Aranzadi de Derecho Ambiental, No. 10, 2011, pp. $13-27$ (p. 14).

19 Consejo de Derechos Humanos, Informe del Experto Independiente sobre la cuestión de las Obligaciones de Derechos Humanos relacionadas con el disfrute de un Medio Ambiente sin riesgos, limpio, saludable y sostenible, John H. Knox, 25 período de sesiones. Doc. A/HRC/25/53 de 30 de diciembre de 2013, párr. 55 y 56.

${ }^{20}$ Abramovich, Víctor., y Courtis, Christian, Los Derechos Sociales como Derechos Exigibles, Trotta, Madrid, 2004, p. 94.
} 
ejemplos de regresión ambiental experimentados en los últimos años en el país ${ }^{21}$. Dentro de estos se cuentan: el relajamiento institucional de las políticas públicas ambientales, la adopción de medidas contrarias al aseguramiento de áreas protegidas, la creación de legislación confusa y altamente contradictoria con los principios ambientales establecidos en la normativa ambiental nacional e internacional con relación al estudio de impacto ambiental, y pronunciamientos judiciales sustentados con fines contrarios al interés público ambiental.

\section{El principio de no regresión en la legislación ambiental panameña}

En Panamá, como en muchos otros países, aun no se cuenta con una norma que expresamente se refiera al principio de no regresión en lo menos con rango constitucional o como mandato legal de la política de ambiente. En donde sí encuentra expresa alusión es en el artículo 399 numeral 9 del Código Penal, en el que se establece la regresión como una agravante del tipo básico del delito ecológico. Así, señala la norma punitiva que la pena de prisión de tres a seis años prevista en el artículo 399, se aumentará de una tercera parte a la mitad entre otros casos "[c]uando el daño sea irreversible". De acuerdo con la disposición "[s]on irreversibles los efectos que supongan la imposibilidad de retornar a la situación anterior".

En otro supuesto, como decimos es notoria la ausencia de un precepto que claramente alude a la prohibición de regresividad como parámetro de las políticas públicas en esta materia. Sin embargo, si hacemos un ejercicio similar al que propone Michel Prieur, inmediatamente nos encontramos con una serie de disposiciones constitucionales y legales que sugieren esta orientación y otras que directamente hacen referencia a las características de este principio.

Como punto de partida, debemos tener como base la norma constitucional. El artículo 118 de la Constitución Panameña consagra el deber del Estado de garantizar un ambiente sano y libre de contaminación, es decir, establece la obligación positiva de garantizar y proteger el ambiente, lo que lleva implícito una condición de acción: de avanzar hacia tal garantía mediante la adopción de medidas legislativas e institucionales progresivas. Por otro lado, tenemos normas constitucionales que expresamente establecen entre las obligaciones del Estado la de -mantener el equilibrio ecológico y evitar la destrucción de los ecosistemas- (art. 119), de -evitar la depredación de los bosques, tierras y aguas y asegurar su preservación, renovación y permanencia- (art. 120), y de -evitar que se deriven perjuicios sociales, económicos y ambientales- (art. 121) ${ }^{22}$. Como vemos, estas disposiciones no hacen una referencia explícita al principio de no regresión ambiental, sin embargo, sí establecen un deber de "evitar" que aunque no entraña una prohibición de retroceso, sí presupone una condición de cautela en el retroceso: evitar desproteger, evitar desregular, evitar desmejorar o perjudicar, etc.

En nuestro medio, este principio puede contar también con el apoyo de la Ley 41 de 1 de julio de 1998, General de Ambiente, y la Ley 8 de 25 de marzo de 2015, que crea el Ministerio de

\footnotetext{
${ }^{21}$ Young, Jessica, El Principio de No Regresión Ambiental del Derecho Ambiental en el contexto legal y jurisprudencial de la República de Panamá, en Peña Chacón, Mario (dir.), El Principio de No Regresión Ambiental en el Derecho Latinoamericano Comparado, op. cit., pp. 321-346.

22 Artículo 119: El Estado y todos los habitantes del territorio nacional tienen el deber de propiciar un desarrollo social y económico que prevenga la contaminación del ambiente, mantenga el equilibrio ecológico y evite la destrucción de los ecosistemas.
}

Artículo 120: El Estado reglamentará, fiscalizará y aplicará oportunamente las medidas necesarias para garantizar que la utilización y el aprovechamiento de la fauna terrestre, fluvial y marina, así como de los bosques, tierras y aguas, se lleven a cabo racionalmente, de manera que se evite su depredación y se asegure su preservación, renovación y permanencia.

Artículo 121: La Ley reglamentará el aprovechamiento de los recursos naturales no renovables, a fin de evitar que del mismo se deriven perjuicios sociales, económicos y ambientales. 
Ambiente y modifica, adiciona y deroga normas de la Ley 41 de 1998. Así, el artículo 1 establece que al Estado le corresponde la administración del ambiente, mientras que el artículo 2 párrafo 36 prescribe el principio de desarrollo sostenible como el "proceso o capacidad de una sociedad humana de satisfacer las necesidades y aspiraciones sociales, culturales, políticas, ambientales y económicas actuales, de sus miembros, sin comprometer la capacidad de las futuras generaciones para satisfacer las propias". De modo más explicito, la misma norma en su párrafo 57 define "protección" como el "conjunto de medidas y políticas para mejorar el ambiente natural y combatir sus amenazas, y evitar su deterioro".

Así pues, como fundamento básico del principio de no regresividad ambiental, puede deducirse que la protección ambiental implica además de su consideración positiva, evitar el deterioro de las medidas y políticas de mejora al ambiente natural; aspecto que subyace al principio de desarrollo sostenible establecido en la Ley 41 de 1998 y la Declaración de Río de 1992 (principio 3), y que como se anotó antes, cabe relacionar con la cláusula de progresividad prevista en ordenamiento internacional.

En estos términos, la Corte en Sentencia de 23 de diciembre de 2013 señaló que:

"En nuestro medio jurídico, este principio se debe deducir de lo establecido en el artículo 2 de la Ley $N^{\circ} 13$ de 27 de octubre de 1976 (que aprueba el Pacto Internacional de Derechos Económicos, Sociales y Culturales), con relación al artículo 1 (La administración del [ambiente] es una obligación del Estado) y 2 (principio de desarrollo sostenible) de la Ley $\mathrm{N}^{\circ} 41$ de 1998; en particular a partir de la norma convencional que establece el principio de progresividad, el Estado se obliga a cumplir con ciertas prestaciones sociales, entre las cuales se encuentran las de carácter ambiental, desarrolladas en la Ley General del Ambiente, y demás regulación sectorial.

En el contexto del señalado artículo 2 lex cit, como explica el profesor de Derecho Ambiental de la Universidad de Costa Rica, Mario Peña Chacón, se entiende que el principio de no regresión tiene por "finalidad evitar (la) supresión normativa o la reducción de sus exigencias por intereses contrarios que no logren demostrar ser jurídicamente superiores al interés público ambiental, ya que en muchas ocasiones, dichas regresiones pueden llegar a tener como consecuencias daños ambientales irreversibles o de difícil reparación".

Ahora, al margen de las disposiciones señaladas, en la Ley General de Ambiente se encuentran también otras prescripciones que aluden al principio de progresividad y que por tanto ahondan en la tesis de la no regresividad. En esa línea, el artículo 22 dispone que el "ordenamiento ambiental del territorio nacional se ejecutará en forma progresiva por las autoridades competentes". Ha de destacarse que esta misma disposición contempla una prohibición de regreso, así: "Las actividades que se autoricen no deberán perjudicar el uso o función prioritaria del área respectiva, identificada en el Programa de Ordenamiento Ambiental del Territorio Nacional'.

Como vemos, la ley condiciona la actividad pública ambiental al principio de progresividad o gradualidad, como dice la misma. Así, se insiste en el artículo 33, que las "normas ambientales que se emitan serán aplicadas por la autoridad competente, en forma gradual y escalonada, preferiblemente en base a procesos de autorregulación y cumplimiento voluntario por parte de las empresas, y de conformidad con el reglamento respectivo".

Otra norma que contempla una cláusula de progresividad es el artículo 38, en el que se dice que en la "determinación de los nuevos niveles de calidad, se aplicará el principio de gradualidad, permitiendo ajustes progresivos a dichos niveles". La norma, como se aprecia, refuerza la idea de que el proceso de revisión y actualización de los instrumentos económicos y de regulación ambiental (que se realiza como mínimo cada cinco años), en cualquier caso será progresivo y no en otros términos. 
Por otro lado, en el marco de las responsabilidades convenidas con la firma de ciertos Tratados de Libre Comercio, podemos identificar la referencia expresa a este principio ambiental. De ese tenor son el artículo 17.02 (b) del Tratado de Libre Comercio de Panamá y Canadá, aprobado mediante Ley 69 de 26 de octubre de 2010, en el que se establece "el compromiso de no derogar leyes ambientales nacionales para estimular el comercio o la inversión". La Ley 53 de 13 de diciembre de 2007, que aprueba el Tratado de Promoción Comercial entre la República de Panamá y los Estados Unidos de América, por su parte consagra en el artículo 17.3 numeral 2 que: "Las Partes reconocen que es inapropiado promover el comercio o la inversión mediante el debilitamiento o la reducción de las protecciones contempladas en sus respectivas legislaciones ambientales. En consecuencia, una Parte no dejará sin efecto o derogará, ni ofrecerá dejar sin efecto o derogar, dicha legislación de manera que debilite o reduzca la protección otorgada por aquella legislación de manera que afecte el comercio o la inversión entre las Partes".

En tanto que, la Ley 4 de 7 de abril de 2014, por la cual se aprueba el Tratado de Libre Comercio entre los Estados AELC (Islandia, Noruega, Liechtenstein y Suiza) y los Estados Centroamericanos, de forma mucho más abarcadora, contempla en su artículo 9.4 lo que denomina como "principio de mantenimiento de los niveles de protección", el cual supone que: "(a) las Partes reconocen que es inapropiado debilitar o reducir los niveles de protección contemplados en sus leyes, regulaciones y estándares medioambientales y laborales, con la única intención de promover la inversión de otra Parte, o de buscar o mejorar una ventaja competitiva de comercio para productores o proveedores de servicios que estén operando en su territorio"; y que "(b) una parte no dejará ni derogará, ni ofrecerá dejar sin efecto o derogar sus leyes, regulaciones y estándares medioambientales y laborales, con el fin de promover la inversión de otra Parte, o de buscar o mejorar una ventaja competitiva de comercio para productores o proveedores de servicios que estén operando en su territorio".

\section{El aporte de la jurisprudencia}

En la doctrina de la Corte Suprema de Justicia se advierte una importante referencia al principio de no regresión ambiental en la Sentencia de 23 de diciembre de 2013. Antes de este fallo, el único precedente conocido que hace alusión a la no regresividad es la Sentencia de 1 de diciembre de 2009. Ahora, si bien el fallo de 2009 no trata materia ambiental, conviene hacer alguna mención del mismo, pues, en éste se precisa la relación del principio de progresividad con su complemento o derivación el principio de no regresión.

Así, interesa destacar que a través de este pronunciamiento la Corte reconoce que la cláusula de progresividad en materia de derechos humanos "exige que los Estados tomen "medidas legislativas o de cualquier otro carácter" para avanzar en el logro de dicha efectividad, o por lo menos para evitar retrocesos en esta materia". Así, la Corte plantea que la "exigencia del requisito de las certificaciones de eficacia terapéutica comprobada, de equivalencia terapéutica y de la calidad de medicamento intercambiable, en las adquisiciones de medicamentos genéricos por parte de instituciones públicas de salud", constituye "una medida de desarrollo progresivo del derecho a la salud de la colectividad". En tanto que, en contraposición, "la no exigencia del referido requisito en la adquisición del Interferón Beta 1B, 250 MCG, inyectable [...] pese a tratarse de la adquisición de un medicamento para el tratamiento de una condición grave o crítica como lo es la esclerosis múltiple", supone "una medida regresiva no justificada que significa un retroceso en el logro de la efectividad de los derechos económicos, sociales y culturales".

Ya en el ámbito ambiental, la predicha Sentencia de 23 de diciembre de 2013, como se adelantó, aplica por primera vez el principio de no regresión ambiental bajo la consideración de que la exclusión del Humedal Bahía de Panamá, del régimen jurídico de protección y 
conservación de los ecosistemas allí existentes, es pues una actuación ilegal que desconoce el carácter especial de área protegida.

En efecto, el fallo establece que la anulación de un acto administrativo de interés general, o público de carácter ambiental, a menos que sea por un interés superior a éstos, acarrea una regresión en el desarrollo de las medidas de protección ambiental.

Para la Sala "el establecimiento de un área protegida trae de suyo un interés general y público, dado que su importancia va ligada a la protección de todo un ecosistema; en este caso, especialmente integrado "como hábitat de aves acuáticas que comprenden extensiones de marismas, pantanos y turberas o superficies cubiertas de agua, sean éstos de régimen natural o artificial, permanentes o temporales, estancadas o aguas marinas, cuya profundidad de mareas bajas no exceda de 6 metros".

De ahí pues, que la fallo sostenga que la declaración de área protegida del Humedal Bahía de Panamá y su inclusión como sitio RAMSAR, "no hace más que reconocer la importancia socioambiental de tal superficie, así como la necesidad de salvaguardar los procesos biológicos que allí se desarrollan". Por consiguiente, la Corte señaló "que si se contempla[...] la anulación del acto administrativo en cuestión, se estaría en clara contradicción con los fines, principios y lineamientos que protege la legislación ambiental panameña". Es decir, dice la Sala: "se daría paso a una regresión en materia ambiental. Regresión que resultaría de excluirse el Humedal Bahía de Panamá, del régimen jurídico de protección y conservación de los ecosistemas existentes en la referida área protegida".

En concreto, la Corte sostuvo que:

"[...] si se deslegitiman los mínimos de protección alcanzados a través de la Resolución $\mathrm{N}^{\circ}$ AG-0072-2009, se dejaría sin resguardo jurídico-ambiental el denominado Humedal Bahía de Panamá, poniéndose en estado de vulnerabilidad el ya frágil ecosistema, y los procesos ecológicos de dicha área.

Dicho de otro modo, la desprotección de la superficie marino-costera establecida dentro del área protegida, expondría al humedal y su zona de amortiguamiento, a actividades incompatibles con la política de protección y conservación de los recursos naturales y culturales que se establece en la legislación vigente, y en el Plan de Manejo del área protegida, que exigen la garantía y mantenimiento de las características ecológicas de los ecosistemas de humedales del área (aspecto que advierte el artículo 8 del acto acusado en concordancia con los establecido en la Convención RAMSAR y la Conferencia de las Partes que establece el Marco de Referencia para la Aplicación de la Convención de RAMSAR).

Tales actividades, como razonablemente advierte el artículo 10 de la Resolución JD-Nº 09-94 de 1994, podrían ser: 1.) La remoción, tala, desmonte, relleno, desecación, extracción y cualquier otra actividad que afecte el flujo hidrológico de los manglares; 2.$)$ El hostigamiento, recolección, captura, cacería, transporte y/o comercialización de especímenes de la fauna silvestre; 3.) La introducción de especies exóticas dentro del Humedal Bahía de Panamá; 4.) El depósito de desechos sólidos, orgánicos e inorgánicos, y de aguas residuales; 5.) El vertimiento de sustancias que contaminan las aguas marinas y fluviales, tales como agroquímicos, hidrocarburos, aguas servidas (industriales, riego, agropecuarias y domésticas) y otras, sin el debido tratamiento de dichas sustancias; 6.) La entrada de nuevos ocupantes a los terrenos que conforman el área protegida; 7.) El establecimiento de actividades que atenten contra la integridad y el mantenimiento de las características ecológicas del ecosistema, así como sus bienes y servicios ambientales, y los fines de conservación y uso sostenible del que pretende dicho Humedal Bahía de Panamá; 8.) La roza y quema de rastrojos mayores de 5 años; 9.) El desmonte (expansión de frontera agrícola), dentro del área; 10.) La pesca, más 
allá de artesanal o de subsistencia; entre otras que puedan causar daños al Humedal y a sus ecosistemas asociados o interferir con las acciones de manejo del área protegida.

Así las cosas, esta Sala después de la ponderación cuidadosa de las normas alegadas y las circunstancias que giran en torno a los efectos jurídicos de la declaratoria del área protegida Humedal Bahía de Panamá, arriba a la conclusión de que el acto demandado, no infringe las normas aducidas así como tampoco afecta el ordenamiento jurídico en general; el cual, vale la pena insistir, en el peor de los casos, sí se vería lesionado con la adopción de una medida legal, administrativa o judicial, que retrotraiga los efectos de protección hasta ahora conseguidos a través de la Resolución NªG0072-2009".

\section{Conclusiones}

Desde hace algún tiempo, un número cada vez mayor de habitantes de la comunidad internacional, Estados, Entidades Gubernamentales y no gubernamentales, se preocupan en mayor o menor grado por la conservación del medio ambiente.

Panamá no escapa a esta realidad. Los problemas generados por la explotación irracional de los recursos naturales, ha motivado para que los Gobiernos, los Ciudadanos y la Sociedad organizada, adquieran compromiso para establecer parámetros que nos permitan mantener una vigilancia permanente sobre los efectos de nuestras actividades sobre el ambiente, de modo que se puedan alcanzar las metas del desarrollo sustentable.

De lo que se trata es de explorar diferentes caminos de acercamiento con la comunidad, para alcanzar así los objetivos de una participación efectiva. Esta realidad nos mandata como máximos tuteladores de la justicia ambiental, para coordinar acciones interdisciplinarias para la divulgación de la normativa legal panameña sobre la temática ambiental.

Se hace necesario que la sociedad organizada conozca y comprenda las formas de interacción entre la sociedad y la naturaleza, así como las causas y consecuencias del deterioro ambiental, con la finalidad de involucrarlos en una actuación integrada y racional con su entorno.

Igualmente, se deben divulgar las diversas normativas legales que tutelan y salvaguardan la protección de los recursos naturales y por ende, del medio ambiente.

Los distintos actores involucrados en los problemas ambientales, debemos unir nuestros mejores esfuerzos para hacer docencia acerca de la importancia de los temas ambientales.

Se trata de una docencia interdisciplinaria, que contemple los diferentes aspectos sociales, económicos, políticos, jurídicos y de supervivencia global, a fin de tomar conciencia del riesgo que conllevan las afectaciones al medio ambiente y su repercusión directa en la vida de calidad del planeta que nos cobija.

Si bien los Estados dentro de la Comunidad Internacional, están haciendo esfuerzos por tipificar la normativa jurídica ambiental, y Panamá, igualmente, se ha sumado a estos esfuerzos, con normativa jurídica ambiental de reciente data. Estas normas, de no ser conocidas por la colectividad, flaco favor le hace a estos esfuerzos por proteger el medio ambiente.

En esta tarea, el fallo de 4 de abril de 2013 y de 23 de diciembre de 2013 constituyen un importante hito en la protección judicial del medio ambiente, y muy en particular, del régimen jurídico de los humedales. La introducción del principio de no regresión ambiental en la doctrina de la Corte Suprema de Justicia, debe considerarse, como un significativo freno al relajamiento expresado por las instituciones públicas de protección ambiental así como un mecanismo eficaz de argumentación a la hora de acceder a la tutela ambiental. 


\section{Bibliografía}

Abramovich, Víctor., y Courtis, Christian, Los Derechos Sociales como Derechos Exigibles, Trotta, Madrid.

Benavides Pinilla, Víctor, Compendio de Derecho Público Panameño, Ediciones Jurídicas Andrés Morales, Bogotá, 2012.

Benedictus, Leonardo, Seguros Ambientales. Nuevas Formas de la SA y DS, Una visión desde el sector productivo, en Sexto Encuentro Internacional de Derecho Ambiental, Memorias, Foro Consultivo Científico y Tecnológico, México, 2008, disponible en:

http://www.foroconsultivo.org.mx/libros_editados/ambientalistas_6.pdf.

Chandeck, Lucía, La Responsabilidad Administrativa Ambiental en Panamá, en Secretaría de Medio Ambiente y Recursos Naturales, Instituto Nacional de Ecología, PNUMA, Memorias del Segundo Encuentro Internacional de Derecho Ambiental, México, 2004, disponible en: http://www2.inecc.gob.mx/publicaciones/consultaPublicacion.html?id_pub=446.

Consejo de Derechos Humanos, Informe del Experto Independiente sobre la cuestión de las Obligaciones de Derechos Humanos relacionadas con el disfrute de un Medio Ambiente sin riesgos, limpio, saludable y sostenible, John H. Knox, 25 período de sesiones.Doc. A/HRC/25/53 de 30 de diciembre de 2013, párr. 55 y 56.

Embid Irujo, Antonio, El Derecho Público de la Crisis Económica, en Blasco Esteve, Avelino (coord.), Actas del VI Congreso de la Asociación Española de Profesores de Derecho Administrativo, Palma de Mallorca, Instituto Nacional de Administración Pública, Madrid, 2011.

Hoyos, Arturo. El derecho contencioso-administrativo de Panamá (1903- 2005): una introducción histórica de derecho comparado y jurisprudencial. Sistemas Jurídicos. Panamá. 2005.

López Ramón, Fernando, El Principio de No Regresión en la Desclasificación de los Espacios Naturales Protegidos en el Derecho Español, Revista Aranzadi de Derecho Ambiental, No. 10, 2011, pp. 13-27.

López Ramón, Fernando, Introducción General: Regresiones del Derecho Ambiental, en López Ramón, Fernando (dir.), Observatorio de Políticas Ambientales 2011, Aranzadi, ThomasReuters, Navarra, 2011, pp. 19-24, disponible en:

http://www.actualidadjuridicaambiental.com/wp-content/uploads/2010/06/09_OPAM-11.pdf.

Martínez Patiño, Rosales, La Responsabilidad Ambiental en Panamá, Ámbitos Administrativo y Penal, en Sexto Encuentro Internacional de Derecho Ambiental, Memorias, Foro Consultivo Científico y Tecnológico, México, 2008,

disponible en: http://www.foroconsultivo.org.mx/libros_editados/ambientalistas_6.pdf.

Ojeda Mestre, Ramón, Del Eterno Retorno a la No Regresión, en Revuelta Vaquero, Benjamín, y López Ramos, Neófito, Acciones Colectivas. Un paso hacia la Justicia Ambiental, Editorial Porrúa, México, 2012.

Peña Chacón, Mario, El Principio de No Regresión Ambiental en la Legislación y Jurisprudencia Costarricense, en Peña Chacón, Mario (dir.), El Principio de No Regresión Ambiental en el Derecho Latinoamericano Comparado, PNUD, San José, 2013.

Peña Chacón, Mario, Gestión Integrada del Recurso Hídrico en la Legislación Costarricense, Editorial Investigaciones Jurídicas, San José, 2008.

Prieur, Michel, El Nuevo «Principio de No Regresión en Derecho Ambiental», en Acto de Investidura del Grado de Doctor Honoris Causa, Prensas Universitarias de Zaragoza, 2010, p. 64. 
Secretaría de la Convención de RAMSAR, Manual de la Convención de RAMSAR: Guía a la Convención sobre los Humedales (RAMSAR, Irán, 1971), 6ta. Edición, Secretaría de la Convención de RAMSAR, Suiza, 2013, disponible en: http://www.ramsar.org/pdf/lib/manual62013-sp.pdf.

Young, Jessica, El Principio de No Regresión Ambiental del Derecho Ambiental en el contexto legal y jurisprudencial de la República de Panamá, en Peña Chacón, Mario, (dir.), El Principio de No Regresión Ambiental en el Derecho Latinoamericano Comparado, PNUD, San José, 2013. 


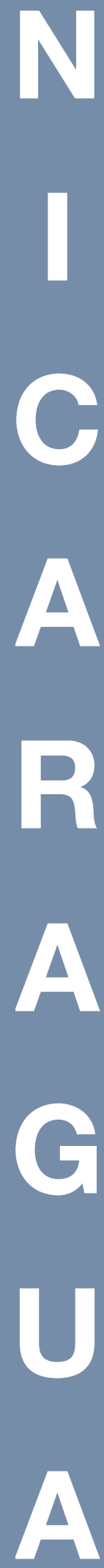



\section{LEY 840, SÍMBOLO DE LA REGRESIÓN EN LA PROTECCIÓN AMBIENTAL NICARAGUENSE}

\section{Marianela Rocha $Z^{*}$.}

"Los Estados deberían dar acceso a la información relativa al medio ambiente y prever la evaluación de los impactos ambientales que puedan interferir en el disfrute de los derechos humanos ${ }^{1}$. John H. Knox

\section{Introducción}

A partir de la vigencia de Constitución Política de 1987 el desarrollo de la normativa ambiental en Nicaragua se destacó por la aprobación de ambiciosas disposiciones encaminadas a la restauración y protección ambiental y de los recursos naturales. Estas normas tenían como finalidad además de proteger los recursos naturales, garantizar el derecho de las personas a un ambiente sano y hacían una clara apuesta por la conservación, uso racional de los recursos naturales y al desarrollo sostenible del País.

Entre los años 1990 a 1995 se dictaron los primeros reglamentos que regulaban el uso sostenible y la protección de los recursos naturales. Normaron el tema forestal, la evaluación de impacto ambiental como requisito previo a la realización de obras o proyecto y los parámetros de descargas de aguas residuales. Asimismo se suscribieron y ratificaron los principales convenios ambientales internacionales y regionales de protección de la biodiversidad, cambio climático, humedales, etc. También en este período se creó el Ministerio de Medio Ambiente y Recursos Naturales (MARENA).

Con la aprobación de la Ley № 217, Ley General del Medio Ambiente y los Recursos Naturales de Nicaragua en el año 1996, se inició el desarrollo de un sistema de gestión ambiental articulado. Se dictaron importantes Decretos de desarrollo de la Ley № 217, así como Ordenanzas Municipales relacionadas al tema ambiental. También se aprobaron la Ley № 462 , Ley de Conservación, Fomento y Desarrollo Sostenible del Sector Forestal (2004); Ley № 620, Ley General de Aguas Nacionales (2007); la Ley № 626, Ley que crea la Comisión de Desarrollo Sostenible de la Cuenca Hídrica del Lago Cocibolca y del Río San Juan (2007); Ley № 807, Ley de Conservación y Utilización Sostenible de la Diversidad Biológica (2012); Ley 833, Ley que declara y define los límites de la Reserva de Biosfera Isla de Ometepe (2013), entre otras.

En general se ha considerado que Nicaragua cuenta con una normativa adecuada que permitiría realizar una gestión y protección adecuada de los abundantes y valiosos recursos

\footnotetext{
* Licenciada en Derecho. Abogada y Notario Público. Máster en Evaluación de Impacto Ambiental del Instituto de Investigaciones Ecológicas de Málaga, España. Posgrado en Dirección y Gestión Ambiental de la Universidad de Barcelona, España. Fue Procuradora Ambiental. Es abogada de las áreas de derecho ambiental de las firmas CCA \& Asociados/Nicaragua y OfficiumLex/Centroamérica y República Dominicana.

1 Tomado del Informe del Experto independiente sobre la cuestión de las obligaciones de derechos humanos relacionadas con el disfrute de un medio ambiente sin riesgos, limpio, saludable y sostenible, John H. Knox. Párrafo 31. Consejo de Derechos Humanos 25 período de sesiones Tema 3 de la agenda Promoción y protección de todos los derechos humanos, civiles, políticos, económicos, sociales y culturales, incluido el derecho al desarrollo. 30 de diciembre de 2013.
} 
naturales que posee, sin embargo, la realidad de la situación ambiental del país refleja que al menos en su implementación esta legislación no ha sido eficaz ni eficiente.

La falta de eficacia normativa es un fenómeno que no sólo ha sucedido en Nicaragua, sino en diversos países del mundo. En la Cumbre de Rio+20 se reconocieron estas dificultades pero se instó a no dar marcha atrás en los compromisos ambientales asumidos por los países ${ }^{2}$.

En efecto, independientemente de que los progresos han sido insuficientes, se debe reconocer el esfuerzo de las instituciones públicas que, con sus limitados recursos, han venido empujando el cumplimiento de estas disposiciones jurídicas. También se debe destacar la mayor conciencia y conocimiento ambiental de la ciudadanía, los importantes programas impulsados por los organismos ambientalistas de la sociedad civil, la investigación ambiental y la formación de capacidades realizada por la academia y el acatamiento por parte de los sectores empresariales regulados, estos últimos, algunas veces persuadidos por disposiciones de financiadores internacionales o bien por asuntos de mercado.

En junio del año 2013, la Asamblea Nacional de Nicaragua aprobó la Ley 840, Ley Especial para el Desarrollo de Infraestructura y Transporte Nicaragüense, Atingente al Canal, Zonas de Libre Comercio e Infraestructuras Asociadas y el Acuerdo Marco de Implementación ${ }^{3}$, donde otorga una concesión por cien años a la empresa Hong Kong Nicaragua Development (HKND) para la realización y explotación de las obras descritas en la Ley 840.

El Canal propuesto en la Ley 840 cruzará todo el territorio nicaragüense de este a oeste. La longitud total es de $278 \mathrm{~km}$ aproximadamente, con un tramo de $105 \mathrm{~km}$ en el Lago Cocibolca. Es criterio de la mayoría de la comunidad científica nicaragüense que el proyecto del canal causará un enorme impacto negativo en los recursos naturales del país.

Paradójicamente la referida Ley 840 , estableció como autoridad ambiental a una instancia ajena al Ministerio del Ambiente y los Recursos Naturales (MARENA) y un régimen de regulación ambiental confuso que ha permitido la aprobación de un proyecto sin haber realizado el o los estudios de impacto ambiental y por ende los permisos correspondientes. Los proponentes del proyecto, así como las propias autoridades nicaragüenses, informan, unas veces, que está elaborando y consultado un estudio de factibilidad ambiental, otras un estudio de impacto ambiental y social, pero no un estudio de impacto ambiental conforme las disposiciones del Decreto 76-2006, Sistema de Evaluación Ambiental ${ }^{4}$, instrumento legal ambiental que por años se había venido perfeccionado para la realización de obras y actividades en el país protegiendo el ambiente y los recursos naturales, que son, como recoge la Constitución misma Patrimonio de la Nación.

La Ministra de Medio Ambiente y Recursos Naturales en carta dirigida a la organización ambientalista Centro Humboldt como respuesta a la solicitud de información sobre el proceso de evaluación de impacto ambiental para el Canal, le aclara que la Ley 840 le otorga esas funciones a la Comisión del Gran Canal Interoceánico de Nicaragua. La Ministra refiere en su nota: "Quisiera informarle que la ley 840 otorga funciones a la comisión del Gran Canal

\footnotetext{
2 "Desde 1992 los progresos han sido insuficientes y se han registrado contratiempos en algunos aspectos de la integración de las tres dimensiones del desarrollo sostenible, agravados por las múltiples crisis financieras, económicas, alimentarias y energéticas, que han puesto en peligro la capacidad de todos los países, en particular los países en desarrollo, para lograr el desarrollo sostenible. A este respecto, es esencial que no demos marcha atrás a nuestro compromiso con los resultados de la Conferencia de las Naciones Unidas sobre el Medio Ambiente y el Desarrollo..... El futuro que queremos. Documento final de la Conferencia. A/CONF.216/L.1. Río de Janeiro (Brasil). 2012.

${ }^{3}$ Publicada en La Gaceta, Diario Oficial № 110 del 14 de junio de 2013.

${ }^{4}$ Publicado en La Gaceta, Diario Oficial No. 248 del 22 de Diciembre del 2006.
} 
Interoceánico de Nicaragua y en el marco de esta institucionalidad se ha definido que el estudio de factibilidad ambiental lo realice la empresa ERM..."

La Ley 840 regula un proyecto que afectará medularmente valiosos recursos ecológicos del país y a éste, según la Ministra de MARENA, no le será aplicado el régimen legal ambiental vigente sino un marco legal que crea la Ley 840 lo que consideramos representa un grave acto de regresión en la normativa de protección de los recursos naturales y del ambiente del país.

\section{Positivación del principio preventivo en la legislación ambiental nicaragüense}

Antes de analizar la referida Ley 840 es pertinente sistematizar algunos antecedentes jurídicos de normas de protección y regulación ambiental en Nicaragua.

La Constitución Política de Nicaragua de $1987^{6}$, plasma una serie de disposiciones que deben inspirar y delimitar el contenido de las leyes ambientales ${ }^{7}$. En su artículo 102 establece que los recursos naturales son patrimonio nacional y que la preservación del ambiente y la conservación, desarrollo y explotación racional de los recursos corresponden al Estado. Por su parte, el Título IV Derechos, Deberes y Garantías del Pueblo Nicaragüense en su Capítulo III referido a los derechos sociales, dispone en su artículo 60, parte conducente, que los nicaragüenses tienen derecho de habitar en un ambiente saludable, así como la obligación de su preservación y conservación ${ }^{8}$.

5 La Prensa del 11 de marzo de 2014. MARENA no vigilará "estudios" del Canal. http://www.laprensa.com.ni/2014/03/11/ambito/186148-marena-no-vigilara-estudios.

${ }^{6}$ Con las reformas siguientes: Reforma Constitucional para las elecciones del 25 de febrero de 1990. Aprobada el treinta de Enero de mil novecientos noventa. Publicada en La Gaceta, Diario Oficial No. 46 del 6 de Marzo de 1990; Ley №. 192, Ley de Reforma Parcial a la Constitución Política de la República de Nicaragua, aprobada el primero de febrero del año mil novecientos noventa y cinco, publicada en La Gaceta, Diario Oficial № 124 del cuatro de julio de 1995; Ley №. 330, Ley de Reforma Parcial a la Constitución Política de la República de Nicaragua, aprobada el dieciocho de enero del año dos mil y publicada en La Gaceta, Diario Oficial N․ 13 del diecinueve de enero del 2000; Ley №. 520, Ley de Reforma Parcial a la Constitución Política de la República de Nicaragua, aprobada el trece de enero del año dos mil cinco, publicada en La Gaceta, Diario Oficial No. 35 del dieciocho de febrero de 2005, con la corrección publicada en La Gaceta, Diario Oficial No. 97 del 23 de mayo del año 2008; Ley N. 521, Ley de Reforma Parcial al artículo 140 de la Constitución Política de la República de Nicaragua, aprobada el trece de enero del año dos mil cinco, publicada en La Gaceta, Diario Oficial $N^{\circ}$. 35 del dieciocho de febrero de 2005; Ley $N^{\circ}$. №. 527, Ley de Reformas Parcial de la Constitución Política, aprobada el quince de enero del año dos mil cinco, publicada en La Gaceta, Diario Oficial N ${ }^{\circ}$. 68 del ocho de abril de 2005; Ley $\mathrm{N}^{\circ}$. 854, Ley de Reforma Parcial a la Constitución Política de la República de Nicaragua, aprobada el veintinueve de enero del año dos mil catorce, publicada en La Gaceta, Diario Oficial No. 26 del diez de febrero de 2014.

${ }^{7}$ Artículo 182 Cn. La Constitución Política es la carta fundamental de la República; las demás leyes están subordinadas a ella. No tendrán valor alguno las leyes, tratados, decretos, reglamentos, órdenes o disposiciones que se le opongan o alteren sus disposiciones.

${ }^{8}$ El artículo continua diciendo: El bien común supremo y universal, condición para todos los demás bienes, es la madre tierra; esta debe ser amada, cuidada y regenerada. El bien común de la Tierra y de la humanidad nos pide que entendamos la Tierra como viva y sujeta de dignidad. Pertenece comunitariamente a todos los que la habitan y al conjunto de los ecosistemas. La Tierra forma con la humanidad una única identidad compleja; es viva y se comporta como un único sistema autoregulado formado por componentes físicos, químicos, biológicos y humanos, que la hacen propicia a la producción y reproducción de la vida y que, por eso, es nuestra madre tierra y nuestro hogar común. Debemos proteger y restaurar la integridad de los ecosistemas, con especial preocupación por la diversidad biológica y por todos los procesos naturales que sustentan la vida. La nación nicaragüense debe adoptar patrones de producción y consumo que garanticen la vitalidad y la integridad de la madre tierra, la equidad social en la humanidad, el consumo responsable y solidario y el buen vivir comunitario. El Estado de Nicaragua asume y hace suyo en esta Constitución Política el texto íntegro de la Declaración Universal del Bien Común de la Tierra y de la Humanidad. 
También dispone en su artículo 99, que el Estado es responsable de promover el desarrollo integral del país, y como gestor del bien común deberá garantizar los intereses y las necesidades particulares, sociales, sectoriales de la nación, y en el artículo 104, que garantiza el pleno ejercicio de las actividades económicas, sin más limitaciones que por motivos sociales o de interés nacional impongan las leyes. Una de estas limitaciones es sin duda la protección del ambiente y el uso racional de los recursos naturales.

De las disposiciones constitucionales 60 y 102 se deriva la Ley 217, Ley General del Medio Ambiente y los Recursos Naturales ${ }^{9}$. Esta ley establece las normas para la conservación, protección, mejoramiento y restauración del medio ambiente y los recursos naturales que lo integran, asegurando su uso racional y sostenible. Contiene un marco general que regula el uso de los recursos naturales estableciendo las normas comunes y formas de adquirir los derechos uso. Partiendo de que los recursos naturales son patrimonio nacional, determina que el dominio, uso y aprovechamiento por parte de los particulares debe ser regulado por las disposiciones que dicta esta ley, otras leyes especiales y sus reglamentos, estableciendo que el Estado podrá otorgar derecho a aprovechar los recursos naturales por concesión, permisos, licencia y cuotas ${ }^{10}$.

Las disposiciones de la Ley 217 son el eje articulador de otras leyes, reglamentos, ordenanzas municipales, regionales y normas técnicas ambientales, que regulan instrumentos de gestión ambiental o protegen recursos naturales específicos.

Uno de los instrumentos considerados claves en la legislación nicaragüense dado su carácter preventivo es el sistema de evaluación ambiental creado en el artículo 27 de la Ley 217. Se establece que todos los proyectos, obras, industrias o cualquier otra actividad, pública 0 privada, de inversión nacional o extranjera, durante su fase de pre-inversión, ejecución, ampliación, rehabilitación o reconversión, que por sus características puedan producir deterioro al medio ambiente o a los recursos naturales, conforme a la lista específica de las categorías de obras o proyectos que se establezcan en el Reglamento respectivo, deberán obtener, previo a su ejecución, el Permiso Ambiental o Autorización Ambiental de acuerdo a la categoría que corresponda. El Sistema de Evaluación Ambiental fue reglamentado por el Decreto 76-2006.

Todo proyecto siempre y cuando estuviese categorizado en el Decreto 76-2006 debe realizar un estudio de impacto ambiental o valoración ambiental. El artículo 15 de este Decreto señala que las obras, proyectos e industrias Categoría I, son considerados proyectos especiales por su trascendencia nacional, binacional o regional; por su connotación económica, social y ambiental y, porque pueden causar Alto Impacto Ambiental Potencial están sujetos a un Estudio de Impacto Ambiental.

El Decreto 76-2006 contempla que el proponente del proyecto solicitará mediante una comunicación escrita al MARENA la guía para elaborar la presentación del proyecto; el Proponente deberá exponer a grandes rasgos el proyecto así como el contexto geográfico de incidencia, acompañado a esta solicitud presentará debidamente llenado el formulario.

La Dirección General de Calidad Ambiental de MARENA una vez que tenga conocimiento de la solicitud, procederá a conformar el equipo interinstitucional, instancia que se encargará de la revisión de la presentación del proyecto y de la elaboración de la guía para los términos de referencia que utilizará el proponente en la elaboración del Estudio de Impacto Ambiental.

\footnotetext{
${ }^{9}$ La Ley 217 fue publicada en La Gaceta, Diario Oficial, No. 105 del 6 de junio de 1996 y fue reformada por la Ley 647 publicada en La Gaceta, Diario Oficial, No. 62 del 3 de abril de 2008.

${ }^{10}$ El otorgamiento de estos derechos de aprovechamiento debe ser bajo las condiciones que la Ley 217 dispone: "todos los habitantes tienen derecho a disfrutar de un ambiente sano de los paisajes naturales y el deber de contribuir a su preservación. El Estado tiene el deber de garantizar la prevención de los factores ambientales adversos que afecten la salud y calidad de vida de la población estableciendo las medidas o normas correspondientes".
} 
El plazo establecido para los Proyectos Categoría I, donde consideramos cabe el proyecto del canal, es de, un mínimo de ciento veinte días hábiles, hasta un máximo de doscientos cuarenta días hábiles para que MARENA proceda a la revisión técnica del proyecto hasta emitir la resolución de permiso ambiental correspondiente para la categoría ${ }^{11}$.

\section{Protección jurídica a la cuenca hídrica del lago Cocibolca}

Para fines de este trabajo es importante resaltar también la importancia ecológica del Lago Cocibolca. Pertenece al sistema de cuencas formadas por la Cuenca del Lago Xolotlán, el Lago Cocibolca y el Río San Juan que en su conjunto suman aproximadamente $41,600 \mathrm{~km} 2$, de los cuales $29,000 \mathrm{~km}$ pertenece a Nicaragua y 12,600 a Costa Rica. Por su volumen el Lago Cocibolca representa una de las fuentes de agua más importante de Nicaragua ${ }^{12}$.

El Lago Cocibolca está protegido por, entre otros instrumentos jurídicos, la Ley 620, Ley General de de Aguas Nacionales y la Ley 626, Ley que crea la Comisión de Desarrollo Sostenible de la Cuenca Hídrica del Lago Cocibolca y del Río San Juan. Estas normas establecen:

"Es responsabilidad del Estado con la participación de los Gobiernos Municipales, Asociaciones de Municipios, Sector Privado, Organizaciones No Gubernamentales y población en general, la protección, conservación y destino de las aguas del Gran Lago de Nicaragua o Cocibolca. Este lago deberá considerarse como reserva natural de agua potable, siendo del más elevado interés y prioridad nacional para la seguridad nacional, debiéndose establecer mecanismos y regulaciones específicas que aseguren y regulen la productividad del agua y al mismo tiempo que aseguren el mantenimiento e incremento de los caudales que permitan el desarrollo de las actividades económicas, sin menoscabo de la producción de agua, tanto en cantidad como en calidad, prohibiendo la introducción y cultivo de especies exóticas invasoras, igual que evitando la contaminación del recurso y el deterioro de su ecosistema por vertidos industriales y domésticos" (Ley 620, Art. 97).

"Es compromiso ineludible del Estado de Nicaragua asegurar el cumplimiento del precepto constitucional que establece que los recursos naturales son Patrimonio Nacional y que como tal está obligado a la preservación y conservación de dichos recursos... En consecuencia a lo anterior, la iniciativa de los gobiernos municipales de la Cuenca del Lago Cocibolca y el Río San Juan, para promover la conservación y uso sostenible del patrimonio natural existente en sus respectivos municipios es parte consustancial y coincidente con las prioridades, políticas y estrategias del gobierno central, en materia del ambiente y el desarrollo sostenible, nacional y local" (Ley 626, parte considerativa).

Según el Director del Centro de Investigaciones de Recursos Acuáticos (CIRA-UNAN) el Lago Cocibolca puede abastecer de agua, no solamente a Nicaragua, sino a toda la población de El Salvador y Costa Rica. Los nicaragüenses tienen 38 mil metros cúbicos por persona por año, los salvadoreños tienen cuatro mil. El lago Cocibolca tiene un gran valor como fuente de agua para el consumo humano y la irrigación ${ }^{13}$. Un proyecto de irrigación con agua de este lago

\footnotetext{
${ }^{11}$ Artículos 2, 3 y 4 de la Resolución Ministerial No. 012-2008, el procedimiento general y los instrumentos normativos complementarios para la tramitación de permisos ambientales y autorizaciones ambientales del sistema de evaluación ambiental. Publicado en La Gaceta No. 128 del 7 de Julio del 2008.

12 Informe Técnico. Análisis de la relación entre las presiones antropogénicas y el estado de la contaminación del Lago Cocibolca de Nicaragua. Fundación Ciudad del Saber. Universidad Nacional Autónoma de Nicaragua, Centro para la Investigación en Recursos Acuáticos de Nicaragua (CIRAUNAN). 2007. Pág. 1.

${ }^{13}$ Actualmente Nicaragua a causa de la sequía causada por el fenómeno del niño enfrenta elevadas pérdidas de la cosecha de diferentes rubros alimenticios. En la mayoría de las comunidades que pertenecen al corredor seco de Nicaragua existe la falta del trabajo temporal en este rubro lo que ha traído como consecuencia la disminución de los medios de vida de los hogares más vulnerables
} 
contribuiría al desarrollo, transformación social y económica del país y es ambientalmente sostenible ${ }^{14}$, contrario a lo que se propone con la realización del canal interoceánico.

\section{Ley 840, Ley Especial para el Desarrollo de Infraestructura y Transporte Nicaragüense, Atingente al Canal, Zonas de Libre Comercio e Infraestructuras Asociadas}

La Ley $840^{15}$ reformó a la Ley 800 , Ley del régimen jurídico del gran canal interoceánico de Nicaragua y de creación de la autoridad del gran canal interoceánico de Nicaragua ${ }^{16}$. La Ley 800 en su capítulo VII referido a la Gestión Ambiental, artículos 20 al 28, hace referencia a la obligatoriedad que tiene el promotor del proyecto en hacer el estudio de impacto ambiental en el marco de la reglamentación nacional e internacional, estos artículos no fueron expresamente derogados por la Ley 840 . Una interpretación jurídica podría ser que, al implementar la Ley 840 , al no haber derogación expresa de lo dispuesto en la Ley 800 , se debería aplicar, conjuntamente, lo dispuesto en los arts. 20 a 28 de la Ley 800 y por ende la Ley 217 y el Decreto 76-2006.

Sin embargo, al analizar diversas disposiciones de la Ley 840 y concatenar ello con las actuaciones materiales del MARENA, de la Autoridad de Canal y su concesionario se observa que la misma no va ni en armonía ni en coherencia con el ordenamiento jurídico descrito en los acápites 1 y 2 del presente trabajo, ni con los artículos 20 y siguientes de la Ley 800. Aparentemente se ha asumido que hay una derogación tácita de tales disposiciones jurídicas. La justificación tal vez la encontramos si revisamos algunos contenidos de la Ley 840.

El artículo 1 de la Ley 840, señala presente Ley tiene por objeto:

afectando la seguridad alimentaria y nutricional, la salud y en general la calidad de vida de la población. Aun más, de cara al calentamiento global y el cambio climático, se sabe que Nicaragua estará siendo afectada seriamente por la sequía y desastres naturales de manera más frecuente. El fenómeno de la sequía podría ser aminorado si se implementaran las normas antes descritas que señalan al Lago Cocibolca como fuente de abastecimiento de agua para consumo humano, mismas que ordenan proteger sus cuencas.

${ }^{14}$ El lago nos puede sacar de la pobreza. Entrevista a Salvador Montenegro Guillén, Director del CIRA. Diario La Prensa. 7 de julio de 2013.

15 El Proyecto del Canal consiste en el diseño, desarrollo, ingeniería, acuerdos de financiación, construcción, propiedad, posesión, operación, mantenimiento y administración, en conjunto denominados el "Desarrollo y Operación", de los siguientes proyectos relacionados con infraestructura, cada uno de los cuales, a efectos de la presente Ley y en lo sucesivo, serán denominados "Sub-Proyecto": a) Un canal tradicional para naves, uniendo los puertos de aguas profundas en el Caribe y litorales del Pacífico de la República de Nicaragua en lo sucesivo referido como "El Gran Canal Interoceánico de Nicaragua"; b) Un puerto, junto con cualquier puerto y terminal asociada, en la costa del Caribe de la República de Nicaragua; c) Un puerto, junto con cualquier puerto y terminal asociada, en la costa del Pacífico de la República de Nicaragua; d) Un oleoducto que conecte áreas en litorales del Caribe y del Pacífico de la República de Nicaragua; e) Un canal seco para la construcción de una vía férrea para transporte de carga, uniendo los puertos de aguas profundas de los litorales del Caribe y del Pacífico de la República de Nicaragua; f) Una zona de libre comercio que se establecerá en las proximidades de donde El Gran Canal Interoceánico de Nicaragua se una con la costa del Caribe de la República de Nicaragua; g) Una zona de libre comercio que se establecerá en las proximidades de donde El Gran Canal Interoceánico de Nicaragua se una con la Costa del Pacífico de la República de Nicaragua; h) Un aeropuerto internacional en las zonas de libre comercio referidas en los literales (f) y $(\mathrm{g})$ mencionados anteriormente o en sus proximidades, o alternativamente, la expansión de un aeropuerto actual en una de las zonas de libre comercio o sus proximidades con la finalidad de manejar el tráfico aéreo tanto doméstico como internacional; i) La infraestructura que no forme parte de ningún Sub-Proyecto indicado anteriormente en los literales del (a) al (h) y que El Inversionista determine que es necesaria para El Desarrollo y Operación de uno o más de tales Sub-Proyectos; y j) Un proyecto global para asegurar

${ }^{16}$ Publicada en La Gaceta, Diario Oficial No. 128 del 9 de Julio de 2012. 
a) Aprobar y autorizar a firmar posteriormente el Acuerdo Marco de Concesión e Implementación (MCA) ${ }^{17}$...

b) Autorizar al Gobierno el cumplimiento y la ejecución de sus obligaciones de conformidad con los términos de EI MCA;

c) El otorgamiento a El Concesionario de los derechos que confiere El Gobierno en virtud a EI MCA; y

d) La definición y establecimiento de las bases y los fundamentos jurídicos necesarios para garantizar el cumplimiento por parte de todas las Entidades del Gobierno de los términos de la presente Ley, incluyendo la creación de la Comisión del Proyecto de Desarrollo del Canal de Nicaragua y el otorgamiento de las concesiones para cada Sub Proyecto, como se dispone en la presente Ley.

Esta ley crea la Comisión del Proyecto de Desarrollo del Canal de Nicaragua. La Comisión será el órgano de gobierno responsable de la supervisión del uso racional y sostenible de los recursos naturales, la protección del ambiente y biodiversidad del área geográfica de influencia alrededor del área de construcción de El Gran Canal Interoceánico de Nicaragua dentro del marco de tratados vinculantes, convenciones internacionales y legislación nacional $(\text { art. } 4)^{18}$. Es decir, inhibe al MARENA de ejercer sus competencias como responsable de la conservación, protección y el uso sostenible de los recursos naturales y del medio ambiente ${ }^{19}$.

El objetivo principal de la Comisión que crea la Ley 840 es ejercer los derechos y cumplir las obligaciones del Gobierno de la República de Nicaragua en virtud a Acuerdo Marco de Concesión e Implementación (MCA), para lo que está facultada, incluyendo pero sin limitar la generalidad de lo anterior, llevar a cabo las siguientes acciones:

Emitir todos los Consentimientos que fueren requeridos por El Inversionista o cualquier otra Parte de Sub-Proyecto para el Desarrollo y Operación de El Proyecto y cualquier otro Sub-Proyecto en los términos requeridos por el MCA y en cada caso sin costo alguno para la Parte de Sub-Proyecto. La Comisión podrá solicitar el apoyo técnico de cualquier Entidad Gubernamental que correspondiere, dependiendo de la naturaleza de la licencia, permiso o consentimiento que esté siendo emitido, en cuyo caso se requiere que la Entidad Gubernamental correspondiente brinde la asistencia pronta y oportuna que hubiere solicitado La Comisión.

Previo a la emisión de cualquier Consentimiento que otorgue derechos de uso sobre recursos naturales en las Regiones Autónomas de la Costa Atlántica, la Comisión mandará a oír al

\footnotetext{
${ }^{17}$ Suscrito previamente entre la Autoridad de El Gran Canal Interoceánico de Nicaragua, el Gobierno, la Comisión del Proyecto de Desarrollo del Canal de Nicaragua, la Empresa Desarrolladora de Grandes Infraestructuras S.A. y HK Nicaragua Canal Development Investment Co. Limited, una compañía de responsabilidad limitada constituida en Hong Kong.

18 Son miembros de la Comisión: El Presidente de la Autoridad de El Gran Canal Interoceánico de Nicaragua; El Ministro del Ambiente y de los Recursos Naturales; El Ministro de Hacienda y Crédito Público; El Delegado de la Presidencia de la República en La Comisión para el desarrollo del Río San Juan; El Delegado de la Presidencia de la República para la Promoción de Inversiones y Facilitación del Comercio Internacional; El Secretario de la Presidencia de la República para el Desarrollo de la Costa Atlántica; El Secretario Privado para Políticas Nacionales de la Presidencia de la República; El Director General del Instituto Nicaragüense de Telecomunicaciones y Correos; El Gerente General de la Empresa Administradora de Aeropuertos Internacionales; El Presidente Ejecutivo de la Empresa Portuaria Nacional; El Presidente de la Junta de la Empresa Nicaragüense del Petróleo; Un representante de la Delegación Presidencial para la Promoción de Inversiones y Facilitación del Comercio; El Presidente y de la Comisión de Infraestructura y Servicios Públicos de la Asamblea Nacional; Un Vice-Presidente de la Comisión de Infraestructura y Servicios Públicos de la Asamblea Nacional; Cualquier representante de cualquier otra Entidad Gubernamental seleccionado por los miembros permanentes de La Comisión (art. $6)$.

${ }^{19}$ Ley 217, artículo 8: EI MARENA como ente regulador y normador de la política ambiental del país, será el responsable del cumplimiento de la presente Ley y dará seguimiento a la ejecución de las disposiciones establecidas en la misma.
} 
Consejo Regional ${ }^{20}$ o Municipalidad correspondiente, quienes dentro de los siguientes siete (7) días de la entrega de la notificación por parte de La Comisión tendrán el derecho de expresar su opinión respecto al (los) Consentimiento(s) correspondientes propuestos. Tras el vencimiento de ese término, habiendo o sin haber recibido opinión de dicho Consejo Regional o Municipalidad, sin requerir el consentimiento o aprobación de dicho Consejo Regional o Municipalidad, La Comisión podrá emitir cualquier Consentimiento requerido para la ejecución de El Proyecto o Sub-Proyecto correspondiente.

Cualquier otro Consentimiento o acción u omisión que sería requerido o que es establecido según una Ley previa, no será requerido para El Proyecto o cualquier Sub-Proyecto. Las decisiones de la Comisión en el ejercicio de sus funciones tendrán carácter erga omnes y serán de obligatorio cumplimiento (Art. 5 Objeto de la Comisión).

Según la Ley ni el Concesionario ni ninguna otra parte de Sub-Proyecto serán responsables o tendrán responsabilidades frente a ninguna persona, incluyendo Entidades Gubernamentales, con respecto a condiciones ambientales preexistentes ya sean de limpieza, manejo o alguna otra acción vinculada a condición ambiental preexistente de ninguna de las áreas donde el Proyecto está ubicado o de las áreas que podrían utilizarse en El Proyecto, incluyendo en cada caso las superficies de tales áreas así como el espacio aéreo, subterráneo y el agua ubicada bajo, sobre o a través de tales áreas. En ese sentido, tanto el Concesionario como cada Parte de Sub-Proyecto no tendrán, ni conjunta ni individualmente, obligación de asumir cualquier remedio o de pagar ninguna compensación, daños u otra cantidad relacionada con condiciones ambientales preexistentes de ninguna de las áreas donde El Proyecto está ubicado o de las áreas que podrían utilizarse en El Proyecto incluyendo en cada caso, las superficies de tales áreas así como el espacio aéreo, subterráneo y el agua ubicada bajo, sobre o a través de tales áreas (Art. 16 Condiciones preexistentes) ${ }^{21}$.

Para cumplir los objetivos y propósitos de la Ley 840, toda entidad gubernamental deberá tomar cualquier acción necesaria para procurar que todas las obligaciones del Gobierno sean satisfechas y que los derechos de El Concesionario y cualquier otra Parte de Sub-Proyecto que son establecidos en EI MCA no se vean afectados de ninguna manera, incluyendo pero no limitándose a la aprobación, implementación, cumplimiento y ejecución de cualquier regulación administrativa que fuere necesaria para permitir y facilitar El Proyecto y las actividades

${ }^{20}$ Esta disposición violenta el artículo 181 de la Constitución Política de Nicaragua, el que en su parte conducente dice: Las concesiones y los contratos de explotación racional de los recursos naturales que otorga el Estado en las Regiones Autónomas de la Costa Caribe deberán contar con la aprobación del Consejo Regional Autónomo correspondiente.

${ }^{21}$ La tesis que han mantenido ambientalistas nicaragüenses que están a favor del canal es que los recursos naturales en Nicaragua están profundamente degradados. Veamos por ejemplo, las declaraciones Camilo Lara, Presidente de FONARE y miembro de la Comisión del Canal: "Vamos por la construcción del Canal de Nicaragua, pero vamos para ayudar a conservar el Medio Ambiente. No es como aquí que se ha venido manejando que viene el gran desastre ecológico, como decían en un periódico de circulación nacional: "desastre" del Canal Interoceánico. Hay mucha ignorancia, y de gente que con todo el respeto que le tengo, igual han estado batallando conmigo por 35 años, siguen manejando un discurso del siglo pasado; y siguen manejando cifras como si el Medio Ambiente o la Naturaleza fuera estática, no la ven en su dinámica completa. Y justamente no va a haber, y se lo puedo decir aquí a cualquiera, se lo puedo mantener... ¡no va a haber ningún Proyecto de Inversión en Nicaragua que tenga la capacidad de restaurar lo que los nicaragüenses hemos destruido en los últimos 60 años! ¿Qué significa? Que sin Canal vamos a estar hablando de las mismas denuncias, de los mismos problemas, que el Lago se nos está secando, que se nos está sedimentando, que se están acabando los recursos hídricos; que aparece el Río San Juan, el Río Coco, en un estrés hídrico mostrando las grandes cantidades de sedimentos, producto del desorden territorial de la Cuenca 69... iEste Canal, señor, viene a ordenar este País territorialmente! Por supuesto, de acuerdo a las Leyes, Procedimientos y la Legislación Ambiental de Nicaragua"

http://www.laluchasigue.org/index.php?option=com_content\&view=article\&id=3258:revista-en-vivo-conalberto-mora \&catid=81: icaragua \& Itemid $=198$. 
relacionadas según lo contemplado en EI MCA así como para el Desarrollo y Operación efectiva de EI Proyecto. La Comisión y cada Entidad Gubernamental correspondiente tienen la obligación de procesar todas las solicitudes de consentimientos presentadas con respecto a cualquier parte de El Proyecto o de cualquier Sub-Proyecto tan eficiente y rápidamente como fuere posible, sin perjuicio del cumplimiento de los requisitos técnicos establecidos en las leyes especiales de la materia (Art. 8 Facilitación).

La Ley 840 crea la "Ventanilla Única Institucional" como órgano interno de La Comisión, cuyos miembros serán nombrados por la misma. El objeto de la Ventanilla será recibir todas las solicitudes de Consentimientos relacionadas con El Proyecto y cada Sub-Proyecto, facilitar la correcta presentación y tramitación de los Consentimientos ante la Entidad Gubernamental o Entidades Gubernamentales correspondientes y tomar todas las acciones que fueren necesarias para propiciar el otorgamiento de los mismos. La operación de dicho órgano interno será supervisada por La Comisión.

Si no existiere respuesta por parte de la Entidad Gubernamental correspondiente a la solicitud dentro del término legal establecido o en caso de no exista tal término dentro de catorce (14) días de la solicitud ${ }^{22}$, se entenderá que hay silencio administrativo positivo a favor de $\mathrm{El}$ Concesionario o cualquier otra Parte de Sub-Proyecto, según fuere aplicable, y dicha solicitud será considerada como aprobada bastando como prueba o documento titular del derecho adquirido una comunicación escrita sobre el asunto entregada por El Concesionario, sus afiliadas o cualquier otra parte afiliada que correspondiere, a La Comisión una vez que el respectivo término hubiere expirado ${ }^{23}$.

\section{Disposiciones del Acuerdo Marco de Concesión e Implementación (MCA)}

Todos los términos del MCA se incorporan a la Ley 840 y cada Entidad Gubernamental está autorizada y obligada a ejecutar todas las acciones que fueren necesarias para asegurar el cumplimiento, evitar conflictos e incumplimiento con los términos del MCA.

Será inaplicable a El Proyecto o los Sub-Proyectos: cualquier ley, código, o decreto que tenga fuerza de ley, así como cualquier reglamento, decreto, ordenanza o resolución emitida por cualquier Entidad Gubernamental que contradiga o impida:

i. El cumplimiento de las obligaciones de cualquier parte del MCA incluyendo cualquier asunto que en base a las disposiciones del MCA el Gobierno deba cumplir, procurar o usar sus mejores esfuerzos para obtener o asegurar, o

ii. El ejercicio de los derechos otorgados a cualquier Parte de Sub-Proyecto en virtud de las disposiciones de EI MCA.

Como se puede observar en estos pasajes de la Ley 840 ninguna autoridad, ninguna ley que se oponga a los sus fines de construcción del canal tendrá vigencia ${ }^{24}$.

\footnotetext{
${ }^{22}$ Vale recordar los plazos establecidos en el Sistema de Evaluación Ambiental (Decreto 76-2006) que van de 120 a 240 días para proyectos categoría 1 versus 14 días que establece esta ley para aprobar un Proyecto integrado por sub proyectos de gran impacto como son: canal húmedo, canal seco, puertos, zona de libre comercio etc.

${ }^{23}$ Este mismo artículo señala que sin perjuicio del efecto jurídico de cualquier silencio administrativo positivo, tal aprobación inferida deberá ser explícitamente confirmada por la Entidad Gubernamental correspondiente tan pronto como fuere posible como un asunto de urgencia, lo cual deberá ser garantizado por la "Ventanilla Única Institucional".

${ }^{24}$ EI MCA en acápite 9.1 referido a la Legislación señala: (a) Sin limitación de cualquier otra obligación por parte del Gobierno, la Autoridad o la Comisión según el presente Acuerdo, el Gobierno deberá efectuar sus mejores esfuerzos para asegurar Leyes o enmiendas a Leyes existentes (inclusive propuesta de Leyes a la Asamblea Nacional de Nicaragua cada cierto tiempo), ya sea en relación a regulación de la
} 
La abogada Mónica López Baltodano, en su recurso de inconstitucionalidad contra la Ley 840 señaló: "se han entregado todos los derechos de uso de tierra, aire, agua, espacios marítimos y recursos naturales, sin valorar la importancia de la integridad ambiental para garantizar la vida de los nicaragüenses... Incluso se cede el derecho a alterar y dragar el Gran Lago, nuestra principal reserva de agua potable, ${ }^{, 25}$. Pero también habría que agregar que explícita y tácitamente se ha derogado diversas disposiciones jurídicas que orientan la protección, gestión, conservación, uso sostenible y recuperación o restauración de los recursos naturales en la zona donde se construirá el canal.

El 4 de julio de 2014 la empresa HKND, sin haber concluido los estudios ambientales, presentó la ruta seleccionada y aprobada por la Comisión para construir el Canal.

La entrada del Canal en el lado Pacífico está cerca de la desembocadura del río Brito. Lo que impactará negativamente en el Refugio de Vida Silvestre la Flor y el Refugio de Vida Silvestre Rio Escalante-Chacocente ${ }^{26}$. La Flor y Chococente son las dos únicas playas donde acontecen arribadas masivas y anidamientos multitudinarios de la tortuga Paslama Lepidochelys olivacea en el litoral del Pacífico de Nicaragua ${ }^{27}$.

La entrada oeste del canal al Lago de Nicaragua está ubicada al sur de Rivas, y la entrada este al Lago está ubicado al norte del rio Tule. Impactando negativamente el Lago Cocibolca, la Reserva de Biósfera Isla de Ometepe $^{28}$ y el Monumento Nacional Archipiélago de Solentiname ${ }^{29}$.

La entrada del canal en el lado del Mar Caribe está cerca de la desembocadura del río Punta Gorda cercenando por la mitad la Reserva de Biósfera del Sureste ${ }^{30}$, parte fundamental del Corredor Biológico Mesoamericano, afectando el Refugio de Vida Silvestre y sitio Ramsar Los Guatusos $^{31}$, y los humedales Ramsar San Miguelito ${ }^{32}$ y de la Bahía de Bluefields ${ }^{33}$.

En resumen el proyecto afectaría: el Corredor Biológico Mesoamericano, sistemas costeros del Caribe y el Pacifico Centroamericano, humedales, biodiversidad, sitios Ramsar y bosques

compañía, derecho de propiedad, legislación sobre valores, derecho ambiental, derecho público, derecho tributario, sector regulado, organización del Poder Ejecutivo, legislación de planificación urbanística, etc., que sean necesarias o deseables.

25 http://monicalopezbaltodano.blogspot.com/2013/09/25-verdades-sobre-la-concesion-del-canal.html.

${ }^{26}$ Decreto Presidencial 1294, publicado en el Diario Oficial La Gaceta, el 17 de Agosto de 1983.

27 http://www.marena.gob.ni/pacifico-sur-region-pacifico-532/rvs-la-flor-region-pacifico-536.

${ }^{28}$ Ley № 833, Ley que declara y define los límites de la Reserva de Biosfera Isla de Ometepe. La Reserva de Biosfera Isla de Ometepe tiene importantes remanentes de bosque seco, uno de los tipos de vegetación con más amenaza en Nicaragua y Centroamérica. Esta pequeña extensión (50 mil hectáreas aproximadamente) alberga valores naturales representativos de la región del Pacífico, Centro y Caribe de Nicaragua, tales como el bosque nuboso, bosque húmedo, bosque de transición, una parte del Lago Cocibolca y gran riqueza arqueológica. Es parte de la Red Mundial de Reservas de la Biósfera del Programa Hombre y Biósfera de la UNESCO (MAB) desde el año 2010. http://www.marena.gob.ni/notasde-prensa/968-unesco-certifica-a-isla-de-ometepe-como-reserva-de-bisfera.

29 Decreto 66-99, Creación de las Áreas Naturales Protegidas del Sureste de Nicaragua. El humedal lacustrino del archipiélago de Solentiname forma parte de un ecosistema único a nivel mundial. Este ha sido identificado como uno de los ecosistemas más importantes y particulares del territorio de Nicaragua ubicado en la depresión de los grandes lagos, cuya importancia se vuelve regional por las siguientes razones: - Incluye especies endémicas de peces; Sitio prioritario de refugio en la ruta migratoria de Anátidos entre Norte y Sudamérica; Sitio prioritario de la ruta migratoria de especies acuáticas de la región Sudeste de Nicaragua.

http://www.sinia.net.ni/wamas/documentos/PM/PLANMANEJOSOLENTINAMEVersionFinal.pdf.

30 Decreto 66-99.

${ }^{31}$ Decreto 66-99.

32 Sitio Ramsar No. 1140.

${ }^{33}$ Sitio Ramsar no. 1139. Ficha Técnica: Sistema de Humedales de la Bahía de Bluefields. República de Nicaragua. http://www.sinia.net.ni/wamas/documentos/humedales/ficha_ramsar_bluefields.pdf. 
tropicales. También serán afectadas las anidaciones masivas de especies protegidas de tortugas que anidan en tanto en el Caribe como en el pacífico.

En un estudio del año 2013 de UICN y PNUMA-WCMC se identificaron vacíos en la red de sitios de Patrimonio Mundial por su biodiversidad, además de sitios potenciales de excepcional biodiversidad que podrían ser meritorios de su inclusión en el listado de Patrimonio Mundial. La Reserva de Biósfera del Sureste de Nicaragua, área protegida que será intervenida por el proyecto del canal, se identificó como una de las principales 100 áreas protegidas para todas las especies. Por ello estos organismos están considerando su propuesta para declararla parte del Patrimonio Mundial ${ }^{34}$.

Como se puede observar que el país posee un importante cúmulo de recursos naturales y si bien es cierto estos recursos tiene un alto grado de deterioro aún conservan su importancia ambiental y su situación de degradación y amenaza se podría revertir si se aplicara con más eficacia la legislación ambiental que se derivó de las disposiciones constitucionales de 1987.

Sin embargo a raíz de la Ley 840 del año 2013, y más recientemente de las reformas constitucionales de $2014^{35}$, se plantea una nueva situación jurídica de total desprotección de los recursos naturales y por ende del derecho de los ciudadanos al ambiente sano. El artículo 102 reformado incorporó el siguiente párrafo: “... Dada la ventajosa posición geográfica del país, a través de Ley, el Estado podrá celebrar contrato u otorgar concesión para la construcción y explotación racional de un canal interoceánico...".

Al vincular la nueva redacción del artículo 60 de la Constitución, que eliminó la obligación expresa del Estado a la preservación, conservación y rescate del medio ambiente y de los recursos naturales, con el nuevo párrafo del artículo 102, es interesante retomar lo que señalan los profesores de Derecho Constitucional Gabriel Alvarez y Joan Vintró al referirse a la reforma de estos artículos ${ }^{36}$ :

"Resulta interesante la nueva regulación del artículo 60. Aparentemente, con la incorporación de términos, conceptos y valores de no muy clara virtualidad jurídica pero propios de una cosmovisión muy sensible con los temas ecológicos, podría interpretarse que se produce un reforzamiento del derecho de los nicaragüenses a habitar en un ambiente saludable. Sin embargo, la eliminación en el propio artículo 60 de la obligación expresa del Estado a la preservación, conservación y rescate del medio ambiente y de los recursos naturales permite, al menos, señalar una cierta incoherencia con la retórica ambientalista que caracteriza a este precepto. En cualquier caso, es difícil no relacionar este tema con una de las grandes finalidades de la presente reforma constitucional cual es el blindaje constitucional de la construcción de un canal interoceánico en Nicaragua para dar retroactivamente la máxima cobertura jurídica al marco legal en la materia y a los compromisos con el concesionario establecidos anteriormente a lo largo del año 2013. En este sentido el nuevo artículo 102, que autoriza al Estado para celebrar contrato u otorgar concesión para la construcción de un canal interoceánico, combinado con la eliminación en el artículo 60 de la obligación del Estado de preservar el medio ambiente, facilitaría la interpretación de que los daños ambientales que pueda ocasionar la construcción del canal interoceánico no necesariamente significarían una contravención constitucional'37.

\footnotetext{
${ }^{34}$ Biodiversidad Terrestre y la Lista de Patrimonio Mundial Identificación de vacíos y potenciales sitios candidatos a ser incluidos en la red de Patrimonio Mundial Natural. UICN y PNUMA-WCMC. 2013.

${ }^{35}$ Ley 854, Ley de reforma parcial a la Constitución Política de la República de Nicaragua. Publicada en La Gaceta, Diario Oficial No 26 del 10/02/14.

${ }^{36}$ Alvarez Arguello, G. y Vintró Castells, J. Nicaragua: claroscuros de la reforma constitucional de 2014. Revista Catalana de Dret Públic. Blog 19 de marzo de 2014. http://blocs.gencat.cat/blocs/AppPHP/eapcrcdp/2014/03/19/nicaragua-claroscuros-de-la-reforma-constitucional-de-2014-gabriel-alvarez-y-joan-vintro/

${ }^{37}$ Alvarez, Gabriel. y Vintró, Joan. Nicaragua: claroscuros de la reforma constitucional de 2014. Revista catalana de dret públic.
} 
Analizando lo expuesto, no podemos más que destacar los regresivos cambios en la institucionalidad ambiental nicaragüense, todo ello en aras de un proyecto de enorme impacto ambiental que solamente profundizará la degradación de los recurso naturales del país que repercutirá en la seguridad y costumbres de la sociedad nicaragüense, serán miles los ciudadanos desplazados, entre éstos, pueblos originarios.

Sin embargo, como señala Dessiré Elizondo ex Directora General de Medio Ambiente de MARENA, "Por mucho que la concesión canalera nos haya despojado a los nicaragüenses de muchos derechos constitucionales, y se diga que la legislación ambiental y otras leyes del país están subordinadas a la concesión, un proceso que viola todos los principios y normas que regulan los procedimientos para conducir evaluaciones ambientales y sociales jamás tendrá legitimidad, ni podrá ser aceptado como parte de los requisitos para acceder a préstamos de organizaciones financieras respetables, ${ }^{, 38}$.

\section{Conclusiones}

El Gobierno de Nicaragua suscribió la Alianza Centroamericana para el Desarrollo Sostenible $(\text { ALIDES) })^{39}$ en el año1994 donde se comprometió a impulsar el crecimiento económico con equidad social y en armonía con la naturaleza, sin comprometer y garantizando la vida de las generaciones futuras. Sin embargo, lo establecido en la Ley 840 desmonta todo el engranaje legal que por años se desarrollo en el país para cumplir con lo dispuesto en la Constitución Política respecto a la protección de los recursos naturales y derecho al ambiente sano, a lo dispuesto en las normas infraconstitucionales que desarrollaron estos preceptos y contra los diversos convenios internacionales suscritos y ratificados en Nicaragua en materia ambiental y de derechos humanos.

Nicaragua, como el resto de países de Centroamérica, es un país altamente vulnerable a los impactos adversos del cambio climático. Sus efectos están impactado en la producción, infraestructura, medios de vida, salud pública, seguridad de la población. Una obra como la que se plantea en la Ley 840 profundizaría aún más la vulnerabilidad del país ante los efectos del cambio climático.

De manera que podemos afirmar que el proyecto de construcción del canal pone en riesgo además del derecho al ambiente sano, el derecho al acceso al agua, a la seguridad y soberanía alimentaria, a la salud y a la propia vida de los nicaragüenses.

Un supuesto proyecto de desarrollo, el cual es tachado de inviable por la casi totalidad de la comunidad científica, jurídica y económica, no puede ser sostenible si no es bajo la condición que las reglas de protección del ambiente devengan intangibles, como lo es el derecho fundamental a la vida que se aplica no solamente a beneficio de las generaciones presentes, pero igualmente a beneficio de las generaciones futuras ${ }^{40}$.

http://blocs.gencat.cat/blocs/AppPHP/eapc-rcdp/page/1/?s=Alvarez+Gabriel\&x=0\&y=0.

${ }^{38} \mathrm{http}: / /$ www.confidencial.com.ni/articulo/18665/iquest-quien-fiscaliza-a-erm-y-hkndn

${ }^{39}$ Suscrita en Managua, Nicaragua el 10 de octubre de 1994 por los Presidentes de la Región Centroamericana.

${ }^{40}$ Peña Chacon, Mario. Director. El principio de no regresión ambiental en el derecho comparado latinoamericano. PNUD. San José. 2013. Pág. 8. 


\section{Bibliografía}

Alianza para el Desarrollo Sostenible (ALIDES). Managua, Nicaragua el 10 de octubre de 1994.

AAVV. El Canal Interoceánico por Nicaragua. Aportes al debate. Academia de Ciencias de Nicaragua (ACN). Serie. Ciencia, Técnica y Sociedad. 2014.

Alvarez, Gabriel y Vintró, Joan. Nicaragua: claroscuros de la reforma constitucional de 2014. Revista catalana de dret públic. 19 Març 2014 http://blocs.gencat.cat/blocs/AppPHP/eapcrcdp/2014/03/19/nicaragua-claroscuros-de-la-reforma-constitucional-de-2014-gabriel-alvarez-yjoan-vintro/.

Biodiversidad Terrestre y la Lista de Patrimonio Mundial Identificación de vacíos y potenciales sitios candidatos a ser incluidos en la red de Patrimonio Mundial Natural. UICN y PNUMAWCMC. 2013.

El futuro que queremos. Documento final de la Conferencia. A/CONF.216/L.1. Río de Janeiro (Brasil). 2012.

Informe Técnico. Análisis de la relación entre las presiones antropogénicas y el estado de la contaminación del Lago Cocibolca de Nicaragua. Fundación Ciudad del Saber. Universidad Nacional Autónoma de Nicaragua, Centro para la Investigación en Recursos Acuáticos de Nicaragua (CIRA-UNAN). 2007.

Knox, John. H. Informe del Experto independiente sobre la cuestión de las obligaciones de derechos humanos relacionadas con el disfrute de un medio ambiente sin riesgos, limpio, saludable y sostenible. Consejo de Derechos Humanos 25ำ período de sesiones. 30 de diciembre de 2013.

Ficha Técnica: Sistema de Humedales de la Bahía de Bluefields. República de Nicaragua. http://www.sinia.net.ni/wamas/documentos/humedales/ficha_ramsar_bluefields.pdf.

La Prensa del 11 de marzo de 2014. MARENA no vigilará "estudios" del Canal. http://www.laprensa.com.ni/2014/03/11/ambito/186148-marena-no-vigilara-estudios.

Peña Chacon, Mario. Director. El principio de no regresión ambiental en el derecho comparado latinoamericano. PNUD. San José. 2013.

Situación actual de los efectos de la sequía en siete municipios que pertenecen al Corredor Seco de Nicaragua. Acción Contra el Hambre. 2010. 


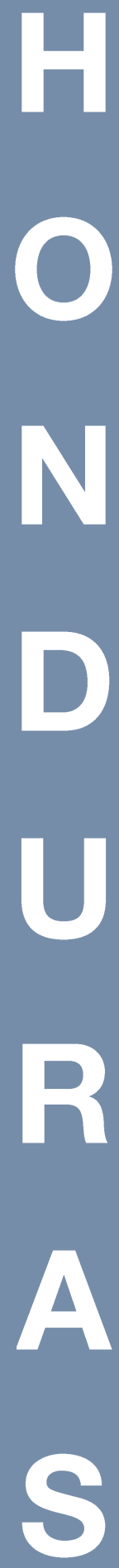



\title{
LA PROTECCIÓN LEGAL E INSTITUCIONAL DEL AMBIENTE Y LOS RECURSOS NATURALES DE HONDURAS: LA RUTA DEL PRINCIPIO DE NO REGRESIÓN
}

\author{
Laura Palmese $H^{1}$
}

"El rol que juegan los principios del derecho ambiental en las decisiones ambientales deber ser revisado, en especial, el principio de no regresión".

\section{Introducción}

La problemática ambiental de Honduras es normalmente atribuida al fracaso de la administración pública en particular y de los funcionarios estatales en general de cumplir y hacer cumplir las leyes ambientales. La queja constante de la ciudadanía sobre la no aplicación de la Ley, parece tener una fácil solución: simplemente, comenzar a aplicar la Ley. La cuestión es: ¿cuál Ley?

Honduras es un Estado de Derecho, donde la existencia de cuerpos normativos que regulan el actuar del Estado y que reconocen los derechos fundamentales, constituye - o debería constituir - su principal característica. De hecho, una consultoría independiente elaborada en 2003, reveló que Honduras tenía vigentes (hace más de 10 años) más de 4,000 leyes, relacionadas a casi todos los aspectos de la vida cotidiana familiar, comercial, estatal y demás relaciones humanas. El bienestar colectivo y el interés público suponen el marco de creación de estas leyes y las que vendrán en el futuro.

Las instituciones, por su parte, tienen el mandato constitucional de cumplir y hacer cumplir ésas leyes, asumiendo responsabilidad, hasta criminal, en el caso de no hacerlo o de dictar actos al margen de lo "legalmente establecido".

La importancia de determinar las verdaderas razones del fracaso del gobierno en proteger el medio ambiente y los recursos naturales es indiscutible. El fracaso en la protección ambiental ha conllevado a una acelerada destrucción de los recursos naturales de Honduras, un país subdesarrollado pero con una riqueza enorme en recursos naturales y minerales.

El señalamiento de la ineficacia institucional es válido. En efecto, la protección ambiental que debe venir desde los entes estatales, no se está efectuando. Pero tampoco la Ley - la Ley, en que se incluyen todos los instrumentos jurídicos - es clara en sus objetivos. Las instituciones deben fundamentar sus resoluciones en la Ley, y lo hacen, aunque no en beneficio del ambiente.

Es necesario entonces, elaborar una nueva ruta de protección, una distinta de la Ley y de las instituciones, pero que utilice las estructuras existentes. Esta ruta utiliza la fuente básica y primaria del derecho: los principios. El rol que juegan los principios del derecho ambiental en las decisiones ambientales deber ser revisado, en especial, el principio de no regresión.

Este documento pretende elaborar una síntesis de la legislación ambiental en Honduras y la forma de aplicación de esa legislación, a fin de identificar las lagunas que son utilizadas para mermar la protección ambiental. Se realizará un mapeo del marco normativo e institucional, especificando las bondades de la legislación ambiental de Honduras. Se identificarán casos en los que esas bondades no representaron obstáculos para legalizar la destrucción ambiental y

\footnotetext{
${ }^{1}$ Abogada del Instituto de Derecho Ambiental de Honduras
} 
de qué manera, la aplicación del principio de no regresión puede cubrir las lagunas, redundando en decisiones más congruentes con los fines del Estado y los anhelos de la sociedad.

Tenemos leyes y tenemos instituciones. Las estructuras existentes son válidas y deben continuar legitimándose, pues son teóricamente funcionales. La práctica, sin embargo, demuestra que su actuar ha sido fallido. Si se establece un norte, una política de protección, una ruta de acción en la que se respeten las estructuras para una mejor gestión de los recursos, podremos decir que vamos por buen camino. El norte propuesto es el principio de no regresión.

\section{Fuentes de progresividad ambiental (y regresión)}

La regulación ambiental y de los recursos naturales de Honduras sigue varias corrientes que han dependido del panorama internacional, la voluntad política y los intereses de los grupos de poder. La óptica del aprovechamiento o producción ha generado leyes mediante las cuales se determinan procedimientos y condiciones para su autorización. La óptica de conservación ha generado leyes declarativas de derechos y procedimientos para el establecimiento de áreas protegidas, zonas restringidas y prohibiciones de actividades. La óptica institucional, por su parte, ha generado instrumentos mediante los cuales se crean instancias gubernamentales encargadas de ejecutar unas y otras leyes, interpretándolas para aplicarlas a situaciones 0 recursos concretos.

La dispersión normativa e institucional de Honduras constituye el reto de la aplicación. Es necesario estudiar una gran cantidad de instrumentos jurídicos, cuyos conceptos pueden resultar repetitivos y/o contradictorios. Además, como se ha visto, estos instrumentos también crean instituciones cuyas atribuciones también pueden adolecer de esas características.

La Constitución de la República, vigente desde 1982, es la carta magna del Estado. En ella se contienen disposiciones doctrinarias, reconociendo derechos fundamentales y disposiciones orgánicas, que organizan los poderes del Estado y definen los principios de su actuar. La Constitución manda que "la persona humana es el fin supremo del Estado" y para ello reconoce el derecho a un medio ambiente sano, a la salud, al agua y a la integridad física. La Constitución declara de utilidad pública la explotación técnica y racional de los recursos naturales, debiendo el Estado fijar las condiciones de su aprovechamiento por los particulares.

Los tratados internacionales pasan a formar parte del derecho interno luego de su ratificación, pero tienen una prelación sobre leyes ordinarias en caso de conflicto. También puede invocarse un recurso ordinario de inconstitucionalidad cuando una ley ordinaria violenta una disposición contenida en un tratado internacional. De esta forma se reconoce un híbrido constitucional-legal de los tratados internacionales, cuyas disposiciones reafirman la existencia de una relación armónica con la comunidad internacional.

Las Leyes secundarias u ordinarias, continúan en la escala normativa. Estas son creadas por el Poder Legislativo, representado por el Congreso Nacional de 128 diputados de los 18 departamentos de Honduras. Las Leyes deben ser creadas de acuerdo al proceso legislativo establecido en la Constitución, en cuanto a su forma, debiendo contar con el veto o sanción del Presidente del Poder Ejecutivo, además de la mayoría de votos de los diputados. En cuanto a su fondo o contenido, sus disposiciones deben estar en consonancia con los preceptos constitucionales. De lo contrario, puede invocarse el ya mencionado Recurso de Inconstitucionalidad, como una medida de control del Poder Judicial sobre el actuar del Poder Legislativo.

Los decretos o acuerdos ejecutivos contienen reglamentos, declaraciones y regulaciones especiales que son promovidas a instancia de uno o varios miembros del gabinete de gobierno. 
Estos instrumentos pueden provenir directamente del Presidente de la República, del Consejo de Ministros o de un Ministro en específico. Pueden desarrollar las leyes secundarias, o regular una cuestión de interés administrativo. También se incluyen las ordenanzas municipales y las decisiones de aplicación general que cualquier institución de gobierno decida adoptar.

Finalmente, las resoluciones de aplicación individual que son Ley para las partes interesadas, pero que, al igual que todas las regulaciones que se han contemplado en esta estructura normativa, deben responder, respetar y desarrollar las disposiciones de la jerarquía superior, limitándose a ellas, no rebasándolas bajo ningún concepto. Aquí se encuentran las licencias y permisos ambientales, las respuestas a las denuncias y las sentencias de las demandas. El actuar individualizado del poder administrador y el actuar corriente del poder judiciario serán creadores de ésta fuente del derecho, que más es una interpretación de toda la estructura normativa que ya se ha enunciado.

Los principios del derecho ambiental pueden considerarse base y pilar de esta pirámide imaginaria. Los encontramos dispersos en diferentes cuerpos normativos, desde la misma constitución, los tratados internacionales y leyes secundarias, hasta los reglamentos emanados del ejecutivo. La no inclusión de ellos en los textos legales podrá dificultar su invocación por los aplicadores de la Ley, aún cuando sea solicitado por los peticionarios, pero la falta de aplicación de un principio, definitivamente, impactará las decisiones ambientales.

\section{2 ¿Hacen falta más provisiones legales?}

Paralelamente, el derecho humano a un medio ambiente sano reafirmado cuando la Constitución establece que el fin supremo del Estado es la persona humana, significa que toda actividad emprendida o autorizada por los entes estatales, será tendiente al bienestar de la persona humana y al respeto de los derechos inherentes a su condición, sean estos reconocidos en la Constitución de la República o no.

Es así como el aprovechamiento técnico y racional de los recursos naturales, la regulación de las condiciones de tal aprovechamiento y la declaración que la protección de los bosques es del interés público, se desarrollan en la firma de tratados, convenios o convenciones internacionales que pasan a formar parte del derecho interno, con jerarquía superior a otras leyes secundarias u ordinarias.

Existen más de 30 instrumentos internacionales coercitivos suscritos, 10 de derecho blando adoptados, más de 100 leyes secundarias que regulan en forma general y específica los recursos naturales, algunas creadoras de estructuras protectoras (instancias gubernamentales o figuras jurídicas), otras reguladoras de la actividad comercial en torno a determinado recurso (requisitos para la expedición de permisos, concesiones o licencias), otras de tipo mixto, donde se incluyen instancias de conservación por una parte e instancias de expedición de permisos y concesiones por otra.

La Ley General del Ambiente, vigente desde 1993, fue impulsada en Honduras después de la Cumbre de Rio de Janeiro de 1992, debido a los compromisos internacionales adquiridos. Desde entonces, la normativa ambiental ha ido aumentando en cantidad, aunque no siempre en calidad.

También existen 43 reglamentos o acuerdos ejecutivos que no alcanzan la jerarquía normativa de las leyes, pues son accesorias a éstas, dependen de ellas y se sujetan a ellas. Estos reglamentos y acuerdos ejecutivos no han requerido de una Ley marco a reglamentar, de hecho, han regulado situaciones jurídicas no contempladas en las leyes secundarias, lo cual viene a ampliar el marco jurídico ambiental, de forma difusa y poco coercitiva.

La dispersión de la normativa de este sector, convierte en específica la regulación por una parte, pero difusa la aplicación por otra. 


\section{La "protección" de las áreas protegidas}

Honduras es un país de vasta riqueza ecológica, particularmente debido a la amplia biodiversidad y variedad cultural, sus 91 áreas protegidas representan un sistema de reservas biológicas, ecológicas, culturales, hogares de flora y fauna silvestre, algunas incluida en los listados CITES y RAMSAR. Las áreas protegidas en Honduras se encuentran protegidas por la normativa ambiental general y sectorial, entre otras, la Ley Forestal, Áreas Protegidas y Vida Silvestre, el acuerdo ejecutivo de creación y el acuerdo legislativo de declaración.

Adicional a la protección de las áreas protegidas antes explicada, se encuentra el Registro en el Catálogo del Patrimonio Público Forestal Inalienable, donde se inscribe el dominio del predio que contiene el área protegida, a favor del Estado de Honduras, por lo tanto, no sujeta al arbitrio de dueños particulares, quienes continúan ejerciendo el dominio, únicamente con las restricciones que le impone la regulación especial de la zona.

La Ley General de Minería, contiene una disposición referente a las zonas de exclusión de actividades mineras. En esta no incluye a todas la áreas protegidas si no únicamente a aquellas que se encuentren inscritas en el Catálogo del Patrimonio Público Forestal Inalienable - que son únicamente 5 de las 91 . Ello permitiría, por omisión, que las otras áreas protegidas de Honduras no gocen de la misma suerte. Pero lo anterior no sería una amenaza para las áreas protegidas, puesto que éstas se encuentran bajo otro régimen de protección, el de su decreto de creación, decreto de declaración en su caso o simplemente la propuesta presentada ante la autoridad forestal, de áreas protegidas o vida silvestre.

Este caso de la minería podría solucionarse con una simple interpretación legislativa, en la que debería primar el principio in dubio pro natura, o del de la globalidad, o simplemente los preceptos constitucionales relativos al derecho a un medio ambiente sano.

Hay más sobre esta Ley General de Minería. En 2006, grupos de la sociedad civil, entre ellos los habitantes del Valle de Siria afectados por la explotación de la Mina San Martín, promovieron un recurso de inconstitucionalidad contra la Ley vigente desde 1998. El recurso se declaró con lugar, dejando la Ley con varios artículos derogados, por lo que el entonces Presidente de la República promovió una moratoria a la minería metálica. Años más tarde, surge la iniciativa de crear una nueva Ley minera, que dio como resultado un instrumento normativo que vuelve a incluir los preceptos antes declarados inconstitucionales... la sociedad civil ha promovido un nuevo recurso contra la nueva ley, pero mientras tanto, la autoridad minera sigue en su aplicación.

\section{La falsa dicotomía entre economía y ambiente}

Existen, sin embargo, en la legislación hondureña, otras corrientes tendientes a disminuir la protección ambiental de ciertas áreas del territorio, pero con miras a atraer la inversión. El caso de la construcción de un muelle de cruceros en la isla de Roatán es un claro ejemplo de ello. Para facilitar la realización de este proyecto, el Congreso Nacional aprobó un decreto legislativo - es decir, un decreto con fuerza de Ley - donde se dispensaba a la autoridad ambiental de cumplir con las Normas Generales para el control del desarrollo de las Islas de la Bahía - una zona protegida por el decreto de creación del Parque Nacional Marino Islas de la Bahía. En otras palabras, se dispensaba a la autoridad de cumplir con las normas ambientales de protección de la zona donde se instalaría el muelle, ya que dichas normas, prohibían las edificaciones en el mar, para proteger la segunda barrera de arrecife coralino más grande del mundo, ubicada en la zona.

La interpretación legislativa en este caso también tiene dificultades. Las normas generales para el control del desarrollo de las Islas de la Bahía son un acuerdo ejecutivo, de jerarquía inferior a 
la del decreto legislativo que dispensaba de su cumplimiento. Nos remitimos a la formalidad de la interpretación legislativa de jerarquía, por la forma o la de fondo? Además de lo anterior, la construcción del muelle de cruceros se declaró de interés público, como también es de interés público la explotación técnica y racional de los recursos.

\section{$5 \quad$ El rol de las instituciones legislativas}

No bastarán los ejemplos anteriores. Otras formas de inaplicabilidad del principio de no regresión han sido producidas por las asambleas legislativas y siguen en fabricación. Se han promovido decretos de zonas de exclusión de áreas protegidas, donde se han legalizado las invasiones que atentan contra la integridad de estas zonas. También se han promovido proyectos de remedidas de estas áreas donde las zonas núcleo y de amortiguamiento son reducidas sin atender criterios técnicos confiables para las comunidades aledañas y para la sociedad civil organizada que trabaja en el rubro. Las iniciativas de ley han buscado cambiar el significado de las palabras, al establecer vedas que permiten la extracción de especies en peligro, época de apareamiento, reproducción o desove, bajo la bandera de la investigación científica, pero permitiendo el posterior aprovechamiento.

Se han creado nuevas estructuras jurídicas e instancias de inaplicabilidad de las leyes. El establecimiento de Zonas de Empleo y Desarrollo Económico, conocidas popularmente como Chárter Cities, son ejemplos de zonas donde, deliberadamente, no se aplicarán todas las leyes de protección ambiental que han creado las legislaturas pasadas y las que seguirán creando si acaso - las legislaturas futuras. También tenemos la Ley para la Promoción del Desarrollo y Reconversión de la Deuda Pública, donde los terrenos "ociosos" del territorio nacional se colocarán en el mercado a manera de bienes hipotecados, sometidos a la decisión de los particulares acreedores del Estado, sin que éste pueda establecer condiciones de su aprovechamiento.

Es evidente la existencia de una corriente legislativa orientada a la promoción del desarrollo a costa de la inaplicabilidad de las leyes ambientales y estructuras proteccionistas del pasado. Basta con ver los textos de las normas que se han ido aprobando, que cuando son específicas favorecen la inversión a toda costa y cuando son generales, no mandan, prohíben o permiten, como debería ser toda ley, sino que dejan a los funcionarios de gobierno la última palabra, como se verá en el siguiente acápite. Si acaso, se habla de la creación de Manuales o Guías de Buenas Prácticas, y se deja la conservación ambiental a la merced de la "responsabilidad social empresarial", que se realiza con fines de mercadeo, evasión fiscal y manipulación de la opinión comunitaria.

No obstante, Honduras suscribió un tratado de libre comercio - CAFTA-DR - donde se comprometió a no disminuir su legislación ambiental para promover la inversión. Esta es una ley más, por lo tanto, la aplicabilidad de éste, y la inaplicabilidad de los decretos que lo contrarían debía alegarse por los interesados.

La producción legislativa se ha orientado hacia la promoción del comercio, amparándolo en causal indispensable del desarrollo.

\section{$6 \quad$ El rol de las instituciones administrativas y judiciales}

A falta de regulaciones que contengan disposiciones prohibitivas de actividades destructoras y potencialmente contaminantes, la protección ambiental se está subordinando a los criterios técnicos de las instancias gubernamentales, cuyos dictámenes amañados no son confiables para la población. Los intereses prevalecientes en estas instituciones no son de preservación ambiental o de desarrollo sostenible. 
La ambigüedad de las regulaciones proteccionistas permite la imposición de criterios "técnicos" que inciden en la re-categorización de proyectos para no exigir Estudios de Impacto Ambiental y en la autorización de proyectos ambientalmente inviables.

Es importante notar la autoridad ambiental se beneficia de la expedición de licencias, generando ingresos a un gobierno necesitado urgentemente de fondos para cumplir sus enormes y desproporcionales gastos corrientes. La atención de denuncias ambientales no es importante para las autoridades pues lejos de generar un ingreso, genera un gasto su investigación. Las multas por incumplimientos a la legislación ambiental son irrisorias y no existe, a la fecha, ningún privado de libertad por delitos ambientales. Los criterios de oportunidad son comunes en este tipo de delitos.

El marco institucional tampoco se encuentra inter-coordinado, el Estado de Honduras suscribe contratos con empresas concesionarias antes de verificar la viabilidad ambiental del proyecto. Es así como la autoridad minera suscribe contratos de concesión sin contar con el dictamen de la autoridad forestal, o de la autoridad ambiental, ya que la licencia ambiental es un requisito más, previo al inicio de operaciones. Este requisito, cabe resaltar, no es cumplido. La autoridad tiene un plazo mínimo para resolver la petición, sino, se considera como concedida la licencia. En el caso que la empresa nunca haya solicitado su licencia ambiental, se puede imponer una multa irrisoria, que ya está contemplada en el presupuesto de las empresas.

\section{Conclusiones}

¿Debería respetarse el formalismo jerárquico al momento de interpretar las normas ambientales? ¿Debería dejarse al arbitrio de criterios técnicos la protección ambiental, o regularse anticipadamente?

El principio de no regresión consiste en que no se puede retroceder en las estructuras protectoras del ambiente. Una vez que han alcanzado determinado nivel, no puede disminuirse, tergiversarse o simplemente interpretarse en aras de su destrucción. Al contrario, el avance en las leyes, debe suponer un avance en la protección de los bienes y servicios de vida, indispensables para la supervivencia humana, considerando la realidad mundial del cambio climático y la realidad de la vulnerabilidad de ésta región.

Las decisiones ambientales del gobierno deberían abordar, en su motivación, de qué manera se están respetando las estructuras jurídicas de protección ya existentes en el pasado, en aplicación del principio de no regresión.

Se necesita una política de protección, de respeto a los derechos humanos y de conservación de la naturaleza, una política que no descarte el desarrollo, por el contrario, que lo adopte como fin último y único, reconociendo que la única manera de lograrlo es bajo los criterios de sostenibilidad, prevención y precaución.

Debería existir un auto acordado, una circular institucional, un instrumento de administración que recuerde las pautas del actuar administrativo y judicial. Una Ley, si acaso, que establezca la forma de interpretar las normas ambientales, una Ley que materialice el jus congens, respetando el derecho mundialmente reconocido a la vida, a la salud, al agua, dependientes de un medio ambiente adecuado, administrado con criterios de sostenibilidad, aprovechado técnica y racionalmente, con la supervisión del propietario inalienable e imprescriptible de los recursos: El Estado.

No debe descartarse la relación con la doctrina del fideicomiso público, donde el Estado tiene el deber de conservar el medio ambiente adecuado para las futuras generaciones, y es, por lo tanto, execrable toda acción que promueva daños ambientales irreversibles, cuyos impuestos generen divisas a éste gobierno y condenen a las futuras generaciones a un ambiente devastado. 


\section{Bibliografía}

Berros, María Valeria, Construyendo el principio de no regresión en el derecho argentino, en Doctrina del Instituto por un Planeta Verde, 2011, disponible en:

http://www.planetaverde.org.ar/biblioteca.php.

Peña Chacón, Mario, Hacia una nueva hermenéutica ambiental, en Revista Internacional Direito Ambiental (RIDA), número 6, diciembre 2013, Brasil. 



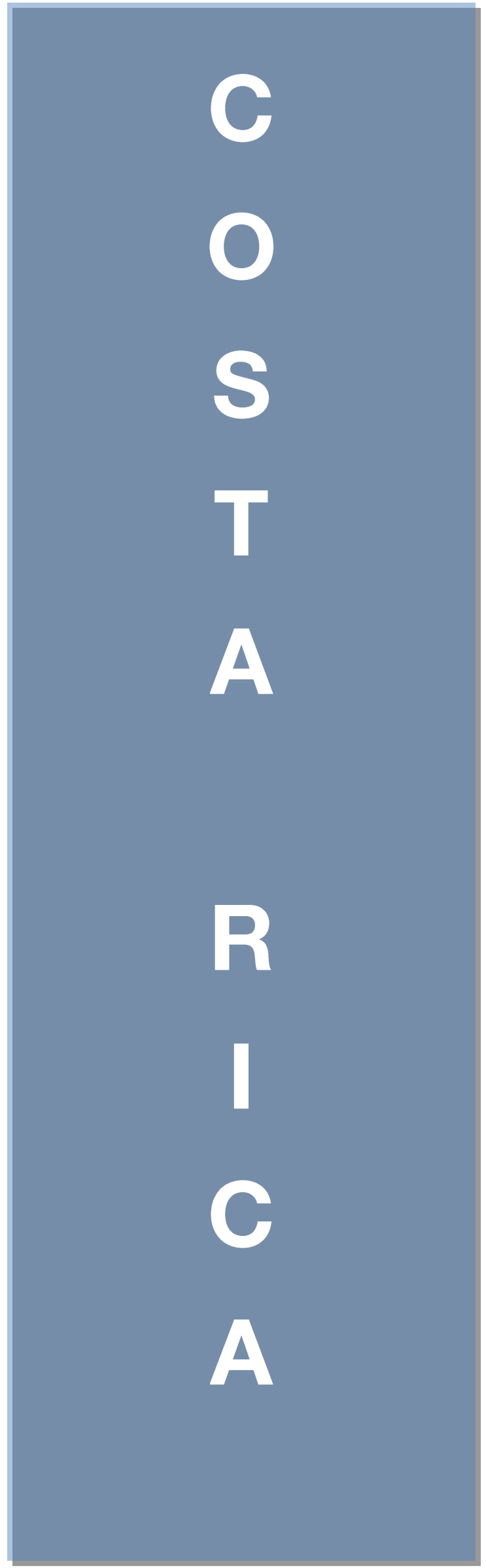




\title{
EL TEST DE REGRESIVIDAD AMBIENTAL
}

\author{
Mario Peña Chacón*
}

"La Tierra no podrá soportar más regresiones sin vengarse". Michel Prieur

\section{Introducción}

A partir de las sentencias constitucionales 2012-13367 y 2013-10158 que reconocieron de manera expresa al principio de no regresión del derecho ambiental y su condición de parámetro de constitucionalidad, se torna especialmente relevante identificar los criterios, lineamientos y condicionantes que permitan medir, de manera objetiva, el nivel de progreso o retroceso de la legislación ambiental, facilitando con ello los controles de constitucionalidad, convencionalidad y legalidad.

\section{$1 \quad$ El ABC del Principio de no Regresión}

En otros trabajos académicos hemos expuesto que el principio de no regresión o de prohibición de retroceso dispone que la normativa y la jurisprudencia no deberían ser modificadas si esto implicare retroceder respecto a los niveles de protección ambiental alcanzados con anterioridad, por ello la nueva norma o sentencia, no debe ni puede empeorar la situación del derecho ambiental preexistente en cuanto a su alcance, amplitud y efectividad. ${ }^{1}$

Su finalidad es evitar la supresión normativa o la reducción de sus exigencias por intereses contrarios que no logren demostrar ser jurídicamente superiores al interés público ambiental, e implica necesariamente una obligación negativa de no hacer, por lo que el nivel de protección ambiental ya alcanzado debe ser respetado, no disminuido, sino más bien incrementado.

\footnotetext{
*Este artículo fue redactado dentro del Proyecto de Investigación denominado "Las clínicas del Derecho Ambiental y Gestión de Riesgos Climáticos a través de una cultura jurídica de la sostenibilidad y no regresión" inscrito ante la Vicerectoría de Investigación y el Instituto de Investigaciones Jurídicas de la Universidad de Costa Rica bajo el código 722-B3-193.

* Profesor de Derecho Ambiental de la Facultad de Derecho de la Universidad de Costa Rica y de las Maestrías de Derecho Ambiental y Derecho Público Comparado Franco-latinoamericano del Sistema de Estudios de Posgrados de la Universidad de Costa Rica. Coordinador de la Maestría de Derecho Ambiental de la Universidad de Costa Rica. Miembro de la Comisión de Derecho Ambiental de la Unión Internacional para la Conservación de la Naturaleza (UICN). mariopenachacon@gmail.com.

${ }^{1}$ Para mayor información puede consultarse los ensayos académicos de este mismo autor denominados: "Principio de no regresión ambiental a la luz de la jurisprudencia constitucional costarricense", en la Revista Iberoamericana de Derecho Ambiental y Recursos Naturales, número 3, febrero 2012, Argentina, accesible en: http://www.ijeditores.com.ar/index.php?ididioma=1\&idcontenido=-\&idpublicacion=19\&view=1; La Ley Orgánica del Ambiente y el Principio de No Regresión, en Revista Iberoamericana de Derecho Ambiental y Recursos Naturales, número 7, febrero 2013, accesible en:

http://www.ijeditores.com.ar/articulos.php?idarticulo=64177\&print=2; Los principios de objetivación de la tutela ambiental, irreductibilidad de espacios sometidos a régimen especial de protección y su relación con la prohibición de retroceso, en Revista Iberoamericana de Derecho Ambiental y Recursos Naturales, número 7, febrero 2013, accesible en: http://www.ijeditores.com.ar/articulos.php?idarticulo=64426\&print=2 y EI CAFTA-DR y la prohibición de retroceso ambiental en Revista Iberoamericana de Derecho Ambiental y Recursos Naturales, número 7, febrero 2013, accesible en:

http://www.ijeditores.com.ar/articulos. php?idarticulo=64426\&print=2.
} 
Como contenido mínimo o núcleo duro es posible identificar la obligación constitucional de tutela del interés público ambiental, sea el deber estatal de garantizar, defender y preservar el derecho a un ambiente sano y ecológicamente equilibrado. ${ }^{2}$

La principal obligación que conlleva su correcta aplicación es la de no retroceder al status quo ante, respetando al menos, el nivel de protección ambiental ya alcanzado; no afectar los umbrales y estándares de protección ambiental actualmente adquiridos; no derogar, modificar, relajar ni flexibilizar la normativa vigente en la medida que esto conlleve disminuir, menoscabar o de cualquier forma afectar negativamente el nivel actual de protección; asegurar la calidad de las normas ambientales; no vulnerar el derecho de las futuras generaciones a gozar de un ambiente sano y ecológicamente equilibrado, ni disminuir el patrimonio a transmitir a las generaciones futuras como garantía de progreso, todo lo anterior con la finalidad de asegurar condiciones ambientales aptas para la posteridad.

Es posible afirmar que la prohibición de regresión actúa como una limitación a la potestad normativa estatal, inhibiendo la derogación, reducción, relajamiento o desaplicación de la legislación ambiental, lo cual encuentra justificación como garantía de mantenimiento del nivel actual de protección, y de toda mejora experimentada desde entonces.

A la vez, la prohibición de regresividad funciona como una garantía sustantiva que protege a los titulares de derechos frente a normas regresivas, vedando al Estado el "dar un paso hacia atrás".3

Debido al carácter finalista del derecho ambiental y siendo sus objetivos la tutela de la vida, la salud y el equilibrio ecológico a través de normas jurídicas que busquen aumentar la biodiversidad y disminuir la contaminación, éste únicamente podrá ser eficaz cuando las modificaciones que le afecten conlleven un medio ambiente mejor y no peor que el anterior, por tanto, cualquier retroceso sería inmoral.

En contraste, su contracara el principio de progresión o progresividad, conlleva siempre una obligación positiva de hacer que se traduce en "progreso" o "mejora continua en las condiciones de existencia". Aquí el imperativo manda "hacer", el Estado debe" moverse hacia delante" y generar progresivamente la ampliación de la cobertura y protección ambiental mediante medidas sostenidas, graduales y escalonadas.

De esta forma, mientras el principio de no regresión reconoce un nivel mínimo ${ }^{4}$ de protección ambiental que debe respetarse, el de progresión busca el avance sistemático de la normativa ambiental. Por ello, este principio no se opone a la idea de evolución clásica ni a la mutabilidad propia del derecho (modificación permanente e inevitable) a raíz de que no existe

\footnotetext{
2 "La Constitución Política establece que el Estado debe garantizar, defender y preservar ese derecho. Prima facie garantizar es asegurar y proteger el derecho contra algún riesgo o necesidad, defender es vedar, prohibir e impedir toda actividad que atente contra el derecho, y preservar es una acción dirigida a poner a cubierto anticipadamente el derecho de posibles peligros a efectos de hacerlo perdurar para futuras generaciones. El Estado debe asumir un doble comportamiento de hacer y de no hacer; por un lado debe abstenerse de atentar él mismo contra el derecho a contar con un ambiente sano y ecológicamente equilibrado, y por otro lado, debe asumir la tarea de dictar las medidas que permitan cumplir con los requerimientos constitucionales". Voto número 1999-644 del 29/01/1999, Sala Constitucional de la Corte Suprema de Justicia.

${ }^{3}$ Berros, María Valeria y Sbresso Luciana, Primeras señales sobre el principio de no regresión en materia ambiental en Argentina. Un estado de la cuestión, en El nuevo principio de no regresión en derecho ambiental, Bruxelles : Editions Bruylant, 2012.

4 "La idea de "mínimo" pone de manifiesto una de las cuestiones más complejas que podría postularse en torno a la no regresión, que es la determinación del "volumen de transferencia" hacia las generaciones futuras. Su delimitación podría oscilar entre la mantención de un mínimo existencial de todo aquello que fuera posible según un juicio de razonabilidad o la consolidación de un máximo a transferir, lo cual da cuenta del riesgo que se corre al consolidar un idea de "mínimo" en lugar de "máximo" a transferir, lo que podría traducirse en términos de un esfuerzo mínimo o máximo en relación con el porvenir" Berros, María Valera, Construyendo el principio de no regresión en el Derecho argentino", JA, 2011-IV, fasc. N.13, 2011.
} 
derecho alguno que sea inmutable o eterno. El derecho siempre debe evolucionar por medio de procesos de modificación y derogación legislativas, reglamentarias e incluso jurisprudenciales. A lo que sí se opone el derecho ambiental a partir de la puesta en práctica del principio de no regresividad es a cambios en el bloque de legalidad que tengan como finalidad la eliminación o disminución del nivel de protección ya alcanzado a favor de intereses no ambientales.

Sería posible entonces afirmar que el principio de no regresión actúa como una obligación negativa inherente a la obligación constitucional de carácter positivo de garantizar, defender y preservar el derecho a un ambiente sano y ecológicamente equilibrado.

En primera instancia el principio de no regresión no es ilimitado ni irrestricto. Al igual que como sucede con el derecho a un ambiente sano y ecológicamente equilibrado, se encuentra condicionado por los principios constitucionales de razonabilidad y proporcionalidad, así como por las reglas unívocas de la ciencia, técnica, conveniencia y la lógica. A la vez, la actuación del Estado en esta materia se ve limitada por el deber de tutela del interés público ambiental, por los principio de desarrollo sostenible y uso racional, precautorio o evitación prudente y por la vinculatoriedad de la normativa ambiental. ${ }^{5}$

Este principio encuentra en los procesos de desregulación y simplificación de trámites a su principal enemigo y amenaza permanente. Las ideas desreguladoras, mal entendidas y aplicadas, pueden traer consigo efectos negativos en la política ambiental, en especial la reducción de presupuestos, desmantelamiento de programas de intervención del Estado, así como la rebaja, disminución o relajación e incluso la derogación de normativa que protege al medio ambiente en pro de lo que algunos han llegado a denominar "mejoramiento del clima de negocios". En la práctica, muchos países se han escudado en la simplificación de trámites para disminuir de forma insidiosa el nivel de protección ambiental, procediendo en realidad a un retroceso del derecho existente.

Al estado actual de su desarrollo es posible deducir su contenido, alcances y limitaciones acudiendo al Derecho Internacional Ambiental, Derecho Internacional de los Derechos Humanos, Derecho Internacional regulador del Libre Comercio y las Inversiones, así como a la Constitución Política y el derecho interno, y en especial, a la jurisprudencia emanada de la Sala Constitucional de la Corte Suprema de Justicia.

\section{Hacia la formulación de un test de regresividad ambiental}

\section{1 ¿Cuándo una norma puede catalogarse regresiva y por ende violatoria del principio de no regresión?}

Una norma podrá ser catalogada regresiva cuando su grado de efectividad resulte ser inferior en comparación al alcanzado con anterioridad, en la medida que derogue, limite, restrinja, reduzca, relaje o flexibilice el nivel de protección ambiental previamente adquirido, siempre y cuando no cuente con justificación ni respaldo técnico-científico que permita determinar, en grado de certeza, la no afectación del bien jurídico objeto de tutela. De esta forma, la nueva norma no debe ni puede empeorar la situación del derecho ambiental preexistente, desde el punto de vista de su alcance, amplitud y especialmente, de su efectividad.

También califica como regresión la omisión, por parte de los poderes estatales, de ejercer su potestad normativa, especialmente la reglamentación de leyes ambientales, o bien, cuando

\footnotetext{
${ }^{5} \mathrm{Al}$ respecto puede consultarse el voto constitucional 2006-17126.
} 
esta potestad se ejerce de manera parcial, incompleta o errónea desde un punto de vista científico, técnico y jurídico, tornando al derecho inaplicable y por tanto, ineficaz. ${ }^{6}$

A la vez, la ineficacia a raíz del incumplimiento e inobservancia sistemática en la aplicación de la legislación ambiental, por si misma, constituye una regresión.

\section{2 ¿Cuándo una norma no califica como regresiva?}

A contrario sensu, todas aquellas modificaciones normativas que si bien limitan, restringen, reducen, relajan y/o, flexibilizan el nivel de protección ambiental previamente adquirido, pero que cuenten con total y absoluta justificación y respaldo técnico-científico que permita determinar, con grado de certeza, la no afectación del bien jurídico tutelado, quedan descartadas como violaciones al principio de no regresión.

En todos los casos la regresividad en los niveles de protección debe estar plenamente justificada. Los estudios tienen que justificar con criterio científico sustentado que la modificación normativa es una medida viable desde la perspectiva ambiental en el marco de una político de desarrollo sostenible, de lo contrario deviene en una transgresión del principio de no regresividad y una violación material del principio de inderogabilidad singular de las normas.

La inaplicación temporal o espacial de normas ambientales o bien, la relajación de umbrales de protección en situaciones de emergencia, urgencia y necesidad, tampoco califican como regresiones, siempre y cuando se cumplan todos y cada uno de las siguientes condiciones exigidas por la jurisprudencia constitucional:

- Debe tratarse de situaciones excepcionales justificadas en un estado de urgencia, emergencia o necesidad declarado;

- Las medidas adoptadas deben ser transitorias, tener como propósito el bien común y ser justas, razonables proporcionadas;

- Subsiste la obligación de aplicar todas aquellas normas ambientales no relacionadas con la atención de la emergencia;

- Las actuaciones de la administración deben orientarse a mitigar y eventualmente compensar cualquier posible impacto ambiental ocasionado.

\subsection{Criterios y lineamientos para un test de regresividad ambiental}

La ejecución de un test de regresividad requiere constatar:

\subsubsection{Promulgación de nueva normativa que modifique el nivel de protección ambiental adquirido previamente}

Se parte de la preexistencia de una norma ambiental y de la promulgación de una nueva regulación jurídica que la derogue, limite, restrinja, reduzca, relaje y/o flexibilice afectando

\footnotetext{
6 "No obstante, para acreditar como inconstitucional una omisión de reglamentar una ley, es necesario que una norma legal o superior (constitucional o de un tratado internacional) disponga en forma expresa esa debida regulación reglamentaria. Además, debe tenerse en cuenta que esa omisión acusada debe impedir el ejercicio de un derecho fundamental; es decir, debe establecerse una situación concreta de lesión o amenaza a los derechos de un administrado para que el amparo sea admisible, caso contrario, se trataría de un problema de mera legalidad, no susceptible de ser conocido en esta jurisdicción, sino más bien en la contencioso-administrativa (con fundamento en el artículo 49 de la Constitución Política); lo anterior, por cuanto el recurso de amparo está previsto para la tutela de los derechos fundamentales (artículo 48 constitucional). Por ello, se permite la impugnación de la actuación administrativa tanto por acción como por omisión, e incluso amenaza, que se estime lesiva de algún derecho fundamental (artículo 29 de la Ley de la Jurisdicción Constitucional), con lo cual, es claro que no es cualquier omisión reglamentaria la que es susceptible de ser conocida en la vía del amparo". Sentencia número 201314446 del 30 de octubre de 2013, Sala Constitucional de la Corte Suprema de Justicia.
} 
negativamente el nivel previo de protección ambiental. Debe tenerse claro que la nueva normativa que se promulga y que calificaría como regresiva, podría ser de cualquier rango o jerarquía, sea constitucional, derecho internacional, ley, reglamento, directriz, circular, etc.

\subsubsection{Ausencia o insuficiencia de justificación y respaldo técnico-científico que permita determinar, en grado de certeza, la no afectación al bien tutelado}

En virtud del vínculo inquebrantable y relación simbiótica que une al derecho ambiental con las reglas unívocas de la ciencia y la técnica, conocido como principio de objetivación de la tutela ambiental o principio de razonabilidad en relación al derecho ambiental, existe la obligación estatal de acreditar, mediante estudios técnicos y científicos, la toma de decisiones en materia ambiental, ya sea en relación con actos administrativos individuales o bien, disposiciones de carácter general de cualquier rango o jerarquía, reforzando con ello el deber de contar siempre y en toda situación con posibilidad de impacto negativo sobre el ambiente, con estudios técnicos y científicos serios, exhaustivos y comprehensivos que garanticen la no afectación o al menos, el menor impacto ambiental posible sobre el bien jurídico tutelado.

Por lo anterior, toda actuación en materia ambiental, así como toda normativa, no puede desvincularse, bajo ninguna circunstancia, de esta regla de oro sin incurrir en un vicio de constitucionalidad por violación al criterio de razonabilidad, o bien, de ilegalidad por infringir las reglas unívocas de la ciencia y la técnica.

Por ello, el principio de objetivación de la tutela ambiental actúa como una especie de requisito sine qua non de ciertas regresiones ambientales, en la medida que podría catalogarse de regresivas todas aquellas normas ambientales que no se fundamenten ni sustenten en las reglas unívocas de la ciencia y la técnica, y que además tengan como consecuencia el deterioro o puesta en peligro del bien ambiental tutelado. De esta forma, el principio de objetivación actuaría como un condicionante del principio de no regresión.

\subsubsection{Menoscabo o empeoramiento del nivel de protección jurídica preexistente, en cuanto a su alcance, amplitud y efectividad}

La nueva normativa promulgada, además de ser insuficiente o carecer de justificación científica y técnica, debe degradar, rebajar, disminuir, menoscabar o empeorar el nivel de protección antes adquirido.

De lo anterior se deduce que toda modificación que no tenga como consecuencia la afectación negativa de la normativa ambiental no calificaría como regresiva, aunque carezca de justificación científica, y por tanto, trasgreda los criterios de razonabilidad, objetivación, y con ello la constitucionalidad o la legalidad.

Entonces, sería posible que se diera el supuesto, a título de ejemplo, donde por medio de una norma jurídica se aumenten los niveles o estándares de protección ambiental haciéndolos más estrictos, pero que estos no se ajusten a los criterios de la ciencia y la técnica. En esta situación, se violentaría y vulnerarían los principio de objetivación de la razonabilidad y proporcionalidad, pero no así el de prohibición de retroceso, en la medida que no tendría como consecuencia el deterioro o puesta en peligro del bien jurídico tutelado ambiente.

Por su parte, tratándose exclusivamente de situaciones especiales de omisión y desaplicación normativa:

\subsubsection{Omisión de reglamentación de normas ambientales indispensable para su operativización y aplicación eficaz}

Únicamente calificarán como regresiones aquellas omisiones al deber de reglamentación de normas ambientales cuyo incumplimiento hagan inoperable e ineficaz la norma sin reglamentar, de manera total o parcial. Por el contrario, aquellas omisiones e incumplimientos al deber de 
reglamentación que no impidan su aplicación práctica no podrían llevar el calificativo de regresiones omisivas.

Por su parte, la reglamentación parcial, incompleta o errónea de una norma, desde un punto de vista científico, técnico y jurídico, y que vuelven inaplicables la norma que se pretende regular, violentan el principio de prohibición de retroceso por impedir su correcta y eficaz aplicación.

\subsubsection{Incumplimiento en la aplicación de la legislación ambiental tornándola absolutamente ineficaz}

En virtud de los principios de legalidad, vinculatoriedad de la normativa ambiental e inderogabilidad singular, toda inaplicación o incumplimiento sistemático que no encuentre respaldo en situaciones exclusivas y calificadas de excepción, específicamente estados de emergencia, urgencia y necesidad debidamente declarados según la legislación especial respectiva, califican como claras regresiones ambientales.

\subsection{Condicionantes, límites y restricciones a considerar}

De lo aquí expuesto, puede deducirse que el principio de no regresión no es ilimitado ni irrestricto, y se encuentra condicionado por otros principios generales del derecho de carácter constitucional y legal, tales como:

- Deber de garantizar, defender y preservar el derecho a un ambiente sano y equilibrado (interés público ambiental)

- Principios de razonabilidad y proporcionalidad

- Principios de desarrollo sostenible y uso racional

- Principio precautorio o de evitación prudente

- Principios de irretroactividad de las normas y de seguridad jurídica

- Principios de legalidad, reserva de ley $^{7}$, vinculatoriedad de la normativa ambiental e inderogabilidad singular ${ }^{8}$

\footnotetext{
7 "En primer lugar, el principio mismo de "reserva de ley", del cual resulta que solamente mediante ley formal, emanada del Poder Legislativo por el procedimiento previsto en la Constitución para la emisión de las leyes, es posible regular y, en su caso, restringir los derechos y libertades fundamentales -todo, por supuesto, en la medida en que la naturaleza y régimen de éstos lo permita, y dentro de las limitaciones constitucionales aplicables-; En segundo, que sólo los reglamentos ejecutivos de esas leyes pueden desarrollar los preceptos de éstas, entendiéndose que no pueden incrementar las restricciones establecidas ni crear las no establecidas por ellas, y que deben respetar rigurosamente su "contenido esencial"; $y$ en tercero, que ni aun en los reglamentos ejecutivos, mucho menos en los autónomos u otras normas o actos de rango inferior, podría válidamente la ley delegar la determinación de regulaciones o restricciones que sólo ella está habilitada a imponer; de donde resulta una nueva consecuencia esencial: Finalmente, que toda actividad administrativa en esta materia es necesariamente reglada, sin poder otorgarse a la Administración potestades discrecionales, porque éstas implicarían obviamente un abandono de la propia reserva de ley". Voto número 1992-3550, del 24/11/1992, Sala Constitucional de la Corte Suprema de Justicia.

8 "De la vinculatoriedad de la normativa ambiental, como consecuencia directa del principio de legalidad regulado en el artículo 11 constitucional y 11 de la Ley General de la Administración Pública, la Administración Pública está obligada a cumplir con el bloque de legalidad; sujeción que tiene especial connotación en relación con la tutela del ambiente, en tanto, al tenor de la obligación impuesta al Estado en su conjunto en el artículo 50 constitucional, es que se denota su indisponibilidad respecto de las instituciones públicas -condición que también se da respecto de los particulares-, esto es, no está sujeto a pacto o convenio en razón de la trascendencia que tiene para la vida y sobrevivencia de la humanidad; lo que hace imposible su excepción, salvo claro está, en situaciones de urgencia o emergencia, que en sí mismo, es una condición de fuente de derecho (al respecto consultar la sentencia 2340-92). Es así como resultan vinculantes para las instituciones públicas el conjunto que conforma el Derecho Ambiental, formado tanto los principios constitucionales ambientales -que delimitan el contenido de este derecho fundamental-, como las diversas disposiciones normativas sobre la materia (legales y reglamentarias), así como los estándares ambientales, y requisitos dispuestos para la realización de proyectos que incidan sobre el ambiente; y que, están inmersos en la gestión pública encomendada a cada una. Por ello, es que
} 
- Principio de objetivación de la tutela ambiental

- Reglas unívocas de la ciencia y la técnica, la justicia, la lógica

- Estados de emergencia, urgencia y necesidad debidamente declaradas ${ }^{9}$

\section{Test de regresividad ambiental en la práctica}

A continuación se analizarán una serie de situaciones que serán sometidas a un test de regresividad de conformidad con los criterios, lineamiento, condicionantes, límites y excepciones ante expuestos.

\subsection{Modificación de conceptos jurídicos ambientales}

Este supuesto parte de la existencia de un concepto jurídico ambiental debidamente definido y delimitado, el cual es modificado por norma posterior que menoscaba o empeora su alcance, amplitud y efectividad original.

Para este tipo de situación, el test de regresividad debe iniciar analizando la existencia o no de criterio científico y/o técnico que justifique la modificación operada. De esta forma, la inexistencia o insuficiencia de fundamentación científica que permita determinar, con grado de certeza, la no afectación negativa del bien jurídico tutelado por la norma modificada sería suficiente para confirmar su carácter regresivo en relación a los principios de razonabilidad, objetivación de la tutela del ambiente y precautorio, violentándose además el deber constitucional de garantizar, defender y preservar el derecho a un ambiente sano y equilibrado.

Costa Rica cuenta con un precedente que encuadra perfectamente en el supuesto aquí analizado. Se trató de la modificación del concepto jurídico "bosque" a partir de la promulgación de la Ley Forestal número 7575 que disminuyó y restringió en cuanto a especies y superficie, sin justificación razonable y en perjuicio del bien jurídico tutelado "bosque", el alcance de cobertura y protección que abarcaba la anterior definición contenida en la normativa derogada.

Mediante el voto número 2007-3923 del 21 de marzo del 2007, la Sala Constitucional de la Corte Suprema de Justicia declaró la inconstitucionalidad del artículo 28 de la Ley Forestal en cuanto a la omisión relativa de establecer medidas precautorias que aseguraran la protección del ambiente.

En lo que interesa expuso la Sala:

"Ciertamente la reforma a esta ley, que se produjo mediante ley No. 7575 de 5 de febrero de 1996, tuvo como fin el promover e incentivar la reforestación en nuestro país, para lo cual intentó librar de trámites innecesarios la corta de determinado tipo de árboles. No obstante lo anterior, considera este Tribunal que al haber pasado la ley de una definición amplia de bosque, con mayor cobertura de protección, a una tan

son exigibles la realización de estudio de impacto ambiental, la conformidad de los proyectos con los planes reguladores (en las municipalidades donde hay), la adecuación del funcionamiento de las plantas y proyectos a los estándares ambientales, etc.; caso contrario, sería admitir un "derecho del Estado a contaminar", lo que es imposible en atención al contenido del propio artículo 50 constitucional, según se ha indicado anteriormente, y como lo ha entendido este Tribunal (entre otras, consultar las sentencias número 5668-94, 5654-95, 8001-97, 2004-1923, 2005-15769, 2006-1963 , y 2006-4497), al haber exigido a diversas instituciones públicas el cumplimiento de esa normativa a fin de tutelar de la manera debida el derecho a un ambiente sano y ecológicamente equilibrado". Voto número 2006-17126, del 28/11/2006, Sala Constitucional de la Corte Suprema de Justicia.

${ }^{9}$ Al respecto se recomienda referirse a las sentencias: 2003-06322 del 03/07/2003 y 2012-3266 del 07/03/2012, Sala Constitucional de la Corte Suprema de Justicia. 
restringida en cuanto a especies y superficie, hace que la protección dada con anterioridad al ambiente, haya sido disminuida sin una justificación razonable, que vaya más allá de la necesidad de reforestar y eliminar las trabas administrativas, como un incentivo de esta actividad, pero sin asegurar previamente, que está en su ejecución, no pusiera en peligro el ambiente. Debemos recordar que nuestro país ha suscrito compromisos internacionales de protección al ambiente y uno de los principios que debe resguardar es el principio precautorio ya citado, según el cual, la prevención debe anticiparse a los efectos negativos, y asegurar la protección, conservación y adecuada gestión de los recursos. Consecuentemente, este principio rector de prevención, se fundamenta en la necesidad de tomar y asumir todas las medidas precautorias para evitar o contener la posible afectación del ambiente o la salud de las personas. De esta forma, en caso de que exista un riesgo de daño grave o irreversible -o una duda al respecto-, se debe adoptar una medida de precaución e inclusive posponer la actividad de que se trate. Sin duda alguna, para ello se requiere de una posición preventiva, activa y alerta por parte de la administración, pues una conducta posterior y únicamente sancionatoria, haría nugatoria cualquier acción efectiva que se pretenda a favor del ambiente, donde una vez producido el daño, difícilmente puede ser restaurado y sus efectos nocivos pueden afectar no sólo a nivel nacional, sino mundial. $Y$ es que este, es uno de los principios rectores en materia ambiental, la prevención. Con ello no se trata tampoco de evitar el desarrollo y detener el progreso y la economía, sin embargo se debe procurar un equilibrio que le permita al ser humano desarrollarse, pero también vivir y disfrutar ese desarrollo, al cual tienen derecho no sólo las generaciones actuales, sino también las venideras. (...) Según el análisis practicado al artículo impugnado, el legislador modificó el concepto de bosque a partir del cual se desarrolla la protección, restricciones y permisos otorgados en la Ley Forestal -como es el caso del artículo 28 en cuestión "Excepción de permiso de corta"-, de tal manera que, restringió sin fundamento técnico, el concepto anterior de bosque existente en la ley previo a su reforma. De modo que fueron dejadas sin protección vía ley, las especies no autóctonas y las áreas inferiores a dos hectáreas que constituyeran bosque, trayendo como consecuencia, que a través del artículo 28 impugnado, no se requiera de permiso para talar, ni siquiera de inspección previa, que permita asegurar que se trata del supuesto que la norma quiso incentivar, toda plantación forestal, sistema agroforestal o cualquier árbol plantado, quedando expuestas áreas que por su ubicación, cantidad y la función que han ejercido durante muchísimos años, amerita la conservación y regulación de su tala, independientemente de la naturaleza de su especie y de la naturaleza del terreno donde se ubique. Así las cosas, esta Sala considera de conformidad con lo expuesto, que en este caso, se produce una inconstitucionalidad por omisión relativa".

En esta misma línea, mediante la resolución 2012-12716 del 12 de setiembre del 2012, la Sala Constitucional declaró la inconstitucionalidad del artículo 2 del Decreto Ejecutivo 33957-MINAE que definía el término "terreno forestal o de aptitud forestal", disponiendo al efecto:

"Así, la determinación de la norma impugnada de que se entenderán por terrenos forestales o de aptitud forestal aquellos que tengan una pendiente promedio superior al $75 \%$ y una profundidad efectiva no menor a 60 centímetros, en contravención de sólidos criterios técnicos expuestos por las partes y la Procuraduría General de la República, establece un criterio de terreno forestal o de aptitud forestal que pone en peligro el derecho fundamental al medio ambiente sano y ecológicamente equilibrado, siendo por ello inconstitucional, particularmente, por la interpretación y aplicación que de ella puedan hacer las autoridades públicas, así como de los efectos en la extensión de la protección del ambiente". 


\subsection{Modificación de criterios, estándares, umbrales, indicadores o requisitos ambientales}

Al igual que el supuesto anterior, se parte de la existencia de normas que establecen umbrales o indicadores de contaminación que son modificados por nueva normativa que deroga, reduce, relaja o flexibiliza el nivel de los estándares de protección ambiental previamente fijados.

Debe tomarse en cuenta que los estándares y umbrales ambientales, en buena teoría, responden a estudios técnicos serios y exhaustivos, muchas veces avalados por entidades especializadas tales como la Organización Mundial de la Salud, Organización Panamericana de la Salud, Agencia Europea Ambiental, Agencia Ambiental de los Estados Unidos, universidades, etc.; y que permiten determinar en grado de certeza los "niveles óptimos de contaminación" y por consiguiente la no afectación negativa del bien jurídico regulado.

En virtud de lo anterior, el examen de regresividad debe iniciar analizando la existencia o no de criterio científico y/o técnico que justifique la modificación operada sobre los estándares ambientales. La ausencia o insuficiencia de fundamentación científica que permita determinar, con grado de certeza, la no afectación negativa del bien jurídico tutelado por medio del umbral anteriormente fijado, confirmaría la violación al principio de prohibición de retroceso, así como del criterio precautorio y los principios de razonabilidad y objetivación, todo en contraposición al deber estatal de tutela al interés público ambiental.

Contrariamente, todas aquellas modificaciones que derogan, reducen, relajan o flexibilizan los estándares y umbrales ambientales, pero que cuenten con justificación a la luz de las reglas unívocas de la ciencia y la técnica, no califican como regresiones.

Por su parte, todas aquellas modificaciones que impongan mayores y más estrictos estándares ambientales, pero que no cuenten con sustento científico ni técnico que justifiquen su promulgación, si bien no calificarían como regresiones, lo cierto del caso es que violentarían los principios constitucionales de razonabilidad y proporcionalidad, lo cual los convertiría en inconstitucionales o ilegales.

La Sala Constitucional ha tenido la oportunidad de pronunciarse en varias ocasiones en relaciones a modificación de estándares y umbrales ambientales que no contaron con justificación científica. Al efecto es posible citar el voto número 2012-12081 del 31 de agosto del 2012 que declaró la inconstitucionalidad de la Nota del Cuadro 3 del Anexo I, del Decreto Ejecutivo No. 37083-S, Reglamento para la Calidad de Agua para Consumo Humano en Establecimientos de Salud, por medio del cual se aumentó el valor máximo permitido de arsénico en agua en violación a los principios de objetivación y precautorio:

"Sobre el nivel recomendado de arsénico en el agua de consumo humano. Consta idónea y fehacientemente que en el Decreto Ejecutivo número 37083-S, Reglamento para la Calidad del Agua para Consumo Humano en Establecimientos de Salud, se incluyó una Nota en el Cuadro 3 del Anexo I, que indica, lo siguiente: "en sistemas de abastecimiento de agua clorados el Arsénico valencia 3 pasa a Arsénico valencia 5, disminuyendo su toxicidad 10 veces. En estas condiciones se podría permitir un valor máximo de50 3g/L de Arsénico" (los autos). Según reconoció la Ministra de Salud, permitir que el agua para consumo humano posea una cantidad de arsénico superior a un valor de $10 \mathrm{3g} / \mathrm{L}$, puede poner en riesgo la salud de la población (informe). Precisamente, al carecer ese Ministerio de estudios técnicos que sustenten, técnicamente, la variación dispuesta en la nota en cuestión, estima la Sala que se produjo el agravio reclamado".

También es posible citar el voto constitucional número 2009-2019 del 11 de febrero de 2009 que dispuso la inconstitucionalidad de la derogatoria que se llevó a cabo a través del artículo 14 del Decreto No. 32734-MINAE-S-MOPT-MAG-MEIC, Reglamento de Procedimientos de 
Evaluación de Impacto Ambiental, que excluyó del procedimiento de EIA a las concesiones de aguas superficiales y subterráneas, sin justificación técnica ni científica alguna y en flagrante violación al criterio constitucional de precaución:

"Esta Sala estima que la derogatoria que se llevó a cabo a través del artículo 14 del Decreto No. 32734-MINAE-S-MOPT- MAG-MEIC, deviene, a todas luces, en inconstitucional, dado que, se excluye, con respecto a los aprovechamientos (concesiones) de aguas superficiales y subterráneas que no forman parte de un proyecto sin justificación técnica alguna $y$, en contravención de lo dispuesto en el artículo 50 constitucional-, cualquier ponderación de los efectos acumulativos en el ambiente y en el cauce o cuerpo de agua (suma de impactos individuales que producen diferentes actividades presentes o futuras predecibles), corrección del impacto ambiental de un uso especial, la prevención, mitigación, compensación, restauración y recuperación por daños ambientales o impactos ambientales no controlados del uso particular, fiscalización o monitoreos ambientales, etc.. A mayor abundamiento, esta Sala hace notar que si bien en los informes rendidos a esta Sala de parte de las diversas autoridades accionadas se hace referencia al presunto fundamento técnico por el cual se dispuso excluir de la evaluación de impacto ambiental los aprovechamientos (concesiones) de aguas superficiales $y$ subterráneas que no forman parte de un proyecto, actividad u obra, lo cierto del caso es que, tal y como se indicó líneas atrás, éstos últimos criterios no fueron desarrollados en los considerandos del Decreto impugnado. De modo tal que, en la especie, la derogatoria incorporada a través del Decreto No. 32734-MINAE-S-MOPT-MAG- MEIC, resulta irrazonable y quebranta, flagrantemente, el derecho a disfrutar de un ambiente sano $y$ ecológicamente equilibrado, así como el principio preventivo en materia ambiental, por cuanto, deja al margen del ordenamiento jurídico, la protección que, originalmente, era brindada por el Estado, concretamente, por parte de la Secretaría Técnica Nacional Ambiental, al recurso hídrico, sea, a aquellas aguas superficiales y subterráneas dadas en concesión y que no forman parte de un proyecto, actividad u obra".

Por su parte, y mediante el voto número 2006-16276 del 8 de noviembre del 2006, la Sala Constitucional declaró inconstitucional el artículo 70 del Reglamento para las Actividades de Aviación Agrícola, por medio del cual se redujo la franja de no aplicación aérea de plaguicidas entre el campo a fumigar y las casas, poblados y otros. Entre otras razones, la Sala indicó que la inconstitucionalidad se dio debido a que el artículo impugnado constituyó un menor nivel de protección en relación al artículo 75 del Reglamento anterior, lo cual fue violatorio al principio precautorio en la medida que no existió fundamento científico ni técnico que justificare la disminución de la franja.

Bajo este mismo razonamiento, a través del voto 2012-18298 del 19 de diciembre del 2012, la Sala Constitucional declaró la inconstitucionalidad del Decreto Ejecutivo número 34303-MPMIVAH, publicado en la Gaceta número 31 del 13-02-2008, por vulnerar el derecho constitucional a un ambiente sano y ecológicamente equilibrado a raíz de la exclusión arbitraria y cambio de uso de suelo del $70 \%$ de la zona de reserva creada para fines de protección y esparcimiento recreacional de los habitantes del Distrito de Hatillo, sin estudios técnicos que lo justificaren.

Nótese que tanto la ausencia o insuficiencia de justificación, aunado a la incerteza científica que esto implica, es lo que lleva a la Sala a declarar la respectiva inconstitucionalidad, ejemplo de ello es la sentencia número 2013-6615 del 15 de mayo de 2013, que anuló el Acuerdo de Junta Directiva número 4230 del Servicio Nacional de Aguas Subterráneas, Riego y Avenamiento que autorizó la sustitución o traslado de tanques de combustible en estaciones de servicio y de almacenamiento para autoconsumo, sin necesidad de presentar un estudio de impacto ambiental: 
"El acuerdo dictado eximió del estudio de impacto ambiental, lo que tendría consecuencias que no se han podido cuantificar porque nada de ello se le ha informado a la Sala, de manera que podría ser engañoso sencillamente desestimar la acción sobre la pretensión de la Procuraduría General de la República, el Ministro de Ambiente, Energía y Telecomunicaciones y las razones dadas por SENARA. Si bien el Estudio de Impacto Ambiental (EsIA) está contenido en la EIA (Evaluación de Impacto Ambiental), y es una parte del segundo, precisamente el EIA se establece como el trámite para obtener este tipo de autorizaciones, porque es una garantía de que la actividad humana, especialmente cuando es de categoría D1, para actividades catalogadas de alto y moderado impacto ambiental potencial, logrará mitigar sus impactos. De este modo, para posibilitar cualquier corrección a nivel administrativo o judicial en la aplicación inconstitucional del acuerdo impugnado por la infracción al principio precautorio, debe declararse con lugar la acción para extirpar del ordenamiento jurídico cualquier amenaza al derecho a un ambiente sano $y$ ecológicamente equilibrado. Debe anularse cualquier acto o acuerdo con el fin de proteger el derecho ambiental establecido en el artículo 50 constitucional, y su posible aplicación, además de la infracción señalada al artículo 129 de la Ley General de la Administración Pública".

Recientemente y mediante el voto 2013-6615 del 15 de mayo de 2013, la Sala Constitucional tuvo la oportunidad de dirimir una controversia entre desregulación versus el derecho fundamental a un ambiente sano y equilibrado, disponiendo que toda actuación del Estado debe guardar un justo equilibrio entre todos los intereses involucrados, siendo que cuando existe un estado de certeza por un bajo impacto ambiental sobre ciertas actividades, podría ser procedente relevar ciertos estudios y evaluaciones de impacto ambiental, pero cuando ello no está presente, el Estado debe resguardar otros principios. De esta forma, el interés por agilizar los trámites administrativos nunca puede ceder ante el principio precautorio, especialmente si se está frente a actividades peligrosas para el ambiente, y para el ser humano. $^{10}$

Por lo anterior, la eliminación de excesos en los trámites administrativos, no podría generar bajo ningún supuesto la desprotección del ambiente, por tratarse de un interés jurídico superior. Consecuentemente, para simplificar o racionalizar trámites y requisitos o suprimir los no imprescindibles en el control y regulación de actividades económicas, no podría nunca atentarse contra el ambiente, ya que los niveles de protección ambiental alcanzados deben ser respetados, no disminuidos, sino más bien incrementados. ${ }^{11}$

\subsection{Desafectación o reducción de espacios naturales sometidos a regímenes especiales de protección ambiental}

La reducción, disminución, desafectación, exclusión, segregación y limitación de los espacios naturales sometidos a un régimen especial de protección, en virtud que albergan ecosistemas considerados jurídicamente relevantes, tales como bosques, humedales, áreas

\footnotetext{
10 "Es evidente que el acuerdo impugnado busca la flexibilización de los trámites de los administrados, un fin aparentemente legítimo contenido en el artículo 41 constitucional, pero que debe acordarse de modo que toda actuación del Estado guarde un justo equilibrio entre los intereses involucrados, especialmente aquellos referentes al derecho fundamental al ambiente sano y ecológicamente equilibrado. Cuando hay un estado de certeza por un bajo impacto ambiental sobre ciertas actividades, podría ser procedente relevar ciertos estudios y evaluaciones técnicas científicas de impacto ambiental, pero cuando ello no está presente, el Estado debe resguardar otros principios. Toma en cuenta la Sala que el interés por agilizar los trámites administrativos nunca puede ceder ante el principio precautorio, especialmente si se está frente a actividades peligrosas para el ambiente, y para el ser humano". Voto número 2013-6615, del 15/05/2013, Sala Constitucional de la Corte Suprema de Justicia.

${ }^{11}$ Al respecto se recomienda consultar el dictamen 319-2009 del 18 de noviembre de 2009 y la opinión jurídica OJ- 113-2000 de 11 de octubre de 2000, ambos de la Procuraduría General de la República.
} 
silvestres protegidas, zona marítima terrestre, territorios indígenas, en la medida que se realicen y ejecuten por medio de normas que no cuenten con criterio técnico ni científico que los justifique y que permita determinar, con grado de certeza, el grado de afectación negativa, constituyen un claro ejemplo de regresividad.

Es importante señalar que bajo ciertas situaciones especiales que encuentran justificación en el mismo ordenamiento jurídico, es lícito la desafectación y reducción de este tipo de sitios ecológicos. Tanto la Convención para la Protección de la Flora, de la Fauna y de las Bellezas Escénicas Naturales de los Países de América, como la Ley Orgánica del Ambiente, exigen que dichas modificaciones, cuando operen sobre Áreas Silvestre Protegidas, sean realizadas por ley, y cuenten con estudios técnicos y científicos que demuestren el no deterioro o puesta en peligro del espacio natural, existiendo por tanto, un vínculo directo con los principios de reserva de ley, objetivación de la tutela ambiental, preventivo, precautorio. ${ }^{12}$

De esta manera, el test de regresividad requerirá la corroboración de la existencia de dictámenes técnicos y científicos que justifiquen fehacientemente la desafectación o reducción del espacio objeto de protección, y tratándose de Áreas Silvestres Protegidas se debe verificar además la existencia de una ley de la república que así lo permita. No está por demás señalar que la ausencia o insuficiencia de dictámenes técnicos trae aparejado la existencia de un grado de incerteza científica que justificaría también la aplicación del principio precautorio.

12 "V. En relación con la alegada violación del artículo 3 del Convenio para la protección de la flora, de la fauna y de las bellezas escénicas naturales de los países de América -aprobado por Ley número 3763, de primero de octubre de mil novecientos sesenta y seis- en relación con el artículo 7 constitucional, que en lo que interesa dice así: "Los Gobiernos Contratantes convienen en que los límites de los parques nacionales no serán alterados ni enajenada parte alguna de ellos sino por acción de la autoridad legislativa competente. Las riquezas existentes en ellos no se explotarán con fines comerciales. Los Gobiernos Contratantes convienen en prohibir la caza, la matanza y la captura de especímenes de la fauna y la destrucción y recolección de ejemplares de la flora en los parques nacionales, excepto cuando se haga por las autoridades del parque o por orden o bajo vigilancia de las mismas o para investigaciones científicas debidamente autorizadas". Deben esas normas interpretarse en sentido restrictivo, de manera que, la exigencia de establecer los límites de los parques nacionales a través de una ley es únicamente cuando va en detrimento del mismo, es decir, cuando se quiera reducir su extensión, y no cuando se quieran extender los límites de las zonas protectoras del patrimonio forestal del Estado. Este artículo debe completarse con el artículo 40 de la Ley Forestal que dice: "El área de las reservas forestales, zonas protectoras, parques nacionales, refugios de vida silvestre, reservas biológicas del patrimonio forestal, sólo podrá ser reducida por ley de la República, previos estudios técnicos correspondientes que justifiquen esta medida". Y esto es así en virtud de que el bien jurídico que se protege es el "recurso forestal", término que "significa la protección y preservación de la integridad del medio ambiente natural," (resolución de la Sala Constitucional número 2233-93, de las nueve horas treinta y seis minutos del veintiocho de mayo de 1993) que existe en la zona declarada como parque nacional, y que es reconocido tanto por la legislación internacional, por las leyes especiales dictadas al efecto, como por los textos de las cartas políticas. En este sentido, el artículo 69 de la Constitución Política es que habla de "explotación racional de la tierra", constituyéndose un principio fundamental su protección (...)".Es evidente entonces que el Poder Ejecutivo, no puede reducir los límites territoriales un área silvestre, pero sí puede extenderlos. De ahí que los Decretos cuya derogación o puesta en vigencia hayan producido como consecuencia inmediata el aumento del territorio de una determinada área protegida, son constitucionales". De todo lo cual se pueden derivar dos conclusiones. Por un lado, cuando de la ampliación de los límites de las zonas protectoras del patrimonio forestal del Estado se trata es posible hacerlo vía reglamento, pero cuando de su reducción se trata únicamente se puede hacer vía legal, claro está, siempre y cuando exista un criterio previo que justifique la medida. Por otro lado, la derogatoria del artículo $6^{\circ}$ del decreto ejecutivo DE-16614, incluyendo las zonas urbanas de Gandoca, Manzanillo y Puerto Viejo implicó un aumento del territorio del Refugio Nacional de Vida Silvestre de GandocaManzanillo, siendo entonces que la exclusión de dichas zonas dentro del territorio del refugio implica una reducción del territorio de este". Voto número 1999-5399, del 26/10/1999, Sala Constitucional de la Corte Suprema de Justicia. 
La regla de la irreductibilidad de espacios sometidos a regímenes especiales de protección ambiental ha encontrado eco en la jurisprudencia constitucional, la cual en múltiples ocasiones, ha declarado la inconstitucionalidad de normativa que, sin estudios técnicos o bien, en violación del principio de reserva de ley, ha pretendido la desafectación o reducción de este tipo de espacios especiales de protección.

Tratándose de la prohibición de cambio de uso de suelo en bosques ubicados en terrenos privados, la Sala Constitucional de la Corte Suprema de Justicia en el considerando VIII del voto 16975-2008 del doce de noviembre del 2008, expuso:

"Como lo señalara la Procuraduría General de la República, el Tribunal de Casación Penal ha insistido también en que el cambio ilícito del uso del suelo del bosque, para dedicarlo a otros fines, es una actividad nociva al ambiente; al efecto, ha derivado de las disposiciones existentes el principio de irreductibilidad del bosque y dispuesto la restitución del área de bosque afectada al estado anterior a los hechos, para garantizar el derecho constitucional de un ambiente sano y equilibrado. El Decreto impugnado regula únicamente la actividad o proyectos de ecoturismo en los bosques de la zona marítimo terrestre, demarcados por el MINAE, y omite hacerlo para las demás áreas silvestres protegidas y bosques del Patrimonio Natural del Estado. Con todo, no justifica esta diversidad de trato, que riñe con los principios constitucionales de razonabilidad y proporcionalidad en materia ambiental. Esta regulación parcial o fragmentaria, que adversa la unidad de gestión, la actividad y proyectos de ecoturismo en los bosques del Patrimonio Natural del Estado quedan sujetos a regulaciones dispares, según se hallen o no en la zona marítimo terrestre. Esto atentaría contra el principio de igualdad, por la disímil normativa aplicable a los interesados en llevarlos a cabo, en razón de la ubicación de los inmuebles. El Decreto, artículos $1^{\circ}, 2^{\circ}, 3^{\circ}, 5^{\circ}$ y $7^{\circ}$, en concordancia con el $4^{\circ}$ inciso 2 , subordina las áreas de bosque de la zona marítimo terrestre en que se realizarán proyectos ecoturísticos implicativos de corta de árboles y aprovechamiento forestal, a una simultánea y divergente planificación, con distintos objetivos, normas y técnicas regulatorias: los Planes Reguladores y Planes de Manejo. Lo que es contrario a la utilización racional y sostenible de ese recurso (artículo 50 constitucional)".

La línea jurisprudencial de la Sala Constitucional ha sido consistente al reiterar que únicamente es posible reducir, segregar o excluir la superficie de un área silvestre protegida mediante una ley (principio de reserva de ley) y siempre que medien estudios técnicos y científicos que lo justifiquen (principio de objetivación de la tutela ambiental). En este sentido, en el voto 19987294 del 13 de octubre de 1998 por medio del cual se declaró inconstitucional el artículo 71 de la Ley Forestal debido a la reducción de la superficie de la Zona Protectora Tivives, se indicó:

"Sin embargo, se debe tener presente que la declaratoria y delimitación de una zona protectora, en cumplimiento de lo preceptuado en el artículo 50 constitucional, implica una defensa del derecho fundamental al ambiente $y$, por ello, la reducción de cabida no debe implicar un detrimento de ese derecho, situación que debe establecerse en cada caso concreto. No resulta necesariamente inconstitucional el hecho de que por medio de una ley posterior se reduzca la cabida de una zona protectora, una reserva forestal, un Parque Nacional o cualesquiera otros sitios de interés ambiental, siempre y cuando ello esté justificado en el tanto no implique vulneración al derecho al ambiente. (...) Así, no toda desafectación de una zona protegida es inconstitucional, en el tanto implique menoscabo al derecho al ambiente o amenaza a éste. De allí que para reducir un área silvestre protegida cualquiera, la Asamblea Legislativa debe hacerlo con base en estudios técnicos suficientes y necesarios para determinar que no se causará daño al ambiente $o$ se le pondrá en peligro $y$, por ende, que no se vulnera el contenido del artículo 50 constitucional" 
En esa misma línea, mediante el voto constitucional 2003-3480 del 02 de mayo de 2003 la Sala señaló:

"Nuestro ordenamiento confiere una protección especial a los bienes medioambientales de las áreas silvestres protegidas y para reducir su área exige un acto con rango de ley, sobre la base de estudios técnicos previos que justifiquen la conveniencia de la medida; no por acto reglamentario".

En la sentencia número 2009-1056 del 28 de enero de 2009, que declaró inconstitucional el Decreto Ejecutivo 34043-MINAE del 11 de setiembre del 2007, que agregó al Refugio Nacional de Vida Silvestre Gandoca-Manzanillo un área marina que originalmente no formaba parte del mismo, pero que a la vez le segregó áreas terrestres, el Tribunal Constitucional estimó que la exclusión de áreas terrestres del Refugio equivalió a una reducción del áreas silvestre protegida, independientemente de la ampliación de la zona marina, y por tanto, consideró tal exclusión como contraria al artículo 50 de la Constitución y al principio de reserva legal.

Ante una situación similar, aumento del área marina incluyendo unos islotes pero a la vez, exclusión de partes terrestres del Refugio de Vida Silvestre Isla San Lucas a través del Decreto Ejecutivo 34282-TUR-MINAE-C del 25 de enero del 2008, la Sala Constitucional en el voto 2010-13099 del 04 de agosto de 2010, estimó que la exclusión de una parte terrestre del Refugio equivalía a una reducción del mismo, independientemente de la ampliación de la zona marina, siendo dicha exclusión contraria a los artículos 11,50 y 89 de la Constitución por violación al principio de reserva de ley. ${ }^{13}$

En el reciente voto 2013-10158 del 24 de julio de agosto de 2013, la Sala Constitucional fundamentada en los principios precautorio y de progresividad evacuó consulta de constitucionalidad del proyecto de ley de Territorios Costeros Comunitarios, disponiendo al efecto:

"Respecto al Refugio Nacional de Vida Silvestre Ostional en acatamiento del Principio Precautorio, se requiere de previo a la declaratoria como territorio costero comunitario y a la concesión-tal y como lo señalan las y los diputadas y disputados consultantes- de un estudio de impacto ambiental evaluado por parte de Secretaría Técnica Ambiental, de modo tal que se demuestre el tipo de daño y las medidas que deban adoptarse, estudio que se echa de menos en esta iniciativa de ley, ya que no podría dejar de protegerse un refugio sin criterios técnicos que así lo respalden. Por lo tanto dicha omisión implica una violación del principio precautorio y del principio de progresividad del ámbito de tutela de los derechos fundamentales, aspecto señalado en el vicio de forma analizado en esta sentencia."

Por último es posible citar en el caso del anillo de contención del Gran Área Metropolitana, mediante los decretos ejecutivos 29415 -MP-MIVAH-MINAE del 28 de marzo del 2001, 33757MP-MIVAH-MINAE del 11 de abril del 2007 y 35748-MP-MINAET-MIVAH del 8 de enero del 2010, el Poder Ejecutivo intentó su ampliación desafectando áreas que formaban parte del mismo permitiendo con ello nuevos usos de suelo, incluyendo su desarrollo inmobiliario. La Sala Constitucional declaró la inconstitucionalidad de los citados decretos ejecutivos en virtud de la ausencia de estudios técnicos y evaluación de impacto ambiental (EIA), dejando

\footnotetext{
13 "Sin embargo, contrario al caso del Refugio Nacional de Vida Silvestre Gandoca-Manzanillo, en este caso la Sala declaró inconstitucional y anuló únicamente la disposición del decreto que hizo la referida exclusión, dejando vigentes todos los demás artículos que creaban un régimen especial para las áreas excluidas" FERNÁNDEZ FERNÁNDEZ (Edgar), "La incoherencia del régimen jurídico surgido del voto de la Sala Constitucional para el Refugio de Vida Silvestre San Lucas", en Ambientico, No. 206, noviembre 2010.
} 
incólume el área original prevista para el anillo de contención, salvo por los derechos adquiridos de buena fe durante la vigencia de los decretos. ${ }^{14}$

\subsection{Reformas procesales}

Las regresiones pueden afectar tanto de normas sustantivas como procesales. En este supuesto se parte de la existencia de normativa procesal que regula materia ambiental que se ve modificada por la promulgación de nueva norma también procesal que menoscaba 0 empeora su alcance, amplitud y efectividad original.

Reglas básicas de la responsabilidad por daño ambiental tales como la responsabilidad objetiva, inversión de la carga de la prueba, solidaridad, imprescriptibilidad de la acción por daños ambientales colectivos, o bien la prohibición del instituto del silencio positivo en materia de permisos ambientales, entrarían dentro de la categoría aquí analizada; también podría pensarse en la derogación, reducción, relajamiento o flexibilización de las normas que regulan los procedimientos donde se dirimen controversias jurídicas ambientales, como podría ser una jurisdicción ambiental especializada o un tribunal ambiental administrativo.

En estos casos, el examen de regresividad se focalizaría en la determinación de la razonabilidad y proporcionalidad de la nueva norma promulgada respecto al alcance, amplitud y efectividad de la norma modificada, especialmente en relación a los criterios de justicia, equidad, lógica y conveniencia, tomando como norte la obligación constitucional de garantizar, defender y preservar el interés público ambiental.

En relación a este supuesto, es posible citar el voto constitucional 2012-1283 del 03 de febrero del 2012, donde la Sala en protección a su propia línea jurisprudencial, confirmó la constitucionalidad de la prohibición del instituto procesal del silencio positivo en materia de permisos ambientales, al respeto dispuso:

"En relación con los artículos 17 y 29 del Decreto $N^{\circ}$ 35884-MINAET, no son inconstitucionales si se interpreta que el transcurso de la audiencia sin pronunciamiento de los entes respectivos, incluyendo claro está SENARA, no significa su conformidad, por lo que la falta de pronunciamiento no significa un criterio favorable".

\subsection{Denuncia de tratados internacionales ambientales}

Una vez ratificado un convenio internacional este entra a formar parte del bloque de legalidad. A partir de la sentencia 1993-6240 del 26 de noviembre de 1993, la Sala Constitucional instauró el criterio jurisprudencial por medio del cual, los instrumentos ambientales internacionales son de obligado acatamiento y gozan de plena ejecutoriedad, en tanto sus normas no precisen de mayor desarrollo legislativo, y por ende, deben ser respetadas en tanto el rango normativo de aquellos es superior. ${ }^{15}$

\footnotetext{
${ }^{14} \mathrm{Al}$ respecto puede consultarse el ensayo de este mismo autor denominado "Los derechos adquiridos de buena fe y sus implicaciones ambientales", publicado en elDial.com, Biblioteca Jurídica Online, Suplemento de Derecho Ambiental, setiembre 2013, Argentina, disponible en:

http://www.eldial.com/suplementos/ambiental/ambiental.asp.

15 "De las sentencias 719-90 de las 16:30 horas del 26 de junio de 1990 y 282-90 de las 17 horas del 13 de marzo de 1990 se desprende por una parte, que el Derecho Internacional es en Costa Rica, inmediatamente operable y aplicable por sí mismo, sin necesidad de leyes u otras normas que los desarrollen o lo hagan aplicable, salvo cuando la misma naturaleza de la norma internacional lo exija; y por otra, que aún en los casos en que esta exigencia sea a texto expreso, la aplicabilidad inmediata del Derecho Internacional de los Derechos Humanos implica que basta con la existencia de otros remedios o, en general, de medios razonablemente aplicables, para que no haga falta ningún desarrollo legal ni institucional" Piza Escalante, Rodolfo, La Justicia Constitucional en Costa Rica, Editorial Investigaciones Jurídicas, 2004.
} 
Aplicando el anterior criterio y en múltiples ocasiones, la Sala Constitucional costarricense, al resolver recursos de amparo por violaciones al derecho a un ambiente sano y ecológicamente equilibrado, o bien, acciones de inconstitucionalidad en esta materia, ha procedido a fundamentar sus fallos por medio del derecho internacional ambiental haciendo uso incluso de aquellos principios rectores contenidos en las declaraciones de soft law, gozando de especial preponderancia los principios precautorio y desarrollo sostenible. ${ }^{16}$

Costa Rica ha suscrito un numeroso elenco de convenios ambientales donde destacan: Convenio Diversidad Biológica, Convenio Marco de Cambio Climático, Convenio para la Protección de la Capa de Ozono, Convenio sobre el Control de los Movimientos Transfronterizos de desechos peligrosos y su eliminación, Convención para la Protección de la Flora, de la Fauna y de las Bellezas Escénicas naturales de los países de América, Convenio CITES sobre Comercio Internacional de Flora y Fauna Silvestre, Convención Ramsar sobre Humedales de Importancia Internacional, y a nivel regional: Convenio sobre Cambios Climáticos, Convenio para la Conservación de la Biodiversidad y Protección de Áreas Silvestres Protegidas en América Central, Acuerdo Regional sobre Movimiento Transfronterizos de Desechos Peligrosos, Convenio Regional para el Manejo y Conservación de los Ecosistemas Forestales y el desarrollo de Plantaciones Forestales.

A la fecha, no existe un solo precedente donde Costa Rica denuncie un tratado internacional ambiental, sin embargo a nivel internacional podría citarse a Canadá, que anunció en marzo del 2013 su decisión de abandonar el Convenio de las Naciones Unidas contra la desertificación, convirtiéndose en el primer país del mundo en hacerlo. ${ }^{17}$

Tomando en cuenta que el derecho internacional ambiental posee una vocación finalista buscando siempre mejorar las condiciones ambientales, bajo la premisa "proteger más contaminar menos", la denuncia de una convención internacional ambiental, a todas luces tendrá como consecuencia la degradación, rebaja, disminución, y empeoramiento del nivel de protección ambiental previamente adquirido. Por ello, el test de regresividad conllevaría simplemente la verificación de la ratificación de un tratado internacional ambiental y su posterior denuncia, lo cual siempre constituiría una regresión.

\subsection{Reducción de normas presupuestarias}

Si bien las leyes presupuestarias no califican como normas estrictamente ambientales, lo cierto del caso es que es perfectamente factible la modificación presupuestaria que tenga como fin la reducción de fondos destinados a la protección del ambiente.

La línea jurisprudencial de la Sala Constitucional ha establecido que la carencia de recursos económicos no puede justificar que un órgano o ente público no adopte las medidas que sean necesarias para preservar el ambiente, o para suspender cualquier actividad que atente contra esa finalidad; al respecto pueden citarse los votos 1996-695, 1995-915 y 1998-726:

"...dada la jerarquía y trascendencia del valor humano y constitucional en juego; sea, la salud de las personas, así como su derecho a un ambiente sano, y en último caso, su derecho a respirar y vivir en una atmósfera dentro de las normas de salud; la simple excusa de falta de medios materiales para enfrentar los problemas por parte del

\footnotetext{
${ }^{16}$ A manera de ejemplo, la sentencia constitucional número 1250 de las once horas con veinticuatro minutos del diecinueve de febrero de 1999, declaró la inconstitucionalidad del decreto ejecutivo 14524-A que permitía la caza y explotación de la carne de la tortuga lora y la tortuga verde por contravenir abiertamente la Convención sobre el Comercio Internacional de Especies Amenazadas de Flora y Fauna Silvestres (CITES), la Convención de la Flora, de la Fauna y de las Bellezas Escénicas naturales de los países de América, el Convenio sobre la Diversidad Biológica, así como el principio 15 de la Declaración de Río Sobre Medio Ambiente y Desarrollo.

17 http://noticias-ambientales-internacionales.blogspot.com/2013/03/canada-tambien-abandonara-lacnuld.html.
} 
Estado, no es admisible, porque en estos casos la Administración tiene la obligación de dar prioridad a las soluciones y realizar con sus recursos limitados, lo que conforme con el ordenamiento jurídico sea necesario para llevarlas a cabo con prontitud".

Así las cosas, el examen de regresividad implicaría confrontar la norma presupuestaria y la justificación dada para promulgarla, frente a la obligación estatal de garantizar, defender y preservar el derecho a un ambiente sano y equilibrado; los criterios de vinculatoriedad de la normativa ambiental que impide su derogación temporal o espacial para casos particulares; de razonabilidad, proporcionalidad, justicia, lógica y conveniencia. De esta forma, únicamente aquellas modificaciones presupuestarias que logren demostrar fehacientemente la no afectación al nivel de protección ambiental soportarían el control de regresividad. ${ }^{18}$

\subsection{Omisión al deber de desarrollar vía legal o reglamentaria normas ambientales}

Calificarían como regresiones aquellas omisiones al deber de reglamentación de normas ambientales cuyo incumplimiento haga inoperable $e$ ineficaz la norma que requiere reglamentación, de manera total o parcial.

Tratándose de omisión total de reglamentación, el examen de regresividad utilizaría como parámetro la norma ambiental aún no reglamentada y su posibilidad de cumplir a cabalidad con sus objetivos propuestos, mientras que en supuestos de reglamentaciones parciales, incompletas o erróneas, el test verificará la eficacia de la norma principal frente a las omisiones, limitaciones o restricciones impuestas vía reglamentaria.

La reglamentación parcial, incompleta o errónea de una norma, desde un punto de vista científico, técnico y jurídico, volviéndola inaplicable, violenta el principio de prohibición de retroceso por impedir su eficacia. Tómese en cuenta que aquellas omisiones e incumplimientos al deber de reglamentación que no impidan su aplicación eficaz no podrían llevar el calificativo de regresiones omisivas.

A partir de la sentencia número 1990-101 la Sala Constitucional considera violatorio al inciso 3 del numeral 140 constitucional las omisiones del Poder Ejecutivo respecto a reglamentar leyes, en el tanto que si bien en principio el ejercicio de la potestad reglamentaria es de carácter discrecional, esa posibilidad es inaplicable cuando el legislador ha impuesto al Poder Ejecutivo la obligación de reglamentar una ley. ${ }^{19} \mathrm{Al}$ amparo de este criterio jurisprudencial, la omisión a

\footnotetext{
${ }^{18}$ Al respecto puede consultarse los apartados 11 y 12 de la Observación General número 3 (1990) del Comité de Derechos Económicos, Sociales y Culturales al Pacto Internacional de Derechos Económicos, Sociales y Culturales.

19 “...distinto es el caso en el cual el legislador expresamente le impone en la ley el deber de reglamentarla. Aquí se hace inescapable para el Poder Ejecutivo el ejercicio de esa competencia. Dentro del ilimitado espacio de la legislación, aquí el destinatario de un deber hacer es el Poder Ejecutivo y, como tal, queda sujeto a la orden contenida en la Ley. Desaparece para él toda discrecionalidad, pues la norma legal regló su actuación, de modo que el ejercicio de la competencia se hace inevitable. En el tanto se haya apartado de lo ordenado, en ese tanto hay una infracción constitucional, pues como se sabe, el Poder Ejecutivo tiene una doble sumisión al estar sujeto a la Constitución y a la Ley. No es dable entender, como ya se ha intentado, que, derivada la potestad reglamentaria de la Constitución Política, el legislador tiene vedado el regular la oportunidad de su ejercicio". De lo anterior se deduce que existe una doble vinculación del Poder Ejecutivo, por un lado a la ley y por otro a la Constitución. Por ello, es evidente que la Administración no cuenta con discrecionalidad alguna para excusarse de reglamentar una ley si así ha sido ordenado por el Legislador o por el Constituyente -teniendo en cuenta, asimismo, los alcances del principio de legalidad-. Cabe mencionar que el artículo 140 inciso 3) de la Constitución Política establece el deber del Poder Ejecutivo de sancionar,
} 
reglamentar normas ambientales representa una regresión ambiental que violenta el derecho a un ambiente sano y ecológicamente equilibrado, tal y como lo reiteró la Sala Constitucional al obligar al Poder Ejecutivo a reglamentar la Ley de Pesca y Acuicultura; el artículo 71 de la Ley Orgánica del Ambiente sobre contaminación visual; así como la Ley de Gestión Integral de Residuos especialmente respecto a los Lineamientos para la recuperación y limpieza de suelos contaminados:

"El artículo 49 párrafo segundo de la Ley de la Jurisdicción Constitucional, permite analizar por la vía del amparo la omisión del Poder Ejecutivo de reglamentar o hacer cumplir lo dispuesto por una norma, cuando dicha inactividad guarde relación con la tutela de un derecho fundamental. En el presente asunto, los recurrentes cuestionan la omisión del Poder Ejecutivo de reglamentar la Ley de Pesca y Acuicultura, la cual fue publicada en la Gaceta 78 del veinticinco de abril de dos mil cinco. Sobre el particular, debe mencionarse que el artículo 175 de la norma de cita establece que el Poder Ejecutivo debía emitir el reglamento respectivo para dicha ley, dentro del plazo de noventa días a partir de su publicación, no obstante del informe rendido por las propias autoridades recurridas se desprende que a la fecha no se procedido a cumplir con lo dispuesto por dicho ordinal. A criterio de este Tribunal la inactividad del Poder Ejecutivo constituye una clara violación de los recurridos a lo dispuesto por el artículo 140 inciso 3) de la Constitución Política, omisión que es susceptible de ser conocida por vía del amparo, al estar en peligro el derecho a un ambiente sano y ecológicamente equilibrado debido a la falta de emisión del reglamento antes mencionado. Lo anterior, por cuanto la norma que se echa de menos debe regular una serie de puntos relacionados con la pesca y la explotación adecuada de los recursos marítimos, conforme lo dispone la propia Ley 8436, tales como: a) la garantía económica que deberán rendir las entidades y empresas nacionales o extranjeras a las que se otorgue permiso de pesca con fines exploratorios -artículo 18-; b)las especies de tiburón carentes de valor comercial y el aprovechamiento que se dará a éstas para otros fines de la actividad pesquera -artículo 40-; c) el tamaño y pesos proporcionales de cada especie de camarón por capturar -artículo 45-; d) los requisitos de sustitución, construcción e importación de las embarcaciones palangreras, así como las dimensiones y los sistemas o artes de pesca -artículo 62-; e) el trámite que debe seguir el titular de un proyecto acuícola, desee introducir una o más especies diferentes de las concedidas inicialmente, ampliar o modificar el área que le fuera autorizada -artículo $85-$; f) los lineamientos que debe seguir cualquier actividad de cultivo y manejo, independientemente del nivel y estadio de desarrollo de especies de flora y fauna acuáticas, para fines productivos o de investigación por parte de instituciones públicas o privadas -artículo 89-; g) los requisitos y las condiciones de traslado de especies

promulgar y reglamentar las leyes. Por ese motivo, este precepto resulta vulnerado si el Poder Ejecutivo soslaya su obligación de reglamentar las leyes, aún cuando no se afecta otra norma constitucional. Es decir, en todos los casos en que exista una omisión reglamentaria, el Poder Ejecutivo lesiona al menos el inciso 3) del artículo 140, eso sin contar la posible vulneración a cualquier otra norma que reconozca un derecho y que se vea afectada por esa omisión; en tales casos, dicha omisión es susceptible de control por la vía del recurso de amparo si esa inactividad está vinculada al disfrute de un derecho fundamental; de no ser así, siempre se puede efectuar el control por la vía de la acción de inconstitucionalidad por omisión. Lo anterior, evidencia que el Poder Ejecutivo no cuenta con ningún grado de discrecionalidad en los casos en que la Constitución o la ley le establecen una obligación de reglamentar (...)" Sentencia número 1990-101. 
acuáticas, nativas o exóticas, de un cuerpo de agua a otro del país - artículo 97- ; h) los requisitos y las condiciones necesarios que deberán cumplir los patrones de pesca 0 capitán de la embarcación pesquera.-artículo 118-; i) los requisitos mínimos que deberán cumplir las instalaciones portuarias y marinas utilizadas para el desembarco y la limpieza de las capturas. Los aspectos mencionados anteriormente, sin lugar a dudas guardan una íntima relación con la explotación y aprovechamiento sostenible de los recursos marítimos del país, de ahí que la falta de reglamentación adecuada de los mismos, sin duda alguna conlleva a poner en peligro los ecosistemas marinos y el medio ambiente en general, situación que puede generar repercusiones para la población de Costa Rica con el tiempo. Por otra parte, y sin demérito de lo anterior, conviene agregar que al estar de por medio el derecho a un medio ambiente sano y ecológicamente equilibrado, las autoridades recurridas se encuentran en la obligación de garantizar la participación ciudadana en la elaboración del reglamento a la Ley de Pesca y Acuicultura, pues ello es un derecho que es inherente a los habitantes del país, en razón de lo dispuesto por el propio constituyente, tal y como se indicó en el considerando $V$ de esta sentencia". Voto número: 2009-8065.

"Del análisis del caso este Tribunal verifica que la Ley Orgánica del Ambiente fue publicada en la Gaceta número 215 del trece de noviembre de mil novecientos noventa y cinco, de manera que, el Poder Ejecutivo desde hace trece años tenía la obligación legal de conformidad con los artículos 11 y 194 de la Constitución Política de regular el contenido del artículo 71 de la ley 7554, referente a la contaminación visual. De lo expuesto, y de conformidad con el artículo 49 párrafo segundo de la Ley de la Jurisdicción Constitucional mismo que establece: "Si el amparo hubiere sido establecido para que una autoridad reglamente, cumpla o ejecute lo que una ley u otra disposición normativa ordena, dicha autoridad tendrá dos meses para cumplir con la prevención"; lo procedente es declarar con lugar el recurso por la omisión del Poder Ejecutivo de reglamentar el artículo 71 de la Ley Orgánica del Ambiente número 7554 publicada en la Gaceta número 215 del trece de noviembre de mil novecientos noventa y cinco. Se concede al Poder Ejecutivo el plazo de dos meses a partir de la notificación de esta sentencia, para que proceda a la reglamentación del artículo 71 de la Ley 7554". Voto número: 2008-11696.

"Ahora bien, luego de analizar los elementos aportados a los autos, estima este Tribunal que el accionante lleva razón en su reclamo, pues pese a que el numeral antes mencionado es claro en señalar que el Ministerio de Salud establecerá reglamentariamente los lineamientos generales para la recuperación y limpieza de los suelos afectados por contaminación, lo cierto es que han transcurrido más de 2 años desde la emisión de la Ley número 8839, el Poder Ejecutivo no ha procedido a emitir la normativa prevista por el artículo citado. Dicha omisión sin lugar a dudas constituye una lesión al artículo 50 de la Constitución Política, pues la falta del reglamento al artículo 46, impide contar con los parámetros y lineamientos técnicos del caso, para poder proceder a llevar a cabo la limpieza de las superficies contaminadas, por aquellas personas que resulten obligadas a ello. Así, en virtud de lo anterior, el recurso debe ser acogido, como en efecto se hace". Voto número: 2013-2656.

"La mayoría de los alegatos del recurrente referidos a las omisiones e incumplimientos del Ministerio de Salud respecto de la Ley número 8839, Ley para la Gestión Integral de Residuos, están relacionados con la falta de emisión de los distintos reglamentos a que hace referencia dicha ley. Para esta Sala dichas omisiones, y otras, pueden ser solventadas con la publicación de todos los reglamentos que faltan para implementar dicha ley. Así entonces, si bien es cierto el Ministerio recurridos ha procedido con la emisión de cuatro de los reglamentos de la Ley no.8839, es lo cierto que falta el reglamento general y varios importantes, como los mismos recurridos 10 
reconocen, ha sido una omisión que ha impedido cumplir a cabalidad con lo establecido en dicha ley, en detrimento del derecho a gozar de un ambiente sano. Se declara PARCIALMENTE CON lugar el recurso, en consecuencia de conformidad con lo dispuesto en el artículo 49 párrafo $2^{\circ}$ de la Ley de la Jurisdicción Constitucional, se ordena al Poder Ejecutivo, integrado por quienes ocupen los cargos de Presidente de la República y Ministros de Salud, y Ambiente, Energía y Telecomunicaciones que dentro del plazo de dos meses contados a partir de la notificación de esta sentencia, procedan a elaborar y emitir todos los reglamentos que hagan falta para implementar la Ley número 8839, "Ley para la Gestión Integral de Residuos", en cuenta, el Reglamento sobre la declaratoria de residuos de manejo especial, el Reglamento para la Clasificación y Manejo de Residuos Peligrosos, y el Reglamento sobre Sitios Contaminados y Valores Guía de Contaminantes de Suelos, Metodología para Estudios de Generación y Composición de residuos sólidos ordinarios; y cualquier otro que haga falta; $y$ además a cumplir a cabalidad con todas las obligaciones dispuestas en dicha ley". Voto número 2013-3837.

\subsection{Falta de aplicación sistemática -espacial o temporal- de la legislación ambiental}

Toda inobservancia o incumplimiento sistemático, espacial o temporal, de la legislación ambiental, que no encuentren respaldo en situaciones especiales calificadas de anómalas, excepcionales y coyunturales, tales como estados declarados de emergencia, urgencia y necesidad, calificaría como regresión ambiental.

En estos supuestos, el test de regresividad buscará determinar el grado de incumplimiento en la obligación de la aplicación efectiva de la normativa, así como la existencia o no del estado de urgencia, emergencia o necesidad declarado, de manera que si el incumplimiento es sistemático y no se encuentra justificado en una situación de excepción previamente declarada, se estará frente a una clara violación al principio de no regresión.

En virtud de los principios de legalidad, vinculatoriedad de la normativa ambiental e inderogabilidad singular, en relación con el deber estatal de tutela del interés público ambiental, la aplicación eficaz del derecho ambiental se constituye en un imperativo.

Mediante el voto 2013-8596 del 26 de junio de 2013, la Sala Constitucional de la Corte Suprema de Justicia tuvo la oportunidad de referirse a situaciones sostenidas y recurrentes de inobservancia de las disposiciones de la Ley de Zona Marítima Terrestre:

"De manera que se estaría tolerando lo que considero una sistemática inobservancia de la Ley sobre la Zona Marítimo Terrestre, esto es, una deliberada desaplicación de esa normativa, pues nótese que en previas y reiteradas ocasiones la legislación ha pretendido regularizar ocupaciones ilegales, sin lograr erradicar la situación que se pretende justificar en cada ocasión. Así las cosas, a pesar de la ley número 5602 y de la gradualidad con que se dispuso aplicar la ley número 6043, con el transcurrir de los años lo que se ha dado es una franca desobediencia a esa normativa sin que se trate de problemas estructurales de la sociedad de origen espontáneo, sino de dificultades cuya génesis radica en la inercia del Estado. De conformidad con lo expuesto, una reforma legal como la propuesta y en una materia tan sensible en que se consientan actos de vulnerabilidad, lesiona en mi criterio, no solo la res pública y el principio constitucional de legalidad, sino que además significaría tolerar la falta de observancia por parte del Estado de otros principios, como el de in dubio pro natura, el cual tiene como objeto que exista una vigilancia activa, previa y oportuna por parte de las autoridades que no permita afianzar construcciones ilegales. De manera que 10 evidenciado más bien, es que se han omitido seguir los controles previos dispuestos por el Estado para dar cumplimiento efectivo no solo a la normativa en general, sino 
también a la protección ambiental, toda vez que en este momento apenas podrían entrarse a determinar cuáles de esas construcciones han producido un daño o no al ambiente, cuando lo requerido es su prevención. Esta situación en el caso concreto, como indiqué, implica una violación al principio de legalidad, que sin duda alguna deviene de relevancia constitucional en la medida que se afecta la propia validez y efectividad del ordenamiento jurídico, así como al Estado de Derecho".

En el voto 2010-16378 del 01 de octubre de 2010, la Sala Constitucional en virtud de la omisión del Ministerio de Ambiente y Energía de cobrar el canon por vertidos y del Instituto Costarricense de Acueductos y Alcantarillados de pagarlo, declaró con lugar un recurso de amparo por violación por omisión del derecho a un ambiente sano y equilibrado, obligando a ambas instituciones estatales en un plazo de dos meses proceder con su implementación:

"Del anterior cuadro fáctico se concluye que el amparo es procedente. En efecto, en primer lugar, desde la fecha de entrada en vigencia del decreto No. 34431-MINAE, ha transcurrido un año y medio, sin que se haya comenzado con el cobro del canon a las personas que utilizan la red de alcantarillado sanitario del AyA. Dicha omisión evidentemente lesiona el derecho de los costarricenses a un ambiente sano $y$ ecológicamente equilibrado, toda vez que el destino de los montos recaudados por el cobro de este canon, va encaminado a financiar proyectos de protección al medio ambiente $y$ al recurso hídrico. Es entendible que el proceso de fijar los montos y establecer el canon a cobrar al AyA en el caso de los usuarios que utilizan la red de alcantarillado sanitario, conlleva un trámite complejo y coordinado. Sin embargo, resulta irrazonable que a dos años y medio aproximadamente de emitido el Reglamento del Canon Ambiental por Vertidos, todavía no se ha implementado el cobro. Nótese que de acuerdo a lo indicado a folio $67 \mathrm{del}$ expediente, desde mayo del año pasado existe un acuerdo en el monto del canon para el sector domiciliar, comercial e industrial. En ese sentido, las omisiones apuntadas resultan reprochables. De acuerdo con 10 expuesto, debe declararse con lugar recurso en cuanto este extremo. En mérito de lo dicho, corresponde declarar con lugar el recurso en cuanto a este extremo se refiere, pues como ha quedado acreditado, la omisión del AyA ha causado un retardo injustificado en el cobro del Canon Ambiental por Vertidos".

En cuanto a las situaciones de excepción que justifican la desaplicación temporal o espacial de la normativa ambiental, la Sala Constitucional ha expuesto:

"Estados de necesidad y crisis hídrica: En circunstancias anómalas, excepcionales y coyunturales que provocan una calamidad pública o conmoción interna (v. gr. sequías extraordinarias, sobreexplotación grave de acuíferos o intrusión salina generalizada de éstos), el Estado a través del Poder Ejecutivo- $y$, con fundamento en el principio de necesidad, puede adoptar las medidas necesarias e idóneas respecto a la utilización del dominio público hidráulico para superar ese estado de cosas o evitar que se agrave. Cuando cesa el estado de necesidad y se restablece la normalidad se pueden adoptar otro tipo de medidas como las anteriormente expuestas (perímetros de protección, declaración de acuíferos sobreexplotados o en proceso de salinización)." Voto número 2004-1923

"De la vinculatoriedad de la normativa ambiental, como consecuencia directa del principio de legalidad regulado en el artículo 11 constitucional y 11 de la Ley General de la Administración Pública, la Administración Pública está obligada a cumplir con el bloque de legalidad; sujeción que tiene especial connotación en relación con la tutela del ambiente, en tanto, al tenor de la obligación impuesta al Estado en su conjunto en el artículo 50 constitucional, es que se denota su indisponibilidad respecto de las instituciones públicas -condición que también se da respecto de los particulares-, esto es, no está sujeto a pacto o convenio en razón de la trascendencia que tiene para la 
vida y sobrevivencia de la humanidad; lo que hace imposible su excepción, salvo claro está, en situaciones de urgencia o emergencia, que en sí mismo, es una condición de fuente de derecho (al respecto consultar la sentencia 2340-92). Es así como resultan vinculantes para las instituciones públicas el conjunto que conforma el Derecho Ambiental, formado tanto los principios constitucionales ambientales -que delimitan el contenido de este derecho fundamental-, como las diversas disposiciones normativas sobre la materia (legales y reglamentarias), así como los estándares ambientales, y requisitos dispuestos para la realización de proyectos que incidan sobre el ambiente; $y$ que, están inmersos en la gestión pública encomendada a cada una. Por ello, es que son exigibles la realización de estudio de impacto ambiental, la conformidad de los proyectos con los planes reguladores (en las municipalidades donde hay), la adecuación del funcionamiento de las plantas y proyectos a los estándares ambientales, etc.; caso contrario, sería admitir un "derecho del Estado a contaminar", Io que es imposible en atención al contenido del propio artículo 50 constitucional, según se ha indicado anteriormente, y como lo ha entendido este Tribunal (entre otras, consultar las sentencias número 5668-94, 5654-95, 8001-97, 2004-1923 , 200515769, 2006-1963 , y 2006-4497), al haber exigido a diversas instituciones públicas el cumplimiento de esa normativa a fin de tutelar de la manera debida el derecho a un ambiente sano y ecológicamente equilibrado". Voto número 2006-17126

"Sólo el estado de necesidad declarado excepciona el cumplimiento de las normas ambientales: El estado de emergencia es fuente de Derecho, que conlleva, en algunos casos, un desplazamiento, $y$ en otros un acrecentamiento de competencias públicas, precisamente con la finalidad de que pueda hacerle frente a la situación excepcional que se presente ("necesidades urgentes o imprevistas en casos de guerra, conmoción interna o calamidad pública"); de manera que se faculta al Poder Ejecutivo excepcionar los normales procedimientos de sus actividades o trámites, previéndose para tales casos, procedimientos excepcionales, más expeditos y simplificados. Se trata, por definición, de situaciones transitorias y que son urgentes en las que se hace necesario mantener la continuidad de los servicios públicos, de manera que se permite a la Administración improvisar una autoridad para el servicio de los intereses generales que no pueden ser sacrificados a un prurito legalista (...)". Votos 2003-06322 y 2012-3266 del 07/03/2012.

Como conclusión final, es posible afirmar que el test de regresividad, correctamente aplicado, se convierte en una primordial herramienta que permite medir el nivel de avances y retrocesos de legislación y con ello, mejorar la eficacia del derecho ambiental.

\section{Bibliografía}

Berros, María Valeria y Sbresso Luciana, Primeras señales sobre el principio de no regresión en materia ambiental en Argentina. Un estado de la cuestión, en El nuevo principio de no regresión en derecho ambiental, Bruxelles : Editions Bruylant, 2012.

Berros, María Valera, Construyendo el principio de no regresión en el Derecho argentino, JA,2011-IV, fasc. N.13, 2011.

Fernández Fernández, Edgar, La incoherencia del régimen jurídico surgido del voto de la Sala Constitucional para el Refugio de Vida Silvestre San Lucas, en Revista Ambientico, No. 206, noviembre 2010.

Peña Chacón, Mario, El Principio de no regresión ambiental en el derecho comparado latinoamericano, PNUD, 2013. 
Peña Chacón, Mario, El Derecho Internacional Ambiental como fundamento del Principio de Prohibición de Retroceso, en Revista lberoamericana de Derecho Ambiental y Recursos Naturales, número 8, mayo 2013, accesible en:

http://www.ijeditores.com.ar/index.php?ididioma=1\&idcontenido=-

2\&idpublicacion=19\&view=1\&PHPSESSID=b0a1ae9fea7edbe0d33db7164ecbad6e;

en Dial.com, Biblioteca Jurídica Online, Suplemento de Derecho Ambiental, junio 2013, Argentina, http://www.eldial.com/suplementos/ambiental/ambiental.asp.; en Derecho Ambiental y Cultural, Revista del Instituto Peruano de Derecho Ambiental y Patrimonio Cultural, número 1, agosto 2013, Perú.

Peña Chacón, Mario, La Ley Orgánica del Ambiente y el Principio de No Regresión, en Revista Iberoamericana de Derecho Ambiental y Recursos Naturales, número 7, febrero 2013, accesible en: http://www.ijeditores.com.ar/articulos. php?idarticulo=64177\&print=2; en IDial.com, Biblioteca Jurídica Online, Suplemento de Derecho Ambiental, marzo 2013, Argentina, http://www.eldial.com/suplementos/ambiental/ambiental.asp.

Peña Chacón, Mario, Los principios de objetivación de la tutela ambiental, irreductibilidad de espacios sometidos a régimen especial de protección y su relación con la prohibición de retroceso, en Revista Iberoamericana de Derecho Ambiental y Recursos Naturales, número 7, febrero 2013, accesible en:http://www. ijeditores.com.ar/articulos. php?idarticulo=64426\&print=2; en Dial.com, Biblioteca Jurídica Online, Suplemento de Derecho Ambiental, abril 2013, Argentina, http://www.eldial.com/suplementos/ambiental/ambiental.asp; en Revista Judicial 108, junio 2013, Costa Rica; en Revista de Direito Ambiental, RDA año 18, número 71, julio setiembre 2013, Brasil.

Peña Chacón, Mario, El CAFTA-DR y la prohibición de retroceso ambiental en Revista Iberoamericana de Derecho Ambiental y Recursos Naturales, número 7, febrero 2013, accesible en: http://www.ijeditores.com.ar/articulos. php?idarticulo=64426\&print=2.

Peña Chacón, Mario, Gobernanza Territorial y principio de no regresión, en elDial.com, Biblioteca Jurídica Online, Suplemento de Derecho Ambiental, julio 2013, Argentina, www.eldial.com/suplementos/ambiental/ambiental.asp; en Revista Iberoamericana de Derecho Ambiental y Recursos Naturales, número 9, agosto 2013, accesible en: http://www.ijeditores.com.ar/abm_news_publicacion. php?idpublicacion=19\&idedicion=270; en Lex, Difusión y Análisis, 4ta época, año XVIII, junio y julio 2013, México.

Peña Chacón, Mario, Los derechos adquiridos de buena fe y sus implicaciones ambientales, publicado en elDial.com, Biblioteca Jurídica Online, Suplemento de Derecho Ambiental, setiembre 2013, Argentina, disponible en:

http://www.eldial.com/suplementos/ambiental/ambiental.asp.

Piza Escalante, Rodolfo, La Justicia Constitucional en Costa Rica, Editorial Investigaciones Jurídicas, 2004.

Prieur, Michel, El nuevo principio de no regresión en derecho ambiental, Bruxelles: Editions Bruylant, 2012. 


\title{
LÍMITES, RESTRICCIONES Y EXCEPCIONES DEL PRINCIPIO DE PROHIBICIÓN DE REGRESIVIDAD AMBIENTAL*
}

\author{
Mario Peña Chacón* \\ "El derecho a un ambiente sano no tiene por qué estar en conflicto con otros derechos \\ fundamentales" John H. Knox
}

Como todo principio de derecho, la prohibición de regresividad ambiental no es ilimitada ni mucho menos irrestricta, encontrándose condicionada de forma general por la totalidad del elenco de derechos fundamentales con los que el derecho a un ambiente sano y equilibrado debe coexistir en justo equilibrio, y de forma específica, por los principios de razonabilidad y proporcionalidad, por las reglas unívocas de la ciencia, técnica, conveniencia y la lógica, por el deber de tutela del interés público ambiental, por los principios de desarrollo sostenible y uso racional, precautorio o evitación prudente, y por la vinculatoriedad de la normativa ambiental.

De esta forma, las medidas regresivas que pueden afectar derechos ambientales no están prohibidas per se a los Estados, y bajo ciertas circunstancias muy calificadas, encuentran justificación y validez a la luz del derecho internacional de los derechos humanos.

\section{Derechos Humanos y Medio Ambiente}

En virtud del carácter universal, indivisible e interdependiente de los derechos humanos se hace necesario e indispensable integrar los derechos humanos y las consideraciones relativas al medio ambiente, en la medida de que la degradación del entorno puede afectar negativamente el disfrute de muy diversos derechos humanos, entre ellos el derecho a la vida y la salud. ${ }^{1}$

Partimos de la existencia de un modelo constitucional de Estado democrático, social y ambiental de derecho, entendiendo por éste: "aquella forma de Estado que se propone aplicar los principios de solidaridad económica y social para alcanzar el desarrollo sustentable, orientado a buscar la igualdad sustancial entre los ciudadanos, mediante el control jurídico del uso racional del patrimonio natural"2, cuya principal misión, según BIRNFELD, es la de estructurar marcos legales que lleven la vida económica hacia un objetivo de solidaridad sustancial. $^{3}$

\footnotetext{
Este artículo fue redactado dentro del Proyecto de Investigación denominado "Las clínicas del Derecho Ambiental y Gestión de Riesgos Climáticos a través de una cultura jurídica de la sostenibilidad y no regresión" inscrito ante la Vicerectoría de Investigación y el Instituto de Investigaciones Jurídicas de la Universidad de Costa Rica bajo el código 722-B3-193.

* Profesor de Derecho Ambiental de la Facultad de Derecho de la Universidad de Costa Rica y de las Maestrías de Derecho Ambiental y Derecho Público Comparado Franco-latinoamericano del Sistema de Estudios de Posgrados de la Universidad de Costa Rica. Coordinador de la Maestría en Derecho Ambiental de la Universidad de Costa Rica. Miembro de la Comisión de Derecho Ambiental de la Unión Internacional para la Conservación de la Naturaleza (UICN). mariopenachacon@gmail.com

1 "Los daños ambientales pueden tener consecuencias negativas, tanto directas como indirectas, en el disfrute efectivo de los derechos humanos", Consejo de Derechos Humanos, resolución 16/11.

${ }^{2}$ Capella, Vicente Bellver, Ecología: de las razones a los derechos. Granada, Ecorama, 1994.

${ }^{3}$ Birnfeld, Carlos André Souza, A emergencia de uma dimensao ecológica para a ciudadania, alguns subsídios aos operadores jurídicas, 1997.
} 
Bajo el enfoque de Estado socio-ambiental de derecho, ${ }^{4}$ éste se encuentra inhibido de interferir, de forma ilegítima, en el ámbito de protección de la totalidad de los derechos humanos (medidas de carácter negativo) y a la vez, se ve obligado a protegerlos y promoverlos mediante medidas de carácter positivo, también conocidas como prestacionales.

De esta forma, el Estado no sólo debe asegurar un mínimo adecuado de protección de los derechos fundamentales, sino que además, tratándose de derechos ambientales, está obligado a salvaguardar un mínimo existencial socio-ambiental, ${ }^{5}$ que en palabras de SARLET y FENSTERSEIFER, actúa como una especie de garantía del núcleo esencial de los derechos económicos, sociales, culturales y ambientales. ${ }^{6}$

En virtud de lo anterior, el Estado socio-ambiental de derecho está obligado a cumplir una serie de obligaciones procedimentales y sustantivas inherentes al disfrute de un medio ambiente sin riesgos, limpio, saludable y sostenible.

Como obligaciones procedimentales es posible mencionar: los deberes de evaluar el impacto ambiental en los derechos humanos y hacer pública la información relativa al medio ambiente; facilitar la participación en la toma de decisiones ambientales, entre otras cosas protegiendo los derechos de expresión y de asociación; y dar acceso a reparaciones cuando se produzcan daños al medio ambiente, obligaciones que se fundamentan en los derechos civiles y políticos, pero que se han aclarado y ampliado en el contexto del medio ambiente sobre la base de todos los derechos humanos que están en peligro a causa del deterioro del medio ambiente. ${ }^{7}$

En relación a las obligaciones sustantivas, los Estados deben aprobar marcos jurídicos e institucionales que protejan contra los daños ambientales que interfieran en el disfrute de los derechos humanos, incluidos los daños ocasionados por actores privados. Existen además obligaciones relacionadas con la protección de los miembros de grupos en situaciones vulnerables, como las mujeres, los niños y los pueblos indígenas. ${ }^{8}$

\footnotetext{
${ }^{4}$ En su reciente obra "Daño ambiental" los autores Morato Leite y Ayala Araujo mencionan que el modelo de Estado Constitucional Ecológica o Estado democrático, social y ambiental de derecho fue propuesto inicialmente por el alemán Rudolf Steinberg. Por su parte, en Brasil autores como Antonio Benjamin, Molinaro, Helini Sivini, Belchoir, Patricia Bianchi, Leonor Ferreira, Carolina Ruschel y los mismos José Rubens Morato Leite y Patryck Ayala Araujo han sido sus principales impulsores a nivel doctrinario. En Costa Rica, es a partir de de la sentencia 2013-10540 del 07 de agosto de 2013 que la Sala Constitucional innova a través de la creación jurisprudencial de un nuevo principio de "desarrollo sostenible democrático", donde ya no sólo se trata de garantizar el aprovechamiento de los recursos existentes por las presentes generaciones, y de asegurar la subsistencia de las futuras, sino que para lograrlo, también se debe asegurar que el acceso a esos recursos y a la riqueza generada por las actividades económicas se distribuya equitativamente en la sociedad, de modo que alcance al mayor número posible de personas y permita el progreso solidario. Por medio de una nueva interpretación sistémica y sistemática de los artículos 50, 74 y 89 constitucionales, la Sala Constitucional costarricense otorgó especial relevancia al elemento social del desarrollo sostenible como un componentes de la justicia social propio del Estado de Derecho que se verifica a través del reparto más adecuado de la riqueza y el ambiente sano, así como en el deber estatal de procurar una política permanente de solidaridad nacional.

${ }^{5}$ La idea de mínimo existencial socio-ambiental encuentra asidero en la Observación General número 3 del Comité de Derechos Económicos, Sociales y Culturales que desarrolló la obligación mínima de cada Estado Parte del PIDESC de asegurar la satisfacción de por lo menos niveles esenciales de cada uno de los derechos.

${ }^{6}$ Sarlet, Ingo Wolfgang y Fensterseifer, Tiago, Direito Constitucional Ambiental, 4ta edición, Sao Paulo: Editora Dos Tribunais, 2014.

7 Informe A/HRC/25/53 del Experto Independiente de la Organización de las Naciones Unidas sobre la cuestión de las obligaciones de derechos humanos relacionadas con el disfrute de un medio ambiente sin riesgos, limpio, saludable y sostenible, del 30 de diciembre del 2013.

${ }^{8}$ Al respecto se recomiendo al lector remitirse al Informe $\mathrm{A} / \mathrm{HRC} / 25 / 53$ del Experto Independiente de la Organización de las Naciones Unidas sobre la cuestión de las obligaciones de derechos humanos relacionadas con el disfrute de un medio ambiente sin riesgos, limpio, saludable y sostenible, del 30 de diciembre del 2013.
} 
Tomando en cuenta la naturaleza interdependiente e indivisible de los derechos sociales y ambientales, los autores SARLET y FENSTERSEIFER, ${ }^{9}$ como forma de incorporar la evolución histórica de los derechos fundamentales y humanos integrando la tutela del ambiente como núcleo privilegiado de protección del ser humano, modifican la tradicional denominación de los Derechos Económicos, Sociales y Culturales (DESC), evolucionando hacia una nueva dimensión ampliada de Derechos Económicos, Sociales, Culturales y Ambientales (DESCA).

Esta innovadora visión encuentra sustento tanto en el principio 25 de la Declaración de Río sobre Medio Ambiente y Desarrollo el cual dispone que la paz, el desarrollo y la protección ambiental son interdependientes e indivisibles, como en el Protocolo de San Salvador adicional a la Convención Americana de Derechos Humanos sobre Derechos Económicos, Sociales y Culturales, que incorpora en su artículo 11.1 de manera expresa, los derechos ambientales. De igual forma, el Pacto Internacional de Derechos Económicos, Sociales y Culturales de 1966, de forma incipiente, relaciona los DESC con los derechos ambientales a través de sus artículos 12.1 y 12.2.b, que reconocen el derecho a un nivel de vida adecuado y a la mejora continua de las condiciones de vida, así como el derecho de toda persona a disfrutar de los más elevados niveles de salud física y mental relacionados con mejoras en todos los aspectos de higiene del trabajo y medio ambiente.

\section{Derechos Humanos y Prohibición de Regresividad}

El artículo 2.1. del Pacto Internacional de Derechos Económicos, Sociales y Culturales (PIDESC) dispone:

"Cada uno de los Estados Partes en el presente Pacto se compromete a adoptar medidas, tanto por separado como mediante la asistencia y la cooperación internacionales, especialmente económicas y técnicas, hasta el máximo de los recursos de que disponga, para lograr progresivamente, por todos los medios apropiados, inclusive en particular la adopción de medidas legislativas, la plena efectividad de los derechos aquí reconocidos."

Siguiendo la doctrina de los autores COURTIS y ABRAMOVICH, ${ }^{10}$ del artículo 2.1 del PIDESC es posible extraer distintas pero complementarias nociones de progresividad, una primera relacionada con la gradualidad de las medidas que deben ser adoptadas por los Estados en el tiempo, y la segunda vinculada al concepto de progreso, como deber estatal de mejorar las condiciones de goce y ejercicio de los derechos económicos, sociales y culturales.

En primer lugar, la progresividad implica un reconocimiento de la necesidad de un esfuerzo prolongado por parte de los Estados, para alcanzar la plena satisfacción de los derechos reconocidos en el PIDESC. Esta idea de progresividad encuentra fundamento en la Observación General número 3 del Comité de Derechos Económicos Sociales y Culturales que al efecto dispuso:

"El concepto de progresiva efectividad constituye un reconocimiento del hecho de que la plena efectividad de todos los derechos económicos, sociales y culturales en general no podrá lograrse en un breve período de tiempo (...). Sin embargo, el hecho de que la efectividad a lo largo del tiempo, o en otras palabras progresivamente, se prevea en relación con el Pacto no se ha de interpretar equivocadamente como que priva a la obligación de todo contenido significativo (...). Por otra parte, la frase debe interpretarse a la luz del objetivo general, en realidad la razón de ser del Pacto, que

\footnotetext{
${ }^{9}$ Sarlet, Ingo Wolfgang y Fensterseifer, Tiago, Direito Constitucional Ambiental, 4ta edición, Sao Paulo: Editora Dos Tribunais, 2014.

${ }^{10}$ Abramovich Víctor y Courtis Christian, Los derechos sociales como derechos exigibles, Madrid, Trotta, 2002.
} 
es establecer claras obligaciones para los Estados Partes con respecto a la plena efectividad de los derechos de que se trata. Este impone así una obligación de proceder lo más expedita y eficazmente posible con miras a lograr ese objetivo."

Por su parte, la segunda noción de progresividad trae consigo una obligación de aumento sostenido en el nivel de satisfacción de los derechos económicos, sociales y culturales, sea una idea de "progreso" entendida como mejora gradual, constante y sistemática de los resultados en materia de derechos sociales. Al respecto, el párrafo 9 de la Observación General número 3 impone la obligación de moverse tan rápido y efectivamente hacia la meta, mientras que su párrafo 2 dispone que las medidas que el Estado debe adoptar para la plena efectividad de los derechos reconocidos, deben ser deliberadas concretas y orientadas hacia el cumplimiento de las obligaciones reconocidas en el Pacto.

Esta interpretación se ve reforzada por el artículo 11.1 del PIDESC que al efecto establece:

"Los Estados Partes en el presente Pacto reconocen el derecho de toda persona a un nivel de vida adecuado para sí y su familia, incluso alimentación, vestido y vivienda adecuados, y a una mejora continua de las condiciones de existencia. Los Estados Partes tomarán medidas apropiadas para asegurar la efectividad de este derecho, reconociendo a este efecto la importancia esencial de la cooperación internacional fundada en el libre consentimiento."

Al respecto COURTIS ${ }^{11}$ recalca que el PIDESC requiere la mejora continua de las condiciones de existencia, es decir, la progresividad en el sentido de progreso, o ampliación de la cobertura y protección de los derechos sociales. De esta obligación estatal de implementación progresiva de los DESC, a criterio del mencionado autor, es posible extraer algunas obligaciones concretas, entre ellas, la obligación mínima asumida por el Estado de no regresividad, sea, la prohibición de adoptar medidas, ya se trate de políticas, normas jurídicas, prácticas administrativas, que empeoren la situación de los DESC de los que gozaba la población al momento de adoptar el tratado internacional respectivo, o bien en cada mejora progresiva.

Para COURTIS, dado que el Estado se compromete a mejorar la situación de estos derechos simultáneamente asume la prohibición de reducir los niveles de protección de los derechos vigentes, o en su caso, de derogar los derechos ya existentes. Al efecto, el Comité de Derechos Económicos, Sociales y Culturales, en su Observación General número 3 identificó una serie de obligaciones de inmediato cumplimiento por parte de los Estados signatarios del Convenio, dentro de las que destacan: adoptar medidas legislativas, administrativas y judiciales; comprometer hasta el máximo de los recursos disponibles; garantizar el disfrute de los derechos sociales sin ningún tipo de discriminación; garantizar, incluso en situaciones de crisis, el contenido esencial de los derechos sociales; vigilar la situación de los derechos sociales y contar con información detallada al respecto; y la de no adoptar medidas de carácter deliberadamente regresivas.

Específicamente sobre esta última obligación, la Observación General número 3 en su párrafo 9, dispuso que cualquier medida deliberadamente regresiva requerirá la más cuidadosa consideración y deberá ser justificada plenamente por referencia a la totalidad de los derechos previstos en el PIDESC y en el contexto del aprovechamiento pleno del máximo de recursos de que se dispone.

En aplicación de lo dispuesto en la Observación General número 3, el Comité de DESC se ha referido a la prohibición de regresividad en sus Observaciones Generales 12, 13, 14, 15, 16,18 y 19 relativas al derecho a una alimentación adecuada, a la educación, al disfrute del más alto

11 Courtis, Christian, La prohibición de regresividad en materia de derechos sociales: apuntes introductorios, Ciudad Autónoma de Buenos Aires, Editores del Puerto, 2006. 
nivel posible de salud, al agua, a la igualdad del hombre y la mujer en el disfrute de los derechos reconocidos en el Pacto, al trabajo y a la seguridad social, respectivamente.

El Informe sobre la Prohibición de Regresividad en los Derechos Económicos, Sociales y Culturales de Colombia 2002-2008, ${ }^{12}$ desarrollando la doctrina delineada por el Comité de DESC por medio de sus Observaciones Generales, califica tres tipos o modalidades de medidas regresivas:

- Derogar o suspender oficialmente la legislación necesaria para seguir disfrutando uno o varios de los derechos reconocidos en el Pacto.

- Promulgar legislación o adoptar políticas que sean manifiestamente incompatibles con las obligaciones jurídicas nacionales o internacionales preexistentes en relación con uno o varios de los derechos reconocidos en el Pacto.

- Adoptar medidas que sean incompatibles con las obligaciones básicas de los Estados parte del PIDESC.

Tal y como se expuesto en relación al artículo 2.1. del PIDESC, también es posible extraer y derivar la prohibición de regresividad de los instrumentos de derechos humanos del Sistema Interamericano, específicamente del artículo 26 de la Convención Americana de Derechos Humanos y del artículo 1 del Protocolo de San Salvador que prevén respectivamente la obligación de progresividad:

"Artículo 26. Desarrollo progresivo. Los Estados parte se comprometen a adoptar providencias, tanto a nivel interno como mediante la cooperación internacional, especialmente económica y técnica, para lograr progresivamente la plena efectividad de los derechos que se derivan de las normas económicas, sociales y sobre educación, ciencia y cultura, contenidas en la Carta de la Organización de los Estados Americanos, reformada por el Protocolo de Buenos Aires, en la medida de los recursos disponibles, por vía legislativa u otros medios apropiados".

"Artículo 1. Obligación de adoptar medidas. Los Estados parte en el presente Protocolo Adicional a la Convención Americana sobre Derechos Humanos se comprometen a adoptar las medidas necesarias tanto de orden interno como mediante la cooperación entre los Estados, especialmente económica y técnica, hasta el máximo de los recursos disponibles y tomando en cuenta su grado de desarrollo, a fin de lograr progresivamente, $y$ de conformidad con la legislación interna, la plena efectividad de los derechos que se reconocen en el presente Protocolo".

Aunado a las dos disposiciones antes citadas, la Asamblea General de la Organización de Estados Americanos adoptó el 7 de junio de 2005, mediante Resolución AG/RES. 2074 Las normas para la confección de informes periódicos previstos en el artículo 19 del Protocolo de San Salvador. Las normas de confección de informes definen la obligación de progresividad de la siguiente manera:

"5.1. A Los fines de este documento, por el principio de progresividad se entenderá el criterio de avance paulatino en el establecimiento de las condiciones necesarias para garantizar el ejercicio de un derecho económico, social y cultural."

A la vez, las referidas normas conceptualizan "medidas regresivas" de la siguiente forma:

"Se recuerda que por medidas regresivas se entienden todas aquellas disposiciones o políticas cuya aplicación signifique un retroceso en el nivel del goce o ejercicio de un derecho protegido. Se recuerda también que el carácter acotado en el tiempo de ciertas medidas regresivas como consecuencia o a continuación de situaciones excepcionales permite una evaluación distinta."

\footnotetext{
${ }^{12}$ Disponible en: http://www.coljuristas.org/documentos/libros_e_informes/inf_2010_n1.pdf.
} 
Como bien lo señala COURTIS, ${ }^{13}$ la idea de progresividad en el sentido de progreso también encuentra asidero en la interpretación que le ha venido dando la Comisión Interamericana de Derechos Humanos al artículo 26 de la Convención Americana:

"Si bien el artículo 26 no enumera medidas específicas de ejecución, dejando que el Estado determine las medidas administrativas, sociales, legislativas o de otro tipo que resulten más apropiadas, expresa la obligación jurídica por parte del Estado de encarar dicho proceso de determinación y de adoptar medidas progresivas en este campo. El principio del desarrollo progresivo establece que tales medidas se adopten de manera tal que constante y consistentemente promuevan la plena efectividad de esos derechos". Informe sobre la situación de los derechos humanos en Ecuador, 1997.

"El carácter progresivo con que la mayoría de los instrumentos internacionales caracteriza las obligaciones estatales relacionadas con los derechos económicos, sociales y culturales implica para los Estados, con efectos inmediatos, la obligación general de procurar constantemente la realización de los derechos consagrados sin retrocesos". Segundo Informe sobre la situación de los derechos humanos en Perú, 2000.

De lo anteriormente expuesto es posible concluir que dentro del Sistema Interamericano de Derechos Humanos existen disposiciones suficientes que dan sustento a la obligación de progresividad y su consecuente prohibición de regresividad.

Por último, vale la pena citar las Directrices de Maastricht sobre Violaciones a los Derechos Económicos, Sociales y Culturales, ${ }^{14}$ que al igual que el PIDESC y el Sistema Interamericano de Derechos Humanos, considera como violatorio de los DESC:

- La derogación o suspensión de la legislación necesaria para el goce continuo de un derecho económico, social o cultural del que ya se goza; (Principio 14.a)

- La adopción de legislación o de políticas manifiestamente incompatibles con obligaciones legales preexistentes relativas a esos derechos; (Principio 14.d);

- La adopción de cualquier medida deliberadamente regresiva que reduzca el alcance en el que se garantiza el derecho. (Principio 14.e)

A todas luces, la cláusula de progresividad y de prohibición de regresividad inherente a los derechos económicos, sociales y culturales, también engloba a los derechos estrictamente ambientales, incluyendo todas aquellas medidas políticas, jurídicas y administrativas que puedan afectar el nivel de protección ambiental alcanzado con anterioridad, así como la obligación de mejora progresiva y sistemática del nivel de calidad ambiental. En este contexto, la regla general es que el derecho fundamental al ambiente, salvo por las excepciones que se analizarán posteriormente, únicamente podría ser modificado in mellius y nunca in pejus. ${ }^{15}$

Ante el proceso constante e inacabado de conformación y consolidación de los derechos humanos y dentro de ellos los derechos estrictamente ambientales, el Estado se ve compelido en brindarles respeto y garantía, obligación que es creciente, gradual y progresiva en procura siempre de mejores y más adecuadas instancias de protección y exigible en todos los estados de su desarrollo y crecimiento. Esta misma obligación impide a la vez, todo género de medidas

13 Courtis, Christian, La prohibición de regresividad en materia de derechos sociales: apuntes introductorios, Ciudad Autónoma de Buenos Aires, Editores del Puerto, 2006.

${ }^{14}$ Comité de Derechos Económicos, Sociales y Culturales, Directrices de Maastricht sobre las violaciones de los derechos económicos, sociales y culturales, 24 período de sesiones, doc. E/C.12/2000/13, 2 de octubre de 2000. Las directrices constituyen un instrumento interpretativo al que acuden con frecuencia los órganos de supervisión de tratados internacionales en materia de derechos económicos, sociales y culturales.

${ }^{15}$ Texeira, Orci, O direito ao ambiente ecologicamente equilibrado como direito fundamental, Porto Alegre, Livraria do Advogado, 2006. 
regresivas sobre lo ya alcanzado que supongan un retroceso en su tutela y efectividad a través de disposiciones legales o administrativas carentes de motivación y justificación suficiente.

Frente a esta realidad, el principio de prohibición de regresividad se posiciona actualmente como una garantía sustantiva de los derechos ambientales que prohíbe al Estado adoptar políticas y aprobar normas que empeoren, sin justificación razonable ni proporcionada, el nivel actual de protección y toda mejora que haya experimentado desde entonces, en beneficio de las presentes y futuras generaciones. De esta forma, la prohibición de regresividad actúa como una obligación negativa inherente a la obligación de carácter positivo y progresivo de garantizar, defender y preservar el derecho a un ambiente sin riesgos, limpio, saludable y sostenible.

\section{Presunción de invalidez y criterios de justificación de medidas regresivas}

A partir de la Observación General número 3 relativa a las obligaciones estatales, el Comité de DESC de las Naciones Unidas ha venido desarrollando de manera amplia, la obligación de prohibición de regresividad. ${ }^{16}$ Al efecto, la citada Observación General señaló:

"Más aún, cualquier medida deliberadamente regresiva al respecto requerirá la más cuidadosa consideración y deberá ser justificada plenamente por referencia a la totalidad de los derechos previstos en el Pacto y en el contexto del aprovechamiento pleno del máximo de los recursos de que se dispone".

En relación a la expresión "deliberadamente regresivas", la autora SEPÚLVEDA ha señalado:

"En general, se puede concluir que el Comité se refiere al significado común de la palabra "deliberada", esto es, aquellas medidas que sean adoptadas de manera intencional o voluntarias por el Estado. Con ello, el Comité implícitamente está afirmando que determinadas medidas regresivas adoptadas debido, por ejemplo, a fuerza mayor, no constituirían una violación al Pacto. Sin perjuicio de ello, como se verá, en caso de que la medida no sea "deliberadamente" regresiva, la carga de la prueba sigue siendo del Estado, que deberá demostrar que la medida se debió a motivos ajenos a su control (por ejemplo, un desastre natural), y no podrá excusarse de cumplir con las demás limitaciones aplicables a las medidas regresivas" ${ }^{\prime 17}$.

En virtud de lo expuesto a través de la Observación General número 3, y de conformidad al derecho internacional de los derechos humanos, las medidas regresivas deben ser consideradas, prima facie y iuris tantum, violatorias de los compromisos internacionales asumidos por los Estados, y por tanto inválidas.

La prohibición de regresividad opera como una presunción de invalidez de las medidas de retroceso, presunción iuris tantum que debe ser desvirtuada por el Estado en la medida que logre demostrar y acreditar fehacientemente, que las disposiciones regresivas adoptadas

\footnotetext{
16 Tomando como base la Observación General número 3, el Comité DESC delineó la prohibición de regresividad en sus Observaciones Generales 12, 13, 14, 15, 16, 18 y 19 relativas al derecho a una alimentación adecuada, a la educación, al disfrute del más alto nivel posible de salud, al agua, a la igualdad del hombre y la mujer en el disfrute de los derechos reconocidos en el Pacto, al trabajo y a la seguridad social, respectivamente.

17 Sepúlveda, Magdalena, La interpretación del Comité de Derechos Económicos, Sociales y Culturales de las obligaciones derivadas de la expresión "progresivamente" contenida en el artículo 2.1 del Pacto Internacional de Derechos Económicos, Sociales y Culturales, en Ni un paso atrás, La prohibición de regresividad en materia de derechos sociales, Christian Courtis (Comp.), Buenos Aires, CEDAL - CELS, 2006.
} 
fueron tomadas con estricto apego a los criterios definidos previamente por el Comité de DESC a partir de sus Observaciones Generales.

Como efecto directo e inmediato de la presunción prima facie y iuris tantum, opera la inversión de la carga de la prueba, recayendo en el Estado la obligación de justificación válida sobre las medidas de retroceso que hubiere adoptado en materia de derechos económicos, sociales, culturales y ambientales.

Los criterios de justificación de medidas regresivas señalados en el PIDESC y complementados por el Comité a través de la Observaciones Generales número 3 pueden desglosarse de la siguiente manera: ${ }^{18}$

- Que se haya implementado a través de una ley formal con el objeto de promover el bienestar general en una sociedad democrática;

- Que se hubiere implementado bajo la más cuidadosa consideración de todas las alternativas posibles, y que la elegida sea la menos lesiva para los derechos involucrados;

- Que se justifique por referencia a la totalidad de los derechos previstos en el PIDESC;

- Que se enmarque dentro de un contexto de aprovechamiento pleno del máximo de los recursos de que se dispone.

En complemento de lo anterior, mediante la Observación General número 19 sobre el derecho a la seguridad social, el Comité reiteró los criterios para la justificación de medidas regresivas de la Observación General número 3, y además señaló los alcances del estricto escrutinio al que deben ser sometidas:

- Existencia de justificación razonable;

- Existencia de estudios exhaustivos de las posibles alternativas;

- Verificación de una verdadera participación de los grupos afectados en el examen de las medidas y alternativas propuestas;

- Determinación de si las medidas eran directa o indirectamente discriminatorias;

- Determinación de si las medidas tendrán una repercusión sostenida en el ejercicio del derecho a la seguridad social o un efecto injustificado en los derechos adquiridos en materia de seguridad social, o si se priva a alguna persona o grupo del acceso al nivel mínimo indispensable de seguridad social; $y$

- Verificación de si se hizo un examen independiente de las medidas a nivel nacional

En su tratado sobre la prohibición de la regresividad en materia de derechos sociales, COURTIS señala que los Estados, para adoptar una medida regresiva, deben justificar:

- La existencia de un interés estatal calificado;

- El carácter imperioso de la medida;

- La inexistencia de cursos de acción alternativos menos restrictivos del derecho en cuestión.

En la misma línea del Comité de DESC, conforme a los estándares del Sistema Interamericano de Derechos Humanos, una vez que se ha probado la regresividad de una medida, le corresponde al Estado respectivo justificar su adopción, de acuerdo a los criterios señalados en el artículo 5 del Protocolo de San Salvador, que al respecto dispone:

18 Informe sobre la prohibición de regresividad en derechos económicos, sociales y culturales de Colombia 2002-2008, Disponible en: www.coljuristas.org/documentos/libros_e_informes/inf_2010_n1.pdf 
"Alcance de las Restricciones y Limitaciones. Los Estados partes sólo podrán establecer restricciones y limitaciones al goce y ejercicio de los derechos establecidos en el presente Protocolo mediante leyes promulgadas con el objeto de preservar el bienestar general dentro de una sociedad democrática, en la medida que no contradigan el propósito y razón de los mismos".

Como puede observarse, también dentro del Sistema Interamericano de Derechos Humanos opera la presunción iuris tantum respecto a que las medidas regresivas constituyen una violación de los compromisos asumidos por los Estados ante el derecho internacional de los derechos humanos, presunción que únicamente puede ser desvirtuada si el Estado logra demostrar motivos razonables, conforme a lo señalado en el artículo 5 del Protocolo de San Salvador.

Sobre este aspecto, los autores ABRAMOVICH y COURTIS nos recuerdan que no le basta al Estado demostrar que el propósito de las disposiciones adoptadas es admisible y que el medio escogido es potencialmente adecuado, sino que además, debe probar que el objetivo que persiguen las medidas adoptadas resulta necesario y que el medio utilizado es estrictamente imperioso.

En todo caso, incluso si se admite la justificación ofrecida por un Estado a favor de una medida regresiva en materia de DESC, para COURTIS, tal medida deberá tener un carácter temporal. Lo anterior se debe a que, aunque resulte admisible la adopción de una legislación o política regresiva, persiste para el Estado el deber de alcanzar de forma progresiva la plena satisfacción de los derechos reconocidos en el PIDESC. En consecuencia, aún si fuera admitida la justificación en beneficio de una medida de retroceso, en los términos señalados por el propio Comité, resulta contrario al Pacto que llegue a ser establecida de manera permanente. ${ }^{19}$

Adicionalmente, opera una prohibición de carácter absoluto de adoptar medidas regresivas cuando las políticas o normas implementadas impliquen un desconocimiento de alguna de las obligaciones básicas e inmediatas de los Estados parte, tales como la de asegurar como mínimo la satisfacción de niveles esenciales de cada uno de los derechos, la de garantizar el disfrute de los derechos reconocidos en el PIDESC sin discriminaciones, o la de comprometer hasta el máximo de los recursos disponibles. Al respecto, la Observación General número 3 en su apartado 10 dispuso:

"10. Sobre la base de la extensa experiencia adquirida por el Comité, así como por el organismo que lo precedió durante un período de más de un decenio, al examinar los informes de los Estados Partes, el Comité es de la opinión de que corresponde a cada Estado Parte una obligación mínima de asegurar la satisfacción de por lo menos niveles esenciales de cada uno de los derechos. Así, por ejemplo, un Estado Parte en el que un número importante de individuos está privado de alimentos esenciales, de atención primaria de salud esencial, de abrigo y vivienda básicos o de las formas más básicas de enseñanza, prima facie no está cumpliendo sus obligaciones en virtud del Pacto. Si el Pacto se ha de interpretar de tal manera que no establezca una obligación mínima, carecería en gran medida de su razón de ser. Análogamente, se ha de advertir que toda evaluación en cuanto a si un Estado ha cumplido su obligación mínima debe tener en cuenta también las limitaciones de recursos que se aplican al país de que se trata. El párrafo 1 del artículo 2 obliga a cada Estado Parte a tomar las medidas necesarias "hasta el máximo de los recursos de que disponga". Para que cada Estado Parte pueda atribuir su falta de cumplimiento de las obligaciones mínimas a una falta de recursos disponibles, debe demostrar que ha realizado todo esfuerzo para utilizar

19 Courtis, Christian, La prohibición de regresividad en materia de derechos sociales: apuntes introductorios, Ciudad Autónoma de Buenos Aires, Editores del Puerto, 2006. 
todos los recursos que están a su disposición en un esfuerzo por satisfacer, con carácter prioritario, esas obligaciones mínimas.(...)"

De esta manera, las obligaciones básicas que competen a los Estados en cuanto al respeto, protección y satisfacción de los DESC se convierten en un núcleo intangible, que no puede sufrir menoscabo por parte de las autoridades estatales. Ante este supuesto, la regresividad no admite justificación alguna, y cualquier medida que se adopte en ese sentido constituye "sin más" una violación de los compromisos asumidos a la luz del derecho internacional de los derechos humanos. ${ }^{20}$

\section{Justificaciones válidas para la implementación de medidas regresivas en materia ambiental}

Tratándose el derecho a un medio ambiente sin riesgos, limpio, saludable y sostenible de un derecho reconocido en instrumentos internacionales de derechos humanos, se beneficia de las teorías previamente existentes que tienen por objetivo aumentar su eficacia, por ello la obligación de progresividad o de avance continuo inherente a los derechos sociales se traduce jurídicamente en una prohibición de regresión que permea también a los derechos ambientales.

En artículos académicos anteriores ${ }^{21}$ hemos expuesto que una norma puede ser catalogada regresiva cuando su grado de efectividad resulte ser inferior en comparación al alcanzado con anterioridad, en la medida que derogue, limite, restrinja, reduzca, relaje o flexibilice el nivel de protección ambiental previamente adquirido, siempre y cuando no cuente con justificación ni respaldo técnico-científico que permita determinar, en grado de certeza, la no afectación del bien jurídico objeto de tutela. De esta forma, la nueva norma no debe ni puede empeorar la situación del derecho ambiental preexistente, desde el punto de vista de su alcance, amplitud y especialmente, de su efectividad.

A contrario sensu, todas aquellas modificaciones normativas que si bien limitan, restringen, reducen, relajan y/o flexibilizan el nivel de protección ambiental previamente adquirido, pero que cuenten con total y absoluta justificación y respaldo técnico-científico que permita determinar, con grado de certeza, la no afectación del bien jurídico tutelado, quedan descartadas como violaciones al principio de no regresividad ambiental.

Así mismo, la inaplicación temporal o espacial de normas ambientales o bien, la relajación de umbrales de protección en situaciones de emergencia, urgencia y necesidad, por no tratarse de medidas "deliberadamente regresivas" califican como tales, siempre y cuando se cumplan todos y cada uno de las siguientes condiciones exigidas a nivel jurisprudencial: ${ }^{22}$

\footnotetext{
20 Informe sobre la prohibición de regresividad en derechos económicos, sociales y culturales de Colombia 2002-2008, Disponible en: www.coljuristas.org/documentos/libros_e_informes/inf_2010_n1.pdf

${ }^{21}$ Peña Chacón, Mario, Test de Regresividad Ambiental, en Revista Internacional Direito Ambiental (RIDA), número 6, Brasil, diciembre 2013.

${ }^{22}$ Sobre este tipo de situaciones excepcionales en materia ambiental ha sostenido la Sala Constitucional de la Corte Suprema de Justicia de Costa Rica: "De la vinculatoriedad de la normativa ambiental, como consecuencia directa del principio de legalidad regulado en el artículo 11 constitucional y 11 de la Ley General de la Administración Pública, la Administración Pública está obligada a cumplir con el bloque de legalidad; sujeción que tiene especial connotación en relación con la tutela del ambiente, en tanto, al tenor de la obligación impuesta al Estado en su conjunto en el artículo 50 constitucional, es que se denota su indisponibilidad respecto de las instituciones públicas -condición que también se da respecto de los particulares-, esto es, no está sujeto a pacto o convenio en razón de la trascendencia que tiene para la vida y sobrevivencia de la humanidad; lo que hace imposible su excepción, salvo claro está, en situaciones de urgencia o emergencia, que en sí mismo, es una condición de fuente de derecho (al respecto consultar la sentencia 2340-92). Es así como resultan vinculantes para las instituciones públicas el conjunto que conforma el Derecho Ambiental, formado tanto los principios constitucionales ambientales - que delimitan el contenido de este derecho fundamental-, como las diversas disposiciones normativas
} 
- Debe tratarse de situaciones excepcionales justificadas en un estado de urgencia, emergencia o necesidad declarado;

- Las medidas adoptadas deben ser transitorias, tener como propósito el bien común y ser justas, razonables proporcionadas;

- Subsiste la obligación de aplicar todas aquellas normas ambientales no relacionadas con la atención de la emergencia, urgencia o necesidad;

- Las actuaciones de la administración deben orientarse a mitigar y eventualmente compensar cualquier posible impacto ambiental ocasionado.

Tal y como se ha expuesto, de las observaciones generales del Comité del PIDESC se desprende la existencia de un deber de no retroceso o prohibición de regresividad en materia de DESC, que impide a los Estados adoptar medidas que disminuyan el goce o ejercicio de los DESC, tomando en cuenta los niveles de reconocimiento que se han llegado a alcanzar. A pesar de ello, las medidas de carácter regresivo no están prohibidas per se a los Estados, pero estas deben ser de carácter excepcional y temporal, requieren una consideración cuidadosa y deben justificarse tomando en cuenta la totalidad de los derechos fundamentales. ${ }^{23}$

Teniendo claro lo anterior, procedemos a analizar el margen de maniobra con el que cuentan los Estados para implementar medidas regresivas de carácter ambiental que encuentran justificación y validez a la luz del derecho internacional de los derechos humanos.

En un primer orden de ideas, el Informe A/HRC/25/53 del Experto Independiente de la Organización de las Naciones Unidas sobre la cuestión de las obligaciones de derechos humanos relacionadas con el disfrute de un medio ambiente sin riesgos, limpio, saludable y sostenible,$^{24}$ refiriéndose a medidas regresivas sostuvo:

"255. Otro factor pertinente para determinar si una ley medioambiental se ajusta a las obligaciones de derechos humanos es ver si es regresiva. El Comité de Derechos Económicos, Sociales y Culturales ha desaconsejado enérgicamente las medidas regresivas respecto del disfrute de los derechos protegidos por el Pacto Internacional, a la luz de la obligación recogida en el Pacto de avanzar lo más rápidamente posible hacia la plena efectividad de los derechos. En su Observación general sobre el derecho

sobre la materia (legales y reglamentarias), así como los estándares ambientales, y requisitos dispuestos para la realización de proyectos que incidan sobre el ambiente; y que, están inmersos en la gestión pública encomendada a cada una. Por ello, es que son exigibles la realización de estudio de impacto ambiental, la conformidad de los proyectos con los planes reguladores (en las municipalidades donde hay), la adecuación del funcionamiento de las plantas y proyectos a los estándares ambientales, etc.; caso contrario, sería admitir un "derecho del Estado a contaminar", lo que es imposible en atención al contenido del propio artículo 50 constitucional, según se ha indicado anteriormente, y como lo ha entendido este Tribunal (entre otras, consultar las sentencias número 5668-94, 5654-95, 8001-97, 20041923, 2005-15769, 2006-1963, y 2006-4497), al haber exigido a diversas instituciones públicas el cumplimiento de esa normativa a fin de tutelar de la manera debida el derecho a un ambiente sano y ecológicamente equilibrado". Voto 2006-17126.

"Sólo el estado de necesidad declarado excepciona el cumplimiento de las normas ambientales: El estado de emergencia es fuente de Derecho, que conlleva, en algunos casos, un desplazamiento, y en otros un acrecentamiento de competencias públicas, precisamente con la finalidad de que pueda hacerle frente a la situación excepcional que se presente ("necesidades urgentes o imprevistas en casos de guerra, conmoción interna o calamidad pública"); de manera que se faculta al Poder Ejecutivo excepcionar los normales procedimientos de sus actividades o trámites, previéndose para tales casos, procedimientos excepcionales, más expeditos y simplificados. Se trata, por definición, de situaciones transitorias y que son urgentes en las que se hace necesario mantener la continuidad de los servicios públicos, de manera que se permite a la Administración improvisar una autoridad para el servicio de los intereses generales que no pueden ser sacrificados a un prurito legalista (...)". Votos 2003-06322 y 2012-3266.

${ }^{23}$ Abramovich, Víctor y Courtis Christian, Los Derechos Sociales como Derechos Exigibles, disponible en: http://es.scribd.com/doc/155159492/Los-Derechos-Sociales-Como-Derechos-Exigibles-Victor-Abramovichy-Christian-Courtis.

${ }^{24}$ Informe A/HRC/25/53 del 30 de diciembre del 2013. 
al disfrute del más alto nivel posible de salud, el Comité señaló que "(a)l igual que en el caso de los demás derechos enunciados en el Pacto, existe una fuerte presunción de que no son permisibles las medidas regresivas adoptadas en relación con el derecho a la salud". Si se adoptan cualesquiera medidas deliberadamente regresivas, corresponde al Estado demostrar que se han aplicado tras un examen exhaustivo de todas las alternativas posibles y que esas medidas "están debidamente justificadas por referencia a la totalidad de los derechos enunciados en el Pacto en relación con la plena utilización de los recursos máximos disponibles del Estado Parte" (párr. 32) ${ }^{25}$.

80. Las obligaciones de derechos humanos relacionadas con el medio ambiente incluyen también las obligaciones sustantivas de aprobar marcos jurídicos e institucionales que protejan contra los daños ambientales que interfieran en el disfrute de los derechos humanos, incluidos los daños ocasionados por actores privados. La obligación de proteger los derechos humanos de los daños ambientales no exige a los Estados que prohíban todas las actividades que puedan degradar el medio ambiente; los Estados pueden optar por lograr un equilibrio entre la protección del medio ambiente y otros intereses sociales legítimos. Sin embargo, este equilibrio debe ser razonable y no conducir a violaciones previsibles e injustificadas de los derechos humanos. Para determinar si un equilibrio es razonable, pueden resultar especialmente pertinentes las normas nacionales e internacionales relativas a la salud. También se desaconsejan enérgicamente las medidas regresivas."

El Tribunal Europeo de Derechos Humanos ha dispuesto que los Estados pueden optar por lograr un equilibrio entre la protección del medio ambiente y otras cuestiones importantes para la sociedad, como el desarrollo económico y los derechos de otros. Sin embargo, este equilibrio debe ser razonable y no conducir a violaciones previsibles e injustificadas de los derechos humanos. Asimismo, este Tribunal ha dictado sentencias en que ha declarado que los Estados no lograron establecer un equilibrio justo entre la protección de los derechos contra los daños ambientales y la protección de otros intereses. ${ }^{26}$

Por su parte, la Comisión Africana de Derechos Humanos ha dejado claro que la Carta Africana no exige a los Estados renunciar a todas las explotaciones petroleras. En el caso Ogoniland, la Comisión citó los enormes daños ambientales que habían afectado a los derechos de los habitantes de la región del delta del Níger al dictaminar que no se tuvo el cuidado que se debía haber tenido, entre otras cosas adoptando medidas razonables, para prevenir la contaminación y la degradación ecológica por la producción de petróleo. ${ }^{27}$

Dentro del Sistema Interamericano de Derechos Humanos, la Corte Interamericana en la sentencia del caso Pueblo Saramaka versus Surinam del 28 de noviembre de 2007, determinó que el derecho de propiedad comunal no es absoluto y que los Estados pueden restringir su uso y goce cuando hayan sido establecidas previamente por ley; sean necesarias; proporcionales y tengan como fin lograr un objetivo legítimo en una sociedad democrática.28

\footnotetext{
${ }^{25}$ Se recomienda al lector remitirse a la Observación general № 15 del Comité, párrafo 19.

${ }^{26}$ Se remite al lector a los casos López Ostra contra Reino de España, № 16798/90, 9 de diciembre de 1994; y Tatar v. Romania, № 67021/01, 27 de enero de 2009.

${ }^{27}$ Informe A/HRC/25/53 del 30 de diciembre del 2013.

28 "127. No obstante, la protección del derecho a la propiedad conforme al artículo 21 de la Convención no es absoluta y, por lo tanto, no permite una interpretación así de estricta. Aunque la Corte reconoce la interconexión entre el derecho de los miembros de los pueblos
}

indígenas y tribales al uso y goce de sus tierras y el derecho a esos recursos necesarios para su supervivencia, dichos derechos a la propiedad, como muchos otros de los derechos reconocidos en la Convención, están sujetos a ciertos límites y restricciones. En este sentido, el artículo 21 de la Convención establece que "la ley podrá subordinar [el] uso y goce de [los bienes] a los intereses de la sociedad". Por ello, la Corte ha sostenido en otras ocasiones que, de conformidad con el artículo 21 de la Convención, el Estado podrá restringir el uso y goce del derecho a la propiedad siempre que las 
En línea similar, la Sala Constitucional de la Corte Suprema de Justicia de Costa Rica a través de la histórica resolución número 2012-13367 que desarrolló ampliamente el principio de no regresividad como una garantía sustantiva de los derechos ambientales que prohíbe al Estado adoptar medidas, políticas ni aprobar normas que empeoren, sin justificación razonable ni proporcionada, los derechos alcanzados con anterioridad, estableció:

"Este principio no supone una irreversibilidad absoluta pues todos los Estados viven situaciones nacionales, de naturaleza económica, política, social o por causa de la naturaleza, que impactan negativamente en los logros alcanzados hasta entonces y obliga a replantearse a la baja el nuevo nivel de protección. En esos casos, el Derecho a la Constitución y los principios bajo examen obligan a justificar, a la luz de los parámetros constitucionales de razonabilidad y proporcionalidad, la reducción de los niveles de protección". (...) La regresividad en los niveles de protección debe estar plenamente justificada. El estudio tiene que justificar con criterio científico sustentado que la desafectación es una medida viable desde la perspectiva ambiental en el marco de una política de desarrollo sostenible, de lo contrario deviene en una transgresión del principio de no regresividad o irreversibilidad de la protección en los términos explicados supra y una violación material del principio de inderogabilidad singular de las normas".

De lo aquí expuesto es posible concluir que las medidas regresivas en materia ambiental que encontrarían justificación deben cumplir al menos con los siguientes parámetros:

- Carácter excepcional y temporal;

- Examen exhaustivo por parte del Estado de todas las alternativas posibles y que la elegida sea la menos lesiva para los derechos involucrados;

- Carácter no discriminatorio y verificación de una verdadera participación de los grupos afectados en el examen de las medidas y alternativas propuestas;

- Justificación tomando en cuenta el equilibrio razonable de la totalidad de los derechos fundamentales en relación con la plena utilización de los recursos máximos disponibles del Estado;

- Medida debe ser necesaria/imperiosa, razonable, justa, proporcionada y debe tener como fin lograr un objetivo legítimo en una sociedad democrática en el marco de una política de desarrollo sostenible.

\section{Justo equilibrio entre el derecho a un ambiente sano y los demás derechos fundamentales. El caso de las comunidades costeras que habitan dentro de áreas silvestres protegidas de Costa Rica}

Por invitación del Gobierno de Costa Rica, el Experto independiente de las Naciones Unidas sobre la cuestión de las obligaciones de derechos humanos relacionadas con el disfrute de un medio ambiente sin riesgos, limpio, saludable y sostenible, visitó el país del 28 de julio al 1 de agosto de 2013.

restricciones: a) hayan sido previamente establecidas por ley; b) sean necesarias; c) proporcionales y d) que tengan el fin de lograr un objetivo legítimo en una sociedad democrática. En consonancia con esta disposición, el Estado podrá restringir, bajo ciertas condiciones, los derechos de los integrantes del pueblo Saramaka a la propiedad, incluidos sus derechos sobre los recursos naturales que se encuentren en el territorio". Sentencia caso Pueblo Saramaka versus Surinam del 28 de noviembre de 2007, Corte Interamericana de Derechos Humanos. 
El propósito de la visita fue examinar la forma en que Costa Rica hace efectivos los derechos humanos relacionados con la protección del medio ambiente, determinar las buenas prácticas y las enseñanzas extraídas y analizar las dificultades con que se enfrenta el país para hacer realidad los derechos humanos relacionados con el medio ambiente.

Durante su inspección, el Experto independiente constató la existencia de varios conflictos entre las políticas que promueven la conservación, por una parte, y los derechos de las personas que viven en las áreas protegidas, por otra, en particular a raíz de la interpretación estricta de las leyes que prohíben la construcción de estructuras dentro de una cierta distancia de la costa. A raíz de esa interpretación, se han derribado algunos edificios antiguos, incluidos hoteles de la costa del Caribe, y comunidades enteras corren el riesgo de ser expulsadas de los lugares en que han vivido por generaciones.

Las comunidades afectadas son predominantemente un grupo minoritario de origen afrocaribeño. Los miembros de esas comunidades le manifestaron al Experto independiente que la interpretación estricta de la ley no toma en cuenta sus derechos e intereses, e incluso refleja cierto grado de discriminación odiosa en su contra.

En su Informe final, ${ }^{29}$ el Experto independiente expuso que la conservación no debería imponer un costo indebido a las comunidades que tienen profundas raíces históricas en las zonas de importancia ambiental. El derecho a un ambiente sano no tiene por qué estar en conflicto con otros derechos fundamentales. A la vez, recomendó a Costa Rica que acelere sus actuaciones a fin de resolver esta situación antes de que expire, en el 2014, la moratoria de dos años sobre la expulsión de las comunidades costeras que viven en las áreas protegidas, y que lo haga de un modo que:

a) Salvaguarde tanto el derecho a un ambiente sano y ecológicamente equilibrado como los derechos de quienes viven, desde hace muchos años, en las áreas protegidas o cerca de ellas;

b) Tenga en cuenta que muchas de las personas afectadas son miembros de grupos minoritarios que históricamente han vivido al margen de la vida política de Costa Rica, y garantice que la solución de la situación no entrañe discriminación por ninguno de los motivos prohibidos;

c) No considere que la falta de títulos legales formales priva necesariamente a las personas de sus derechos, puesto que pueden existir derechos en relación con bienes ocupados por largo tiempo incluso en ausencia de tales títulos;

d) Permita la participación plena e informada de todas las personas afectadas en el proceso de búsqueda de una solución.

A manera de conclusión, es posible afirmar que el derecho a la protección del ambiente no es absoluto, siendo imperativo encontrar un justo y razonable equilibrio en relación a los demás intereses legítimos, y con ello evitar todo tipo de violaciones previsibles e injustificables de los demás derechos humanos.

En un Estado socioambiental de derecho, el orden público ambiental es el medio idóneo para alcanzar el fin superior de conservación y uso racional, sostenible, equitativo y solidario de los bienes y servicios ambientales. Por ello, debe descartarse, a toda costa, caer en la tiranía del derecho, mediante la interpretación y aplicación de las normas ambientales que conviertan al derecho en un fin en sí mismo y no en aquel medio ideal para lograr satisfacer el interés público socioambiental.

\footnotetext{
29 Informe A/HRC/25/53/Add.1 del Experto independiente sobre la cuestión de las obligaciones de derechos humanos relacionadas con el disfrute de un medio ambiente sin riesgos, limpio, saludable y sostenible. Adición Misión a Costa Rica.
} 


\section{Bibliografía}

Abramovich, Víctor y Courtis, Christian, Los derechos sociales como derechos exigibles, Madrid, Trotta, 2002.

Abramovich, Victor, Los Derechos Económicos, Sociales y Culturales en la denuncia ante la Comisión Interamericana de Derechos Humanos, accesible en: http://www.iidh.ed.cr/documentos/herrped/PedagogicasEspecializado/02.pdf.

Abramovich, Víctor y Courtis Christian, Los Derechos Sociales como Derechos Exigibles, disponible a través del enlace: http://es.scribd.com/doc/155159492/Los-Derechos-SocialesComo-Derechos-Exigibles-Victor-Abramovich-y-Christian-Courtis.

Abramovich, Víctor y Rossi, Julieta, La tutela de los derechos económicos, sociales y culturales en el artículo 26 de la Convención Americana sobre Derechos Humanos, en Revista de Estudios Socio-jurídicos, volumen 9, Bogotá, abril 2007.

Birnfeld, Carlos André Souza, A emergencia de uma dimensao ecológica para a ciudadania, alguns subsídios aos operadores jurídicas, 1997.

Capella, Vicente Bellver, Ecología: de las razones a los derechos. Granada, Ecorama, 1994.

Comisión Interamericana de Derechos Humanos, lineamientos para la elaboración de indicadores de progreso en materia de derechos económicos, sociales y culturales, 2008.

Courtis, Christian, La prohibición de regresividad en materia de derechos sociales: apuntes introductorios, Ciudad Autónoma de Buenos Aires, Editores del Puerto, 2006.

Informe sobre la Prohibición de Regresividad en los Derechos Económicos, Sociales y Culturales de Colombia 2002-2008.

Informe A/HRC/25/53 del Experto Independiente de la Organización de las Naciones Unidas sobre la cuestión de las obligaciones de derechos humanos relacionadas con el disfrute de un medio ambiente sin riesgos, limpio, saludable y sostenible.

Informe A/HRC/25/53/Add.1 del Experto independiente sobre la cuestión de las obligaciones de derechos humanos relacionadas con el disfrute de un medio ambiente sin riesgos, limpio, saludable y sostenible. Adición Misión a Costa Rica.

Morato Leite, José Rubens y Ayala Araujo, Patryck, Daño Ambiental, Editora Dos Tribunais, Sao Paulo, 2014.

Peña Chacón, Mario, Test de Regresividad Ambiental, en Revista Internacional Direito Ambiental (RIDA), número 6, diciembre 2013, Brasil.

Peña Chacón, Mario, El Principio de no regresión ambiental en el derecho comparado latinoamericano, PNUD, 2013.

Sarlet, Ingo Wolfgang y Fensterseifer, Tiago, Direito Constitucional Ambiental, 4ta edición, Sao Paulo: Editora Dos Tribunais, 2014.

Sepúlveda, Magdalena, La interpretación del Comité de Derechos Económicos, Sociales y Culturales de las obligaciones derivadas de la expresión "progresivamente" contenida en el artículo 2.1 del Pacto Internacional de Derechos Económicos, Sociales y Culturales, en Ni un paso atrás, La prohibición de regresividad en materia de derechos sociales, Christian Courtis (Comp.), Buenos Aires, CEDAL - CELS, 2006.

Texeira, Orci, O direito ao ambiente ecologicamente equilibrado como direito fundamental, Porto Alegre, Livraria do Advogado, 2006. 



\title{
(IN)JUSTIFICACIONES CONSTITUCIONALES QUE HAN PERMITIDO REGRESIONES AMBIENTALES
}

\author{
Álvaro Sagot Rodríguez*
}

“... en la historia de los derechos humanos se pueden observar diversos momentos clave, tanto en su desarrollo como en su regresión, ya que la historia de los derechos casi siempre es la historia de la violaciones de los mismos; la historia de la promesas incumplidas"

Gregorio Mesa Cuadros

\section{Introducción}

El principio de no regresión en materia ambiental es aquel que genera un blindaje a nuestro Ordenamiento Jurídico para no permitir que se hagan nuevas normas, o interpretaciones de las mismas, que conlleven a tener retrocesos de los logros alcanzados en protección de la biodiversidad y derechos asociados a su tutela.

Este novedoso norte del moderno derecho al desarrollo sustentable implica en la práctica la imposición de una coraza protectora, por medio de la cual no se permite a los funcionarios públicos, o a los operadores de justicia, hacer más laxo el derecho que nos rige o hacer un cambio; salvo que se trate de situaciones que mejoren integral y sustancialmente los diques alcanzados.

Escribía hace un tiempo en un ensayo titulado: "El Principio de No Regresión en materia Ambiental. Análisis de dos casos de directrices transgresoras"1: "En la práctica profesional hemos visto como en Costa Rica, se ha tratado de violentar el principio que da título a este artículo en reiteradas situaciones. Normalmente las acciones directas proceden desde la Administración Pública... Pero en todas las ocasiones, se han interpuesto las respectivas acciones de inconstitucionalidad desde la sociedad civil y la Sala IV las ha encontrado con lugar, anulando esas modificaciones..." Lo anterior resulta importante comentarlo de nuevo, pues había elaborado en ese artículo una tesis, donde señalaba avances y alcances del principio de no regresión en Costa Rica, pero es menester que también hablemos, en este momento, sobre los aspectos grises u oscuros de nuestra jurisprudencia constitucional, donde los magistrados de ese máximo órgano jurisdiccional constitucional han cometido transgresiones, rompiendo con lo prefijado en la doctrina más aceptada en materia ambiental; e incluso, muchas veces separándose sin justificación de líneas claras que se venían siguiendo en sentencias anteriores, o peor aún, haciendo negativas interpretaciones del soft law imperante y reconocido tal y como veremos en el transcurso de este ensayo.

Se advierte a las y los lectores que tal y como lo elaboro, es claro que el tema será apenas enunciado y mi única aspiración es la de hacer una breve introducción a una problemática muy seria que está distorsionando logros alcanzados.

\footnotetext{
* Abogado, máster en Derecho Ambiental por la Universidad del País Vasco. Académico en Universidad Nacional de Costa Rica (UNA) en la Escuela de Ciencias Ambientales y en la maestría en Desarrollo Sostenible de la Universidad de Costa Rica (UCR). Profesor en Maestría de derecho ambiental del País Vasco, España. mailto:asagotr@racsa.co.cr

${ }^{1}$ Ver Sagot, A. 2013. El Principio de No Regresión en materia Ambiental. Análisis de dos casos de directrices transgresoras disponible en:

http://www.eldial.com.ar/nuevo/archivo-doctrina_nuevo.asp?base=50\&id=6582\&t=d y también dispone en: http://www.actualidadjuridicaambiental.com/?p=9262
} 


\section{La Sala constitucional y su jurisprudencia en Costa Rica}

La Sala Cuarta Constitucional nace en $1989^{2}$ y con ella inicia un nuevo ciclo del reclamo por violaciones a nuestro derecho constitucional y a los derechos humanos.

Si bien desde 1989 se reconocía el derecho a un ambiente sano y ecológicamente equilibrado desde un rango constitucional haciendo la integración del derecho a vida contemplado en el numeral $21^{3}$ y la protección del paisaje del artículo $89^{4}$, así como retomando convenciones internacionales ratificadas, o usando el soft law de la Declaración de Estocolmo y otros instrumentos más, no fue sino hasta que en 1994 tenemos en Costa Rica el numeral $50^{5}$ que hizo plasmar con mayor seguridad y garantía expresa nacional el derecho al desarrollo sustentable. Hay que observar, que si bien ese nominal 50 es de redacción limitada, ha servido para que los magistrados constitucionales dispongan que esa norma tiene contenido el derecho humano al agua en cantidad y calidad suficiente, el hacer ordenamiento territorial, el derecho al aire, la evitación de la contaminación, se reconoce además el principio precautorio, preventivo, el de progresividad, quien contamina paga y otros tantos más y hasta el moderno principio de no regresión ${ }^{6}$.

Por su parte tenemos, que conforme a la ley constitutiva la Sala Constitucional, en defensa del derecho a la biodiversidad, o derechos relacionados como los procesales ${ }^{7}$ se permite interponer recursos de amparo $^{8}$, acciones de inconstitucionalidad ${ }^{9}$, o consultas de constitucionalidad ${ }^{10}$.

\footnotetext{
${ }^{2}$ Ley No. 7135 de 11 de octubre de 1989.

${ }^{3}$ Artículo Constitucional 21: "La vida humana es inviolable"

4 Artículo Constitucional 89: "Entre los fines culturales de la República están: proteger las bellezas naturales, conservar y desarrollar el patrimonio histórico y artístico de la Nación, y apoyar la iniciativa privada para el progreso científico y artístico."

5 Artículo Constitucional 50: "Toda persona tiene derecho a un ambiente sano y ecológicamente equilibrado. Por ello está legitimada para denunciar los actos que infrinjan ese derecho y para reclamar la reparación del daño causado. El Estado garantizará, defenderá y preservará ese derecho. La ley determinará las responsabilidades y las sanciones correspondientes. "Norma reformada mediante Ley No. 7412 de 24 de mayo de 1994, publicada en La Gaceta No. 111 de 10 de junio de 1994.

${ }^{6}$ Voto 2013-10158 del 24 de julio de agosto de 2013 que dice en lo que interesa: "Un proyecto como el que se consulta contiene múltiples imprecisiones en su diseño normativo, comprobándose los argumentos que exponen los consultantes, referidos a: ... la falta de límites a la cantidad de concesiones a otorgar o al plazo de estas... la nula delimitación de las áreas que ameritan un trato especial ... inexistencia de un inventario claro de quienes resultarán ser los eventuales beneficiarios de la ley (la identificación de los beneficiarios, y su individualización), la determinación del impacto ambiental, entre muchas otras omisiones. Estas omisiones e imprecisiones confirman que al pretender hacer regular una situación irregular, se está haciendo en detrimento frontal de nuestro demanio público, pues ello implicaría una regresión en la zona marítimo terrestre y esa regresión deviene en inconstitucional."

${ }^{7}$ Tales como Intereses difusos, acción popular.

${ }^{8}$ Ley de la Jurisdicción Constitucional, artículo 29: "El recurso de amparo garantiza los derechos y libertades fundamentales a que se refiere esta Ley, salvo los protegidos por el de hábeas corpus. Procede el recurso contra toda disposición, acuerdo o resolución y, en general, contra toda acción, omisión o simple actuación material no fundada en un acto administrativo eficaz, de los servidores y órganos públicos, que haya violado, viole o amenace violar cualquiera de aquellos derechos. El amparo procederá no sólo contra los actos arbitrarios, sino también contra las actuaciones u omisiones fundadas en normas erróneamente interpretadas o indebidamente aplicadas."

${ }^{9}$ Ley de la Jurisdicción de Constitucional, artículo 73: "Cabrá la acción de inconstitucionalidad: a) Contra las leyes y otras disposiciones generales, incluso las originadas en actos de sujetos privados, que infrinjan, por acción u omisión, alguna norma o principio constitucional. b) Contra los actos subjetivos de las autoridades públicas, cuando infrinjan, por acción u omisión, alguna norma o principio constitucional, si no fueren susceptibles de los recursos de hábeas corpus o de amparo. c) Cuando en la formación de las leyes o acuerdos legislativos se viole algún requisito o trámite sustancial previsto en la Constitución o, en su caso, establecido en el Reglamento de Orden, Dirección y Disciplina Interior de la Asamblea Legislativa. ch) Cuando se apruebe una reforma constitucional con violación de normas constitucionales de procedimiento. d) Cuando alguna ley o disposición general infrinja el artículo 7º, párrafo primero, de la
} 
La misma normativa establece en el artículo 13 -que podría ser negativo y requerir modificación- que: "La jurisprudencia y los precedentes de la jurisdicción constitucional son vinculantes erga omnes, salvo para sí misma."

Es claro, que con esa norma, resulta que la Sala no tiene limitaciones en hacer modificaciones a sus interpretaciones anteriores. El punto peligroso se puede dar, cuando esas nuevas reinterpretaciones son negativas o transgreden el principio de no regresión, pues con ello nos abrimos a retrocesos odiosos en materia ambiental. La jurisprudencia constitucional señalaba allá en $1991^{11}$ que todo debería ir acorde con el principio de progresión, es decir superándonos,

Constitución, por oponerse a un tratado público o convenio internacional. e) Cuando en la suscripción, aprobación o ratificación de los convenios o tratados internacionales, o en su contenido o efectos se haya infringido una norma o principio constitucional o, en su caso, del Reglamento de Orden, Dirección y Disciplina Interior de la Asamblea Legislativa. En este evento, la declaratoria se hará solamente para los efectos de que se interpreten y apliquen en armonía con la Constitución o, si su contradicción con ella resultare insalvable, se ordene su desaplicación con efectos generales y se proceda a su denuncia."

${ }^{10}$ Artículo 96 de la Ley de la Jurisdicción Constitucional: "Por la vía de la consulta de constitucionalidad, la jurisdicción constitucional ejercerá la opinión consultiva previa sobre los proyectos legislativos, en los siguientes supuestos: a) Preceptivamente, cuando se trate de proyectos de reformas constitucionales, o de reformas a la presente Ley, así como de los tendientes a la aprobación de convenios o tratados internacionales, inclusive las reservas hechas o propuestas a unos u otros."

11 Han señalado los magistrados constitucionales: “... Es también tarea de la Sala Constitucional, en cuanto interprete supremo de la Carta Política, ir adecuando el texto constitucional conforme a las coordenadas de tiempo y espacio..." (Voto No 720-91 de las 15 horas del 16 de abril de 1991) En la misma línea han señalado más recientemente también: "En el marco del Estado Social y Democrático de Derecho, los Derechos Humanos de Segunda Generación -también denominados Derechos Económicos, Sociales y Culturales- tienen como objetivo fundamental garantizar el bienestar económico y el desarrollo del ser humano y de los pueblos. En sentido subjetivo, los derechos fundamentales prestacionales, demandan la actividad general estatal -en la medida de las posibilidades reales del país- para la satisfacción de las necesidades individuales o colectivas. Objetivamente, se configuran como mínimos vitales para los individuos por parte del Estado. En este particular, la satisfacción de esas necesidades supone crear las condiciones necesarias y el compromiso de lograr progresivamente su goce, lo que se encuentra condicionado a que se produzcan cambios profundos en la estructura socio- económica de un país. Respecto al disfrute de esas condiciones, el artículo 26 de la Convención Americana sobre Derechos Humanos, impone a los poderes públicos una obligación de cumplimiento progresivo, que incluye respeto, protección, garantía y promoción" (Voto No. 2007-1378 ). Ver también: "Nótese, adicionalmente, que a tenor del artículo 26 de la Convención Americana sobre Derechos Humanos (aprobada por la Ley No. 4534 del 23 de febrero de 1970), los Estados deben adoptar medidas internas para "(...) lograr progresivamente la plena efectividad de los derechos que se derivan de las normas económicas, sociales y sobre educación, ciencia y cultura (...)", razón por la cual los poderes públicos deben mantener en sus políticas de mejoramiento cuantitativo y cualitativo del sistema educacional una tónica que revele un ritmo progresivo o, por lo menos, sostenido y no adoptar políticas y realizar actuaciones que lejos de implicar un progreso supongan un retroceso" (Voto No. 2002-11515). También leer: "La Sala no soslaya que la existencia de normas internas sobre estos aspectos obedecen a razones clínicas o médicas de carácter general, pero es claro que su aplicación debe valorarse siempre de conformidad con las situaciones particulares, pues sujetarse a la mera o simple descripción normativa riñe tajantemente con una plena protección de los derechos fundamentales, donde las características de continuidad y progresividad imponen criterios de interpretación ágiles y versátiles alejados de dogmatismos jurídicos ampliamente superados”. (Voto No. 2011-13641). En protección a la biodiversidad recientemente externó la Sala Constitucional sobre la progresividad: "De tal forma, el principio precautorio encuentra aplicación en la medida que se carezca de certeza en cuanto al daño a producir y las medidas de mitigación o reparación que deben implementarse, pues al tenerse certeza sobre el tipo o magnitud del daño ambiental que puede producirse y de las medidas que deberán adoptarse en cada momento, se elimina todo sesgo de duda y, por consiguiente, resultaría impropio dar aplicación al principio precautorio. Dicho de otro modo, el principio precautorio debe ser aplicado en supuestos de duda razonable o incerteza, mas no cuando se tiene certeza del tipo de daño y de las medidas que deban adoptarse, ya que por su propia naturaleza resulta inviable la aplicación de este principio. Sin embargo, en el presente caso se echa de menos esta valoración. Ciertamente, cada concesión requerirá de previo un estudio de impacto ambiental evaluado por parte de SETENA, no obstante lo anterior, algunos de estos ecosistemas, por ejemplo las reservas marinas, son áreas que fueron protegidas precisamente con la intención de que en esta zona no se realice ninguna actividad extractiva y no se vea afectada tampoco, por ningún tipo de contaminación (escapes de motores, contaminaciones acústicas, contaminaciones luminosas, etc.), para que la flora y la fauna se vayan regenerando a lo largo del tiempo, hasta que sus poblaciones alcancen el mayor número de ejemplares que pueda haber en ese sitio; lo cual es totalmente excluyente con la 
pero ¿existe un recurso ulterior si se dieran retrocesos? Recordemos que la misma Ley de la Jurisdicción señala en el numeral $12^{12}$ que las sentencias de esta Sala sólo podrán ser adicionadas o aclaradas, es decir no existe una instancia o recurso ante superior que revise lo dispuesto por estos altos magistrados. $Y$ es con ello donde encontramos un problema muy serio que de hecho, como veremos más adelante, abre el paso a violaciones a derechos fundamentales cometidas por los mismos jueces que paradójicamente tienen como deber el garantizarlos. Ahora, si bien es cierto que existe la jurisdicción Contenciosa Administrativa para llevar a discutir lo que se hubiera rechazado por los magistrados constitucionales; este no es el punto delicado como se comprenderá.

\section{El principio preventivo y el precautorio en regresión}

\subsection{Lo preventivo}

Lo preventivo y lo precautorio son principios primigenios del derecho a un ambiente sustentable. Tratan de proteger la biodiversidad de los daños ambientales y son vitales a tener en cuenta siempre por todos los tomadores de decisiones indudablemente.

La doctrina y algunos juzgadores los confunden normalmente y los hacen sinónimos, aunque ello no debiera ser por precisión técnica, empero; para los fines de este artículo ${ }^{13}$ no se cambia la esencia del tema que es actuar proactiva y prudentemente.

El principio preventivo es uno de carácter general que trata de anticipar el daño para prevenir las causas de este. En esta línea, señala la doctrina argentina, con Goldenberg y Cafferatta (2001):

"... Pero la procedencia del remedio preventivo deviene incuestionablemente, cuando se trata de contrarrestar los efectos lesivos que ya ha comenzado a originar una determinada actividad, con el fin de paralizar el daño, deteniendo su desarrollo. Tiene por objeto el daño todavía no provocado, pero que podría posteriormente ser causado, si la actividad siguiera o actuando entonces después que el daño ha empezado a ocasionarse, para combatirlo obstaculizando su producción, atacándolo en su causa, en su raíz"

Para Santana Plata (2013) lo preventivo conlleva a:

“... conocer anticipadamente las consecuencias que una determinada actividad puede tener para el medio ambiente, considerada en una escala de tiempo que corresponde al mediano y largo plazo..."

concesión de una marina turística por los efectos que evidentemente lo alterarán. Otros ecosistemas de los citados puede ser que no requieran necesariamente una veda absoluta de toda actividad, pero cualquier autorización en ese sentido debe ser valorada y anticipada. Como ya se indicó, resulta irrazonable proteger unas zonas y otras no sin un criterio técnico que así lo sustente, pues ello resulta lesivo del principio precautorio y del principio de progresividad del ámbito de tutela de los derechos fundamentales..."(Voto No. 2010-18702).

12 Ley de la Jurisdicción Constitucional, artículo 12: "Las sentencias que dicte la Sala podrán ser aclaradas o adicionadas, a petición de parte, si se solicitare dentro de tercero día, y de oficio en cualquier tiempo, incluso en los procedimientos de ejecución, en la medida en que sea necesario para dar cabal cumplimiento al contenido del fallo."

${ }^{13}$ Sobre la discusión y diferenciación de los dos principios, se recomienda leer de mi persona la obra: "Aspectos Conceptuales y Jurisprudencia Constitucional Ambiental de los Principios Precautorio y Preventivo". Análisis conceptual sobre los principios y el tratamiento que les da la Sala" 
Según Santana Plata (2013):

"Su fundamento es el conocimiento anticipado del daño y de las medidas que podrían adoptarse para evitarlo..."

En Costa Rica sobre lo preventivo existen diversas normas, pero más puntualmente encontramos lo pertinente en la Ley Orgánica del Ambiente en el numeral 61 que señala:

"Contingencias ambientales. La autoridad competente dictará las medidas preventivas y correctivas necesarias cuando sucedan contingencias por contaminación ambiental..."

Y además tenemos el artículo 11 inciso 1 de la Ley de la Biodiversidad que dice:

"Criterio preventivo: Se reconoce que es de vital importancia anticipar, prevenir y atacar las causas de la pérdida de la biodiversidad o sus amenazas."

Nuestra jurisprudencia constitucional ha señalado:

"Se reclama además, por la inexistencia de una normativa que establezca los límites de sonido permitidos en los restaurantes, pues se alega que sólo existe para establecimientos industriales. Analizado este argumento, se tiene que entratándose de la salud, derecho fundamental de alta jerarquía constitucional, el Ministerio de Salud, es el órgano encargado de velar por aquél preciado derecho. De allí que, tomando en cuenta su amplia competencia, otorgada por la Ley General de Salud, para actuar directamente en caso de necesidad, no es indispensable la existencia de una norma expresa para el caso en cuestión, pues es una competencia implícita el recurrir a medios técnicos para comprobar si se cumple con una obligación como la de confinar el ruido. Véase que el Ministerio de Salud al determinar la existencia de contaminación sónica en el local denominado Bar Baco, ordenó la presentación de un plan de confinamiento de ruidos y en resolución 6454-95 de 23 de noviembre de 1995, le indicó con claridad a la empresa aquí accionante, el límite de cuarenta decibeles de ruido permitido en el local. Este límite fue aceptado por la empresa al no recurrir contra el mismo, por lo que aceptado dicho nivel máximo, el mismo se convirtió en norma aplicable para el caso en concreto, por vía de jurisprudencia administrativa". (Voto 3691-96)

Asimismo:

"El principio de protección del medio ambiente no es una recomendación o una intención que da la Constitución, sino que, por lo contrario, es un derecho de aplicación inmediata, por lo que existe una obligación por parte de los organismos gubernamentales de vigilar porque se cumplan las disposiciones legales que tiendan a proteger el medio ambiente...".(Voto 132-99)

También ha señalado:

"La Constitución Política establece que el Estado debe garantizar, defender y preservar el derecho a un ambiente sano. Prima facie, garantizar es asegurar y proteger el derecho contra algún riesgo o necesidad, defender es vedar, prohibir e impedir toda actividad, que atente contra el derecho y preservar, es una acción dirigida a poner a cubierto anticipadamente, el derecho de posibles peligros, a efecto de hacerlo perdurar para futuras generaciones. El Estado debe asumir un doble comportamiento de hacer y de no hacer, por un lado, debe abstenerse de atentar él mismo, contra el derecho a contar con un ambiente sano y ecológicamente equilibrado y por otro lado, debe asumir la tarea de dictar las medidas que permitan cumplir con los requerimientos constitucionales. En el presente caso, la Municipalidad recurrida con su omisión deja de cumplir con esa obligación constitucional, de esta forma, está 
violando el derecho de todos a un ambiente sano para su desarrollo y la normativa constitucional que ordena garantizar, defender y preservar ese derecho". (Voto 55372000)

Entonces, como se aprecia, existe una clara línea para aplicar lo preventivo sin lugar a dudas desde hace muchísimos años, incluso se utiliza como han señalado los altos magistrados en ausencia de norma, pues existe una obligación de rango constitucional de no generar daños ambientales.

\subsection{Lo precautorio}

Por su parte, lo precautorio es a nuestro criterio una especie de especialización de lo preventivo ante los casos de incertidumbre clara y manifiesta.

Históricamente se ha señalado que lo precautorio tiene sus orígenes en Alemania, especialmente desarrollado en la década del setenta (del siglo pasado) y deriva de la palabra vorsorgeprinzip, que significa anticipación, en el manejo ambiental, aún ante la ausencia de riesgos. (Walsh 2000)

En 1990, en la conferencia de Bergen, sobre Desarrollo Sustentable, se expuso: “... que es preferible estar más o menos acertado, pero a tiempo, dadas las graves consecuencias de una equivocación grande, que estar precisamente acertado, una vez que ya sea tarde" (Walsh, 2000) y con esto queda claro, con un lenguaje entendible para todo el público, lo que significa actuar precautoriamente.

Pero ¿cuál es el significado práctico de lo precautorio? Cabrera (1994) nos señala lo siguiente:

"El Indubio Pro Natura es la figura jurídica, según la cual en caso de duda, debe decidirse por aquello que sea más favorable a la conservación del ambiente. La aplicación práctica de este principio es cotidiana. Por ejemplo, procede su aplicación a la hora de decidir o conceder o no una autorización para realizar una determinada actividad, cuyo impacto sobre el ambiente es incierto."

Cabrera (1994) nos amplía el tema diciendo:

"De igual forma, las prácticas administrativas de ciertos entes públicos en otros países se basan en este principio: si existe incerteza sobre los resultados que la liberalización en el ambiente de una planta transgénica tendrá, o bien de los efectos tóxicos de un plaguicida, la decisión es prohibirlo, es decir, ante la duda (indubio) escoger a favor del ambiente. La forma de llamarse este criterio es lo de menos. Lo que debe hacerse es diferenciar claramente este caso, del llamado conflicto de intereses que tantos problemas ha dado a la Sala Constitucional. Según este, ante la presencia de intereses contradictorios, por ejemplo, la propiedad privada y la libertad de comercio, por un lado y por otro, la protección al ambiente, debe tratarse de escoger entre uno u otro de los valores en juego o intentar, si es posible compatibilizarlos. No obstante, este conflicto únicamente puede ser resuelto caso por caso, según las condiciones particulares de éste."

Goldenberg y Cafferatta (2001) señalan:

“... Un elemento central del principio precautorio es la idea, hasta intuitiva, de que todo decisor político debe actuar en forma anticipada, antes de contar con la certidumbre científica, con la finalidad de proteger al ambiente y por consiguiente los intereses de las generaciones futuras. El principio de precaución plantea, a su respecto, un presupuesto de incertidumbre, en relación al cual convendría estar particularmente atento, aunque sea mediante abstención." 
Artigas dice (2001):

"La aplicación del principio debe ser precedida de una evaluación científica tan completa como sea posible...El principio o enfoque precautorio supone que frente a una eventual obra o actividad con posibles impactos negativos en el medio ambiente, la decisión política que no da lugar a su realización, se base exclusivamente en indicios del posible daño sin necesidad de requerir la certeza cientifica absoluta..."

Santana Plata (2013) señala la certeza científica y lo precautorio:

"Se basa en la falta de certeza científica que en algunos casos puede ser absoluta y, en otros, dependiendo del mecanismo que lo consagre, puede ser solamente cuestionable."

Artigas (2001) siguiendo esa misma línea, nos refuerza el planteamiento al señalar:

"El principio o enfoque precautorio supone que frente a una eventual obra o actividad con posibles impactos negativos en el medio ambiente, la decisión política que no da lugar a su realización, se base exclusivamente en indicios del posible daño sin necesidad de requerir la certeza científica absoluta...".

En lo internacional, lo precautorio lo encontramos en diversos instrumentos internacionales. Nos establece el principio 15 de la Declaración de Río de 1992:

"Con el fin de proteger el medio, los Estados deberán aplicar ampliamente el criterio precautorio conforme a sus capacidades. Cuando haya peligro de daño grave irreversible, la falta de certeza científica absoluta no deberá utilizarse como razón para postergar la adopción de medidas eficaces en función de los costos para impedir la degradación del medio ambiente".

Como podemos leer de este texto, se nos deja claro, que lo perseguido por el sistema internacional, con la materia precautoria, no es otra cosa que entender que la duda -del tipo que sea- , debe interpretarse, a favor del ambiente y no de los empresarios, o el mismo Estado.

En lo internacional lo precautorio, cautelar, o indubio pro natura se reconoce desde el siglo pasado como decíamos. Entre otros instrumentos podemos citar la Primera y Segunda Conferencia Internacional sobre la protección del Mar del Norte de los años 1984 y 1987 respectivamente cuando señalaban: lo preventivo aplica "cuando haya razones para suponer que es probable que tales sustancias causen daño a los recursos vivientes en el mar, incluso si falta prueba científica de un nexo causal entre emisiones y efectos". También en el Protocolo de Montreal sobre sustancias que debilitan la capa de ozono se expuso en 1987: "Las partes que concurren a este Protocolo... han determinado proteger la capa de ozono con la adopción de medidas precautorias para controlar de manera equitativa las emisiones globales totales de sustancias que la debiliten, con el objetivo último de eliminarlas, utilizando el desarrollo del conocimiento científico...". Ya para 1990 en la Declaración final de la Tercera Conferencia Internacional sobre la Protección del Mar del Norte se dijo: "Los participantes... continuarán aplicando el principio de precaución, esto es, realizando acciones para impedir los impactos potencialmente dañinos de sustancias que son persistentes, tóxicas y susceptibles de bioacumularse, aún cuando no haya evidencia científica que pruebe un vínculo causal entre las emisiones y los efectos...". Asimismo, contamos también con lo señalado en la Convención marco sobre Cambio Climático de 1992 que expuso: "Las Partes deberían tomar medidas de precaución para prever, prevenir o reducir al mínimo las causas del cambio climático y mitigar sus efectos adversos. Cuando haya amenaza de daño grave o irreversible, no debería utilizarse la falta de total certidumbre científica como razón para posponer tales medidas, tomando en cuenta que las políticas y medidas para hacer frente al cambio climático deberían ser eficaces en función de los costos a fin de asegurar beneficios mundiales al menor costo posible. A tal fin, esas políticas y medidas deberían tener en cuenta los distintos contextos 
socioeconómicos, ser integrales, incluir todas las fuentes, sumideros y depósitos pertinentes de gases de efecto invernadero y abarcar todos los sectores económicos. Los esfuerzos para hacer frente al cambio climático pueden llevarse a cabo en cooperación entre las Partes interesadas."; o el Tratado de Maastricht (1992) y Ámsterdam (1994) mediante los cuales se constituye lo que hoy es la Unión Europea, que en el artículo 130.2 dijo: "La política de la Comunidad en el ámbito del medio ambiente tendrá como objetivo alcanzar un nivel de protección elevado, teniendo presente la biodiversidad de situaciones existentes en las diferentes regiones de la Comunidad. Se basará en los principios de precaución y de acción preventiva, en el principio de corrección de los atentados al medio ambiente preferiblemente en la fuente misma y en el principio de que quien contamina paga...".

Otro ejemplo de entre tantos, también lo tenemos en el Protocolo de Cartagena sobre Bioseguridad del año 2000, que en su artículo primero, señala:

"Objetivo. De conformidad con el enfoque de precaución que figura en el Principio 15 de la Declaración de Río sobre el Medio Ambiente y el Desarrollo, el objetivo del presente Protocolo es contribuir a garantizar un nivel adecuado de protección en la esfera de la transferencia, manipulación y utilización seguras de los organismos vivos modificados resultantes de la biotecnología moderna que puedan tener efectos adversos para la conservación y la utilización sostenible de la diversidad biológica, teniendo también en cuenta los riesgos para la salud humana, y centrándose concretamente en los movimientos transfronterizos."

Con base a lo anterior; es claro que ningún Estado podría alegar desconocimiento del sentido y alcances de lo precautorio sin lugar a dudas, pues este es un tema que se ha discutido mucho en diversas cumbres internacionales.

Por su parte lo precautorio emana también de varias normas nacionales como por ejemplo el numeral 17 de la Ley Orgánica del Ambiente que señala desde 1995:

"Las actividades humanas que alteren o destruyan elementos del ambiente o generen residuos, materiales tóxicos o peligrosos, requerirán una evaluación de impacto ambiental por parte de la SETENA. Su aprobación previa, de parte de este organismo, será requisito indispensable para iniciar las actividades, obras o proyectos...".

En la Ley de la Biodiversidad, 1998, en su artículo 11 reza:

"Son criterios para aplicar esta ley: ... 2.- Criterio precautorio o indubio pro natura: Cuando exista peligro o amenaza de daños graves o inminentes a los elementos de la biodiversidad y al conocimiento asociado con éstos, la ausencia de certeza científica no deberá utilizarse como razón para postergar la adopción de medidas eficaces de protección."

Nuestra Sala Constitucional ha dicho sobre lo precautorio:

“... El principio de protección del medio ambiente no es una recomendación o una intención que da la Constitución, sino que, por lo contrario, es un derecho de aplicación inmediata, por lo que existe una obligación por parte de los organismos gubernamentales de vigilar porque se cumplan las disposiciones legales que tiendan a proteger el medio ambiente..." (Voto 132-99)

Puntuando aún mejor; señaló sobre lo precautorio:

“... Para el caso de las aguas subterráneas... el principio precautorio, supone que cuando no existan estudios conforme a las regla unívocas de la ciencia ... que permitan arribar a un estado de certeza absoluta acerca de la inocuidad de la actividad que se pretende desarrollar, los órganos de la administración ... deben abstenerse de autorizar, aprobar o 
permitir toda solicitud nueva o de modificación, suspender las que estén en curso, hasta que se despeje el estado dubitativo...". (Voto 2004- 01923)

Para el 2005 exponían nuestros magistrados:

"La aprobación de un estudio de impacto ambiental requiere - de conformidad con los compromisos internacionales adquiridos por Costa Rica y encomendados a SETENA un análisis pormenorizado que incluya, como lo exige el artículo 24 de la Ley Orgánica del Ambiente, los criterios técnicos y los porcentajes de ponderación que hace posible la aprobación del estudio. Además, debe responder a las normas, los objetivos de ordenación y prioridades ambientales del Estado nacional y del gobierno local, tal y como lo recoge el principio 11 de la Declaración de Río. El daño que se pueda causar al ambiente siempre es de difícil o imposible reparación y la aprobación de un estudio de impacto ambiental requiere de la total certeza de mínima afectación de los recursos naturales, pues así lo dispone por fuerza propia el artículo 50 de la Carta Política...". (Voto 1174- 05)

Cerramos este aparte, citando un extracto que rescata todo lo anterior cuando los jueces constitucionales dispusieron:

"Es así, como hoy en día la acción preventiva del Estado debe ir encaminada a la tutela del medio ambiente, a pesar de que no existan pruebas concluyentes que reflejen una relación causa-efecto entre la actividad que se ejerce y las posibles consecuencias nocivas como resultado de la misma...". (Voto 1174- 05) (el resaltado es nuestro)

Es nuestro criterio, que con lo anterior se evidenciaría en principio para Costa Rica una sólida y clara concordancia entre lo dispuesto internacionalmente y lo nacional sobre lo preventivo y precautorio, pero como veremos en el siguiente aparte, pareciera que ello no es del todo cierto.

\subsection{Las regresiones en lo preventivo y lo precautorio en la jurisprudencia nacional relacionadas con campos electromagnéticos y torres de telefonía celular}

\subsubsection{Campos electromagnéticos}

Unos de los casos más llamativos sobre redacciones de votos constitucionales que conllevan a regresiones los hemos visto en las situaciones de la contaminación electromagnética, pues no obstante que estaban presentes claramente todos los elementos de la incertidumbre, contrario a aplicar lo reconocido, tanto internacionalmente, como en lo nacional en forma reiterada, nuestros magistrados dispusieron, que más bien ante este tipo de contaminación, si no existían estudios que fehacientemente la evidenciaran (aunque no la descartaron) y ante ello, todo debería inclinarse a favor de los empresarios proyectistas. Pareciera que para los altos operadores de justicia existe una excepción a la regla para cuando de contaminación electromagnética hablamos, lo cual censuramos y no justificamos desde ningún punto de vista, pues ni desde la doctrina, o las mismas ciencias físicas o naturales hemos encontrado razones para hacer diferencias, dado que la contaminación electromagnética es otro tipo más de contaminación y punto; por tanto, nada justifica rechazar -como línea jurisprudencial- todo lo relacionado con los campos electromagnéticos, mientras que han sido contundentes con la de los mantos acuíferos ${ }^{14}$ como supra.

\footnotetext{
14 “... Para el caso de las aguas subterráneas... el principio precautorio, supone que cuando no existan estudios conforme a las regla unívocas de la ciencia ... que permitan arribar a un estado de certeza absoluta acerca de la inocuidad de la actividad que se pretende desarrollar, los órganos de la administración ... deben abstenerse de autorizar, aprobar o permitir toda solicitud nueva o de modificación, suspender las que estén en curso, hasta que se despeje el estado dubitativo..." (voto 200401923)
} 
En todo caso ahora no vamos a entrar a analizar si la contaminación electromagnética es seria, o si al cabo de 10 o 20 años generará cáncer u otros problemas a la salud, o sí la misma simplemente es una sacada a la luz pública por ambientalistas para socavar las bases de un supuesto "desarrollo", puesto que ello no es el tema de este artículo . Lo que sí debemos aportar es que consideramos, que contrario a avocarse a defender las tesis aceptadas tanto doctrinalmente, como a nivel internacional por diversos instrumentos sobre lo precautorio, los altos jueces; motivados por extrañas intenciones que podrían ser más políticas ${ }^{15}$ que jurídicas, vinieron a invertir lo deseado y esperado por un sistema que se supone defensor de los derechos humanos, que no era otra cosa, que tener claro que ante la duda, o falta de estudios sobre contaminación electromagnética, la menor incerteza debía inclinarse por no aprobar el permiso solicitado.

Expusieron nuestros magistrados constitucionales lo siguiente, lo cual cito a modo por ejemplo:

"Por último, apunta la promovente que "...la contaminación magnética que produciría en su propiedad la instalación del tendido de alta tensión, tal cual se ha definido en este momento, sería de tal grado que se haría inutilizable el inmueble por su parte..", con el consecuente daño al ambiente y la salud pública. Sobre este tema, esta Sala, en las sentencias 3267-95, 3268-95 y 3334-95, entre otras, ha dispuesto lo siguiente: "...PRIMERO.- HECHOS PROBADOS.- Como tales se tienen los siguientes: A) varios profesionales en medicina elaboraron lo que llamaron "Dictamen Médico" de los efectos de los cables de alta tensión en donde se analizan publicaciones extranjeras al efecto (folio 13); B) copias de las escrituras mediante las cuales se establecieron servidumbres de paso de los tendidos eléctricos corren a partir del folio 72 del expediente; C) un estudio del Ingeniero Hernán Robles respecto del tema que nos ocupa aparece a folio 102. SEGUNDO.- Ciertamente, la constitución de las servidumbres de paso del tendido eléctrico del proyecto Arenal-Ciudad Quesada, que se demostró recaen sobre algunas de las propiedades de los que ahora reclaman en amparo, lógicamente descalifican la promoción del recurso que nos ocupa, pues en su momento los propietarios fueron debidamente indemnizados por las molestias que el proyecto ocasionaría. Además, como se informa bajo la fe de juramento, al iniciarse el proyecto no existían casas en los lugares como Cedral de Cuidad Quesada, lo cual también se puede inferir de las fotografías que corren a partir del folio 116 del expediente, que demuestran la reciente construcción de la mayoría de edificaciones que en ellas se estampa. TERCERO.- Lo impugnado no es contra un acto administrativo en concreto, sino por los posibles efectos tanto para la salud como al ambiente que el proyecto pueda ocasionar, pero se debe tomar en cuenta que los trabajos realizados están fundados en el ejercicio del servicio público que presta la Institución accionada; y por otra parte, no se ha probado fehacientemente que las

\footnotetext{
${ }^{15}$ Señala Embid Tello (2009): “... Es posible hablar de dos tipos de peligros que la radiación genera. Los primeros provienen del calentamiento de los tejidos vivos (efectos térmicos), se hallan completamente estudiados y no plantean ningún tipo de duda científica. Los segundos, más diversos, englobados bajo el concepto de efectos no térmicos, se revelan fundamentalmente a través de una sintomática observada en la población sometida a radiación en el marco de estudios epidemiológicos o a través de otro tipo de estudios in vitro o con animales, pero el mecanismo causal que relaciona la radiación con dichos síntomas se resiste a ser determinado científicamente, existiendo múltiples hipótesis explicativas... esta situación se ha intentado evitar mediante la asignación a los comités científicos o a diversas instituciones científicas de un papel fundamental en la evaluación del riesgo, lo que en el sector de la radiación no ionizante se traduce en la asignación de un poder casi absoluto de evaluación de los hechos a la Organización Mundial de la Salud (OMS) y a la Comisión Internacional para la protección frente a la radiación no ionizante (ICNIRP), instancias que no recomiendan un enfoque precautorio y que en sus recomendaciones hasta el día de hoy ha coincidido siempre con las pretensiones de los sectores industriales afectados, que no desean que la radiación pueda ser vista como peligrosa por la sociedad. Los Comités científicos de la Unión Europea y la mayoría de organismos científicos designados por los Estados miembros con la finalidad de evaluar el riesgo de la radiación no ionizante han calcado sus informes de las mencionadas instituciones internacionales... la OMS es una organización internacional de Estados y, por lo tanto, sus decisiones se basan más en razones políticas que en científicas."
} 
afectaciones alegadas se hayan dado anteriormente en el país, pues el Instituto Costarricense de Electricidad, bajo la fe de juramento, ha indicado en su informe que ha utilizado este sistema de tendido eléctrico de alta tensión y baja frecuencia desde hace 36 años sin conocer efectos negativos. Sobre el punto, las publicaciones extranjeras que han sido analizados por los profesionales en ciencias médicas que aparecen en los autos, no necesariamente coinciden con hechos acaecidos en nuestro país, pues las circunstancias, lugar y otros factores pueden variar en nuestro medio de casos ocurridos en otros lugares del planeta. Sin que lo resuelto en este recurso cierre la discusión respecto de los efectos ocasionados por campos electromagnéticos, lo cual deberá dilucidarse en su momento oportuno, por lo pronto, a falta de pruebas contundentes de perjuicio o amenaza evidente, que debiliten la posición del instituto recurrido, lo procedente es declarar sin lugar el recurso..." (sentencia 3267-95 de las nueve horas seis minutos del veintitrés de junio de mil novecientos noventa y cinco). De la sentencia transcrita, en punto a la contaminación magnética aludida, se desprende que no se ha logrado demostrar -en los últimos años-, en forma fehaciente, que las líneas de alta tensión que coloca la Institución recurrida, en el desarrollo de los proyectos que le ha encomendado la ley, produzca los efectos que acusa ahora también la promovente, sobre el ambiente o la salud pública, efectos respecto a los cuáles ella tampoco aporta ningún elemento de convicción que los acredite, o al menos, que logre desvirtuar o descalificar los informes rendidos ante esta Sala por el Instituto recurrido, en los diferentes recursos que, sobre este tema, se han presentado. En consecuencia, como no existe ningún elemento que le permita a esta Sala modificar el criterio que sobre el particular ha sostenido, el amparo, en cuanto a este extremo, resulta improcedente, como en efecto se dispone." (voto 7864-97) (el resaltado es nuestro)

Es decir, con ello vemos una clara reiteración de transgresiones a lo precautorio y por ende a la no regresión cuando de contaminación electromagnética se trata, desde 1995 a 1997.

Cuando en la Declaración de ministerial de Bergen sobre desarrollo sustentable de 1990 se dijo que "... la falta de certidumbre científica total no debe usarse como razón para posponer medidas destinadas a prevenir el deterioro ambiental..." pensaban precisamente en casos como en el que nuestros magistrados tenían que decidir, pero como vimos, operó todo lo contrario en Costa Rica. La misma Artigas (2001) nos había señalado sobre lo precautorio como vimos supra- que más bien con solo tener indicios ya era aplicable y razonable el utilizar una medida que detuviera todo el proyecto, pero los juzgadores, en manifiesta y abierta regresión dejaron para nuestra historia judicial la frase célebre de que: "Sobre el punto, las publicaciones extranjeras que han sido analizados por los profesionales en ciencias médicas que aparecen en los autos, no necesariamente coinciden con hechos acaecidos en nuestro país, pues las circunstancias, lugar y otros factores pueden variar en nuestro medio de casos ocurridos en otros lugares del planeta. Sin que lo resuelto en este recurso cierre la discusión respecto de los efectos ocasionados por campos electromagnéticos, lo cual deberá dilucidarse en su momento oportuno, por lo pronto, a falta de pruebas contundentes de perjuicio o amenaza evidente, que debiliten la posición del instituto recurrido, lo procedente es declarar sin lugar el recurso..."

Contextualizando el escenario sobre el cual resolvieron los magistrados en 1997 el voto citado, recordemos que en este caso la decisión era aprobar o no un proyecto que traía el impulso y presión del Poder Ejecutivo para que la transnacional, líder de las computadoras, INTEL ${ }^{16}$, se instalara en nuestro país y consideramos que como un primer atisbo político y no jurídico, ello pudo ser una razón que (mal) motivó a reiterar lo ya resuelto en años anteriores en otras sentencias relacionados con la contaminación electromagnética. Creemos que los altos

${ }^{16}$ Intel Corporation es el mayor fabricante de circuitos integrados del mundo, tal y como se señala en Wikipedia, ver: https://es.wikipedia.org/wiki/Intel_Corporation (Consultado 10 de agosto 2015). 
jueces, al menos debieron de haber aplicado en 1997 el principio de progresividad, modificando y redimiendo erradas posiciones del pasado, pero lastimosamente se volvió a negar la aplicación del principio indubio pro natura. El meollo del asunto es que no sólo se perdió la oportunidad de modificar para bien, sino que continuamos acentuando un retroceso abiertamente, con una redacción totalmente errada.

\subsubsection{Torres de telefonía celular}

Otro caso interesante -y podríamos hablar que relacionado con lo anterior- es lo ocurrido con las torres de telefonía celular (TTC) que igualmente tienen campos electromagnéticos, que conforme a estudios realizados internacionalmente señalan alteraciones a la salud humana ${ }^{17}{ }^{18}$, pero reiteramos que sobre esos aspectos no ahondaremos acá.

Recordemos que en razón de la apertura telefónica, luego de la firma del Tratado de Libre Comercio entre República Dominicana, Centro América y Estados Unidos ${ }^{19}$ se permite la entrada de transnacionales a competir por el servicio telefónico nacional, sobre todo el móvil. Lo anterior dispara la necesidad de construir TTC en toda la Nación, conllevando lo anterior a tener que regular ambientalmente la instalación de las mismas, aspecto que genera dos directrices ${ }^{20}$ desde la Secretaría Técnica Nacional Ambiental ${ }^{21}$ (SETENA).

Con lo anterior, muchas empresas se dieron a la tarea de hacer la "siembra" de estas estructuras, donde según datos oficiales de SETENA su construcción era pujante llegando en el 2009 a varios miles ${ }^{22}$ de ellas.

Todo lo mencionado conllevó a que se presentara una acción de inconstitucionalidad contra las directrices, alegándose que la normativa que las permitía tenía serios roces con el derecho a un ambiente sano y ecológicamente equilibrado, que se afectaba la salud y el paisaje, amén del principio precautorio y por ende el de no regresión, puesto que se consideró que las normas patrias exigían que solo vía estudios de impacto ambiental integrales previos se podrían aprobar las construcciones respectivas y que lo elaborado por SETENA era un absurdo jurídico/ambiental, puesto que no les pedía a las compañías torreras requisitos serios para dar los permisos y más bien todo se había convertido, - repito, vía directrices- en una posibilidad de

\footnotetext{
17 Ver sobre investigaciones y estudios de los campos electromagnéticos en: http://www.contaminacionelectromagnetica.org/investigacion.htm

18 Para mayor abundamiento sobre la contaminación electromagnética ver información en: http://www.gigahertz.es/noticias_electrosensibles.html

${ }^{19}$ Ley $N^{\circ} 8622$

20 Resolución № 0123-2010-SETENA del Ministerio de Ambiente Energía y Telecomunicaciones y la
} Secretaría Técnica Nacional Ambiental, que es resolución de las 08 horas 00 minutos del 20 de enero del 2010, acuerdo de Comisión Plenaria, modificación de la resolución № 02031-2009-SETENA (instalación de torres de telecomunicaciones para el sistema móvil avanzado 3G (SMA-SG) y 2- Resolución № 02031-2009-SETENA del Ministerio de Ambiente Energía y Telecomunicaciones y la Secretaría Técnica Nacional Ambiental, de las 09 horas 00 minutos del 26 de agosto del 2009. Acuerdo de Comisión Plenaria, para la instalación de torres de telecomunicaciones para el sistema móvil avanzado 3G (SMA$\mathrm{SG})$

${ }^{21}$ Señala la Ley Orgánica del Ambiente: "Las actividades humanas que alteren o destruyan elementos del ambiente o generen residuos, materiales tóxicos o peligrosos, requerirán una evaluación de impacto ambiental por parte de la Secretaría Técnica Nacional Ambiental creada en esta ley..."

22 Javier Córdoba, en Semanario Universidad señaló en el 2009: "Ante la cercanía de la apertura en el mercado de telecomunicaciones, ya suman cientos las solicitudes aprobadas por la SETENA, que solo de enero a finales de abril, alcanzan las 800. Al 26 de abril pasado, SETENA había aprobado 808 construcciones de torres, las cuales en su mayoría pertenecen a la empresa Compañía Las Torres, a las que se suman las otorgadas a Costa Pacífico Torres Ltda, Altavista Towers y Costa Pacífico Operaciones; además del Instituto Costarricense de Electricidad. Astorga y Llamado Urgente estiman que con la apertura del sector, cerca de 3000 torres nuevas se instalarán en el país, 2000 de ellas en la Gran Área Metropolitana, por ser el lugar de mayor concentración de población..." 
considerar las viabilidades ${ }^{23}$ como unos documentos de mero trámite, antes que verdaderas licencias que emite la Administración competente, donde previamente se analizaran todos los factores sociales y de la biodiversidad necesarios que demuestren que no se está ante riesgos y afectaciones al paisaje, la salud y que incluso garantizaran una participación ciudadana efectiva y oportuna en la formación de esas conductas administrativas.

Se expuso en la acción de inconstitucionalidad:

“... considero que la inconstitucionalidad de los actos relacionados radica en que ambos establecen modificaciones a normativa ambiental de rango superior, sin existir la POTESTAD constitucional para ello. Explicando lo anterior tenemos que tomar en cuenta que LEY DE LA AUTORIDAD REGULADORA DE LOS SERVICIOS PÚBLICOS en sU artículo 16 señala:"Estudio del impacto ambiental: Para autorizar la explotación de un servicio público, a juicio del Ministerio del Ambiente y Energía o por ley expresa, es requisito indispensable presentar, ante el ente encargado de otorgarla, un estudio de impacto ambiental, aprobado por ese Ministerio. El costo del estudio correrá por cuenta del interesado. El estudio del impacto ambiental deberá incluir una declaración jurada, suscrita por los solicitantes y los autores, de que la información suministrada y la evaluación son ciertas. La resolución emitida por el Ministerio del Ambiente y Energía, sobre la evaluación ambiental, será vinculante para el ente encargado de otorgar la concesión o el permiso."

Por su parte la misma Ley General de Telecomunicaciones señala:

ARTíCULO 3.- "Principios rectores: ... k) Sostenibilidad ambiental: armonización del uso y la explotación de las redes y la prestación de los servicios de telecomunicaciones, con la garantía constitucional de contar con un ambiente sano y ecológicamente equilibrado. Los operadores y proveedores deberán cumplir toda la legislación ambiental que les resulte aplicable".

En contraste con el texto legal citado, en la Resolución № 02031-2009-SETENA se señala en sus "considerandos" que partiendo de que el impacto de una torre, o también llamada de una radio base, será de "baja significancia" o que dado que el área de infraestructura de una torre es pequeña, o que como no se generan aguas residuales, se justifica que la valoración del impacto se haga vía la metodología de un instrumento D2. (ver el "por tanto" PRIMERO)

Se destaca en su "por tanto" SEGUNDO de esa resolución № 02031-2009-SETENA, que solo en los proyectos de torres o radio bases o antenas de telefonía celular que se ubiquen en área frágiles ambientalmente serán valoradas conforme a un D1, a efecto de llevar a cabo una evaluación profunda.

Por su parte, en la resolución № 0123-2010-SETENA se ratifica la resolución anterior y se señala que toda valoración de este tipo de proyectos, no será vía estudio de impacto ambiental o un D1 por su baja significancia ambiental... Pero ello es absolutamente violatorio a aspectos incluso constitucionales, al principio precautorio, al principio de discrecionalidad, al de proporcionalidad y al de razonabilidad y amerita que se acoja esta acción... Tengamos presente que el Decreto Ejecutivo Número 31849-MINAE-SALUD-MOPT-MAG-MEIC, que es el Reglamento General sobre los procedimientos de Evaluación de Impacto Ambiental (EIA), del 28 de junio del 2004 señala que los proyectos que tienen que cumplir con el trámite de permisos ambientales pertenecen a dos grupos, los del Anexo 1 y los del Anexo 2.

\footnotetext{
${ }^{23}$ En el Reglamento General de Procedimientos de Evaluación (EIA) de SETENA, se define la viabilidad ambiental de la siguiente manera: "Viabilidad (Licencia) Ambiental (VLA): Representa la condición de armonización o de equilibrio aceptable, desde el punto de vista de carga ambiental, entre el desarrollo y ejecución de una actividad, obra o proyecto y sus impactos ambientales potenciales, y el ambiente del espacio geográfico donde se desea implementar. Desde el punto de vista administrativo y jurídico, corresponde al acto en que se aprueba el proceso de Evaluación de Impacto Ambiental, ya sea en su fase de Evaluación Ambiental Inicial, o de Estudio de Impacto Ambiental o de otro documento de EIA."
} 
Los del Anexo 1 son aquellos para los cuales existe una ley específica que ordena la realización de un estudio de impacto ambiental.

El artículo que se cita a continuación (de ese reglamento), dice:

Sección I - A Categorización, clasificación y calificación de actividades, obras o
proyectos

Artículo $4^{\circ}$. - Actividades, obras o proyectos sujetos a la EIA.

Las actividades, obras o proyectos nuevos, que están sujetos a trámite de obtención de viabilidad (licencia) ambiental ante la SETENA, según el artículo 17 de la Ley Orgánica del Ambiente, se dividen en: Aquellas actividades, obras o proyectos para los cuales existe una ley específica que ordena el cumplimiento del trámite. El Anexo No. 1, que forma parte integral de este reglamento, enumera estas actividades, obras o proyectos.

El artículo 28 del Reglamento General de EIA explica el procedimiento que deben cumplir las actividades, obras o proyecto del Anexo 1 señalando lo siguiente:

"Artículo 28․ - Requisitos para los proyectos de la Lista del Anexo No. 1.

Aquellas actividades, obras o proyectos para los cuales existe una ley específica que ordena la elaboración y aprobación de un Estudio de Impacto Ambiental, podrán cumplir alternativamente cualquiera de los siguientes dos procedimientos:

Cumplimiento del trámite de Evaluación Ambiental Inicial, presentando a la SETENA el Documento de Evaluación Ambiental (D1) con el fin de obtener la viabilidad ambiental potencial y los términos de referencia para la elaboración del EsIA.

Presentación a la SETENA, de forma directa, bajo su responsabilidad, de un Estudio de Impacto Ambiental, elaborado en concordancia con las guías ambientales que la SETENA pondrá a su disposición en el Manual de EIA y de conformidad con lo establecido en el Capítulo III del presente reglamento. En este último caso, la actividad, obra o proyecto no gozará de una viabilidad ambiental potencial, hasta tanto la SETENA así lo indique en la resolución administrativa sobre el EsIA..."

Se agregó en el escrito de interposición de la acción de inconstitucionalidad:

“...El suscrito considera que la intención de los funcionarios de SETENA, al poner en vigencia ambas resoluciones administrativas fue la de facilitar la instalación de radio bases o torres de telefonía mediante el debilitamiento y reducción de los requisitos ambientales (umbrales de protección) contemplados expresamente en el Reglamento de Procedimientos de SETENA y las leyes de la Autoridad Reguladora de Servicios Públicos y la Ley General de Telecomunicaciones, con el único fin; de promover la inversión extranjera en telefonía celular. A todas luces se estaría violentando de no declararse la inconstitucionalidad de esos actos, el principio de regresión y su contraparte, el principio de progresividad en materia ambiental..."

Es decir, como se aprecia, era groseramente manifiesta la inconstitucionalidad al pretender "rebajarse" vía directriz, una disposición legal que exigía un estudio de impacto ambiental (EsIA) integral (o conocido con el término D1) y por tanto; ello generaba una regresión; es decir, se argumentó que por simples disposiciones administrativas se pasó a hacer más laxa la exigencia de un EsIA, que a la postre permitiría la proliferación masiva de TTC.

Nuestros magistrados constitucionales, analizando los anteriores argumentos dispusieron en voto № 2012-014111, resolución de las dieciséis horas y cero minutos del nueve de octubre del dos mil doce lo siguiente:

"El accionante fundamenta la acción en lo dispuesto por el artículo 16 de la Ley de la Autoridad Reguladora de los Servicios Públicos, normativa que remite a los servicios 
públicos a un estudio de impacto ambiental, cuando lo exija una ley o así lo disponga la SETENA. De igual manera, en el inciso k) de la Ley General de Telecomunicaciones, que contiene entre los principios rectores de la ley, la sostenibilidad ambiental. Para analizar la petición deducida en el expediente, es necesario que esta Sala determine el alcance del numeral 16 de la Ley de la Autoridad Reguladora de los Servicios Públicos, en el ámbito de las regulaciones de las Telecomunicaciones (Ley General de Telecomunicaciones, Ley No. 8642 y Ley de Fortalecimiento y Modernización de las entidades del sector de Telecomunicaciones, Ley No. 8660), lo cual ya ha sido definido por esta Sala Constitucional, y a pesar de que el accionante no advierte de las reformas legales que afectaron ésta y otras disposiciones, las que permiten deducir que la actividad de telecomunicaciones no se puede reputar más como un servicio público. Precisamente se desestima este argumento, toda vez que este punto fue discutido en la jurisdicción preventiva de constitucionalidad, cuando la Sala conoció de la consulta al proyecto legislativo de la Ley General de Telecomunicaciones, la que se evacuó mediante la sentencia No. 2008-004569, y estableció entre otras cosas que: "En lo tocante a la falta de caracterización de las telecomunicaciones como un servicio público, es preciso señalar que la publicatio, esto es, la asunción de la titularidad pública de un servicio público para ser prestado o gestionado directa o indirectamente por una administración pública, es una cuestión que se encuentra reservada a la libertad de conformación o configuración del legislador ordinario, de modo que es una cuestión de oportunidad y conveniencia legislativa calificar una actividad o no como servicio público o de interés público o general -salvo que la propia Constitución lo haga, tanto que, tradicionalmente, la doctrina afirma que esa declaración es reserva de ley." En consecuencia, de lo dicho, no se trata de un servicio público que deba someterse a lo dispuesto por el artículo 16 de la Ley de la Autoridad Reguladora de los Servicios Públicos..."

Ahora, de una simple lectura encontramos el primer error que conlleva a la transgresión del principio de no regresión, pues los señores magistrados con lo supra expuesto escudan su razonamiento, para debilitar los estándares ambientales alcanzados, con el simplista argumento de que las telecomunicaciones no pueden ser catalogadas como un "servicio público" y por esto según ellos, no existía exigencia legal de hacer un serio EsIA, dejando de lado el peso que conlleva la defensa a un derecho humano, sobre una posición formalista como la utilizada. Recordemos que esa misma Sala ha catalogado que la defensa de un ambiente sano y equilibrado conlleva a la garantía y primacía de los derechos fundamentales.

Con relación a lo indicado, por ejemplo:

"La Sala Constitucional ha indicado, en reiterada jurisprudencia, que la Constitución Política y los Instrumentos Internacionales suscritos por Costa Rica, reconocen el derecho de los habitantes de la República a disfrutar del derecho a la salud y de un ambiente sano y ecológicamente equilibrado (art 21,50, 73, y 89 de la Carta Magna). En este sentido este tribunal en sentencia No. 3705-93 de las 15 horas del 30 de julio de 1993 indicó: "... La calidad ambiental es un parámetro de esa calidad de vida; otros parámetros no menos importantes son salud, alimentación, trabajo, vivienda, educación, etc., pero más importante que ello es entender que si bien el hombre tiene derecho de hacer uso del ambiente para su propio desarrollo, también tiene el deber el protegerlo y preservarlo para el uso de generaciones presentes y futuras, lo cual no es tan novedoso, porque no es más que la traducción a esta materia del principio de "lesión", ya consolidado en el derecho común, en virtud del cual el legítimo ejercicio de un derecho tiene dos límites esenciales. Por un lado, los iguales derechos de los demás y por el otro el ejercicio racional y del disfrute útil del derecho mismo..." De aquí se extrae una directriz mínima, según la cual el Estado costarricense debe velar por la salud pública y la protección del ambiente. Ello implica no sólo que se deben tomar las 
medidas necesarias para impedir que se atente contra ellos, sino también que se debe adoptar medidas que los refuercen..." (Voto 2473 - 04)

También los magistrados continuaron haciendo una regresión ambiental más acentuada; cuando en ese voto № 2012-014111 dijeron:

"Si la tramitación de un Estudio de Impacto Ambiental para la colocación de las radio bases carece de una expresa remisión legal, entonces es lógico conforme al mencionado artículo 16, como segundo argumento, que el mecanismo para determinar el impacto ambiental queda en el criterio de la SETENA. En este sentido, lo que impugna el accionante es una decisión discrecional de la Administración Pública, porque lo que se quiere combatir es un acto administrativo ayuno de requisitos, los que, a juicio del interesado, la SETENA debe exigir criterios técnicos más rigurosos. En este sentido, lo pretendido en el escrito de interposición de la acción es que esta Sala declare que se carece de criterios técnicos y científicos que permitan entender que la decisión del órgano, es errónea, inviable e insuficiente para tutelar el medio ambiente, por lo que lo resuelto por la SETENA no está suficientemente sustentado, y que esa circunstancia permite concluir que las resoluciones impugnadas, desde el punto de vista técnico y científico, son improcedentes por tratarse de actividades de alto riesgo ambiental. El examen de constitucionalidad, en estos términos, no se puede residenciar aquí, pues más allá de la posibilidad de atacar ciertas resoluciones con carácter general en esta jurisdicción, es lo cierto que para arribar a la conclusión que se pide, este Tribunal debe valorar si se trata de una actividad de alto, moderado o bajo riesgo ambiental, lo que requiere de otro tipo de análisis, además de los elementos de la discrecionalidad del acto, que sugiere el informe del Secretario General de la SETENA y la Procuraduría General de la República. Esto nos lleva a un problema de legalidad que debe dirimirse en la vía administrativa o en un proceso judicial en que medie la discusión de estos criterios, donde haya o no pruebas directas de las afirmaciones del accionante, con peritajes, evaluaciones científicas plausibles por la comunidad científica, entre otros. Como es evidente, la evaluación de la especificación, lista o detalle de requisitos técnicos como una exigencia que garantice la protección del medio ambiente, no es un tema que debe dirimirse en esta jurisdicción..."

Al decirse que la Sala Constitucional no encontraba ninguna inconstitucionalidad porque no hay norma expresa que obligue a hacer una EsIA, dado que no se habla de un servicio público, descartan una obligación legal cuando sí la hay, pero peor aún, ellos desechan y plantean con ello un retroceso al resolver que; como jueces constitucionales no pueden anular por inconstitucional una directriz administrativa que evidentemente roza con el derecho previsto en nuestra norma máxima del artículo 50 de la Carta Fundamental que dice que se debe garantizar, defender y preservar el derecho a un ambiente sano; es decir, que al parecer los altos jueces olvidan sus responsabilidades y le dan primacía a la discrecionalidad de la Administración, por sobre lo previsto en instrumentos internacionales y la misma Constitución Política. Consecuentemente, para los jueces es correcto pensar que la discrecionalidad administrativa debe desplazar un derecho constitucional.

Y conforme a lo anterior, para ellos en este caso, la obligación constitucional de proteger el ambiente debe pasar de lado. Y entonces, como se aprecia, los operadores de justicia constitucional entran a exponer -con un argumento ultra regresivo-, que cualquier otra decisión está en el orden de las potestades de SETENA, olvidando que ellos han señalado que la discrecionalidad de la Administración no puede sobrepasar los derechos constitucionales, donde precisamente estos juzgadores son los llamados a hacer valoraciones y contrastes de las normas y las actuaciones administrativas. Por sobre todo a nuestro criterio, olvidan ellos también el principio de progresividad, pues en este caso nunca se justificó el por qué no era necesario hacer una valoración integral ambiental. Señalaron los magistrados que ellos no 
podían entrar a conocer o ponderar si algo es de alto, o mediano, o bajo riesgo, puesto que eso le corresponde a la jurisdicción de los Tribunales Contencioso Administrativo, pero ese argumento no concuerda con lo resuelto en reiterados votos constitucionales, donde estos mismos señores y señoras fueron a la médula del asunto, sin evadir las garantías fundamentales y manifestaron:

"El daño que se pueda causar al ambiente siempre es de difícil o imposible reparación y la aprobación de un estudio de impacto ambiental requiere de la total certeza de mínima afectación de los recursos naturales, pues así lo dispone por fuerza propia el artículo 50 de la Carta Política... La aprobación de un estudio de impacto ambiental requiere - de conformidad con los compromisos internacionales adquiridos por Costa Rica y encomendados a SETENA - un análisis pormenorizado que incluya, como lo exige el artículo 24 de la Ley Orgánica del Ambiente, los criterios técnicos y los porcentajes de ponderación que hace posible la aprobación del estudio..." (Voto 117405) (el resaltado es nuestro)

O bien:

"...el Estudio de Impacto Ambiental previo constituye el instrumento técnico idóneo para cumplir el principio precautorio que rige la materia ambiental, razón por la cual, prescindir de él implica omitir la prevención debida tratándose de la intervención humana en el medio..." (Voto: 6322-03)

Por otro lado, interesante es este voto que presentamos a continuación, pues los altos jueces aclararon que el deber de pronunciarse sobre aspectos como los acá discutidos eran obligatorios para ellos por lo dispuesto en la norma 50 de la Constitución Política. Además, si leemos infine observamos que los magistrados ya hasta han expuesto -lo mismo que la Contraloría General de la República- que la SETENA no es una oficina de confianza. Externaron propiamente:

"V.- En cuanto al caso concreto, no corresponde a este Tribunal evaluar técnicamente el impacto ambiental de la actividad de extracción de hidrocarburos: el recurso de amparo no es una vía plena que tenga a disposición los medios probatorios necesarios para tal cometido. Sin embargo, el artículo 50 de la Constitución Política, tal como se señaló, ordena al Estado que garantice el derecho a un ambiente sano. Tal obligación implica que el Estado debe tomar todas las medidas técnicas posibles para asegurarse de que la actividad que aprueba no causará daños al ambiente. Si bien el pronunciamiento del órgano estatal encargado es en sí un asunto técnico, el deber de pronunciarse y la exigencia de rigurosidad es un asunto jurídico... La Constitución no exige solo cumplir con ciertas formalidades, sino utilizar como se dijo todos los medios jurídica y fácticamente posibles para preservar el ambiente... Es decir, en SETENA recae todo el deber del Estado de garantizar un ambiente sano y ecológicamente equilibrado, como indica el artículo 50 constitucional. Ante tan importante responsabilidad, sería razonable esperar la fortaleza técnica y administrativa del órgano encargado. No obstante, hay razones para dudar. La Contraloría General de la República, en las conclusiones del Informe No.04-PFA "Fiscalización sobre Evaluación de Impacto Ambiental" rendido en el año 2000, dice: "Los resultados obtenidos en la presente fiscalización muestran que la Secretaría Técnica Nacional Ambiental ha tenido una serie de debilidades en su gestión, que pueden estar incidiendo en el cumplimiento de su función primordial, cual es, lograr un equilibrio entre los procesos productivos y el medio ambiente... " Lo indicado no garantiza que esa entidad esté contribuyendo adecuadamente a la conservación del medio ambiente, además que esté previniendo y mitigando los impactos ambientales generados por las actividades de desarrollo ..." Voto: 13295-01) (el resaltado es nuestro) 
Es decir ¿Si para otros casos fueron detallistas y exigen plena objetividad, por qué en este asunto de las TTC, en aplicación del criterio jurídico de la progresividad y del precautorio no quisieron acoger la acción? De hecho, nos parece que con el razonamiento de los magistrados se desconstitucionalizan los fines ambientales constitucionales ampliamente protegidos en el pasado tal y como veíamos también en la jurisprudencia citada supra, cuando comentamos las generalidades de lo preventivo y lo precautorio. La gravedad del asunto está dada en que los jueces dispusieron que la necesidad de valorar más a fondo las torres, queda excluida de sus potestades constitucionales y con ello se desresponsabilizaron. En este sentido ellos reafirman que no tenían criterios para determinar si la proliferación de torres era o no algo de alto impacto cuando las mismas directrices habían sido claras al señalar que el asunto era masivo ${ }^{24}$. Ahora, a nuestro criterio, les faltó a los magistrados hacer una simple lectura de las directrices y ello conllevó a la regresión que tendía a permitir que miles de torres se hicieran con requisitos y exigencias ambientales escasas, incluso, sin participación ciudadana como hablaremos en el próximo aparte. No hace falta ser un buen calificador para entender que una sola torre no es un impacto significativo si la misma se hace en una zona abandonada, a lo largo de una carretera, pero si hablamos de miles de ellas y muchísimas de estas en zonas residenciales, la visión debió de haber cambiado y se debió de aplicar el criterio de progresividad y proporcionalidad, pero todo ello falló, muy convenientemente, para los intereses de las transnacionales torreras, que de haberse encontrado con lugar la acción, hubieran visto eventualmente la necesidad de invertir más dinero en los estudios ambientales integrales y es posible que de un análisis en conjunto de las torres existentes y promediando las que pudieran venir en futuro, no hubiera permitido considerar oportuno instalarlas a distancias de 300 metros entre ellas en residenciales, zonas de escuelas, iglesias, y plazas públicas.

Mención especial requiere tener presente lo que por voto salvado o de minoría dispusieron los magistrados Armijo Sancho y Cruz Castro, que externaron que la acción de inconstitucionalidad sí debió de ser declara con lugar, pues según ellos, efectivamente lo que se dijo fue esa especie de desconstitucionalización de la protección ambiental que hemos hablado con base a reiterados votos. Dispusieron estos insignes operadores de justicia:

“... no comparten los suscritos el criterio vertido por esta Sala en el sentido de que la actividad de telecomunicaciones ya no se puede reputar como un servicio público, puesto que, aunque tal calificación haya sido variada legalmente, para la determinación de su naturaleza, como tal, tienen mayor relevancia otros criterios referidos a las necesidades sociales. Ya esta Sala en varias ocasiones ha calificado ciertas actividades como servicio público, más allá que el legislador las haya denominado como tales. Los derechos fundamentales se debilitan notablemente si la tutela depende de definición legislativa, sin que su esencia haya cambiado..."

Yendo más a profundidad, nos argumentan los jueces del voto de minoría que jamás una interpretación o modificación legal puede trascender la naturaleza del servicio y menos pueden hacer que los derechos fundamentales como lo es la protección a la biodiversidad pasen a menos, o se relajen por cambios legales. Señalaron ellos reconociendo tácitamente la regresión ambiental a la que hemos hecho referencia:

"Por lo tanto, en este caso, a diferencia de lo que consideró el voto de mayoría, sí resulta aplicable la obligación de un estudio de impacto ambiental para los servicios públicos (artículo dieciséis de la Ley de la ARESEP), pues las telecomunicaciones, por la trascendencia que representan hoy en día en sociedad, son un servicio público, independientemente del sujeto que lo preste. La participación convergente de particulares en la prestación de un servicio público no se dilucida por una definición legal, sino que se define por la naturaleza misma del servicio que se presta, que nunca

\footnotetext{
${ }^{24}$ En directriz que es la resolución № 02031-2009-SETENA se dice en el considerando cuarto: "Que dado que la proliferación de torres de telecomunicaciones será masiva..." (el resaltado es nuestro)
} 
es una actividad privada. La variación en el régimen legal que regula una actividad, no le quita su naturaleza de servicio público, porque su contenido material, su propia naturaleza, evidencia que tiene relevancia pública. Resulta incomprensible que el cambio del régimen legal excluya el cumplimiento de una garantía tan importante como el estudio de impacto ambiental. El cambio de la naturaleza jurídica con la intervención de sujetos privados, no puede debilitar la tutela del medio ambiente, que es un valor constitucional de especial relevancia, si nos atenemos a la propia redacción del artículo cincuenta de la Constitución..."

Sobre el aspecto de la mala visión del voto de mayoría al disponerse que la Administración puede aplicar la discrecionalidad y rebajar los estándares de aplicación del principio precautorio que igualmente resultaron en una regresión señalaron:

"Por otro lado, en atención al principio precautorio que opera en materia ambiental y que tiene rango constitucional, no es admisible que quede en manos de un órgano administrativo, de creación legal, la determinación de un impacto ambiental mediante una resolución que carezca de suficiente fundamentación, tal como ocurrió en este caso. A pesar de que en esta sede no corresponda determinar el grado de impacto ambiental de una actividad, sí es posible examinar la fundamentación que da SETENA para arribar a tal determinación, máxime en este caso, pues se trata de un servicio público. Motivación que es particularmente ayuna de los argumentos que legitimen la decisión y que por demás, no tomó en cuenta el criterio de la ciudadanía..."

Como hemos podido leer, en el caso de los campos electromagnéticos y el de las torres de telefonía, los altos jueces han generado regresiones serias y lamentables. Es claro que no hablamos de errores simples de interpretación, sino que hablamos que quienes tienen el poder más alto de velar por derechos fundamentales y constitucionales colaboran en transgresiones que son retrocesos muy serios que perjudican a personas que incluso no han nacido.

\section{La participación ciudadana en regresión}

\subsection{La participación}

La participación ciudadana informada ha sido un aspecto destacado en varios instrumentos internacionales y es claro que tal ha sido su relevancia que la misma es reconocida como un principio referencial del derecho a un desarrollo sustentable.

En la Declaración de Río 92, queda manifiesta la voluntad internacional consagrada en el Principio 10, denominado como "Participación Ciudadana", señala el principio:

"El mejor modo de tratar las cuestiones ambientales es con la participación de todos los ciudadanos interesados, en el nivel que corresponda. En el plano nacional, toda persona deberá tener acceso adecuado a la información sobre el medio ambiente de que dispongan las autoridades públicas, incluida la información sobre los materiales y las actividades que ofrecen peligro en sus comunidades, así como la oportunidad de participar en los procesos de adopción de decisiones. Los Estados deberán facilitar y fomentar la sensibilización y la participación del público poniendo la información a disposición de todos. Deberá proporcionarse acceso efectivo a los procedimientos judiciales y administrativos, entre éstos el resarcimiento de daños y los recursos pertinentes." (el resaltado es nuestro)

El artículo 13 de la Carta de la Tierra, incluido en el aparte IV, con un significativo título de democracia, no violencia y paz, busca lo mismo, pero acoge además la necesidad de transparencia y gobernabilidad al declarar: 
"Fortalecer las instituciones democráticas en todos los niveles y brindar transparencia y rendimiento de cuentas en la gobernabilidad, participación inclusiva en la toma de decisiones y acceso a la justicia" (el resaltado es nuestro)

Como se puede apreciar perfectamente, desde lo internacional se nos señala la hoja de ruta, donde obliga a que los Estados deban dar el derecho de participación y el de información previo a adoptar decisiones, pues lo contrario es un sin sentido y una burla a esas garantías.

Todo lo anterior no es nuevo, sino que tiene historia vieja, tal y como leemos el Principio 19 de la Declaración de Estocolmo de 1972 que señala:

"Es indispensable una labor de educación en cuestiones ambientales, dirigida tanto a las generaciones jóvenes como a los adultos y que preste la debida atención al sector de población menos privilegiado, para ensanchar las bases de una opinión pública bien informada, y de una conducta de los individuos, de las empresas y de las colectividades inspirada en el sentido de su responsabilidad en cuanto a la protección y mejoramiento del medio ambiente en toda su dimensión humana. Es también esencial que los medios de comunicación de masas eviten contribuir al deterioro del medio ambiente humano y difundan, por el contrario, información de carácter educativo sobre la necesidad de protegerlo y mejorarlo, a fin de que el hombre pueda desarrollarse en todos los aspectos"

En la Convención sobre el acceso a información, la participación pública en el proceso de adopción de decisiones y el acceso a la justicia en asuntos ambientales denominada Convención Aarhus se dice:

"Art. 2. Cada parte (cada Estado) tratará de velar porque los funcionarios y autoridades asistan y orienten al público en la búsqueda de acceso a la información, el fomento de la participación en el proceso de adopción de decisiones y el acceso a la justicia en cuestiones ambientales" (el resaltado es nuestro)

Sobre el valor de todos los instrumentos que hablan de protección a derechos fundamentales nuestra Sala Constitucional ha señalado:

"... hay que rescatar la referencia específica que hoy la Constitución hace de los "instrumentos internacionales", significando que no solamente convenciones, tratados o acuerdos, formalmente suscritos y aprobados conforme al trámite constitucional mismo (tal el caso que ahora nos ocupa), sino cualquier otro instrumento de tenga la naturaleza propia de la protección de los Derechos Humanos, aunque no ha sufrido ese trámite, tiene vigencia y es aplicable en el país..." (2313-95)

Por su parte nuestra Constitución Política incluso señala en su numeral $9^{25}$ que Costa Rica es un Estado democrático y participativo, por ello no es extraño que incluso en la Sala Constitucional se haya resaltado el derecho de participación en muchos de sus votos, donde destacamos los siguientes:

"...Existen diversos mecanismos para alcanzar mayores niveles de transparencia administrativa en un ordenamiento jurídico determinado, tales como la motivación de los actos administrativos, las formas de su comunicación -publicación y notificación-, el trámite de información pública para la elaboración de los reglamentos y los planes reguladores, la participación en el procedimiento administrativo, los procedimientos de contratación administrativa, etc., sin embargo, una de las herramientas más preciosas para el logro de ese objetivo lo constituye el derecho de acceso a la información administrativa..." (voto № 2120-03)

25 Artículo 9 constitucional: "El Gobierno de la República es popular, representativo, participativo, alternativo y responsable. Lo ejercen el Pueblo y tres Poderes distintos e independientes entre sí..." 
También ha expuesto:

"... El derecho de acceso a la información administrativa tiene un profundo asidero en una serie de principios y valores inherentes al Estado Social y Democrático de Derecho, los cuales, al propio tiempo, actúa. Así, la participación ciudadana efectiva y directa en la gestión y manejo de los asuntos públicos resulta inconcebible si no se cuenta con un bagaje importante de información acerca de las competencias y servicios administrativos, de la misma forma, el principio democrático se ve fortalecido cuando las diversas fuerzas y grupos sociales, económicos y políticos participan activa e informadamente en la formación y ejecución de la voluntad pública..." (voto No. № 2120-2003) (el resaltado es nuestro y conlleva a tener claro que ese derecho debe ser dado previo a la emisión de la conducta administrativa)

Además:

“... La participación ciudadana carecería, totalmente, de sentido si no se brinda a los administrados facilidades para informarse sobre los criterios técnicos y demás circunstancias que sustentan determinado proyecto o decisión..." (voto №. № 21202003)

Por su parte, en la resolución № 18106-09 de la Sala se dispuso:

"III.- Sobre el derecho de participación ciudadana. El principio de participación ciudadana en la toma de decisiones se ha convertido en uno de los pilares fundamentales sobre los que descansa el sistema democrático. En nuestro país, el legislador constitucional recogió el principio de cita en el artículo 9 de la Constitución Política al disponer que el Gobierno de la República es popular, representativo participativo, alternativo y responsable. Asimismo, tanto a nivel constitucional como legal, se han establecido una serie de mecanismos que buscan que el principio antes mencionado pueda ser aplicado en forma efectiva, y no quede únicamente en el papel, tales como el referéndum para la aprobación o derogación de leyes y reformas parciales a la Constitución, o la iniciativa popular en la formación de leyes. En cuanto a este tema, conviene destacar lo dicho por esta Sala en su sentencia número 200505649 de las catorce horas con treinta y nueve minutos del once de mayo del dos mil cinco, en la que se señaló en lo que interesa: "...En efecto, el principio democrático contenido en el preámbulo y artículo $1^{\circ}$ de la Constitución Política del 7 de noviembre de 1949, supone, necesariamente, el de la participación política directa, efectiva, libre y consciente de los ciudadanos en la toma de las decisiones políticas fundamentales en cuanto les atañen. Sobre este último principio, el artículo $9^{\circ}$ de la Constitución Política, en su versión actual, después de la reforma parcial verificada por la Ley No. 8364 del $1^{\circ}$ de julio del 2003, dispone que "El Gobierno de la República es popular, representativo, participativo, alternativo y responsable. Lo ejercen el pueblo y tres Poderes distintos e independientes entre sí: El Legislativo, el Ejecutivo y el Judicial". No cabe la menor duda que la última reforma parcial al artículo $9^{\circ}$, fue jalonada, en buena parte, por la que se produjo, casi un año antes, de los ordinales 105 y 123 de la Constitución, en cuanto se enfatiza el carácter participativo del Gobierno de la República y se señala explícitamente que, además de los tres Poderes, éste lo ejerce el pueblo, obviamente, a través de su participación en el diseño de las grandes líneas políticas del país, mediante el referéndum y la iniciativa popular en la formación de la ley. En el ámbito de los instrumentos internacionales de derechos humanos es menester indicar que existe una convergencia absoluta de estos en consagrarle y garantizarle a las personas el derecho de participar o tomar parte directamente en el gobierno o en la dirección de los asuntos públicos de su país, así lo establecen, a título de ejemplo, los artículos 21, párrafo $1^{\circ}$, de la Declaración Universal de los Derechos Humanos del 10 de diciembre de 1948, 20 de la Declaración 
Americana de los Derechos y Deberes del Hombre de 1948, 23, párrafo $1^{\circ}$, inciso a), de la Convención Americana sobre Derechos Humanos del 22 de noviembre de 1969 y 25, inciso a), del Pacto Internacional de Derechos Civiles y Políticos del 19 de diciembre de 1966..." (el resaltado es nuestro)

En lo legal se dice en Costa Rica en la Ley Orgánica del Ambiente, numeral 6:

"Participación de los habitantes: El Estado y las municipalidades, fomentarán la participación activa y organizada de los habitantes de la República, en la toma de decisiones y acciones tendientes a proteger y mejorar el ambiente" (el resaltado es nuestro)

Por su parte en el Código Municipal se señala en el artículo 5:

"Las municipalidades fomentarán la participación activa, consciente y democrática del pueblo en las decisiones del gobierno local..." (el resaltado es nuestro)

\subsection{La participación y las regresiones en el caso de las torres de telefonía}

Teniendo en cuenta el anterior marco, vemos que en nuestro Estado existe -o debería existirun rango amplio de participación ciudadana y como leíamos de los votos constitucionales, esta participación, para ser efectiva debe ser un derecho ejercido previamente al otorgamiento de un permiso, puesto que lo contrario sería todo un sin sentido. Pero resulta que a pesar de lo anterior, en el voto de la acción de inconstitucionalidad de TTC antes comentada, los magistrados de mayoría incurrieron en una seria regresión al tener por buena una participación ciudadana otorgada para luego de dar los permisos ambientales a cada torre de telefonía.

Dispusieron los magistrados en ese voto № 2012-014111:

"Por otra parte, en la acción se aborda el problema de la participación y la infracción al derecho a la información, como el establecimiento de mecanismos para vertebrar la sociedad y su relación con las instituciones públicas, es decir, para permitir que el ciudadano pueda formarse su opinión, así como pronunciarse en asuntos que sean de su interés y de relevancia para sus aspiraciones de vida en sociedad. Sin embargo, también se ha analizado, en forma reiterada el tema, mediante los recursos de amparo en los que se reclama contra la falta de participación e información, autorizado por las resoluciones y medidas de la SETENA, lo que ha sido conocido entre otras sentencias por las números: 2011-5516, 2011-8316, 2011-12704, 2011-12745, 2011-15288, 2011$15763,2012-6711$ y 2012-08270. En este sentido, el punto quedó resuelto por la Sala con la sentencia No. 2011-05516, en cuanto establece lo siguiente: "De previo debe indicarse, que no le corresponde a este Tribunal determinar las especificaciones que debe cumplir el administrado en lo que se denomina un "Plan de Comunicación a la Comunidad" como reclama el amparado. Si bien es cierto esta Sala ha reconocido la existencia del derecho de participación ciudadana en asuntos de índole ambiental, este derecho debe ser comprendido, al menos para ser de conocimiento de esta jurisdicción, para aquellos proyectos que por su índole especial y de gran trascendencia o afectación pueda afectar sensiblemente a una comunidad. Tratándose de un principio constitucional, resulta consecuente su adoptación también en otra normativa de índole legal, incluso abarcando mayores ámbitos a los que constitucionalmente se tutelen vía amparo, lo cual es acorde al ordenamiento jurídico, sin embargo la verificación de estas audiencias o comunicaciones, no corresponde ser verificada en todos los casos por esta jurisdicción, sino únicamente en aquéllos en que éstas resulten indispensables por su grado de afectación, como los casos considerados técnicamente de alto impacto ambiental, supuesto que no es al que nos enfrentamos en el presente caso, ya que se trata de una obra que se encuentra calificada como de 
"bajo impacto ambiental potencial" Precisamente, un principio fundamental lo debemos encontrar en la propia Ley General de la Administración Pública, cuando establece que: "Artículo 16. - En ningún caso podrán 1. dictarse actos contrarios a reglas unívocas de la ciencia o de la técnica, o a principios elementales de justicia, lógica o conveniencia. 2." En este sentido, el accionante propone en su demanda la prelación, a las decisiones políticas como las jurídicas, a la participación ciudadana, para que éstas disciplinas encuentren límites previos en él y en el derecho ambiental, lo que, a su juicio, debe ser así con la actividad de instalación de torres y de radio bases, la considera de alto impacto ambiental. Pero como se indicó arriba, lo anterior debe ser dirimido en otra jurisdicción diferente a la constitucional, pues si el legislador al regular el ámbito del sector de las Telecomunicación dejó al criterio de la SETENA lo referente al posible impacto ambiental, y ello lo hizo al amparo del principio de atención del criterio versado del legislador. En este sentido, la Asamblea Legislativa se permite aconsejar y escuchar por los mejores criterios técnicos y científicos sobre una determinada materia técnica, o deja ciertas áreas reguladas, abiertas a la flexibilidad propia de la actividad e intensidad regulatoria administrativa, a la que no puede descender la función legislativa. De este modo, aunque sea quien toma la decisión final, si el legislador no lo reguló en concreto, entonces permitió que la SETENA lo resolviera diferentemente. Así, señala que en España la colocación de torres de telecomunicaciones no se considera de alto impacto, y si ello está confirmado por las reglas unívocas de la ciencia o de la técnica, entre otros principios, entonces efectivamente conducen a un tratamiento menos exigente por un menor impacto ambiental al señalado por el accionante. Lo que determina la norma es que si la ciencia y la técnica proponen un tratamiento unívoco, las decisiones jurídicas como políticas deben estar guiadas por éstas. En este sentido, entre mayor peligrosidad exista en una actividad, más estrictas deben ser las exigencias; por el contrario, si una determinada práctica o actividad es de bajo impacto ambiental, las exigencias políticas y jurídicas pueden relajarse, como en efecto se ha descrito en los sendos escritos de las autoridades informantes, como de los coadyuvantes. En este sentido, el derecho ambiental no podría conducir a una tiranía de la participación ciudadana privilegiándola por encima de las reglas exactas de la técnica y la ciencia, si éstas permiten relajar o flexibilizar la oportunidad, y si no existen razones al día de hoy para estimar un cambio normativo, tampoco lo sería para establecer que un tratamiento distinto al unívoco de la ciencia y de la técnica. Por lo expuesto, este extremo al igual que el anterior debe declararse sin lugar..." (el resaltado es nuestro)

Hay que destacar varios aspectos; para iniciar tenemos que ver que los magistrados señalan que las torres de telefonía y radio base son proyectos designados como de bajo impacto, pero al igual que señalamos arriba ${ }^{26}$, la sumatoria de todas y cada una de esas miles de estructuras son afectaciones serias con una capacidad de carga que no quiso ser dimensionada por los jueces, aspecto que conllevó a "descuidar" la verdadera significancia del derecho de participación, que como hemos dicho, debe ser previo al otorgamiento de cualquier permiso. Por otro lado, como se aprecia en los razonamientos o (in) justificación judicial citada, los magistrados llegan a la extraña e irracional conclusión de que la participación ciudadana solo debe ser previa si la misma es para proyectos de alta significancia, conllevando ello a una línea muy delicada, pues hacer perder lo que incluso ha sido reconocido por diferentes instrumentos internacionales que no hace ese tipo de diferencias, e incluso se desconoce lo dicho por esa misma Sala anteriormente y, todo ello, es verdaderamente algo muy serio por el retroceso, nos hacen ver que existe una "nueva" línea de interpretación restrictiva, que sin lugar a dudas, favorece solamente a los proyectistas de torres, pero no a la ciudadanía, ni a la defensa del derecho a un ambiente sano y equilibrado. Finalmente, vemos de manera grotesca como estos

\footnotetext{
${ }^{26} \mathrm{Y}$ sin entrar a los efectos de la contaminación electromagnética.
} 
jueces han reconocido abiertamente la regresión de derechos fundamentales cuando dicen que el derecho de participación debe "relajarse", aspecto este que es perjudicial para un Estado que se ha proclamado y es reconocido internacionalmente como defensor de los derechos fundamentales.

En el voto de minoría los magistrados Gilbert Armijo y Fernando Cruz señalan:

"Efectivamente cuando en la resolución impugnada SETENA estableció que la participación ciudadana a las comunidades procede hasta luego de otorgada la viabilidad ambiental incurrió en una violación al principio de participación ciudadana. La participación del ciudadano debe ser previa y no únicamente posterior al otorgamiento de los permisos. Justamente el ciudadano debe informarse y expresar su opinión ante las Autoridades Administrativas, antes que estas dicten sus correspondientes actos administrativos, para con ello poder presentar argumentos que enriquezcan el sustento de las decisiones de la Administración Pública. Toda participación ciudadana tiene la aspiración de influir en la decisión, no se trata solamente de expresar opinión y argumentos que al fin y al cabo no tengan ninguna trascendencia en las decisiones administrativas que se toman respecto de la comunidad. La consulta posterior se convierte en un formalismo que debilita significativamente la participación de la ciudadanía. El control ciudadano en temas de medio ambiente no sólo se deriva del artículo nueve de la Constitución, sino que se funda en el propio artículo cincuenta de la carta fundamental, porque brinda una acción de control calificada a cualquier ciudadano. De la lectura de esta norma se infiere, sin duda alguna, que la participación ciudadana en materia de medio ambiente, debe producirse antes de adoptar la decisión, porque control activo de la ciudadanía debe darse en un escenario que asegure su incidencia efectiva, ya que la que se hace posteriormente, no es más que una notificación de lo que ya se resolvió..."

Por su parte el magistrado Paul Rueda, en su voto salvado independiente, dentro de este mismo expediente, ampliando aún más señala al respecto de la participación ciudadana:

"Como indiqué en los votos números 2013-003121, 2012-014990 y 2012-005866, la construcción de torres de telefonía celular requiere audiencia específicamente cuando esto conlleva una modificación a un plan regulador, en virtud de lo dispuesto de manera expresa en el artículo 17 de la Ley de Planificación Urbana. Tal audiencia significa una manifestación del derecho constitucional al gobierno participativo, cobijado constitucionalmente en el artículo 9 de nuestra Ley Fundamental. Hecha la aclaración anterior, a los efectos de este asunto, existirán situaciones en que la instalación de torres de telefonía celular no sea - per se- de bajo impacto ambiental (verbigracia: cuando la planta de emergencia de una torre opere con algún hidrocarburo y se encuentre sobre un manto acuífero vulnerable); en tales casos muy específicos, que no comportan la generalidad de las situaciones, contrario al criterio de la mayoría, estimo, por un lado, que SETENA se encuentra obligada a conferir audiencia previo al otorgamiento del permiso ambiental y, por el otro, que esta instancia sí puede ejercer control de constitucionalidad, como en efecto ya lo ha hecho (ver sentencia número 2012-016866 de las 14:30 horas del 4 de diciembre de 2012)..."

Como podemos leer, es claro que se evidencia una inequívoca discrepancia de criterios entre los magistrados de mayoría con los disidentes, por lo cual nos deja entrever también que el asunto de las violaciones fueron bien discutidas, por lo que no fue por cuestión de olvidos, o de errores casuísticos y al azar; que se generaron las regresiones odiosas en materia ambiental, al menos en estos casos de las torres de telefonía celular. 


\section{Conclusiones}

Si bien ya habíamos entendido -por nuestra práctica profesional- que existían regresiones generadas desde la Sala Constitucional, fue mediante este análisis que estructuramos la información necesaria que nos permite enunciar casos particulares, donde se denota el cambio de timón serio que evidencia las regresiones de parte de los que son llamados a defender los derechos humanos de tercera generación.

En el caso de los campos electromagnéticos es preocupante que siendo un caso claro, donde se podía aplicar el criterio precautorio sobre la incertidumbre, más bien los magistrados dispusieran; que como las informaciones eran contradictorias, se debía declarar sin lugar el amparo.

En la acción de inconstitucionalidad por las antenas de telefonía celular vemos que los altos jueces, de nuevo, prefieren acudir a argumentos formalistas antes que aplicar razonamientos que van encausados a defender los derechos humanos fundamentales, lo cual se torna verdaderamente lamentable. Un sistema que antepone la forma; antes que el fondo, no progresa y está destinado a ser tomado por fuerzas que no conllevan a poder materializar un desarrollo sustentable inclusivo, sino uno donde los fines antropocéntricos tengan relevancia.

La verdad parece, que luego de venir argumentándose a lo lardo de la historia de la existencia de la Sala Constitucional una clara defensa del derecho de participación ciudadana, resulta un contra sentido resolver; que en cuanto al asuntos de TTC se dispusiera que el sistema tenía que relajarse, pues ello deja entrever que se entra a una fase peligrosa, donde se pone por delante los derechos empresariales antes que los de la ciudadanía. Véase que externar que "... el derecho ambiental no podría conducir a una tiranía de la participación ciudadana privilegiándola por encima de las reglas exactas de la técnica y la ciencia, si éstas permiten relajar o flexibilizar la oportunidad y si no existen razones al día de hoy para estimar un cambio normativo..." nos devuelve, cuando menos, 50 años en la historia de las reivindicaciones de la luchas en defensa de causas ambientales al alrededor del mundo.

Tal y como lo señala el epígrafe de este artículo, sentimos la necesidad de investigar el tema de las regresiones ambientales relacionadas con las posturas de los jueces constitucionales, pues hay aspectos que merecen ser analizados para buscar nuevas rutas que nos hagan al menos no retroceder de los diques logrados, para bien de gente que incluso no ha nacido.

Es claro, que se debe sistematizar toda la jurisprudencia constitucional ambiental para detallar aún más lo que acá apenas hemos enunciado; esa labor será saludable para poder construir el derecho al desarrollo sustentable nacional que nos merecemos y por el que hemos luchado.

Finalmente, sabiendo que las regresiones ambientales protegen el derecho humano a un ambiente sano y ecológicamente equilibrado y que éstas tienen la función vital de blindar nuestro ordenamiento ambiental, sería válido cuestionarnos lo siguiente: ¿existirán consecuencias penales, civiles o administrativas para los operadores de justicia que rompan los diques y disminuyan la protección alcanzada? ¿Estaremos ante conductas penales como el prevaricato ${ }^{27}$ ? Estas dudas se tendrán que resolver en futuras investigaciones, pero nos parece que es vital incursionar en esos estudios pues sino; el tema de las regresiones no trascenderá, dejando huellas de peso más allá del mundillo académico.

Somos fieles creyentes que no es correcto, justo y menos sano, para los derechos humanos, considerar que el rebajar los estándares ya alcanzados, por parte de los magistrados, sea tomado como aspectos que están dentro de las potestades legales de estos funcionarios, pues esa lógica puede hacernos llegar a prácticas judiciales muy peligrosas para Estados que; por tradición son civilistas y respetuosos de los derechos fundamentales.

${ }^{27}$ Dictar resoluciones contrarias a la ley. 


\section{Bibliografía}

Artigas, C. El principio precautorio en el derecho y la política internacional. CEPAL-ECLAC. Chile, 2001.

Cabrera, J. Indubio pro natura. Boletín de la Fundación Ambio No. 3 Costa Rica, 1994.

Córdoba Morales, J. Torres de telefonía: Grupo denuncia vía rápida para otorgar permisos ambientales. Semanario Universidad. Costa Rica, 2009. Disponible en http://kioscosambientales.ucr.ac.cr/index.php?option=com_content\&view=article\&id=442:torresde-telefonia-grupo-denuncia-via-rapida-para-otorgar-permisos-ambientales- $\&$ catid=40: noticiasambientales\&ltemid $=60$.

Embid Tello, A. Retos jurídicos de la radiación no ionizante. Tesis doctoral, Universidad Carlos III de Madrid. España, 2009.

Goldenberg, I. y Cafferatta, N. Daño ambiental. Problemática de su determinación causal. Ediciones Albeledo-Perrot. Argentina, 2001.

Peña Chacón, M. "El principio de no regresión ambiental a la luz de la jurisprudencia constitucional costarricense". Revista Judicial, No. 103, San José, marzo 2012. Disponible en: http://www.poder-judicial.go.cr/escuelajudicial/archivos\%20actuales/documents/revs_juds/ revista\%20104\%20por\%20archivo/07-principio\%20no\%20regresion.pdf.

Milano, A. El principio precautorio. Editorial Jurídica Continental. Costa Rica, 2005.

Mesa Cuadros, G. Derechos ambientales en perspectiva de integralidad. Concepto y fundamentación y resistencias actuales hacia el Estado ambiental de derecho. Universidad Nacional de Colombia. Colombia, 2007.

Sagot, A. El Principio de no regresión en materia ambiental. Análisis de dos casos de directrices transgresoras, 2013. Disponible en: http://www.eldial.com.ar/nuevo/archivodoctrina_nuevo.asp? base $=50 \& i d=6582 \& t=d$.

Sagot, A. Aspectos conceptuales y jurisprudencia constitucional ambiental de los principios precautorio y preventivo. Análisis conceptual sobre los principios y el tratamiento que les da la Sala" Costa Rica, 2013.

Santana Plata, P. Las controversias en el derecho internacional ambiental y los retos en la aplicación del principio de precaución en el ámbito local. Revista de Derecho Público. Enero/Junio. Universidad de los Andes. Colombia, 2013.

Walsh, R. et al. Ambiente, derecho y sustentabilidad. Ediciones Ley. Argentina, 2000. 


\title{
DOING BUSINESS, UNA POLÍTICA REGRESIVA DEL BANCO MUNDIAL
}

\author{
Rafael González Ballar*
}

\section{Introducción}

En una reciente publicación, llamo la atención sobre tres verdades incómodas que son un verdadero peligro a nivel planetario: el cambio climático, el acaparamiento de tierras y la firma indiscriminada de tratados de libre comercio, sin que los países tomen medidas adecuadas y oportunas para equilibrar su impacto ${ }^{1}$. Nos interesa en este artículo resaltar el acaparamiento de tierras no solo como una verdad incómoda, sino con la agravante de ser una política regresiva de parte del Banco Mundial por medio de lo que ellos han dado llamar el doing business.

\section{Una política regresiva y contraria al desarrollo sostenible}

El doing business propicia el "acaparamiento de tierras" como parte de una política regresiva del Banco Mundial. Una política de una realidad a la que debemos ponerle atención, por sus consecuencias ambientales, sumadas a las de soberanía y seguridad alimentaria, así como violación a los derechos humanos de millones de campesinos y agricultores en el mundo, esencialmente de los países en vías de desarrollo y de la que me permito transcribir su dinámica:

"El Banco Mundial es un impulsor primordial de las apropiaciones de tierras que despojan y empobrecen a las comunidades rurales en el mundo entero. Es un actor central que utiliza su poder financiero y modelo de desarrollo pre-determinado, basado en los principios neoliberales de privatización, desregulación, bajos impuestos a las empresas y en la mantra fundamentalista del "libre mercado". La evidencia muestra claramente que este modelo favorece en gran parte los intereses de las grandes empresas agroindustriales, en detrimento de los campesinos, y está diseñado para maximizar la extracción de los valiosos recursos naturales y humanos de los países en vía de desarrollo.

Desde 2002, el Banco Mundial ha promovido este modelo a través de los rankings Doing Business. Los rankings clasifican los países según si los burócratas de Washington creen que mejoran, o no, la "facilidad de hacer negocios". Las declaraciones del propio Banco Mundial muestran que estos rankings anuales son seguidos muy de cerca por los inversores extranjeros, y que el Banco Mundial y los donantes bilaterales también los utilizan para guiar su financiación. Por lo tanto, el Doing Business es un instrumento clave para liberalizar aún más las economías con el objetivo de atraer las inversiones extranjeras directas.

Los rankings Doing Business ya tuvieron un impacto sustancial sobre los sectores agrícolas y son conocidos por facilitar la adquisición de tierras a gran escala. Incitan a

\footnotetext{
* Exdecano, ex miembro del Consejo Universitario, profesor de la Facultad de Derecho de la Universidad de Costa Rica.

1 "Tres verdades incómodas para la seguridad alimentaria en el mundo", en Penser une democratie alimentaire, Nantes, Larcier, 2013.
} 
los Gobiernos a considerar la tierra como un bien comerciable, vendible para beneficios a corto plazo, sin que sean tomados en cuenta los impactos ambientales y sociales. Pero lo peor está por venir.

Respondiendo a la demanda del G-8 en 2012, y con la financiación de la Fundación Gates y de las agencias de desarrollo del Reino Unido, EE. UU., Holanda y Dinamarca, el Banco Mundial está desarrollando un nuevo instrumento llamado Benchmarking the Business of Agriculture (BBA), para notar específicamente a los sectores agrícolas de los países. Iniciados a finales de 2013, los estudios pilotos ya están en marcha en 10 países, y serán ampliados a 40 países en 2014. El BBA se basa en el modelo de Doing Business y lo adapta a la agricultura. A pesar de un lenguaje que pretende preocuparse por los pequeños agricultores, el objetivo de este nuevo sistema de clasificación centrado en la agricultura es demasiado claro: profundizar la apertura de los sectores agrícolas a los inversores extranjeros.

El ranking Doing Business debe acabar con la forma indiscriminada como poner en ejecución una política sin que se tomen en cuenta los derechos humanos de las comunidades, la protección del ambiente y la soberanía y seguridad alimentaria". ${ }^{2}$

La gráfica y el mapa que a continuación presentamos expresa muy bien el fenómeno y nos da una idea de los millones de hectáreas hoy en manos de diferentes países e inversionistas. Los países afectados son principalmente los africanos y no es de extrañarse que nos quieran exportar la genial política a algunos países de América Latina.

Una forma diferente de acaparamiento la han estado realizando las compañías piñeras en Costa Rica. Es necesario poner atención a los procesos de deforestación provocados por cambio en el uso del suelo, sobre todo para agricultura, y los llamados commodities y su relación con los procesos de comercio globalizado ${ }^{3}$.

Además, se violan claramente derechos fundamentales, como el derecho a una alimentación y una nutrición suficientes y de calidad, pues está llevando a procesos de pobreza, desnutrición y subnutrición a las poblaciones mismas; el derecho al ambiente, específicamente al hacer más vulnerables los ecosistemas necesarios para la agricultura y no facilitar los procesos de adaptación y mitigación y propiciar el cambio climático; el derecho a la propiedad, al desplazar poblaciones, relocalizarlas sin una expropiación; y por último, el derecho a la participación en el proceso de desarrollo.

\footnotetext{
2 The Oakland Institute http://www.oaklandinstitute.org, consultado en marzo del 2014.

${ }^{3}$ Rautmer, M., Leggett, M, Davis , F. El pequeño libro de las grandes causas de la deforestación. Oxford: Global Company Program, 2013.
} 


\begin{tabular}{|c|c|c|c|}
\hline Investor Country & Target Country & Area $(\mathrm{Ha})$ & Crop - Aim of Project \\
\hline Austria & Ethiopia & 50,000 & Biofuel \\
\hline Bahrain & Philippines, Turkey, UAE & 10,000 & Agro-fishery \\
\hline Belgium & Kenya & 42,000 & Sugarcane \\
\hline Canada & Kenya, Mozambique, Ghana & 293,000 & Biofuel \\
\hline China & $\begin{array}{l}\text { DR Congo, Mozambique, Tanzania, } \\
\text { Zambia, Philippines, Cameroon, Sierra } \\
\text { Leone }\end{array}$ & $6,512,300$ & $\begin{array}{l}\text { Biofuel, rice, sugarcane, } \\
\text { maize }\end{array}$ \\
\hline Egypt & Sudan & 526,000 & Wheat, maize, sugar beets \\
\hline Germany & Ethiopia & 13,000 & Biofuel \\
\hline India & Ethiopia, Sierra Leone & 348,258 & $\begin{array}{l}\text { Flower, sugar, maize, rice, } \\
\text { vegetables, Palm oil }\end{array}$ \\
\hline Iran & Sierra Leone & 10,117 & Biofuel, lemon grass \\
\hline Israel & Ghana, Ethiopia & 202,000 & Biofuel \\
\hline Italy & Ghana, Mozambique & 20,000 & Biofuel \\
\hline Japan & Brazil, Kenya & 100,000 & Soybeans, biofuel \\
\hline Jordan & Sudan & 25,000 & Livestock, crops \\
\hline Kuwait & Kenya, Sudan & 170,000 & Rice \\
\hline Libya & Mali, Ukraine, Liberia & 364,000 & Rice \\
\hline Luxembourg & Sierra Leone & 62,475 & Biofuel, Palm oil, rubber \\
\hline Norway & Ghana & 427,660 & Biofuel \\
\hline Portugal & Mozambique, Sierra Leone & 151,000 & $\begin{array}{l}\text { Biofuel, rice, pineapple, } \\
\text { cassava, vegetables }\end{array}$ \\
\hline Qatar & Philippines, Sudan , Kenya & 140,000 & Fruits, vegetables \\
\hline Republic of Korea & Russia, Sudan, Indonesia & 715,000 & Wheat, palm oil \\
\hline Saudi Arabia & $\begin{array}{l}\text { Sudan, Tanzania, Indonesia, Ethiopia, } \\
\text { Egypt }\end{array}$ & $5,520,000$ & $\begin{array}{l}\text { Rice, wheat, vegetables, } \\
\text { barley, animal feeds }\end{array}$ \\
\hline South Africa & Congo (Brazzaville), Benin & 80,000 & Livestock, rice, vegetables \\
\hline Switzerland & Sierra Leone & 26,000 & Sugarcane \\
\hline UAE & Pakistan, Sudan, Ethiopia & 707,000 & $\begin{array}{l}\text { Corn, alfalfa, wheat, } \\
\text { potatoes, beans }\end{array}$ \\
\hline UK & $\begin{array}{l}\text { Ethiopia, Angola, Ghana, Madagascar, } \\
\text { Mozambique, Ukraine, Sierra Leone }\end{array}$ & $1,046,348$ & Biofuel \\
\hline USA & Brazil, Sudan, Ukraine, Ethiopia & 690,000 & Sugarcane (biofuel) \\
\hline Viet Nam & Cambodia, Lao & 200,000 & Rice, rubber \\
\hline
\end{tabular}

Fuente: Ver Figura 2

(Gráfico proporcionado por el profesor Mekele Bekele Tekle, Universidad Adís Abeba, Etiopía, 2012).

Se observa en la matriz anterior, en la columna de la izquierda, los países acaparadores; en la siguiente, los anfitriones; luego, el número de hectáreas, y por último, el cultivo planeado. Solamente China, Arabia Saudita e Inglaterra suman más de trece millones de hectáreas acaparadas (13.078.368 ha). En la mayoría de los casos, la producción es para biocombustibles, maíz y caña de azúcar, lo cual no resuelve en nada la posible producción de 
alimentos necesarios para las poblaciones mismas desplazadas o a escala mundial para evitar problemas de mercado con la especulación de precios ${ }^{4}$.

Todo lo anterior evidencia una política claramente regresiva y es un reto al derecho en general, pero, esencialmente, al ambiental, alimentario y al agrario. En los países en vías de desarrollo, necesitamos políticas más integrales e integradas, al igual que instrumentos jurídicos que combatan este tipo de iniciativas. De una manera interdisciplinaria, se deben resolver los problemas y no permitir que se conviertan en conflictos que ya empezamos a sentir y que amenazan con empeorar en el futuro próximo.

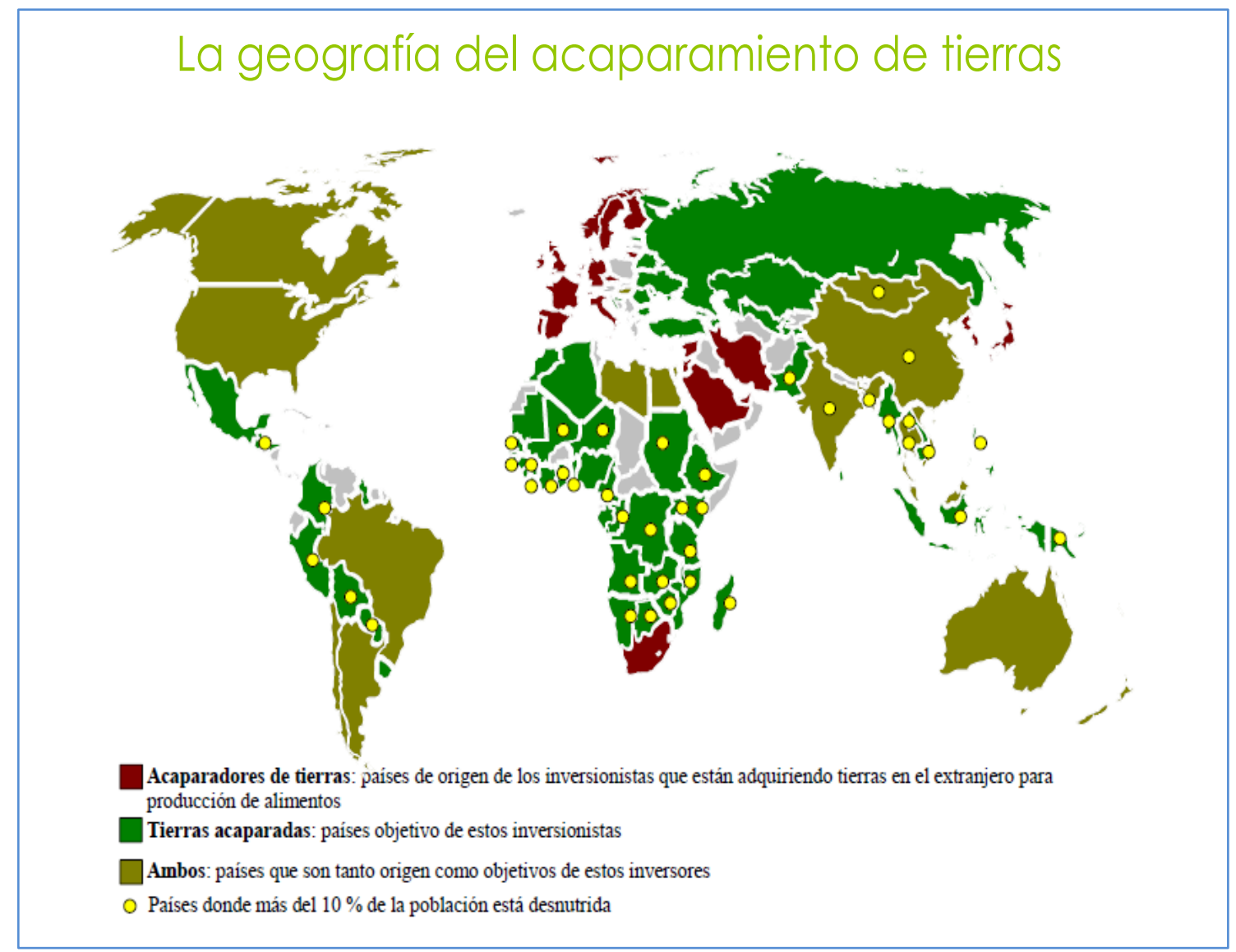

Fuente: http://viacampesina.org/downloads/pdf/sp/acapGRAIN-dec2011.pdf

El Banco Mundial en ocasiones nos muestra su cara de protector del ambiente y en otras, por el contrario, propicia el desequilibrio en la ecuación hacia el desarrollo sostenible de los países, sobre todo en vías de desarrollo. No vemos clara una producción eficiente y eficaz, ni una protección con un objetivo de integridad ecológica para los ecosistemas más sensibles para la seguridad alimentaria; no hay garantía de una participación ciudadana en la mayoría de estos procesos; estamos cayendo en aumentos en los niveles de pobreza y desnutrición en el mundo.

\footnotetext{
${ }^{4}$ Daphne Hewitt, Potential Legality Issues from Forest Conversion Timber, in Forest Trends Report Series, Forest Trade and Finance, Nov. 2013. Ver: http://www.forest-trends.org.
} 


\section{Una política regresiva para el desarrollo sostenible en un ambiente internacional peligrosamente anquilosado}

Hemos manifestado con anterioridad nuestra preocupación por lo que consideramos un anquilosamiento del ambiente internacional para resolver aspectos sensibles para el ambiente ${ }^{5}$. Basta poner atención al informe de la Organización Mundial del Comercio (OMC) del 2012, en el sentido de que falta una "claridad jurídica y coherencia de los acuerdos internacionales", refiriéndose a los países anfitriones de la inversión extranjera sobre los recursos naturales al momento de la interpretación y aplicación de dichos acuerdos y los ambientales ${ }^{6}$.

En nuestro criterio, bastaría aplicar el "test de regresividad" propuesto por el profesor Mario Peña Chacón ${ }^{7}$, y fácilmente notaríamos que lo expuesto en el presente artículo cumple el test, pero aplicado al campo de las políticas internacionales y aceptadas a escala nacional que afectan el concepto ampliamente acogido del desarrollo sostenible. Nos manifiesta el profesor Peña Chacón:

La principal obligación que conlleva su correcta aplicación es la de no retroceder al statu quo anterior, respetando al menos, el nivel de protección ambiental ya alcanzado; no afectar los umbrales y estándares de protección ambiental actualmente adquiridos; no derogar, modificar, relajar ni flexibilizar la normativa vigente en la medida en que esto conlleve disminuir, menoscabar o de cualquier forma afectar negativamente el nivel actual de protección; asegurar la calidad de las normas ambientales; no vulnerar el derecho de las futuras generaciones a gozar de un ambiente sano y ecológicamente equilibrado, ni disminuir el patrimonio a transmitir a las generaciones futuras como garantía de progreso; todo lo anterior, con la finalidad de asegurar condiciones ambientales aptas para la posteridad. (La negrita no es del original la enfatizamos para entender mejor en qué aspecto consideramos cumple el test de regresividad).

Insistimos, entonces, en que al test propuesto nosotros le agregaríamos aquellas acciones y omisiones, que son una evidente falta de ética, al propiciar, a escalas internacional y nacional, un anquilosamiento que provoca que las políticas, la legislación y los proyectos de organismos internacionales y nacionales no propicien el desarrollo sostenible.

Lo percibimos fácilmente en las agencias y comisiones, como el Centro Mundial para el Desarrollo Sostenible, el Programa de la Naciones Unidas para el Medio Ambiente (PNUMA) y la Comisión para el Desarrollo Sostenible entre otros, al no poder dar continuidad y efectividad a las obligaciones de la Agenda $21^{8}$.

El fracaso de la reciente cumbre de Río+20, en la cual de una manera reveladora manifiestan que "(...) desde 1992 los progresos han sido insuficientes (...) y han puesto en peligro la capacidad de todos los países, en particular los países en desarrollo, para lograr el desarrollo

\footnotetext{
5 Nuestro artículo "Algunas propuestas para potenciar la buena gobernanza ambiental. (Especial referencia al cambio climático)", 2013, próximo a publicarse en Brasil.

6 OMC, Informe sobre el comercio mundial 2010, El comercio de los recursos naturales, p. 160 (http://wto.org/spanish/res_s/booksp_s/anrep_s/world_trade_report10_s.pdf).

${ }^{7}$ Test de regresividad ambiental, en Revista Internacional Direito Ambiental (RIDA), número 6, diciembre 2013, Brasil; en Revista Lex, difusión y análisis, noviembre 2013, número 221, México; y en Revista Monfrague, Desarrollo Resiliente, volumen II, número 2, abril 2014, España, accesible en: http://www.monfragueresiliente.com/numero4/indice4.html

${ }^{8}$ Robinson, Nicholas A. "Reflecting on Rio: Environmental Law in the Coming decades", in Environmental Law and Sustainability after Rio, pp. 10, 11, 12, EE, 2011.
} 
sostenible $(\ldots)^{n 9}$, cumbre de la cual solo sugerencias y buenas intenciones llenan la declaración final.

El ambiente internacional mencionado y la política del Banco Mundial tienen resultados que solamente los podemos calificar de regresivos. Vamos a tomar el ejemplo de Etiopía, con información resumida suministrada por el profesor Mekele Bekele Tekle, de la Universidad de Adís Abeba ${ }^{10}$, sobre el acaparamiento de tierras producto de la política del Banco Mundial sobre doing business, para entender mejor la forma y los resultados regresivos y contrarios al desarrollo sostenible:

- Los contratos firmados con los inversionistas oscilan entre 30 y 50 años. Muchos de ellos por más de 100.000 hectáreas.

- La totalidad inicial de la tierra comprometida por el Gobierno etíope es de 7 millones de hectáreas para el 2015. Lo más serio es que en materia ambiental no hay compromisos para realizar estudios de impacto ambiental (EIA) en los proyectos.

- Se les garantiza libre uso de recursos hídricos superficiales para irrigación.

- Los contratos firmados con el Gobierno no requieren ser registrados en ninguna parte.

- No existe obligación de vender parte de la producción al Gobierno de Etiopía.

- No hay garantías financieras ni seguros que permitan tener conocimiento de la seriedad del proyecto para posibles futuros daños.

- Los conflictos socioambientales ya están presentes pues existe el peligro de que varios humedales se estén drenando. Muchos campesinos muertos por conflictos con sus tierras y los inversionistas amenazados de muerte ${ }^{11}$.

- Los conflictos con el Gobierno, por los desplazamientos de campesinos y grupos tribales, son constantes; lo anterior, con irrespeto a sus lugares sagrados y los monasterios, zonas de protección y terrenos con vocación forestal específica ${ }^{12}$.

\section{Conclusiones}

Es regresivo para el desarrollo sostenible el fomento de políticas que afecten el progreso de los países para llegar a un equilibrio en los factores ecológico, social y económico. Lo anterior, sobre todo cuando lo sufren los países en vías de desarrollo y las políticas no se acompañan de mecanismos que propicien beneficios a los anfitriones de dichas políticas.

El acaparamiento de tierras producto del doing business es un ejemplo nefasto y regresivo que debe eliminarse o readecuarse para dar más beneficios a los anfitriones. El ejemplo escogido de Etiopía es solo uno que tiene que multiplicarse por la cantidad de países que hoy lo padecen no solo en África sino también en Asia. América Latina no es la excepción y el disfraz del "doing business" puede tener muchas máscaras.

\footnotetext{
${ }_{9}^{9}$ Declaración final Río+20, ONU, A/conf.216/L.1, Río de Janeiro, 20 al 22 junio 2012.

${ }^{10}$ Mekele Bekele Tekle, Conferencia brindada en el Coloquio de la Academia de Derecho Ambiental de UICN, realizada en la Universidad de Maryland en Baltimore, EE. UU., en 2013.

11 Pueden revisar los informes de desplazamientos en http://www.amnesty.org.es o por igual http://www.hrw.org.es.

${ }^{12}$ Mekele Bekele, Ibíd.
} 


\section{Bibliografía}

Daphne Hewitt, Potential Legality Issues from Forest Conversion Timber, in Forest Trends Report Series, Forest Trade and Finance, Nov. 2013.

González Ballar, Rafael, Penser une democratie alimentaire, Nantes, Larcier, 2013.

Robinson, Nicholas A. "Reflecting on Rio: Environmental Law in the Coming decades", in Environmental Law and Sustainability after Rio, UK, Elgar, 2013.

Peña Chacón Mario, Test de regresividad, San José, 2013. Proyecto de Investigación denominado "Las clínicas del Derecho Ambiental y Gestión de Riesgos Climáticos a través de una cultura jurídica de la sostenibilidad y no regresión", Vicerrectoría de Investigación Universidad de Costa Rica. Test de regresividad ambiental, en Revista Internacional Direito Ambiental (RIDA), número 6, diciembre 2013, Brasil; en Revista Lex, difusión y análisis, noviembre 2013, número 221, México; y en Revista Monfrague, Desarrollo Resiliente, volumen II, número 2, abril 2014, España,

accesible en: http://www.monfragueresiliente.com/numero4/indice4.html.

Mekele Bekele Tekle, Land Grabbing in Ethiopia, 2012. Conferencia impartida en el Coloquio de la Academia de Derecho Ambiental de UICN, realizada en la Universidad de Maryland en Baltimore, EE. UU., 2013.

OMC, Informe sobre el comercio mundial 2010, El comercio de los recursos naturales.

Rautmer, M., Leggett, M, Davis, F. El pequeño libro de las grandes causas de la deforestación. Oxford: Global Company Program, 2013. 



\title{
LA REGRESIÓN EN EL ACCESO AL JUEZ CONSTITUCIONAL PARA LA DEFENSA DEL DERECHO AL AMBIENTE EN COSTA RICA: ¿UNA "DIABOLIZACIÓN" DE LA MATERIA AMBIENTAL EN SEDE CONSTITUCIONAL?
}

\author{
Edgar Fernández Fernández*
}

\section{Introducción}

La Sala Constitucional de la República de Costa Rica, creada en $1989^{1}$, se convirtió desde muy temprano en un baluarte de la tutela del derecho de toda persona a un ambienta sano y ecológicamente equilibrado, el cual la misma Sala reconoció como un derecho fundamental desde antes de su inclusión en el texto del artículo 50 de la Constitución en $1994^{2}$. Múltiples e importantes han sido las sentencias a través de las cuales la Sala le ha brindado contenido y amparo jurídico a este derecho.

El papel así desempeñado por la Sala Constitucional ha sido en gran parte posible gracias a las posibilidades de acceder a ella que ofrecen la Ley de la Jurisdicción Constitucional ${ }^{3}$ y la misma Constitución Política, a la amplísima legitimación reconocida por la Sala a toda persona en casos atinentes a la defensa del derecho al ambiente, así como a los amplios criterios que la Sala ha utilizado para determinar su propia competencia en materia ambiental.

Sin embargo, el rol del juez constitucional en la tutela del derecho a un ambiente sano y ecológicamente equilibrado corre hoy en día un serio riesgo de verse drásticamente disminuido. Por diversas razones, el amplio acceso al juez constitucional ha ido creando anticuerpos tanto a lo externo como a lo interno de la Sala Constitucional, al punto que podríamos preguntarnos si no estamos ante una especie de "diabolización" de la materia ambiental en sede constitucional. Lo anterior se ha manifestado tanto a nivel legislativo, a través de ciertas iniciativas para reformar la Ley de la Jurisdicción Constitucional, como a nivel judicial, a través de posiciones restrictivas asumidas en los últimos años en el seno de la Sala Constitucional, en cuanto a la delimitación de su competencia en materia ambiental.

A través del presente estudio se pretende realizar un breve análisis de estas iniciativas legislativas (I) y posiciones de los magistrados de la Sala Constitucional (II) a la luz del principio de no regresión, el cual, en forma muy resumida y citando a Mario Peña Chacón, podríamos decir que "enuncia que la normativa y la jurisprudencia ambiental no deberían ser revisadas si esto implicare retroceder respecto a los niveles de protección alcanzados con anterioridad"4. )

\footnotetext{
* Doctor en Derecho, Universidad de Nantes. Investigador del Instituto de Investigaciones Jurídicas, Universidad de Costa Rica. Investigador asociado al Institut Ouest : Droit et Europe (IODE), Universidad de Rennes, Francia.

${ }^{1}$ Reforma al artículo 10 de la Constitución Política mediante Ley n. ${ }^{\circ} 7128$ del 18 de agosto de 1989.

${ }^{2}$ Reforma al artículo 50 de la Constitución Política mediante Ley n. ${ }^{\circ} 7412$ del 3 de junio de 1994.

${ }^{3}$ Ley $n .{ }^{\circ} 7135$ del 11 de octubre de 1989.

4 Peña Chacón, Mario, "El Principio de No Regresión Ambiental a la Luz de la Jurisprudencia Constitucional Costarricense", Revista Judicial, No. 103, San José, marzo 2012, p. 143.
} 


\section{La regresión en el acceso al juez constitucional en materia ambiental como consecuencia de iniciativas para reformar la Ley de la Jurisdicción Constitucional}

La Ley de la Jurisdicción Constitucional trajo consigo grandes avances en materia de acceso al juez constitucional respecto de la legislación que derogó. Por ejemplo, se eliminó el requisito de agotamiento previo de la vía administrativa para la presentación de un recurso de amparo, y se introdujeron excepciones a la regla de la existencia de un asunto previo pendiente de resolver ante los tribunales para la presentación de una acción de inconstitucionalidad 5 .

La forma en que está redactada la Ley de la Jurisdicción Constitucional ha permitido a la Sala Constitucional brindar una amplísima legitimación en materia ambiental para la presentación, tanto del recurso de amparo, como de lo que la propia Sala ha llamado "la acción de inconstitucionalidad directa", es decir, aquella cuya presentación no está sujeta a la existencia de un asunto previo pendiente de resolver.

El artículo 33 de esta ley dispone: "Cualquier persona podrá interponer el recurso de amparo". La Sala Constitucional ha sostenido en múltiples sentencias que este artículo no establece una acción popular para el control de la legalidad constitucional. En este sentido, ha aclarado que "cualquier persona" se refiere tanto al agraviado en un derecho constitucional (el titular del derecho lesionado), como a todas aquellas personas que interpongan el recurso a su favor ${ }^{6}$. De ahí que la Sala ha deducido, como regla general, la obligación del recurrente de determinar las personas tuteladas en el recurso (a favor de quién o quiénes lo promueve), y de concretar la existencia de una lesión o amenaza individual o individualizable ${ }^{7}$. Sin embargo, este requisito de la lesión o amenaza individual o individualizable nunca ha sido exigido por la Sala tratándose de casos en los que está de por medio la defensa del derecho a un ambiente sano y ecológicamente equilibrado, por lo que es posible afirmar que en materia ambiental el recurso de amparo sí constituye en realidad una verdadera acción popular.

Por su parte, el artículo 75 de esta misma ley establece como regla general, en su párrafo primero, que "para interponer la acción de inconstitucionalidad es necesario que exista un asunto pendiente de resolver ante los tribunales, inclusive de hábeas corpus o de amparo, o en el procedimiento para agotar la vía administrativa, en que se invoque esa inconstitucionalidad como medio razonable de amparar el derecho o interés que se considera lesionado". Sin embargo, seguidamente, en sus párrafos segundo y tercero, establece excepciones a esta regla. El párrafo segundo dispone: "No será necesario el caso previo pendiente de resolución cuando por la naturaleza del asunto no exista lesión individual y directa, o se trate de la defensa de intereses difusos, o que atañen a la colectividad en su conjunto". Finalmente, el párrafo tercero reza: "Tampoco la necesitarán el Contralor General de la República, el Procurador General de la República, el Fiscal General de la República y el Defensor de los Habitantes". Igual que lo ha hecho para el recurso de amparo, la Sala Constitucional ha indicado que tratándose de la acción de inconstitucionalidad la Ley de la Jurisdicción Constitucional tampoco previó una especie de acción popular; esto por cuanto para la presentación directa de la acción debe estarse en presencia de alguna de las excepciones establecidas en este artículo. Sin embargo, tratándose de asuntos en los que está de por medio el derecho a un ambiente sano y ecológicamente equilibrado, también podríamos decir que existe en realidad una especie de acción popular, ya que la Sala siempre ha reconocido

\footnotetext{
${ }^{5}$ Sobre la ampliación de las posibilidades de presentar la acción de inconstitucionalidad con respecto a la legislación anterior, ver la sentencia $n .^{\circ} 234-90$ de las 14:00 horas del 28 de febrero de 1990, citada por sentencia $n .^{\circ} 2001-7609$ de las 14:36 horas del 8 de agosto de 2001.

${ }^{6}$ Ver votos $93-90,2001-11338$ y $2004-13706$, entre otros.

${ }^{7}$ Ver voto $2005-6002$.
} 
que en estos casos se está ante alguna de las excepciones que establece el párrafo segundo del artículo 75: ya sea la defensa de intereses difusos, o la defensa de intereses que atañen a la colectividad en su conjunto.

La ampliación de las posibilidades de acceso al juez constitucional que se dio con la promulgación de la Ley de la Jurisdicción Constitucional, así como el reconocimiento de una amplísima legitimación para acceder al mismo en materia ambiental, han sido grandemente aprovechados por la población para la defensa de sus derechos fundamentales, tal como lo demuestran las estadísticas de la Sala Constitucional ${ }^{8}$. Sin embargo, la Sala ha sido víctima de su propio éxito: la gran cantidad de casos que recibe le ha causado evidentes problemas prácticos, por lo que ha debido tomar medidas internas de organización para poder adaptarse a las circunstancias y brindar la más rápida y eficiente tutela posible de dichos derechos.

Por otra parte, es claro también que el fácil acceso de cualquier persona a la jurisdicción constitucional para la defensa del derecho a un ambiente sano y ecológicamente equilibrado, así como la efectiva tutela de este derecho por parte de la Sala Constitucional, han incomodado a ciertos grupos económicos y políticos, quienes perciben esta situación como un obstáculo y un freno a sus proyectos e intereses.

Es en este marco que varios proyectos de ley han sido presentados ante la Asamblea Legislativa, bajo el argumento de querer descongestionar y agilizar la jurisdicción constitucional $9^{9}$. En dos de estos proyectos, las propuestas se han limitado al traslado de la competencia para resolver los recursos de hábeas corpus y de amparo a otros tribunales diferentes a la Sala Constitucional ${ }^{10}$, o a la creación de dos secciones a lo interno de la propia Sala Constitucional, con competencia exclusiva para resolver amparos y hábeas corpus ${ }^{11}$. Sin embargo, otros dos proyectos de ley han incluido propuestas dirigidas a limitar el acceso a la jurisdicción constitucional. Se trata de los proyectos n..$^{\circ} 13225$ y n. ${ }^{\circ} 17743$, ambos presentados por el Diputado Luis Fishman Zonzinski, el 23 de julio de 1998, y el 2 de junio de 2010, respectivamente. El proyecto $n .{ }^{\circ} 13225$, antecedente del proyecto $n .^{\circ} 17743$, fue archivado el 16 de julio de 2002, por lo que nos avocaremos de seguido únicamente al análisis del proyecto n. ${ }^{\circ} 17743$, el cual se encuentra aún en la corriente legislativa. El proyecto de ley n. ${ }^{\circ} 17743$ ha tenido hasta el momento tres textos sustitutivos, por lo que partiremos del análisis del texto base y lo compararemos con el último texto sustitutivo, de fecha 30 de abril de 2013.

Si bien el texto base del proyecto de ley n. ${ }^{\circ} 17743$ no hizo en ningún momento referencia expresa a la materia ambiental, pareciera que una de sus intenciones fue la de limitar el acceso al juez constitucional en esta materia, ya que no se previó ninguna salvaguardia al respecto.

Una de las formas de limitar el acceso al juez constitucional propuestas en el texto base del proyecto de ley $n .^{\circ} 17743$, y que constituye una clara regresión tratándose no sólo de la materia ambiental sino también de los derechos fundamentales en general, es el restablecimiento del agotamiento previo de la vía administrativa como requisito para poder presentar el recurso de amparo. En efecto, la propuesta de reforma al artículo 30 de la Ley de

\footnotetext{
${ }^{8}$ Entre 1989 y 2013, fueron presentados a la Sala Constitucional un total de 209,641 casos, de los cuales 185,974 corresponden a recursos de amparo, y 4,206 a acciones de inconstitucionalidad. http://sitios.poder-judicial.go.cr/salaconstitucional/estadisticas.htm. Consultado el 18 de junio de 2014.

${ }^{9}$ En esta línea, podemos mencionar los proyectos de ley $n .{ }^{\circ} 13225$, denominado "Reforma a varios artículos de la Ley n. ${ }^{\circ} 7135$, de jurisdicción constitucional y otras disposiciones del 11 de octubre de 1989", n. ${ }^{\circ} 16791$, denominado "Reforma del artículo 4 de la Ley de la Jurisdicción Constitucional", n. ${ }^{\circ}$ 17743, denominado "Ley de reforma de la jurisdicción constitucional", y n.` 17926, denominado "Reforma del tratamiento de la jurisdicción constitucional en la Constitución Política".

${ }^{10}$ Proyecto de ley n. ${ }^{\circ} 17926$, denominado "Reforma del tratamiento de la jurisdicción constitucional en la Constitución Política".

11 Proyecto de ley n. ${ }^{\circ}$ 16791, denominado "Reforma del artículo 4 de la Ley de la Jurisdicción Constitucional".
} 
la Jurisdicción Constitucional incluyó, entre los casos en los que no procede el amparo, aquéllos en los que "el recurrente no haya agotado la vía administrativa". En la exposición de motivos se indica que esta "oportunidad" que se le da "al administrado de encontrar remedio de su queja ante el propio jerarca administrativo" es una de las dos soluciones conjuntas que se propone ante "la carencia de elementos de selección a la hora de admitir recursos", la cual "ha tenido como consecuencia que la resolución de aquellos asuntos donde realmente se requiere la acción inmediata de la justicia constitucional, deba ser retrasada para atender gestiones estériles y temerarias". La otra solución, según la exposición de motivos, es "la oportunidad" que se le brinda a la Sala Constitucional "de darle prioridad a los asuntos verdaderamente urgentes, pues se admite que el administrado pueda acudir directamente a la jurisdicción constitucional, cuando estime que su caso tiene esa característica". En este sentido, el texto base del proyecto de ley incluyó en la propuesta de reforma del artículo 31 de la Ley, entre las excepciones al requisito del agotamiento previo de la vía administrativa, los casos en que "al recurrente le amenacen de manera cierta e inminente daños o perjuicios graves de imposible $o$ difícil reparación, a juicio de la sección competente o del Pleno en caso de avocación". Si bien podría interpretarse que, por la trascendencia del ambiente para el ser humano y por las características del daño ambiental, cualquier violación al derecho a un ambiente sano y ecológicamente equilibrado constituye una amenaza de "daños o perjuicios graves de imposible o difícil reparación", ello constituye precisamente un asunto de interpretación. La regresión existiría siempre entonces, ya que se crea un requisito de admisibilidad - que no existía anteriormente - para acceder en forma directa al juez constitucional por la vía del recurso de amparo. Hemos de resaltar el hecho de que en el último texto sustitutivo de este proyecto de ley no aparece propuesta alguna para reformar los artículos 30 y 31 de la Ley, ni para restablecer el requisito del agotamiento previo de la vía administrativa.

También constituye una regresión en el acceso al juez constitucional en materia ambiental la redacción propuesta por el texto base del proyecto de ley $n .^{\circ} 17743$ al artículo 33 de la Ley de la Jurisdicción Constitucional: "El recurso deberá presentarlo el agraviado, salvo que razones calificadas le impidan hacerlo. En este último caso, cualquier persona podrá hacerlo en su nombre, pero el interesado deberá comparecer en el proceso y manifestar su interés en la prosecución del mismo, dentro de los quince días hábiles posteriores a que cese el motivo de impedimento". En efecto, la manera en que está redactada esta disposición pareciera partir del supuesto de que el agraviado sólo puede ser un individuo, y que por lo tanto el daño a amenaza debe poder ser individualizado. De esta forma, pareciera que se ignora deliberadamente el hecho de que la Sala Constitucional ha calificado reiteradamente la protección del ambiente como un interés difuso, y algunas veces incluso más allá que eso, como un interés que atañe a la colectividad nacional en su conjunto, y que por lo tanto en materia ambiental el daño o amenaza no siempre puede ser individualizado. Resaltamos sin embargo el hecho de que en el último texto sustitutivo de este proyecto de ley no se propone reforma alguna al artículo 33 de la Ley.

Finalmente, constituye también una clara regresión en el acceso al juez constitucional en materia ambiental, la propuesta de reforma al artículo 75 de la Ley de la Jurisdicción Constitucional contenida en el texto base del proyecto de ley $n .^{\circ} 17743$, puesto que elimina dos de las tres excepciones que el párrafo segundo del artículo 75 de la Ley establece a la regla de la existencia de un asunto previo pendiente de resolver ante los tribunales para la interposición de la acción de inconstitucionalidad: "la defensa de intereses difusos, o que atañen a la colectividad en su conjunto". En efecto, el texto base propone como redacción del párrafo segundo de este artículo: "No será necesario el caso previo pendiente de resolución cuando por la naturaleza del asunto no exista lesión individual y directa". Sin embargo, se aprecia que en el último texto sustitutivo de este proyecto de ley, si bien es cierto siempre se reforma el artículo 75 de la Ley, se mantienen las tres excepciones contenidas actualmente en su párrafo segundo, con idéntica redacción. 
Pero la regresión en el acceso al juez constitucional para la defensa del ambiente puede darse no sólo a través de la modificación de normas directamente relacionadas con la legitimación y los requisitos de admisibilidad de una acción o recurso, sino también a través de reformas que tengan la consecuencia de desincentivar dicho acceso. En este sentido, el texto base de este proyecto de ley proponía una reforma que tenía la intención, clara y manifiesta, de actuar como un desincentivo.

En efecto, el texto base proponía una reforma al artículo 41 de la Ley con el fin de desincentivar la presentación "temeraria" y "de mala fe" de recursos de amparo. Esta intención se expresa claramente en la exposición de motivos: "En primer lugar, la ley actual dispone que la suspensión del acto administrativo impugnado de inconstitucionalidad opera de pleno derecho, luego de admitido el recurso de amparo. Esto ha provocado que algunos litigantes actúen de mala fe y planteen recursos de amparo carentes de sustento, con el objeto único de paralizar a la Administración. Esto se facilita, por cuanto la ley actual no contempla la condenatoria en costas por actuaciones temerarias. Se propone por ello invertir el proceso del artículo 41 para que la suspensión del acto o norma administrativa impugnada solo opere excepcionalmente, cuando al amparado le perjudiquen o amenacen de manera cierta e inminente graves daños o perjuicios de imposible o muy difícil reparación". Una reforma al artículo 41 de la Ley de la Jurisdicción Constitucional en el sentido que lo indica la exposición de motivos del texto base, no necesariamente constituiría una regresión en el acceso al juez constitucional en materia ambiental, ya que podría discutirse si ello tiene o no la consecuencia de desincentivar dicho acceso. Sin embargo, tal reforma podría eventualmente implicar otro tipo de regresiones en materia ambiental y de derechos fundamentales en general, en el caso en que, por la redacción que se le dé a dicho artículo, se vuelva muy difícil o casi imposible obtener la suspensión del acto que viola o amenaza de violar tales derechos, así como la obtención de otras medidas cautelares que garanticen - citando la redacción actual del artículo 41 - que no se haga "ilusorio el efecto de una eventual resolución del recurso a su favor"; sin embargo ello no entra en el objeto del presente trabajo. Por otra parte, notamos que el último texto sustitutivo del proyecto de ley mantiene la reforma al artículo 41 de la Ley en el mismo sentido del texto base.

En otro orden de ideas, la "condenatoria en costas por actuaciones temerarias" a la que se hace mención en el extracto recién citado de la exposición de motivos del texto base, constituye sin lugar a dudas un desincentivo al acceso al juez constitucional. Sin embargo, dicho texto base propuso una reforma en ese sentido únicamente tratándose del recurso de hábeas corpus - artículo 26 de la Ley -, por lo que dejó por fuera el recurso de amparo. Por su parte, el último texto sustitutivo no contiene ninguna propuesta de reforma de este tipo, para ningún tipo de recurso.

Una última posible regresión en el acceso al juez constitucional en materia ambiental se encuentra en la reforma propuesta por el texto base del proyecto de ley al artículo 30 de la Ley, pues se incluye entre los casos en los que no procede el amparo: "f) Cuando solo se alegue la inobservancia, violación o errónea interpretación de normas de rango legal'. En efecto, es bien sabido que en ocasiones la Sala Constitucional ha aceptado entrar a conocer recursos de amparo en los que - retomando la redacción propuesta - únicamente se alega la inobservancia, violación o errónea interpretación de normas de rango legal, cuando esta situación conlleva la violación o amenaza al derecho fundamental a un ambiente sano y ecológicamente equilibrado. La Sala ha actuado así con base en la facultad exclusiva que le otorga el artículo 7 de esta ley para resolver sobre su propia competencia. El citado inciso f) propuesto por el texto base del proyecto de ley busca claramente limitar esta facultad otorgada por el artículo 7 de la ley, lo cual constituiría una regresión en el sentido de que se elimina la posibilidad de que la Sala Constitucional valore en casos concretos admitir recursos de amparo para su estudio a pesar de que sólo se invoca la inobservancia, violación o errónea 
interpretación de normas de rango legal. En todo caso, observamos que tal propuesta de reforma no aparece en el último texto sustitutivo de este proyecto de ley.

En conclusión, pareciera entonces que en el último texto sustitutivo del proyecto de ley $n .^{\circ}$ 17743 se han eliminado la casi totalidad de propuestas de reformas a la Ley de la Jurisdicción Constitucional, contenidas originalmente en el texto base, que podrían implicar una regresión en el acceso al juez constitucional en materia ambiental.

\section{La regresión en el acceso al juez constitucional en materia ambiental ante criterios restrictivos de los magistrados para delimitar la competencia de la Sala Constitucional}

Desde sus primeras sentencias, la Sala Constitucional ha establecido criterios para determinar su competencia, de manera a distinguir entre los casos que deben ser de su conocimiento y los que deben ser resueltos en la vía de legalidad ordinaria; lo anterior en aplicación del artículo 7 de la Ley de la Jurisdicción Constitucional, el cual dispone: "Le corresponde exclusivamente a la Sala Constitucional resolver sobre su propia competencia (...)". La determinación de su competencia en casos concretos muchas veces ha sido sui generis, pues conforme al artículo 13 de esta ley, "la jurisprudencia y los precedentes de la jurisdicción constitucional son vinculantes erga omnes, salvo para sí misma".

Tratándose de recursos de amparo, en no pocas ocasiones la Sala ha asumido una posición amplia, aceptando conocer asuntos en los que están de por medio infracciones a normas legales o reglamentarias, debido al vínculo de estas infracciones con la lesión a algún derecho fundamental, como el derecho a un ambiente sano y ecológicamente equilibrado. Esta tendencia se daba de forma más pacífica antes de que el Código Procesal Contencioso Administrativo entrara en vigencia, el primero de enero de 2008 (A). Empero, a partir de este acontecimiento, y con el argumento de que el nuevo Código establecía un procedimiento mucho más expedito que el de la derogada Ley Reguladora de la Jurisdicción Contencioso Administrativa, la Sala empezó a asumir una posición más restrictiva acerca de su competencia, enviando más fácilmente a la vía ordinaria asuntos en los cuales la lesión de un derecho fundamental se alegaba como consecuencia de la inobservancia de una ley o decreto (B). Más recientemente, algunos magistrados propietarios de la Sala Constitucional han adoptado una posición todavía más extrema, pretendiendo que el conocimiento de los asuntos ambientales por parte de la esta Sala sea algo excepcional (C).

\subsection{La adopción de criterios amplios anterior a la entrada en vigencia del Código Procesal Contencioso Administrativo}

Salvo algunas excepciones, el período anterior a la entrada en vigencia del Código Procesal Contencioso Administrativo, el primero de enero de 2008, se caracterizó por la utilización de criterios amplios por parte de la Sala Constitucional para determinar su competencia en materia ambiental, aceptando entrar a conocer aspectos de legalidad por su relación directa con la tutela del derecho a un ambiente sano y ecológicamente equilibrado.

En algunas sentencias, uno de los argumentos brindados por la Sala para aceptar entrar a conocer asuntos relacionados con el derecho al ambiente en especial, y con derechos fundamentales en general, aún cuando involucren aspectos de legalidad, es la idoneidad del proceso de amparo para la protección de este tipo de derechos debido a la "tutela expedita" que este proceso, por su carácter sumario, garantiza. Un ejemplo de ello lo constituye el Considerando II de la sentencia $n .^{\circ} 2000-10466^{12}$, por medio de la cual la Sala resolvió un

\footnotetext{
${ }^{12}$ Sala Constitucional, sentencia n. ${ }^{\circ} 2000-10466$ de las 10:17 horas del 24 de noviembre de 2000.
} 
recurso de amparo en el que los recurrentes reclamaban, entre otros, que el procedimiento administrativo que desembocó en el otorgamiento de una concesión de aguas a una compañía privada resultaba abiertamente lesivo a los principios que integran el debido proceso, lo que incidía en su derecho a un ambiente sano y ecológicamente equilibrado ${ }^{13}$ : "La Sala estima que los aspectos que plantean los recurrentes y que se relacionan con el medio ambiente deben ser resueltos por este tribunal, ya que es esta la vía creada por la Constitución para la tutela de los derechos fundamentales que se alegan amenazados; estos derechos, por su especialidad, requieren de una tutela expedita que sólo puede garantizar el proceso sumario del amparo ${ }^{14}$. El tema que se plantea, además, por la naturaleza de los bienes que están involucrados: el recurso hídrico y su aprovechamiento - bienes demaniales y de la Nación -, es de la mayor relevancia constitucional y los aspectos de legalidad relacionados con este tema deben, necesariamente, ser examinados en el amparo, en tanto tienen relación directa con las tutelas del orden fundamental, sin que sea admisible calificar el conflicto planteado de mera legalidad (...)".

En otras sentencias, la única justificación brindada por la Sala para entrar a conocer aspectos de legalidad en la vía del amparo fue la vinculación de éstos con la lesión a un derecho fundamental, en este caso el derecho a un ambiente sano y ecológicamente equilibrado, omitiendo hacer referencia al carácter sumario y a la "tutela expedita" del proceso de amparo. Un ejemplo de ello es la sentencia $n .^{\circ} 2001-2074^{15}$, por medio de la cual se resolvió un recurso de amparo en el que los recurrentes reclamaban que el Ministerio de Hacienda había infringido "su obligación de asignar en el Presupuesto de la República los recursos que corresponden a los programas forestales en virtud de lo dispuesto por el artículo 69 de la Ley $n .^{\circ} 7575$ (Ley Forestal) y el artículo 32 de la Ley n. ${ }^{\circ} 7798$ (Ley de Creación del Consejo Nacional de Viabilidad), es decir, un tercio del total recaudado anualmente por concepto del impuesto selectivo de consumo con el que se grava a los combustibles y otros hidrocarburos" ${ }^{\prime 16}$. Al respecto, la Sala indicó que "en principio se podría afirmar que lo discutido se refiere a la violación de normas legales sustantivas en relación con las normas de presupuesto, lo que constituye una cuestión de legalidad, que debe ser discutida en otras instancias y no en la vía de amparo ante esta Sala. Sin embargo, debe tenerse presente que en reiteradas ocasiones ha dicho la Sala que "en la vía del amparo, sólo cabe aducir la violación del principio de legalidad cuando ello se haga de manera concomitante con la de algún otro derecho o garantía fundamental" (resolución No 1547-98 del 6 de marzo de 1998) ${ }^{17}$. En este sentido, los asuntos sometidos a conocimiento de esta Sala, si bien pueden hacer referencia al incumplimiento de determinada normativa de naturaleza infraconstitucional, deben implicar necesariamente una lesión a las libertades o derechos fundamentales protegidos por la Constitución. En este caso, se alega que la asignación de recursos establecida en las normas sobre la materia es fundamental para darle seguimiento a las medidas que se han adoptado para restaurar $y$ proteger los valiosos bosques que se han visto enfrentados a un proceso desmedido de deforestación. Desde ese punto de vista, en tanto el incumplimiento en la asignación de

\footnotetext{
${ }^{13}$ Considerando I.

${ }^{14}$ En términos más generales pero en este mismo sentido, en sentencia n. ${ }^{\circ}$ 3705-93 de las 15:00 horas del 30 de junio de 1993, la Sala Constitucional se refirió a la jurisdicción constitucional "como medio jurídicamente idóneo y necesario para garantizar la supremacía del derecho de la Constitución".

${ }^{15}$ Sala Constitucional, sentencia n. ${ }^{\circ} 2001-2074$ de las 8:51 horas del 16 de marzo de 2001.

${ }^{16}$ Considerando II.

${ }^{17}$ En la citada sentencia n. ${ }^{\circ}$ 1547-98, por medio de la cual se resolvió un recurso de amparo que no tenía relación alguna con la materia ambiental, y en el cual el único derecho constitucional que el actor citó como infringido fue el llamado principio de legalidad de las actuaciones administrativas, establecido en el artículo 11 de la Constitución, la Sala justificó su incompetencia para conocer el asunto en el hecho que la intención del recurso de amparo "(...) no es la de servir como un instrumento genérico para garantizar el derecho de legalidad (...)", sino exclusivamente la de "asegurar la vigencia de los derechos y libertades fundamentales que enuncia la Carta Política, salvo los protegidos por el hábeas corpus".
} 
recursos para el sector forestal lesiona las posibilidades de hacer efectivo el derecho de toda persona a gozar de un ambiente sano y ecológicamente equilibrado que protege el artículo 50 constitucional, el asunto discutido se logra enmarcar dentro del ámbito de competencia de este Tribunal de garantías fundamentales." ${ }^{\text {18 }}$ (la negrita es del original) (...) "De todo lo expuesto se concluye que la negación de los recursos económicos que por ley le corresponden a los programas de protección y restauración forestal conlleva una infracción a los postulados del artículo 50 de la Constitución Política, y por ello se trata de un asunto que rebasa sensiblemente lo que pudiera estimarse como un mero incumplimiento legal, para adquirir relevancia constitucional, toda vez que implica la inobservancia por parte del Estado de la obligación que expresamente le impone esa norma en el sentido de garantizar, defender, y preservar el derecho de toda persona a gozar de un ambiente sano $y$ ecológicamente equilibrado"19 (la negrita es del original). Las anteriores consideraciones fueron incluso utilizadas por la Sala como justificación para entrar a analizar la conformidad de un decreto ejecutivo con normas de rango legal, en el marco de la acción de inconstitucionalidad contra el Decreto 31750-MINAE-TUR del 22 de abril de $2004^{20}$.

Otro ejemplo similar al anterior es la sentencia n. ${ }^{\circ} 2001-13294^{21}$, a través de la cual la Sala Constitucional resolvió un recurso de amparo contra la adjudicación de bloques de exploración petrolera a una empresa privada. En el Considerando II de esta sentencia, la Sala indicó: "Valga aclarar también que esta Sala se pronuncia sobre las alegaciones de la recurrente en la medida en que esas supuestas violaciones lesionen un derecho fundamental. Al contrario, si los errores no violan, en el caso concreto, derecho fundamental alguno, estamos ante un vicio de mera legalidad que se debe atacar en la vía correspondiente".

Bajo esta lógica, en múltiples ocasiones la Sala Constitucional ha hecho de su conocimiento cualquier tipo de asunto en el que las actuaciones administrativas podrían conllevar una lesión o amenaza a alguno de los principios que la Sala Constitucional ha derivado del derecho fundamental a un ambiente sano y ecológicamente equilibrado, establecido en el artículo 50 de la Constitución Política. Al respecto, es importante referirse a la sentencia n. ${ }^{\circ}$ 2003-6322 de las 14:14 horas del 3 de julio de 2003, en la cual, bajo el título de "parámetros constitucionales para el uso y disposición del ambiente", la Sala Constitucional realizó una enumeración abierta de principios rectores que garantizan la tutela efectiva del derecho a un ambiente sano y ecológicamente equilibrado, y que se pueden derivar de la doctrina, normativa vigente y jurisprudencia constitucional. Se trata de los siguientes: 1. La tutela del derecho ambiental a cargo del Estado; 2. El principio de uso racional de los recursos, a fin de que exista un equilibrio entre el desarrollo del país y el derecho al ambiente; 3. El principio de calidad ambiental; 4. El principio precautorio; 5 . La realización del estudio de impacto ambiental previo a la iniciación de obras; 6 . Sólo el estado de necesidad declarado excepciona el cumplimiento de las normas ambientales; 7 . La falta de recursos económicos de las instituciones públicas no es excusa que justifique la omisión de dar protección al derecho ambiental; 8. Coordinación entre diversas dependencias públicas a fin de garantizar la protección del medio ambiente; 9. La lesión a este derecho ambiental se da tanto por acción como por omisión; 10. No opera el silencio positivo en materia de utilización de recursos naturales; y 11. Participación ciudadana en los asuntos ambientales.

\footnotetext{
${ }^{18}$ Considerando II.

${ }^{19}$ Considerando III.

20 Sala Constitucional, sentencia n. ${ }^{\circ} 2008-16975$ de las 14:53 horas del 12 de noviembre de 2008: "Aunque la infracción de un Decreto a textos de Ley se ubica, en principio, en el plano de legalidad, cuando la misma afecta a la vez derechos fundamentales, como sería el derecho a un medio ambiente adecuado, el vicio trasciende a la esfera constitucional y adquiere esa connotación (SALA CONSTITUCIONAL, sentencias números 459-91, 3550-91 y 4702-93, 2001- 02074, entre otros). Concretamente, en la sentencia número 2001-02074, la Sala consideró que: (...)”.

${ }^{21}$ Sala Constitucional, sentencia n. ${ }^{\circ}$ 2001-13294 de las 12:05 horas del 21 de diciembre de 2001.
} 
Un caso interesante es el de la sentencia $n \cdot{ }^{\circ} 2001-13294^{22}$, anteriormente citada, puesto que la Sala Constitucional entró a evaluar el otorgamiento de una concesión - en la especie de exploración petrolera - a pesar de haber sido otorgada en cumplimiento de lo dispuesto en la ley sectorial respectiva - la Ley de Hidrocarburos -. Concretamente, analizó si con dicho otorgamiento se había violentado el principio de la tutela del derecho ambiental a cargo del Estado, específicamente en cuanto el mismo implica acciones positivas por parte del mismo. Como resultado, la Sala reprochó al Ministerio del Ambiente y Energía el haberse circunscrito a la letra de la Ley de Hidrocarburos, limitándose a verificar la existencia y aprobación, por parte de la Secretaría Técnica Nacional Ambiental (SETENA), de un estudio de impacto ambiental, en lugar de haberla trascendido para garantizar el derecho a un ambiente sano y ecológicamente equilibrado. Ello por cuanto del informe brindado por la Ministra de Ambiente y Energía se desprendía claramente que en el proceso de licitación no fueron tomados en consideración aspectos regulados en disposiciones jurídicas de mayor rango que la misma ley, como los convenios internacionales aprobados por el país; por ejemplo: si existen o no comunidades indígenas en los bloques adjudicados, si se ha tenido en cuenta o no la existencia de parques nacionales $u$ otras áreas protegidas en esos bloques, o la incidencia que en el futuro pueda tener la eventual explotación comercial de hidrocarburos. Adicionalmente, basándose en dos informes de la Contraloría General de la República y de la Defensoría de los Habitantes, la Sala cuestionó la capacidad técnica, administrativa y financiera de la SETENA para cumplir su función en el marco de la evaluación de impacto ambiental. La Sala aclaró que este tipo de consideraciones eran de tipo jurídico, no técnico, por lo que ella podía realizarlas en la vía del amparo: "No corresponde a este tribunal evaluar técnicamente el impacto ambiental de la actividad de extracción de hidrocarburos: el recurso de amparo no es una vía plena que tenga a disposición los medios probatorios necesarios para tal cometido. Sin embargo, el artículo 50 de la Constitución Política ordena al Estado que garantice el derecho a un ambiente sano. Tal obligación implica que el Estado debe tomar todas las medidas técnicas posibles para asegurarse de que la actividad que aprueba no causará daños al ambiente. Si bien el pronunciamiento del órgano estatal encargado es en sí un asunto técnico, el deber de pronunciarse y la exigencia de rigurosidad es un asunto jurídico. En términos generales, el deber estatal de garantizar el derecho a un ambiente sano no se reduce a satisfacer un simple requisito (...) dentro del proceso licitatorio. La constitución no exige sólo cumplir con ciertas formalidades, sino utilizar todos los medios jurídica y fácticamente posibles para preservar el ambiente" ${ }^{\prime 23}$.

De las anteriores consideraciones de la Sala Constitucional saltan a la vista dos criterios importantes para delimitar su competencia en materia ambiental. En primer lugar, la Sala Constitucional no puede entrar a evaluar criterios técnicos. Esta imposibilidad se deriva de la forma en que está diseñado el proceso de amparo, la cual responde a su naturaleza sumaria para la tutela expedita de los derechos fundamentales. Este diseño del proceso de amparo constituye entonces a la vez una garantía para la tutela de los derechos fundamentales, y un límite intrínseco - sobre el cual profundizaremos más adelante - para tratar cualquier asunto en el que medie una lesión a un derecho de este tipo. En segundo lugar, la obligación a cargo del Estado de garantizar, defender y preservar el derecho de todos a un ambiente sano y ecológicamente equilibrado, establecida en el párrafo tercero del artículo 50 de la Constitución Política, implica una tutela real, no meramente formal, por lo que para su respeto no basta con

\footnotetext{
${ }^{22}$ Sala Constitucional, sentencia n. ${ }^{\circ}$ 2001-13294 de las 12:05 horas del 21 de diciembre de 2001.

${ }^{23}$ Estas afirmaciones fueron retomadas por la Sala en el Considerando V de su sentencia n. ${ }^{\circ}$ 2001-13295 de las 12:07 horas del 21 de diciembre de 2001. Además, en este mismo sentido, en diferentes sentencias, como por ejemplo la n. ${ }^{\circ} 2005-16967$ de las 8:56 horas del 9 de diciembre de 2005 y la n. ${ }^{\circ}$ 2011-3951 de las 18:07 horas del 23 de marzo de 2011, la Sala Constitucional afirmó: "el papel del juez constitucional no puede extenderse al de verificador de los criterios técnicos dados por las autoridades administrativas en materia ambiental, sino que deberá limitarse a constatar si las dependencias estatales competentes han cumplido la obligación que les impone el artículo 50 de la Constitución Política".
} 
cumplir con los requisitos establecidos en las leyes y reglamentos. Dicha obligación requiere una actitud proactiva, responsable, y eficaz por parte del Estado, de acuerdo a los requerimientos que ha definido la Sala Constitucional ${ }^{24}$. Por ello, como en este caso, la Sala, dentro de los límites intrínsecos del proceso de amparo, debería entrar a verificar si el Estado ha tenido tal actitud. Es en este contexto que debería interpretarse entonces la siguiente afirmación realizada por la Sala Constitucional en sentencia n. ${ }^{\circ}$ 2000-9513 de las 9:25 horas del 27 de octubre de 2000: "la competencia de esta Sala, entonces, queda limitada a la verificación de la existencia de un estudio de impacto ambiental de previo a la realización del proyecto" $^{\prime 25}$. De lo contrario, no habría manera para la Sala de verificar si el Estado cumplió con su deber de tutela del derecho ambiental, más allá de la simple satisfacción de ciertas formalidades.

A partir de la constatación de la existencia de límites intrínsecos en el proceso de amparo, la Sala ha elaborado criterios - no siempre muy claros - para describir el tipo de lesión o amenaza a un derecho fundamental que es revisable en esta vía. Es el caso, por ejemplo, de la exigencia que la lesión o amenaza sea directa y grosera, y revista además un carácter apremiante. Al respecto, a partir de su sentencia n. ${ }^{\circ}$ 3484-98 de las 16:51 horas del 27 de mayo de 1998, la Sala ha repetido cientos de veces, en términos más o menos similares: "En general, la procedencia del recurso de amparo está condicionada no sólo a que se acredite la existencia de una turbación, o amenaza de turbación, a uno de los derechos o garantías contemplados en la Carta Política o los instrumentos internacionales de derechos humanos suscritos por el país; sino que, además, se trate de una amenaza o quebranto directo y grosero, que por su carácter apremiante no permita esperar a que surtan efecto los remedios jurisdiccionales ordinarios. Esta última circunstancia pone de relieve el carácter eminentemente sumario del proceso de amparo, cuya tramitación no se aviene bien con la práctica de diligencias probatorias lentas y complejas, o con la necesidad de entrar previamente a examinar -con carácter declarativo- si existen en realidad o no derechos de rango infra constitucional que las partes citen como parte del elenco fáctico del recurso de amparo o del informe de ley, según sea el caso. Es evidente que esa es una competencia de la que esta Sala carece" ${ }^{\prime 26}$ (la negrita es del original).

La anterior sentencia pareciera tener su antecedente en la n. ${ }^{\circ} 2806-98$ de las 14:30 horas del 28 de abril de 1998, en la cual la Sala Constitucional indicó que el propósito del proceso de amparo "es el de proveer a quienes vean lesionados o amenazados sus derechos fundamentales de una vía expedita y efectiva para obtener tutela jurisdiccional, sin agotar necesariamente el examen de las cuestiones de hecho o de derecho derivadas del conflicto que se plantea. En pocas palabras, no se trata de sustituir a la jurisdicción ordinaria, que es -

\footnotetext{
${ }^{24} \mathrm{El}$ "deber de pronunciarse" y la "exigencia de rigurosidad", mencionados por la Sala en su sentencia n. 2001-13294, anteriormente citada, fueron reiterados como aspectos jurídicos, no técnicos, que forman parte del deber del Estado de garantizar el derecho a un ambiente sano y ecológicamente equilibrado, en sentencias de esta sala $n .^{\circ} 2004-5934$ de las 11:40 horas del 28 de mayo de $2004, n .^{\circ} 2007-17330$ de las 15:31 horas del 28 de noviembre de 2007, n. ${ }^{\circ} 2010-14180$ de las 14:35 horas del 25 de agosto de 2010, y n. ${ }^{\circ}$ 2011-3951 de las 18:07 horas del 23 de marzo de 2011. Por otra parte, en varias sentencias también, como por ejemplo la n. ${ }^{\circ}$ 2007-17206 de las 15:59 horas del 27 de noviembre de 2007 y la n. ${ }^{\circ}$ 2013-10891 de las 9:30 horas del 16 de agosto de 2013, la Sala Constitucional caracterizó dicha obligación que impone el artículo 50 de la Constitución como una "de asumir una actuación responsable y oportuna respecto a la protección ambiental'.

${ }^{25}$ Esta frase ha sido retomada en varias sentencias, como por ejemplo, la n. ${ }^{\circ} 2006-1576$ de las 15:24 horas del 14 de febrero de 2006.

${ }^{26}$ En el mismo sentido, entre muchas otras, ver la sentencia $n .^{\circ} 2000-3692$ de las 16:44 horas del 2 de mayo de 2000. Del mismo modo, en diversas sentencias, como por ejemplo la n. ${ }^{\circ} 1010-98$ de las 15:30 horas del 17 de febrero de 1998, la Sala Constitucional afirmó que el amparo "es un proceso en el cual no es material ni razonablemente posible entrar a un complicado sistema probatorio o a un análisis de hechos que vayan más allá de los actos impugnados en sí, circunscribiéndose más bien a las hipótesis fácticas en que estos actos se fundan (...)".
} 
en definitiva - la llamada a fallar los casos con la autoridad de la cosa juzgada que a sus sentencias otorgan la Constitución y la ley. Esta es la esencia del deslinde entre la jurisdicción constitucional y la contencioso administrativa, tan comentada en doctrina: el carácter tanto tutelar como sumario - ojalá sumarísimo - del proceso de amparo exige que la lesión constitucional se tenga por configurada ( $y$, consecuentemente, por estimatoria la correspondiente sentencia) ante la constatación de un quebranto directo y grosero de la Carta Fundamental; de modo que si no es viable apreciar una infracción tal, no se puede más que desestimar el recurso y remitir a la parte a que vaya a someter el conflicto al juez de lo contencioso administrativo" (el subrayado es del original). En esta sentencia, la Sala brindó además una definición de lo que debería entenderse por "quebranto directo y grosero": "Bajo esta perspectiva, se entiende que la lesión es directa cuando deriva de la simple "confrontación del texto de la norma o acto cuestionado, de sus efectos, o de su interpretación o aplicación por las autoridades públicas, con las normas y principios constitucionales" (artículo 3 de la Ley de la Jurisdicción Constitucional), sin necesidad de recurrir a otros textos normativos de rango subordinado para apreciar su existencia o valorar su extensión. Paralelamente, la infracción es grosera cuando a simple vista y sin mayor lucubración ofende el contenido o el espíritu de una norma o principio constitucional' (la negrita es del original).

Empero, la sentencia $n .^{\circ} 2806-98$ aparentemente sólo fue citada una vez - en sentencia n. ${ }^{\circ}$ 2008-747 de las 10:47 horas del 18 de enero de 2008 -. En su lugar, a partir de su sentencia n. ${ }^{\circ}$ 2001-135 de las 9:43 horas del 5 de enero de 2001, la Sala Constitucional ha sostenido otro criterio acerca de lo que debe entenderse por lesión o violación directa a un derecho fundamental, susceptible - por este motivo - de ser conocida en el proceso de amparo: " $Y$ este Tribunal ha explicado reiteradamente que para que una violación de un Derecho Fundamental sea susceptible de ser conocida en la vía del amparo, debe ser directa, y con ello, lo que se quiere decir es que no toda presunta violación de un derecho fundamental es idónea para ser discutida en esta vía, sino que, además, ésta debe poner en peligro aquella parte del contenido del derecho que le es esencial y connatural; es decir, esa misma parte que le presta su peculiaridad y lo hace reconocible como derecho perteneciente a un determinado tipo. Se trata del contenido mismo del derecho, el cual es ineludiblemente necesario para que su titular pueda obtener la satisfacción de aquellos intereses para cuya consecución ese derecho se ha otorgado" ${ }^{27}$.

Finalmente, es necesario mencionar que esta exigencia de que la lesión o amenaza al derecho fundamental sea directa pareciera tener su origen en la distinción que, desde muy temprano y con el objeto de delimitar su competencia, la Sala Constitucional realizó entre lesiones - 0 violaciones - directas e indirectas a los derechos fundamentales. La sentencia más citada que estableció esta distinción es la n. ${ }^{\circ} 1610-90$ de las 15:03 horas del 11 de setiembre de $1990^{28}$, aún cuando no las definió ni las diferenció claramente: "En esencia, la idea básica puede estar en la distinción entre la lesión directa y otra indirecta de los derechos fundamentales. En buena doctrina constitucional el criterio se basa en que cualquier infracción aún de legalidad, en cuestiones relacionadas con esos derechos, puede causar eventualmente lesión de aquellos derechos fundamentales, pero cuando se trata de una lesión simplemente indirecta, por existir dentro del aparato estatal, órganos que pueden y deben resguardar ese derecho y reparar sin violación, les corresponde a ellos conocer y no a esta Sala". Esta distinción, cuya citación expresa sólo fue esporádicamente realizada por la Sala Constitucional en los años noventa ${ }^{29}$, fue retomada con fuerza a partir de la sentencia n. ${ }^{\circ}$ 2001-135 de las 9:43 horas del 5 de enero

\footnotetext{
${ }^{27}$ Este desarrollo fue retomado por la Sala, de manera casi idéntica, de su sentencia n. ${ }^{\circ} 2000-7337$ de las 15:05 horas del 22 de agosto de 2000.

${ }^{28}$ Esta sentencia retoma casi exactamente lo afirmado por la misma Sala en sentencia n. ${ }^{\circ} 1593-90$ de las 14:12 horas del 11 de setiembre de 1990 .

${ }^{29}$ Por ejemplo en sentencias n. ${ }^{\circ} 932-91$ de las 15:02 horas del 14 de mayo de 1991, y 2946-95 de las 18 horas del 7 de junio de 1995.
} 
de 2001. No fue sino hasta más recientemente que la Sala realizó expresamente el ligamen entre esta distinción y las ventajas y limitantes propias de la naturaleza sumaria del proceso de amparo. Así por ejemplo, en sentencia n. ${ }^{\circ} 2003-171$ de las 14:53 horas del 14 de enero de 2003, la Sala afirmó: "la jurisprudencia constitucional ha precisado que el problema de las violaciones directas e indirectas a la Constitución involucra, también, una necesaria apreciación de la idoneidad y naturaleza expedita que debe caracterizar a la vía del amparo".

\subsection{La adopción de criterios restrictivos posterior a la entrada en vigencia del Código Procesal Contencioso Administrativo}

A inicios del año 2008, con la entrada en vigencia del Código Procesal Contencioso Administrativo, la Sala Constitucional comenzó a emitir una serie de sentencias en las que adoptaba una posición que podríamos calificar de restrictiva en cuanto a los criterios para admitir asuntos en la vía del amparo. Podemos distinguir dos grupos de sentencias en este sentido: uno que expresamente tenía por blanco la materia ambiental, y otro más general, que no se refería a ninguna materia en específico.

En el primer grupo, compuesto de sentencias que aparentemente son todas del $2008^{30}$, la Sala exponía su nueva posición en dos considerandos. En el primero, la Sala resaltaba las bondades de la reforma al proceso contencioso administrativo, a través de la cual "se establecen o fortalecen los mecanismos procesales tendentes a lograr un control plenario y universal de la función administrativa, a efecto de tutelar los derechos subjetivos y los intereses legítimos - ya sean: difusos, colectivos o corporativos - de toda persona" ${ }^{\prime 1}$. Seguidamente, en un considerando aparte, la Sala exponía su cambio de criterio en cuanto a la determinación de su competencia en materia ambiental. Al respecto, indicaba que "aunque la jurisdicción constitucional -hasta antes del primero de enero del dos mil ocho y ante la carencia de otras vías jurisdiccionales expeditas y eficaces-, ha asumido el conocimiento y resolución de asuntos, en los que si bien es cierto, se alega una violación a lo dispuesto en los párrafos 20. y 3o. del artículo 50 de la Constitución Política, en el fondo implican conflictos cuya resolución exceden la naturaleza sumaria del recurso de amparo, pues implican procesos largos $y$ complejos para determinar: a) si las acciones u omisiones en que presuntamente incurren la Administración Pública o los sujetos de derecho privado, implican una violación a las normas legales, reglamentarias o contenidas en planes reguladores tendentes a garantizar, defender $y$ preservar el derecho fundamental a un ambiente sano y ecológicamente; y b) para establecer en definitiva, si la infracción al ordenamiento jurídico infraconstitucional, tiene o no la virtud de lesionar el derecho fundamental antes señalado", lo cierto es que, partiendo de lo dicho reiteradamente por la Sala Constitucional en cuanto a violaciones directas e indirectas a los derechos fundamentales - cita la sentencia n. ${ }^{\circ} 2006-13048$ de las 14:46 horas del 5 de setiembre de 2000, la cual a su vez cita la n. ${ }^{\circ} 1610-90$ de las 15:03 horas del 9 de diciembre de 1990 -, "si lo planteado a través del recurso de amparo implica una presunta violación indirecta al derecho fundamental a un ambiente sano y ecológicamente equilibrado, que tiene como sustento cualquier infracción por acción u omisión al ordenamiento jurídico infraconstitucional y que por ende, no implica una violación directa al contenido esencial de ese derecho, deberá ser planteada en la vía contencioso administrativa y civil de hacienda (...)".

\footnotetext{
${ }^{30}$ Al realizar una búsqueda en la página de Internet del Sistema Costarricense de Información Jurídica (http://200.91.68.20/SCIJ_PJ/main_jurisprudencia.aspx), encontramos únicamente siete sentencias de este tipo, todas del 2008: 2008-3049 de las 11:07 horas del 29 de febrero de 2008, 2008-4471 de las 17:25 horas del 25 de marzo de 2008, 2008-4646 de las 10:15 horas del 27 de marzo de 2008, 2008-4792 de las 12:41 horas del 27 de marzo de 2008, 2008-9894 de las 15:38 horas del 17 de junio de 2008, 200810309 de las 16:34 horas del 19 de junio de 2008, y 2008-14283 de las 9:58 horas del 26 de setiembre de 2008.

${ }^{31}$ Por ejemplo, sentencias n. ${ }^{\circ} 2008-3049$ de las 11:07 horas del 29 de febrero de 2008, y n. ${ }^{\circ} 2008-9894$ de las 15:38 horas del 17 de junio de 2008.
} 
Paralelamente, también desde el año 2008 y hasta el día de hoy, la Sala Constitucional ha emitido cientos de sentencias en las que, con ocasión de la entrada en vigencia del Código Procesal Contencioso Administrativo, se adopta una posición restrictiva en cuanto a la admisibilidad de recursos de amparo en general, sin referirse específicamente a la materia ambiental $^{32}$. En este grupo de sentencias, el tema es tratado en un solo considerando, titulado "nueva justicia administrativa mecanismo célere y cumplido para la protección de situaciones jurídicas sustanciales de los administrados". En él se indica: "La Sala Constitucional, desde su fundación, ha utilizado criterios amplios de admisibilidad en vista de la ausencia de cauces procesales expeditos y céleres para la protección de las situaciones jurídicas sustanciales que tienen asidero en el ordenamiento jurídico infra-constitucional o parámetro de legalidad, que guardan conexión indirecta con los derechos fundamentales y el Derecho de la Constitución. Sobre el particular, no debe perderse de perspectiva que la Constitución por su supremacía, súper- legalidad y eficacia directa e inmediata da fundamento indirecto a cualquier situación jurídica sustancial imaginable de las personas. No obstante, bajo una mejor ponderación y ante la promulgación del Código Procesal Contencioso- Administrativo (Ley No. 8508 de 24 de abril de 2006) y su entrada en vigencia a partir del $1^{\circ}$ de enero de 2008, ha quedado patente que ahora los justiciables cuentan con una jurisdicción contencioso-administrativa plenaria y universal, sumamente expedita y célere por los diversos mecanismos procesales que incorpora al ordenamiento jurídico esa legislación, tales como (...). Todos esos institutos procesales novedosos tienen por fin y propósito manifiesto alcanzar la economía procesal, la celeridad, la prontitud y la protección efectiva o cumplida de las situaciones jurídicas sustanciales de los administrados, todo con garantía de derechos fundamentales básicos como el debido proceso, la defensa y el contradictorio. En suma, la nueva jurisdicción contencioso-administrativa es un cauce idóneo, por sus nuevas características de simplicidad, celeridad y prontitud para el amparo y protección efectiva de las situaciones jurídicas sustanciales de los administrados en las que se requiera recabar prueba o definir algunas cuestiones de legalidad ordinaria."

A primera vista, podría parecer que ambos grupos de sentencias se limitan a reiterar criterios que ya la Sala Constitucional había sostenido anteriormente, como el de la distinción entre violaciones directas e indirectas a los derechos fundamentales, por lo que podría argumentarse que no establecen criterios más restrictivos que los que la Sala Constitucional había invocado reiteradamente antes de la entrada en vigencia del Código Procesal Contencioso Administrativo. Sin embargo, la restricción, y probablemente la regresión también, de una posición tan simplista, se encuentran en que la Sala misma busca autosuprimirse la posibilidad, que ella misma se había creado, de entrar a conocer casos en los que el recurrente invoca que la inobservancia a un deber legal trae aparejada la violación de un derecho fundamental.

Con esta posición, se corre el riesgo de que, por un simple tecnicismo, la Sala pase por alto claras violaciones a los derechos fundamentales cuya constatación no requiere evacuar mayor prueba, sobre todo en casos en los que los recurrentes mencionan tanto lesiones a estos derechos como infracciones al ordenamiento jurídico infraconstitucional. Un claro ejemplo de ello lo constituyen dos sentencias por medio de las cuales se resolvieron sendos recursos de amparo que fueron interpuestos contra el Poder Ejecutivo por la manera en que fue emitido el Decreto Ejecutivo n. ${ }^{\circ}$ 34456-MP-MIVAH-TUR-MINAE-COM del 9 de abril de 2008 que estableció la "Metodología y Directrices Generales para el Ordenamiento Territorial de la Región Chorotega". El primero fue rechazado de plano mediante sentencia n. ${ }^{\circ} 2008-9894$ de las 15:38 horas del 17 de junio de 2008, mientras que el segundo fue declarado con lugar por sentencia n. ${ }^{\circ}$ 2010-8645 de las 9:09 horas del 14 de mayo de 2010. Lo que más llama la atención, fue que el motivo por el cual el segundo recurso fue declarado con lugar - la falta de

\footnotetext{
${ }^{32}$ Por citar sólo un ejemplo: la sentencia n. ${ }^{\circ} 2008-8690$ de las 8:43 horas del 23 de mayo de 2008. En muchas de estas sentencias, la Sala ha rechazado de plano recursos de amparo relacionados con la violación del derecho a la justicia pronta y cumplida, establecido en el artículo 41 de la Constitución Política.
} 
integración de la variable ambiental en un instrumento de ordenamiento territorial - fue invocado por los recurrentes en ambos recursos. Veamos más de cerca ambos casos. En el primero, las recurrentes alegaron: en primer lugar, que en el trámite de elaboración del "PlanUrbano Territorial de la Región Chorotega”, contenido en el Anexo I del Decreto, se omitió considerar la variable ambiental al punto que nunca se obtuvo la viabilidad ambiental por parte de la SETENA, con lo que se violentaba el artículo 50 de la Constitución Política; en segundo lugar, que al aprobar dicho plan las autoridades recurridas se habían arrogado competencias que por ley le corresponden al Instituto Nacional de Vivienda y Urbanismo (INVU), con lo que se lesionaba el artículo 11 de la Constitución Política; en tercer lugar, que el Poder Ejecutivo había excedido su poder de dirección sobre el INVU al obligarlo a incluir dentro del Plan Regional Urbano de la Región Chorotega las reglas de desarrollo urbano establecidas en el Anexo I, con lo que se violaban los artículos 11 y 188 de la Constitución; y, en cuarto lugar, que las violaciones a los artículos 11 y 188, al haber expuesto al ambiente a daños de gravísimas consecuencias, implicaban igualmente la violación al artículo 50 constitucional. En cuanto al primer punto, las recurrentes invocaron tanto sentencias en las que la Sala Constitucional había identificado como un requisito fundamental el que todo plan regulador del desarrollo urbano debía contar con un examen del impacto ambiental antes de ser aprobado, como disposiciones reglamentarias que constituían el desarrollo de dicho requisito constitucional. A pesar de haberse citado tales sentencias y de haberse alegado que la inobservancia de este requisito constituía una violación al artículo 50, la Sala, de forma muy simplista, indicó como fundamento para rechazar de plano el recurso, en el Considerando III de la sentencia n. ${ }^{\circ} 2008$ 9894: "Partiendo de lo expuesto, como en este caso lo que se pretende con la interposición del amparo, es que esta Sala determine la legalidad del recurrido Decreto Ejecutivo a partir del cumplimiento o no de los requisitos establecidos legalmente para su emisión, a esta Sala no le corresponde establecer si los actos impugnados resultan o no ajustados a Derecho, y por ende, si esa presunta violación al principio de legalidad que plantean las recurrentes tiene o no la virtud de lesionar de manera indirecta lo dispuesto en los párrafos segundo y tercero del artículo 50 de la Constitución Política (...)". Por su parte, en el segundo recurso, el recurrente tuvo el cuidado de omitir cualquier referencia a una lesión al principio de legalidad establecido en el artículo 11 de la Constitución Política, centrándose exclusivamente en la violación al artículo 50 de la Constitución por falta de integración de la variable ambiental. Además, insistió en que la integración de esta variable en materia de planificación u ordenamiento del uso del suelo constituía un desarrollo jurisprudencial que la propia Sala había realizado a partir de lo establecido en el artículo 50. En esta ocasión - contrario a lo indicado en sentencia n. ${ }^{\circ} 2008$ 9894 -, por sentencia n. ${ }^{\circ}$ 2010-8645, la Sala resolvió: "De los autos se desprende que el Plan Urbano-Territorial de la Región Chorotega, Decreto Ejecutivo número 34456-MP-MIVAH-TURMINAE-COM del 09 de abril de 2008, (...), no pasó por el proceso de viabilidad ambiental por parte de la SETENA, de previo a su aprobación. Si bien es cierto, esta Sala observa que en el caso concreto, las autoridades recurridas han hecho un gran esfuerzo por emitir la normativa necesaria, tendiente al ordenamiento del desarrollo urbanístico y territorial de la Región Chorotega, la omisión apuntada constituye una amenaza ilegítima al derecho que asiste al amparado de disfrutar de un ambiente sano y ecológicamente equilibrado, que sí amerita la tutela constitucional por la vía del amparo. Este Tribunal ha señalado en su reiterada jurisprudencia, que la tutela del ambiente es una obligación que le impone la propia Constitución Política al Estado y que ha sido desatendida en esta oportunidad por la Administración Central. En consecuencia, el amparo deviene procedente, por eso se procede a estimarlo, con las consecuencias que de seguido se dirán".

Este caso pone en evidencia que los principios con los que la Sala Constitucional le ha dado contenido al derecho a un ambiente sano y ecológicamente equilibrado existen independientemente de la normativa infraconstitucional que constituye su expresión. Un ejemplo de ello es lo indicado por la Sala en sentencia n. ${ }^{\circ}$ 2004-13414 de las 9:29 horas del 26 
de noviembre de $2004^{33}$, en el sentido de que "el principio preventivo en materia ambiental incorporado al régimen constitucional (sentencia 2001-13295 de las 12:06 horas del 21 de diciembre del 2001) se ve también reforzado por lo dispuesto en el artículo 34 del Código de Minería (...)". Otro ejemplo es la siguiente afirmación realizada por la Sala en sentencia n. ${ }^{\circ}$ 7294-98 de las 16:15 horas del 13 de octubre de 1998: "El principio de razonabilidad, en relación con el derecho fundamental al ambiente, obliga a que las normas que se dicten con respecto a esta materia estén debidamente motivadas en estudios técnicos serios, aún cuando no existiera otra normativa legal que así lo estableciera expresamente. A juicio de este Tribunal Constitucional, la exigencia que contiene el artículo 38 de la Ley Orgánica del Ambiente $N^{\circ}$ 7554 , en el sentido de que para reducir un área silvestre protegida por ley formal deben realizarse, de previo, los estudios técnicos que justifiquen la medida, no es sino la objetivación del principio de razonabilidad en materia de protección al ambiente".

Finalmente, llama la atención que la posición desarrollada por la Sala Constitucional en los grupos de sentencias presentados en este acápite se fundamenta, en gran medida, en una equivalencia bastante simplista entre violaciones indirectas a los derechos fundamentales y procesos largos y complejos. Varios de los ejemplos que hemos presentado más arriba, como la sentencia $n .{ }^{\circ}$ 2001-2074 - por medio de la cual la Sala consideró que el incumplimiento por parte del Ministerio de Hacienda del deber legalmente establecido de asignar recursos para el sector forestal lesiona las posibilidades de hacer efectivo el derecho a un ambiente sano y ecológicamente equilibrado - demuestran que ello no siempre es así. Por ello, en cuanto a la determinación de su competencia se refiere, la Sala haría bien en discriminar caso por caso en lugar de establecer categorías generales.

En ciertos casos, la inaptitud del proceso de amparo para la evacuación de la prueba necesaria a la constatación de la violación o amenaza a un derecho fundamental alegada puede ser evidente desde que se valora el asunto para su admisión, por lo que en estos casos el recurso podría ser rechazado de plano por inadmisible. Sin embargo, en otros casos en los que la inaptitud no es tan evidente, lo más sano y favorable a la tutela de los derechos fundamentales por parte de la jurisdicción constitucional podría ser admitir el recurso de amparo para su conocimiento y luego valorar si con los informes rendidos por las autoridades recurridas y la prueba documental que consta en el expediente se puede constatar, de forma simple, una lesión a estos derechos, dejándose abierta la posibilidad de acudir a la vía contencioso administrativa en caso de que el recurso sea finalmente declarado sin lugar ${ }^{34}$.

\footnotetext{
${ }^{33}$ Por medio de esta sentencia, la Sala Constitucional declaró con lugar un recurso de amparo, y anuló la concesión de explotación minera otorgada a una empresa privada, al estimar que el otorgamiento de la concesión sin la aprobación previa del estudio de impacto ambiental constituye una violación al principio preventivo en materia ambiental.

${ }^{34}$ Un ejemplo de esto es la conclusión brindada por la Sala en su sentencia n. ${ }^{\circ}$ 2007-3664 de las 10:34 horas del 16 de marzo de 2007: "En el presente asunto, de los elementos probatorios no es posible concluir que efectivamente las autoridades recurridas hayan puesto, a través de sus acciones $u$ omisiones, en peligro al medio ambiente, pues de las probanzas que constan en el expediente no se logra determinar que efectivamente el ambiente se haya puesto en peligro por las acciones desplegadas por parte del Desarrollador del Proyecto Condominio Residencial Agua Clara, por el contrario, constan en el expediente, una serie de permisos tramitados por esta empresa, tanto ante la Municipalidad recurrida como ante SETENA, lo que a criterio de este Tribunal permite concluir, que tanto las actuaciones de la empresa como de las de las autoridades administrativas -en lo referente a la autorización de los permisosha sido la correcta, sin que exista la posibilidad de efectivamente se constate una violación al ambiente, esto por ser esta vía -la del recurso de amparo- de carácter sumarísimo, lo cual impide recabar una serie de elementos probatorios que sí pueden ser recabados en otros procesos, ya que, para poder localizar un daño al ambiente en este caso concreto, sería necesario realizar una serie de pericias, experticias y otras dictaminaciones técnicas, las cuales no pueden ser realizadas por esta Sala Constitucional, por escapar por completo de sus posibilidades materiales y de las funciones que le han sido encomendadas a esta Sala. Por lo expuesto supra, se hace necesario desestimar el recurso en lo atinente a la posible violación al ambiente alegada por los recurrentes".
} 


\subsection{La radicalización más reciente de ciertos magistrados}

En los últimos años, se ha dado una tendencia, todavía minoritaria pero creciente, a que los magistrados propietarios de la Sala Constitucional se radicalicen en contra de que esta Sala acepte conocer recursos de amparo en los que se alega la violación al derecho fundamental a un ambiente sano y ecológicamente equilibrado.

Esta tendencia la inició el Magistrado Jinesta Lobo, aparentemente desde inicios del $2012^{35}$, por medio de votos salvados y notas separadas a través de las cuales reitera una serie de argumentos sobre los cuales fundamenta su decisión de declarar ya sea sin lugar, o inadmisibles, los recursos de amparo que versan sobre temas ambientales. Al comienzo contó con la adhesión del magistrado suplente Piza Rocafort, y actualmente cuenta con la de los magistrados propietarios Salazar Alvarado y Hernández López. Esta última - la Magistrada Hernández López -, aparentemente desde inicios de $2014^{36}$, empezó a emitir sus propios votos salvados y notas separadas en los cuales manifiesta coincidir con los razonamientos del Magistrado Jinesta Lobo, pero brinda además sus propias razones. Veamos ambos argumentos.

Los votos salvados y notas separadas redactados por el Magistrado Jinesta Lobo contienen tres partes, de las cuales nos referiremos seguidamente a las dos primeras ${ }^{37}$.

La primera se titula "Derecho a un ambiente sano y ecológicamente equilibrado y su desarrollo infra constitucional a través de un vasto entramado normativo". En ella, el Magistrado Jinesta Lobo da cuenta de cómo "después de la reforma parcial al numeral 50 de la Constitución en 1994, se ha venido desarrollando un denso, amplio y prolijo marco normativo Infra constitucional para la protección efectiva del goce y ejercicio del derecho a un ambiente sano y ecológicamente equilibrado (...) que se traduce en diversas leyes, reglamentos y decretos ejecutivos (...)", y de cómo "adicionalmente, ese ordenamiento jurídico sub constitucional, ha establecido una organización administrativa extensa y compleja para actuar los imperativos y obligaciones constitucionales contenidas en el párrafo $3^{\circ}$ del artículo 50 constitucional".

En la segunda parte, denominada "Necesidad de deslindar el control de constitucionalidad y de legalidad en materia de protección del derecho a un ambiente sano y ecológicamente equilibrado", el Magistrado Jinesta Lobo desarrolla, de forma algo confusa, los criterios que él considera deberían ser utilizados para realizar este deslinde, cuya necesidad justifica en "el denso marco normativo o ordenamiento jurídico infra constitucional" al cual hizo referencia en la primera parte.

En primer lugar, establece dos criterios en presencia de cualquiera de los cuales los amparos que versen sobre materia ambiental no deberían ser conocidos por la Sala Constitucional, sino por la jurisdicción contencioso administrativa. Como primer criterio, indica el Magistrado Jinesta Lobo que "cuando respecto de una actividad, obra o proyecto haya intervenido un poder público - ente u órgano administrativo - efectuando estudios, evaluaciones, informes o valoraciones de cualquier naturaleza, por aplicación del denso y vasto ordenamiento jurídico infra constitucional, es claro que la cuestión debe ser residenciada ante la jurisdicción ordinaria y no la constitucional. (...) Desde el momento en que un poder público ha intervenido ejerciendo sus competencias legales y reglamentarias, sustanciando un procedimiento - serie concatenada de actuaciones administrativas - y dictando actos administrativos, el asunto estará fuera de la órbita del control de constitucionalidad, (...). (...) cuando un poder público ha

\footnotetext{
35 La sentencia más antigua en la que pudimos encontrar un voto salvado redactado por el Magistrado Jinesta Lobo en este sentido es la n. ${ }^{\circ} 2012-2275$ de las 11:44 horas del 17 de febrero de 2012.

${ }^{36}$ La primera sentencia en la que pudimos encontrar un voto salvado redactado por la Magistrada Hernández López en este sentido es la n. ${ }^{\circ}$ 2014-542 de las 9:05 horas del 17 de enero de 2014.

${ }^{37}$ En la tercera parte, titulada "Corolario", se indica que, por las razones expuestas en las dos primeras, se rechaza de plano o se declara sin lugar el recurso, según sea el caso.
} 
intervenido efectuando estudios, avalando u homologando experticias presentadas por las partes interesadas, rendido informes, emitiendo resoluciones administrativas, permisos, licencias o cualquier otro acto administrativo formal o, en general, sustanciando uno o varios procedimientos administrativos, el proceso de amparo no es la vía para fiscalizar tales actuaciones sino el proceso contencioso-administrativo". Este criterio lo justifica en la naturaleza sumaria y la simplicidad del proceso de amparo. Como segundo criterio, según el Magistrado Jinesta Lobo, un caso tampoco debería ser conocido en la jurisdicción constitucional, sino en la ordinaria, "cuando un poder público ha omitido cumplir con las obligaciones que le impone, en materia de protección del ambiente y de los recursos naturales, el ordenamiento jurídico infra constitucional sea de naturaleza legal o reglamentario". Este criterio lo justifica en la existencia de "poderosos y eficientes instrumentos en sede administrativa (régimen sancionador, quejas, el Tribunal Ambiental Administrativo) y, en último término, en una jurisdicción contencioso-administrativa cuya función es controlar la legalidad de la función administrativa (artículo 49 constitucional), dentro de la que figuran las omisiones legales o reglamentarias, materiales o formales, jurisdicción ordinaria que ahora, con la nueva legislación adjetiva, es más flexible, expedita, célere, plenaria y universal'.

Seguidamente, establece lo que parecieran ser cinco criterios que deben ser reunidos conjuntamente para que la Sala Constitucional pueda hacer de su conocimiento recursos de amparo en materia ambiental: "Bajo esta inteligencia, este Tribunal Constitucional debe conocer y resolver un asunto en el proceso de amparo, únicamente, (...)" 1. "(...) cuando ningún poder público haya intervenido ejerciendo sus competencias de fiscalización o de autorización (...)" 2. "(...) y se esté desarrollando una conducta, potencial o actualmente, lesiva del derecho a un ambiente sano y ecológicamente equilibrado, (...)" 3. "(...) adicionalmente, debe tratarse de una violación de ese derecho evidente y manifiesta o fácilmente constatable sin mayor producción o evacuación de prueba - (...)" 4. "(...) y, además, debe revestir gran relevancia o trascendencia (...)" 5. "(...) y ser grave. (...)".

A la vista de los siete criterios anteriormente expuestos, algunos de los cuales parecieran contradecirse entre sí, es difícil imaginarse un ejemplo de un caso de violación al derecho a un ambiente sano y ecológicamente equilibrado que pueda llegar a ser conocido por la Sala Constitucional. En primer lugar, la exigencia de que "ningún poder público debe haber intervenido ejerciendo sus competencias de fiscalización o de autorización", pareciera contradecir el criterio de que un caso debe ser competencia del juez contencioso administrativo "cuando un poder público ha omitido cumplir con las obligaciones que le impone, en materia de protección del ambiente y de los recursos naturales, el ordenamiento jurídico infra constitucional sea de naturaleza legal o reglamentario". En efecto, pareciera lógico pensar que si un poder público no ha intervenido ejerciendo sus competencias de fiscalización o de autorización, es probable que estemos en presencia del incumplimiento de obligaciones impuestas por el ordenamiento jurídico infraconstitucional, ya que éste es el que define dichas competencias. En segundo lugar, el Magistrado Jinesta Lobo no brinda detalle alguno acerca de las circunstancias ante las cuales la violación revestiría "gran relevancia o trascendencia", y sería "grave".

Por otra parte, estamos de acuerdo con el Magistrado Jinesta Lobo en cuanto a que "debe tratarse de una violación de ese derecho evidente y manifiesta o fácilmente constatable - sin mayor producción o evacuación de prueba -". Esto por cuanto la evacuación de la prueba necesaria para constatar la violación de este derecho fundamental debe darse dentro de las posibilidades que ofrece el proceso de amparo, conforme a su naturaleza sumaria. Sin embargo, a diferencia de él, consideramos que éste no es simplemente un criterio adicional a otro más importante que debe ser constatado previamente. Para nosotros, éste debería ser el principal criterio en cualquier caso en el que la consecuencia sea la violación del derecho fundamental a un ambiente sano y ecológicamente equilibrado, independientemente de que 
haya habido o no intervención de un poder público, o una omisión de su parte en el cumplimiento de las obligaciones que le impone el ordenamiento jurídico infra constitucional.

Bajo estos parámetros, nos parece que la posición del Magistrado Jinesta Lobo constituye una clara regresión, entre otros, respecto a la posición sostenida por la Sala Constitucional en numerosas sentencias ${ }^{38}$, según la cual "las omisiones al deber de protección del ambiente y de cumplimiento de la normativa ambiental son de relevancia constitucional, por cuanto a consecuencia de la inercia de la Administración en esta materia, se puede producir un daño al ambiente y a los recursos naturales, a veces, de similares o mayores consecuencias, que de las derivadas de las actuaciones de la Administración; como lo es la autorización de planes reguladores, o construcciones sin la aprobación del estudio de impacto ambiental por parte Secretaría Técnica Nacional Ambiental, o la falta de control y fiscalización en la ejecución de los planes de manejo de las áreas protegidas por parte de la Dirección General de Vida Silvestre del Ministerio del Ambiente y Energía, o el permitir el funcionamiento de empresas sin los permisos de salud en lo que respecta al tratamiento de aguas negras o residuales Acueductos y Alcantarillados y Ministerio de Salud -, o no verificar los controles sónicos en bares, karaokes y discoteques - municipalidades y Ministerio de Salud -".

Por su parte, en los votos salvados y notas separadas redactados por la Magistrada Hernández López, ella califica su propia posición como una "decisión de dar un paso al lado en materia ambiental por parte de este Tribunal", aunque aclara seguidamente que la misma "no debe ser vista como un abandono de la materia ambiental, sino al contrario, de su adecuada tutela en la instancia que mejor se aviene a la naturaleza de su complejidad y diversidad". Y es que en sus votos salvados la Magistrada Hernández López indica que la amplia intervención que en su momento tuvo la Sala en materia ambiental se justificó en circunstancias históricas que han variado considerablemente. Concretamente se refiere a que en su momento la situación se caracterizaba por "la ausencia de normativa y de instancias estatales con competencia apropiada", mientras que la situación actual se caracteriza "por una amplísima producción legal y reglamentaria que incluye reglas de fondo, procedimientos y creación de órganos para el cumplimiento de lo ordenado en la Carta Fundamental". Además, resalta la "entrada en escena tanto de la justicia administrativa como de la jurisdicción ordinaria - prioritariamente la contencioso administrativa, pero también la penal", así como que "en ellas, acorde con la importancia del derecho ambiental, se han regulado de forma amplia vías procesales y medios de legitimación incluyentes, de manera que los administrados puedan hacer valer 10 establecido en ese amplio orden jurídico que se relaciona con el tema ambiental'. Indica que es impropio jurídicamente, así como funcionalmente incorrecto, que la Sala Constitucional desplace o sustituya a los órganos de justicia ordinarios en la realización de su tarea de velar por el efectivo cumplimiento de leyes y reglamentos. "Es impropio jurídicamente porque en la inmensa mayoría de estos casos lo que se solicita es que interprete y haga valer normas legales y reglamentarias con lo que arriesga traslapar sus competencias con las de otros órganos jurisdiccionales que - ellos sí - han sido creados para ejecutar tales tareas; y resulta también funcionalmente incorrecto, porque el diseño de sus procesos se aviene mal con la complejidad que está presente en numerosos conflictos ambientales que se componen de series de hechos y actos técnica y jurídicamente complejos".

En cuanto a los criterios para deslindar lo que corresponde conocer a la jurisdicción constitucional y a la jurisdicción ordinaria en materia ambiental, la exposición realizada por la Magistrada Hernández López también es confusa. En un primer momento, pareciera querer dar a entender que la Sala debe seguir conociendo los casos ambientales "cuya resolución no exige más que la aplicación del derecho de la Constitución". Sin embargo, en un segundo momento, invoca como regla general que "esta Sala debe abstenerse de conocer los reclamos que se le presenten por supuesta infracción al artículo 50 de la Constitución Política para dejar

\footnotetext{
${ }^{38}$ Entre otras, ver la sentencia n. ${ }^{\circ} 2011-16316$ de las 9:41 horas del 25 de noviembre de 2011.
} 
en manos de la justicia administrativa y la jurisdicción contenciosa administrativa su conocimiento". Empero, en un tercer momento, menciona, como excepción a esta regla, los casos en los cuales, a su juicio, el derecho a un ambiente sano y ecológicamente equilibrado estaría mejor tutelado por la Sala Constitucional; lo anterior al reconocer "la existencia de casos particulares o grupos de casos que, según mi criterio, sí resultarían aún mejor tutelados por esta Sala y por tanto deben ser conocidos y resueltos por ella". De conformidad con lo anterior, la Magistrada menciona algunos ejemplos de casos o grupos de casos que ella considera deben ser de conocimiento de la Sala: "los reclamos por infracciones ambientales que además pongan en riesgo directo la salud de las personas, o el acceso o calidad del agua; los casos de violaciones groseras y directas al ambiente y en los cuales se constate una palmaria ausencia de protección por parte de las autoridades estatales"; pero además aclara que ello sería posible "siempre y cuando - además - la naturaleza del reclamo permita ser abordado mediante el instrumento del amparo como instituto procesal sumario y especial, ya que estimo que tampoco se debe "ordinariar" el amparo para abordar, aún en estos casos citados, temas que rebasen la capacidad de ser atendidos adecuadamente en el mismo".

Como vemos, la Magistrada Hernández López realiza una especie de jerarquización de lesiones al derecho a un ambiente sano y ecológicamente equilibrado con el objetivo de discriminar entre aquéllas que deben ser de conocimiento de la Sala Constitucional y aquéllas que no, pero lo hace de manera muy simplista y sin ningún fundamento técnico que la respalde. En efecto, el tema ambiental es tan complejo que se necesitarían estudios científicos sumamente detallados para poder realizar tal jerarquización; pero más aún, con los conocimientos científicos actuales no es posible identificar o predecir todos los efectos que podrían producir las alteraciones causadas por el hombre al ambiente, por lo que hay efectos que no se conocen o que son de muy difícil identificación; todo ello debido a la complejidad de las interrelaciones existentes en los ecosistemas. Además, al momento del estudio de admisibilidad de un recurso de amparo, la Sala Constitucional está absolutamente limitada desde el punto de vista técnico para realizar valoraciones acerca de cuán tan grosero es un impacto al ambiente, ya que ella no cuenta con un cuerpo de expertos científicos que le pueda brindar algún tipo de información u orientación al respecto. Este tipos de criterios se vuelve por lo tanto muy subjetivo.

Coincidimos, sin embargo, con la Magistrada Hernández López en cuanto a que la Sala debe actuar dentro de los límites que impone la naturaleza sumaria del proceso de amparo y que por esta razón no lo debe "ordinariar". Un claro ejemplo de los límites del proceso de amparo para la evacuación de la prueba necesaria para determinar la verdad real de los hechos en asuntos complejos, es el caso del proyecto minero Crucitas, resuelto a través de la sentencia n. ${ }^{\circ} 6922$ 2010 de las 14:35 horas del 16 de abril de 2010. En esta sentencia, extraordinariamente larga para un proceso sumario como el amparo, la Sala Constitucional entró a valorar aspectos técnicos, realizó complejos y extensos análisis respecto a cuestiones de legalidad, y se pronunció acerca de si las actuaciones de la administración habían estado bien o mal fundadas; todo ello a pesar de los límites propios de este proceso, como el hecho de que no hay posibilidad de contradictorio ni de recibir prueba testimonial. A pesar de estos límites, la Sala realizó una especie de "ordinarización" del mismo, pues recibió y analizó gran cantidad de prueba técnica documental aportada por las partes, realizó una vista pública en la que escuchó a todas las partes, y hasta realizó una inspección judicial en los terrenos donde se proyectaba llevar a cabo el proyecto minero. Las carencias de este tipo de ejercicio realizado por la Sala Constitucional en el marco de un proceso de amparo, fueron implícitamente puestas en evidencia por la sentencia n..$^{\circ}$ 4399-2010 de las 10:14 horas del 14 de diciembre de 2010 de la Sección Cuarta del Tribunal Contencioso Administrativo, ya que, contrario a la sentencia de la Sala Constitucional, la cual declaró con lugar el recurso únicamente por haberse aprobado el estudio de impacto ambiental sin el criterio previo del Servicio Nacional de Riego y Avenamiento (SENARA) - pero con la salvedad que tal declaratoria no tenía como efecto 
anular el estudio de impacto ambiental ni retrotraer los procedimientos al momento de la presentación de dicho estudio - la sentencia del Tribunal Contencioso Administrativo, en el marco de un proceso de cognición plena, encontró la existencia de múltiples vicios que volvían absolutamente nulos una serie de actos administrativos relacionados con el proyecto, como la resolución que otorgó la concesión de explotación minera, las resoluciones que otorgaron viabilidad ambiental al proyecto original y a su modificación, el decreto que declaró la conveniencia nacional del proyecto, y el permiso que aprobó el cambio de uso del suelo.

Si bien este caso demostró que en efecto, como lo indica la Magistrada Hernández López, el derecho a un ambiente sano y ecológicamente equilibrado puede ser mejor protegido en la jurisdicción contencioso administrativa, ello no necesariamente es así en la mayoría de los casos. Por esta razón, no debería hacerse de ello una generalización, sino que más bien, como ya lo dijimos anteriormente, la Sala debería evaluar caso por caso si la totalidad o parte de los reclamos formulados por los recurrentes pueden ser conocidos o no en un proceso con la naturaleza y las características del amparo. En este sentido, una posición bastante más balanceada y racional es la expresada por el Magistrado Castillo Víquez en su nota separada en el mencionado voto sobre el proyecto minero Crucitas ${ }^{39}$.

Consideramos que al ser el recurso de amparo una garantía para el respeto de los derechos fundamentales de las personas, los criterios que la Sala Constitucional utilice para determinar su competencia en aquellos casos en los que estén de por medio tales derechos deben ser los más amplios posibles, limitados sólo por la naturaleza sumaria del proceso de amparo y las consecuentes posibilidades probatorias que este proceso ofrece. Esto por cuanto el proceso contencioso administrativo, por más que se haya simplificado y agilizado con el nuevo Código Procesal, contiene ciertas características que no lo hacen tan accesible como el proceso de amparo, situación ésta que no ha sido tomada en cuenta ni por la Sala Constitucional a la hora de adoptar criterios restrictivos con motivo de la entrada en vigencia del Código Procesal Contencioso Administrativo, ni por los magistrados propietarios que han cerrado casi todas las

39 En su extensa nota, el Magistrado Castillo Víquez realiza una síntesis de algunos de los principales criterios vertidos por la Sala Constitucional acerca de la naturaleza propia del recurso de amparo, y a partir de ahí trata de responder a la pregunta sobre cuál es la competencia de la Sala Constitucional en materia ambiental en los procesos de amparo. En cuanto al primer punto, indica que el recurso de amparo tiene una naturaleza sumaria, "incluso sumarísima, característica derivada de la apremiante necesidad de resolver sobre el objeto del recurso, según lo dispuesto en el artículo primero de la Ley de la Jurisdicción Constitucional, circunscrita básicamente a la restitución del derecho fundamental como garantía del respeto a un mínimo de protección a las personas consagrado dentro del derecho de la constitución (...)". Señala que la indicada naturaleza del recurso de amparo resulta en la imposibilidad para que en este proceso pueda darse "la amplitud en la recepción y análisis" de la prueba, y que este es un factor determinante por el cual "Ios asuntos que requieran un estudio más técnico de las probanzas, deben ser remitidos a la jurisdicción contenciosa por su especialidad y por el diseño de procesos ágiles, garantistas y de cognición". En cuanto a cuál debe ser la competencia de la Sala Constitucional en materia ambiental en los procesos de amparo, el Magistrado Castillo Víquez identifica dos ámbitos de competencia: por una parte, la verificación de "que no haya por parte de las autoridades competentes una irrazonabilidad manifiesta en su actuación o decisión". En este ámbito, indica el Magistrado, "el estándar de control de las decisiones y actuaciones de la Administración por parte del Tribunal se limita a la verificación de que estén sustentadas en estudios técnicos que garanticen, precisamente, el derecho fundamental. Hasta aquí llega la competencia del Tribunal. Lo anterior significa, que el proceso de amparo no es una instancia para discutir si un estudio técnico es correcto o incorrecto, si un estudio técnico presenta falencias o no, mucho menos para rebatir los estudios técnicos que se sirvieron de fundamento a las actuaciones y resoluciones de la Administración, si un decreto ejecutivo está bien o mal motivado, si un decreto ejecutivo quebranta la normativa legal, etc., ya que estos asuntos son propios de otra jurisdicción". El segundo ámbito de competencia es el relacionado con "garantizar los principios constitucionales que regentan o informan el derecho a un ambiente saludable y ecológicamente equilibrado", para lo cual remite a los principios señalados en la sentencia n. ${ }^{\circ}$ 2003-6322 de las 14:14 horas del 3 de julio de 2003, a la cual ya nos hemos referido. Finalmente, el Magistrado Castillo Víquez indica que el control de la discrecionalidad administrativa es materia que compete a la jurisdicción contencioso administrativa, no a la constitucional. 
puertas a la posibilidad de que la Sala haga de su conocimiento recursos de amparo en los que se invoca la violación al derecho a un ambiente sano y ecológicamente equilibrado.

Para sustentar esta afirmación, nos interesa resaltar algunas de las características que hacen sumamente accesible el proceso de amparo. En primer lugar, la simplicidad y ausencia de formalidades del recurso propiamente. En este sentido, el artículo 38 de la Ley de la Jurisdicción Constitucional indica, en lo que interesa: "En el recurso de amparo se expresará, con la mayor claridad posible, el hecho o la omisión que lo motiva, el derecho que se considera violado o amenazado, el nombre del servidor público o del órgano autor de la amenaza o del agravio, y las pruebas de descargo. No será indispensable citar la norma constitucional infringida, siempre que se determine claramente el derecho lesionado, salvo que se invoque un instrumento internacional. El recurso no está sujeto a otras formalidades ni requerirá autenticación. (...)". Ello contrasta con las indicaciones que, según el artículo 58, inciso 1), del Código Procesal Contencioso Administrativo, debe contener la demanda: "a) Las partes y sus representantes. b) Los hechos y los antecedentes, en su caso, relacionados con el objeto del proceso, expuestos uno por uno, enumerados y especificados. c) Los fundamentos de Derecho que invoca en su apoyo. d) La pretensión que se formule. d) Cuando accesoriamente se pretendan daños y perjuicios, se concretará el motivo que los origina, en qué consisten y su estimación prudencial. f) Las pruebas ofrecidas. g) Cuando también se demande a sujetos privados, el lugar para notificarle el auto inicial'. En segundo lugar, tenemos la simplicidad en la tramitación del proceso de amparo. De conformidad con los artículos 39 a 48 de la Ley de la Jurisdicción Constitucional, una vez presentado el recurso, si el mismo no fuere oscuro y si no existiere motivo para rechazarlo de plano o resolverlo interlocutoriamente, la Sala deberá solicitar, al órgano o al servidor que se indique como autor del agravio, amenaza u omisión, un informe que deberá ser rendido bajo juramento, así como, eventualmente, el expediente administrativo o la documentación en que consten los antecedentes del asunto; luego de recibido el informe y la documentación solicitada, y si no considera necesaria la práctica de ninguna otra diligencia para mejor proveer, la Sala dictará sentencia. Tal simplicidad no se da en el proceso contencioso administrativo, con excepción del llamado "trámite preferente", conocido también, informalmente, como "amparo de legalidad"; sin embargo, de acuerdo con el artículo 60 del Código Procesal, únicamente se le puede dar trámite preferente a aquellos asuntos que el tribunal de juicio estime que revisten urgencia o necesidad, o que son de gran trascendencia para el interés público, por lo que este trámite reviste un carácter excepcional. En tercer lugar, tenemos la gratuidad, ya que no se necesita patrocinio letrado y no hay condenatoria en costas para el vencido, contrario al proceso contencioso administrativo, el cual sí requiere los servicios de al menos un abogado, y para el cual el artículo 193 del Código Procesal establece la regla de la condenatoria oficiosa en costas al vencido.

Obviamente entonces, acudir al proceso contencioso administrativo requiere de una inversión en tiempo y dinero mucho mayor que la que se requiere en el proceso de amparo. Por ello, a pesar de todas las virtudes del proceso contencioso administrativo establecido en el nuevo Código Procesal, el cerrar las vías para acceder a la jurisdicción constitucional en materia ambiental no va a provocar el que las personas a las que se les niega dicho acceso salgan corriendo en estampida hacia la jurisdicción contencioso administrativa, sino más bien el que muchas personas no accedan del todo a la justicia. Los principales afectados son, por supuesto, las personas y comunidades de escasos recursos económicos. Pero también debe tomarse en consideración que, tratándose de daños ambientales, muchas veces no existe un afectado claramente individualizado o individualizable, por lo que es común que las personas que acuden a la vía judicial en defensa del derecho de todos a un ambiente sano y ecológicamente equilibrado lo hagan en defensa de un interés difuso o colectivo, y no porque hayan sufrido un perjuicio directo e individual. En cualquier caso, no cabe duda que la mayor inversión en tiempo y dinero que requieren los procesos ante la jurisdicción contencioso administrativa constituye un desincentivo a la presentación de demandas en esta vía. Al final 
de cuentas, el resultado de todo esto es que se reduce el nivel de protección del derecho fundamental a un ambiente sano y ecológicamente equilibrado, y se da con ello una regresión ambiental.

\section{Conclusiones}

Al momento en que se realiza este pequeño estudio, las más fuertes amenazas de regresión en el acceso al juez constitucional para la defensa del derecho a un ambiente sano y ecológicamente equilibrado parecieran provenir, no del estado actual de las iniciativas para reformar la Ley de la Jurisdicción Constitucional, sino de posiciones radicales asumidas en el seno mismo de la Sala Constitucional en cuanto al conocimiento específico de recursos de amparo en materia ambiental. Estas posiciones, al tener por blanco único y exclusivo la defensa de este derecho, son el reflejo de lo que podríamos llamar una "diabolización" de la materia ambiental en sede constitucional.

Estimamos que, lejos de adoptar posiciones extremas, la Sala Constitucional debería conservar cierta amplitud en sus criterios de admisibilidad para conocer asuntos que traten de la tutela de derechos fundamentales, sin hacer distinciones entre éstos, y tomando como único o principal criterio de restricción los límites intrínsecos que derivan de la naturaleza sumaria del proceso de amparo. Ello aún cuando a partir de la entrada en vigencia del Código Procesal Contencioso Administrativo se cuente, según palabras de la propia Sala, "con una jurisdicción contenciosoadministrativa plenaria y universal, sumamente expedita y célere" ${ }^{\text {"40 }}$. Esto por diversas razones que hemos apuntado en este trabajo, como el hecho que el amparo es en principio la vía idónea para la tutela judicial expedita de los derechos fundamentales, y el hecho de que el proceso contencioso administrativo no es tan "sencillo, informal y de fácil acceso" amparo, por carecer de ciertas características que tiene este último: simplicidad y ausencia de formalidades del recurso propiamente, simplicidad en la tramitación del proceso, y gratuidad.

La ausencia en el proceso contencioso administrativo de estas características que hacen del amparo un proceso sumamente accesible, constituye a la vez un obstáculo y un desincentivo para acudir al mismo en defensa del derecho a un ambiente sano y ecológicamente equilibrado. Por lo tanto, el establecimiento de una regla general de remisión de casos a la vía ordinaria, a pesar de que en muchos de ellos la violación o amenaza a este derecho fundamental pueda ser constatada sin necesidad de diligencias probatorias complejas que no se ajustan a la naturaleza sumaria del amparo, tiene como efecto reducir el nivel de protección de este derecho, y constituye una regresión respecto a las posibilidades que han existido de acceder y lograr una tutela expedita de este derecho en la vía del amparo. Para que tal remisión no fuere regresiva, se necesitaría de una reforma previa al Código Procesal Contencioso Administrativo, que introdujere en esta jurisdicción las facilidades de acceso apuntadas, para los casos en los que esté de por medio la tutela del derecho a un ambiente sano y ecológicamente equilibrado.

\section{Bibliografía}

Peña Chacón, Mario, "El Principio de No Regresión Ambiental a la Luz de la Jurisprudencia Constitucional Costarricense", Revista Judicial, No. 103, San José, marzo 2012, pp. 143-180.

\footnotetext{
${ }^{40}$ Entre muchas otras, sentencia n. ${ }^{\circ} 2008-8690$ de las 8:43 horas del 23 de mayo de 2008.

${ }^{41}$ Palabras con las cuales el Magistrado Castillo Víquez describió el proceso de amparo.
} 



\section{UICN}

Programa de Derecho Ambiental de la UICN

Centro de Derecho Ambiental

Godesberger Allee 108-112

53175 Bonn, Alemania

Tel: ++ 49228 / 2692231

Fax: ++ $49228 / 2692250$

elcsecretariat@iucn.org

www.iucn.org/law 